\title{
A CULTURAL INTERPRETATION OF THE GENOCIDE CONVENTION
}

by

\section{KURT MUNDORFF}

B.A., The University of Oregon, 1992

M.A., The John Jay College of Criminal Justice, 2001

J.D., The Benjamin Cardozo School of Law, 2004

LL.M., The University of British Columbia, 2007

\section{A DISSERTATION SUBMITTED IN PARTIAL FULFILLMENT OF} THE REQUIREMENTS FOR THE DEGREE OF

DOCTOR OF PHILOSOPHY

in

THE FACULTY OF GRADUATE AND POSTDOCTORAL STUDIES

(Law)

THE UNIVERSITY OF BRITISH COLUMBIA

(Vancouver)

December 2018

(C) Kurt Mundorff, 2018 
The following individuals certify that they have read, and recommended to the Faculty of Graduate and Postdoctoral Studies for acceptance, the dissertation entitled:

A Cultural Interpretation of the Genocide Convention

submitted by Kurt Mundorff in partial fulfillment of the requirements for

the degree of Doctor of Philosophy

in Law

\section{Examining Committee:}

Karin Mickelson, Law

Supervisor

Douglas Harris, Law

Supervisory Committee Member

Adam J Jones, Political Science

Supervisory Committee Member

James G Stewart, Law

University Examiner

Steven Lee, History

University Examiner 


\begin{abstract}
In 1948, a mere four years after Raphael Lemkin coined the word "genocide," the UN General Assembly codified his concept in the Convention on the Prevention and Punishment of the Crime of Genocide (Genocide Convention). Over time, the definition of genocide has become increasingly estranged from the concept originated by Lemkin and adopted by the UN.
\end{abstract}

This dissertation critiques the prevailing materialist interpretation of the Genocide Convention, which originated in a 1996 commentary by the International Law Commission (ILC). As I document, this interpretation has found increasing acceptance among international courts including the International Criminal Tribunal for the Former Yugoslavia, the International Criminal Tribunal for Rwanda, the International Criminal Court, and the International Court of Justice. According to the ILC, the Genocide Convention is concerned only with the "material" existence of human groups and therefore excludes incidents of "cultural genocide."

The interpretive method that I lay out begins with the rules of interpretation embodied in the Vienna Convention on the Law of Treaties and grounds them in postphenomenological hermeneutic theory. Surveying the Genocide Convention's text, its preparatory work or travuax perparatoires, and the historical context of its drafting, I find little support for the "exclusionist" interpretation. Instead, I find that many of its drafters believed the Genocide Convention would protect groups as culturally functioning entities. In fact, as I document, the drafters voted down provisions that would have created an explicitly materialist convention and excluded cultural matters. 
I ascribe this misinterpretation to the historical distance separating the Genocide Convention's drafting from our own time. I use archival sources, including Lemkin's personal papers, State Department documents, and early UN documents, as well as legal documents and the secondary literature, to reconstruct the mid-century conversation on genocide and to situate that conversation in the much broader mid-century discourse on justice and society. At that time, the concept of culture exerted a strong normative pull and was believed to possess tremendous explanatory power. Placed in this context, culture is not a distraction to be read out of the Genocide Convention; culture is the very reason it exists. 


\section{Lay Summary}

This dissertation challenges the prevailing interpretation of the Genocide Convention, which holds that the convention should be understood as excluding "cultural genocide." As I document, this "exclusionist" interpretation is unsupported by the Convention's text and its drafting history. Moreover, because the immediate postwar period of the convention's drafting was a time when the idea of culture held sway in the popular as well as the scholarly imaginations, the exclusionist interpretation is profoundly anachronistic. Using the personal papers of Raphael Lemkin, who originated the concept of genocide and was the Convention's tireless booster, archival materials of the US State Department and the UN, contemporaneous legal documents, and the secondary literature, I situate the convention's meaning in the midcentury context of its drafting. Placed in this context, culture is not a distraction to be read out of the Genocide Convention; culture is the very reason it exists. 


\section{Preface}

This dissertation is original, unpublished, independent work by the author, Kurt

Mundorff. 


\section{Table of Contents}

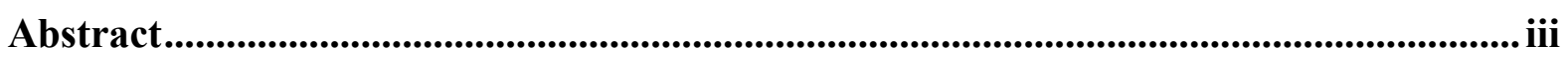

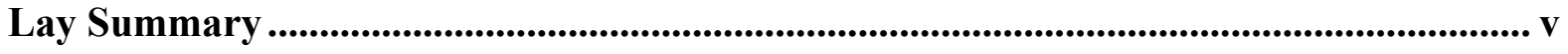

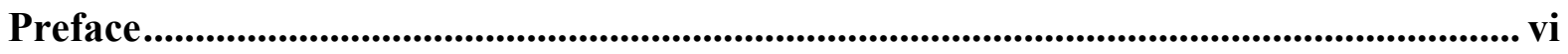

Table of Contents ..................................................................................................... vii

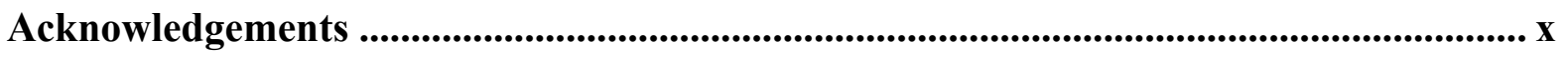

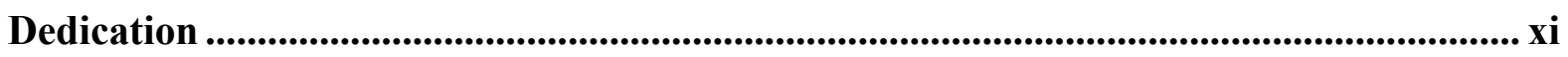

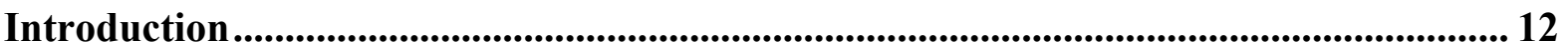

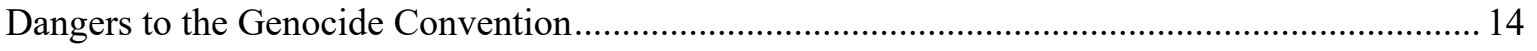

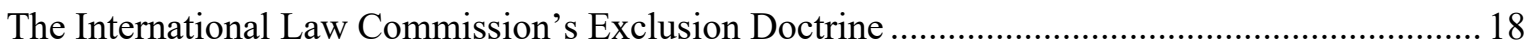

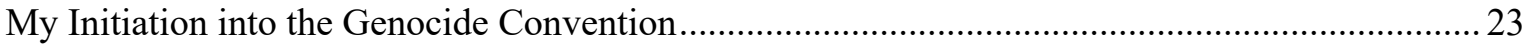

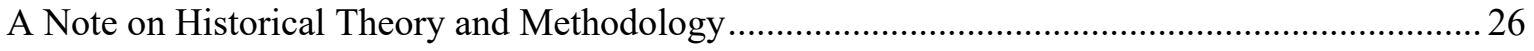

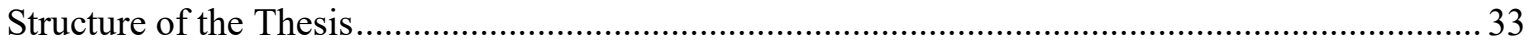

Chapter 1-Outlines of a More Humble Interpretation ...................................................... 36

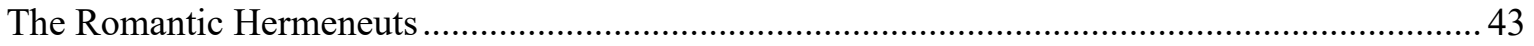

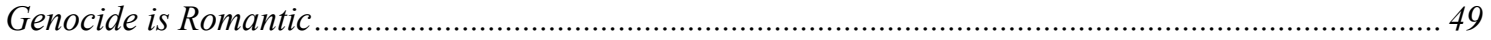

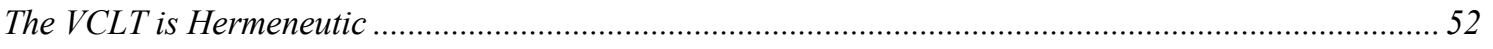

VCLT Article 31: The "General Rule of Interpretation" .........................................................5 53

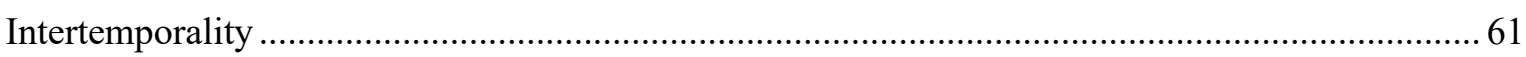

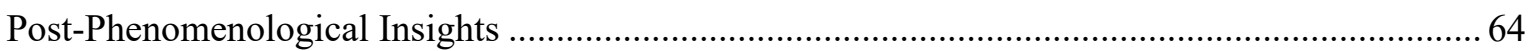

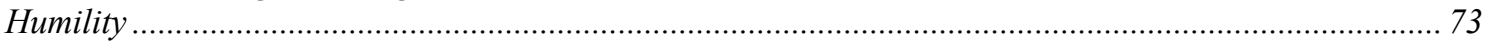

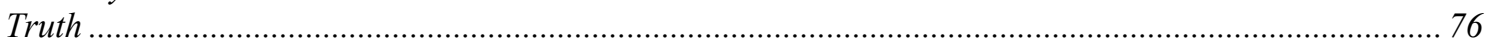

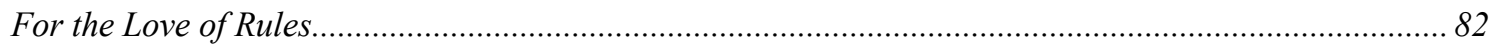

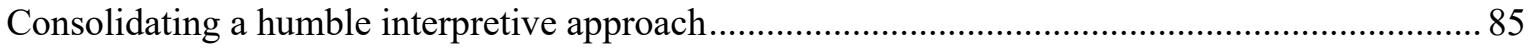

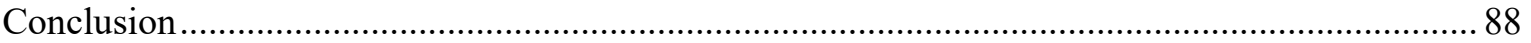

Chapter 2-Lemkin in the Cultural Moment ..................................................................91

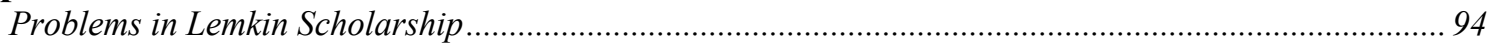

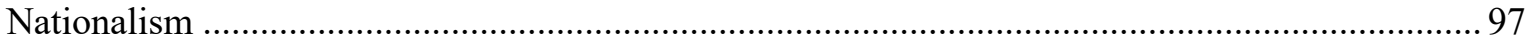

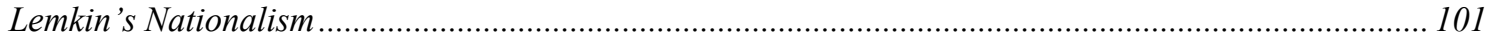

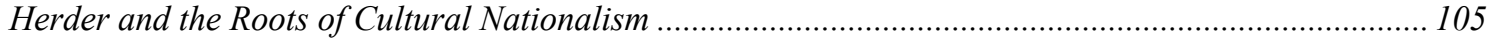

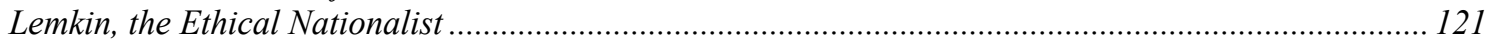

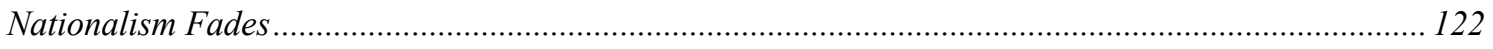

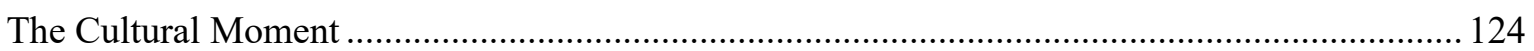

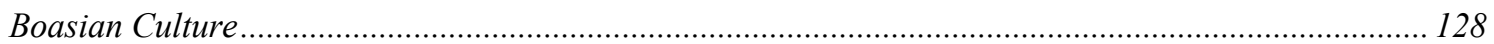

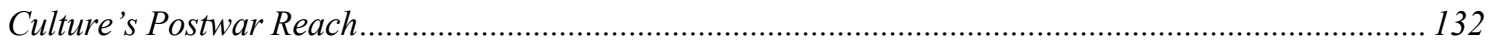

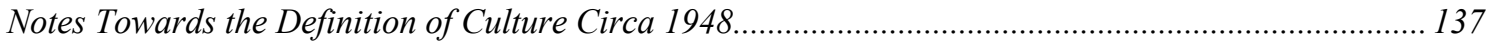

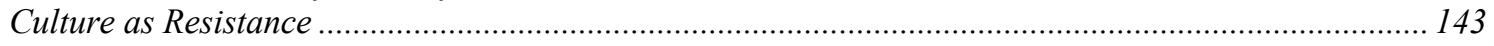

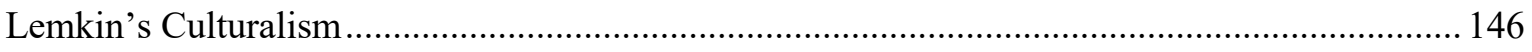




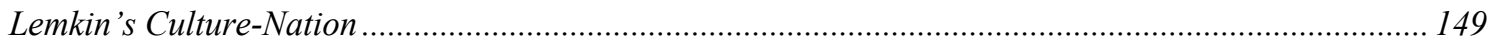

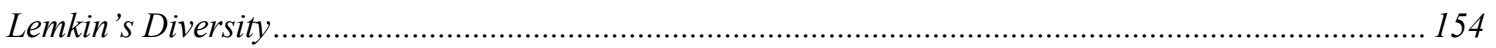

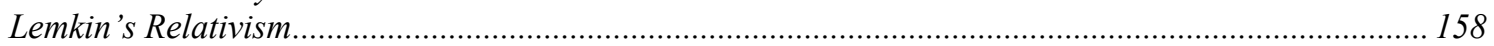

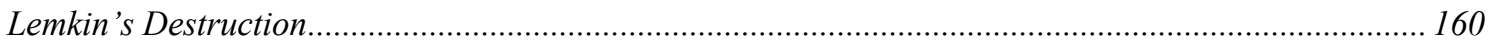

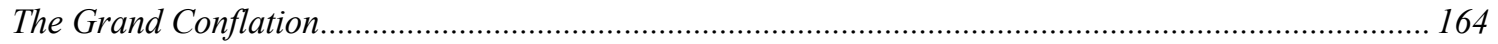

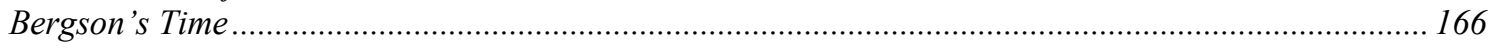

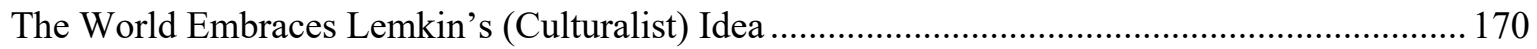

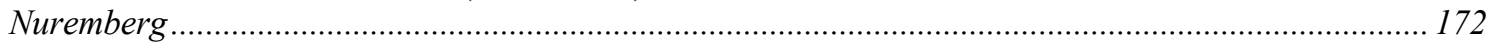

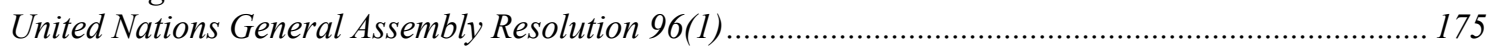

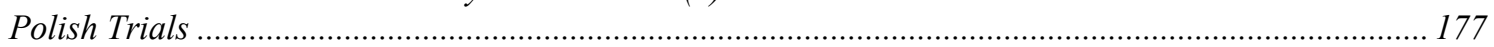

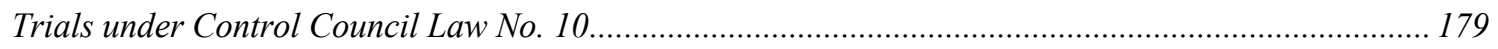

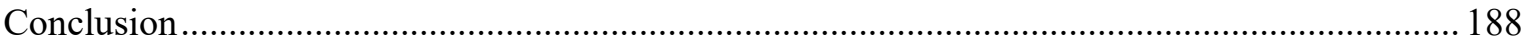

Chapter 3-The Tedious Crucible: A Hermeneutic Inquiry Into Culture's Place in the Genocide Convention According to the Vienna Convention on the Law of Treaties, Article 31 ........................................................................................................................ 192

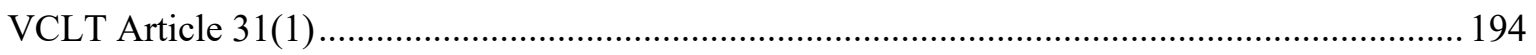

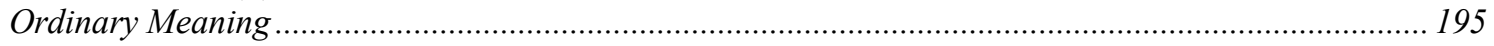

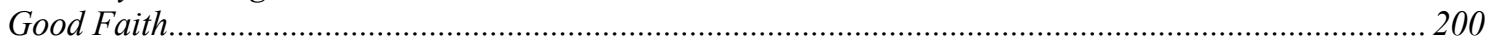

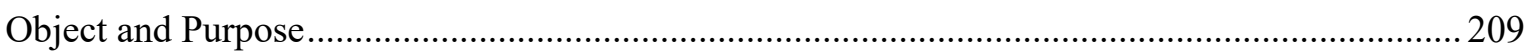

Group Protection: "Safeguard the Very Existence of Certain Human Groups "..................................... 211

"Civilizing Purpose": "[T]o Confirm and Endorse the Most Elementary Principles of Morality"........ 218

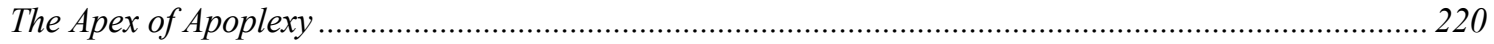

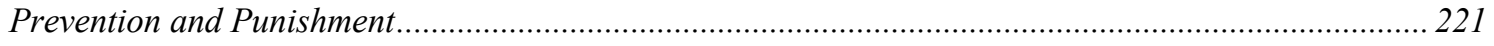

Article 2: An Ordinary Reading ................................................................................................ 222 Article 2 Chapeau: "In the present convention, genocide means any of the following acts committed with intent to destroy, in whole or in part, a national, ethnical, racial or religious group, as such. "............. 223

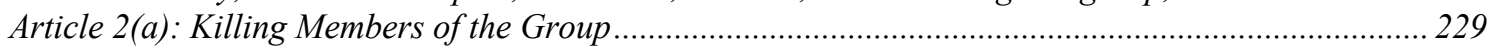
Article 2(b): Causing Serious Bodily or Mental Harm to Members of the Group.................................. 230 Article 2(c): Deliberately Inflicting on the Group Conditions of Life Calculated to Bring About Its

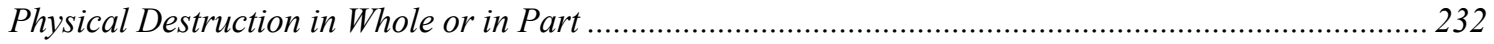
Article 2(d): Imposing Measures Intended to Prevent Births Within the Group ...................................... 234 Article 2(e): Forcibly Transferring Children of the Group to Another Group ……............................... 235

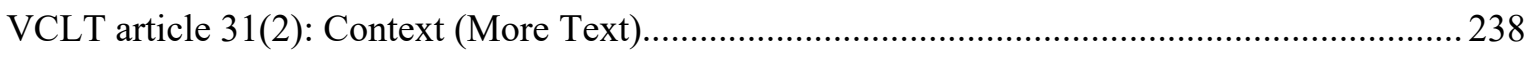

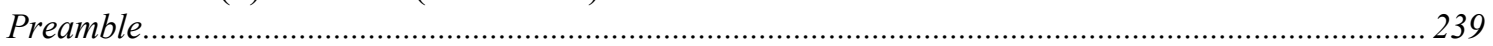

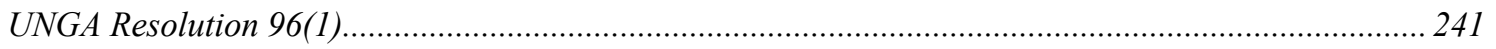

VCLT Articles 31(2)(a)(b) and 31(3)(a)(b): Subsequent Agreement/Practice ............................ 245

VCLT Article 31(3)(c): Relevant Rules of International Law .................................................... 246

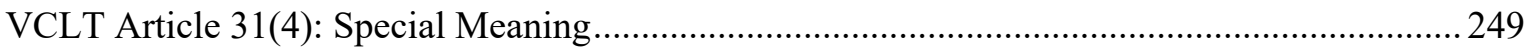

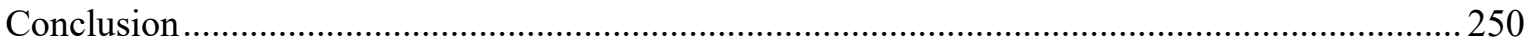

Chapter 4-The Trouble with Travaux ................................................................................. 252

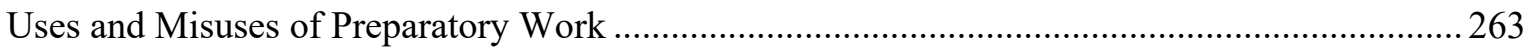

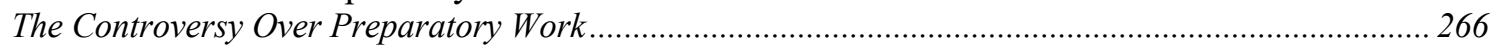

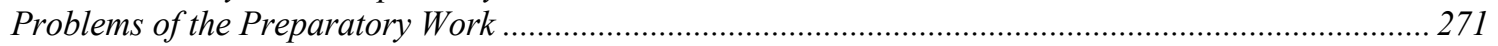

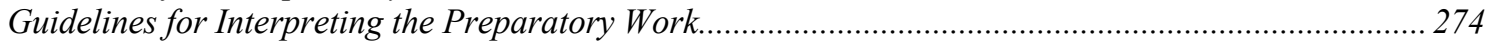

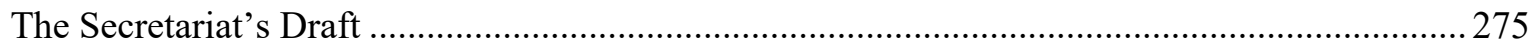

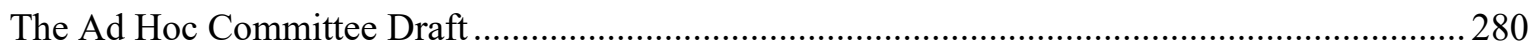




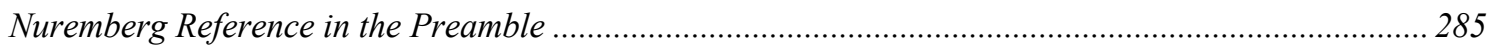

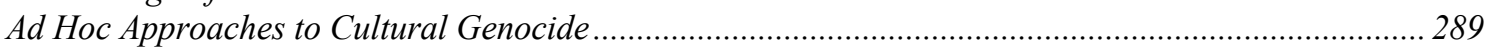

The Ad Hoc Committee Retains Political Groups ……....................................................................... 297

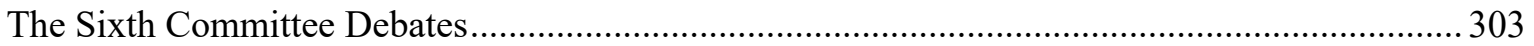

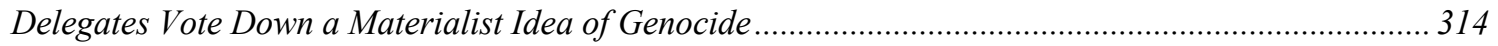

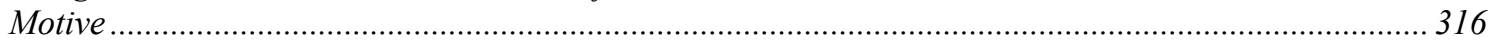

The Sixth Committee Cultural Genocide Debate …………................................................................ 319

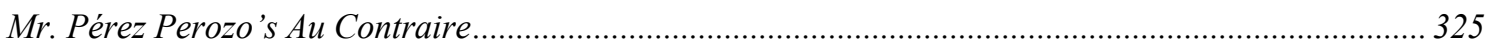

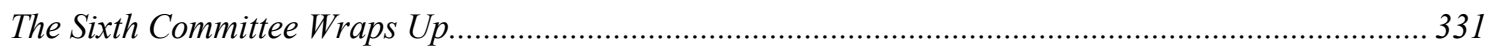

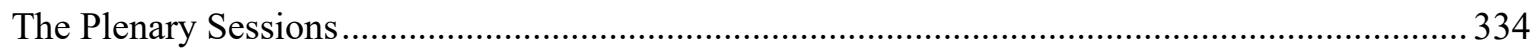

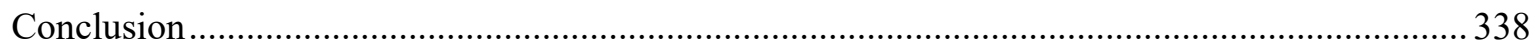

Chapter 5-A History of Exclusion....................................................................... 343

Communist Agents, Human Rights Activists, and the International Law Commission..............................346

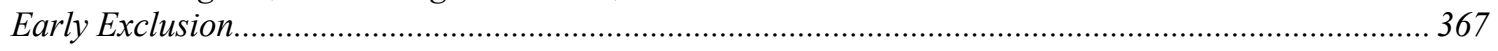

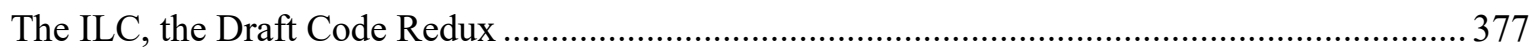

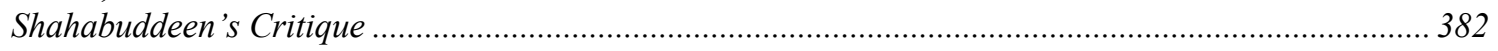

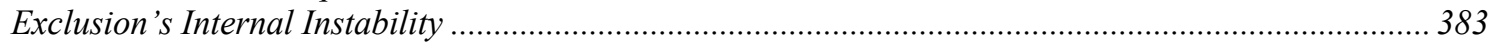

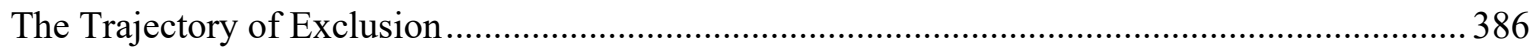

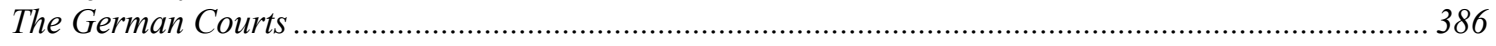

The ICTR

The ICTY

The ICJ

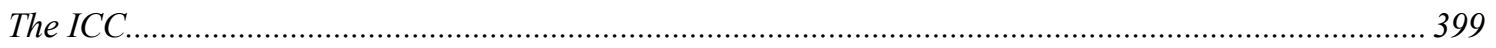

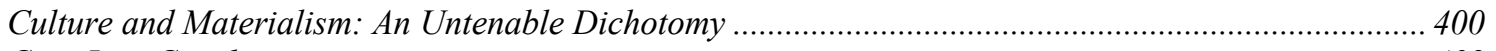

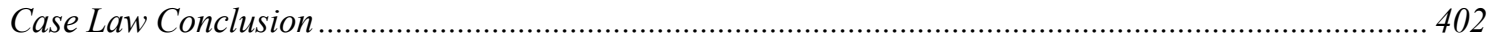

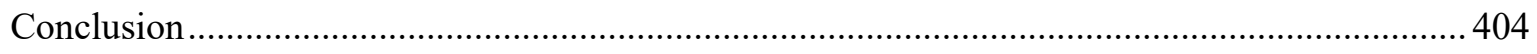

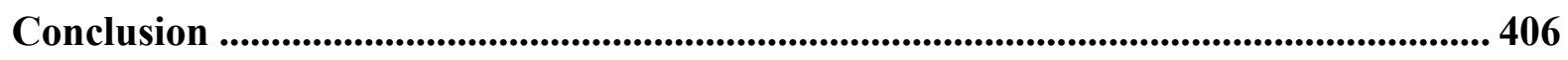

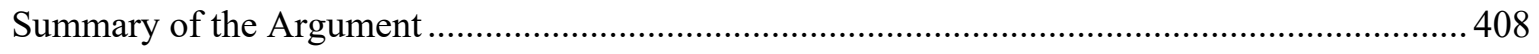

Limitations of This Study and Areas of Future Inquiry ........................................................ 410

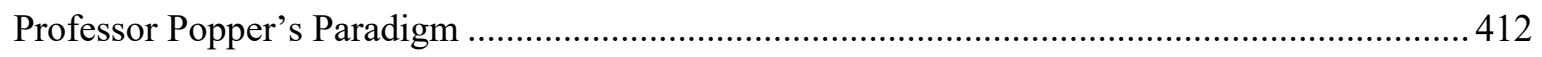

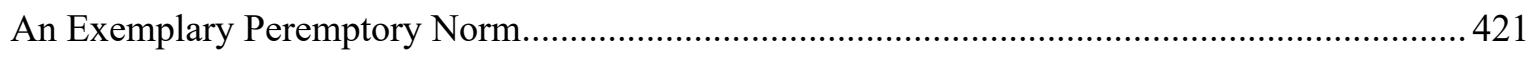

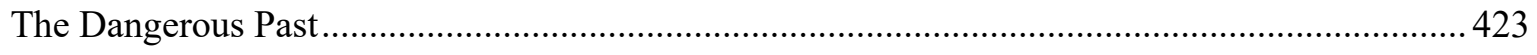

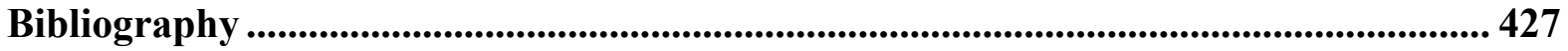

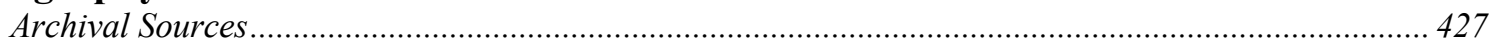

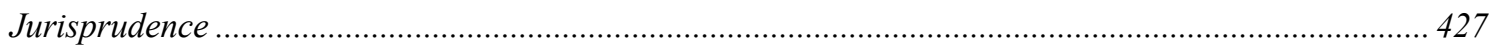

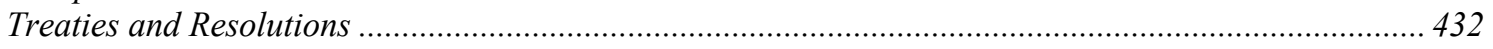

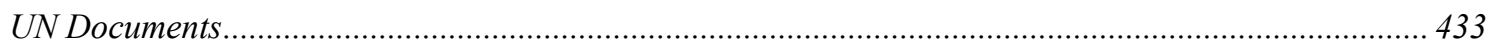

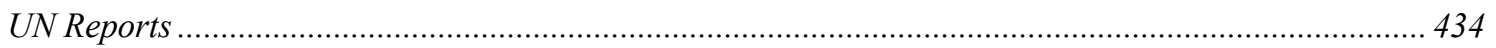

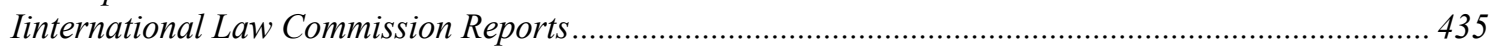

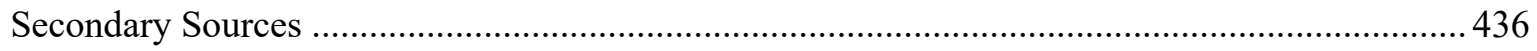

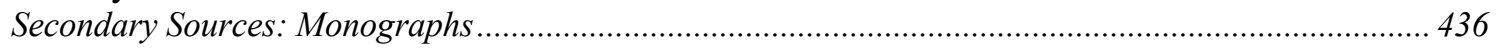

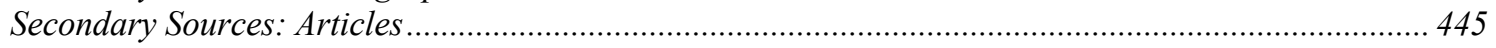

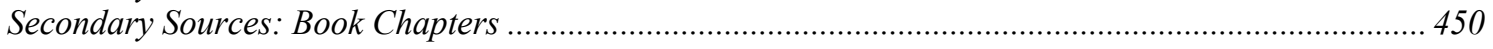

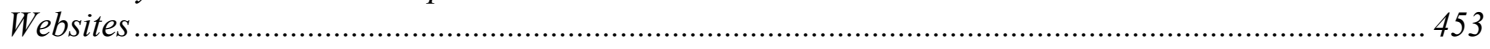

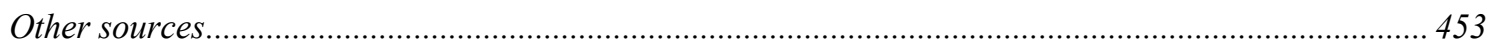




\section{Acknowledgements}

This project has been an often-solitary endeavor, enabled by a vast community of support. I'd like to thank everyone at the Allard School of Law, who have created a uniquely supportive environment for scholarly inquiry. Special thanks go to Karin Mickelson, who shepherded this project from inception to completion. Her tireless support, incisive comments, and unwavering standards shaped this project and made it better. Thanks to Doug Harris, who suggested I look into what the idea of "culture" might have meant at midcentury. And, thanks to Adam Jones who has shared his infectious enthusiasm for, and expertise in, the field of Genocide Studies.

I also want to acknowledge my LL.M. thesis supervisor Judith Mosoff, who provided early guidance on this inquiry, as well as Wes Pue, whose early commentary provided the direction of inquiry for much of this project. Thanks to Joanne Chung for her tremendous warmth and support. And thanks to Elliot Sperber for reading and commenting on early drafts of this work.

I also want to acknowledge the members of my Defence Committee for the time taken to read this work and for valuable comments. And thank you to the external reviewer, Mark Drumbl, for his kind remarks and discerning critique. Thanks also to the University of British Columbia, the Peter A. Allard School of Law, and the Vanier Canada Graduate Scholarship Committee for providing funding that made this project possible.

And, most of all, thanks to Amy Zelson Mundorff and Sarah Mundorff for unwavering support throughout this long and often-trying process. Amy served as sounding board for the earliest iterations of these ideas and Sarah shared her love of poetry. Both improved this project immeasurably. 
To Amy and Sarah 


\section{Introduction}

Indeed, we cannot keep telling the world in endless sentences;- - don't murder members of national and religious groups; don't sterilize them; don't impose abortions on them; don't steal children from them; don't compel their women to bear children for your country, - and so on; but it would be good to tell the world now, when it emerges from darkness - don't practice genocide.

(Raphael Lemkin, 1946) ${ }^{1}$

He who can grasp all these characteristics by coining an authoritative word, comprising within it at the same time their manly justice, intelligence, the completeness of their designs, decisions, executions, and of all the dealings of their world-edifice-let him name his word!

(Johann Gottfried Herder, 1774) ${ }^{2}$

As the world's leaders emerged from the darkness of World War II, they were

confronted by Raphael Lemkin, a Jewish-Polish international lawyer and refugee from the

Nazi atrocities that had claimed all but one other member of his extensive family. ${ }^{3}$ Exhausted

but determined, Lemkin demanded they enact a law against the crime he had named

"genocide."4

\footnotetext{
${ }^{1}$ Raphael Lemkin to John J. Parker, Judge at the International Military Tribunal, Nuremberg (1946) Cincinnati, The Jacob Rader Marcus Center of the American Jewish Archives, Raphael Lemkin Papers (Box 1, File 13) [AJA].

${ }^{2}$ Johan Gottfried Herder, Another Philosophy of History and Selected Political Writings, translated by Ioannis D. Evrigenis \& Daniel Pellerin (Indianapolis: Hackett, 2004) at 22 [emphasis omitted].

${ }^{3}$ There is some discrepancy over the number killed, though of course this grim scorekeeping really doesn't have much significance. Samantha Power, A Problem From Hell: America and the Age of Genocide (New York: Harper Perennial, 2007) sets the number of family members killed at least forty-nine. See also John Hohenberg, "The Crusade that Changed the UN," Saturday Review (9 November 1968) 86, which estimates seventy family members killed by both the Nazis and later by the occupying Soviet forces.

${ }^{4}$ Raphael Lemkin, Axis Rule in Occupied Europe: Laws of Occupation, Analysis of Government, Proposals for Redress (Washington DC: Carnegie, 1944) [Lemkin, Axis Rule]. In 1933, Lemkin had proposed the creation of two international crimes, barbarity and vandalism. As he told all who would listen, his proposals would have encompassed the crimes eventually committed by the Nazis and, had they been adopted, there would have been clear legal grounds for intervening early against Germany. Failing that, there would have at least been grounds for trying even those Nazi crimes unrelated to waging aggressive war.
} 
On December 9, 1948, a mere four years after he had coined the word genocide, Lemkin saw his concept codified by unanimous vote in the United Nations General Assembly as the Convention on the Prevention and Punishment of the Crime of Genocide (Genocide Convention). ${ }^{5}$ With hindsight, Lemkin's audacity is stunning. A second-tier international lawyer with a heavy Polish accent and a talent for irritating people, with no permanent job, no permanent address, no steady income, he nonetheless believed he could conceptualize a new crime, name it, and rally the world to outlaw it.

To mark the twentieth anniversary of the General Assembly's unanimous approval of the Convention, John Hohenberg offered a remembrance in The New York Times. Hohenberg highlighted the months Lemkin devoted to pestering the press and harassing United Nations officials and described how, after the vote, the United Nations press corps found Lemkin sitting alone

in the darkened Assembly chamber in the Pallais de Chaillot. The session had long since adjourned. On the stage where the President of the Assembly had proclaimed the unanimous adoption of the Genocide Convention, a cleaning woman was moving back and forth in the eerie light of a single electric bulb.... When we went to him and said we wanted an interview, he begged off. "Let me stay here alone," he muttered, and the tears rolled down his cheeks. And this was the man we had thought to be a clown, a publicity hound, a self-seeking fanatic. ${ }^{6}$

This campaign drained his finances, his friendships, and his health. But it succeeded.

Lemkin knew how to do things with words. Also trained as a philologist, ${ }^{7}$ he held an unwavering belief in the power of language to shape human relations. He believed "[w]ords

\footnotetext{
${ }^{5}$ Convention on the Prevention and Punishment of the Crime of Genocide, 9 December 1948, 78 U.N.T.S. 277 (entered into force 12 January 1951) [Genocide Convention]. Lemkin first defined genocide in Axis Rule, ibid. Chapter 9, at 79-95.

${ }^{6}$ John Hohenberg, supra note 3.

${ }^{7}$ John Cooper, Raphael Lemkin and the Struggle for the Genocide Convention (New York: Palgrave Macmillan, 2008) 15.
} 
not only convey images, but also communicate moral judgment. In this respect words enter into the conscience of society, fulfilling a constructive mission of separating evil from the good." "As Lemkin hoped, declaring an act to be genocide imposes an unparalleled moral condemnation. Partly, this is due to the hideous crimes associated with this term. But beyond this Lemkin hit upon a uniquely evocative word when he mashed up "the ancient Greek word genos (race, tribe) and the Latin cide (killing). ..."9

\section{Dangers to the Genocide Convention}

The rhetorical power of genocide has been a mixed blessing for Lemkin's concept. It is clear that the emotive value of the hideous acts signified by the term was crucial in Lemkin's drive for codification, just as its continued relevance is assured by its lexical allure. However, genocide's almost unparalleled symbolic value has attracted advocates who would distort the concept of genocide into something that bears only a glancing relation to Lemkin's idea. On one side are those declaring themselves guardians of genocide's purity, who would restrict its use only to the most egregious incidents of mass killing. ${ }^{10}$ On the other are those attempting to shoehorn their victimization into the concept of genocide, trying to occupy its symbolic high ground in their struggles for justice.

\footnotetext{
${ }^{8}$ Raphael Lemkin, "Philosophical and Legal Aspects [of] the Word Genocide" (undated) AJA, supra note 1 (Box 3, File 3).

${ }^{9}$ Lemkin, Axis Rule, supra note 4 at 79.

${ }^{10}$ See David Moshman, "Conceptions of Genocide and Perceptions of History” in Dan Stone, ed, The Historiography of Genocide (Palgrave Macmillan, 2008) 71 at 81, discussing how Lemkin's conception of genocide has been lost as scholars reduce genocide to mass killing. To be sure, this conflation is not restricted to scholars - even some of the Genocide Convention's drafters used "mass murder" as a shorthand for genocide (See e.g. UN GAOR, Sixth Comm., 3rd Sess, 78th Mtg, UN Doc A/C.6/SR.78 (1948), statement of Mr. Chaumont (France). In fact, even Lemkin and the US Committee for a Genocide Convention often conflated genocide and "mass murder," especially when rallying public support. See Washington Committee for the Ratification of the Genocide Convention, Poster: "GENOCIDE IS MASS MURDER!" (1 February 1950) New York, American Jewish Historical Society, Raphael Lemkin Collection (Box 2, File 6) [AJHS] advertising a public meeting to support the Genocide Convention.
} 
Lemkin would not have been surprised. He knew that its codification by the UN

General Assembly did not make the Genocide Convention safe. ${ }^{11}$ He saw enemies around every corner and organized supporters to oppose these threats, an effort the US State

Department dismissed as the result of the "hysterical agitation of Mr. Lemkin."12 Asserting that discrimination is not destruction, he fought against the NAACP and other United States civil rights organizations, whom he accused of invoking the Genocide Convention to bolster their struggle against the American apartheid system in the Jim Crow South. ${ }^{13}$ And he fought human rights activists, calling them "a hidden opposition with smiling humanitarian faces," believing they had been duped by the Soviets into conflating genocide with human rights in

\footnotetext{
${ }^{11}$ See Raphael Lemkin, "Memorandum on the Genocide Convention" (undated) New York, New York Public Library, Archives and Manuscripts, Raphael Lemkin Papers (Reel 3, File 4) [NYPL]: "Since the Assembly of 1950 the Genocide Convention has been attacked piecemeal in order to supplant it with two other proposals or documents," the Human Rights Draft Covenant and the draft code. In addition, Lemkin lists the Reservations to the Convention on the Prevention and Punishment of the Crime of Genocide, Advisory Opinion, [1951] ICJ Reports 15 and the Chinese draft as dangers. He concludes by stating,
}

The unanimous adoption of the Genocide Convention by the United Nations was hailed as a milestone in the history of mankind. The issue of the specific attacks on the Convention is, however, of basic significance to all treaties enacted under the auspices of the United Nations. Should the attacks on the Genocide Convention succeed, then no treaty is safe. The principle of sanctity of treaties and respect for international law would be thus undermined to the detriment of the prestige of the United Nations and the legal culture of mankind. (Ibid. at 4)

${ }^{12}$ Mr. Kotschnig to Mr. Murphy, Office Memorandum: "Letters on Genocide and Discrimination" (3 November 1953) National Archives at College Park, College Park, MD. (Box 1342, 340.1-AJ/1-1452 to 340.1-AM/6-2050, General Records of the Department of State Central Files Record Group 59) [emphasis in original] [NACP].

13 “Memorandum" (undated, post July 1952) AJA, supra note 1 (Box 4, File 6). See "U.S. Accused in U.N. of Negro Genocide" New York Times (18 December 1951), documenting Lemkin's public opposition to a petition by the Civil Rights Congress, entitled "We Charge Genocide." See also Raphael Lemkin to Robert E. Van Deusen, Esq. (9 January 1950) AJHS supra note 10 (Box 2, File 4): "We try not to confuse genocide with human rights which have their counterpart in the controversial issue of civil rights. Obviously discrimination is not destruction, obliteration and annihilation." See also Lemkin, "Memorandum on the Genocide Convention" (Undated, but post 1950) NYPL supra note 11 (Reel 3, File 3), which discusses "the detour of human rights." Lemkin argued that "certain elements of the definition of Genocide like those dealing with the transfer of children to other human groups for the purpose of assimilation and absorption as equals are in direct contradiction to the concept of discrimination." Thus, as Lemkin's example illustrates, it is possible to destroy a group without discriminating against its individual members. 
their effort to enshrine an international human rights covenant. ${ }^{14}$ He even turned against the United States Committee for a UN Convention on Genocide, which he had co-founded, accusing its chairman, James N. Rosenberg, of cooperating with human rights activists to compromise the Convention. ${ }^{15}$

Lemkin also fought a proposed Chinese draft that made several substantive changes to the Genocide Convention. ${ }^{16}$ Most alarming to Lemkin, the Chinese text would have required that, to qualify as genocide, acts had to be committed with "ruthlessness and

\footnotetext{
${ }^{14}$ Letter, Lemkin to Mayor Cyril Coleman, Hartford Conn. (29 Dec. 1949) AJHS, supra note 10 (Box 2, File 2). See also Lemkin to Thomas Mahoney (19 Dec. 1949) AJHS, ibid. (Box 2, File 2): "I am convinced that there is a definite plan to present genocide as a part of human rights and to mix it with Truman's civil rights program." He explained that
}

[s] everal influential persons who are identified with the United Nations Human Rights Project, tried to block the adoption of the Genocide Convention at the Paris Assembly. One of these leaders in the Human Rights movement has an especially great influence with the present Administration. The proponents of the Human Rights Covenant, which is still in drafting stage, are afraid that the Senate will not ratify both the Genocide Convention and the Covenant on Human Rights. They are holding up ratification of the Genocide Convention.

Lemkin also identified a draft convention on forced labour as a threat to the Genocide Convention. See Raphael Lemkin, "Memorandum on the Relationship Between Draft Convention on Forced Labor and the Genocide Convention" NYPL, supra note 11 (Reel 3, File 4), which argues that "a considerable part of the Genocide Convention would be covered by article 1, Point (e) of the Forced Labour Convention. In this respect the Genocide Convention would be considerably weakened by removal of an important field of application." In addition, Lemkin saw in the International Court of Justice's 1951 Advisory Opinion on Reservations (supra note 11) as part of a French plan to insulate itself from genocidal acts committed in Algeria. See Lemkin, "To Avoid Responsibility for Genocide in Algeria the French are Destroying the Genocide convention" (undated) NYPL, ibid. (Reel 3, File 4) at 1; Lemkin, "Memorandum on the Genocide Convention" (undated, but post August 1953) NYPL, ibid. (Reel 3, File 2 at 3$)$.

${ }^{15}$ Raphael Lemkin, "Confusion with Human Rights” (late 1949) AJHS, supra note 10 (Box 2, File 12).

${ }^{16}$ Request of the Government of China for Revision of the Chinese Text of the Convention on the Prevention and Punishment of the Crime of Genocide, UN GAOR, Sixth Committee, 7th Sess, UN Doc A/2221 (1952); UN GAOR, Sixth Committee, 7th Sess, 355th Mtg, UN Doc A/C.6/SR.355 (1952) (discussion on Chinese revised draft). See also Raphael Lemkin, Memorandum: "On the Revision of the Genocide Convention" (undated, likely 1953) AJA, supra note 1 (Box 4, File 5). The Chinese draft also dropped the restrictive enumeration of groups, so that any human group would be protected, and omitted the words "as such" from the chapeau of article 2. According to Lemkin, by de-emphasizing the group element of genocide, these changes robbed the convention of precision and would lead to its conflation with crimes against humanity. Because the Chinese text would be equally authoritative with the English, French, Russian, and Spanish drafts, Lemkin considered this a threat to the integrity of the Genocide Convention. (See Genocide Convention, supra note 5, art 10: "The present Convention, of which the Chinese, English, French, Russian and Spanish texts are equally authentic, shall bear the date of 9 December 1948.") 
cruelty." And so, "[s]ince genocide can also be committed in a devious and subtle manner, e.g. breaking up families or removing children from hungry parents and introducing them into a national community with higher economic standards, (viz, Art. II paragraph e of the Convention) this change amounts to a restriction of the definition of genocide."17

Amidst this hostile landscape, Lemkin believed the Genocide Convention's greatest threat came from the International Law Commission's (ILC) attempt to develop a draft code of offences against the peace and security of mankind. ${ }^{18}$ This effort began before the ILC's formal formation in 1947 and continued in earnest through 1954, when the project petered out, unable to define the crime of waging aggressive war. ${ }^{19}$ The proposed draft code was intended to complie existing crimes in international law in a comprehensive code that might serve as a legal framework for an eventual international criminal court. ${ }^{20}$ Because the code was to be comprehensive, many ILC members felt they could not omit genocide. Yet Lemkin believed their attempts to incorporate this new crime threatened to undermine the Genocide Convention. First, the draft code project would allow states to avoid ratifying the Convention by claiming they were awaiting this more comprehensive code. Second, incorporating genocide into the draft code also distorted it by encumbering the crime of genocide with ancillary contextual requirements and robbing the Convention of prestige. Finally, Lemkin

\footnotetext{
${ }^{17}$ Raphael Lemkin, Memorandum: "On the Revision of the Genocide Convention" (undated, likely 1953) AJA, supra note 1 (Box 4, File 5).

${ }^{18}$ Formulation of the Principles Recognized in the Charter of Nürnberg Tribunal and in the Judgment of the Tribunal, GA Res 177 (II), UN GAOR, 2nd Sess, UN Doc A/Res/177(II) (1947), directing the ILC to “(a) Formulate the principles of international law recognized in the Charter of the Nürnberg Tribunal and in the judgment of the Tribunal and, (b) Prepare a draft code of offences against the peace and security of mankind, indicating the place to be accorded to the principles mentioned in subparagraph (a) above."

${ }^{19}$ See Jeffrey S. Morton, The International Law Commission of the United Nations (Columbia, SC: University of South Carolina Press, 2000) 37-41.

${ }^{20} \mathrm{Ibid}$. at 37.
} 
argued the crimes of the draft code would only be considered chargeable when committed in conjunction with aggressive war, and this threatened a retreat from the Genocide Convention's prohibitions, which outlawed genocide in peace as well as war. ${ }^{21}$

Perceiving an existential threat to the Genocide Convention, Lemkin threw himself into an all-out war with the ILC and supporters of the draft code. In doing so he publicly slandered a former friend, angered many of his closest allies, and alienated himself from the field of international humanitarian law. John Cooper, Lemkin's preeminent biographer and a clear admirer, describes this as a period when "Lemkin grew increasingly isolated, despondent and paranoid." ${ }^{22}$ But Lemkin was right: the ILC draft code project did endanger the Genocide Convention's importance and even its very meaning. Ultimately more prescient than paranoid, Lemkin's prophecy has come to pass.

\section{The International Law Commission's Exclusion Doctrine}

Lemkin died in 1959 and so was unable to defend the Genocide Convention against the ILC's most effective attack, which came in the early 1990s as it resumed its draft code project. ${ }^{23}$ Beginning in the late 1970s, détente and the Cold War's thaw made it possible to

\footnotetext{
${ }^{21}$ Raphael Lemkin, (untitled, undated, but post-1954) NYPL, supra note 11 (Reel 3, File 4), explaining that "in 1954, when the International Law Commission dropped the requirement that crimes against humanity should be connected with aggression[, t] ]he International Law Commission overstepped its mandate to formulate the Nuremberg principles as a law of war by extending them to time of peace." See also Lemkin, "The Legal Nature of Crimes Against Humanity" (undated) NYPL, ibid. (Reel 3, File 4) at 1-2. Additionally, Lemkin argued that the draft code would dilute the Genocide Convention's principle of individual criminal responsibility. See Lemkin, "Memorandum" (undated) NYPL, ibid. (Reel 3, File 4).

${ }^{22}$ Cooper, supra note 7 at 268.

${ }^{23}$ See generally, Benjamin Ferencz, "An International Criminal Code and Court: Where They Stand and Where They're Going" 30 Colum. J. Transnat'1 L (1992) 375. Rosemary Rayfuse, "The Draft Code of Crimes Against the Peace and Security of Mankind: Eating Disorders at the International Law Commission" 8 Crim LF (1997) 43 at 44-49, covering the draft code's drafting history. See also Report of the International Law Commission on the Work of Its Forty-Eighth Session" (UN Doc A/51/10) in Yearbook of the International Law Commission 1996, vol 2, part 2 (New York: UN, 1998) at 45-46 (UNDOC A/CN.4/SER.A/1996/Add.1).
} 
resume work on the draft code, but the Rwandan genocide and Yugoslavia's dissolution made the task urgent. ${ }^{24}$ Then as before, defining the crime of aggression was the sticking point. However, with political winds favoring them, the ILC pushed ahead by simply bracketing that issue. ${ }^{25}$ Through a lengthy process of reports, proposals, and meetings, the ILC hammered out a draft code, culminating in its 1996 report, in which it enunciated its stance on cultural genocide. ${ }^{26}$

According to the ILC, the Genocide Convention addresses only matters pertaining to a group's "physical" or "biological" existence and excludes all matters of culture from its reach. Its two-legged stance asserts, first, that the Convention excludes all acts of cultural genocide, and, second, that it does not address instances of cultural destruction. Thus, while the Genocide Convention prohibits killings (a physical act) and forced abortions (a biological act) it does not include acts targeting a group's culture. Moreover, the ILC argues, any act, even those specifically prohibited by the Genocide Convention, will not be considered genocide if it is intended to cause "cultural destruction." The result is a thoroughly "materialist" conception of genocide that avoids the amorphous idea of culture.

However, the exclusionist argument - that the Genocide Convention prohibits only physical and biological acts of genocide and that it excludes instances of cultural

\footnotetext{
${ }^{24}$ See Ferencz, ibid. at 675 (discussing the resumption of the draft code project).

${ }^{25}$ See Morton, supra note 19 at 52:

In the case of aggression, the original wording by the commission had been virtually copied from the definition of aggression adopted in General Assembly Resolution 3314 (XXIX). A review of government responses, however, indicated that the 1974 definition was too political and lacked the necessary legal precision and rigor. As a result, the commission altered its definition of aggression by reducing the original seven paragraphs and eighth subparagraphs to a single paragraph. The original aggression article sought to provide a standard against which acts could be judged to constitute aggression or not. The revised version simply states that individuals who commit aggression are responsible for a crime of aggression. [Footnotes omitted.]
}

${ }^{26}$ See ibid. at 50-53. 
destruction — strains against the document's actual text. Article 2, which contains the operative language, reads:

In the present Convention, genocide means any of the following acts committed with intent to destroy, in whole or in part, a national, ethnical, racial or religious group, as such:

(a) Killing members of the group;

(b) Causing serious bodily or mental harm to members of the group;

(c) Deliberately inflicting on the group conditions of life calculated to bring about its physical destruction in whole or in part;

(d) Imposing measures intended to prevent births within the group;

(e) Forcibly transferring children of the group to another group. ${ }^{27}$

To an uninitiated reader, article 2 would appear obsessed with matters of group functioning, with group life. Within this paragraph's eighty-nine words, the word group is repeated six times. By contrast, individual members of the group are referred or alluded to three times, but always with reference to a means of destroying the group. Indeed, article 2's chapeau demands the protection of groups "as such," which implies not just the protection of the individuals that make up a group, but the protection of the group as whole. Although it sounds harsh, according to the Genocide Convention's internal logic, harm to individuals matters only insofar as it measures harm to the group. Disregarding the text, the ILC has pursued an approach that all but ignores culture and other aspects of group life.

As it turns out, group life is not so tidy as the ILC would have it. The types of groups protected by the Convention — national, ethnic, racial and religious - exist in and through the medium of culture. Therefore, aside from killing all of a group's members, any of the Genocide Convention's prohibited acts actually destroys the group by disabling its culture. Selectively killing a group's cultural, religious, political, or intellectual leaders, for instance, is a physical act that destroys a group's cultural existence. Lacking the cohesive function of

\footnotetext{
${ }^{27}$ Genocide Convention, Article 2, supra note 5.
} 
these leaders, the group rapidly drifts apart. Similarly, subparagraph 2(e), which prohibits the forced removal of a group's children, clearly implicates cultural functioning. After all, forced removals do not kill children and have often involved efforts to immerse children in another group's culture as a way of denying the targeted group a future. The Genocide Convention's drafters recognized both selective killings and child removals as signal acts of genocide. ${ }^{28}$ Nevertheless, the ILC requirement that, to qualify as genocide, an act must not be aimed at the group's cultural destruction would obviate these means of group destruction.

As I discuss in Chapter 5, ILC members are hardly the only adherents to the exclusion doctrine. In fact, forms of exclusion have been around nearly as long as the Genocide Convention itself. And although there are important dissenting voices, the ILC stance has found a broad and approving audience, especially among Western scholars.

This broad community of exclusionists has been undeterred by text, logic, or fact. They may admit a lack of textual evidence, for the Convention contains no exclusionary language. They may even admit that parts of the Convention appear to implicate cultural concerns. They simply bypass the text, claiming that the parties to the Genocide Convention had intended it to encompass only physical matters and asserting that this intention should trump the actual text. As evidence, they invoke the Convention's preparatory work, the

\footnotetext{
${ }^{28}$ See e.g. Raphael Lemkin, "The Truth About the Genocide Convention" (undated) NYPL, supra note 11 (Reel 3 , File 1), which argues, "Partial destruction is also genocide but it must be of such substantial nature that it affects the existence of the group as such." He accused the Soviets of destroying "[t]he professional people, religious leaders and all those who provide to the nation forces of cohesion. By cutting out the brains of a nation, the entire body become paralyzed. This is the meaning of partial destruction within the definition of the Genocide Convention." See also ibid. 5-6, which catalogues incidents of genocidal child removals from Genghis Kahn to the postwar removals of 28,000 Greek children by Balkan Communists. See also Lemkin, "Supplement" (undated) NYPL, ibid. (Reel 3, File 4) at 1: "To destroy a nation or a religious group 'in part' and 'as such' means to eliminate from a nation or a religious group those elements which provide the forces of cohesion to the entire group and which are the residue of national conscience or religious inspiration."
} 
thousands of pages of debate summaries and documents prepared in connection with drafting.

The move to use authorial intent to fill the inevitable lacunae of a legal text is legitimate, if sometimes controversial, and has been entrenched in legal custom for as long as there has been legal custom. More controversial is the way exclusionists have invoked the preparatory work. Even the most authoritative among them cite not particular documents or statements but the preparatory work writ large. Look to the preparatory work, they claim, and you see that the drafters could not have intended to include cultural forms of destruction.

I cover the preparatory work below, recounting specific debates and proposals in detail. To be sure, the parties rejected provisions prohibiting the destruction of a group by forbidding use of its language or education in that language, and the destruction of culturally important buildings such as places of worship and libraries. Some felt these provisions were vague, others that the acts they addressed were de minimis when placed alongside mass murder and the other prohibited acts. Yet, there is no evidence that a majority of the drafters believed they had eliminated all acts of cultural genocide from the Convention. There is also no evidence that a majority intended to excuse attacks on a group's cultural functioning that thereby cause its destruction. Thus, I argue that neither leg of the ILC stance is supported by the historical evidence. The drafters did not believe they had eliminated all cultural acts from the Genocide Convention, nor did they intend it to exclude instances of cultural destruction.

In fact, my analysis shows there was little unity around the idea of excluding cultural matters from the Convention's reach, though certainly there were those, like the Americans and the French, who tended to favour such an approach. Instead, I find a great deal of evidence to contradict exclusion. Instead of a consensus favouring the excision of cultural 
genocide, the evidence I find supports the idea that a plurality of delegates brought strong culturalist concerns to the debate.

In my analysis, text and history align to reveal an overriding intention not to protect individuals, or the social networks through which individuals exist, but groups themselves, "as such." In the interpretation I lay out below, cultural concerns are not foreign or unwelcome - they are the very reason the Genocide Convention exists.

\section{My Initiation into the Genocide Convention}

I first came to study the Genocide Convention after leaving a job as a Child Protective Specialist in New York City, which involved me, far too often, in the forcible removal of children from their families and communities. ${ }^{29}$ When I first read the Genocide Convention in law school, I was immediately taken with article 2(e). I do not believe my agency's actions amounted to genocide. Yes, our removals were ham-handed, generally unwarranted, and had a deleterious effect on the disproportionately poor and minority communities we targeted. But I saw no evidence of an intent to destroy these groups-this intent being key to any prosecution of genocide. Our actions did aid the ongoing destruction of several of New York City's minority groups, but this was a byproduct of a misguided attempt to rescue children, not a direct aim. Nevertheless, the Genocide Convention's recognition that the forced removal of a community's children could be an effective means of group destruction resonated with me and became my route into its text and history.

My LLM thesis focused on article 2(e) of the Genocide Convention, arguing that the forced removal of children from Australian Aborigines, North American First Nations, Swiss

\footnotetext{
${ }^{29}$ See Kurt Mundorff, Note: "Children as Chattel: Invoking the Thirteenth Amendment to Reform Child Welfare" 1 Cardozo Pub. L. Pol'y \& Ethics J. 131 (2003) (documenting my experience).
} 
Roma, and many other groups violated the Genocide Convention. ${ }^{30}$ In that project, I attempted to fit these acts into the dominant, exclusionist interpretation of the Genocide Convention. However, I had already grown skeptical of exclusion. The doctrine had never made much sense to me, and I found little support for it in the Convention and its drafting materials.

I began my doctoral program intending to apply the analytic framework developed in my LLM thesis to British Columbia's 1953-1959 removal of children from the Sons of Freedom, a dissident faction of the Doukhobors, an anti-materialist Tolstoyan sect that immigrated to Canada from Tsarist Russia in the late nineteenth century. ${ }^{31}$ I saw this as an unambiguous violation of article 2(e). But I kept butting up against the ILC exclusion stance.

Many of the groups that have been victimized by forced child removals have also taken note of the language of article 2(e). As Lemkin intended, its simple admonition that "forcibly transferring children of the group to another group" can amount to genocide evokes a shared experience of victimization and labels this act as among the most odious. Yet, time

\footnotetext{
${ }^{30}$ Kurt Mundorff, "Taking 2(e) Seriously: Forcible Child Transfers and the Convention on the Prevention and Punishment of the Crime of Genocide." Masters of Law Thesis, University of British Columbia. Available at https://circle.ubc.ca/ handle/2429/31682. Published in revised form as Kurt Mundorff, "Other Peoples' Children: A Textual and Contextual Interpretation of the Genocide Convention, Article 2(e)" 50 Harv Intl LJ (2009) 61.

${ }^{31}$ John McLaren, "The State, Child Snatching, and the Law: The Seizure and Indoctrination of Sons of Freedom Children in British Columbia, 1950-1960" in John McLaren, Robert Menzies, and Dorothy E. Chunn, eds, Regulating Lives: Historical Essays on the State, Society, the Individual, and the Law (Vancouver: UBC Press, 2002) 259 at 263. McLaren regards the raids as a move by the government to control this difficult dissident group through a "resocialization strategy" that would force the children to reject the views of their parents and their community (ibid. at 270). The Doukhobors rejected Canadian society. They also resisted taxes, compulsory education, vital statistics registrations, and insisted on holding land in common title. As the federal and provincial governments pressured the Doukhobors to conform to Canadian norms, the Freedomites split from the Doukhobors and began a protest campaign that included nude marches, arsons, and bombings, especially of schools and railroad facilities. (See Colin Yerbury, “The Sons of Freedom' Doukhobors and the Canadian State," 16 Canadian Ethnic Studies (1984) 47 at 59.) Sporadic child removal raids continued, and 170 children were removed through 1959 when courts ordered the last of the children returned.
} 
and again, groups victimized by the forced transfer of their children have been told these acts cannot be considered genocide—maybe "cultural genocide," but not actual genocide. ${ }^{32}$ Invoking the doctrine of exclusion, well-intentioned experts have told them the Convention simply won't reach cultural matters. So long as the doctrine of exclusion stands, there is no reason to think the Sons of Freedom or any other victimized group would fare better. It gradually, grudgingly became clear to me that for the Sons of Freedom project to be convincing, I would first need to address exclusion.

I began a broad reconsideration of the place of culture in the Genocide Convention. I started by considering the text and its preparatory work. Where other interpreters have been stymied by article 2(e), declaring it "enigmatic" 33 or "strangely out of place"34 in the Genocide Convention, it has become my interpretive lodestar. I started from the belief that

\footnotetext{
${ }^{32}$ See The Truth and Reconciliation Commission of Canada, Honoring the Truth, Reconciling for the Future: Summary of the Final Report (2015) at 1, online: The Truth and Reconciliation Commission of Canada $<$ www.trc.ca>, explaining that " $[t]$ he establishment and operation of residential schools were a central element of [Canada's Aboriginal] policy, which can best be described as 'cultural genocide."' On this, the first page of a lengthy report, the authors argue,
}

Physical genocide is the mass killing of the members of a targeted group, and biological genocide is the destruction of the group's reproductive capacity. Cultural genocide is the destruction of those structures and practices that allow the group to continue as a group. States that engage in cultural genocide set out to destroy the political and social institutions of the targeted group. Land is seized, and populations are forcibly transferred and their movement is restricted. Languages are banned. Spiritual leaders are persecuted, spiritual practices are forbidden, and objects of spiritual value are confiscated and destroyed. And, most significantly to the issue at hand, families are disrupted to prevent the transmission of cultural values and identity from one generation to the next. (Emphasis in original).

Yet, as the Commission itself records, the forcible child transfers were part of a larger process of colonization that removed Native communities to marginal land and resulted in "hunger, disease, and poverty." (Ibid. at 134.) And, as the Commission itself documents, the residential schools were scenes of torture, deprivation, sickness, and death. (Ibid. at 90-110.) In fact, the TRC Report documents violations of nearly every material element of the crime of genocide as laid out in the Genocide Convention, all motivated by a desire to destroy Aboriginal groups as such. It uses the supposition that these rapes, tortures, starvations, and killings were carried out in furtherance of a plan to destroy the cultural cohesion of Aboriginal groups to excuse what are obvious acts of genocide.

${ }^{33}$ William A. Schabas, Genocide in International Law: The Crime of Crimes 2nd ed (Cambridge: Cambridge University Press, 2009) at 201.

${ }^{34}$ Lawrence J LeBlanc, The United States and the Genocide Convention (Durham, NC: Duke University Press, 1991) at 115. 
any coherent interpretation of the Genocide Convention would necessarily incorporate both mass killings and forced child removals. I found that while a prohibition on the forcible transfer of children would indeed be "strange" in a convention devoted only to preventing and punishing incidents of mass killing, it makes perfect sense in one intended to protect a group's existence "as such," as a cultural entity.

Once I had completed a textual interpretation of the Genocide Convention and conducted an historical analysis of the preparatory work, finding that neither appeared to support exclusion, I began a wider questioning. After all, if I am right, the legal process seems to have gone off the rails. En masse and against the available evidence, a majority of leading legal scholars have propounded a logic-defying interpretation contradicted by the Convention's text and drafting history. What, I wondered, had prompted this mistake?

\section{A Note on Historical Theory and Methodology}

I came to see the culprit in the intervening discursive shift toward resurgent individualism, which has enabled a materialist worldview to defeat the Genocide Convention's group focus. Although it is the same text in both instances, there seem to be two competing Genocide Conventions depending upon which worldview guides the reader. When situated in the drafters' hybrid worldview, wherein group and individualistic considerations were regarded as legitimate and in constant tension, the Genocide Convention appears obsessed with matters of group life. But when situated in today's unrelentingly atomistic worldview, which has all but eliminated group concerns, its original group focus becomes unrecognizable.

To recover the original convention, I began situating it in the historical context of its drafting. This attempt to contextualize the Genocide Convention has involved extensive use 
of archival documents. These include the Convention's preparatory work as well as other UN documents contemporaneous to the Convention's drafting, which have become increasingly available on the UN website. ${ }^{35}$ I have also used Lemkin's papers, archived in New York City at the New York Public Library (NYPL), ${ }^{36}$ and the American Jewish Historical Society, ${ }^{37}$ and at the Jacob Rader Marcus Center of the American Jewish Archives (AJA) located at Hebrew Union College in Cincinnati, Ohio. ${ }^{38}$ In addition, I found a few interesting documents relating to Lemkin's involvement with the Nuremberg Trials at the UN Archives in New York City. Finally, I visited the United States National Archives (NACP) in College

\footnotetext{
${ }^{35}$ UN Official Document System: https://documents.un.org/prod/ods.nsf/home.xsp

${ }^{36}$ New York, New York Public Library, Archives and Manuscripts, Raphael Lemkin Papers [NYPL]. The NYPL Lemkin materials are only available to the public on microfilm. At the suggestion of a NYPL research librarian, I purchased a copy of Lemkin's papers on microfilm. While expensive, this was far cheaper than spending the many nights in Manhattan it would take to scan these documents.

${ }^{37}$ New York, American Jewish Historical Society, Raphael Lemkin Collection. Many of the AJHS materials are available online:

$<$ http://digital.cjh.org/R/7TEFLFAHIB14QR5JGRYBHG51N8T5T89E41IGH974TX1T96HUST00063 ? func $=$ collections-result\&collection $\% 5$ Fid $=1661 \&$ pds_handle $=$ GUEST $>$.
}

${ }^{38}$ On the Lemkin archives see Tanya Elder, "What You See Before Your Eyes: Documenting Raphael Lemkin's Life by Exploring His Archival Papers,1900-1959" 7 J Genocide Res (2005) 469-499. Others have used many of these materials, and the path through Lemkin's papers seems especially well-travelled. See William Korey, An Epitaph for Raphael Lemkin (Jacob Blaustein Institute for the Advancement of Human Rights, 2001). Power, supra note 3 has popularized Lemkin's writings, though her use of his papers is limited. Cooper, supra note 7 makes extensive use of Lemkin's papers and presents an excellent biography. See also Raphael Lemkin, Lemkin on Genocide, Steven Leonard Jacobs, ed, (Lanham: Lexington Books, 2012). Like Jacobs, I came across these materials in Lemkin's papers. However, I cannot concur with Jacobs's assessment that these are primarily Lemkin's work. I base this disagreement on the many letters Lemkin received from researchers, most of which demanded payment that was very late. See also Michael A. McDonnell \& A. Dirk Moses, "Raphael Lemkin as Historian of Genocide in the Americas" 7 J Genocide Res (2005) 501; Dominik Schaller, "Raphael Lemkin's View of European Colonial Rule in Africa: Between Condemnation and Admiration" 7 J. Genocide Res (2005) 531 (Schaller calls Lemkin "racist," but again it is unclear whether Lemkin - or, more probably, one of his researchers - wrote the writing on which this assessment is based); Daniel Marc Segesser \& Myriam Gessler, "Raphael Lemkin and the International Debate on the Punishment of War Crimes (1919-1948)" 7 J. Genocide Res 453 (2005); Anton Weiss-Wendt, "Hostage of Politics: Raphael Lemkin on 'Soviet Genocide" 7 J. Genocide Res (2005) 551; John Docker, Lecture: "Raphael Lemkin's History of Genocide and Colonialism" Paper for United States Holocaust Memorial Museum, Washington DC: Center for Advanced Holocaust Studies (2004) online: United States Holocaust Memorial Museum $<$ www.ushmm.org>; Ana Filipa Vrdoljak, "Human Rights and Genocide: The Work of Lauterpacht and Lemkin in Modern International Law” 20 EJIL (2009) 1163. 
Park, Maryland, which holds documents related to the United States' involvement in the drafting process and some interesting documents related to Lemkin's struggles with the ILC. I took digital photographs of most of these materials, amounting to several thousand pages, which I then compiled in a rudimentary database ${ }^{39}$ Taken together, these documents yield a fascinating picture of Lemkin's longshot success with the Genocide Convention. Yet time and again, these materials seemed to raise more questions than answers.

As I first read these documents I noticed the use of certain terms, like "human groups," "nation," and "culture," differed from the way we use these words today. In our (elite and increasingly cosmopolitan) world, nationalism, culture, and other group-centric concepts are regarded with skepticism or even cynicism. Back then, these concepts were more real, more like things. To be sure, there are strong continuities between that world and ours, but time and again, I have been surprised by the differences. While one part of this project is set on demonstrating that the Genocide Convention has been misinterpreted, the other attempts to explain the historical factors that have enabled this misinterpretation. For the project to be persuasive, I suspect both points must be proven. I must show how so many well-meaning individuals could have gotten it so wrong.

Among historians, it is axiomatic that a word's meaning can change. ${ }^{40}$ Raymond Williams explained that such terms are not defined in isolation but in relation to other key

\footnotetext{
${ }^{39}$ I used Adobe's Lightroom 4 software, which allowed me to adjust photo quality, catalogue relevant information, and arrange the documents in subject files. However, these documents did not remain in digital form as I printed out those deemed relevant and pored over them again and again, trying to assess their significance.

${ }^{40}$ Marc Bloch, The Historian's Craft: Reflections on the Nature and Uses of History and the Techniques and Methods of Those Who Write It, translated by Joseph R. Strayer (New York: Vintage, 1953) at 158. Marc Bloch recognized the problems that word definition posed for the historian, writing that "history receives its vocabulary, for the most part, from the very subject-matter of its study. It accepts it, already worn out and deformed by long usage; frequently, moreover, ambiguous from the very beginning." He warned that "documents tend to impose their own nomenclature," and the historian who "harkens to them ... is taking
} 
words that form a shifting field. ${ }^{41} \mathrm{He}$ believed that as such terms shift over time, each exerts an influence on those related to it; these keywords reflect societal changes and so provide an important way to track that change. ${ }^{42}$ Early on, I noticed that important keywords, which all addressed some aspect of group life, formed the type of shifting network Williams talked about. Some terms, like "national minorities," have disappeared, while others, like "culture," have changed so radically they can hardly be said to mean the same thing.

The prominent intellectual historian Daniel T. Rodgers noticed this too, documenting an "ideational battle" waged "[a]cross multiple fronts":

from the speeches of presidents to books of social and cultural theory, conceptions of human nature that in the post-World War II era had been thick with context, social circumstance, institutions, and history gave way to conceptions of human nature that stressed choice, agency, performance, and desire. Strong metaphors of society were supplanted by weaker ones. Imagined collectivities shrank; notions of structure and power thinned out. Viewed by its acts of mind, the last quarter of the century was an era of disaggregation, a great age of fracture. ${ }^{43}$

The Genocide Convention's focus on group life was unlikely to thrive in our era of resurgent individualism, in our "great age of fracture."

Understanding this difference, historicizing this change, requires the type of contextualization practiced by intellectual historians. ${ }^{44}$ Quentin Skinner, a leading historical

dictation from an epoch which is each time different." (Ibid. at 158.) He also warned that "changes in things do not by any means always entail similar changes in their names. ..." "The transformations ... almost always take place too slowly to be perceptible to the very men affected by them. They feel no need to change the label, because the change of content escapes them." (Ibid. at 159.)

${ }^{41}$ Raymond Williams, Keywords: A Vocabulary of Culture and Society (London: Fontana Press, 1976) at 22-25.

${ }^{42}$ Raymond Williams, Culture and Society, 1780-1950 (London: Chato \& Windus, 1959) xiii. See, e.g., Williams, Keywords, ibid. at 22: "This does not mean that the language simply reflects the processes of society and history. On the contrary, it is a central aim of this book to show that some important social and historical processes occur within language, in ways which indicate how integral the problems of meanings and relationships really are." [Emphasis in original.]

${ }^{43}$ Rodgers, Age of Fracture (Cambridge, MA: Belknap Press, 2011) at 3.

${ }^{44}$ See also, Quentin Skinner, "A Reply to My Critics" in James Tully, ed, Meaning and Context: Quentin Skinner and His Critics (Princeton, Princeton University Press, 1988) 231 at 275 [Skinner, "A Reply"; Tully, 
contextualist, pleads "for the historical task to be conceived as that of trying so far as

possible to think as they thought and to see things in their way. What this requires is that we should recover the concepts they possessed, the distinctions they drew and the chains of reasoning they followed in their attempts to make sense of their world." 45 Contextualism has its detractors, but even as fierce a critic as Elizabeth Clark admits that contextualists' "attention to the historical nature of language and its particularity, to the uses of language in argument, and to its 'translation' into different historical contexts ..." remains valuable to historians. ${ }^{46}$

Meaning]. Context, as Skinner admitted, is notoriously ill-defined. In a circular process, "[t]the appropriate context for understanding the point of such writers' utterances will therefore be whatever context enables us to appreciate the nature of the intervention constituted by their utterances. To recover that context in any particular case, we may have to engage in extremely wide-ranging as well as extremely detailed historical research.”

But see R. G. Collingwood, The Idea of History. ed by TM Knox (Clarendon Press, 1946) 298-99, discussing Euclid:

Very likely he never thought of his fifth theorem without some such context; but to say that because the theorem, as an act of thought, exists only in its context we cannot know it except in the context in which he actually thought it, is to restrict the being of thought to its own immediacy, to reduce it to a case of merely immediate experience, and so to deny it as thought.

See Quentin Skinner, "Some Problems in the Analysis of Political Thought and Action" in Tully, Meaning, supra note 44, 97 at 102. Skinner urges that "the key to understanding the actual historical meaning of a text must lie in recovering the complex intentions of the author in writing it." Skinner's authors are presumed to act rationally, if sometimes mistakenly, within the genres and conventions. Therefore, he recommends we "focus not just on the text to be interpreted but on the prevailing conventions governing the treatment of the issues of themes with which the text is concerned." (Quentin Skinner, "'Social Meaning' and the Explanation of Social Action" in Tully, Meaning, ibid. at 77.) Skinner argues "that these writers will have been limited in their intentions in writing, by the range of intentions they could have expected to be able to communicate, and thus by whatever stock of concepts, and whatever criteria for applying them, were generally available." (Ibid.at 7778.) Put more starkly, an author could not "have meant to contribute to a debate whose terms were unavailable to him, and whose point would have been lost on him." (Quentin Skinner, "Meaning and Understanding in the History of Ideas" 8 History and Theory (1969) 3 at 8.) See also J.G.A. Pocock, Political Thought and History: Essays on Theory and Method (Cambridge: Cambridge University Press, 2009) at 27. In Pocock's words, it is a "re-entry into linguistic universes of the past."

${ }^{45}$ Skinner, "A Reply" ibid. at 252. See also, James Tully, "The Pen is Mightier than the Sword" in Tully, Meaning, ibid. at 12.

${ }^{46}$ Elizabeth A. Clark, History, Theory Text: Historians and the Linguistic Turn (Cambridge, MA: Harvard University Press, 2004) at 140. In many ways, increasing skepticism about the nature of authorship and a shift to discourse has made Skinner's focus on authorial intent seem dated. However, as David Hollinger argues, the difference is one of emphasis, as recent broader intellectual trends seem to reinforce the long-standing practice of intellectual historians of highlighting intertextuality and the constraining powers of discourse. (See David A. 
But as William Fisher points out, "history (and legal history in particular) is and should be practiced for different purposes. Its intended audiences are various, as are its objectives. Therefore, we should not be surprised if the methodology best suited for one purpose is not ideal for another." ${ }^{47}$ With this in mind, I will use many of the contextualists' insights, but I will also adapt them to this project, which relies heavily on archival documents and is concerned with affixing legal meaning, two subjects the contextualists did not emphasize.

Legal interpretation has struggled with the normative implications of authorial intent, often confusing the issue of textual meaning with what an author had intended it to mean. ${ }^{48}$

Hollinger, In the American Province: Studies in the History and Historiography of Ideas (Baltimore: Johns Hopkins University Press, 1985) at 131-34.) There are differences, to be sure, especially in the way contextualists use J. L. Austin's Speech Act Theory to focus attention on individual interventions and the constitutive power of speech, which are this project's most interesting aspects. However, the emphasis on discourse has remained constant. The contextualists do fall short in providing a "somewhat restricted model of political discourse within a community of relatively equal and autonomous actors sharing a common inventory of languages," and so end up masking the role of power. (John E. Toews, "Intellectual History after the Linguistic Turn: The Autonomy of Meaning and the Irreducibility of Experience" 94 Am Hist Rev (1984) 879 at 893, discussing Pocock's ideas of discourse). Pierre Bourdieu, Language and Symbolic Power, John B. Thompson, ed., trans. by Gino Raymond \& Mathew Adamson (Cambridge, MA: Harvard University Press, 1991) 105-06, highlights power and language in his discussion of Language and Symbolic Power, where he points out the near-magical ability of socially powerful actors to shape the world through utterances. This normatively laden language structures our world by obscuring arbitrary power and replicating hierarchy. In addressing the Genocide Convention's reception history, I will highlight the ways in which interested factions have used power to shape the meaning of the Genocide Convention and structure the way we now think about genocide. This is not to assert that devious factions have cynically and instrumentally manipulated genocide's meaning, though, clearly, at points, they have. Rather, I will highlight the way "interested" actors - as representatives of states or "fields," such as internationalism or law-have intervened on a "pre-conscious" level, often in pursuit of the loftiest of goals, to sculpt genocide's meaning in accordance with those interests. See also John B. Thompson, Studies in the Theory of Ideology (Cambridge: Polity Press, 1984) 59: Bourdieu's "[s]ymbolic violence is not any form of domination exercised through communication: it is the exercise of domination through communication in such a way that the domination is misrecognized as such and thereby recognized as legitimate." [Emphasis omitted.] Oftentimes this has resulted in a "double play and a double profit" as interveners receive credit for protecting genocide's integrity while simultaneously restricting its scope. (Pierre Bourdieu, "Sociologists of Belief and Beliefs of Sociologists" 23:1 Nordic Journal of Religion and Society (2010) 1 at 6.)

${ }^{47}$ William W. Fisher III, “Texts and Contexts: The Application to American Legal History of the Methodologies of Intellectual History" 49 Stan L Rev (1996) 1065 at 1087.

${ }^{48}$ Skinner, "A Reply" supra note 44 at 271. 
Of course, an author may fail to convey the intended meaning due to problems of execution or uptake. Audiences might also ignore authorial intent, preferring the meaning conveyed in the terms of the text. And historical change may render authorial intent irretrievable or simply irrelevant.

In historical analysis, it is sufficient simply to point to what the author had probably intended to mean; a stand on the text's ultimate meaning is unnecessary. This approach will likely dissatisfy lawyers who must propound the correct interpretation, which will uncover a text's "actual" meaning. ${ }^{49}$ I will pursue the lawyer's task in arguing that international law does provide a framework for determining the meaning of the Genocide Convention, and that according to these standards, it does not exclude culture.

The problems of meaning grow more complex as the analysis shifts from the texts of individual authors - the traditional concern of intellectual historians - to collectively authored texts such as the Genocide Convention. As this complexity grows, a more rigorous contextualization is even more important. ${ }^{50}$ Jack Rakove addresses these problems as they affect understandings of the United States Constitution, stating, "Both the framing of the Constitution in 1787 and its ratification by the states involved processes of collective decision-making whose outcomes necessarily reflected a bewildering array of intentions and expectations, hopes and fears, genuine compromises and agreements to disagree." ${ }^{11}$ These problems are magnified in a multilateral treaty drafted by individuals from a dizzyingly

\footnotetext{
${ }^{49}$ Jack N. Rakove, Original Meanings: Politics and Ideas in the Making of the Constitution (New York: Knopf, 1996) at 9, discussing the historian's embrace of ambiguity and the lawyer's craving for determinate meaning.

${ }^{50}$ Martin Hollis, "Say it with Flowers" in Tully, Meaning, supra note 44 at 143, discussing the difficulties of applying Skinner's contextualism to collectively authored texts.

${ }^{51}$ Rakove, supra note 49 at 6.
} 
diverse array of cultural backgrounds, pursuing wildly divergent interests, and arguing in highly stylized diplomatic language.

Yet, the difficulty of the task cannot excuse the search for meaning. In 1948, UN members came together in a unanimous commitment not to perpetrate or tolerate genocide, and they should not be allowed to evade this commitment merely because time has made meaning more difficult. Applying the contextualists' insights, it seems safe to conclude that whatever perspective the drafters brought to the debates, it was not informed by the latetwentieth-century, meritocratic, egalitarian individualism that defines our age. Honouring their commitments means returning, insofar as we are able, to their world.

\section{Structure of the Thesis}

This thesis comprises five major chapters. The first, on methodology, outlines my humble treaty-interpretive approach, which grounds accepted treaty interpretation rules in the hermeneutic tradition, especially the post-phenomenological hermeneutics of Hans-Georg Gadamer and Paul Ricoeur. I point out that because the hermeneutic tradition and the Genocide Convention share roots in German Romanticism, hermeneutics possesses a vocabulary that best evokes the Genocide Convention's concerns. I also make a general plea for a more careful treaty-interpretive approach. Drawing on hermeneutic insights, my approach uses the interpretive rules codified in the Vienna Convention on the Law of Treaties $(\mathrm{VCLT})^{52}$ to establish a hesitant process in which the interpreter constantly tests her preconceptions against the treaty's text, context, and history, winnowing those that cannot

\footnotetext{
52 See Vienna Convention on the Law of Treaties 23 May 1969, 1155 U.N.T.S. 331 (entered into force 27 January 1980), arts $31 \& 32$.
} 
accommodate this evidence. This humble process should lead the interpreter to a more accurate meaning.

My second chapter, "Lemkin in the Cultural Moment," situates Lemkin's writings in the intellectual climate of the Genocide Convention's 1948 conclusion. I argue that a "cultural moment" occurred in the several years following the war, a period when the concept of culture dominated political thinking and social science. I document how Lemkin engaged with the writings of leading anthropologists and used the concept of culture to justify his proposed law against genocide. Ultimately, Lemkin's genocide project succeeded not despite his strange "groupism," as many commentators have asserted, but because his ideas on culture and the value of group life reflected the shared ideas and values of that time.

My third chapter, "The Tedious Crucible," analyzes the Genocide Convention's textual meaning according to the interpretive rules laid out in article 31 of the VCLT. The VCLT rules enshrine a refractory interpretive process in which each part of a treaty is measured against the whole, and the whole is shaped in response to each part. I address the provisions of article 2 of the Genocide Convention and harmonize them with the Genocide Convention's context and teleology. Notably, the Genocide Convention contains no language limiting its scope to physio-biological genocide. Instead the textual evidence points to robust protections for a group's continued existence as a cultural entity.

My fourth chapter, "The Trouble with Travaux," examines the Genocide Convention's preparatory work. Because the Genocide Convention contains no language restricting its scope to encompass only "material" genocide, exclusionists must point to evidence in the preparatory work that proves a majority of the parties held a common belief that the Genocide Convention means something beyond what is says. I find that these 
materials provide little support for the doctrine of exclusion. In fact, in several instances, they evidence the drafters' intent to protect the cultural functioning of groups. This is not to say the delegates achieved a culturalist consensus, but neither did the materialists ever attain a majority. Reflecting the common thinking of their time, it seems the drafters adopted a hybrid conception of human groups that embraced some materialist assumptions yet emphasized the group's cultural functioning.

My fifth chapter, "A History of Exclusion," tracks the development of the legal doctrine of exclusion. Because it does not fit the Genocide Convention's text or teleology, and because it revolves around a core of circular reasoning, exclusion has been controversial and difficult to apply. Although certain prominent scholars have declared exclusion a "dead issue," the controversy continues. ${ }^{53}$ I canvas the international case law on genocidal destruction, revealing its inconsistencies and contradictions as I argue that exclusion artificially truncates the definition of genocide.

Taken as a whole, this project paints a picture of international legal process gone awry. It would be an overstatement to claim that the ILC, ICJ and other actors have operated cynically and instrumentally to disarm the Convention. Yet it would also be inaccurate to excuse these actors as mere unwitting participants in a process of historical change. As they have robbed the Genocide Convention of its humanitarian purpose, they have, time and again, re-interpreted it in a manner that narrows its commitments and makes it easier for the powerful to ignore genocide. They have ignored the Convention's text, context, teleology, and history; have abandoned the most basic principles of treaty interpretation; and have made the world safer — if only slightly—-for those who would commit genocide.

${ }^{53}$ Schabas, supra note 33 at 220. 


\section{Chapter 1-Outlines of a More Humble Interpretation}

Rationalists, wearing square hats,

Think, in square rooms,

Looking at the floor,

Looking at the ceiling.

They confine themselves

To right-angled triangles.

If they tried rhomboids,

Cones, waving lines, ellipses-

As, for example, the ellipse of the half-moon-

Rationalists would wear sombreros.

(Wallace Stevens, from “Six Significant Landscapes" [1916]) ${ }^{54}$

This chapter addresses a timeless question: what makes one interpretation better than any other? In the course of this chapter, I lay out an interpretive approach grounded in the hermeneutic tradition and draw out the contrast between textual hermeneutics and Enlightenment positivism. I argue that because it foregrounds the finitude of an interpreter's viewpoint and thereby imparts an abiding sense of humility, hermeneutics provides a better basis for general interpretation. I also point out that the Convention on the Prevention and Punishment of the Crime of Genocide (Genocide Convention) ${ }^{55}$ and hermeneutic interpretation share a common ancestor in the Romanticism of the eighteenth and nineteenth centuries. This common lineage, I argue, equips hermeneutics with a vocabulary that is especially effective in evoking the Genocide Convention's meaning.

This chapter proceeds in four major sections. First, I explain traditional hermeneutics and Romanticism. Next, I argue that the Vienna Convention on the Law of Treaties (VCLT),

\footnotetext{
${ }^{54}$ Wallace Stevens, "Six Significant Landscapes" in John N Serio ed, Wallace Stevens: Selected Poems (New York: Alfred A Knopf, 2009) at 47.

${ }^{55}$ Convention on the Prevention and Punishment of the Crime of Genocide, 9 December 1948, 78 U.N.T.S. 277 (entered into force 12 January 1951) [Genocide Convention].
} 
which is commonly said to govern interpretation of the Genocide Convention, incorporates key elements of hermeneutic interpretation. ${ }^{56}$ In the third section, I argue that both traditional hermeneutics and the VCLT fall short of providing a method of reliably generating valid interpretations. Both suffer from an overly simplistic view of historical process and therefore both breed an overconfidence that can cause an interpreter to misrecognize textual meaning. I overcome this impasse by arguing that the VCLT's traditional hermeneutic approach ought to be supplemented with key insights gained from post-phenomenological hermeneutic theory, especially that of Gadamer and Ricoeur. Finally, I lay out a humble interpretive approach wherein the VCLT rules are used not to restrain interpreted meaning but to foster understanding.

The theoretical grounding of treaty interpretation is in disarray. The international community set out, in the 1969 VCLT, rules of treaty interpretation that are said to embody the customary international law and thus to bind all interpreters. ${ }^{57}$ But in practice, courts routinely ignore the rules, or at least those rules that might interfere with a desired meaning. ${ }^{58}$ Among scholars, the VCLT rules and the notion of interpretive rules more generally are

\footnotetext{
${ }^{56}$ Vienna Convention on the Law of Treaties 23 May 1969, 1155 U.N.T.S. 331 (entered into force 27 January 1980) [VCLT]. Because the customary international rules of treaty interpretation codified by the Vienna Convention were also current at the time of the Genocide Convention's drafting, the ICJ has recognized that the rules embodied in articles 31 and 32 of the VCLT should guide interpretation of the Genocide Convention (ibid.), even though the latter predates the former by more than thirty years. (See Case Concerning the Application of the Convention on the Prevention and Punishment of the Crime of Genocide (Bosnia and Herzegovina v. Serbia and Montenegro) Judgment [2007] ICJ Rep 45 at 109-10. Courts routinely rely on Articles 31 and 32 of the VCLT in interpreting the Genocide Convention. (See, e.g., Prosecutor v. Jelisić, Case No. IT-95-10-A, Judgment (July 5, 2001) at para 35 (the International Criminal Tribunal for the Former Yugoslavia, Appeals Chamber), online: ICTR < www.ictr.org>; Prosecutor v. Furundžija, Case No. IT-95-17/1A, Declaration of Judge Patrick Robinson (July 21, 2000) at paras 275-77 (the International Criminal Tribunal for the Former Yugoslavia, Appeals Chamber), online: ICTR <www.ictr.org >; Prosecutor v. Tadić, Case No. IT-94-1-A, Judgment (July 15, 1999) at paras 300, 303 online: ICTR <www.ictr.org>.

${ }^{57}$ Richard K Gardiner, Treaty Interpretation (Oxford: Oxford University Press, 2008) at 12-19 (documenting acceptance of the VCLT by national and international courts).

${ }^{58} \mathrm{Ibid}$. at 7.
} 
increasingly questioned. ${ }^{59}$ And sociological approaches that ground interpretation in the practice of international lawyers as they function as an "interpretive community" are also unconvincing. ${ }^{60}$

Current approaches to treaty interpretation can be divided into two broad categories: rule followers and rule skeptics. Rule followers argue that the interpretive scheme laid out in articles 31 and 32 of the VCLT provides a good framework for treaty interpretation and scrupulously chronicle those instances when international courts have adhered to the VCLT

\footnotetext{
${ }^{59}$ Jan Klabbers, "Virtuous Interpretation" [Klabbers, "Virtuous"] in Malgosia Fitzmaurice, Olufemi Elias \& Panos Merkouris eds, Treaty Interpretation and the Vienna Convention on the Law of Treaties: 30 Years On (Leiden: Martinus Nijhoff, 2010) 20 [Fitzmaurice, Elias \& Merkouris], which criticizes the VCLT rules for obscuring the role power plays in interpretation and concludes that interpretation is "not a rule governed activity" [Ibid. at 25]). Contra, Mark E. Villiger, "The Rules on Interpretation: Misgivings, Misunderstandings, Miscarriage? The 'Crucible' Intended by the International Law Commission" in Enzo Cannizzaro, ed, The Law of Treaties Beyond the Vienna Convention (2011) 121 (supporting VCLT arts 31 \& 32 though international courts have occasionally used them as a "fig leaf"). See also the critique of interpretive rules more generally: Hersch Lauterpacht, "Restrictive Interpretation and the Principle of Effectiveness in the Interpretation of Treaties" (1949) 26 Brit YB Int'l L 48, 53 [Lauterpacht, "Restrictive Interpretation"]: “[A]s a rule, [the rules] are not the determining cause of judicial decision, but the form in which the judge cloaks a result arrived at by other means." Julius Stone, "Fictional Elements in Treaty Interpretation: A Study in the Judicial Process" (1953) 1 Sydney L Rev 345, 347, challenges interpretive canons on grounds that they "too often do not compel the interpretation; that even when they appear to do so, some competing but equally authoritative canon might, if invoked, have yielded a different interpretation; and that in any case identical interpretations can usually be reached without invoking any set canons at all." See also Alexander Orakhelashvili, The interpretation of Acts and Rules in Public International Law (Oxford: Oxford University Press, 2008) 303: "In general, ruleskepticism in the field of treaty interpretation has been well represented in all relevant periods of doctrinal development, as well as within different political systems."

${ }^{60}$ By sociological approaches, I mean those like Stanley Fish's, in which interpretation is bounded by the practice of "interpretive communities." See generally, Stanley Fish, Is There a Text in This Class: The Authority of Interpretive Communities (Cambridge, MA: Harvard University Press, 1980) [Fish, Is There a Text?]; Stanley Fish, Doing What Comes Naturally: Change, Rhetoric and the Practice of Theory in Literary and Legal Studies (Durham, NC: Duke University Press, 1989) [Fish, Naturally]. Fish argues against external rules:
}

Since readers are already and always thinking within the norms, standards, criteria of evidence, purposes, and goals of a shared enterprise, the meanings available to them have been preselected by their professional training; they are thus never in the position of confronting a text that has not already been "given" a meaning by the interested perceptions they have become. [Emphasis omitted.] (Ibid. at 133.)

Fish's notion of communal restraint is meant to be reassuring (ibid. at 27), but as I will show throughout this project, community-based interpretation can go wildly off the rails. 
rules. ${ }^{61}$ However, international courts have applied the VCLT rules sporadically, and even in those instances only partially. Therefore, most rule followers also admit that the VCLT scheme does not actually restrain courts but at best merely serves to "guide the interpreters in finding and justifying" treaty language. ${ }^{62}$

Rule skeptics deny the VCLT even this limited role, though they can point to no convincing alternative. Prominent among rule skeptics are Martti Koskenniemi and Jan Klabbers, who disavow rules, instead placing their faith in lawyerly practice. Koskenniemi asserts, "It is in fact hard to think of any approach to interpretation that would be excluded from [VCLT] articles 31-32." 63 Klabbers derides the VCLT, arguing that the "main function [of rules of interpretation] is to stifle today's debate in the name of yesterday's (seeming) agreement."64 Instead, he emphasizes the interpreter's good faith or "virtuousness." However, he does not explain how faith or virtue will yield a better interpretation. After all, equally faithful and virtuous individuals may attribute different meanings to treaty terms, some which may be quite mistaken.

Koskenniemi draws a distinction between "pragmatic instrumentalism," which Klabbers endorses, and his own "'formalist view" on international law that refuses to engage with the question of its objectives precisely in order to constrain those in powerful

\footnotetext{
${ }^{61}$ Richard Gardiner, supra note 57; Ulf Linderfalk, On the Interpretation of Treaties: The Modern International Law as Expressed in the 1969 Vienna Convention on the Law of Treaties (Dordrecht: Springer, 2007). Both books canvass the international case law, documenting the application of rules by various courts.

${ }^{62}$ Isabelle Van Damme, Treaty Interpretation by the WTO Appellate Body (Oxford: Oxford University Press, 2009) 34 .

${ }^{63}$ GA, International Law Commission, Martti Koskenniemi, "Fragmentation of International Law: Difficulties Arising From the Diversification and Expansion of International Law: Report From the Study Group pf the International Law Commission" UN Doc A/CN.4/L.682 (13 April 2006) at para 427 [Koskenniemi, "Fragmentation"].

${ }^{64}$ Klabbers, "Virtuous," supra note 59 at 36.
} 
positions. ${ }^{95}$ He points out that Western hegemony allows large powers a disproportionate voice in assigning priority to international law's objectives, and so it follows that an instrumental, objective-oriented interpretive approach will end up pursuing the objectives of the major powers. Therefore, it is the less powerful who are likely to seek protection in formalism. ${ }^{66}$ However, formalism is vulnerable to the same complaint that Koskenniemi lodges against pragmatic instrumentalism. Just as power shapes pragmatic determinations over the proper ends of law, power is always crucial in shaping the forms formalism imposes. Ultimately, Koskenniemi rejects the VCLT rules and turns, like Klabbers, to the professional practice of international lawyers. Both seem to place their faith in the "invisible college of international lawyers" as it functions as an interpretative community. ${ }^{67} \mathrm{I}$ lack their faith.

Rather than viewing the VCLT rules as antithetical to virtuous interpretation, I will argue they are foundational to the faithful practice Klabbers and Koskenniemi advocate. But interpretive rules will never be up to the task of restraining interpreters, and for this reason I will argue that a humble hermeneutic approach must supplement the VCLT rules. Rules in this sense outline a process meant to provoke the text into disclosing a meaning that, in turn, challenges the interpreter's ideas about the text. Thus I invite the VCLT rules into the hermeneutic circle, where they can guide a virtuous interpreter to a truthful meaning. Of course, a determined mis-interpreter will find a way to obscure the text with her prejudices in a manner that is convincing, at least to her. This is why I argue that virtuous interpretation demands humility of the interpreter, a willingness to engage in dialogue with the text, and

\footnotetext{
${ }^{65}$ Martti Koskenniemi, The Politics of International Law (Oxford: Hart, 2011) at 249.

${ }^{66} \mathrm{Ibid}$. at 256.

${ }^{67}$ See Oscar Schachter, "The Invisible College of International Lawyers" (1977) 72 Nw UL Rev 217 at 217. See also Klabbers, "Virtuous," supra note 59 at footnote 35, connecting Schachter's phrase with Fish's "interpretive community."
} 
openness to what it has to say. But as I also argue, personal virtuousness must be supplemented by transparent rule following. In my approach, the rules do not so much bind meaning as enable understanding.

The hermeneutic tradition that I draw on springs from the Romantic movement of the late seventeenth century. Born in rebellion to the Enlightenment, it was forged in rejection of the belief "that human nature was fundamentally the same in all times and places; that local and historical variations were unimportant ... ; that there were universal human goals; that a logically connected structure of laws and generalisations susceptible of demonstration and verification could be constructed ...." ${ }^{68}$ The Romantics—Hamman, Rousseau, and especially Herder—argued that the Enlightenment's scientific rationalism would always prove inadequate to the task of understanding human affairs. As Isaiah Berlin put it, Herder believed that to understand anything was to understand it in its individuality and development, and that this required a capacity which he called Einfühlung ("feeling into") the outlook, the individual character of an artistic tradition, a literature, a social organisation, a people, a culture, a period of history. To understand the actions of individuals, we must understand the 'organic' structure of the society in terms of which alone the minds and activities and habits of its members can be understood. ${ }^{69}$

Thus, the Romantics, while retaining aspects of Enlightenment epistemology, esteemed the particular over the universal, the cultural and historical over the scientific.

Like hermeneutics, the Genocide Convention also traces its lineage to Romanticism. In a subsequent chapter, I will point out that Lemkin, a philologist by training, often traced his thinking to Herder's and acknowledged the influence of Romantic thinkers. ${ }^{70}$ In fact,

\footnotetext{
${ }^{68}$ Isaiah Berlin, Against the Current: Essays in the History of Ideas (New York: Penguin, 1979) at 1 [Berlin, Against].

${ }^{69}$ Ibid. at $10-11$.

${ }^{70}$ A number of scholars have pointed out Lemkin's debt to Romanticism. See generally, Douglas IrvinErickson, "Genocide, the 'Family Mind' and the Romantic Signature of Raphael Lemkin" 15 J. Genocide Res. (2013) 273 at 276-280; John Cooper, Raphael Lemkin and the Struggle for the Genocide Convention (New
} 
Lemkin was not alone in these influences, as these ideas retained an important intellectual sway with the Genocide Convention's drafters. Throughout this chapter, I will argue that because hermeneutics and the Genocide Convention share a common heritage in Romanticism, the hermeneutic tradition provides a vocabulary that evokes the Genocide Convention's concerns. Specifically, I will point out that the Genocide Convention, hermeneutics, and Romanticism each esteem cultural particularity. Romanticism promotes it, the Genocide Convention protects it, and hermeneutics posits it as the space from which understanding is possible.

Below, I will lay out my humble interpretive approach based on the postphenomenological hermeneutic theory of Gadamer and Ricoeur. Post-phenomenological hermeneutics recognizes the ultimate irretrievability of the author's world and thus of the author's meaning. It rejects Cartesian duality and recognizes the interpreter's permeability, her immersion in a specific time and cultural location. At best, the author's world can only ever be reached partially and tentatively, and even this partial reconciliation is only possible through painstaking assessment of the interpreter's fore-conceptions (or prejudices) as brought to light by clues in the text.

This form of skepticism is hermeneutics' most valuable aspect. Against Enlightenment positivism, it posits a deep hesitancy, a radical skepticism of both the text and oneself. As Gadamer emphasizes, our vision is always limited by our tradition, our embeddedness within a language, and our situatedness in a cultural-temporal setting. But to

York: Palgrave Macmillan, 2008) at 91-92; A. Dirk Moses, "Raphael Lemkin, Culture and the Concept of Genocide" in Donald Bloxham \& A. Dirk Moses, eds, The Oxford handbook of Genocide Studies, (Oxford: Oxford University Press, 2010) 1 at 24; Seyla Benhabib, "International Law and Human Plurality in the Shadow of Totalitarianism: Hannah Arendt and Raphael Lemkin" 16:2 Constellations (2009) 321 at 341. On the lingering influence of Romanticism on international law more generally see, George P. Fletcher, The Storrs Lectures: "Liberals and Romantics at War: The Problem of Collective Guilt" 111 Yale LJ (2001) 1499. 
the extent tradition keeps us from having a perfect understanding of a text, person, or culture, it is also the very thing that makes any understanding possible.

\section{The Romantic Hermeneuts}

Gadamer spots the "emergence" of hermeneutics in the late eighteenth and early nineteenth centuries, when "it obviously denoted only the practical capacity of understanding, in the sense of the intelligent and empathetic entry into another's standpoint.." ${ }^{, 1}$ Romantic hermeneutics drew upon traditional legal and scriptural hermeneutics as well as classical philology and the emerging historical sciences. ${ }^{72}$ Its practitioners sought to transform methods of textual interpretation into a general approach to the human sciences that was applicable to any situation where misunderstanding is possible. ${ }^{73}$ They left behind the long history of exegesis by emphasizing the cultural situation of the work's composition, but their big intervention consisted in "psychologizing" interpretive practice by foregrounding authorial intent in its original context. As Schleiermacher put it, the interpreter's task is "to understand the text at first as well as and then even better than its author." 74 A later wave of hermeneuts would reject and even mock this Romantic "pretension," but we should not dismiss the importance of this idea. ${ }^{75}$ For the

\footnotetext{
${ }^{71}$ Hans-Georg Gadamer, Reason in the Age of Science, translated by Frederick G. Lawrence (Cambridge, MA: MIT Press, 1982) at 113.

${ }^{72}$ See Paul Ricoeur, The Conflict of Interpretations: Essays in hermeneutics (Evanston: Northwestern University Press, 1974) at 3-5 [Ricoeur, Conflict].

${ }^{73}$ Hans-Georg Gadamer, Truth and Method, translated by Joel Weisheimer \& Donald G. Marshall (London: Bloomsbury, 1975) at 179 [Gadamer, Truth].

${ }^{74}$ Gerald L. Bruns, Hermeneutics Ancient and Modern (New Haven: Yale University Press, 1992) at 151. Georgia Warnke, Gadamer, Hermeneutics, Tradition and Reason (Cambridge, UK: Polity Press, 1987) at 73.

${ }^{75}$ Paul Ricoeur, Hermeneutics and the Human Sciences, translated and edited by John B. Thompson (Cambridge, UK: Cambridge University Press, 1981) at 190 [Ricoeur, Hermeneutics](discussing the Romantic pretension").
} 
first time, an interpreter claimed "superiority over his object,",76 and authors had no special claim to the meaning of their work.

Isaiah Berlin labelled Romanticism "the Counter-Enlightenment," "77 which he considered only part of the "The Divorce between the Sciences and the Humanities," which itself dates to Plato yet found its sharpest contrast in the antinomy between the Enlightenment and Romanticism. ${ }^{78}$ As Berlin described,

[t]he central doctrines of the progressive French thinkers ... rested on the belief, rooted in the ancient doctrine of natural law, that human nature was fundamentally the same in all times and places; that local and historical variations were unimportant compared with the constant central core in terms of which human beings could be defined as a species like animals, or plants or minerals; that there were universal human goals; that a logically connected structure of laws and generalisations susceptible of demonstration and verification could be constructed and replace the chaotic amalgam of ignorance, mental laziness, guesswork, superstition, prejudice, dogma, fantasy, and above all, the 'interested error' maintained by the rulers of mankind and largely responsible for the blunders, vices, and misfortunes of humanity.

It was further believed that methods similar to those of Newtonian physics, which had achieved such triumphs in the realm of inanimate nature, could be applied with equal success to the fields of ethics, politics, and human relationships in general. ${ }^{79}$

Thus, Enlightenment thinkers espoused - and still espouse, the ideas of progress, objectivity, and rationality, which they married to a method of scientific verification ${ }^{80}$ From the outset, Enlightenment thought missed the importance of that thing that would come to be

\footnotetext{
${ }^{76}$ Gadamer, Truth, supra note 73 at 193.

${ }^{77}$ Berlin, Against, supra note 68 at 14.

${ }^{78}$ Ibid. at 1. James Turner, Philology: The Forgotten Origins of the Modern Humanities (Princeton: Princeton University Press, 2014) 6, traces this opposition to Plato's diatribes against the poets and argues that the intervening centuries have seen this "dichotomy [appear] again and again, in one form or another." He continues, "[P]hilosophy arrives at universally valid generalizations, whereas philology interprets individual cases. Here lies the embryo of the modern distinction between law-seeking ('nomothetic') natural sciences ... and interpretive ('hermeneutic') disciplines...."

${ }^{79}$ Berlin, Against, supra note 68 at 1.

${ }^{80} \mathrm{Ibid}$. at 20.
} 
known as "culture." Rather than the local or the particular, Enlightenment thinkers pursued the universal. Indeed, according to Clifford Geertz, Enlightenment thought "constructs[s] an image of man as a model, an archetype ..." and uncovers "the elements of this essential type ... by stripping the trappings of culture away from actual men and seeing what then was left—natural man." ${ }^{81}$ Taken to the logical conclusion, archetypal man-it was always men, in fact white Christian men, who provided the archetype-is the foundation for universal laws which apply to everyone, everywhere, at all times. The idea of universality was thus the key to Enlightenment thinking and has been its most durable contribution.

Gerald Bruns explains that universality is ratified by "Cartesian hermeneutics, or the allegory of suspicion, in which the text comes under the control of the reader as disengaged rational subject, unresponsive except to its own self-certitude," a method motivated "to preserve alienation as a condition of freedom from the text...."82 The text is a specimen, fixed to a slide, studied under a microscope. In this manner, "Cartesian hermeneutics proposes the idea of a text as dead letter, a purely analytical object." ${ }^{\prime 83}$ By contrast, hermeneuts take the text not as a corpse to be studied for its ante mortem signification but as an entity, alive and eager to engage. ${ }^{84}$

Ricoeur describes the friction between the Enlightenment and Romanticism as "the milieu in which the opposition between two fundamental philosophical attitudes took shape: on the one side, the Aufklärung and its struggle against prejudices; on the other, Romanticism

\footnotetext{
${ }^{81}$ Clifford Geertz, The Interpretation of Cultures (New York: Basic Books, 1973) at 51 "There is, in brief, a human nature as regularly ordered, as thoroughly invariant, and as marvelously simple as Newton's universe."

${ }^{82}$ Bruns, supra note 74 at 149.

${ }^{83} \mathrm{Ibid}$. at 149.

${ }^{84} \mathrm{Ibid}$. at 153.
} 
and its nostalgia for the past." ${ }^{85}$ Dilthey described this distinction in terms of Verstehen and Eklärung, a "radical distinction between empathic understanding and causal explanation. ..."86 This is a difference between transcendental and dialogical outlooks, whereby the former is set on discovering and applying universal laws and the latter is concerned with "the finite, situated, . . dialogical, indeed political character of human understanding." ${ }^{" 87}$

Where universalism is the central facet of Enlightenment thinking, temporality provides the key to understanding Romanticism. ${ }^{88}$ Isaiah Berlin claimed the heart of Romanticism lay in the belief that meaningful existence is only possible in action, a belief that in turn implies deep temporality. Thus,

one must break up this order: one must break it up by going to the past, or by going within oneself and out of the external world. One must go and seek to be one with some kind of great spiritual drive with which one will never completely identify oneself, or one must idealise some myth which will never quite come to pass, the Nordic myth or the Southern myth or a Celtic myth or some other myth, it does not matter which — class or nation or Church or whatever it may be-which will constantly drive you forward, which will never be fulfilled, the essence and value of which is that it is strictly unfulfillable, so that if it were fulfilled it would be worthless. That is the essence of the romantic movement, so far as I can see: will, and man as an activity, as something which cannot be described because it is perpetually creating; you must not even say that it is creating itself, for there is no self, there is only movement. That is the heart of romanticism. ${ }^{89}$

\footnotetext{
${ }^{85}$ Ricoeur, Hermeneutics, supra note 75 at 66.

${ }^{86}$ G.B. Madison. "Gadamer and Ricoeur" in Richard Kearney, ed, Continental Philosophy in the 20th Century (London, UK: Routledge, 2012) at 292, describing Dilthey's approach and connecting it with the work of Peter Winch.

${ }^{87}$ Bruns, supra note 74 at 112. See also Gadamer, Truth, supra note 73 at 275 (rehabilitation of “prejudice”).

${ }^{88}$ See e.g. Wilhelm Dilthey, "The Hermeneutics of the Human Sciences" in Kurt Mueller-Vollmer, ed, The Hermeneutics Reader: Texts of the German Tradition from the Enlightenment to the Present (New York: Continuum, 1985) 148 at 150.

${ }^{89}$ Isaiah Berlin, The Roots of Romanticism (Princeton: Princeton University Press, 1999) at 138 [Berlin, Roots].
} 
In this light, a human group is an entity that is willed to life, one that must be renewed constantly if it is to survive. Turning again to Berlin,

[t]he subject may be the universe, or the individual, or the class, the nation, the Church-whatever is identified as the truest reality of which the universe consists. But in any case it is a process of perpetual forward creation, and all schemas, all generalization, all patterns imposed upon it are forms of distortion, forms of breaking. When Wordsworth said that to dissect is to murder, this is approximately what he meant; and he was much the mildest of those who expressed this point of view. ${ }^{90}$

Accordingly, Dilthey argued that Enlightenment conceptions of time were meaningless in "human studies." "91 Time, as experienced, cannot be studied, as any attempt to measure time brings it to a stop. Instead, human time is "flow" in which "[w]e despair of the inevitable, strive, work and plan for the future, mature and develop in the course of time." 92 So too, group existence is within flow and cannot be fixed in time. ${ }^{93}$ This idea of temporality as flow, as at once the experience of remembrance and expectation, is ground from which cultures emerge.

The Romantics considered culture the foundation of human possibility. To them, individual consciousness only forms within culture and all understanding happens from within this finite horizon. Language plays a foundational role in the development and delineation of culture. Herder argued that humans are unique in their capacity for language, that language provides the basis for thought, and that language is inherently social, that it is

\footnotetext{
90 Ibid. at 120 .

${ }^{91}$ Dilthey, supra note 88 at 150.

92 Ibid.

${ }^{93}$ Isaiah Berlin, Vico and Herder: Two Studies in the History of Ideas (New York: Viking Press, 1976) at 200, on Herder's idea that "a man is not conceivable outside a group to which, if he is reasonably fortunate, he continues to belong . . . he conveys also the 'collective individuality' - a culture conceived as a constant flow of thought, feeling, action, and expression." [Footnotes omitted.]
} 
formed in the relation between individuals who exist within groups. ${ }^{94}$ Language is also transhistorical; it links an individual "with the past by revealing to him the thoughts, feelings, and prejudices of past generations, which thus become deeply ingrained in his own consciousness." That individual, "in turn, again by means of language, perpetuates and enriches these for the benefit of posterity." ${ }^{95}$ This provides the foundation for a nation or Volk. According to Barnard,

[a] language [for Herder] is the criterion by means of which a group's identity as a homogenous unit can be established. Without its own language, a Volk is an absurdity (Unding), a contradiction in terms. For neither blood and soil, nor conquest and political fiat can engender that unique consciousness which alone sustains the existence and continuity of a social entity. Even if a Volk's State perishes, the nation remains intact provided it maintains its distinctive linguistic traditions. ${ }^{.96}$

Or, as Humboldt put it: "By the same act through which he spins out the thread of language he weaves himself into its tissues. Each tongue draws a circle about the people to whom it belongs, and it is possible to leave this circle only by simultaneously entering that of another people." ${ }^{.97}$ Thus, to the Romantics, language is foundational to both individual and group consciousness, and in fact, these consciousnesses are conjoined so that severing ends both.$^{98}$ Language group vocabularies are unique, forged in the experience of each group.

\footnotetext{
${ }^{94}$ See Frederick M. Barnard, Herder's Social and Political Thought: From Enlightenment to Nationalism (Oxford: Oxford University Press, 1965) at 54-62.

${ }^{95} \mathrm{Ibid}$. at 57.

${ }^{96} \mathrm{Ibid}$. at 57-58 [footnote omitted].

${ }^{97}$ Wilhelm von Humboldt, "The Nature and Conformation of Language" in Mueller-Vollmer, ed, supra note 88, 98 at 105.

${ }^{98}$ See Sonia Sikka, Herder on Humanity and Cultural Difference: Enlightened Relativism (Cambridge: Cambridge University Press, 2011) 178. According to Sikka, Herder believed:
}

Languages are transmitted across generations, and what is transmitted along with them is a way of thinking: a set of beliefs, values, and judgements, a particular, bounded perspective on the world. This perspective is passed on not only through the language we learn as children, but through all education, since "in education we learn thoughts through words." Because "we cannot think without thoughts, and we learn to think through words," "language sets limits and outline for the whole of human cognition." 
Group "character" is revealed in its language, and this language shapes its character. ${ }^{99}$ These ideas found their first and best expression in Herder's egalitarian pluralism, which valued the uniqueness of each culture. They found their most ominous expression with the German nationalists who enabled Nazism. ${ }^{100}$

But in as much as culture is restrictive or parochial, it also provides the foundation for understanding and interpreting other parochial viewpoints. If I am to understand at all, it is only through the thought systems permitted by my language, my culture. And this is where Romanticism, hermeneutics, and the Genocide Convention overlap in a set of common assumptions. For all three, group existence and the culture it generates are the essential conditions of meaningful human existence.

\section{Genocide is Romantic}

Both hermeneutics and the idea of genocide trace their lineage to Romanticism, and because of this common heritage, hermeneutics possesses a vocabulary that renders the Genocide Convention's concerns real and important. As Richard Rorty points out, this ideathat matching the proper vocabulary to the interpreted text better elicits its concernsoriginates with hermeneutic Romanticism. ${ }^{101}$ Rorty is generally resistant to this idea, arguing

... The result is that nations develop a characteristic worldview, inherited from their ancestors. It enables their understanding of the world, but also restricts its scope. [Footnotes omitted.]

See also Vincent P. Pecora, "Introduction" in Vincent P. Pecora, ed, Nations and Identities: Classical Readings (Malden, MA: Wiley-Blackwell, 2001) 20, which discusses Romantic ideas on language and group life.

${ }^{99}$ See e.g., Berlin, Against, supra note 68 at 212, discussing Hamman: "[T]o understand a man, a group, a sect, one must grasp what shapes them - the union of language, tradition and history."

${ }^{100}$ See E. J. Hobsbawm, Nations and Nationalism Since 1780: Programme, Myth, Reality (Cambridge, UK: Cambridge University Press, 1990) at 103-4, discussing the operationalization of Romantic theory into nationalist agenda. See also Pecora, supra note 98 at 22.

${ }^{101}$ Richard Rorty, Consequences of Pragmatism: Essays, 1972-1980 Minneapolis: University of Minnesota Press, 1982) at 142: “'[R]omanticism' [is] the thesis that what is most important for human life is not what propositions we believe but what vocabulary we use." 
that in some cases, “the other person's, or culture's, explanation of what it's up to is so primitive, or so nutty, that we brush it aside." 102 Nevertheless, he endorses the hermeneutic rule "that it's always wise to ask what the subject thinks it's up to before formulating our own hypotheses." 103 As Rorty argues, "one particular vocabulary (Locke's and Boyle's) is not going to be helpful for doing certain things with certain explananda (e.g., people and cultures).” He uses Hillary Putnam's analogy: “if you want to know why a square peg doesn't fit into a round hole you had better not describe the peg in terms of the positions of its constituent elementary particles."104

As it turns out, while the Enlightenment lexicon falls short, the Romantic vocabulary is well-suited to addressing the collective life of humans. To the Romantics, a human group was indeed "a process of perpetual forward creation." 105 To them, human groups were an idealization no less real for having been idealized. A group's life as a nation may have been founded on myth, but these myths gave a direction to living, sometimes a reason for dying and, all too often, a justification for killing. To assert with Enlightenment thinkers that the group exists only through its individual members misses the point. Though this may be true, the group is also an entity, with a history and a destiny of its own, factors that impose obligations on its individual members.

\footnotetext{
102 Ibid. at 200.

${ }^{103}$ Ibid. Nevertheless, he argues that 'this is an effort at saving time, not a search for the 'true meaning' of the behavior. If the explanandum can come up with a good vocabulary for explaining its own behavior, this saves us the trouble of casting about for one ourselves." See also Fish, Is There a Text? supra note 60 at 221 (discussing the benefits of matching theory to text).

104 Ibid. at 201.

105 Berlin, Roots, supra note 89 at 138.
} 
In the Romantic vocabulary, belonging to a group is not a matter of holding membership status or maintaining a particular cluster of social connections, as so many Enlightenment theorists would assert. Enlightenment views assess group existence synchronically, measuring it "not as might be thought, by the specific positive properties of each; but simply by the fact that they cannot be mistaken for one another."106 That is, individual belongingness is determined negatively by assessing the fact that one belongs to a group and therefore not to another group. Thus, group attributes are measured negatively, only for their power to distinguish one group from another. History and culture are not valued as such, and all that matters is the fact of difference. Because of its ahistoricity, this view possesses an admirable egalitarianism, as it leaves no room for esteeming one group above others. It has been an effective means of combating the anti-Semitism, racism, and notions of collective guilt that have plagued human history. ${ }^{107}$ But despite any advantages this might provide, it is not the view held by the Genocide Convention's drafters. Theirs was a time when collective guilt, racism, and anti-Semitism formed a doxic backcloth to all human interactions.

Today's human rights movement appropriates Enlightenment universalism and imposes a radically synchronic, thoroughly de-historicized view of human groups. In fact, its raison d'être is to carve out individual rights against groups and the state. ${ }^{108}$ The human rights prism transforms human groups from entities that have substantial claims on the

\footnotetext{
${ }^{106}$ Ferdinand de Saussure, Course in General Linguistics, ed by Charles Bally, Albert Sechehaye \& Albert Riedlinger, translated by Roy Harris (Chicago: Open Court, 1972) at 117.

107 See generally George P. Fletcher, “Collective Guilt and Collective Punishment” 5:1 Theor Inq L (2004) 163.

${ }^{108}$ Lawrence M. Friedman, The Human Rights Culture: A Study in History and Context (New Orleans: Quid Pro Quo, 2011) at 46-54 makes this point best. He links the globalization of "human rights culture" to the emergence of "expressive individualism" throughout the postwar period.
} 
individual to an intra-individual phenomenon that provides goods (identity and social connections) to the individual.

In most instances, human rights either negates the Genocide Convention's prohibitions or makes them incoherent. For instance, the Genocide Convention's prohibition on removing children from a protected group makes little sense when viewed through the individualistic prism of human rights. A child might be well served by transfer to a more affluent group where she would benefit from better education, more constructive childrearing practices, or better social connections to carry her forward in life. Indeed, removing a child from a harmful group environment might be considered a way of securing her human rights. But the Genocide Convention primarily protects groups and only protects individuals as a means of preventing harm to the group, so that the group's right to retain its children can conflict with the child's human rights. Fundamentally, the human rights vocabulary understands group existence as a status, while Romanticism considers it a process, one that must be constantly renewed if the group is to have an existence. This conceptual distinction is key to understanding the Genocide Convention.

\section{The VCLT is Hermeneutic}

A 1950 conference of the Institute of International Law with Hersh Lauterpacht as rapporteur addressed "the mystery of the [treaty interpretive] canons":

If any single conclusion emerges from this discussion, engaged in by [prominent] authorities ... it is that all the main points challenged a generation before, still remain and still continue to be challenged, today. The primacy of the canon sanctifying the parties' intention was denied as well as asserted. The primacy of the "objective" expression (or, "plain meaning") was asserted and denied, with a vehemence no less great. And despite the earnest and learned labours of two sessions of the Institute, its 
Members finally desisted from the effort to reach an agreed formulation of the canons of interpretation. ${ }^{109}$

Tasked with codifying customary treaty interpretive practice, the ILC immediately confronted these conflicts. Rather than choosing a side in the longstanding debate, which could have provided more coherence, the ILC simply incorporated these conflicts.

This history makes two things apparent. First, to the extent the VCLT rules did simply codify the customary international law of treaty interpretation as it existed in 1969 , it also internalized the conflicted and contradictory state of that law. Second, the ILC and the parties to the VCLT rejected an approach whereby a menu of rules, canons, or maxims was believed to yield a determinative result. Instead, the drafters enshrined an approach that is more avowedly holistic, embracing the entirety of the treaty, its context, its history, and the intentions of its parties. In other words, it seems the ILC rejected a strictly "scientific" approach and turned its affections to hermeneutics.

\section{VCLT Article 31: The "General Rule of Interpretation"}

The VCLT's hermeneutic orientation manifests itself throughout the provisions of articles 31 and 32. According to the ILC, VCLT article 31, which provides the "general rule of interpretation," is "based on the view that the text must be presumed to be the authentic expression of the intentions of the parties; and that, in consequence, the starting point of interpretation is the elucidation of the meaning of the text, not an investigation ab initio into

${ }^{109}$ Stone, supra note 59 at 345:

The canons of interpretation impugned by such skepticism as anything but the most rebuttable of presumptions in particular context, remain sanctified nevertheless by a vast body of doctrine, and by innumerable apparent applications by tribunals. They maintain their hold even in the modern literature, expressions of doubt usually being followed by an account of the canons as if the doubts scarcely existed. [Footnotes omitted.] 
the intentions of the parties." ${ }^{.10}$ However, despite the ILC's textualist pretentions, the interpretive scheme enshrined in the VCLT appears obsessed with the parties' intentions, and treaty terms are never more than a gateway to a broader intentionalist inquiry. ${ }^{111}$

VCLT, article 31(1) does highlight treaty terms, reading, "[a] treaty shall be interpreted in good faith in accordance with the ordinary meaning to be given to the terms of the treaty in their context and in the light of its object and purpose." ${ }^{112}$ Nevertheless, the rest of article 31 locates textual meaning squarely within the parties' intentions. It continues, stating,

2. The context for the purpose of interpretation of a treaty shall comprise, in addition to the text, including its preamble and annexes;

(a) any agreement relating to the treaty which was made between all the parties in connection with the conclusion of the treaty;

(b) any instrument which was made by one or more of the parties in connection with the conclusion of the treaty and accepted by the other parties as an instrument related to the treaty.

3. There shall be taken into account, together with the context;

(a) any subsequent agreement between the parties regarding the interpretation of the treaty or the application of its provisions;

(b) any subsequent practice in the application of the treaty which establishes the agreement of the parties regarding its interpretation;

(c) any relevant rules of international law applicable in the relations between the parties.

110 "Report of the International Law Commission on the Work of its Eighteenth Session" (UN Doc A/CN.4/191) in the Yearbook of the International Law Commission 1966, vol 2 (New York: UN, 1967) at 220, para 11 (UNDOC, A/CN.4/SER.A/1966/Add.1) ["ILC Report on Eighteenth Session"] (discussing Draft Art. 27, which became Art. 31 of the VCLT, supra note 56).

${ }^{111}$ Contra Campbell McLachlan, "The Principle of Systemic Integration and Article 31(3)(C) of the Vienna Convention" 54 ICLQ (2005) 279 at 291: "The Convention eschews taking a fixed stand on any of the great doctrinal debates on interpretation, save that it is firmly focused on objective reference points rather than the chimera of the intentions of the parties." Still, one could argue that although it is necessarily "focused on objective reference points" (how could it be otherwise?) these are only ever a means of getting at intent. See also, Gardiner, supra note 57 at 6: "Ascertainment of intention, however, is one consequence of the exercise if the Vienna rules are properly applied; but this is intention in the sense of the true meaning of the treaty rather than the intention of the parties distinct from it."

${ }^{112}$ VCLT, supra note 56, Article 31(1). 
4. A special meaning shall be given to a term if it is established that the parties so intended. ${ }^{113}$

Moreover, when the VCLT article 31 analysis results in a meaning that is ambiguous, obscure, or unreasonable, article 32 allows interpreters seemingly limitless access to extratextual materials, including the treaty's preparatory work and the "circumstances of [its] conclusion," to better discern the parties' intentions. ${ }^{114}$ Thus, treaty terms are never read in isolation but must be considered in light of the parties' conduct, against the backcloth of international law, and in light of their teleology as revealed in the supplementary means of interpretation. All of these factors are considered evidence of the parties' intentions in entering the treaty language. Of course, this wide-ranging access and focus on authorial intent is inherently hermeneutic.

By listing the means of interpretation but assigning them no priority, the "general rule" of interpretation in VCLT article 31 appears to enshrine the Romantic notion of a "hermeneutic circle" whereby interpreters determine meaning by reading the whole of a treaty against its parts and its parts against the whole. ${ }^{115}$ As the Appellate Body of the World

\footnotetext{
${ }^{113}$ VCLT supra note 56, Article 31.

${ }^{114}$ VCLT supra note 56, Article 32.

${ }^{115}$ Gadamer, Truth, supra note 73 at 291 describes this as "the hermeneutical rule that we must understand the whole in terms of the detail and the detail in terms of the whole. This principle stems from ancient rhetoric, and modern hermeneutics has transferred it to the art of understanding. It is a circular relationship in both cases." The degree to which the process laid out in VCLT art 31 (supra note 56) is linear or circular remains a matter of some (minor) debate. See "ILC Report on Eighteenth Session" vol. II, supra note 110 at 219-20:
}

The Commission, by heading the article "General rule of interpretation" in the singular and by underlining the connexion between paragraphs 1 and 2 and again between paragraph 3 and the two previous paragraphs, intended to indicate that the application of the means of interpretation in the article would be a single combined operation. All the various elements, as they were present in any given case, would be thrown into the crucible, and their interaction would give the legally relevant interpretation. Thus, article [31] is entitled "General rule of interpretation in the singular, not "General rules" in the plural, because the Commission desired to emphasize that the process of interpretation is a unity and that the provisions of the article form a single, closely integrated rule. (Emphasis in original). 
Trade Organization (WTO Appellate Body) put it, interpretation guided by the VCLT is "an integrated operation, where interpretive rules and principles must be understood and applied as connected and mutually reinforcing components of a holistic exercise." 116 Or as Oliver Dörr explains, "[t]he general rule of interpretation does not describe some hierarchical or chronological order in which those principles are to be applied, but sets the stage for a single combined operation taking account of all named elements simultaneously." 117 That is the essence of hermeneutics.

The VCLT's hermeneutic circle is held together by a theory of unitary meaning or coherence. ${ }^{118}$ It adopts the traditional exegetic approach that is concerned, as are all such

David S. Jonas \& Thomas N. Saunders, "The Object and Purpose of a Treaty: Three Interpretive Methods" (2010) 43 Vand J. of Transnat'l L 565, 571, put this nicely: "Article 31 calls for a dialectical interpretive process, oscillating between the specific provisions of a treaty and the general normative logic of a treaty taken as a whole." Koskenniemi, "Fragmentation" supra note 63 at p. 216 para 428 takes a moderate tone asserting that "[a]lthough the Convention does not require the interpreter to apply its process in the order listed in articles $31-32$, in fact that order is intuitively likely to represent an effective sequence in which to approach the task. Contra Orakhelashvili, supra note 59 at 310-11.

${ }^{116}$ WTO Appellate Body, China-Measures Affecting Trading Rights and Distribution Services for Certain Publications and Audiovisual Entertainment products, WT/DS363/AB/R at para 399. Gadamer, Truth supra note 73 at 176-77 explains the long roots of this technique:

This circular relationship between the whole and the parts is not new. It was already known to classical rhetoric, which compares perfect speech with the organic body, with the relationship between head and limbs. Luther and his successors transferred this image, familiar from classical rhetoric to the process of understanding; and they developed the universal principle of textual interpretation that all the details of a text were to be understood from the contextus and from the scopus, the unified sense at which the whole aims. [Footnotes omitted.]

See also ibid. at 291, explaining, "This principle stems from ancient rhetoric, and modern hermeneutics has transferred it to the art of understanding. ... The anticipation of meaning in which the whole is envisaged becomes actual understanding when the parts that are determined by the whole themselves determine this whole."

117 Oliver Dörr, “Article 31: General Rule of Interpretation” in Oliver Dörr \& Kirsten Schmalenbach, Vienna Convention on the Law of Treaties: A Commentary (Berlin: Springer, 2012) 521 at 541.

${ }^{118}$ Peter Goodrich, Reading the Law: A Critical Introduction to Legal Method and Techniques (Oxford: Blackwell, 1986) at 93. The interpreter assumes that the author intended to issue a coherent statement, so those factors that seem to disagree with the proffered interpretation must be somehow reconciled. The development of systematic techniques for generating textual coherence dates to the early exegetes who were concerned with deciphering Biblical and legal texts. As Peter Goodrich explains, "legal exegesis seeks to discover the correct 
exercises, to establish a single, inviolable, authoritative meaning, one that is in harmony with its immediate context and with the whole of the law. ${ }^{119}$ Because neither God nor sovereign would issue an incoherent utterance, the interpreter's task is one of searching the text for concordances and disagreements. Concordances are validating, while disagreements should cause reevaluation. Borrowing from exegetic tradition, the VCLT requires interpreters to take the provision's terms literally, according to ordinary (legal) usage; syntactically, in relation to surrounding terms; grammatically, by attempting to harmonize the provision's logic with that of the greater treaty and other relevant law; and in light of the treaty's purpose. ${ }^{120}$

The impulse toward coherence does not stop at the text's boundaries. As Goodrich puts it, the exegetes postulate "that for institutional and interpretive purposes the text or series of texts are to form a single 'Text,' a system of primary meanings which are, through authoritative commentary, to be repeated and obeyed." 21 This anxiety about unity in text and law finds expression in VCLT article 31(3), especially subparagraph (c), requiring interpreters to account for "any relevant rules of international law applicable in the relations between the parties." 122

meaning of legal rules and to this end it elaborates a series of techniques which will provide, more than anything else, a correct standard of interpretation." (Ibid. at 100.)

${ }^{119}$ Ibid. at 100. But see David Bederman, Classical Canons: Rhetoric, Classicism and Treaty Interpretation (Aldershot: Ashgate, 2001) 64, placing the origins of treaty interpretive principles much earlier, arguing that "ancient peoples self-consciously attempted to develop rules of treaty construction."

${ }^{120}$ See Goodrich, Reading, supra note 118 at 108-121, discussing the techniques of legal exegesis. And VCLT article 31 (supra note 56) conforms in most respects to these traditional techniques, with the traditional "mischief rule" grounding article 31(1)'s requirement that terms be interpreted according to the treaty's "object and purpose."

${ }^{121}$ Goodrich, "Historical Aspects of Legal Interpretation" 61 Ind LJ (1986) 331 at 336 [emphasis omitted].

${ }^{122}$ VCLT, supra note 56. See also McLachlan, supra note 111 at 309, discussing the ICJ's application of this principle through VCLT art 31(3)(c); Phillippe Sands \& Jefferey Commission, "Treaty Custom and Time: Interpretation/Application?" in Malgosia Fitzmaurice, Olufemi Elias \& Panos Merkouris eds., Treaty Interpretation and the Vienna Convention on the Law of Treaties: 30 Years On (2010) 39, at 48-57. Gadamer, Truth, supra note 73 at 294 calls this "the "fore-conception of completeness," which "is obviously a formal 
Lauterpacht stressed unity, stating that "the treaty is law; it is part of international law. As such it knows no gaps. The completeness of the law when administered by legal tribunals is a fundamental — the most fundamental — rule not only of customary law but also of conventional international law." 123 Where inconsistencies were found, he urged the imputation

of the overriding - the higher - common intention of the parties, not less real because it is necessarily implied, may constitute an important aspect of the judicial function of interpretation - a timely and accurate reminder that the function, far from being limited to discovering the meaning of a text, may legitimately impart to it a meaning by reference to the paramount principle of the completeness and the rational development of the law and of the requirements of justice in the light of the purpose of the treaty viewed as a whole. ${ }^{124}$

Lauterpacht was anxious to defend international law from charges of contradiction and incompleteness. The interpreter's job then becomes one of plastering over lacunae and joining together ill-fitting corners. ${ }^{125}$

Like traditional hermeneutics, the VCLT interpretive scheme rests on an assumption that text bears an original and correct meaning. This assumption allows an interpreter to set

condition of understanding. It states that only what really constitutes a unity of meaning is intelligible. So when we read a text we always assume its completeness, and only when this assumption proves mistaken - i.e., the text is not intelligible - do we begin to suspect the text and try to discover how it can be remedied."

${ }^{123}$ Lauterpacht, "Restrictive Interpretation," supra note 59 at 78 . He continues,

It is possible for the parties to adopt no regulation at all. They may expressly disclaim any intention of regulating the particular subject-matter. But in the absence of such explicit precaution, once they have clothed it in the form of a legal rule and once they have found themselves in a position in which that subject-matter is legitimately within the competence of a legal tribunal, the latter is bound and entitled to assume an effective common intention of the parties and to decide the issue. (Ibid. at 78-79.)

${ }^{124} \mathrm{Ibid}$. at 81 .

${ }^{125}$ Martti Koskenniemi, "Fragmentation," supra note 63 at 24: "Legal interpretation, and thus legal reasoning, builds systemic relationships between rules and principles by envisaging them as parts of some human effort or purpose. Far from being merely an 'academic' aspect of the legal craft, systemic thinking penetrates all legal reasoning, including the practice of law-application by judges and administrators." 
aside previous interpretations and to claim the mantle of truth for her own. Discussing humanistic hermeneutics, Goodrich highlights its

assumption that tradition and the texts in which it is contained bear a 'true' meaning which is their original meaning. The task of hermeneutics uris that of elaborating the rules or techniques that will uncover that original meaning and will reinstate it: the purpose of reconstructing a tradition is ultimately to relive it or at least to continue it, to place oneself within a tradition that has been made . . . to speak to the present. ${ }^{126}$

Fealty to authorized interpretive techniques allowed these interpreters to bypass accumulated gloss in order to reveal divine meaning. ${ }^{127}$ So too, VCLT articles 31 and 32 provide a set of authorized techniques to return a text to its original meaning.

In order to reanimate the sovereign's voice, the VCLT incorporates the muchcriticized psychologism of romantic hermeneutics. Romantic hermeneutics privileges the author over the text, and therefore the interpreter's primary task is to recover "by congenial coincidence, the genius of the author . ..."128 The VCLT's concern with authorial intent is embodied in VCLT article 31, which privileges agreements between the parties regarding the treaty's interpretation or application; the parties' subsequent practice in the application of the treaty; relevant rules of international law applicable to the parties, which would shape their understanding of the terms; and in its requirement that "a special meaning shall be given to a term if it is established that the parties so intended." ${ }^{129}$ By allowing recourse to a treaty's drafting history, the circumstances of its conclusion, and other supplementary means of

\footnotetext{
${ }^{126}$ Goodrich, Reading supra note 118 at 133-34.

${ }^{127}$ Ibid at 102 (discussing post-glossators).

${ }^{128}$ See Ricoeur, Hermeneutics, supra note 75 at 52 and at 190, discussing the psychological aspects of Dilthey's hermeneutics: "[I]t is because it stipulates as the ultimate aim of interpretation, not what a text says, but who says it."

${ }^{129}$ VCLT art 31(2) supra note 56.
} 
interpretation, VCLT article 32 incorporates the Romantic assumption that meaning is "primarily a matter of the interpreter's reconstituting the genesis, development, and derivation of the originator's ideas and mental contents." ${ }^{130}$ In this manner, the interpreter enters into dialogue with the author and the text is the medium in which this conversation occurs. ${ }^{131}$

The VCLT's solicitude toward authorial intent is justified on grounds that the parties cannot be held to agreements to which they did not consent. Isabelle Van Damme points out that consensualism, "the principle that all parties should consent to the content of their treaty obligations," serves as something of a Grundnorm for the VCLT. ${ }^{132}$ VCLT article 31 hews to these principles by attributing interpretive weight only to those factors demonstrating the common intent of all treaty parties. ${ }^{133}$ VCLT article $31(2)(b)$ does allow for the consideration of unilateral instruments made in connection the treaty's conclusion, but only where it is "accepted by the other parties as an instrument related to the treaty." 134 Similarly, recourse to

\footnotetext{
${ }^{130}$ Michael Ermarth, "The Transformation of Hermeneutics: 19th Century Ancients and 20th Century Moderns" 64:2 The Monist (1981) 175 at 177.

${ }^{131}$ Paul Ricoeur, Interpretation Theory: Discourse and the Surplus of Meaning (Fort Worth: Texas Christian University, 1976) at 22 points out the dialogic nature of this pursuit. Traditional hermeneutics

tended to identify interpretation with the category of "understanding," and to define understanding as the recognition of an author's intention from the point of view of the primitive addressees in the original situation of discourse. This priority given to the author's intention and to the original audience tended, in turn to make dialogue the model of every situation of understanding, thereby imposing the framework of intersubjectivity on hermeneutics.

${ }^{132}$ Van Damme, supra note 8 at 215.

${ }^{133} \mathrm{Ibid}$. at 215.

${ }^{134}$ VCLT art 31(2)(b), supra note 56.
} 
preparatory work and other supplementary means of interpretation under VCLT article 32 is regarded as legitimate only insofar as they reflect the parties' common agreement. ${ }^{135}$

\section{Intertemporality}

International law deals with temporal issues in treaty interpretation through the doctrine of intertemporal law. According to Judge Huber's classic statement in the Isle of Palmas arbitration, the doctrine of intertemporal law holds that "a juridical fact must be appreciated in the light of the law contemporary with it, and not of the law in force at the time when a dispute in regard to it arises or falls to be settled."136 Judge T. O. Elias wrote that the doctrine of intertemporal law is both a substantive rule of international law and a doctrine of interpretation, which, despite its development in the very specific question of the acquisition of territorial sovereignty from "savages or semi-civilised peoples,"137 may be regarded as "having general applicability in various fields of customary international law."138

\footnotetext{
${ }^{135}$ Hersch Lauterpacht, "Some Observations on the Preparatory Work in the Interpretation of Treaties" 48:4 Harv L Rev (1935) 549 at 582.

${ }^{136}$ Island of Palmas Case (Netherlands, United States) (1928) 2 R. Int'l Arb. Awards 831, 845 (permanent Court of Arbitration). However, he quickly undercut this interpretive lodestar, explaining,
}

As regards the question which of different legal systems prevailing at successive periods is to be applied in a particular case (the so-called intertemporal law), a distinction must be made between the creation of rights and the existence of rights. The same principle which subjects the act creative of a right to the law in force at the time the right arises, demands that the existence of the right, in other words its continued manifestation, shall follow the conditions required by the evolution of law. (Ibid.)

137 Ibid. at 845 .

${ }^{138}$ T. O. Elias, “The Doctrine of Intertemporal Law” 74 AJIL (1980) 285, 285. See also Rosalyn Higgins, "Time and the Law: International Perspectives on an Old Problem" 46 ICLQ (1997) 501, 515. According to Judge Rosalyn Higgins, "[f]ew arbitral dicta have been more widely cited, or have come to assume a more important place in international law" than Judge Huber's statement. Yet when it came time to draft a provision on intertemporality for the VCLT, the ILC punted; the intertemporality provisions proposed by Special Rapporteur Waldock were rejected, and the "temporal element" was considered to be adequately addressed by the "good faith" requirement and VCLT article 31(3)(c), which requires interpreters to account for "any relevant rules of international law applicable in relations between the parties." ("ILC Report on Eighteenth Session" supra note 110 at p 222). See also Sir Humphrey Waldock, "Third Report on the Law of Treaties" (UN Doc A/CN.4/167) in Yearbook of the International Law Commission 1962 vol. 2 (New York: UN, 1964) 1 at 8-9 (UNDOC, A/CN.4/SER.A/1962/Add.1) [“Waldock, 3rd Report”]. Humphrey's proposals included: 
Judge Higgins has suggested that the doctrine of intertemporal law is "an application

of a wider principle - intention of the parties, reflected by reference to the objects and

purpose - that guides the law of treaties." ${ }^{139}$ Similarly, Gerald Fitzmaurice recognized the

broader historical implications of intertemporality and from this formulated the "principle of

contemporaneity" according to which

treaty terms must be interpreted according to the meaning they possessed, or in the sense in which they were normally employed, at the date when the treaty was entered into ... for if it is a rule that the rights of parties to a dispute, as they stood at any given date, must be adjudged on the basis of the law (that is to say according to the state of international law) as it too stood at that date, it follows automatically that, in so far as those rights depend on a treaty, they can only receive a valid determination on the basis of the contemporaneous meaning of the treaty terms at the date of its conclusion, and in light of current usages and practice at that time. ${ }^{140}$

Thus, Fitzmaurice moves beyond measuring treaty terms according to the law extant

at the time of the treaty's conclusion and argues interpreters must also accord treaty language

1) A Treaty is to be interpreted in the light of the law in force at the time when the treaty was drawn up.

2) Subject to paragraph 1, the application of a treaty shall be governed by the rules of international law in force at the time when the treaty is applied.

And see D. W. Greig, Intertemporality and the Law of Treaties (London: British Institute of International and Comparative Law, 2001) 3-4 (discussing criticisms of Waldock's proposed provisions); Koskenniemi, "Fragmentation," supra note 63 at p 218. According to Koskenniemi, intertemporality

is the view that the interpretation and application of a treaty takes always place by reference to other rules of international law and the only question is should those "other rules" be conceived in terms of the normative situation at the conclusion of the treaty or at the moment of its application. As some [ILC] Commission members observed, this followed from the very object of tracing party intent - for that intent was certainly influenced by the rules in force at the time when the treaty was negotiated and adopted but developed in the course of the treaty's life-span ... [footnotes omitted].

See also International Law Commission, Report on the work of its Fifty-Eighth Session (2006), UN GAOR, 61st Session, 2006 Supp. No. 10, UN Doc A/61/10 (2006) 1 at 414-15:

International law is a dynamic legal system. A treaty may convey whether in applying article 31(3)(c) the interpreter should refer only to rules of international law in force at the time of the conclusion of the treaty or may also take into account subsequent changes in the law. Moreover, the meaning of a treaty provision may also be affected by subsequent developments, especially where there are subsequent developments in customary law and general principles of law [footnotes omitted].

${ }^{139}$ Higgins, ibid. at 519.

${ }^{140}$ Sir Gerald Fitzmaurice, "The Law and Procedure of the International Court of Justice 1951-4: Treaty Interpretations and Other Treaty Points" 33 Brit Y.B. Int'l L (1957) 203, at 225. 
the "ordinary meaning" it would have held "in light of current usages and practice at that time."141 This makes sense. Absent evidence that the parties were employing some special sense of the language, one can only assume they were using words in the same manner as their contemporaries.

Therefore, like traditional hermeneutics, international law's doctrine of intertemporality locates authorial intent in the historical context of the text's composition. But also like traditional hermeneutics, the doctrine of intertemporality attempts this by pursuing a rather vulgar conception of historical difference whereby both assume it possible to reconstruct the author's world so completely as to perfectly understand her intent.

Thus, perhaps more by default than design, the VCLT interpretive scheme embraces significant aspects of traditional hermeneutics. Like any traditional hermeneutic approach, the VCLT enshrines a circular approach in which textual and extra-textual factors are weighed equally, one against another, so that none carries greater interpretive weight, in a manner intended to recreate the authors' intentions. It also embodies hermeneutics' naïveté regarding matters of authorial intent and original understanding. Like hermeneutics, the VCLT scheme, in tandem with the doctrine of intertemporality, assesses authorial, or "the

${ }^{141} \mathrm{Ibid}$. See also Case Concerning Kasikili/Sedudu Island (Botswana v. Namibia), Judgment of 13 December 1999, [1999] ICJ Rep. 1045, Declaration of Judge Higgins 1113, 1113, where the court interpreted a centuryold treaty delimiting the boundary between Botswana and Namibia along the "main channel" of the Chobe River. Judge Higgins reveals the complexity arising from the temporal/semantic shift of key terms. She begins by arguing "[ $t]$ he term 'the main channel' is not a 'generic term'- that is to say, a known legal term, whose content the parties expected would change through time." In true philological and hermeneutic form, she goes on to explain,

we must never lose sight of the fact that we are seeking to give flesh to the intention of the parties, expressed in generalized terms in 1890 . We must trace a thread back to this point of departure. We should not, as the Court appears at times to be doing, decide what in abstracto the term "the main channel" might today mean. ... Rather our task is to decide what general idea the parties had in mind, and then make reality of that general idea through the use of contemporary knowledge. (Ibid. at 114.) 
parties'," intent in the historical context in which that intent was expressed. This implies an historical process mirroring Romantic hermeneutics' obsession with establishing rules to allow the reconstruction of original textual meaning. ${ }^{142}$ In fact, the process is quite a bit messier than most international lawyers let on.

\section{Post-Phenomenological Insights}

As I have discussed, the VCLT interpretive scheme embraces the methods of traditional hermeneutics, but in so doing also embraces many of its shortcomings. Now I will incorporate insights from post-phenomenological hermeneutics to attempt a more nuanced and robust interpretive approach. Above all, this approach relies on the insight that all knowledge is local, provisional, and partial and therefore any interpretation should be grounded in an ethic of humility. A humble interpreter knows that her knowledge is limited and her standpoint always corrupted. Humble interpretations are never final, but tentative; never complete, but always partial; and never certain, but merely more probable than a competing interpretation.

Heidegger's assault on Cartesian duality changed forever the hermeneutic landscape. He transformed interpretation from epistemology to ontology, from an activity to a way of being. ${ }^{143}$ As Gadamer points out, “[i]n [Heidegger's] Being and Time the real question was already not how being can be understood, but rather how understanding is being." ${ }^{144}$ To be is to interpret. Importantly, this implies the interpreter's permeability, as she cannot separate herself from the world, from tradition, or from the text. This is why approaching

\footnotetext{
${ }^{142}$ See Goodrich, Reading, supra note 118 at 134.

${ }^{143}$ Ricoeur, Hermeneutics, supra note 75 at 53-56.

${ }^{144}$ Quoted in Warnke, supra note 74 at 38.
} 
interpretation ontologically rather than as a matter of pure epistemology implies a heightened sense of caution — a radical skepticism, not only of text, but also of oneself.

Hermeneuts in the Heideggerian tradition accuse the Romantics of hubris for believing it possible to reconstruct an author's meaning. Gadamer mocked reconstruction as "a divinatory process, a placing of oneself within the whole framework of the author, an apprehension of the 'inner origin' of the composition of a work, a re-creation of the creative act." ${ }^{145}$ For Gadamer, the whole enterprise depends upon making " $[\mathrm{t}]$ he interpreter absolutely contemporaneous with his author,"146 a task that is simply impossible. To him, "[t]he task of hermeneutics is to clarify this miracle of understanding, which is not a mysterious communion of souls, but sharing in a common meaning." 147 Ricoeur too rejects Romantic psychologism, arguing, "Nothing has more harmed the theory of understanding than the identification, central in Dilthey, between understanding and understanding others, as though it were always first a matter of apprehending a foreign psychological life behind a text."148 Instead, post-Heideggerian thinkers incorporate a more robust sense of historicity whereby both author and interpreter are embedded in contexts that are unique and inescapable.

\footnotetext{
${ }^{145}$ Gadamer, Truth, supra note 73 at 186 [footnotes omitted].

146 Ibid. at 233.

${ }^{147} \mathrm{Ibid}$. at 292. However, as Gadamer explains, the move to psychologism was a radical step in the history of interpretation because for the first time the author possessed no special privilege in interpreting her work. Rather, because the interpreter really did understand the author better than the author herself, the interpreter was better placed to understand the author's true meaning.

148 Paul Ricoeur, From Text to Action: Essays in Hermeneutics, II, translated by Kathleen Blamey, \& John B. Thompson (London: Continuum, 2008) at 131 [Ricoeur, Text to Action] [emphasis in original]. See also Ricoeur, Interpretation Theory, supra note 131 at 30. He argues that the Romantics ignored the "distanciation" inherent in committing discourse to writing. By this he means that when discourse is committed to writing, it becomes fixed. It cannot be clarified by the give and take of further questioning, nor by gestures, vocal modulations, or facial expressions - the means we use, often unconsciously, to narrow polysemy. Instead, the text becomes "unmoored" from its author and has "semantic autonomy."
} 
These thinkers have argued for a re-conceptualization of the interpretive process. No longer would interpretation focus exclusively on the interpreted (text and historical context). Instead, interpreters must consider their relationship to these things. And the most important aspect of this relationship lies in negotiating the fore-conceptions an interpreter brings to bear on the objects of interpretation.

Gadamer believes " $[t]$ he tyranny of hidden prejudices ... makes us deaf to what speaks to us in tradition." ${ }^{149}$ Nevertheless, in Truth and Method, he set out to rehabilitate the idea of "prejudice," which he felt Enlightenment thinkers had unfairly maligned. ${ }^{150}$ By "prejudice" he meant "a judgment that is rendered before all the elements that determine a situation have been finally examined." 151 "[P]rejudices and fore-meanings that occupy the interpreter's consciousness are not at his free disposal. He cannot separate in advance the productive prejudices that enable understanding from the prejudices that hinder it and lead to misunderstandings." 152 Thus, according to Gadamer and other thinkers in the phenomenological tradition, we have always formed an understanding before we begin interpreting. ${ }^{153}$

\footnotetext{
${ }^{149}$ Gadamer, Truth, supra note 73 at 272.

${ }^{150} \mathrm{Ibid}$. at 273: "[T] he fundamental prejudice of the Enlightenment is the prejudice against prejudice itself, which denies tradition its power."

${ }^{151}$ Ibid. He continues: "In German legal terminology a 'prejudice' is a provisional legal verdict before the final verdict is reached. For someone involved in legal dispute, this kind of judgment against him affects his chances adversely. Accordingly, the French préjudice, as well as the Latin praejudicium, means simply 'adverse effect,' 'disadvantage,' 'harm."'

152 Ibid. at 295.

153 John D. Caputo, Radical Hermeneutics: Repetition, Deconstruction and the Hermeneutic Project (Bloomington: Indiana University Press, 1987) at 42 explains the ideal of fore-conceptions as developed in Husserl: "To intend is to 'apprehend' or interpret (auffassen), to seize or take (prehendere, fassen) something up (auf) in a determinate way, to take it as a particular such and such." See also ibid. at 41:

Intentionality is possible only to the extent that the object is adequately foreshadowed, traced in advance, prepared for by what we can only call here a certain hermeneutic fore-structuring which provides the
} 
Against Enlightenment thinkers who believed all prejudices interfere with understanding, Gadamer believes that "true prejudices" can be "a source of truth." 154 The interpretive task consists of testing pre-understandings and retaining those that are accurate and therefore helpful, while rejecting those that are inaccurate and interfere with understanding. Crucially, Gadamer cautions the interpreter "not to approach the text directly, relying solely on the fore-meaning already available to him, but rather explicitly to examine the legitimacy —i.e., the origin and validity—of the fore-meanings dwelling within him."155

Also important is the complex relationship of the interpreter and the things being interpreted as they exist in historical space. To overcome this distance, Gadamer leans heavily on the Heideggerian idea of "tradition," which Heidegger explained

takes what has come down to us and delivers it over to self-evidence; it blocks our access to those primordial "sources" from which the categories and concepts handed down to us have been in part quite genuinely drawn. Indeed it makes us forget that they have had such an origin, and makes us suppose that the necessity of going back to these sources is something which we need not even understand. ${ }^{156}$

Similarly, Gadamer asserts that "we are always situated within traditions, and this is no objectifying process - -i.e., we do not conceive of what tradition says as something other, something alien. It is always part of us, a model or exemplar, a kind of cognizance that our later historical judgment would hardly regard as a kind of knowledge but as the most

preliminary or anticipatory preparation for the actual appearance of the object. ... The intentional object is possible only to the extent that it is prepared in advance by an anticipatory fore-structure. The progress of experience is not a matter of continually being amazed by what is ever new or of being confounded by the flux, but rather of filling in (Erfüllung) already predelineated horizons (or, alternately, of revising expectations when we are indeed surprised).

${ }^{154}$ Gadamer, Truth, supra note 73 at 280.

${ }^{155} \mathrm{Ibid}$. at 270.

${ }^{156}$ Martin Heidegger, Being and Time, translated by John Macquarrie \& Edward Robinson (New York: Harper Perennial 2008) at 43. 
ingenious affinity with tradition." ${ }^{157}$ Thus, Heidegger and Gadamer suggest a concept of tradition that overlaps in significant ways with our concepts of culture and ideology. For them, tradition is darkness, blinding us to the origins of the "categories and concepts" that structure us while at the same time obscuring the radically contingent nature of our understanding. But insofar as tradition is darkness, it also provides the only light we receive, for we can only understand from within tradition. For this reason, "[t]o be situated within a tradition does not limit the freedom of knowledge but makes it possible."158

Historical consciousness is pivotal to Gadamer's theory. According to Gadamer, the awareness that consciousness is historically contingent "leads finally to recognizing historical movement not only in events but also in understanding itself. Understanding is to be thought of less as a subjective act than as participating in an event of tradition, a process of transmission in which past and present are constantly mediated." ${ }^{159}$ In Gadamerian terms, the interpreter is always limited by her horizon, the boundary within which things are visible ${ }^{160}$ : "A person who has an horizon knows the relative significance of everything within this horizon, whether it is near or far, great or small." ${ }^{161}$ An historical horizon is achieved not by transposing oneself into the horizon of another, as the Romantics believed, but by calling upon common tradition and by historicizing one's own place within that tradition. A horizon

\footnotetext{
${ }^{157}$ Gadamer, Truth, supra note 73 at 283.

${ }^{158}$ Ibid. at 354.

${ }^{159} \mathrm{Ibid}$. at 291 [emphasis omitted].

${ }^{160} \mathrm{Ibid}$. at 305 . But a horizon, no matter how finite, is not pregiven and instead must be earned. According to Gadamer, "[t]he concept of 'horizon' suggests itself because it expresses the superior breadth of vision that the person who is trying to understand must have," and "[i]t requires a special effort to acquire a historical horizon." 160 (Ibid. at 304.)

${ }^{161}$ Ibid. at 301-02. He continues: "Similarly, working out the hermeneutical situation means acquiring the right horizon of inquiry for the questions evoked by the encounter with tradition."
} 
is dynamic, changing constantly as an interpreter works through her prejudices. Accordingly, "[t]he illumination of this situation — reflection on effective history — can never be completely achieved; yet the fact that it cannot be completed is due not to a deficiency in reflection but to the essence of the historical being that we are. To be historically means that knowledge of oneself can never be complete." ${ }^{162}$ We can never achieve full understanding of ourselves because we can only understand through what is "historically pregiven," through our historical horizon. ${ }^{163}$ Self-understanding is achieved through and limited by the tools at hand, and these are determined by our cultural and historical inheritance. ${ }^{164}$

But we should not lament historical distance. Gadamer argues that historical distance allows "the true meaning of an object to emerge" by exposing the truth or falsity of our prejudices. ${ }^{165}$ Temporal distance provides a critical reflexivity that allows us to understand a text. As he points out, the temporal space separating the text's historical horizon from our own is not empty but filled with dynamic tradition, which is why "[r]eal historical thinking must take account of its own historicity." ${ }^{\prime 166}$ We must, that is, be concerned with how intervening history determines our vision of the text: "If we are trying to understand a historical phenomenon from the historical distance that is characteristic of our hermeneutical

${ }^{162}$ Ibid. at 301 [emphasis omitted].

${ }^{163}$ Ibid.

${ }^{164}$ Ibid. at 278 explains,

In fact history does not belong to us; we belong to it. Long before we understand ourselves through the process of self-examination, we understand ourselves in a self-evident way in the family, society, and state in which we live. The focus of subjectivity is a distorting mirror. The self-awareness of the individual is only a flickering in the closed circuits of historical life. That is why the prejudices of the individual, far more than his judgments, constitute the historical reality of his being. (Emphaisis in original.)

${ }^{165}$ Ibid. at 298.

${ }^{166} \mathrm{Ibid}$. at 299. 
situation, we are always already affected by history." 167 In this manner, the author's historical horizon is used as a coordinate from which to reflect on oneself.

Historical consciousness can also be perilous. Although it is the heart of the hermeneutic enterprise, if used improperly, historical consciousness can recreate a Cartesian subject-object relationship in which the object of historical inquiry is not understood but is objectified, like a scientist viewing a specimen slide. The cost of this objectification accrues to the text, which can make no "claim to be saying something true" but is instead merely studied for the insights it betrays. ${ }^{168}$ The task of interpretation, then, is to understand a text not from within the text or the author's mind, which is impossible, but from within the common tradition shared by interpreter and text. ${ }^{169}$

However, in attacking traditional hermeneutics' reliance on imagined historical sameness, Gadamer proposes a theory of historical consciousness that itself seems to rely on a naïve belief in historical continuity. ${ }^{170}$ According to Gadamer, historical horizons do not exist in fact, but are created through historical consciousness so that appreciating the situation of the text's drafting (its horizon) involves reaching outside one's own horizon and tapping into the universal tradition that encompasses both. ${ }^{171}$ But Gadamer's tradition

\footnotetext{
${ }^{167}$ Ibid. at 300 .

${ }^{168}$ Ibid. at 302 .

${ }^{169}$ See e.g., ibid. at 337: "But neither Schleiermacher nor Humboldt really thought through their positions fully. However much they emphasize the individuality, the barrier of alienness, that our understanding has to overcome, understanding ultimately finds its fulfillment only in an infinite consciousness, just as the idea of individuality finds its ground there as well."

${ }^{170}$ See Caputo, Radical Hermeneutics, supra note 153 at 112.

${ }^{171}$ Gadamer, Truth, supra note 73 at 303: "Everything contained in historical consciousness is in fact embraced by a single historical horizon. Our own past and that other past toward which our historical consciousness is directed help to shape this moving horizon out of which human life always lives and which determines it as heritage and tradition." See also ibid. at 304: "Transporting ourselves consists neither in the empathy of one
} 
minimizes both cultural and temporal difference. We might imagine an overarching tradition that encompasses both horizons (at least where both horizons share a common cultural tradition, as in the "West"), but this offers little assurance that individuals from different horizons (either cultural or historical) will understand one another. As Kuhn explains, change can be both radical and at the same time unrecognizable, at least for a time. ${ }^{172}$ We may share a tradition, even a field, but operate within distinct "paradigms" so that our common language is understood differently. The past is foreign in the same way as another's culture. Looking to tradition, Gadamer found harmony, but historians have increasingly emphasized history as "a discontinuous series of sudden, unexpected, inexplicable and inexplicably violent ruptures." 173

Moreover, by grounding understanding in tradition, which is invariably shaped by dominant interests, hermeneutics risks falling into an apologetic conservatism that ratifies existing power relations. Gadamer exhibits a startling credulity about the perpetuation and legitimation of authority and tradition when he declares, for instance,

[t]hat authority cannot actually be bestowed but is earned, and must be earned if someone is to lay claim to it. It rests on acknowledgement and hence on an act of reason itself which, aware of its own limitations, trusts to the better insight of others. Authority in this sense, properly understood, has nothing to do with blind obedience to commands. Indeed, authority has to do not with obedience but rather with knowledge. It is true that authority implies the capacity to command and be obeyed. But this proceeds only from the authority that a person has. Even the anonymous and impersonal authority of a superior which derives from his office is not ultimately

individual for another nor in subordinating another person to our own standards; rather it always involves rising to a higher universality that overcomes not only our own particularity but also that of the other."

${ }^{172}$ Thomas Kuhn, The Structure of Scientific Revolutions (Chicago: University of Chicago Press, 1996) at 150. Kuhn attributed this to incommensurability, arguing that "the proponents of competing paradigms practice their trades in different worlds." See also David A. Hollinger, In the American Province: Studies in the History and Historiography of Ideas (Baltimore: Johns Hopkins University Press, 1985) at 111-12, on Kuhn's ideas of historical change.

${ }^{173}$ David Harlan, The Degradation of American History (Chicago: University of Chicago Press, 1997) at xxvii. 
based on this hierarchy, but is what makes it possible. Here also its true basis is an act of freedom and reason that grants the authority of a superior fundamentally because he has a wider view of things or is better informed-i.e., once again, because he knows more. ${ }^{174}$

This stubbornly naïve defense of authority is amplified when he lauds its role in perpetuating tradition, which "has a justification that lies beyond rational grounding and in large measure determines our institutions and attitudes." ${ }^{175}$ Even the most casual student of sociology realizes that the authority exercised by those who establish and reaffirm tradition is unlikely to be based upon superior knowledge, as Gadamer asserts, but is generally bestowed arbitrarily according to social position so that those who control the tradition have little interest in reforming it. ${ }^{176}$ This is essentially the complaint lodged by Habermas and others against Gadamer. ${ }^{177}$ If the tradition that provides the condition of our understanding is riddled with ideological distortions, how can we ever hope to reach an external point of justice from which to critique that ideology? ${ }^{178}$

Perhaps it is possible to salvage Gadamer's insight by rescuing it from his sometimes all-too-cozy relationship with authority. Gadamer attempts this when he argues, "It is a grave misunderstanding to assume that emphasis on the essential factor of tradition which enters

\footnotetext{
${ }^{174}$ Gadamer, Truth, supra note 73 at 281.

${ }^{175} \mathrm{Ibid}$. at 282.

${ }^{176}$ See Caputo, supra note 153 at 112, criticizing Gadamer for describing

the continuity of the tradition, but [leaving] unasked the question whether the tradition is all that unified to begin with. He never asks to what extent the play of the tradition is a power play and its unity something that has been enforced by the powers that be. His "tradition" is innocent of Nietzsche's suspicious eye, of Foucaultian genealogy. He does not face the question of the ruptures within tradition, its vulnerability to difference, is capacity to oppress.

177 See Warnke, supra note 74 at 134-38 on Habermas' critique of Gadamer.

${ }^{178}$ But see Bruns, supra note 74 at 206, defending Gadamer's conception of tradition as a critical and dialectical relationship.
} 
into all understanding implies an uncritical acceptance of tradition and socio-political conservatism. . . . In truth the confrontation of our historic tradition is always a critical challenge to the tradition." 179 In his view, tradition is not something that is simply received; it is constantly reaffirmed and reformed. Therefore, as Gadamer sometimes suggests, it should be possible to take a critical stance toward tradition and to use tradition to challenge current conditions, even as we realize that it determines us.

\section{Humility}

Above all, an interpreter's awareness that her viewpoint can be expanded but will always remain limited anchors an overriding sense of humility. ${ }^{180}$ According to Ricoeur, "[t]he gesture of hermeneutics is a humble one of acknowledging the historical conditions to which all human understanding is subsumed under the reign of finitude." 181 To the extent an interpreter possesses an awareness of the limits imposed by prejudice and tradition, she will approach the process with humility, always ready to be "pulled up short by the text." 182 The task, according to Gadamer, is to "break the spell of our own fore-meanings" by remaining "open to the meaning of the other person or text." 183 By this he means that

[a] person trying to understand something will not resign himself from the start to relying on his own accidental fore-meanings, ignoring as consistently and stubbornly as possible the actual meaning of the text until the latter becomes so persistently

\footnotetext{
${ }^{179}$ Quoted in Madison, supra note 86 at 318.

${ }^{180}$ Laurence H. Tribe, "Comment" in Antonin Scalia, A Matter of Interpretation: Federal Courts and the Law (Princeton: Princeton Univ. Press, 1997) 70-73, laying out his humble interpretive approach while critiquing strict textualism.

${ }^{181}$ Ricoeur, Text to Action, supra note 148 at 270.

${ }^{182 .}$ Gadamer, Truth, supra note 73 at 270.

${ }^{183}$ Ibid.
} 
audible that it breaks through what the interpreter imagines it to be. Rather, a person trying to understand a text is prepared for it to tell him something. ${ }^{184}$

Thus, the text provokes the interpreter's fore-conceptions and prejudices and challenges her to assess their validity.

Although it confronts an interpreter with the finitude of her understanding, “openness" also provides opportunity for growth. Accordingly,

where it is successful, understanding means a growth in inner awareness, which as a new experience enters into the texture of our own mental experience. Understanding is an adventure and, like any other adventure, is dangerous. . . . But when one realizes that understanding is an adventure, this implies that it affords unique opportunities as well. It is capable of contributing in a special way to the broadening of our human experiences, our self-knowledge, and our horizon, for everything understanding mediates is mediated along with ourselves. ${ }^{185}$

The capacity to learn from a text requires a certain disposition, which "involves recognizing that I myself must accept some things that are against me, even though no one else forces me to do so." 186 Thus, "[t]he [open] hermeneutical consciousness culminates not in methodological sureness of itself, but in the same readiness for experience that distinguishes the experienced man from the man captivated by dogma." 187 And this openness, which takes the form of questioning, "culminate[s] in a radical negativity: the knowledge of not knowing."188

${ }^{184}$ Ibid. at 271-72. Gadamer continues:

That is why a hermeneutically trained consciousness must be, from the start, sensitive to the text's alterity. But this kind of sensitivity involves neither "neutrality" with respect to content nor the extinction of one's self, but the foregrounding and appropriation of one's own fore-meanings and prejudices. The important thing is to be aware of one's own bias, so that the text can present itself in all its otherness and thus assert its own truth against one's own fore-meanings.

${ }^{185}$ Gadamer, Reason, supra note 71 at 109-10.

${ }^{186}$ Gadamer, Truth, supra note 73 at 355.

${ }^{187}$ Ibid.

${ }^{188}$ Ibid. at 356. 
As Bruns points out, the awareness that an interpreter will grow during the encounter

with the text is not unique to hermeneutic approaches.

Indeed a recurrent theme of the history of interpretation is that the understanding of a text always requires, in some sense a conversion to the text's way of thinking, and what this means is that we always end up having to reinterpret ourselves, and even change ourselves in the light of the text. To understand a text is not only to grasp its meaning; it is to understand the claim that it has on us. ${ }^{189}$

"Openness" is a partial cession of personal sovereignty, a tentative opening to allow

the other's understanding to affect one's own. Or, according to Bruns,

[t]his is what Gadamer means when he says that the end of hermeneutical experience is not meaning or knowledge but openness, where openness, however, means not simply open-mindedness, tolerance for another's views, or the mutual indulgence of liberal pluralists but acknowledgment of what is alien and refractory to one's categories. It means acknowledging the being of what refuses to fit or refuses to be known, that which says no to me. ${ }^{190}$

So too, Ricoeur asserts that "[e]very hermeneutics is . . . explicitly or implicitly, selfunderstanding by means of understanding others." 191 He proposes a "reflective hermeneutics" according to which "the interpretation of a text culminates in the self-

${ }^{189}$ Bruns, supra note 74 at 210. See also Gadamer, Truth, supra note 73 at 271. According to Gadamer, this "openness places hermeneutical work on a firm basis":

Of course this does not mean that when we listen to someone or read a book we must forget all our foremeanings concerning the content and all our own ideas. All that is asked is that we remain open to the meaning of the other person or text. But this openness always includes our situating the other meaning in relation to the whole of our own meanings or ourselves in relation to it. Now, the fact is that meanings represent a fluid multiplicity of possibilities, . . but within this multiplicity of what can be thought-i.e., of what a reader can find meaningful and hence expect to find - not everything is possible; and if a person fails to hear what the other person is really saying, he will not be able to fit what he misunderstood into the range of his own various expectations of meaning. Thus there is a criterion here also. The hermeneutical task becomes of itself a questioning of things and is always in part so defined. [Emphasis in original.]

${ }^{190}$ Bruns, supra note 74 at 210.

${ }^{191}$ Ricoeur, Conflict, supra note 72 at 17. See also Ricoeur, Hermeneutics, supra note 75 at 159 "[I]n hermeneutical reflection - or in reflective hermeneutics - the constitution of the self is contemporaneous with the constitution of meaning." [Emphasis in original]. 
interpretation of a subject who thenceforth understands himself better, understands himself differently, or simply begins to understand himself." 192

Reflective change need not be world shattering. This is not the change one seeks in psychotherapy. Instead, reflective change asks only that the interpreter remain open to adjusting her worldview — to reforming her fore-conceptions - in response to the text. In this sense, the interpreter occupies a dynamic position within the hermeneutic circle, one that shifts as the text provokes her to reconsider her fore-conceptions. It is a process from which neither emerges unchanged.

\section{Truth}

But the humble and hesitant aspects of Gadamer's approach, which I find so admirable, can lead to a kind of solipsistic relativism, and this is especially so if one rejects his reliance on continuous tradition and universal consciousness, as I have. If the interpreter is in a dynamic relationship with the text, a relation mediated by cultural and historical prejudices, fore-understandings, and horizons, and if the real interpretive action is internal to the interpreter, how can it be proved that she has arrived at a true interpretation? This is not to say that Gadamer is unconcerned with truth. In fact, as conveyed by the title of his magnum opus Truth and Method, the idea of truthful interpretation is central to his approach. ${ }^{193}$ But Gadamer's truth is achieved as the interpreter winnows fore-conceptions,

\footnotetext{
${ }^{192}$ Ricoeur, Conflict, supra note 72 at 17. But he cautions that "reflection must be doubly indirect: first, because existence is evinced only in the documents of life, but also because consciousness is first of all false consciousness, and it is always necessary to rise by means of a corrective critique from misunderstanding to understanding."

${ }^{193}$ But see Gadamer, Truth, supra note 73 at 295 , where any discussion of truth is fleeting and he explicitly denies developing a method, leaving one to wonder whether the title was intended ironically.
} 
eliminating false ones and keeping those that are true. ${ }^{194}$ The work of his hermeneutics "is not to develop a procedure of understanding, but to clarify the conditions in which understanding takes place." ${ }^{\prime 95}$ His focus, after all, is the interpreter, not the interpreted. Therefore, it is unsurprising that he provides no real criteria for the interpreter, or the rest of us, to judge the proposed meaning of a text either true or false. To answer these questions, one must turn elsewhere.

The impulse to find truth in text is central to legal interpretation, and it is hard to imagine it otherwise. As Goodrich reminds us, "[t]he origins of the legal profession within the Roman, continental and English legal systems have all been to some degree religious. The Digest of Justinian refers to lawyers as 'priests of the law' (sacerdotes legum) and a comparable religious status and function can be discerned in most of the other early legal communities." ${ }^{196}$ And according to Derrida,

The shared necessity of exegesis, the interpretive imperative, is interpreted differently by the rabbi and the poet. The difference between the horizon of the original text and exegetic writing makes the difference between the rabbi and the poet irreducible.... The original opening of interpretation essentially signifies that there will always be rabbis and poets. And two interpretations of interpretation. ${ }^{197}$

${ }^{194}$ See Gadamer, Reason, supra note 71 at 44 , where he discusses

the insight that the truth of a single proposition cannot be measured by its merely factual relationship of correctness and congruency; nor does it depend merely upon the context in which it stands. Ultimately it depends upon the genuineness of its enrootedness and bond with the person of the speaker in whom it wins its truth potential, for the meaning of a statement is not exhausted by what is stated. It can be disclosed only if one traces its history of motivation and looks ahead to its implications.

${ }^{195}$ Gadamer, Truth, supra note 73 at 295.

${ }^{196}$ Goodrich, Reading, supra note 118 at 145

${ }^{197}$ Caputo, supra note 153 at 116, quoting Jacques Derrida, Writing and Difference, translated by Alan Bass (Chicago: University of Chicago Press, 1978) 67 [emphasis omitted]. 
Law won't survive the death of truth, and it will always be the role of lawyers to seek it in text. The notion of textual truth may be, as Derrida argued, "a necessary fiction," but it is necessary nonetheless. ${ }^{198}$

Since Nietzsche, the idea of "Truth" has received a well-deserved critique. But all too often, those who point out the perils of claiming a general truth — to which the rest of us are made to conform — end up denying the existence of any truth, no matter how local or provisional. Crucially, I am arguing only that a text can convey a local truth, not that there is some greater Truth that one must recognize. (Maybe there is, and maybe one ought, but that is beyond the scope of this writing.) Put differently, it is important not to conflate the truth of the Genocide Convention with the ontological truth pursued by Heidegger or the truth conveyed by the word of God. It is possible to believe the Genocide Convention contains a truth, discloses a world, embodies a commitment, without peering into Heidegger's vast “open," without stripping oneself naked in front of God. ${ }^{199}$

Gadamer made use of the concept of "play," an indistinct concept by which he highlighted the often-unconscious interaction of interpreter and interpreted. I want to use this concept in a narrower sense. As Gadamer points out, in all of the metaphorical uses of play, "what is intended is to-and-fro movement that is not tied to any goal that would bring it to an

${ }^{198}$ Caputo ibid. at 145, discussing Derrida:

Truth after all, is necessary - that is to say, we need our fictions. We cannot function without taming the wildness of the play, without imposing normality, without a certain measure of stilling the flux. Derrida does not object to such recourse to pragmatic fiction. His point is only to remind us of this coefficient of uncertainty attached to all such fiction/truths, to raise our level of vigilance about their constituted, contingent nature, lest we become so habituated to them as to forget that they are fictions . . . and begin treating as "self-evident" what are no more than contingent effects of repetition, temporary stabilizations of the flow. [Footnotes, emphasis omitted.]

${ }^{199}$ Caputo ibid. at 100-02, discussing Heidegger's “open.” 
end.... The movement backward and forward is obviously so central to the definition of play that it makes no difference who or what performs this movement." ${ }^{200}$

What I want to highlight is the looseness of fit, the play between the parts, the inexactitude of interpreted meaning. This sense of play is also nearly synonymous with "tolerance" as it is used in engineering, as "[a]n allowable amount of variation in the dimensions of a machine or part." 201 This sense of "play" as the stuff that fills reason's interstices, as the realm of the poets, is central to Caputo's Radical Hermeneutics. ${ }^{202} \mathrm{He}$ argues reason is never gapless, that it has an endpoint, one that human consciousness will inevitably confront. That interpreters will encounter these gaps is inevitable and irrelevant; what matters is how they account for the missing bits. He asks interpreters to revel in the flux, to embrace the indeterminate. ${ }^{203}$ And so any humble interpretation will be playful and tolerant, acknowledging and reveling in its looseness of fit.

Legal interpretation is conducted at varying levels of abstraction. In concrete interpretations, involving an application to specific facts, we are less tolerant of play. In these instances, play is called indeterminacy and is said to subvert the principles of legality and democracy by placing undue discretion in the hands of the judges. At higher levels of abstraction — as in my analysis — we tend to accommodate play. In such instances the

\footnotetext{
${ }^{200}$ Gadamer, Truth, supra note 73 at 104.

${ }^{201}$ Oxford English Dictionary, Shorter, 5th ed, sub verbo "tolerance."

${ }^{202}$ Caputo, supra note 153 at 225 . As Caputo points out, Gadamerian "play" is taken from Heidegger. Heidegger
}

took reason seriously just long enough to show that there is sphere of play outside the reach of the principle of reason, outside the reach of the long arm of the law. There is a sphere of poetizing and thinking which forever eludes rationalization, reason giving, rendering reasons. Heidegger shows us that reason is one of the powers which only pretend to be, and that we ought not to take its pretentions to universal jurisdiction seriously. [Emphasis omitted.]

${ }^{203} \mathrm{Ibid}$. at 234. 
interpretation may contain a significant amount of play yet still support the interpretation's rather broad thesis. It is one thing to say, as I have, that the Genocide Convention implies an overriding concern with culture; it is quite another to apply this insight to concrete circumstances.

However, while it is important to acknowledge that "play" will figure differently in different levels of interpretation, it is a mistake to assert that the play present in a rather abstract interpretation—such as this one — makes it irrelevant to concrete applications. ${ }^{204}$ Rather, in hermeneutic form, the abstract interpretation shapes the concrete application, yet is revised in light of problems presented by a concrete application. When that inevitable moment is reached, when a judge must choose one outcome over another, the abstract interpretation narrows the range of acceptable outcomes. That the judge must ultimately leap at an alternative - and that sometimes that leap will seem arbitrary —is the unavoidable heart of judging. However, far from negating their validity, the fact that interpretations leave gaps is simply an unavoidable reality. Not even math or God give firm answers all the time.

Clearly, my interpretation has significant play. In fact, at this high level of abstraction, all I am claiming is that the Genocide Convention possesses directionality ("thrownness," in Heideggerian terms), which, if projected correctly, limits its range of available meanings. As I will argue in subsequent chapters, an examination of the interpretive considerations laid out in the VCLT (text, context, teleology, drafting history, and circumstances of conclusion) shows the Genocide Convention has a culturalist lean. Once adduced, this direction can be projected onto more concrete facts. For example, a court, confronted by an instance in which a protected group's political, cultural, or religious leaders

${ }^{204}$ Dilthey, supra note 88 at 162-63. 
have been killed with intent to destroy the group, faces two interpretive possibilities, one exclusionist the other culturalist. The exclusionist interpretation might find the level of killing did not endanger the group's physical existence and that therefore there was no intent to commit genocide. A culturalist interpretation might find that an attempt to kill the individuals most responsible for perpetuating group culture is clear evidence of the intent to destroy the group by interfering with its cohesion. In each case, the abstract interpretation shapes the more concrete application.

But it is one thing to declare that a text discloses a truth, it is quite another to point to reliable means of discovering and then proving that truth. Hirsch argues that "[e]very interpretation begins as a guess, and no one has ever devised a method of making intelligent guesses."205 As Hirsch explains,

[a]n interpretive hypothesis is ultimately a probability judgment that is supported by evidence. Normally it is compounded of numerous subhypotheses (i.e. construction of individual words and phrases) which are also probability judgments supported by evidence. $^{206}$

If this is true, as I believe it is, the next step involves evaluating the guess in light of the available evidence. Thus, we should not say an interpreter has reached a text's "true meaning" but merely that, given what is known, the attributed meaning is more likely than competing meanings. Or, as Ricoeur concludes, "if it is true that there is always more than one way of construing a text, it is not true that all interpretations are equal."207 "[T]he text is

\footnotetext{
${ }^{205}$ E. D. Hirsch Jr, Validity in Interpretation (New Haven: Yale University Press, 1967) at 170.

206 Ibid. at 180.

${ }^{207}$ Ricoeur, Interpretation Theory, supra note 131 at 79.
} 
a limited field of possible constructions"-and some interpretations land beyond its borders. ${ }^{208}$

Ricoeur argues that showing "that an interpretation is more probable in the light of what we know is something other than showing that a conclusion is true. So in the relevant sense, validation is not verification. It is . . . a logic of uncertainty and of qualitative probability. ${ }^{209} \mathrm{He}$ argues,

Guess and validation are in a sense circularly related as subjective and objective approaches to the text. But this circle is not a vicious one. That would be the case if we were unable to escape the kind of "self-confirmability" which, according to Hirsch threatens the relation between the guess and the validation. But to the procedures of validation there also belong procedures of invalidation similar to the criteria of falsifiability proposed by Karl Popper in his Logic of Discovery. Here the role of falsification is played by the conflict between competing interpretations. An interpretation must not only be probable, but must be more probable than another interpretation. ${ }^{210}$

But which criteria does one use to determine whether an interpretation has landed on the "field of possible constructions"? Ricoeur ducks this question, asserting that the admittedly subjective process of weighing competing interpretations will yield the one most probably likely. But this is unlikely to satisfy. I think Hirsch is correct when he argues that there must be an objective marker of interpretive accuracy. ${ }^{211}$

\section{For the Love of Rules}

Theorists suggest various interpretive lodestars including authorial intent, original meaning, notions of living or dynamic text, and flavors of textualism; and have proposed

\footnotetext{
${ }^{208}$ Ricoeur, Hermeneutics, supra note 75 at 213.

${ }^{209}$ Ricoeur, Interpretation Theory, supra note 131 at 78.

${ }^{210} \mathrm{Ibid}$. at 79 [footnotes omitted].

${ }^{211}$ Hirsch, supra note 205 at 202-08. Of course his preferred criterion, authorial intent, is no more satisfying that Ricoeur's process-oriented approach.
} 
complementary means of validation for each. These debates have not been foreign to international law. Writing in 1951, Fitzmaurice identified "three main schools of thought" on treaty interpretation, which he identified as 'the 'intentions of the parties' or founding fathers' school; the 'textual' or 'ordinary meaning of the words' school; and the 'teleological' or 'aims and objects' school.".212 As he pointed out, these approaches have not been applied singly but in tandem. That is, rarely were treaty interpreters wedded to a single approach. Instead, they have tended to incorporate aspects of all three schools in a single interpretation. As I have discussed, in codifying extant interpretive practice circa 1969, the VCLT also incorporated all of these approaches. This ecumenicity frustrates purists but appears well-suited to a hermeneutic approach wherein the rules serve not to bind meaning but to enable understanding.

Thus far, I have argued only that the VCLT rules provide a good framework for an interpreter to follow in developing an understanding of the text. Now I want to argue that an interpretation's degree of compliance with the VCLT process is a good marker of its validity. Because the VCLT rules provide a pretty good approach to discerning textual meaning, and because they represent an agreed upon "interpretive angle," one that has been codified and

\footnotetext{
${ }^{212}$ Sir Gerald Fitzmaurice, "The Law and Procedure of the International Court of Justice: Treaty Interpretation and Other Treaty Points" 28 Brit. YB Intl L (1951) 1, at 1. As he pointed out, these "schools are not necessarily exclusive of one another ..." and are generally applied in tandem. The VCLT, which was adopted in 1969 following twenty years of drafting and debate, takes an all-of-the-above approach and incorporates methods from each of these schools. See also I. M. Sinclair, The Vienna Convention on the Law of Treaties (Manchester: Manchester University Press, 1973) at 70; and Martin Ris, "Treaty Interpretation and ICJ Recourse to Travaux Préparatoires: Towards a Proposed Amendment of Articles 31 and 32 of the Vienna Convention on the Law of Treaties" 14:1 Boston College Int'1 \& Comp L Rev (1991) 111 at 111. See also Bederman, supra note 119 at 198 , describing this division as "the modern trichotomy of text-intent-purpose."
} 
imposed on international lawyers, an interpretation's compliance with these rules is evidence of its validity. ${ }^{213}$

However, this places an obligation on interpreters to make explicit the bases of their interpretation - in colloquial terms, to show their work. ${ }^{214}$ Too often, even when they do cite the VCLT rules, courts and other treaty interpreters give little indication how they arrived at their interpretation. Humble interpretation demands that the interpreter specify the process by which she arrived at her interpretation. It demands that she conduct an interpretation according to VCLT article 31, spelling out each of the textual and contextual factors she has considered and the decisions she has reached. And when circumstances mandate, she must consider and document all of the relevant evidence found in the supplementary means of interpretation.

All too often, interpretation resembles the metaphorical black box, in which the important action is unobservable. Exclusionists simply assert that the Genocide Convention's preparatory work demonstrates that it was not intended to reach cultural matters. They never engage the overall debate and rarely cite any specific comment. And even assuming they are correct about the drafting debates, they never explain why or how these discussions outweigh the Genocide Convention's text. Instead, all this interpretive action has been hidden within

\footnotetext{
${ }^{213}$ But see Klabbers, "Virtuous" supra note 59, arguing the VCLT does not meet the definition of law and imposes little obligation on interpreters.

${ }^{214}$ George Schwarzenberger, "Myths and Realities of Treaty Interpretation: Articles 27-29 of the Vienna Draft Convention on the Law of Treaties" 9 Va. J. Int'l L. (1968) 1 at 12-13, addressed the need for transparency:

If, as is the case with most judicial international institutions, awards and judgments have to be reasoned, the parties are entitled to be informed of the operative reasons and have every right to object to these real reasons being shrouded in mystery. Growing awareness that disclosure of the operative reasons is the last thing to be expected from international courts and tribunals is one of the least discussed grounds for the spreading disenchantment with international adjudication. "Explicit rationality" in the interpretation of treaties, which after all, is the major sphere of international judicial work, might assist in counteracting this trend. [Emphasis, footnotes omitted.]
} 
the black box. And because it is hidden, it is exceedingly difficult to challenge. Asking interpreters to show their work not only helps assure their compliance with the VCLT process, it is the cornerstone of transparency and accountability.

Despite all the scorn heaped upon them, the VCLT rules just don't seem all that bad. If applied holistically as a single process, the rules appear well-suited to reducing the range of possible meanings a treaty term might hold, of rendering one interpretation more probable than another. This is not to deny that the rules leave a significant amount of play in textual meaning, but even with all that "indeterminacy," some interpretations will fall outside the boundaries of reasonableness. As I will demonstrate in subsequent chapters, even accepting all the residual indeterminacy present in both the VCLT and the Genocide Convention, applying the former to the latter shows exclusion to be quite unreasonable.

\section{Consolidating a humble interpretive approach}

Throughout this chapter I have shied away from announcing a methodology, claiming only that I am developing an interpretive "approach." I have done so because this approach will not restrain a determined mis-interpreter. For several decades now, we have been obsessed with the idea that legal interpretation can be restrained by rules or theories of textual meaning. ${ }^{215}$ But an interpreter who is unwilling to challenge her prejudices, unwilling to change her standpoint in response to the text, will always cover the text's meaning with her own and will likely find some basis in rules or theory for doing so. Restraint will always fail us. What is required to overcome the tendency to read a text through one's own concerns

\footnotetext{
${ }^{215}$ See Laura Kalman, The Strange Career of Legal Liberalism (New Haven: Yale University Press, 1998) at 108, documenting, at least in the American legal academic realm, a transition from an obsession with the counter-majoritarian difficulty to an emphasis on hermeneutics and judicial introspection.
} 
is an open disposition; a willingness to be brought up short by the text, to challenge one's fore-conceptions, and to change one's standpoint.

These post-phenomenological insights form the foundation of the humble interpretive approach that I am proposing. In this approach, the insight that knowledge is limited, provisional, and corrupted grounds an abiding humility that causes the interpreter to provoke and evaluate her fore-conceptions and to winnow those that are unhelpful. As I have argued, the VCLT provides a workable framework for this process. By enshrining the principles of refractory hermeneutics, the interpretive scheme laid out in VCLT articles 31 and 32 encourages just this sort of testing. Measuring individual terms against the treaty as whole, accounting for its teleology, and verifying these against its context and supplementary means of interpretation encourages interpreters to challenge their fore-meanings. The VCLT's better instincts have always been hermeneutic.

But we should not simply trust interpreters to work through their processes in private. Humble interpretation demands that an interpreter make explicit the bases of her interpretation, and the VCLT rules provide a workable framework for doing so.

As I have also argued, the traditional hermeneutic approach to historical change, which is mirrored in the doctrine of intertemporality, falls short. A humble interpreter knows that the past is only ever imperfectly retrievable and that the really interesting aspect of historicity is in providing a perspective from which to evaluate one's own historical context. By accounting for the distance between the context of the text's drafting and her own, an interpreter will notice the strangeness of the past but more crucially she has the opportunity to apprehend the contingent nature of the present. It is her questioning of the naturalness of her worldview that allows her to better understand the past. 
Notably, my approach has retained the idea of textual truth, which is vital if there is to be any way of deeming one interpretation better than another. To let go of truth is to send the matter over to rhetoric, where all that matters is persuasiveness. ${ }^{216}$ As I will document in a following chapter, the Genocide Convention has been relentlessly misinterpreted for several decades. These misinterpretations have yielded significant inconsistencies and contradictions, which should have signaled their inaccuracy. Yet the Genocide Convention's interpretive community has, for the most part, embraced these misinterpretations. To let go of truth and descend into rhetoric is to place the matter of legitimacy in the hands of the invisible college of international lawyers where, as Lemkin argued, justice often takes a backseat. ${ }^{217}$

Like Ricoeur, I believe that a text "discloses a world," which is simply a much prettier way of saying that it possesses lean or directionality. Textual truth is made visible though the interpretive process, whereby the interpreter works through her fore-conceptions and historicizes the context of her understanding. I will argue in subsequent chapters that the Genocide Convention possesses a culturalist lean: that its words, the broader context of these words, as well as its drafting history and the circumstances of its conclusion, all signal a world in which group culture is important and worth protecting. As I will also point out, this lean has been consistently overlooked by interpreters unwilling to challenge their own prejudices.

\footnotetext{
${ }^{216}$ See Madison, supra note 86 at 320, discussing Gadamer's thoughts on the relationship between hermeneutics and rhetoric.

217 See below chapter 4, text accompanying notes 12-33; chapter 5, text accompanying notes 9-33.
} 


\section{Conclusion}

In the nearly seven decades since its conclusion, the Genocide Convention has been increasingly allegorized. In this sense, allegory is an interpretive strategy "of reading a prefabricated meaning into patterns that have no necessary relationship to it whatsoever." 218 Over these intervening decades, interpreters embedded in the vocabularies of human rights and international criminal law have embraced the Genocide Convention's power but in doing so have imposed on it these alien discourses, ignoring its world and filling it with their concerns. They have ignored its group protections and its obsession with culture. This is not unexpected, for as Bruns points out, "Western culture has always been deeply allegorical in its operations and results; it has a special genius for constructing ways of reading poetry, or any alien discourse, so as to make it consistent with its own prevailing cultural norms."”219

But interpreters would do well to resist this move and, instead, read the Genocide Convention counter-allegorically, as satire. Bruns explains that "[s]atire is the discourse of the Other against the Same...." And for Bruns, satire is at the heart of hermeneutics, for it "explodes the conceptual schemes or mechanical operations of the spirit by which we try to objectify and control things, including all that comes down to us from the past." ${ }^{220} \mathrm{~A}$

\footnotetext{
${ }^{218}$ Fish, Is There a Text? supra note 60 at 254 . Bruns, supra note 74 at 85 suggests two more definitions: 1 ) "Allegory is, crudely, the squaring of an alien conceptual scheme with one's own on the charitable assumption that there is a sense (which it is the task of interpretation to determine) in which they are coherent with one another," and 2) Allegory is "a way of assigning "truth conditions to alien sentences to make speakers right when plausibly possible according, of course, to our view of what is right."”

${ }^{219}$ Bruns, Ibid. at 231.

${ }^{220} \mathrm{Ibid}$. at 204. See also Robert W. Gordon, "Forward: The Arrival of Critical Historicism," 49 Stan. L. Rev. (1996) 1023, 1024. In this sense, Bruns's satirical reading has much in common with Robert Gordon's critical legal history, which he defines as

any approach to the past that produces disturbances in the field - that inverts or scrambles familiar narratives of stasis, recovery or progress; anything that advances rival perspectives (such as those of losers rather than the winners) for surveying developments, or that posits alternative trajectories that
} 
hermeneutic encounter with the past nurtures its strangeness, does not attempt to domesticate it but allows the blossoming of its alien flowers. Our encounter with tradition forces a sense of our own historicity and reveals the contingent nature of our institutions. It mocks us by confronting us with what was and therefore with what might have been. As Gadamer intimated, the past does not always ratify but instead may challenge the present. History is not a tale of inexorable progress, as the Enlightenment thinkers believed, but of fits and starts, of advances and retreats, of promises made and left unfulfilled.

As I will show, an open reading of the Genocide Convention discloses a distant world, one whose values and expectations are not ours and are not what we might expect. Nevertheless, like any good satire, it has much to teach us. The Genocide Convention was written at a crucial juncture when a world torn apart struggled with what it was to become, a time when all was flux, a time much different from the ossified Cold War politics that followed so closely. In this sense, the Genocide Convention is a message in a bottle that the drafters tossed into the sea long ago. While we may be tempted to impose our will upon it, we would do well to read it openly, to search out its apparent contradictions, to acknowledge its strangeness, and to ask what this discloses of the drafters and their ideas.

As I have pointed out, both the hermeneutic tradition and the Genocide Convention trace their heritage to nineteenth-century Romanticism, which was itself born in rebellion to the Enlightenment's relentless scientism. Against the Enlightenment's dissecting epistemology, the Romantics proposed a means of getting at those things that make human existence unique. Tasked with compiling preliminary drafts of the VCLT, special Rapporteur 
Waldock recognized the relevance of this distinction to treaty interpretation. In commentary to his proposed draft rules, which would eventually morph into articles 31 and 32 of the VCLT, he argued that "the interpretation of documents is to some extent an art, not an exact science." ${ }^{221}$ His statement appears to reject or even ridicule the idea that an ethic of scientific precision can be brought to bear fruitfully on the process of treaty interpretation and proposes a different approach to knowing the text, an approach that is less "exact" and more of an "art"; more hermeneutic. Returning to the epigram that began this chapter, he might be taken as suggesting that interpreters set aside their square hats to don sombreros.

\footnotetext{
${ }^{221}$ Waldock 3rd Report, supra note 138 at 54. See also Panos Merkouris, Introduction, "Interpretation: Art or Science?" in Vienna Convention 30 Years On, supra note 5, 8 at 8, providing an insightful disquisition on the art versus science controversy and its origins.
} 


\section{Chapter 2-Lemkin in the Cultural Moment}

We won't forsake the land we came from, We won't let our speech be buried.

We are the Polish nation, the Polish people, From the royal line of Piast.

We won't let the foe Germanize us.

So help us God! So help us God!

To the last blood drop in our veins

We will defend our Spirit

Till into dust and ash shall fall,

The Teutonic windstorm.

Every doorsill will be a fortress for us.

So help us God! So help us God!

The German won't spit in our face, Nor Germanize our children, Our host will arise in arms, Holy Spirit will lead the way. We'll set out when the golden horn calls.

So help us God! So help us God!

We won't have Poland's name defamed, We won't step into a coffin alive.

In Poland's name, in its worship

We lift our foreheads proudly, A grandson will regain his forefathers' land So help us God! So help us God! (Maria Konopnicka, "Rota” [The Oath], 19081)

In June 1942, Raphael Lemkin received a telegram "offering an appointment as chief consultant" with the Board of Economic Warfare, which he accepted immediately. ${ }^{2}$ Moving from a job teaching law at Duke University in North Carolina to Washington, DC, Lemkin found himself in a "city teeming with people and energy." ${ }^{3} \mathrm{He}$ recalled how "every day, the

\footnotetext{
${ }^{1}$ See Maja Trochimczyk, "Essay: Rota (the Oath) University of Southern California, Polish Music Center, online $<$ https://polishmusic.usc.edu/research/national-anthems/rota-the-oath $>$.

${ }^{2}$ Raphael Lemkin, Totally Unofficial: the Autobiography of Raphael Lemkin, Donna-Lee Frieze, ed, (New Haven: Yale University Press, 2013) at 112 [Lemkin, Unofficial].

${ }^{3}$ Ibid.
} 
trains and planes poured thousands of newcomers into the city from every corner of the country: in new military uniforms ready to report and in civilian clothes to assume authority; businessmen, professors, lawyers, men and women, old and young" all showed up eager to help defeat the Axis.

Many scholars were among the vast crowds decamping to the city, creating a vibrant intellectual milieu where academic insight was harnessed to serve state policy. ${ }^{4}$ Those arriving in Washington included a broad coalition of anthropologists and social scientists. ${ }^{5}$ They brought with them an electrifying new concept: culture. As government cafeterias turned into impromptu lunchtime academic seminars, this concept, culture, served as the intellectual terrain along which other concepts travelled. Lemkin, who was notably active in the Washington scene, ${ }^{6}$ was likely an eager participant in these discussions, and his writings document his embrace of the anthropological idea of culture.

The anthropological idea of culture, as the way of life or folkways of a group, was a fairly recent arrival to Western discourse, but it was believed to hold tremendous explanatory power. In this cultural moment, poets, scholars, policymakers, and the military applied the idea of culture both empirically, to understand the world around them, and normatively, to

\footnotetext{
${ }^{4}$ See Lois W. Banner, Intertwined Lives: Margaret Mead, Ruth Benedict, and Their Circle (New York: Vintage Books, 2004) at 417, describing an "exciting Washington environment [where] academics in government formed lunchtime study groups in government cafeterias and evening study groups in people's homes." Washington's intellectual milieu became increasingly international. For instance, from 1942 to 1946, Isaiah Berlin was stationed at the British embassy, where he was responsible for writing weekly reports on the American political scene. (See Joshua Cherniss \& Henry Hardy, "Isaiah Berlin," Stanford Encyclopedia of Philosophy, online: $<$ https://plato.stanford.edu/entries/berlin/.>)

${ }^{5}$ See also Peter Mandler, Return From the Natives: How Margaret Mead Won the Second World War and Lost the Cold War (New Haven: Yale University Press, 2013) at 65: "[C]ontemporaries estimated that a half of all anthropologists were employed in full-time war work. As early as December 1942, there were at least a hundred in in Washington, enough to hold a business meeting that substituted for the annual meeting of the American Anthropological Association."

${ }^{6}$ See Philippe Sands, East West Street: On the Origins of "Genocide" and "Crimes Against Humanity" (New York: Vintage Books, 2017) at 319. ("Lemkin socialized ... and became something of a man-about-town.")
} 
condemn the fascists' virulent racism. As I will show later in this chapter, at mid-century, on the cusp of the Cold War, there was likely no concept more influential than "culture."

This chapter contextualizes Lemkin's writings by situating them in the mid-century discourse on human groups and the value of group life. The first section considers Lemkin's ideas on nationalism in light of the lengthy discourse on nationalism. I argue that his ideas fit comfortably in the tradition of cultural or "ethical" nationalism, a tradition that remained lively at the onset of World War II. However, the Nazis' appropriation of the nationalist ideal as well as its increasing resonance in the colonial world tarnished nationalism, at least in the eyes of most Western thinkers. As the idea of nationalism fell out of favor, a world still obsessed with the vagaries of group relations turned to the anthropological idea of culture. The second section documents the mid-century influence of this idea and attempts a consensus view of what the term meant at that time. The third section considers Lemkin's writings on culture and genocide in light of this mid-century view and shows the profound influence of culture on his concept of genocide. To Lemkin, culture became the object of the Convention on the Prevention and Punishment of the Crime of Genocide's (the Genocide Convention's) protections and justified the Convention's interference in state sovereignty. ${ }^{7}$ Throughout this chapter, I point out that these views were not unique to Lemkin. Rather, in the war's immediate aftermath, a culturalist outlook such as the one adopted by Lemkin garnered a broad plurality of support.

\footnotetext{
${ }^{7}$ Convention on the Prevention and Punishment of the Crime of Genocide, 9 December 1948, 78 U.N.T.S. 277 (entered into force 12 January 1951).
} 


\section{Problems in Lemkin Scholarship}

Lemkin is a tempting subject for scholars. His life story is compelling, and he left a trove of papers that reveal both his skillful advocacy and the trajectory of his thought. A number of scholars have engaged with these materials, encouraging a more nuanced understanding of his thinking. Their efforts have been so prodigious that some have even declared the emergence of a new subfield of "Lemkin studies." ${ }^{8}$ However, as writings on Lemkin have proliferated, some analyses have fallen short, mostly by reading him out of context.

One group of scholars has emphasized what they refer to as Lemkin's "groupism." The failure of vocabulary here is telling. Western society, situated at what may be the twilight of neoliberal globalism, seems to have no ready terms for these concepts. After a half century of attack, concepts of "culture," "human groups," "nationalities," and the like have either been abandoned or denuded beyond usefulness. (In a time when a corporation or a university class can be said to possess a "culture," there seems little left of its earlier meaning. And the mere existence of "Red Sox nation" degrades the term's historical meaning.) Cora Diamond described this as "losing your concepts," a zero-sum process in which adopting one set of understandings negates others and either irreparably distorts concepts or renders them invisible. ${ }^{10}$ Among these distorted and invisible concepts are many

\footnotetext{
${ }^{8}$ See A. Dirk Moses, dust jacket blurb on Douglas Irvin-Erickson, Raphaël Lemkin and the Concept of Genocide (Philadelphia: University of Pennsylvania Press, 2017).

${ }^{9}$ See A. Dirk Moses, "Raphael Lemkin, Culture, and the Concept of Genocide" in Donald Bloxham \& A. Dirk Moses, The Oxford Handbook of Genocide Studies (Oxford: Oxford University Press, 2010) 1 at 22, discussing Lemkin's "groupism," and attributing the origin of the term to Rogers Brubaker, "Ethnicity Without Groups" in Andreas Wimmer et al, eds, Facing Ethnic Conflicts: Towards a New Realism (Lanham: Rowan and Littlefield, 2004). See also Ibid. at 67.

${ }^{10}$ Cora Diamond, "Losing Your Concepts" 98 Ethics (1988) 255-77.
} 
that are central to understanding the Genocide Convention, including our ideas about human groups and culture. Applying Diamond's insight, it seems we have lost the concepts that might enable us to understand what the Genocide Convention was all about.

This is not to say scholars have ignored the central place of concepts like culture and groups within Lemkin's thinking. Several have highlighted his ideas on culture and group life, crediting these ideas with forming the foundation of his idea of genocide. They emphasize the profound influence on Lemkin of the Herderian tradition of Romantic thought, which held group life precious. However, while Lemkin acknowledged his intellectual debt to Herder, these scholars slight Lemkin by locating his writings not in the mid-twentiethcentury context of the Genocide Convention, but in late-eighteenth-century, pre-unification Germany. This approach treats Lemkin as something of an eccentric crank, emphasizing his foreignness, his Jewishness, his abrasiveness. It presents his views as antique, idiosyncratic, or "atavistic," implying that Lemkin's concept of genocide succeeded not because it found broad support, but because the parties to the Genocide Convention misrecognized Lemkin's idea. ${ }^{11}$ According to this thinking, the parties accepted Lemkin's words but abandoned his meanings. Cosmopolitan Western-educated diplomats, these scholars assume, would not have, could not have, accepted Lemkin’s atavistic “groupism.” In picturing Lemkin as antique, foreign, and eccentric, these scholars bypass his engagement with then-current

\footnotetext{
${ }^{11}$ Adam Jones, Genocide: A Comprehensive Introduction, 2nd ed (Abingdon, UK: Routledge, 2010 ) at 12. Lemkin's attachment to ideas on human groups "was almost atavistic." See also Matthew Cole, "The Language of Genocide" Bass Connections Field Paper: (Fall 2014) 8-9 online:

$<$ http://kenan.ethics.duke.edu/humanrights/files/2014/10/20141120LanguageofGenocide-MatthewCole.pdf $>$, which finds that "those who prefer a more capacious definition of genocide, not to mention a less essentialist rendering of culture, have described Lemkin's argument as 'archaic,' 'illiberal,' and 'even atavistic."' [Footnotes omitted.]
} 
scholarship in the social sciences. Lemkin did cite Herder repeatedly, but he also cited Boas, Bergson, Eliot, Benedict and many other thinkers who were influential at that time.

While one group of genocide scholars has located Lemkin in the late eighteenth century, another reads him through the lens of the anti-totalitarian, anti-communist discourse that developed in the 1950s. Indeed, it seems the most common way to make sense of Lemkin is to read him through the work of Hannah Arendt. Arendt's work, especially The Origins of Totalitarianism (1951) and Eichmann in Jerusalem (1963) have become canonical texts, framing the way we think about tyranny, genocide, and the Holocaust. Her work, perhaps even more than Lemkin's, has come to serve as the foundational text of genocide studies. But no matter how much her insights resonate with today's scholars, those insights were unavailable to Lemkin and the Convention's drafters. The Genocide Convention did not have the benefits of Cold War insights.

In this chapter, I argue that Lemkin's ideas on culture and the importance of human groups were neither strange and idiosyncratic nor antique and atavistic. I will contextualize Lemkin's thinking not in the duchies of pre-unification Germany, nor in the antitotalitarianism discourses that arose in the Cold War, but in the war's immediate aftermath, when culture was king. I will demonstrate that Lemkin's ideas were of a piece with contemporaneous scholarship on nationalism. I will also point out that, at that time, the Herderian tradition was alive and well, masquerading as anthropological theory. As I explain below, Franz Boas, the father of modern anthropological thinking, was a product of the same intellectual milieu that nurtured Lemkin. Boas carried this "exotic" approach with him as he immigrated to the United States and used it to transform anthropological theory in the English-speaking world. Through the wide popularity of Boas's anthropological concept of 
culture, much of the Herderian Romantic tradition had been incorporated into Western popular and scholarly discourses. Although well disguised and transformed, Herderian thought was never so influential in the West as it was during World War II.

Throughout this chapter, I make extensive use of quotations in the text and especially in the footnotes. The aim is to re-create the intellectual milieu of the Genocide Convention's drafting. In doing so, it is necessary to sketch the longstanding debate on the relative importance of group life. While it has since abated, at mid-century this debate remained lively. Moreover, this reconstruction reveals a remarkable continuity of thought and language, which stretches back to the late eighteenth century. Of course, it is impossible to fully re-create historical context, and apparent continuities can be deceiving. Words change meaning and debates shift in emphasis. These are the hazards of any project in the history of ideas. Yet it does seem possible to reconstruct enough of this debate to show that Lemkin, as cranky and idiosyncratic as he was, was not isolated in his thinking. Instead, his writings reveal a deep understanding of the historical debate and an enthusiastic engagement with the ideas around him.

\section{Nationalism}

Writing in 1942, Georges Kaeckenbeeck, who later became an influential drafter of the Genocide Convention, declared nationalism "[ $\mathrm{t}]$ he quarrel one may always command." 12 He would have known. As president of the Arbitral Tribunal of Upper Silesia, he had

\footnotetext{
${ }^{12}$ Georges Kaeckenbeeck, The International Experiment in Upper Silesia (Oxford: Oxford University Press, 1942) at 222, paraphrasing Bacon, Essay on the True Greatness of Kingdoms and Estates (1612, expanded 1625) found in Homer B. Sprague, ed., Masterpieces of English Literature (New York: JW Schermerhorn \& Co, 1874) vol 1 at 101: "The Turk hath at hand, for cause of war, the propagation of his law or sect, a quarrel that he may always command."
} 
managed interwar relations between Poles, Germans, and Jews in that most contested place at that most dangerous time. After years at the heart of international efforts to mitigate interethnic conflicts, he declared "[t]he problem . . . a hard and bitter one."13

Hard and bitter indeed. Throughout the nineteenth century and into the twentieth, nationalism gained "an enormous resonance-first among large numbers of educated people and then within the broad populace - until it promised to displace all rival forms of loyalty and identification." 14 From the end of World War I, the lands between Germany and Russia had been plagued by constant inter-ethnic squabbles, which erupted during World War II into massive bloodletting as groups sought to rid territory of groups seen as competitors. The idea of nationalism was fuel on those flames. ${ }^{15}$ And yet, there should be no denying the power of

\footnotetext{
${ }^{13}$ Kaeckenbeeck, ibid. at 221.

${ }^{14}$ Geoff Eley and Ronald Grigor Suny, "Introduction" in Geoff Eley and Ronald Grigor Suny, eds., Becoming National: A Reader (Oxford: Oxford University Press, 1996) 1 at 11.

${ }^{15}$ Carlton J. H. Hayes, The Historical Evolution of Modern Nationalism (New York: Macmillan, 1948) vii-viii. Early twentieth-century scholars commonly distinguished between competing strands of nationalism. For instance, Hayes outlined five types of nationalism: "humanitarian" (Herder, Rousseau, Bolingbroke), from which the other forms had sprung; "democratic" or "Jacobin;" "traditional" (Burke, Bonald, Schlegel); "Liberal" (Bentham, Guizot, Welcker, Mazzini); "integral" (Nazis). See also Alfred Cobban, National SelfDetermination (Chicago: University of Chicago Press, 1944) 58-59. Cobban distinguished Western thought, which "tended to regard the nation as the result of a 'vouloir-vivre collectif', the product of a common consciousness which was derived far more from living in common and sharing common ideals than from any racial linguistic or cultural inheritance," from German or Eastern European ideas on nation, which were "struggling to move out of the field of culture into that of politics." But he also acknowledged that "in Western Europe cultural nationality was emerging from its political casing." (Ibid. at 59.) See also Hans Kohn, The Idea of Nationalism: A Study in its Origins and Background (New York: Macmillan Company, 1948) at 4: "Where the third estate became powerful in the eighteenth century - as in Great Britain, in France and in the United States - nationalism found its expression predominantly, but never exclusively, in political and economic changes. Where, on the other hand, the third estate was still weak and only in a budding stage at the beginning of the nineteenth century, as in Germany, Italy, and among the Slavonic peoples, nationalism found its expression predominantly in the cultural field." See also ibid. at 331:
}

Nationalism in the West was based upon a nationality which was the product of social and political factors; nationalism in Germany did not find its justification in a rational societal conception, it found it in the "natural" fact of a community, held together, not by the will of its members nor by any obligations of contract, but by traditional ties of kinship and status.

Louis Dumont, German Ideology: From France to Germany and Back (Chicago: University of Chicago Press, 1994) at 10 [Dumont, German Ideology], contrasts "ethnic" with "elective" nationalism, "which derives the nation from the will of the individuals that compose it." He asserts that "the Frenchman's "idea of himself". . 
the nationalist ideal in the lead-up to World War II, even among Western scholars and policymakers. For more than a century, the concept of nationalism had been invoked to explain nearly every social phenomenon. In the early twentieth century, there were vital arguments within nationalist framings, but very few actually stood outside of it.

For example, Sir Alfred Zimmern, historian and political theorist, believed nationalism was "one of the most formidable and sinister forces . . . and one of the chief obstacles to human progress at the present time."16 But he also lauded the "vast reservoir of spiritual power [that] is lying ready, in the form of national feeling, to the hands of teachers and statesmen, if only they can learn to direct it to wise and liberal ends." ${ }^{17} \mathrm{He}$ argued "that nationalism is not a mere fashion and foible, . . but springs from deep roots in man's inherited nature. You may cut these if you will, but you cut them at your peril." ${ }^{18}$ He believed that "nationalism rightly understood and cherished is a great uplifting and life-giving force, a bulwark alike against chauvinism and against materialism—against all the decivilizing impersonal forces which harass and degrade the minds and souls of modern men." 19

is [as] a man by nature and a Frenchman by accident, while the German feels he is first a German and then a man through his being a German.” (Ibid. at 199.)

${ }^{16}$ Alfred E. Zimmern, Nationality and Government With Other War-Time Essays (New York: Robert McBride \& Company, 1918) at 46 [Zimmern, Nationality and Government].

${ }^{17} \mathrm{Ibid}$. at 53.

${ }^{18}$ Ibid. at 99. He continued,

If you doubt this, just look around you. Compare the nationalists and the cosmopolitans or Bolsheviks of your own acquaintance; and ask yourself why it is that the latter are so often so arid, so cantankerous, so thin-blooded, so mean-spirited, so unworthy of their cause (which, after all, includes many noble elements, little as one might conclude so from most of its exponents). Such people are like cut flowers: they draw no nourishment from their native soil.

${ }^{19}$ Ibid. at 100. See also Franz Boas, Anthropology and Modern Life (New York: Dover, 1986) at 97 [Boas, Modern Life]. Even Boas, who stood against so much that the nationalists espoused, "recognize[d] in the realization of national ideals a definite advance that has benefited mankind." 
Liberals, who might have been put off by nationalism's holism, recognized its power and attempted to domesticate it to their ends. They believed enfranchised states faced constant centrifugal pressures that threatened to fracture society along class lines. In a fully democratic society, they asked: what would restrain the vast underclasses from using the state to requisition and redistribute wealth downward? Nationalism held the power to bind these disparate interests. ${ }^{20}$ Whether its power lay in unleashing the human potential nurtured within groups or in uniting nations against disintegrative forces, nationalism was considered crucial, if not unproblematic. As Zimmern despaired in 1918, "The whirligig of time and of events has made us all Nationalists now. ..."21

\footnotetext{
${ }^{20}$ Hayes, supra note 15 at 24, deduced from Rousseau's theories "quite logically the idea that a people - a nation - consists not of unequal classes but of individuals equal in rights and duties, and also the idea that a popular or national state is strictly secular and absolutely sovereign." Hayes, a prominent but controversial historian who was accused of being overly cozy with Franco when he served as FDR's wartime ambassador to Spain (see Peter Novick, That Noble Dream: The "Objectivity Question" and the American Historical Profession (Cambridge, UK: Cambridge University Press, 1988) at 321-22), declared nationalism "the driving force in the world today":

Since the eighteenth century the idea that each nationality should cherish its distinctive language and culture and should constitute an independent polity has been advanced by intellectual and political leaders in one country after another and has been accepted and acted upon by the masses of mankind. From elementary textbooks can be gathered the outlines of the swift story of how nationalism within a century and a half has consolidated France, unified Italy and Germany, and restored political independence of Poland, Finland, Norway, Czechoslovakia, Greece, and the Balkan states, whilst breaking up the Ottoman Empire, the Austrian Empire, the Russian Empire. From a sketchy perusal of newspapers can be gleaned the information that nationalism is stirring Hindus and Chinese and Turks and Filipinos and the most outlandish peoples and that it is threatening the security of overseas possessions of the great imperial powers of Europe and America. (Ibid. at 289.)
}

And Hayes continued, asserting, nationalism was so embedded in daily thought and activity that most took it for granted. "Without serious reflection they imagine it to be the most natural thing in the universe and assume it must have always existed." (Ibid.) But Hayes overestimated its staying power, for at the very moment he wrote his opus on nationalism, the concept was crumbling. See also Edward Hallett Carr, The Twenty Years Crisis, 1919-1939: An Introduction to the Study of International Relations (New York: St. Martin's Press, 1939) at 231. Carr lauded nationalism as "one of the forces by which the seemingly irreconcilable clash of interest between classes within the national community was reconciled."

${ }^{21}$ Zimmern, Nationality and Government, supra note 16 at 63. 


\section{Lemkin's Nationalism}

Although Lemkin decried the destructive proclivities of "egotistical nationalism," his theory of genocide is steeped in the long tradition of nationalist thought. He praised Giuseppe Mazzini as "the prophet of [the] nineteenth-century idea of nationality in a humanist, democratic form with a strong admixture of romanticism."22 In Axis Rule, Lemkin argued that civilizational progress is marked by "the respect for and appreciation of the national characteristics and qualities contributed to world culture by the different nations. ${ }^{23} \mathrm{He}$ declared that "nations are essential elements of the world community. The world represents only so much culture and intellectual vigor as are created by its component national groups. ${ }^{24}$ He continued,

Essentially the idea of a nation signifies constructive cooperation and original contributions, based upon genuine traditions, genuine culture, and a well-developed national psychology. The destruction of a nation, therefore, results in the loss of its future contributions to the world. Moreover, such destruction offends our feelings of morality and justice in much the same way as does the criminal killing of a human being: the crime in the one case as in the other is murder, though on a vastly greater scale. Among the basic features which have marked progress in civilization are the respect for and appreciation of the national characteristics and qualities contributed to world culture by the different nations - characteristics and qualities which, as illustrated in the contributions made by nations weak in defense and poor in economic resources, are not to be measured in terms of national power and wealth. ${ }^{25}$

${ }^{22}$ Raphael Lemkin, Lemkin on Genocide, Steven Leonard Jacobs, ed, (Lanham: Lexington Books, 2012) at 25 [Lemkin, on Genocide]. He continued,

Every people, [Mazzini] thought, become an independent nation, for "nationality is the share that God has assigned to any given people in the progress of humanity. It is a mission each people must fulfill.... It is the work which gives a people the right to citizenship in the world. It is the sign of that people's personality and of the rank it occupies among other peoples, like brother." Only when all people have become organized and independent nation-states, can an international federation of free nations be created.

${ }^{23}$ Raphael Lemkin, Axis Rule in Occupied Europe: Laws of Occupation, Analysis of Government, Proposals for Redress (New York: Howard Fertig, 1973) at 91.

${ }^{24}$ Ibid. at 91.

${ }^{25}$ Ibid. 
Thus, Lemkin espoused the basic tenets of nationalism according to which a nation is a

whole, integrated by culture and "national psychology." He argued that national groups

possess "characteristics and qualities," and he marked civilizational progress by the respect

and appreciation accorded to even the weakest, poorest nations for their contributions to "the

world."

Yet a footnote to this passage implies some ambivalence. Lemkin states that " $\mathrm{t}] \mathrm{he}$

idea of a nation should not, however, be confused with the idea of nationalism. To do so

would be to make the same mistake as confusing the idea of individual liberty with that of

egoism." ${ }^{26}$ That is, while the principle of individual liberty is good, it should not descend into

${ }^{26} \mathrm{Ibid}$. at note 51. Similarly, Lemkin quoted J. S. Mill, who

complained that nationalism makes men indifferent to the rights and interests "of any portion of the human species, save that which is called by the same name and speaks the same language as themselves." He also characterized the new feelings of exclusive nationalism and of appeals to historical rights as barbaric, and remarked bitterly that "in the backward parts of Europe and even (where better things might be expected) in Germany, the sentiment of nationalism so far outweighs the love of liberty that the people are willing to abet the rulers in crushing the liberty and independence of any people not of their race and language."

Thus, Lemkin uses Mill to condemn nationalist excess. However, Mill was very much a nationalist in the Herderian tradition, and one who acknowledged Herder's influence on his thinking. (See F. M. Barnard, Herder on Nationality, Humanity, and History (Montreal: McGill-Queen's University Press, 2003) at 95 (discussing Herder's influence on Mill: "Mill had made no secret of his indebtedness to Herder." citing as an example J.S. Mill, On Bentham and Coleridge, ed by F.R. Leavis [London: Chato and Windus, 1950]). While he recognized the complexities and even dangers of nationalism, Mill argued that " $[\mathrm{w}]$ here the sentiment of nationality exists in any force, there is a prima facie case for uniting all the members of the nationality under the same government, and a government to themselves apart. This is merely saying that the question of government ought to be decided by the governed." (John Stuart Mill, Considerations on Representative Government in Vincent P Pecora, ed, Nations and Identities: Classical Readings (Malden, MA: Wiley-Balckwell, 2001) 142 at 144). See also Raymond Williams, Culture and Society, 1780-1950 (London: Chato \& Windus, 1959) at 60, quoting J. S. Mill:

The culture of the human being has been carried to no ordinary height, and human nature had exhibited many of its noblest manifestations, not in Christian countries only, but in the ancient world, in Athens, Sparta, Rome; nay even barbarians, as the Germans, or still more unmitigated savages. The wild Indians, and again the Chinese, the Egyptians, the Arabs, all had their own education, their own culture; a culture which whatever might be its tendency upon the whole, had been successful in some respect or other. Every form of polity, every condition of society, whatever else it had done, formed its type of national character.

According to Mill, "[s]uch views are, more than anything else, the characteristic feature of the Goethian period of German literature; and are richly diffused through the historical and critical writings of the new French 
unbridled greed and selfishness. Likewise, the nation as a concept is valuable, but should not be used to justify the oppression of other nations.

This move - to dissociate the concept of nation and nationalism as a social theory from nationalism as a justification for violence and subjugation - is a recurrent theme in Lemkin's writings. He noted that

the evolution of nationalism from the eighteenth-century Herderian Romantic approach brought the cultural self-determination concept of the Revolution of 1848 up to the power complexes of twentieth-century nationalism. If nationalism was only contemplative in the eighteenth century, it became culturally atavistic in the nineteenth century and politically aggressive in the late nineteenth and the first half of the twentieth centuries. ${ }^{27}$

Discussing the increasingly powerful self-determination movements in Africa and Asia, he asserted that "[n]ationalism in itself, as long as it is limited to cultural expression and both economic and political independence, has nothing to do with genocide." 28 Yet he also acknowledged that "when coupled with the strive for power, aggrandizement, internal anxieties, and disrespect for minorities, it can well create a climate which, with certain conditions, might be misused for the perpetration of genocide."29

By today's standards, Lemkin seems to want it both ways: to embrace what he views as the positive communitarian aspects of nationalism while decrying the excesses of prejudice that can accompany it. However, at mid-century, Lemkin was hardly alone in his

school, as well as of Coleridge and his followers." (Quoted ibid.) And so, in using Mill to condemn the excesses of nationalism, Lemkin is endorsing the Herderian tradition of ethical nationalism, which Mill embraced.

${ }^{27}$ Lemkin, on Genocide supra note 22 at 52-53.

${ }^{28} \mathrm{Ibid}$. at 52-53. See also Lemkin, "The protection of Basic Human Rights of Minorities In the Forthcoming Peace Treaties" (undated) New York, American Jewish Historical Society (Box. 7, File 2, at 2) [AJHS]. Lemkin argued, "Ultranationalism fostered in the Axis satellite countries during World War II by totalitarian regimes, and even before the war by extremely militaristic cliques, left deep roots in the political thinking of Bulgaria, Roumania and Hungary. It is doubtful that the genocidal spirit of these nations will disappear in short order."

${ }^{29}$ Lemkin, on Genocide supra note 22 at 53. 
attempt to save nationalism from itself. This move to distinguish what many regarded as nationalism's beneficial aspects from its propensity to descend into chauvinism was a common theme that dated from the origins of nationalism, when Herder warned of “prejudice, loutishness, narrow nationalism." 30 In 1862, Lord Acton recognized nationalism as a necessary step in overturning absolute monarchies, yet damned it as "a confutation of democracy, because it sets limits to the exercise of the popular will, and substitutes for it a higher principle." ${ }^{31}$ Similarly, in 1915, Max Huber felt that "[t]he principle of nationality has fulfilled its mission. It has swept away the worn out political forms of feudalism and absolutism." 32 But he warned that when "the principle of nationality ceases to connote a claim for free development and ... toleration and becomes an element of hatred and of blind and reckless sate egoism, it leads to self-annihilation." 33 Thus, Lemkin was part of a lengthy tradition that believed nationalism was a force capable of yielding tremendous gains while also recognizing it could be misdirected to cause tragedy.

\footnotetext{
${ }^{30}$ Johan Gottfried Herder, Another Philosophy of History and Selected Political Writings, translated by Ioannis D. Evrigenis \& Daniel Pellerin (Indianapolis: Hackett, 2004) at 29 [Herder, Another]. See also Barnard, Herder on Nationality, supra note 26 at 35 . Herder was by no means "insensitive to the danger of nationalist chauvinism, "the most fatal malaise throughout history ... a fearful mania, to which in all epochs the feebleminded are particularly prone ... especially if politically induced." Quoting J. G. Herder, Sämtliche Werke, ed. B. Suphan (Berlin: Weidmann, 1877-1913) vol. XXIII p. 214. Contra J. Holland Rose, Nationality in Modern History (New York: Macmillan, 1916) 12, which argues that "when two or more hostile or jealous races coalesce, the result is a notable increase of mental vigor ...." Military collisions often cause cultural bloom. For, "[e]nlarge the outlook of peoples previously cramped and you quicken all their faculties. The result is frequently seen in an outburst of song, as happens with birds at mating time."

${ }^{31}$ Lord Acton, "Nationalism - the Last Phase of Revolution" in Alfred Zimmern, ed, Modern Political Doctrines (Oxford: Oxford University Press, 1939) 182, at 183 [Zimmern, Modern].

${ }^{32}$ Max Huber, "The Swiss Concept of the State" in Zimmern, ibid. at 215 at 216.

${ }^{33}$ Ibid. at 217.
} 


\section{Herder and the Roots of Cultural Nationalism}

Lemkin hewed to a particular strain of nationalism first enunciated by Herder in the

late eighteenth century and alternatively labelled "ethnic," "humanitarian," 34 or "cultural"35

nationalism. The Herderian tradition is relevant to the Genocide Convention in two primary

ways. First, Herder's ideas directly influenced Lemkin and shaped his idea of genocide. This

is wholly unsurprising given Lemkin's Central European education. Second, through its

importation as Boasian anthropological theory, the Herderian tradition also shaped Western

ideas on social and political relations at the time of the Genocide Convention's conclusion.

Thus, the Herderian tradition provided the intellectual heritage from which the Genocide

Convention emerged and informed the intellectual context in which the Convention was

drafted.

${ }^{34}$ See Koppel S. Pinson, "Introduction" in Simon Dubnow, Nationalism and History, ed by Koppel S. Pinson (Philadelphia: Jewish Publication Society of America, 1958) at 41: "[G]reat humanitarian nationalists, such as Herder, Mazzini, ... Masaryk, [and] Dubnow distinguis[h] sharply between a positive and negative kind of nationalism. Positive nationalism is human, an expression of national individuality and, above all, liberating in its effect. Negative nationalism is national egotism ... a nationalism that is motivated not by a desire to generate freedom and liberate the creative forces of a people but rather one of struggle and forced assimilation." See also Hayes, supra note 15 at 16-17. Of the doctrines of "humanitarian nationalism," which preceded all other manifestations of modern nationalism, Hayes wrote that

they all were infused with the spirit of the Enlightenment. They were based on natural law. They were evolved by more or less pure reason. They were presented as inevitable and therefore desirable steps in human progress. In object they were strictly humanitarian. They were urged, in truth, with motives so obviously humanitarian - with so kindly an eye to the wellbeing of the whole human race, with so touching a regard for the rights of other nationalities, and with so resentful an attitude toward jingoism and intolerance - that they may justly be described as variant species of a single humanitarian nationalism.

${ }^{35}$ Hayes, ibid. at 29:

Herder was interested only incidentally in politics. His absorbing interest was in culture. Indeed his greatest contribution was his conception of cultural nationalism, his exposition of what most basically distinguishes one nationality from another. Bolingbroke had assumed differences among nationalities and had founded his aristocratic nationalisms on such an assumption. Rousseau had talked much about "the people," and frequently as if it were a nationality, but he had nowhere clearly defined it. Herder elaborated a whole philosophy of nationality and national differences. 
For these reasons, I will explicate a few of Herder's key concepts-those of individuals, cultures, nations, and humanity—that will recur throughout this chapter. Herder's writings were voluminous and his ideas nuanced, so a comprehensive review of his thought is well beyond the scope of this thesis. However, highlighting these ideas makes it possible to trace their influence into the mid-twentieth century, when they contributed to the distinct intellectual climate of the Genocide Convention's drafting and conclusion.

In Herder's schema, the relation of an individual to her group is complex. He did not view the relation of the individual to the nation as a zero-sum one, in which the freedom accorded an individual was taken from the nation's sphere of authority, and vice versa. ${ }^{36}$ Happiness in any meaningful sense was secured by the individual's embeddedness in a nation, or nations. Individual wants, and therefore individual choices, occur within the specific social context of a nation and are shaped by that context. ${ }^{37}$

In the Herderian schema, the individual's relation to her context begins with language. Herder was the first to argue that the peculiarly human faculty of reason can only develop within language, that language sets the limits of what can be reasoned, and that

\footnotetext{
${ }^{36}$ Herder, Another, supra note 30 at 31: "No one is alone in his age; he builds on what has come before, which turns into and wants to be nothing but the foundation of the future." (Emphasis omitted). Frederick M. Barnard, Herder's Social and Political Thought: From Enlightenment to Nationalism (Oxford: Oxford University Press, $1965)$ at 146 explains,

He conceived "becoming" as both an individual and a social process, for, although he agreed that it was only meaningful to speak of "becoming" in terms of the development of individual human beings, he also insisted that man can develop his potentialities only as a member of society. And the social milieu that seemed to him the most conducive to man's "becoming" was that of an ethnic community or Volk. Herder's emphasis, therefore on the rights of nations rather than on the rights of individuals was not a denial of the importance of the individual. He was too much a child of his century to have thought of the moral in political summum bonum other than in terms of individual happiness. Nevertheless, in making the right to individual happiness and the development of individual potentialities contingent on man's membership of a national community, Herder marked the watershed which divides the "liberal" thought of the Enlightenment from nineteenth century liberalism in Europe [footnotes omitted].

${ }^{37}$ Sonia Sikka, Herder on Humanity and Cultural Difference: Enlightened Relativism (Cambridge: Cambridge University Press, 2011) 121.
} 
languages originate in specific geographical areas. ${ }^{38}$ This particular type of reason, bounded by language and shaped by geography, is the process by which a culture develops. ${ }^{39}$ It is something more than mere customs; it is quite literally a way of thinking. Possession of a common way of thinking and culture would coalesce into a culture group alternatively called a nation or Volk. ${ }^{40}$ Because culture is geographically demarcated, Herder reasoned, a harmonious state would be coextensive with the geography of a particular Volk or nation. ${ }^{41}$ But his ideas on this were complex; he also lauded the Jews, who lacked any state, as the preeminent example of a nation. ${ }^{42}$ At any rate, Herder was hostile to the idea of a state, believing that a harmonious nation would have no need for a repressive state apparatus. ${ }^{43}$ Nevertheless, Herder was an individualist of a sort. In fact, the individual retains a vital role in Herder's thinking. This should be unsurprising for, as Barnard points out, Herder, although he inspired the Romantics, was very much of the Enlightenment. Herder's

${ }^{38} \mathrm{Ibid}$. at 180.

${ }^{39} \mathrm{Ibid}$. at 212.

${ }^{40} \mathrm{Ibid}$. at 256.

${ }^{41}$ Dumont, German Ideology, supra note 15 at 25; Barnard, Herder's Social, supra note 36 at 59, quoting Herder: "“The most natural State is a community with its own national character.' . . States comprised of more than one nation were 'patched up fragile contraptions known as State-machines ... wholly devoid of inner life. . .. Without national character they are just life-less monsters." See also Cobban, supra note 14 at 56:

From this cultural idea of the nation Herder passed on, but only secondarily, to the idea of the nation as a political unity. His political theory is as simple as possible. The human race is naturally divided up into nations speaking different languages, and each nation should rightfully be a separate and independent state. That is the sum total of it, and if, put thus baldly, it sounds ridiculous, this does not affect its historical importance, for it is the view that has increasingly prevailed in modern Europe.

But see Barnard, Herder on Nationality, supra note 26 at 48-49, arguing that to Herder, a true nationstate would be able to dispense with the apparatus of power: "Ethnic ingredients, in conjunction with customs, legal traditions, and established standards of reciprocity were apparently sufficient agents of coordination and integration once a nation had attained political maturity."

42 Bernard, Herder on Nationality, ibid. at 40-41.

${ }^{43} \mathrm{Ibid}$. at 10 . "Herder was hostile to all states, and merely conceded that, though they were also artifacts, nation-states could be considered the least unnatural." (Emphasis in original). 
individuals are culturally determined but can shape that culture; they are culturally bound but can expand their horizons by encountering other cultures and languages. Herder did not value the individual for her ability to conform to the state; he judged the state according to its capacity to nurture individual genius. ${ }^{44}$

An individual's struggle for Bildung, her reaching to achieve her own personal destiny, occurs in relation to her cultural context. ${ }^{45}$ In the German tradition, Bildung connotes self-cultivation through education and personal transformation. But as Barnard relates, in the Herderian schema, "Bildung is identified not with a particular state of a person's accomplishments, 'breeding,' or refinement—its usual meaning in German—but rather with an interactive process in which humans draw from and add to their particular social heritage." ${ }^{\prime 6}$ The reciprocity of this relationship is vital.

Barnard argues that "Herder's advocacy of multiple affiliations, where individuals can move between, or belong to, a diversity of groups" should be distinguished from "the romantics [who] revived the medieval idea of social immobility and the total and exclusive

\footnotetext{
${ }^{44}$ Herder, Another, supra note 30 at 138: "It is evident from this what it is about the Roman constitution that actually made possible such a short but bright and worthy period for the sciences, namely, in part the need of the states at that high level of public affairs and in part the delightful example of its noblest men and families. How vital were the matters that the Roman orator addressed!" (Emphasis omitted.) See also ibid. at 135: "The air, the climate, the education, the character of the Greeks remains the same, but they lack the constitution, the government, without which they can never be what they were. The spirit animating their talents and limbs is gone; talents and limbs are dead." See also Barnard, Herder on Nationality, supra note 26 at 44.

${ }^{45}$ See Isaiah Berlin, The Crooked Timber of Humanity: Chapters in the History of Ideas, ed by Henry Hardy (New York: Vintage Books, 1992) 39 [Berlin, Crooked], arguing that in Herder's schema, "[m]en are not selfcreated: they are born into a stream of tradition, above all language, which shapes their thoughts and feelings, which they cannot shed or change, which forms their inner life." Louis Dumont, Essays on Individualism: Modern Ideology in Anthropological Perspective (Chicago: University of Chicago Press, 1986) at 130-131 at 138 [Dumont, Individualism]: "[I]n this sense, this purely internal individualism [bildung] leaves the surrounding holism standing."

${ }^{46}$ Barnard, Herder on Nationality, supra note 26 at 146 [emphasis and footnotes omitted].
} 
submission of an individual to a single group. ${ }^{, 47}$ Many scholars have missed this distinction.

They read Herder as a precursor to later German nationalists who "claim[ed] that an

individual human being could be reduced to a particular nation or culture." ${ }^{48}$ In Herder's

schema, individuals were nurtured by, not locked into, culture.

In the Herderian schema, nothing is more important than culture. ${ }^{49}$ To Herder, Kultur constituted both individuals and groups and served as the medium within which all of these things — individuals, culture groups, and nations — interacted. Herder used Kultur to embody the "manner and form" of a Volk's "collective consciousness," which, as Barnard points out, "was a new conception of the word, wholly at odds with the prevailing outlook of the Enlightenment which tended to identify culture with civilization and intellectual sophistication, opposing it to the original simplicity of nature." ${ }^{50}$ According to Herder's more egalitarian conception, culture is not restricted to those possessing the means to acquire the markers of distinction. Even the lowliest peasants contribute to, and are members of, a culture.

\footnotetext{
${ }^{47}$ Ibid. at 58.

${ }^{48}$ Douglas Irvin-Erickson, Raphaël Lemkin and the Concept of Genocide (Philadelphia: University of Pennsylvania Press, 2017) at 200.

${ }^{49}$ See Herder, Another, supra note 30 at 126: "Besides, the inequality of human beings by nature is not as great as it becomes through education, as the condition of one and the same people under diverse types of government shows." See also Barnard, Herder's Social, supra note 36 at 118 and at 143; Barnard, Herder on Nationality, supra note 26 at 10 . To Herder, culture "included all creative activities, whatever their content or place in the hierarchy of values. Nor did it exclude myths, legends, or even prejudices; for, to dismiss any of these, together with religion, as irrational vagaries, would be to deprive national cultures of significant moulding agents." (Emphasis in original.) See also Berlin, Crooked, supra note 45 at 55. Berlin contextualizes Herder's thinking on culture as part of a broader late-eighteenth century movement "critical of those who took it for granted that the past was to be judged by the degree of the proximity of its theory and practice to the canons of taste of our own enlightened day." He credits Herder as "[t]he most famous proponent of this approach."

${ }^{50}$ Barnard, Herder's Social, ibid. at 118.
} 
Possession of a common culture led groups to develop what Herder called a "national character" or "national genius." ${ }^{11}$ For, he argued, "[j]ust as entire nations have one language in common, so they also share favorite paths of the imagination, certain turns and objects of thought: in short, one genius that expresses itself ...." ${ }^{, 52}$ To Herder, a poet himself, poetry exemplified a nation's highest contribution because, "in words of poetry," "the entire soul of a nations shows itself most freely." ${ }^{53}$ And "[i]f poetry is the blossom of the human spirit, of human mores, ... then I should think he is happy to whom it is granted to pick that blossom from the crown of the tree of the most enlightened nation." ${ }^{54}$ According to Herder's oftemployed garden metaphor, the most enlightened nations possess the richest cultural soils that yield the best blossoms, blossoms the rest of the world could enjoy. But Herder's praise of the most enlightened nations should not be taken as cultural chauvinism.

To Herder, there could be no "favorit-volk," no culture, no people any better than another ${ }^{55}$ Sikka explains that Herder

claims, most basically, that every people should be appreciated for what it is, given that "every nation, in its time and place, was only that which it could be" while calling for awareness of one's own limitations as well as those of others. For Herder, the truly impartial vision regards every nation not with indifference to its merits and

\footnotetext{
${ }^{51}$ See Herder, Another, supra note 30 at 125-26. Herder believed national character was formed by a number of factors including climate, geography, and history, yet "education," by which he meant culture and other learned behaviours, was the strongest influence, mediating "physical" factors.

${ }^{52}$ Ibid. at 119.

${ }^{53} \mathrm{Ibid}$. at 119-20.

${ }^{54} \mathrm{Ibid}$. at 119 . He continued,

It is surely no small advantage of our inner life that we are able to speak not only with the Orientals and the ancients, but also with the noblest spirits of Italy, Spain, and France, and that they are able to notice with each how he sought to robe his heart's concepts and desires, those most ardent with him, in the most worthy fashion and to present them to the world present and future in an agreeable, even enrapturing, fashion.

${ }^{55}$ Barnard, Herder on Nationality, supra note 26 at 64.
} 
demerits, but with an equality of love, and this love does lead, within the ecology of Herder's thought, to a kind of deep ecology about human cultures, past and present. ${ }^{56}$

She again quotes Herder, stating, "The humblest genius hates comparison and ordering according to rank ... lichen moss, ferns, and the richest flowering herb; each blooms in its place in God's order." ${ }^{57}$ Thus, each group is unique, each has its spot in the greater order, and each makes an invaluable contribution to the whole.$^{58}$ Or as Isaiah Berlin put it, to Herder, "[a]11 cultures are equal in the sight of God, each in its time and place."59

But as Sikka argues, to the degree that Herder seems to favour relativism or incommensurability, these inclinations were limited. In his writings, Herder repeatedly critiqued other societies, so he cannot have believed such evaluations were impossible, as some have argued he did. ${ }^{60}$ Rather, Herder urged a hermeneutic approach, whereby different cultures "should be interpreted from their own perspectives, in light of their own values and ideals, rather than being viewed through an alien lens." ${ }^{91}$ Herder's thought leads not to relativistic skepticism, but to an abiding political and methodological pluralism.

\footnotetext{
${ }^{56}$ Sikka, supra note 37 at 86 [emphasis and footnotes omitted].

${ }^{57} \mathrm{Ibid}$. See also Herder, Another, supra note 30 at 28. As if to declare which human societies have been the happiest, he argued that "human nature is no vessel for an absolute, independent, immutable happiness, as defined by the philosopher; rather, she everywhere draws as mush happiness towards herself as she can: a supple clay that will conform to the most different situations, needs, and depressions. Even the image of happiness changes with every condition and location...."

${ }^{58}$ Isaiah Berlin, Vico and Herder: Two Studies in the History of Ideas (New York: Viking Press, 1976) at 212 [Berlin, Vico and Herder]. As Berlin explains, "Each 'collective individuality' is unique, and has its own aims and standards, which will themselves inevitably be superseded by other goals and values - ethical, social, and aesthetic. Each of these systems is objectively valid in its own day, in the course of 'Nature's long year' which brings all things to pass."

${ }^{59} \mathrm{Ibid}$.

${ }^{60}$ Sikka, supra note 37 at 26 . As Sikka explains, "Herder also thinks that suspending one's cultural values so as to approach the study of others in a non-partisan spirit has moral benefits for oneself, as such an approach more easily permits one's own cultural prejudices to be put into question and facilitates learning something genuinely new." (Ibid. at 28.)

${ }^{61} \mathrm{Ibid}$. at 26.
} 
Although cultures were distinct, this did not prevent inter-cultural borrowings. ${ }^{62}$ Herder lauded the processes by which cultures were strengthened by the cultural contributions of other cultures, whether those cultures were historically antecedent or geographically adjacent: 63 "The history of Europe Herder traces in the Ideas contains many such moments of renewal, from the incursion of northern Germanic tribes from the north, to the renaissance of a Greek heritage that had fortunately been preserved in the Arab world. At such moments, an exhausted culture rises again." ${ }^{64}$ Thus, Herder recognized, as Sikka puts it, "that new cultural identities are born from fusions," that "the majority of peoples at advanced stages of history are the product of many such fusions." ${ }^{65}$ Yet Herder also decried the degradation of the Jewish nation, which had dispersed across other cultures and been subjected to assimilationist pressures as Jews took up local languages. To Herder, diversityof individuals, cultures, and nations — is a qualified good. Through the exchange of cultural values and ideas, each might be enriched, and by its diverse influences Humanität is made stronger. Yet he mourned the passing of pure cultures. ${ }^{66}$

In addition to existing in relation to one another, the individual, the Kultur, and the nation interact with Humanität. To Herder, "[t]he goal is humanität," which "is the common

\footnotetext{
${ }^{62}$ Ibid. at 21, quoting Herder: "A notable expansion takes place in the human soul when it dares to venture outside the circle that climate and education have drawn around it."

${ }^{63}$ Herder, Another, supra note 30 at 18: "How much the education of Europe owes to the swindling, avaricious Phoenician!" See also ibid. at 19-21.

${ }^{64}$ Sikka, supra note 37 at 105.

${ }^{65}$ Sikka, supra note 37 at 172.

${ }^{66}$ Herder, Another, supra note 30 at 21: "That Greece received seeds of culture, language, arts, and sciences from elsewhere strikes me as undeniable and is easily demonstrated by their sculpture, architecture, mythology, literature." And ibid. at 20: "Yet who could deny that, just thereby, unspeakably much of the old, earlier strength and nourishment had to be lost? As the Egyptian hieroglyphs were stripped of their heavy cover, it is always possible that something deep, meaningful, natural, which had been the character of this nation, would have evaporated as it crossed the sea." [Emphasis omitted.]
} 
ideal to which each nation contributes by unfolding the potentialities that are proper to it, by tending its own plot in the garden of humanity." ${ }^{67}$ As Sikka explains, it is because "Herder believes that human beings possess Humanität as a common nature that he can posit for them Humanität as a common goal." 68 Barnard quotes Herder to argue that "[i]t is the very essence of Humanität that it should forge the links between man as a member of a national and of humanity at large: 'Serve the State, if you must and serve humanity, if you can', is its 'categorical imperative." 69 But "a belief in Humanität does not displace the belief in Nationalität."70 To Herder, "nationalism and internationalism were not currents that ran in opposite directions but rather successive stages of historical development." ${ }^{, 71}$ According to Barnard, "The sort of international 'unity' that Herder had in mind was essentially the consciousness of common interests, needs and purposes of diverse nations, each of which

\footnotetext{
${ }^{67}$ Sikka, supra note 37 at $86-87$.

${ }^{68} \mathrm{Ibid}$. at 21.

${ }^{69}$ Barnard, Herder's Social, supra note 36. at 94.

${ }^{70}$ Barnard, Herder on Nationality, supra note 26 at 73.

${ }^{71}$ Barnard, Herder's Social, supra note 36 at 86 . See also Ernest Renan, "What is a Nation?" in Zimmern, Modern, supra note 31, 188 at 204. Renan believed nations would one day dissolve into a confederated Europe. But he also argued, "Nowadays it is a good, and even a necessary, thing that nations should exist. Their existence is the guarantee of liberty, which would be lost, if the world had but one law and one master." The relationship between nationalism and internationalism was, to say the least, complex. Yet few would deny nationalism a role. See Zimmern, Nationality and Government, supra note 16 at 61:"[T] he road to Internationalism lies through Nationalism" and "no theory or ideal of Internationalism can be helpful in our thinking or effective in practice unless it is based on a right understanding of the place which national sentiment occupies and must always occupies in the life of mankind." Hayes, supra note 15 at 11-12, defined internationalism as "a relationship between states which presumably are national and nationalist and also it is a movement for sympathetic understanding, mutual comity, and universal peace among the several self-conscious nations. . . . In this sense, internationalism presupposes nationalism." See also J. Holland Rose, Nationality in Modern History (New York: Macmillan, 1916) 202. Rose, writing in 1916, believed nationalism was a stage in the development of broader, more benevolent internationalism. Ending his influential book on Nationality in Modern History, he predicted that, moving forward, Europe "would be happier than ever" because "all the great peoples will have sorted themselves out, like to like; and it may be assumed that all dynasties hostile to that healthy process will have disappeared." He looked forward to the not-so-distant time when "civic freedom and "national solidarity" will have weakened "the national instinct" to merge into "the nobler sentiment of human brotherhood. ..."
} 
had a natural right to separate and independent existence."72 He was dismissive of "empty

cosmopolitanism" that desired the elimination of difference. His universality would jealously

guard particularity.

Herder believed in human universals, "roughly common concepts or ethical rules,"

but reason — a product of language and culture and therefore relative — was not one of them. ${ }^{73}$

\section{Dummont reads Herder's work as}

an impassioned polemic against the Enlightenment with it [sic] platitudinous rationalism and its narrow conception of progress and, above all, against the hegemony of that universalist rationalism which despises all that is foreign to it and presumes to impose its senile refinement everywhere. . . . Instead of history consisting in the accession of reason, a reason disembodied and everywhere identical to itself, Herder sees in history the contrasted interplay of individual cultures or cultural individuals, each constituting a specific human community, or Volk, in which an aspect of general humanity is embodied in a unique and irreplaceable manner. ${ }^{74}$

\footnotetext{
${ }^{72}$ Barnard, Herder's Social, supra note 36 at 105. See also Sikka, supra note 37 at, 123-23, discussing Herder's universalism:

He is perfectly aware that there are conditions of want and oppression under which human beings cannot be happy, and that these can be both diagnosed and ameliorated. What one cannot do, he suggests, is to compare and rank the happiness of happy individuals across different cultures. And that happiness is not merely idiosyncratic; it is the product of a given society. There is then a very real sense in which one cannot assess whether there is "progress" in individual happiness over history, as the forms of happiness which different societies enable are incommensurable. This view is not inconsistent with allowing the possibility of some increase in the overall sum of human happiness as a result of the progressive realization of the moral and political ideals Herder supported.
}

E. P. Thompson, The Romantics: England in a Revolutionary Age (New York: The New Press, 1997) at 9. Romantics incorporated these ideas, applying them not only to individuals, but also to nations. See, Hayes, supra note 15 at 22, discussing Bolingbroke's conception of nationalism, which "was humanitarian. Every nationality had a 'genius' and every nationality was entitled to a polity consonant with its genius."

${ }^{73}$ See Sikka, supra note 37 at 212. See also Barnard, Herder on Nationality, supra note 26 at 92:

Herder affirmed the principle of individual self-direction and personal accountability, and . . expressed serious misgivings about its exclusively secular are rationalist underpinnings. This is not because he was the inveterate antagonist of the Enlightenment that he is at times taken for, but because he questioned the excessively "universalist" and "progressivist" understandings of the inherited concept of Humanität in the Age of Reason. We are not rational automats, nor are we capable of global brotherhood, of lovingly embracing millions of our fellows - as Schiller sings in the "Ode to Joy"-for no human life is as extensive as that."

\footnotetext{
${ }^{74}$ Dumont, Individualism, supra note 45 at 116 (footnotes omitted).
} 
Herder believed, as Sikka puts it, that "[r]eflection is the most fundamental shared capacity, the one that defines the species, and it is responsible for the fact that human beings are creatures of culture." 75 Thus our common humanity is not found in the capacity for reason but in the universal human capacity for language, reflection, and culture.

Although their shape or content is historically contingent, these things—individuals, cultures, nations, and Humanität — are each imbued with a purpose or destiny. For Herder, like the other Romanticists, movement is everything and thus each is more a process than a status. ${ }^{76}$ Each must pursue its unique struggle for Bildung. And these entities are in relation with one another. An individual can only exist within a culture, yet she also affects the shape or content of that culture. Similarly, nations form the bedrock of Humanität. But they also shape the nature of Humanität while at the same time being nurtured by it. Because of this relational, processual schema, failure in any aspect can affect the whole. An individual deprived of her freedom to pursue Bildung cannot affect positive change in the culture, depriving not only the nation, but all humanity, of her gift.

Finally it is worth noting the Herderian tradition's pervasive holism. To Herder, the individual and the nation are "mutually inter-dependent [yet] none the less unique and active wholes in themselves." ${ }^{.77}$ As a collective individual, a nation, like an individual, possesses a personality, unique and irreplaceable, which we would call culture. The seeds of Herder's holism bore fruit for, as Dumont argues, throughout the nineteenth century the many

\footnotetext{
${ }^{75}$ Sikka, supra note 37 at 212.

${ }^{76}$ Barnard, Herder on Nationality, supra note 26 at 82; Isaiah Berlin, The Roots of Romanticism (Princeton: Princeton University Press, 1999) at 138.

${ }^{77}$ Barnard, Herder's Social, supra note 36 at 69.
} 
competing conceptions of nationalism coalesced around "an antinomy internal to the nation as being both a collection of individuals and a collective individual."78

Although often unrecognized, Herder's influence was profound. ${ }^{79}$ Goethe, whom he counted as a personal friend, was moved by Herder's thinking. ${ }^{80}$ So too was Hegel, who built his philosophy of history on Herder's foundation. ${ }^{81}$ Mathew Arnold, who introduced the "literary idea of culture" to the English-speaking world, also credited Herder, ${ }^{82}$ as did J. S. Mill. ${ }^{83}$ Wilhelm Dilthey and Max Weber celebrated Herder's contribution, especially his

\footnotetext{
${ }^{78}$ Dumont, Individualism, supra note 45 at 130-131, argued that in developing the idea of kultur, the Germans had already accepted and incorporated into their thinking a deep sense of individualism, a heritage of Luther's Protestantism. See also Dumont, German Ideology, supra note 15 at 10. He describes the Herderian conception of nation as a Janus. "On the one hand, it is a vindication of Teutonic culture and an application of the holistic perception, on the other it considers the cultures from the vantage point of an individualistic universalism that was simply transposed from one level to another. Through the latter it adheres to individualism and extends it." I have provided a rather positive sketch of Herder's political ideas, focusing on those ideas that Lemkin seemed to incorporate into his own work. But Herder likely would have been the first to object to this rendering of his thinking. Given his radical historicism, his insistence that writings be judged within the context of their generation, he must have known aspects of his thought would not age well. As he put it, "[t]here is no doubt that even Machiavelli, in our age would not have written as he wrote." . . " [S]till it would be a blessing if these changes were made, and everyone who wrote like Machiavelli were stoned." (Herder, Another, supra note 30 at 90.) Over time, a few of Herder's ideas have come to seem untoward. He deserves his share of criticisms, as all of us will eventually. But considering his underlying ethical pluralism, anti-racism, anti-colonialism, and his egalitarianism, he deserves far fewer criticisms than many of his contemporaries. It is easy to understand how Herder's ideas continued to inspire, well into the twentieth century.
}

${ }^{79}$ See Berlin, Vico and Herder, supra note 58 at 212. "The consequences of Herder's doctrines did not make themselves felt immediately ... a and perhaps [do] not altogether even today." Berlin credited

Herder's dominant influence on romanticism, vitalism, existentialism, and, above all, on social psychology, which he all but founded; as well as the use made of his imprecise, often inconsistent, but always many-faceted and stimulating thought by such writers as the Schlegels and Jakob Grimm (especially in their philological excursions), Savigny (who applied to law his notions of organic national growth), Görres (whose nationalism is rooted in, even if it distorts, Herder's vision), Hegel (whose concepts of becoming, and of the growth and personality of impersonal institutions, begin their lives in Herder's pages), as well as historical geographers, social anthropologists, philosophers of language and of history, and historical writers in the nineteenth and twentieth centuries. (Ibid. at 147, note 1.)

${ }^{80}$ Ioannis D. Evrigenis \& Daniel Pellerin, "Introduction" in Johann Gottfried Herder, Another Philosophy of History translated by Ioannis D. Evrigenis \& Daniel Pellerin (Hackett Publishing, Indianapolis; 2004) at Xv.

${ }^{81}$ Ioannis D. Evrigenis \& Daniel Pellerin, "Introduction" in Johann Gottfried Herder, Another Philosophy of History translated by Ioannis D. Evrigenis \& Daniel Pellerin (Hackett Publishing, Indianapolis; 2004) at xxxix.

${ }^{82}$ Matthew Arnold, Culture and Anarchy (Dog's Tails Books) at 34.

${ }^{83}$ Barnard, Herder's Social, supra note 36 at 3. 
conception of Verstehen ${ }^{84}$ Herder is widely regarded as a founder of the German

Romanticist movement, while his esteem of Slavic identity made his thought popular in central and eastern Europe. ${ }^{85}$ Yet the true reach of Herder's influence has often gone unrecognized, for, as Barnard argues, "[s]o many [of his] words and concepts ... have entered the thought and speech patterns of intellectual discourse that their users are no longer aware of their Herderian origins." 86 This is especially true in discussions of genocide, which revolve around questions of individuality, group life, and humanity. Whether we realize it or not, we are all arguing in Herder's shadow. ${ }^{87}$

One of those inspired by Herderian thought was Simon Dubnow, a historian of Judaism and prominent Central European thinker. ${ }^{88}$ Lemkin's autobiography recounts that in 1939, as he fled the Nazi invasion of Poland, he stopped in Riga to visit Dubnow, who offered encouragement for the project to outlaw group destruction. ${ }^{89}$ Douglass IrvinErickson, in his recent book on Lemkin's thought, credits Dubnow's work with exerting a

\footnotetext{
${ }^{84}$ Barnard, Herder on Nationality, supra note 26 at 7.

${ }^{85}$ Barnard, Herder's Social, supra note 36 at 153-177.

${ }^{86}$ Barnard, Herder on Nationality, supra note 26 at 5. Terms Herder originated include Nationalcharakter, Volksleid, and Zeitgeist.

${ }^{87}$ Isaiah Berlin, Vico and Herder, supra note 58 at 176. As Berlin put it, "[a]ll regionalists, all defenders of the local against the universal, all champions of deeply rooted forms of life, both reactionary and progressive, both genuine humanists and obscurantist opponents of scientific advance, owe something, whether they know it or not, to the doctrines which Herder . . . introduced into European thought."

${ }^{88}$ See Dubnow, supra note 34 at 103, citing Herder's ideas.

${ }^{89}$ Lemkin, Totally Unofficial, supra note 2 at 71-72. Notably, Lemkin claims Dubnow praised his ideas for group protections, but is silent as to his opinion on Dubnow's work. Lemkin also reported pleading with Dubnow to flee the Nazis, but Dubnow resisted, minimizing the danger. Dubnow was later killed as the Nazis expanded their occupation of Poland. See also Koppel S. Pinson, supra note 34 at 8. On December 8, 1941, the eighty-one-year-old Dubnow "was driven into the street together with all the other aged and feeble Jews and ordered into a waiting bus. Dubnow, sick and with high fever, did not move quickly enough ... whereupon a drunken Latvian guard fired a bullet into him." He died instantly and "was buried in a mass grave in the Jewish cemetery in Riga."
} 
profound influence on Lemkin's idea of genocide.${ }^{90}$ It is difficult to assess the degree of Dubnow's direct influence on Lemkin, because, while he cites many writers as shaping his ideas, Lemkin never directly cites Dubnow. ${ }^{91}$ However, as a leading Jewish thinker of Lemkin's time, Dubnow is likely someone whom Lemkin would have read and admired..$^{92}$ At the very least, Dubnow's work shows the power that Herder's cultural nationalism retained into the mid-twentieth century.

Despite their lack of a territory, Dubnow, like Herder, insisted that the Jews formed a legitimate nation. In fact, he argued that the lack of territory benefited the Jews, because it fostered a focus on the spiritual and the cultural. He argued that "the decisive factor for the destiny of a nation is not its external power but its spiritual force, the quality of its culture and the inner cohesion of its members." ${ }^{" 93}$ For "the future of the nation depends mainly on the depth of this consciousness, on the strength of the national spirit, on the power of the cultural

\footnotetext{
${ }^{90}$ Irvin Erickson, supra note 48 at 59-60.

${ }^{91} \mathrm{Ibid}$. at 264, note 99, cites index cards found in Lemkin's papers (AJHS). This may be an instance of Lemkin tailoring his citations to suit an English-speaking audience that would have been largely unfamiliar with Dubnow. Or Lemkin, as he often did, might have been minimizing his connection to Jewish influences as he sought to universalize the appeal of his ideas. Lemkin's published writings do mention Heine and Herder but never Dubnow. Irvin-Erickson claims that " $[\mathrm{w}]$ hereas liberal thinkers - from Woodrow Wilson to John Stuart Mill — saw nations as communities with concrete borders defined by blood or language, Lemkin followed national cultural autonomy theorists, ... the Austro-Hungarian Social Democrats, Otto Bauer and Karl Renner." (Ibid. at 59.) But again, while Lemkin quoted Mill, he never mentioned Bauer or Renner. (See Erickson, ibid. at 201, note 26 [quoting Lemkin, citing Mill].) To support his contention, Irvin-Erikson cites an "intuition" on the part of A. Dirk Moses. (Ibid. at 263, fn. 92, citing Moses, supra note 9 at 24).

${ }^{92}$ Irvin Erickson, ibid. at 59, argues that "Lemkin was not simply absorbing these ideas from his milieu in the 1930s but directly drawing on Dubnow as an inspiration, taking seriously the historian's thinking on the Soviet destruction of the Jews."

${ }^{93} \mathrm{Ibid}$. at 79.
} 
foundation created over generations and on the ability of the nation to further develop its creative powers." 94

Stripped of territorial concerns, Dubnow's was a particularly culturalist conception of nationalism. His nations were "individuals" with "collective personalities." He believed that "[t]o the degree that a people creates its own history it is itself in equal measure created by it. In each generation it creates its own culture and is itself in turn the product of the creative efforts of all past generations. A nation is not merely an aggregate of individuals, but also of successive generations, a community of the living and the dead." interact in a living nation: the accumulation of culture and accumulated culture, the efforts of the living generation and the cultural storehouse and creative tools of the preceding generations." ${ }^{" 96}$ It follows that "[t]he national principle stands between the individual and the social principle. It is not the abstract man, but the man as a member of a definite nationality, that is the actual member of the social organism."97 Thus, "[i]t is the fruitful and creative will of a national group to remain true to itself, to improve and to adorn its historical forms, and to defend the freedom of its collective personality." $" 98$

Dubnow distinguished "ethical nationalism" from what he derided as "national egotism," "which represents the ambition of the ruling nationality to dominate over the

\footnotetext{
${ }^{94} \mathrm{Ibid}$. at 80 . See also Barnard, Herder on Nationality, supra note 26 at 20, noting that the history of Judaism played a foundational role in Herder's idea of the nation and that he too appeared to consider Jews the preeminent example of a nation, though they lacked a national territory.

${ }^{95}$ Dubnow, supra note 34 at 85 . Compare Herder, Another, supra note 30 at 31 . "No one is alone in his age; he builds on what has come before, which turns into and wants to be nothing but the foundations of the future."

${ }^{96}$ Ibid.

${ }^{97} \mathrm{Ibid}$. at 97.

${ }^{98} \mathrm{Ibid}$. at 95
} 
dependent national groups." ${ }^{99} \mathrm{He}$ declared, "If the nineteenth century was able to secure the legal recognition by the community of the principle of freedom of the individual, the twentieth century is faced with the task of establishing the freedom or autonomy of the national individual." 100 To Dubnow,

[t]he logical conclusion from the concept of national individuality is that, if I accept the right and, what is more, the duty to protect my own national individuality, I must accord the same right to members of other nationalities. And if my own national aspirations and tendencies have ethical value in my own eyes, then I must also respect the national aspirations and tendencies of other peoples and honor them as much as my own. ${ }^{101}$

Thus, "the curtailment of the freedom on another nationality is as much a crime as the protection of the freedom on a national individuality is a moral duty." ${ }^{102}$ For, he contended, "[a]ll national cultural groups, irrespective of their size or political conditions, are equal with respect to the sanctity of their national rights." 103

\footnotetext{
${ }^{99} \mathrm{Ibid}$. at 96. He continued, "It constitutes the negation of freedom and equality in relations between nationalities. National egotism is characterized by strife, hostility and aggression; national individualism fights only in self-defense."

${ }^{100} \mathrm{Ibid}$. at 141. He also declared that "in keeping with the principles of ethics and social progress symbolized in the slogan of Liberty, Equality and Fraternity ... [t] the freedom of the national individual flows from the individual as a human being. Just as the individual enjoys freedom in the community, the nation also needs to be free in the international community."

${ }^{101} \mathrm{Ibid}$. at 129.

102 Ibid. at 101.

${ }^{103} \mathrm{Ibid}$. at 96. See also Lemkin, Totally Unofficial, supra note 2 at 126-27. Lemkin recounts another fortuitous encounter, this one with Jan Masaryk, Czechoslovakia's Minister of Foreign Affairs. Lemkin recalled using flattery to enlist Masaryk's aid in convincing the Soviets to support UNGA Resolution 96(1). Lemkin claimed he "had known the Masaryk family." He said, "Your Excellency, I have studied the writings of your father, Professor Tomáš Masaryk, who devoted his life to explaining the cultural personality of nations, not only to his own people, but to the world at large." Lemkin continued, "When a nation is murdered, its culture goes too. The dead cannot write literature. Through its culture, the life of a nation continues, when the physical life of the individual members is finished." Interestingly, Jan Masaryk was also to meet a violent end when he was forcibly defenestrated on March 10, 1948, likely the victim of communist agents. (See Robert England, "The Masaryk Mystery" 3 Dalhousie Rev (1952) 26.) The father, Tomáš Masaryk, was not only a leading sociologist and political philosopher, but, after playing a critical role in cleaving Czechoslovakia from the Austrian Empire, served as its first president, from 1918 through 1935. It is unclear how well Lemkin may have known the Masaryk family, as we know relatively little of his pre-immigration activities. But it is clear that Lemkin and President Masaryk shared a common interest in the type of cultural nationalism first espoused by Herder. See
} 


\section{Lemkin, the Ethical Nationalist}

The effect of the Herderian tradition on Lemkin was profound. He regarded "[n]ational freedom [as] a basic prerequisite for cultural creation and thus it is a natural condition for a nation's mission in the world." ${ }^{104}$ Lemkin insisted that, "The mission, without becoming a mythical or an over-emotional concept must not overstep the natural boundaries of a nation's own freedom nor the freedom of other nations. It must lead neither to exclusiveness nor to aggressive nationalism." 105 And he argued that "[t]he interest in other nations must not lead to subjugation, but to seeking a common grouping for cooperation in order to enrich common civilization and to establish a ... system for protecting the basic values of mankind." 106 Echoing Herder, he argued,

The right of nations to exist as nations and bearers of national cultures is not a privilege given by the strong to the weak. Every nation fulfills a necessary function in enriching world civilization through its own culture. It works like a concert in which every national culture represents a different musical part and contributes on its own to the harmony of the whole. If one musical instrument is destroyed, the harmony of the concert and the full and rich quality of the performance is gone. A multiplicity and variety of tones are basic for the creation of music so the variety of cultural

Barnard, Herder on Nationality, supra note 26 at 85. Barnard, a leading Herder scholar, declares it "no exaggeration to say that the similarity between the ideas of Thomas Masaryk and those of Herder is at times breathtaking."

${ }^{104}$ Lemkin, "Philosophical and Legal Aspects of the Word Genocide," Cincinnati, The Jacob Rader Marcus Center of the American Jewish Archives, Raphael Lemkin Papers [AJA] (undated, unpaginated) (Box 3, File 3. p. 2) [Lemkin, "Philosophical"].

${ }^{105} \mathrm{Ibid}$. See also Lemkin, "Definition” (Nature of Genocide), New York, American Jewish Historical Society, Raphael Lemkin Collection (Box 7, File 2 (undated) p. 17) [AJHS]. Echoing the long tradition of nationalist thought, Lemkin believed "[a] national group leads a common life based upon the conscience of a common culture, common heritage, and common ideals and aspirations for the group conceived as an entity." Among those groups thinking themselves into existence, he included the "Americans, Frenchmen, the Poles, the Czechs, the Irish," which are "groups because they have this conscience of being responsible for their common heritage to be preserved and cultivated in the future." But while he lauded the accomplishments of these groups, he recognized that "[t]his way of life puts these groups in conflict with other groups." These "[n]ational groups mostly subsist on their own territory. Sometimes their territory is taken over by other groups which try to exterminate the first in a so-called peaceful process of mass destruction."

${ }^{106}$ Lemkin, "Philosophical and Legal Aspects of the Word Genocide," AJA, supra note 104 (Box 3, File 3. p. $2)$. 
contributions is basic for the very process of world creation in the field of culture. Cultural pluralism means full and free cultural life. Cultural uniformity means poverty, decay and enslavement. ${ }^{107}$

Thus, to Lemkin, as to Herder, the recognition of national identity was a means of safeguarding the contributions of even the most marginal groups to humanity. ${ }^{108}$

\section{Nationalism Fades}

The humane and ethical nationalism of Herder and Dubnow, among others, stands in stark contrast to the nationalism of the Nazis. Fascist nationalism emphasized the genetic component, described at the time as "blood nationalism," which had long existed, to varying degrees, across the spectrum of nationalist doctrine. ${ }^{109}$ Boas asserted this was a "confusion

${ }^{107}$ Ibid. See also Lemkin, Part I, Ch. II, Sec. II. p. 3 "The Nature of the Groups Concerned," AJA supra note 104 (Box 7, File 2) [Lemkin, "Nature of Groups"]: "The world at large can be compared to a concerto in which every nation brings the tone of its own instrument. It is the harmony and interplay of individual musical tonations which make the beauty of the concert." Notably, Lemkin's oft-quoted but overwrought orchestral analogy was not his own. Renan, supra note 71 at 204, had used it, and it was common to mid-century discussions of culture, nation, and internationalism: "By their various, and often contrasting, attainment, the nations serve the common task of humanity; and all play some instrument in that grand orchestral concert of mankind, which is, after all the highest ideal reality that we attain.” (Ibid.) See also Inis Claude, National Minorities: An International Problem (Cambridge, Harvard University Press,1955) 85, describing the common twentieth-century view that "[e]ach nation has a unique tone to sound in the symphony of human culture; each nation is an indispensable and irreplaceable player in the orchestra of humanity." Lemkin's orchestral metaphor is a notable update on Herder's "favourite" botanical metaphor, in which, as Sonia Sikka recounts, "the world [is] a garden in which plants grow in harmony with one another, forming a beautiful and peaceful whole, but remaining in their separate spots." (Sikka, supra note 37 at 246). In Lemkin's metaphor, the elements which comprise the orchestral whole are fluid and variable, moving separately but harmoniously to constitute the whole. By contrast, tending Herder's garden means fixing the constituent plants to a geographical location and implies a mandate to weed out those considered to be non-conformists or interlopers, an unfortunate image given subsequent events.

${ }^{108}$ Lemkin, "Nature of Groups," ibid. And yet, Lemkin also acknowledged "The originality of culture arises in itself two elements; a blessing to mankind and the seeds of self destruction. Original cultures do not come from a vacuum, nor do they enter a vacuum. They rather enter a space which is already impregnated by another culture. ... Tension or conflict between cultures arise." He gave examples of "bloody conflicts" between paganism and Christianity, Christianity and Islam, the Poles and the Russians, France and Germany, and Spain and the indigenous cultures of the New World. "This conflict is directed first of all against the bearers of the culture then again against its symbols. The victim however, is unmistakably the national group. Since we are dealing here with absolute values the tendency is to secure absolute victory. This is where genocide begins and ends." (Ibid.)

${ }^{109}$ Ralph F. Bischoff, Nazi Conquest Through German Culture (Cambridge, MA: Harvard University Press, 1942) at 3. 
between the concepts of race and of nationality as a linguistic and cultural group." 110 But as he admitted, this "confusion" was shared widely around the world. The Nazis joined their fantastical ideal of racial nationalism to a fetishized version of German folk culture, creating a grotesque caricature of their own distorted reality. Kohn declared that "[o]nly fascism, the uncompromising enemy of Western civilization, has pushed nationalism to its very limit, to a totalitarian nationalism, in which humanity and the individual disappear and nothing remains but the nationality, which has become the one and the whole."111 Similarly, Lemkin argued, “Hitler's conception of genocide is based not upon cultural but upon biological patterns. He believes that 'Germanization can only be carried out with the soil and never with men."'112 That is, where early nationalist visions had centred on culture, the Nazis' racial nationalism revolved around a twisted conception of biology. In the East especially, the Nazis dispensed with assimilation, preferring instead a practice of decimation.

Sullied by the Nazi embrace and regarded by political elites as too dangerous to be useful, nationalism fell out of favour with Western thinkers, who rued its many excesses. ${ }^{113}$ Cobban declared, "We are bound to conclude that among the reasons for the long continuance of a state of crisis [between the wars] not the least was the constant tension resulting from minority unrest or other aspects of the continuing pressure towards selfdetermination." 114 Writing in 1948, Hans Kohn despaired that “[o]nce [nationalism] was a

\footnotetext{
${ }^{110}$ Boas, Modern Life, supra note 19 at 82.

${ }^{111}$ Kohn, supra note 15 at 21.

${ }^{112}$ Lemkin, Axis Rule, supra note 23 at 81 [footnotes omitted, emphasis in original].

${ }^{113}$ Isaiah Berlin, Against the Current: Essays in the History of Ideas (New York: Penguin, 1979) at 337-38 [Berlin, Against]. According to Berlin, "most of the prophets of the nineteenth century" regarded nationalism in Europe as a passing phase.

${ }^{114}$ Cobban, supra note 14 at 38 .
} 
great force of life, spurring on the evolution of mankind; now it may become a dead weight upon the march of humanity." 115

By contrast, at mid-century, the concept of culture remained untarnished. Nationalism implied duties for the individual, the nation, and ultimately the international system, which was expected to honour the nation through recognition and sovereignty. Culture, as a social science concept, was merely descriptive and demanded comparatively little. Culture, which Boas had defined as the antithesis of race, was entirely learned and therefore carried no biological baggage. And while the international community might feel obligated to offer some rudimentary protections for cultural practice, cultures did not demand sovereign states. In fact, the idea of subcultures and the tendency of cultures to borrow and even merge with one another implied that cultures should coexist within states.

Culture also had an important theoretical advantage over nationalism. Nationalism implied a degree of sentimentalism, with common sentiment underpinning the group. Culture, by contrast, was thought to be a "scientific" concept, so, applying the tools of science, it would be possible to evaluate a culture or compare one with another. Whereas nationalism had been the province of historians and political theorists, culture was increasingly owned by social scientists. And in sharp contrast to nationalism, few were eager to die or to kill for culture. As the war ended, "culture" appeared poised to enjoy its moment.

\section{The Cultural Moment}

Culture indeed had its moment, as brief as it was profound. The anthropological idea of culture had entered into a space abandoned by nineteenth-century individualism. Under broad assault since the First World War, it seemed laissez -faire economics and rugged

\footnotetext{
${ }^{115}$ Kohn, supra note 15 at 22.
} 
individualism had finally succumbed, blamed for the economic mayhem they seemed to foster, and even blamed for creating the conditions that led to World War II. ${ }^{116}$ By the early 1940s, the metaphorical atomized individual operating in a self-regulating marketplace had

\footnotetext{
${ }^{116}$ See Daniel T. Rodgers, Atlantic Crossings: Social Politics in a Progressive Age (Cambridge, MA: Belknap Press, 1998) at 274-81 (dating the disenchantment with market utopianism to World War I), and ibid. at 448-49 (viewing the Great Depression as ending laissez faire and leading to an effort "to create a landscape beyond individualism."); Carr, supra note 20 at 50: "We have now . . . returned, after the important, but abnormal, laissez-faire interlude of the nineteenth century, to the position where economics can be frankly recognised as a part of politics." (Ibid. at 116.) Angus Burgin, The Great Persuasion: Reinventing Free Markets Since the Great Depression (Cambridge Mass: Harvard University Press, 2012) 44. But see Alan Brinkley, Liberalism and its Discontents Cambridge Mass: Harvard University Press, 1998) at 46, arguing that the late 1930s empowered a shift in the United States from a regulatory state to "a compensatory government, which would redress weaknesses and imbalances in the private economy without directly confronting the internal workings of capitalism." Condemnation of laissez faire individualism was de rigueur across the ideological spectrum. On the left, the culturally oriented economist Karl Polanyi asserted "that the origins of the [war] lay in the utopian endeavor of economic liberalism to set up a self-regulating market system." (Karl Polanyi, The Great Transformation (Boston: Beacon Press, 1944) 29.) Polanyi argued not only that colonial exploitation "debased" weaker societies, resulting in a "cultural void," but that "nothing obscures our social visions as effectively as the economistic prejudice." (Ibid. at 158-59.) Earlier he stated, "The outstanding discovery of recent historical and anthropological research is that man's economy, as a rule, is submerged in his social relationships. He does not act so as to safeguard his individual interest in the possession of material goods; he acts so as to safeguard his social standing, his social claims, his social assets. He values material goods only in so far as they serve this end." (Ibid. at 46.) On the right, Joseph A. Schumpeter, in his 1942 classic Capitalism, Socialism and Democracy, summed up wartime feelings toward capitalism:
}

The atmosphere of hostility to capitalism ... makes it much more difficult than it otherwise would be to form a rational opinion about its economic and cultural performance. The public mind has by now so thoroughly grown out of humor with it as to make condemnation of capitalism and all its works a foregone conclusion - almost a requirement of the etiquette of discussion. . . Any other attitude is voted not only foolish but anti-social and is looked upon as an indication of immoral servitude.

(Joseph A. Schumpeter Capitalism, Socialism and Democracy (New York: Harper Perennial, 2008) at 63.) Reinhold Niebuhr, who moved across the political spectrum in the course of his career, argued that "[h]uman behavior being less individualistic than secular liberalism assumed, the struggle between classes, races and other groups in human society is not as easily resolved by the expedient of dissolving the groups as liberal democratic idealists assumed." (Reinhold Niebuhr, The children of Light and the Children of Darkness: A vindication of Democracy and a Critique of its Traditional Defense (New York: Scribner's Sons, 1944) at 21.) Laissez faire, he argued, "does not understand the perennial power of particularity in human culture." (Ibid. at 131.) He argued that as a political philosophy, laissez faire "encouraged an unrestrained expression of human greed at the precise moment in history when an advancing industrialism required more, rather than less, moral and political restraint upon economic forces." (Ibid. at 30.) "The most pathetic aspect of the bourgeois faith [in laissez faire] is that it regards its characteristic perspectives and convictions as universally valid and applicable, at the precise moment in history when they are being unmasked as the peculiar convictions of a special class which flourished in a special situation in Western society." (Ibid. at 131.) 
been overtaken by a fascination with the social. ${ }^{117}$ Competition ceded to cooperation.

Intellectuals discarded the idea of the rational individual as they pursued collective harmony.

In the public imagination, businessmen became bogeymen whose selfish actions had stoked

the world's destructive fires. ${ }^{118}$ In 1936, FDR captured the tenor of these times, declaring, "I

believe in individualism ... up to the point where the individualist starts to operate at the

expense of society.... We have all suffered in the past from individualism run wild. Society

has suffered and business has suffered."119

During this brief period, activists, intellectuals, and policymakers found solutions not in the rational action of individuals but in the collective action of the state, of society. At the same time, Hitler, Stalin, and even the perceived excesses of the New Deal revived a wariness of state power. The period that stretched from the 1930s to the cusp of the Cold War was one in which leaders sought to escape the entrenched dogmas on either side of the

\footnotetext{
${ }^{117}$ Rodgers, Age of Fracture (Cambridge, MA: Belknap Press, 2011) at 4: "Structuralist interpretations of society and culture of this sort ran hard through the big books of the postwar years."

${ }^{118}$ See Arthur M. Schlesinger Jr., The Vital Center: The Politics of Freedom (Da Capo Press, 1988). Schlesinger's Vital Center was not only a place of racism and misogyny, it was also remarkably anti-business: " $[\mathrm{O}] \mathrm{n}$ virtually all the issues of controversy Americans now believe the business community to have been wrong. ... . Dominated by personal and class considerations, business rule tends to bring public affairs to a state of crisis and to drive the rest of the community into despair bordering on revolution." See also John Dewey, Individualism Old and New (New York: Capricorn Books, 1962) at 57, decrying "the 'business mind' which has become so deplorably pervasive." Angus Burgin, supra note 116 at 44, states that "[m]arket advocacy in the United Sates during the 1930s was dispersed, concessionary, politically abstemious, and deeply conflicted in its conception of the social ideal."

${ }^{119}$ Franklin D. Roosevelt: “Address at Chicago, Ill.," October 14, 1936. Online by Gerhard Peters and John T. Woolley, The American Presidency Project. <http://www.presidency.ucsb.edu/ws/?pid=15185>. See also Harvey J. Kay, The Fight for the Four Freedoms: What Made FDR and the Greatest Generation Truly Great (New York: Simon \& Schuster, 2014) at 32. As Kaye documents, Roosevelt's struggle to move the discourse beyond the individualism/collectivism dichotomy dates at least to 1911, when he was governor of New York.
} 
individualism-collectivism divide, to "create a landscape beyond individualism," but only just. ${ }^{120}$

The fascination with "culture" was a manifestation of a broader focus on the "problem" of inter-group relations, whether domestic or international. Louis Wirth warned in his essay, "The Problem of Minority Groups,"

As the war approaches a climax and the nature of the peace becomes a matter of public discussion the minorities question again moves to the center of world attention. It is becoming clear that unless the problems involved, especially on the continent of Europe, are more adequately solved than they were upon the conclusion of the first World War, the prospects for an enduring peace are slim. ${ }^{121}$

Similarly, in 1945, Karl Llewellyn, an influential American legal scholar, argued, "The fundamental fact is the human being is a group product, and therefore develops into a group member." 122 The problem as Llewellyn described it was that the "us-ness" fostered by group enculturation, while it provided civilization's "soul" and is "what we most vitally need," interferes with our ability to understand other peoples and leads to the development of

\footnotetext{
${ }^{120}$ Rodgers, Atlantic Crossings, supra note 116 at 449. In using this phrase, Rodgers is discussing New Dealers of the 1930s. See also "Report of the Liberal Industrial Inquiry" in Zimmern, Modern, supra note 31 at 119, reflecting the growing consensus:
}

It is not a choice between nailing to the mast of the Jolly Roger of piratical cut-throat individualism, each man for himself and the devil take the rest, or on the other hand, the Servile Society of a comprehensive State Socialism. Nor is the alternative between standing still and violent change. The world moves on anyhow at a smart pace; it is only the ideas of Conservatives and Socialists which remain as they were.

See also Robert L. Heilbroner, The Worldly Philosophers: The Lives, Times and Ideas of the Great Economic Thinkers 6th ed (New York: Simon \& Schuster, 1986) at 125, explaining the depth, scope, and influence of nineteenth-century economic thought.

${ }^{121}$ Louis Wirth, "The Problem of Minority Groups" in Ralph Linton ed., The Science of Man in the World Crisis (Columbia Univ. Press: New York, 1945) 347, 347. He continued, "The influence which the United States will exert in the solution of these problems abroad is contingent upon the national conscience and policy toward minorities at home, for it is unlikely that our leaders in ... making ... the peace will be able to advocate a more enlightened course for others than we are able to pursue ourselves."

${ }^{122}$ Karl N. Llewellyn, "Group Prejudice and Social Education" in R.M. MacIver, Civilization and Group Relationships (New York: Harper \& Brothers, 1945) 11, 15 [emphasis in original]. He explained that "the first and utter necessity of channeling each new small ball of random energy into group ways before it (he or she) can become either at all bearable or recognizable as a person." (Ibid.) 
group prejudices. ${ }^{123}$ In the wake of World War II, these imperatives - to understand particularism and to cope with prejudice — drove the intellectual agenda. The notion of culture appeared exquisitely suited to this need.

\section{Boasian Culture}

Franz Boas was a primary author of the cultural moment. Educated in physics and geography at Heidelberg University as well as Bonn and Kiel, Boas carried with him the long tradition of German thought when he immigrated to the United States in $1896 .{ }^{124}$ Boas's approach was relentlessly empirical. ${ }^{125}$ Nevertheless, while he insisted on developing an approach grounded in empirical observation, his ideas on science and culture owed much to the German historicist and hermeneutic tradition originated by Herder. As Matti Bunzl explains, Boas

was grounded in a German anthropological tradition extending back through Bastian and Ritter, through Steinthal and Waitz, to the brothers Alexander and Wilhelm von Humboldt. It is in that tradition that one finds the roots of Boas' critique of evolutionism and its racialist concomitants, as well as of his linguistic relativism and his cultural historicism. By this route, one may trace the later American anthropological idea of culture back through Bastian's Völkergedanken and the folk psychologist's Volksgeister to Wilhelm von Humboldt's Nationalcharakter - and behind that, although not without a paradoxical and portentous residue of conceptual and ideological ambiguity, to the Herderian ideal of Volksgeist. ${ }^{126}$

\footnotetext{
${ }^{123} \mathrm{Ibid}$. at $16-17$.

${ }^{124}$ Matti Bunzl, "Franz Boas and the Humboldtian Tradition" in George W. Stocking, Jr., ed, Volksgeist as Method and Ethic: Essays on Boasian Ethnography and the German Anthropological Tradition (Madison: University of Wisconsin Press, 1996) 17 at 52 [Stocking, Volksgeist]. See also Julia E. Liss, "The Bildung of Franz Boas" in Stocking, ibid. 155 at 179. Adam Kuper, Culture: The Anthropologists' Account (Cambridge, MA: Harvard University Press, 1999) at 61.

${ }^{125}$ Michael A. Elliott, The Culture Concept: Writing and Difference in the Age of Realism (Minneapolis: University of Minnesota Press, 2002) at 16.

${ }^{126}$ Bunzl, supra note 124 at 73 [footnote omitted]. According to Bunzl,

Boas tied together the theoretical currents of historicist Counter-Enlightenment thinking: first, the skepticism of finding natural laws governing human behavior; second, the rejection of a psychic unity of humanity, operating according to rational principles regardless of time and space; third, the focus on the individuality and diversity of phenomena as opposed to their similarity and universality; finally the
} 
And in an early essay, Boas praised the work of Alexander von Humboldt, the other

Humboldt brother, especially his notion of the "Kosmos," which Boas contrasted to

“Comte's system of sciences." 127 Boas argued that all Comte's

sciences have the one aim, to deduce laws from phenomena. The single phenomenon itself is insignificant: it is only valuable because it is an emanation of a law and serves to find new laws to corroborate old ones. To this system of sciences Humboldt's "Cosmos" is opposed in its principle. Cosmography, as we may call this science, considers every phenomenon as worthy of being studied of its own sake. Its mere existence entitles it to a full share of our attention; and the knowledge of its existence and evolution in space and time fully satisfies the student, without regard to the laws which it corroborates or which may be deducted from it. ${ }^{128}$

Boas was hardly alone in his admiration of Humboldt's cosmos, which was one the most influential concepts of the nineteenth century. Humboldt, in his three-volume, 2,000-page exposition, had sought to unify all branches of the sciences, which he linked to the arts and humanities. Humboldt's theory sought to encompass everything "[f]rom the distant vastness's of the Milky Way to the minutest animal organisms detectable under a microscope, from the nature of the interior of the earth to the migrations of the human race

emphasis on actual historical development in place of conjectures and speculation, on induction as opposed to deduction. (Ibid. at 61.)

Given this background, it is unsurprising that Boas treated cultures as texts to which he applied hermeneutic and philological techniques. (Ibid. at 68.) See also Zimmern, Nationality and Government, supra note 16 at 4, pegging blame for the idea of culture squarely on the Germans and asking, "What do German thinkers regard as Germany's contribution to human progress? The answer comes back with a monotonous reiteration which has already sickened us of the word. is Kultur, or, as we translate it, culture." He explained, "Kultur is a difficult word to interpret. It means 'culture' and a great deal more besides. Its primary meaning, like that of 'culture,' is intellectual and aesthetic: when a German speaks of 'Kultur' his is thinking of such things as language, literature, philosophy, education, art, science and the like." Thus far, he argued, British and German ideas on culture converged. But Germans give Kultur a further meaning: "the product of the disciplined intellect and the disciplined imagination. Kultur has in it an element of order, or organization, of civilization."

${ }^{127}$ Franz Boas, "The Study of Geography” in Stocking, Volksgeist, supra note 124, 9 at 12.

The cosmographer ... holds to the phenomenon which is the object of his study, may it occupy a high or low rank in the system of physical sciences, and lovingly tries to penetrate into its secrets until every feature is plain and clear. This occupation with the object of his affection affords himself a delight not inferior to that which the physicist enjoys in his systematical arrangement of the world.

${ }^{128}$ Ibid. at 12 . 
across its surface." 129 The particularity of each unified in the whole. This approach, with its loud Herderian echoes, galvanized Boas's early thought.

Boas's approach also developed in reaction to the evolutionary theory that had dominated Western anthropology at the turn of the century. Evolutionary anthropologists believed cultures progressed in relatively fixed stages from "lower savagery" to degrees of "barbarism" and finally to "civilization." 130 They spoke in terms of a universal standard of civilization rather than individual cultures, and their self-appointed task was to compare artifacts in order to measure cultural development. ${ }^{131}$ Their museums organized artifacts according to type, so, for instance, fishhooks from across several continents would be displayed together, revealing the hierarchy of sophistication between them. The evolutionists' own societies invariably topped the hierarchy, confirming racial and national prejudices and indirectly justifying all sorts of domination and exploitation.

Boas challenged the evolutionists' universalist assumption that all societies developed along a common trajectory. Instead, he insisted that each group should be considered in its unique spatial and historical context. ${ }^{132} \mathrm{He}$ grouped artifacts geographically into culture areas and developed the type of dioramas we see in museums today, which contextualize artifacts by showing them in use by members of the culture that generated them. Although jarring to

\footnotetext{
${ }^{129}$ Douglas Botting, Humboldt and the Cosmos (London: Sphere Books, 1973) 259.

${ }^{130}$ Marvin Harris, The Rise of Anthropological Theory: A History of Theories of Culture (New York: Crowell, 1968) at 181 (documenting the early diffusionists).

${ }^{131}$ Elliott, supra note 125 at 18.

${ }^{132}$ Franz Boas, Letter “The Occurrence of Similar Inventions in Areas Widely Apart” 9 Science (1887) 486-87.
} 
American anthropology, Boas's intervention involved little more than his assertion that American museums ought to adhere to standards developed by German ethnographers. ${ }^{133}$

Boas's idea of culture was also forged in his deep opposition to the racialist theories that dominated American social science well into the twentieth century. His early research used the tools of the biological anthropologists to debunk their ideas of racial superiority, demonstrating, for instance, that stature was influenced more by diet than genetics. Like Herder, he insisted that the best explanation of the differences between groups of people lay not in biology but in culture and environment. ${ }^{134}$ The most meaningful aspects of difference, he argued, were not genetically heritable but passed from one generation to the next through the process of enculturation. This meant individuals were not genetically predetermined to possess certain habits, traits, or capacities. Instead, given the right conditions, individuals

\footnotetext{
${ }^{133}$ Bunzl, supra note 124 at 56 . Boas also challenged the diffusionists who, in direct opposition to the evolutionists, denied the likelihood of similar but independently invented cultural phenomena occurring in varying locations. (Harris, supra note 130 at 177.) They argued that between-culture similarities resulted from inter-group borrowing. Strong diffusionists like Grafton Elliot Smith and his followers had highlighted innovative and distinctive features of Egyptian archaeology and traced these features to similar objects throughout Europe and Central America to support their claim that these far-flung peoples had appropriated Egyptian advances. (Paul A. Erickson \& Liam D. Murphy, A History of Anthropological Theory 2nd ed (Peterborough, ON: Broadview, 2003) at 55.) Boas did not deny diffusion but demanded rigorous inquiry to confirm each case. (Bunzl, supra note 124 at 69.) As Bunzl explains, "after 1900, his interest shifted gradually toward the retrospectively rationalizing and imperfectly synthesizing process by which the 'genius of a people' assimilated the elements brought together in a similar culture by historical accident." (Bunzl, ibid. at 60.)
}

${ }^{134}$ Boas, Modern Life, supra note 19 at 82. Boas wrote that "[i]n the United States Immigration Commission English, French, German, and Russian are designated as races. In common parlance also no clear distinction is made between cultural groups and racial strains." See Susan Hegeman, Patterns for America: Modernism and the Concept of Culture (Princeton: Princeton University press, 1999) at 30, concluding that "[t]he idea of culture was thus a kind of corollary hypothesis drawn on spatial-contextual lines, which was needed largely to offer some nonracial account of difference." See also Renan, supra note 71 at 196:

Discussions on race are endless, because the word "race" is taken by historians who are philologists and by anthropologists with physiological leanings in two quite different senses. For the anthropologists race has the same meaning as it has in zoology: it connotes real descent—blood relationship. Now the study of languages and history does not lead to the same divisions as physiology. ... [T] he zoological origins of the human race are vastly anterior to the origins of culture, civilization and language. The primitive Aryan, Semitic and Turanian groups were joined in no physiological unity. These groupings are historical facts which took place at a certain period, let us say fifteen or twenty thousand years ago; whereas the zoological origins of the Human race is lost in impenetrable darkness. 
born to any group might acculturate to another group. At the time, this idea was as dangerous as it now sounds anodyne. ${ }^{135}$

It would take some time for this hesitating gesture towards the particularity of specific groups to mature into Boas's theory of culture and even longer for his theory to dominate popular and scholarly discussions. ${ }^{136}$ But the trajectory was clear. Although he died in 1942 - reportedly falling into the arms of Claude Lévi-Strauss after delivering a talk at Columbia University's faculty club ${ }^{137}$ _Boas cast a long shadow over the period of the Genocide Convention's germination and codification.

\section{Culture's Postwar Reach}

In 1945, Raymond Williams noticed the prominence of "culture" when he returned to Cambridge after fighting in the British Army. He found himself

preoccupied by a single word, culture, which it seemed I was hearing very much more often. ... What I was now hearing were two different senses, which I could not really get clear: first in the study of literature, a use of the word to indicate, powerfully, but not explicitly, some central formation of values; . . . secondly, in more general discussion, but with what seemed to me very different implications, a use which made it almost equivalent to society: a particular way of life-_American culture," "Japanese culture."138

\footnotetext{
${ }^{135}$ Banner, supra note 4 at 385: "Boas's works were among the first books that the Nazis publicly burned." See also $i$ bid. at 385-408 discussing race and anthropology at mid-century and the prominent positions held by racists within the profession at that time.

${ }^{136}$ Crediting Boas with bringing the concept of culture to America has at times been controversial. See A. L. Kroeber \& Clyde Kluckhohn, "Culture: A Critical Review of Concepts and Definitions," 47:1 Peabody Museum Papers (Cambridge MA: Peabody Museum, 1952) at 151: "As Boas in one way or another influenced almost all his successors in American anthropology, the result was that directly he contributed little to Tylor's attempt to isolate and clarify the concept of culture as such, and that indirectly he hindered progress by diverting attention to other problems." See also Kuper, supra note 124 at 59-68.

${ }^{137}$ Elliott, supra note 125 at 4.

${ }^{138}$ Raymond Williams, Keywords: A Vocabulary of Culture and Society (London: Fontana Press, 1976) at 12. See also, Marc Manganaro, Culture, 1922: The Emergence of a Concept (Princeton: Princeton University Press, 2002 ) at 23 , pointing out that Williams was better versed in literary-intellectual history than in the history of anthropological theory and consistently underrated the influence of the latter. See also ibid. at 128, arguing, "Williams does not stress sufficiently ... the role that the emerging discipline of anthropology played in
} 
A. L. Kroeber and Clyde Kluckhohn agreed, finding "that by roughly 1940 'culture' in its anthropological sense had become fairly familiar [even] to educated Englishmen." ${ }^{139}$ They began their comprehensive 1952 "critical review" of culture by declaring that

few intellectuals will challenge the statement that the idea of culture, in the technical anthropological sense, is one of the key notions of contemporary American thought. In explanatory importance and in generality of application it is comparable to such categories as gravity in physics, disease in medicine, evolution in biology. Psychiatrists and psychologists, and, more recently, even some economists and lawyers, have come to tack on the qualifying phrase "in our culture" to their generalizations, even though one suspects it is often done mechanically in the same way that mediaeval men added a precautionary "God Willing" to their utterances. ${ }^{140}$

The popularity of the idea of culture extended well beyond the English-speaking world.

Kuper documents how, as Europe coped with World War II, "a longstanding . . . discourse on culture had suddenly burst into life again. Throughout Europe, the same themes recurred in the most diverse debates, drawing in radicals and reactionaries - and also both humanists and social scientists." ${ }^{\prime 14}$

More than anyone else, two American women, Ruth Benedict and Margaret Mead, both students of Boas, were responsible for popularizing the anthropological idea of culture. Mead and Benedict—friends, collaborators, and sometimes lovers—-took the concept beyond

promoting the notion of culture as representative of the whole social fabric versus the notion of culture as the property of the privileged."

${ }^{139}$ Kroeber \& Kluckhohn, supra note 136 at 35.

${ }^{140} \mathrm{Ibid}$. at 3. Bronislaw Malinowski, A Scientific Theory of Culture and Other Essays (New York: Galaxy, 1960) at 5, urged anthropology to contribute a more scientific approach to culture, because "[c]ulture, as the widest context of human behavior, is as important to the psychologist as to the social student, to the historian as to the linguist." He hoped

economics as an inquiry into wealth and welfare, as means of exchange and production, may find it useful in the future not to consider economic man completely detached from other pursuits and considerations, but to base its principles and arguments on the study of man as he really is, moving in the complex, many-dimensional medium of cultural interests.

${ }^{141}$ Kuper, supra note 124 at 46. 
academia, placing it on drugstore bookracks alongside romance novels and detective stories. ${ }^{142}$ In its first hardcover edition, Benedict's Patterns of Culture sold only a few hundred copies, but its 1945 paperback edition sold more than a million copies over the subsequent fifteen years. ${ }^{143}$ In her preface to the 1959 edition, Mead pointed out that when

Benedict began her work in anthropology in 1921, the term "culture," as we use it today for the systematic body of learned behavior which is transmitted from parents to children, was part of the vocabulary of a small and technical group of professional anthropologists. That today the modern world is on such easy terms with the concept of culture, that the words "in our culture" slip from the lips of educated men and women almost as effortlessly as do the phrases that refer to person and to place is in very great part due to this work. ${ }^{144}$

This is part of the reason David Hollinger calls it "one of the most widely read books ever produced by a social scientist in any discipline." ${ }^{145}$ She repeated this success a year later with the even more successful Chrysanthemum and the Sword, which applied her "culture and personality" approach to develop a sympathetic understanding of Japan, the recently defeated foe. ${ }^{146}$ Susan Hegeman argues that Benedict's work "convey[s] a clear pragmatic message about the military and diplomatic utility" of cultural knowledge, which "did much to legitimate national-culture studies of fully industrialized societies." ${ }^{147}$

\footnotetext{
${ }^{142}$ Peter Watson, The Modern Mind: An Intellectual History of the $20^{\text {th }}$ Century (New York: Harper Collins, 2001 ) at 281. On the relationship between Benedict and Mead see Banner, supra note 4 at 225.

143 Jim Cullen, The Art of Democracy: A Concise History of Popular Culture in the United States (New York: Monthly Review Press, 2002) at 250.

${ }^{144}$ Margaret Mead, "Preface" in Ruth Benedict, Patterns of Culture (Boston: Houghton Mifflin, 1959) at vii.

${ }^{145}$ David A. Hollinger, "Cultural Relativism" in Theodore M. Porter \& Dorothy Ross, eds, The Modern Sciences, in David C. Lindberg \& Ronald L. Numbers, eds, Cambridge History of Science vol 7 (Cambridge: Cambridge University Press, 2003) 708 at 714.

${ }^{146}$ Susan Hegeman, supra note 134 at 165.

${ }^{147} \mathrm{Ibid}$. at 165 . Mead observed, "It was the kind of book that colonels could mention to generals and captains to admirals without fear of producing an explosion against "jargon."”
} 
Also popular was Mead's And Keep Your Powder Dry, which she described as an experiment in "making a statement about a culture acceptable to those it described." wildly successful experiment in relativizing American culture to Americans made her a firsttier public intellectual: “she wrote for Vogue, Mademoiselle, House and Garden, Woman's Day, Look, Harper's, and the New York Times."149 Eleanor Roosevelt asked her advice on confronting racism, Henry Luce told his friends that And Keep Your Powder Dry was "one of the most influential books he had read in ages," and the Washington Post declared her one of the "eight outstanding women of the modern world." ${ }^{150}$ Even Marvin Harris, a fierce critic, admitted, "The artful presentation of cultural differences to a wide professional and lay pubic by Mead and Benedict must be reckoned among the important events in the history of American intellectual thought."151

Mead and Benedict recognized the importance of their culturalism to the field of international relations especially in showing "how different character structures in different cultures would condition the interaction between cultures, and how knowledge of these differences could be used to establish more or less co-operative modes of communication."152 International relations, they believed, would centre on "the orchestration of cultures," and their brand of cultural expertise would be crucial to the process. ${ }^{153}$

\footnotetext{
${ }^{148}$ Mandler, Return, supra note 5 at 88. See also Watson, supra note 142 at 279: Mead's 1928 Coming of Age in Samoa was also "phenomenally successful"

${ }^{149}$ Mandler, ibid. at 88.

${ }^{150} \mathrm{Ibid}$. at 84 .

${ }^{151}$ Harris, supra note 130 at 409.

${ }^{152}$ Peter Mandler, "One World, Many Cultures: Margaret Mead and the Limits of Cold War Anthropology” 68 Hist Workshop J (2009) 149 at 152 [Mandler, "One World"].

${ }^{153}$ Mandler, Return, supra note 5 at 63. As Mandler explains, "[t]his was a direct echo of her 1930s programs for education in multicultural America: 'orchestration' of cultural differences now not on a national but on an international basis." See also Lawrence K. Frank, Society as the Patient: Essays on Culture and Personality
} 
By the war's end, Peter Mandler argues, these "intercultural understandings of international relations that had been developed in wartime remained embedded in the system." ${ }^{154}$ F. S. C. Northrop, the prominent Yale law and philosophy professor, captured this culturalist thinking when he wrote, "A symphony of diverse cultures, the richer because of the diversity, rather than the dull monotony of all the nations fiddling away frantically on one string, is the vision of an idealistically informed and realistically wise foreign policy." 155

(New Brunswick: Rutgers University Press, 1948) at 302. Frank, a prominent child development expert, social scientist, and philanthropist, argued,

So soon as we begin to regard diverse cultures as so many different answers proposed by man to the same tasks or questions, so may different solutions offered to the same vital problems, then we may find it less difficult to think of world order, not in terms of a dominant coercive imposition of one cultural formation upon all others, but in terms of orchestrating cultural diversities to the larger theme of achieving meaning and significance, values, and order in human living.

${ }^{154}$ Mandler, Return, ibid. at 202. See also Ruth Emily McMurry and Muna Lee, The Cultural Approach: Another way in International Relations (Chapel Hill: University of North Carolina Press, 1947) 1: "[P]eace is no chance growth but must be planned" by fostering "cultural relations, ... efforts toward mutual acquaintance and the mutual understanding that such acquaintance brings." See also H. Munro Chadwick, The Nationalities of Europe and the Growth of National Ideologies (Cambridge: Cambridge University Press, 1945) at 198:

$[\mathrm{H}]$ ope of the future depends on our being able to work in harmony with our friends, ... [D]ifficulties can be overcome by mutual goodwill - if we make a serious effort towards a fuller understanding of foreign nations. ... We must learn to realise and appreciate the difficulties of other peoples.... We must learn to respect their characteristics and traditions, their national feelings and ideologies, even when these differ from our own.

${ }^{155}$ F. S. C. Northrop, The Taming of the Nations: A Study of the Cultural Bases of International Policy (New York: Macmillan, 1952) at 306. Writing as the Cold War was in full flight, Northrop argues (presciently) against Acheson's "power politics theory," urging an approach that looks within nations, to understand their cultures, as a more beneficial approach to foreign policy (ibid. at 302). See also John Lewis Gaddis, Strategies of Containment: A Critical Appraisal of Postwar American National Security Policy (Oxford: Oxford University Press, 1982) at 27-28. Echoing anthropological insights, George F. Kennan, America's preeminent theorist of the Cold War, saw that Americans approached foreign policy in two distinct ways: with (1) the "universalistic approach;" and (2) the "particularized approach." Gaddis argues that

Kennan considered universalism an inappropriate framework for American interests because it assumed "that men everywhere are basically like ourselves, that they all react to substantially the same hopes and inspirations, that they all react in substantially the same way in given circumstances." For him the most notable characteristic of the international environment was its diversity, not its uniformity.

Moreover, Kennan believed the United States had a leg up in the Cold War because "of the Russians' chronic inability to tolerate diversity." (Ibid. at 42.) The American concern with diversity finally petered out in the 1970s, when it was abandoned in favour of universal human rights. Though, as Gaddis notes, "[t]he American commitment to diversity [had] not extend[ed] to the acceptance of governments that might in some way upset the balance of power." (Ibid. at 339.) 
And, as Mandler argues, "[a]bove all, Mead and Benedict could feel in 1945 that they had succeeded triumphantly in doing what they did best—influencing the climate of opinion from the outside, by writing ... for the widest possible audiences." ${ }^{156}$ When FDR wrote the night before he died that "[t]oday we are faced with the pre-eminent fact that if civilization is to survive, we must cultivate the science of human relationships - the ability of all peoples, of all kinds, to live together and work together in the same world at peace," he may as well have been quoting Mead. ${ }^{157}$

\section{Notes Towards the Definition of Culture Circa 1948}

It is one thing to say that the idea of culture dominated the immediate postwar period, but another to define what the term meant at that time. At mid-century, there were at least as many definitions of culture as there were scholars addressing the subject. ${ }^{158}$ In Keywords, Raymond Williams began his canonical statement on culture by stating that it "is one of the two or three most complicated words in the English language." 159 In his 1948 Notes Towards the Definition of Culture, T. S. Eliot suggested,

It includes all the characteristic activities and interests of a people: Derby Day,

\footnotetext{
${ }^{156}$ Mandler, Return, supra note 5 at 174.

${ }^{157}$ Quoted McMurry \& Lee, supra note 154 at 1.

${ }^{158}$ See generally Kroeber \& Kluckhohn, supra note 136. In fact, definitions of "culture" may have outnumbered the scholars of culture, as many proffered multiple definitions.

${ }^{159}$ Raymond Williams, Keywords, supra note 138 at 87. See also Barnard, Herder's Social, supra note 36 at 118, quoting Herder: "Nothing is more indeterminate than this word [Kultur] and nothing more deceptive than its application to all nations and to all periods." See also The Oxford English Dictionary sub verbo "culture, n. online $<$ http://www.oed.com.ezproxy.library.ubc.ca/view/Entry/45746?rskey=SuaVFZ\&result=1\&is Advanced=false\#eid $>$. The O.E.D. provides seven meanings divided into three word branches and points the reader back to Williams's Keywords (ibid.) for an account of culture's complex development from the start of the nineteenth century. According to the O.E.D., one might culture a pearl or bacteria, or this term might refer to the cultivation of a crop or to the land more generally. Or, it can refer to the cultivation of the mind, "the devoting of attention to or the study of a subject or pursuit; [or] the refinement of mind, taste, and manners; artistic and intellectual development. Hence: the arts and other manifestations of human intellectual achievement regarded collectively." And then there is meaning 7(a), "the distinctive ideas, customs, social behavior, products, or a way of life of a particular nation or society, people, or period. Hence: a society or group characterized by such customs, etc."
} 
Henley Regatta, Cowes, the twelfth of August, a cup final, the dog races, the pin table, the dart board, Wensleydale cheese, boiled cabbage cut into sections, beetroot in vinegar, nineteenth-century gothic churches and the music of Elgar. The reader can make his own list. ${ }^{160}$

Despite his serial list of manifestations of culture, he argued that "culture is not merely the sum of several activities, but a way of life." ${ }^{161}$ In his conception, "culture' is . . the creation of the society as a whole; being from another aspect, that which makes it a society." 162 Thus, Eliot believed society is created by yet also creates culture.

In summarizing their giant 1952 compendium of definitions of culture, Kroeber and Kluckhohn concluded that "if there be any central tendency in the attempts to conceptualize culture over eighty years, it has been that of denying in principle a search for 'the' factor."163 Still, although culture had no single defining factor, there was a remarkable level of agreement among mid-century thinkers that a group is the necessary prerequisite for a culture. Thus, Kroeber and Kluckhohn were not surprised "that reference to the group appears in so many of our definitions of culture. Sometimes the reference is to human society generally, or 'the social;' more often, to a society or group or community or segment within the human species."164 They "agreed" there was little novel about these ideas: "Spencer's superorganic, Durkheim's faits sociaux, Sumner's folkways and the anthropologists' culture refer to essentially the same collective phenomena." 165 Marc Manganaro argues that by mid-

\footnotetext{
${ }^{160}$ T. S. Eliot, Notes Towards the Definition of Culture (New York: Harcourt Brace, 1949) at 30 [Eliot, Notes].

161 Ibid. at 40.

162 Ibid. at 35 .

${ }^{163}$ Kroeber \& Kluckhohn, supra note 136 at 180.

${ }^{164}$ Ibid. at 154.

${ }^{165}$ Ibid. at 94.
} 
century the anthropological consensus coalesced around the understanding "that a culture was, ipso facto, whole, integral, working, functional (in the Malinowskian sense), and made up of a 'complex' array of parts or features that in fact cohere into a 'whole."'166

Although there was near consensus among social scientists as to the holistic character of group existence, different perspectives emerged on an individual's degree of autonomy from group culture, and on the degree to which that individual could influence the broader culture. ${ }^{167}$ In 1917, Kroeber engaged this debate, denying the individual much, if any, role in the formation and transference of culture. ${ }^{168}$ By contrast, Boas ended his 1928 exposition on Anthropology and Modern Life by arguing there can be "no 'mystic entity' that exists outside the society of its individual carriers, and that moves by its own force."169 A culture "depends upon the interactions of the individuals under the stress of traditional behavior. It is not the

\footnotetext{
${ }^{166}$ Manganaro, supra note 138 at 3. See also Malinowski, supra note 140 at 43 . Malinowski declared, "The essential fact of culture as we live it and experience it, as we can observe it scientifically, is the organization of human beings into permanent groups." He argued for "taking an individual culture as a coherent whole," which would allow social scientists to "produce a number of predictive statements as guides for field research, as yardsticks for comparative treatment, and as common measure in the process of cultural change." (Ibid. at 38.) According to Malinowski, culture "obviously is the integral whole consisting of implements and consumers' goods, of constitutional charters for the various social groupings, of human ideas and crafts, beliefs and customs." (Ibid. at 36.) Thus to Malinowski, anthropological holism was the hallmark of its status as a social science.
}

${ }^{167}$ A. L. Kroeber, "The Superorganic" 19 Am Anthropologist (1917) 163, 193 [Kroeber, "Superoganic"] made an early and incendiary entrance to this debate, arguing, "Civilization, as such, begins only where the individual ends; and whoever does not in some measure perceive this fact, though as a brute and rootless one, can find no meaning in civilization." And, he continued, "a thousand individuals do not make a society. They are the potential basis of a society, but they do not themselves cause it." Tradition, he argued, "is only a message. It must of course be carried: but the messenger after all is extrinsic to the news, so, a letter must be written; but as its significance is in the meaning of the words, as the value of a note is not in the fiber of the paper but in the characters inscribed on its surface, so tradition is something superadded to the organisms that bear it, imposed upon them, external to them." (Ibid. at 178.) See also Thomas Buckley, “"The Little History of Pitiful Events': The Epistemological and Moral Contexts of Kroeber's Californian Ethnology" in George W. Stocking, ed, Essays on Boasian Ethnography and the German Anthropological Tradition (Madison: University of Wisconsin Press, 1996) 257, 267, noting that Kroeber later admitted his nod toward the "superorganic" was riddled with metaphysics.

\footnotetext{
${ }^{168}$ Kroeber, "Superorganic," supra note 167 at 178.

${ }^{169}$ Franz Boas, Modern Life, supra note 19 at 245.
} 
sum of the activities of the individuals; rather individuals and society are functionally related." ${ }^{\prime 70}$ When a society changes, he argued, it is not the result of abstract cultural shifts, but of the actions of individuals constituting social groups.

Edward Sapir, in his influential 1922 essay, "Culture, Genuine and Spurious," also advocated individualizing culture. He argued, "The true locus of culture is the interactions of specific individuals and, on the subjective side, in the world of meanings which each one of these individuals may unconsciously abstract for himself from his participation in these interactions." ${ }^{171}$ Sapir's individuals were also members of subcultures, which were the true vehicles of societal change. But he argued, "There is no real opposition, in the last analysis, between the concept of a culture of the group and the concept of an individual culture. The two are interdependent. A healthy national culture is never a passively accepted heritage from the past, but implies the creative participation of the members of the community; implies in other words the presence of cultured individuals." ${ }^{\prime 72}$ He likewise argued that "there is no sound and vigorous individual incorporation of a cultured ideal without the soil of a genuine communal culture; and no genuine communal culture without the transforming personalities at once robust and saturated with the cultural values of their time and place."173 As Hegeman puts it, to Sapir, culture "was a special combination of the individual 'genius'

\footnotetext{
${ }^{170} \mathrm{Ibid}$. at 246. Compare Barnard, Herder's Social, supra note 36 at xxi, describing Herder's group ontology: "He argued as if he were a nominalist, since he did not conceive of Volk as a substantive entity or thing with a corporate existence of its own over and above, or separate from the individuals who composed it. Volk was a relational event, a historical and cultural continuum." (Emphasis in original.)

${ }^{171}$ Edward Sapir, "Cultural Anthropology and Psychiatry" in David G. Mandelbaum, ed, Selected Writings of Edward in Language, Culture and Personality (Berkeley: University of California Press, 1949) 509, 515.

${ }^{172}$ Edward Sapir, "Culture, Genuine and Spurious" in David G. Mandelbaum, ed, Selected Writings of Edward in Language, Culture and Personality (Berkeley: University of California Press,1949) 308 at 321.

${ }^{173} \mathrm{Ibid}$. at 322.
} 
and the national whole - indeed it was the embodiment of that genius in the national

whole." $" 174$

Unlike many of today's commentators on the Genocide Convention, for whom the

concept of human groups has become a conceptual sticking point, mid-century thinkers were

remarkably unconcerned by arguments over the ontological status of groups and culture.

Most readily accepted that culture can only be located in the individuals who practice it. ${ }^{175}$

\begin{abstract}
${ }^{174}$ Hegeman, Patterns, supra note 134 at 88.
175 Benedict, Patterns, supra note 144 at 251 . Benedict derided "the nineteenth-century dualism [that] was the idea that what was subtracted from society was added to the individual and was subtracted from the individual was added to society." She ascribed the "quarrel in anthropological theory"-around the relative importance of culture and individual attributes - to that dualism, which had fed now-discredited "[p]hilosophies of freedom, political creeds of laissez faire, [and] revolutions that have unseated dynasties." She declared that "[i]n reality, society and the individual are not antagonists." Society "is never an entity separable from the individuals who compose it" nor can an individual "even arrive at the threshold of his potentialities without a culture in which he participates." .. "The problem of the individual is not clarified by stressing the antagonism between culture and the individual, but by stressing their mutual reinforcement." (Ibid. at 253.) Benedict addressed the "controversy over whether or not society is an organism," dismissing it as largely a verbal quarrel. (Ibid. at 23031.) And she declared it "obvious that the sum of all the individuals in Zuñi make up a culture beyond and above what those individuals have willed and created. . . . It is quite justifiable to call it an organic whole." (Ibid. at 231.) None of the "so-called organicists" really believed groups possessed a supra-individual mind wherein culture would reside, and even the most vigorous critics of the "group-fallacy admitted that the scientific study of groups is necessary." (Ibid. at 231.) She argued, "The whole, as modern science is insisting in many fields, is not merely the sum of all its parts, but the result of a unique arrangement and interrelation of the parts that has brought about a new entity." (Ibid. at 46-47.) Just as the discovery of electrons did not negate the need to study the behaviour of atoms, she seems to say, so the knowledge that culture resides in individuals does not make it any less real or worthy of study. She argued, "These group phenomena must be studied if we are to understand the history of human behavior, and individual psychology cannot of itself account for the facts with which we are confronted." (Ibid. at 232.) Kroeber \& Kluckhohn, supra note 136 at 63, similarly argued,
\end{abstract}

The development of the social sciences has been impeded by a confusion between the 'real' and the concrete. Psychologists, typically, are reluctant to concede reality in the social world to anything but individuals. The greatest advance in contemporary anthropological theory is probably the increasing recognition that there is something more to culture than artifact, linguistic texts, and lists of atomized traits.

However, they argue, it is clear

from ordinary experience that an exhaustive analysis of reality cannot be made within the limitations of an atomistic or narrow positivistic scheme. Take a brick wall. Its "reality" would be granted by all. ... Then let us take each brick out of the wall. A radical, analytic empiricist would be in all consistency obliged to say we have destroyed nothing. Yet it is clear that while nothing concrete has been annihilated, a form has been eliminated.

Even Kroeber, who argued the existence of a "superorganic" realm of culture, also admitted that "civilization is not mental action itself; it is carried by men, without being in them. But its relation to mind, its absolute rooting in human faculty, is more than plain." Kroeber, "Superorganic," supra note 167 at 189. See also Niebuhr, supra 
Kroeber and Kluckhohn, who were perhaps culture's strongest proponents, acknowledged danger in the reification or hypostatization of culture, which would mean "to view it as a distinctive substance or actual superorganism, and then to assume that it moves through autonomous, immanent forces. ${ }^{176}$ They also acknowledged "considerable spillover" from the "mere insistence of the importance of recognizing culture as a distinct domain of phenomena ... to the hasty and usually hazy attitude which sees culture as a special kind of entity or substance." ${ }^{177}$ And they argued for viewing culture as a useful scientific abstraction, insisting that "in science, abstractions at different levels are both permissible and desirable, so long as there remains awareness of the level of abstraction at which the investigator is operating."178 However, they also pointed out that, at mid-century, anthropologists were preoccupied with method and did not much concern themselves with the ontological status of things like culture and human groups. ${ }^{179}$

note 116 at 48: "The individual is related to the community (in its various levels and extensions) in such a way that the highest reaches of his individuality are dependent upon the social substance out of which they arise and they must find their end in a fulfillment in the community." He continued,

The individual and the community are related to each other on many levels. The highest reaches of individual consciousness and awareness are rooted in social experience and find their ultimate meaning in relation to the community. The individual is the product of the whole socio-historical process, though he may reach a height of uniqueness which seems to transcend his social history completely. His individual decisions and achievements grow into, as well as out of, the community.

Thus, to these mid-century thinkers, the individual and the culture group were conceptually distinguishable, but divorcing them would render the individual meaningless.

${ }^{176}$ Kroeber \& Kluckhohn, supra note 136 at 148.

${ }^{177}$ Ibid. at 187.

${ }^{178}$ Kroeber \& Kluckhohn, ibid. at 186: "At the cultural level of abstraction it is perfectly proper to speak of relations between cultures, the mutual influencing of cultures, in the same way that, more concretely, we speak of relations between persons."

${ }^{179}$ Ibid. at 148. See also Clyde Kluckhohn \& William H. Kelly, "The Concept of Culture" in Ralph Linton, ed, The Science of Man in the World Crisis (New York: Columbia University Press, 1945) 78, 93. In this essay, a philosopher posed the question, "where is the locus of culture-in society or in the individual?" To which an anthropologist replied, 


\section{Culture as Resistance}

At mid-century, culture was seen as the antithesis of materialism, as a stubborn holdout against the market, against industrialism, and against the anomie that accompanies modernism. As I document in Chapter 4, this second-layer signification played a role in the Genocide Convection drafting debates. Although the parties rejected protection for certain manifestations of culture, they also rejected measures that would have grounded the Convention in purely material concerns. Thus, understanding not only culture's meaning, but also its signification, is important to understanding the Genocide Convention.

The idea of culture had always signified stubborn resistance to the homogenizing and dehumanizing effects of materialistic individualism. As Kuper explains, Herder "had taken the term [Kultur] from Cicero, who wrote metaphorically of cultura animi extending the idea of agricultural cultivation to apply to the mind." Kultur therefore implied cultivation, Bildung a personal progression toward spiritual perfection." ${ }^{180}$ Bildung entails a struggle toward cultivation for its own sake, with a disregard for concerns such as status or pecuniary reward. In the German tradition, kultur was juxtaposed with the idea of civilization, seen by the Germans as coming out of the French Revolution and suspect for embodying a "material"

\footnotetext{
Asking the question in that way poses a false dilemma. Remember that "culture" is an abstraction. Hence culture as a concrete, observable entity does not exist anywhere - unless you wish to say that it exists in the "minds" of the men who make the abstractions. The objects and events from which we make our abstractions do have an observable existence. But culture is like a map. Just asa map isn't the territory but an abstract representation of the territory so also a culture is an abstract description of trends toward uniformity in the words, acts, and artifacts of human groups. . . Note, however, that "culture" may be said to be "supraindividual" in at least two non-mystical, perfectly empirical senses: 1. Objects as well as individuals manifest culture, [and; 2 . The continuity of culture never depends upon the continued existence of any particular individuals.
}

Thus, like their peers across fields other than philosophy, Kluckhohn and Kelly appear unfazed by, and not even particularly interested in, problems of group ontology.

${ }^{180}$ Kuper, supra note 124 at 31. 
form of individualism, wherein the individual is shaped by social institutions as opposed "to inward individualism, which was spiritual." 181

The idea of culture as resistance to Enlightenment materialism also found its way into the British tradition. Williams's first major work, Culture and Society, traced the idea of culture in British literature, highlighting its origins in the concept of "a general common humanity," which he finds in Shelley, and which developed to counter "the aggressive individualism and the primarily economic relationships which the new society embodied."182 Coleridge had declared his fear that "in a few years we shall either be governed by an aristocracy, or, what is still more likely, by a contemptible democratical oligarchy of glib economists, compared to which the worst form of aristocracy would be a blessing." 183 Culture, as Williams argued, "became the normal antithesis to the market."184 When Sapir argued that "this ideal of a genuine culture has no necessary connection with what we call efficiency," he was tapping into this lengthy intellectual tradition. ${ }^{185} \mathrm{He}$ believed that "[t]he great cultural fallacy of industrialism, as developed up to the present

\footnotetext{
${ }^{181}$ Louis Dumont, German Ideology, supra note 15 at 57-58.

${ }^{182}$ Williams, Culture and Society, supra note 26 at 42. Note that Mill considered that "such views [of culture] are, more than anything else, the characteristic feature of the Goethian period of German literature; and are richly diffused through the historical and critical writings of the new French school, as well as of Coleridge and his followers." (Quoted in ibid. at 60.)

${ }^{183}$ Quoted in ibid. at 58. Notably, nationalism was also seen as a means of resisting modernist cosmopolitanism. Williams highlighted J. S. Mill's (1838) use of culture from "the Germano-Coleridgian school" to counter Benthamite commercial individualism. (Ibid. at 59-60.) See Zimmern, Nationality and Government, supra note 16 at 53: Nationalism "is a safeguard of self-respect against the insidious onslaughts of a materialistic cosmopolitanism. It is the sling in the hands of weak undeveloped peoples against the Goliath of material progress."

${ }^{184}$ Williams, Culture and Society, supra note 26 at 35. Or, as he put it elsewhere, "the court of appeal in which real values were determined, usually in opposition to the 'factitious' value thrown up by the market and similar operations of society." (Ibid. at 34.) Thus, the idea of culture was used in the British tradition "not merely to influence society, but to judge it." (Ibid. at 63.)

${ }^{185}$ Sapir, "Genuine," supra note 172 at 315.
} 
time, is that in harnessing machines to our uses it has not known how to avoid the harnessing of the majority of mankind to its machines." 186 Sapir believed this would throw the culture out of harmony, for while "[c]ivilization, as a whole, moves on; culture comes and goes." 187

The idea that culture was an interrelated whole, unique and irreplaceable, fed a morbid anxiety with cultural destruction. An errant tug at one aspect of a culture could, they worried, begin an unravelling that would lead to the culture's destruction. In the late nineteenth century, this idea fostered the expansion of ethnography as anthropologists interested in "salvaging" folkways uncorrupted by outside contact rushed to document indigenous cultures. In the early twentieth century, Boas and his contemporaries continued to view "salvaging" as an ethical imperative, but shifted the focus from removing exceptional artifacts to collecting as much information about the culture as scientifically possible. ${ }^{188} \mathrm{In}$

\footnotetext{
${ }^{186}$ Sapir, "Genuine," supra note 172 at 316. See also John Dewey, supra note 118 at 133. Dewey explored this antinomy, arguing that while a routinized, mechanized economy guided only by efficiency could nurture a small cadre of cultural elites, so long as "multitudes are excluded from occasion for the use of thought and emotion in their daily occupations," no broader, distinctly American culture could flourish. To Dewey, the enemy of an organic American culture was "Americanism," by which he meant, "[q]uantification, mechanization, and standardization [which are] the marks of the Americanization that is conquering the world." This phenomenon threatened not only American culture, but the cultures of all those societies that had come to esteem it. (Ibid. at 24.) See also Hegeman, supra note 134 at 58-60, discussing how the idea of plural cultures was invoked in opposition to another American obsession at the time, the idea of America as "melting pot."

${ }^{187}$ Sapir, "Genuine," supra note 172 at 317.

${ }^{188}$ Elliott, supra note 125 at 10 . While this did not exclude the aggressive collection of many of the group's best artifacts, Boasian salvage also focused on the less tangible aspects of group culture, including documenting its rituals, myths, and more mundane social practices: "For instance, when requesting funds for a project on the 'Vanishing Tribes of North America,' he argued that future generations 'will owe a debt of gratitude to him who enables us to preserve his knowledge, which without great effort on the part of our own generation, will be lost forever." See also Benedict, Patterns, supra note 144 at 249. Benedict warned that blindness to our own cultural traits could lead to "revolution or breakdown." She urged that capitalism and other "dominant traits of our civilization" needed "special scrutiny" because they were "compulsive" and "overgrown" and had grown out of proportion to any human need. (Ibid. at 249.) See also Polanyi, supra note 116 at 157, using the destruction of one culture by another as a metaphor to explain the damage caused by economic upheavals like the industrial revolution. He pointed to the "intrinsic" similarities between economic upheaval and the exploitation by stronger cultures of weaker ones, arguing that both have a devastating effect not primarily through "economic exploitation, as often assumed, but the disintegration of the cultural environment of the victim is then the cause of the degradation." "[O]f course," he explained, "a social calamity is primarily a cultural not an economic phenomenon."
} 
the wake of World War I, when so much and so many had been destroyed so pointlessly, the obsession with cultural demise spread from the specialized field of anthropology into popular discourse. ${ }^{189}$ Manganaro points to T. S. Eliot's The Waste Land, Joyce's Ulysses, and Malinowski's Argonauts, among others, as exemplifying this concern. ${ }^{190}$ In the scholarly discourse and the popular imagination, culture was seen as both precious and precarious.

Thus, "culture" had its moment in the immediate postwar period. To the extent that such a thing existed, the consensus view held, first, that laissez-faire individualism had failed; second, that human nature contains an inclination to group identity that could be both destructive and constructive; and finally, that the concept of culture could allow the world's leaders to navigate these treacherous shoals. Anthropologists, the keepers of this pivotal concept, enjoyed — briefly — a degree of influence usually reserved only for physicists and economists. So it is unsurprising that the technicians in charge of constructing postwar international governance turned, also briefly, to the anthropological idea of culture.

\section{Lemkin's Culturalism}

As he acclimated to life in the United States, Lemkin embraced the anthropologists' "culture." Where American social scientists found culture new and electrifying, to Lemkin it would have seemed comfortable and familiar. He had received his legal education at Jan Kazimierz University in Lwów, Poland, and for a time had attended the University of Heidelberg, where Boas had received his doctorate. ${ }^{191}$ Equipped with this background,

\footnotetext{
${ }^{189}$ Manganaro, supra note 138 at 65, 101.

${ }^{190} \mathrm{Ibid}$. at 26, 59-60, 108.

${ }^{191}$ Irvin-Erickson, supra note 48 at 34 . Lemkin enrolled in but did not complete a program in philosophy. Lemkin's culturalism reinforced and was buttressed by his methodology, which was steeped in the German tradition. He admitted that "[g]enocide occurs in various cultures, and therefore we will undoubtedly find certain common elements." Raphael Lemkin, "The Concept of Genocide in Social and Individual Psychology"
} 
Lemkin had arrived in America primed to accept the idea of culture. So it is unsurprising that his papers document his engagement with anthropological theory. ${ }^{192}$ Also unsurprising is the foundational role culture came to play in his theory of genocide.

(undated), New York, New York Public Library, Raphael Lemkin Papers [NYPL] (Reel 2, File, "Introduction to the Study of Genocide, Part 1" [Lemkin, "Introduction"]). Also available in Jacobs, supra note 22 at 26. Yet he warned that "we must not conclude from this that human nature is the same everywhere." (Ibid. at 2.) In arguing against the Enlightenment systematizers who would reduce genocide to common processes, he couched his German hermeneutics in the language of anthropology. Violent acts, he asserted, exist everywhere, but they serve different functions in each society where they occur and are to varying degrees acceptable or condemned: "Similarly emotions, non-psychological human drives, and psychological abberations [sic] vary from culture to culture, because they are to a great extent culturally determined." (Ibid. at 3.) And arguing against Freud's universalism, he pointed out that "contemporary psychiatrists and psychologists have taken their cue from anthropology and sociology and have become increasingly aware of their impotence in explaining behavior in non-Western cultures on the basis of their empirical knowledge of the West." (Ibid. at 3.)

${ }^{192}$ In his never-completed work, "Introduction to the Study of Genocide," Lemkin had intended to address a chapter to anthropology, where he acknowledged the influence of anthropologists on his thinking. See Lemkin, "Introduction," supra note 191, reprinted in Jacobs, supra note 22 at 39 n. 36. Lemkin cites Clyde Kluckhohn, Ruth Benedict, Franz Boas, Ralph Linton, and "Herscovitz" (likely Melville Herskovits). Lemkin highlighted,

Frazer who is generally considered to be the father of modern anthropology was aware of a sociological fact: that all human beings have so-called derived needs which are just as necessary to their existence as the basic physiological needs. These needs find expression in social institutions or, to use an anthropological term, the culture ethos. If the culture of a group is violently undermined, the group itself disintegrates and its members must either become absorbed in other cultures which is a wasteful and painful process or succumb to personal disorganization and, perhaps, physical destruction. Malinovsky [sic], the founder of the functional school in anthropology, regards culture as having three interdependent dimensions: a material base, social ties, and symbolic acts. He believes that no definite line of demarcation can be drawn between form and function. According to this view it is clear that the destruction of cultural symbols is genocide, because it implies the destruction of their function and thus menaces the existence of the social group which exists by virtue of its common culture.

He cited the anthropologists in distinguishing his idea of cultural genocide from anthropological theories of cultural diffusion:

Within Western culture diffusion is a familiar process. It is the essence of modern science. For better or worse, Western culture has been and still is the master diffuser of the world. What then is the exact distinction between diffusion and genocide? In the first place, genocide implies complete and violent change, that is, the destruction of a culture. This is the premeditated goal of those committing cultural genocide. Diffusion is gradual and relatively spontaneous, although it may lead to the eventual disintegration of a weak culture. Secondly, cultural genocide need not involve the substitution of new culture traits (such as forceful conversion), but may maliciously undermine the victim group to render its members more defenseless in the face of physical destruction. (Lemkin, Lemkin on Genocide, ibid. at 41.)

In Lemkin's conception, diffusion and cultural genocide lie at opposite ends of a spectrum, with assimilation somewhere in the middle. Diffusion, a benign process of cultural borrowing, was simply part of the daily interchange between cultures while cultural genocide was clearly unacceptable. Of assimilation, he wrote that "[s]ince culture is an expression of ideas, natural intermingling and borrowing and even mutual penetration must take place. If it is done on a voluntary basis by acceptance of the vigor and beauty of what seems to be a higher cultural concept, we call it assimilation." (Lemkin, "Philosophical," supra note 104.) Harris, supra note 
Lemkin was preoccupied with the vagaries of group life and saw the protection of group existence as central to the emerging international system. Writing under the letterhead of the Committee for a Genocide Convention, he argued, "Once the right of existence of human groups is established" under "international law and their destruction proclaimed to be an international crime, international guarantees of individual human rights should soon follow." ${ }^{193}$ But he always insisted that group protection should come first. In his unsuccessful bid to have prohibitions on genocide added to the peace treaties signed at the end of World War II, Lemkin argued, "Historically and numerically speaking the greatest part of persecutions have been committed against groups, and individual members of such groups served only as scapegoats or symbols in such persecutions. The emphasis should therefore be on the rights of human groups and not on the rights of individuals." 194

However, protections for groups inevitably raise certain issues of definition. In a January 1950 letter, Vera Michaels Dean noted "problems in connection" with an article submitted by Lemkin. Foremost among these, she wrote, "[y]ou use the words group, nation, race interchangeably without specific illustrations." And she asked, "Could we settle for

\footnotetext{
130 at 379 , argued that the diffusionist schools of the late nineteenth and early twentieth centuries "were palpably bankrupt by mid-century." However, this thinking apparently held enough sway that Lemkin felt he must address it, if only to distance himself from it.

${ }^{193}$ United States Committee for a United Nations Genocide Convention, "Genocide" (undated) AJA, supra note 104 at Box 3, File 4 p.3

${ }^{194}$ Lemkin, "Memorandum on the Necessity of Including Anti-Genocide Clauses in the Peace Treaties" (undated) AJHS, supra note 105 at Box 6, File 2. Lemkin, "Outline of an Article on Genocide," AJHS Box 7, File 3: "The principle that a government has the right to destroy entire groups of its citizens has been valid until Dec. 12, 1946" - when the UN General Assembly approved The Crime of Genocide, UNGA Resolution 96(1) UN GAOR. $1^{\text {st }}$ Sess, UN Doc. A/BUR 5.50 (1946) (Res. 96[I]): "The resolution signifies the first step to protect internationally the most basic of all human rights - the right of existence." Thus, to Lemkin, the right of certain groups to exist came before all other rights, even the right of individual life.
} 
some one generic term — perhaps group?" 195 Indeed, Lemkin often used these terms interchangeably and sometimes lumped all of these groups together, considering them all to be "national groups." In his conception, a "national group leads a common life based upon the conscience of a common culture, common heritage, and common ideals and aspirations for the groups conceived as an entity." ${ }^{196}$ But in his draft book on genocide, Lemkin argued, "It is without consequence whether the borderlines between the above four groups are overlapping. Sometimes a man can belong to a religious group which is at the same time a national group. It is not important whether the classification of the groups is scientific. The main thing is that the offenders recognize these groups and destroy them." ${ }^{197}$ Lemkin's dismissiveness of the need to scientifically classify groups tracks other mid-century scholars who, as I pointed out above, bracketed such issues and focused instead on method. And despite a certain definitional fuzziness and apparent contradictions, Lemkin's thinking on groups, as that of his peers, was unified around one idea: culture.

\section{Lemkin's Culture-Nation}

As was common at mid-century, Lemkin believed cultures grew organically and were impervious to attempts at managing them. He cited "T. S. Eliot in his book on [the]

Definition of Culture [which] says that culture cannot be premeditated." 198 "National culture"

\footnotetext{
${ }^{195}$ Letter, Vera Michaels Dean, Foreign Policy Association, to Lemkin 10 January 1950, AJHS, supra note 105 at Box 2, File 4. Dean was Research Director of the Foreign Policy Association.

${ }^{196}$ Lemkin, "Definition [nature of groups]" p. 17 AJHS, supra note 105 (Box 7, File 2. At 17).

197 Ibid.

198 Lemkin, "Nature of Groups," supra note 107 at 2:

Culture bearing groups: National, ethnical, and religious groups are the bearers of specific cultures. These cultures find expression in specific creations in the fields of music and art, literature, scientific achievement, linguistics, religious concepts, and so forth. Since time immemorial national cultures
} 
he argued, "develops and grows though natural processes. It cannot be planned, blue-printed, pre-ordained. Although it can be encouraged by the creation of natural conditions, the very process of creation is a leap in the future and not the fulfillment of a plan." ${ }^{199}$ And he continued, "Since it is a creation of the free spirit and of a crossing of invisible elements, it is unique as an achievement. Hence, it is irreplaceable." ${ }^{200}$ Echoing Eliot and Sapir, he argued that " $[r]$ eal culture cannot be imitated or re-created. When it has gone it has gone forever. When it has been destroyed it has perished forever. Therein lies the historic drama of the irrevocability of its death."201

This idea of an organic culture, valuable yet vulnerable, grounded Lemkin's conception of human groups. He asserted that "[s]ince time immemorial, national cultures originated and grew within closed societies. They have grown their vital essence from the folklore, mythology, and other forms of collective emotionalism": ${ }^{202}$

National, ethnical, racial and religious groups put together on an intercontinental basis create the sum total of the human universe. In this respect the human universe must be distinguished from the physical universe. These four groups can be found on every continent, under every meridian of the universe. They are universal in their nature. By protecting one of these groups we necessarily protect a basic and essential

originated and grew within [closed] societies. They have grown their vital essence from the folklore, mythology, and other forms of collective emotionalism. (Ibid.)

Citing T. S. Eliot and Powys, he also asserted,

Every society indeed develops in the course of ages culture bearing elements which develop a supreme capacity of transforming the substrata of national ethos into great works of art, music or literature. Whether their name is Voltaire, Joyce, Hemingway, Tolstoy, or Gabriela Mistral, it is everywhere clear that they have drawn from the deepest layers of national concienceness [sic] for the purpose of creating original works. (Ibid.)

${ }^{199}$ Ibid.

${ }^{200}$ Ibid.

${ }^{201}$ Ibid.

${ }^{202}$ Lemkin, Part 1, Ch. 2, Sec. 1, "International Collective Responsibility for the Survival of National, Racial, Religious, and Ethnical Groups," AJA, supra note 104 (Box 7, File 2). 
section of the human universe. It is only natural to say that by protecting these groups we are protecting ourselves. ${ }^{203}$

Thus, the four groups protected in the Genocide Convention were chosen "because these groups occupy a special position in world civilization and also because of their sufferings throughout human history." 204 He argued that

[s]ince antiquity, collectivities, later called nations, have attracted the attention of their neighbors and of the world at large, not so much because of their physical characteristics as through their spiritual life expressed in art, music, literature, law and other technics and media of social engineering. Nations themselves became conscious of other cultures and made it part of the national tradition. Focillon called nation "the families of minds." Gradually the world became aware of the basic value of cultural contributions of different nations to world civilization. One has learned to appreciate the Romans for their legal culture, the Phoenicians for their trade, the Jews for their Bible, the Italians for their art, the Chinese for their philosophy and so forth. The cultural personality of nations has become an acknowledged fact. ${ }^{205}$

As was common among mid-century scholars, Lemkin conceived of nations as individuals, each with a unique "personality," each with unique contributions to make to "world culture."206

\footnotetext{
${ }^{203}$ Lemkin, "Nature of Groups," supra note 107 at 1 . See also Raphael Lemkin, "Philosophical," supra note 104: "Nations, religious groups, races, [and] ethnic groups are the four basic groups of which mankind is made. These groups have a transcendental and unparalleled value because they include precious and all-embracing entities. Destruction of a nation affects everything essential which is connected with the life of a nation...." The result of genocide, then, is the destruction of innumerable values which the nation has created: "Burning a house means annihilating not only the walls, but everything which hangs on the walls and stands on the floor, including indescribable spirit which is connected with the function of living in the house. Indeed the life of a nation like life itself is so rich it can hardly be evaluated by an inventory." (Ibid.)

${ }^{204}$ Raphael Lemkin, "Philosophical," supra note 104 (Box 3, File 3).

${ }^{205}$ Lemkin, "Philosophical," supra note 104 at 1. Compare Herder, Another, supra note 30 at 21. See also Lemkin, "The Genocide Convention" (undated) NYPL, supra note 191 (Reel 3, File 1, p. 5): "The Convention has also a deep cultural meaning. Every nation produces its own culture. When a nation is destroyed, its culture, language, tradition go forever. It takes centuries and sometimes thousands of years to create a national culture, but Genocide can destroy a culture instantly, like fire can destroy a building in an hour. By preventing Genocide one preserves national cultures as component parts of world culture."

${ }^{206}$ Given his familiarity with contemporary anthropological theory, Lemkin's use of the phrase "cultural personality of nations" should be read as a reference to the culture and personality movement championed at that time by Benedict, Mead, and other prominent anthropologists. In June 1946, Benedict proposed a "systematic study of national characters that might assist bilateral and multilateral co-operation, 'a laboratory of all nations' as she called it. ..." (Mandler, "One World," supra note 152 at 156.) Benedict argued that "[a] culture, like an individual, is a more or less consistent pattern of thought and action." (Benedict, Patterns, supra note 144 at 46.) "Cultural configurations stand to the understanding of group behavior in the relation that personality types stand to the understanding of individual behavior." "Cultures from this point of view are
} 
In Lemkin's pluralism, “[n]ational freedom is a basic prerequisite for cultural creation and thus

is a natural condition for a nation's mission in the world." ${ }^{207}$

Lemkin echoed Boas's interest in Humboldtian cosmography when he argued that

"Genocide is defined as the deliberate destruction of one of the four basic groups of mankind

(national, religious, racial or ethnical), whose totality of members form the human

cosmos. ${ }^{208}$ As with Alexander von Humboldt's theory of the Kosmos, Lemkin's idea of the

human cosmos brought together difference into a unified whole. He believed that "[ $[\mathrm{t}] \mathrm{he}$

individual psychology thrown large upon the screen, given gigantic proportions and a long time span." (Kroeber \& Kluckhohn, supra note 136 at 102, quoting Ruth Benedict, "Configurations of Culture in North America" 34 Am. Anthropologist 1, 23-24.) Throughout 1940 and 1941, Mead searched for "ways to 'explain' a culture in abstractions that were both theoretically satisfying and of potential use to the war effort." 206 (Mandler, Return, supra note 5 at 56.) Entranced with Freudian personality theory, she and her collaborators looked to culturally entrenched child-rearing practices to explain a culture's broader characteristics, or its "national character." (Mandler, ibid. at 63, explaining that Mead's "long-term goal ... was the incorporation of 'national character' into the future organization of world government - not to make other peoples more like Americans (probably impossible and definitely not desirable), but to get Americans and others to acknowledge their national differences in the great projects of international cooperation that awaited.") In 1949, Mead's close collaborator Geoffrey Gorer studied Russian child rearing and found that they were permissive in breastfeeding and toilet training, but restrictive in tightly swaddling infants. According to Gorer, this led to rage and a unique form of primitive, inchoate guilt, among other deleterious consequences. As this manifested in adulthood, Russians consistently would try to relive those moments of un-swaddled freedom, which predisposed them to bouts of orgiastic eating, drinking, copulation, and violence: "At one moment they are lonely, filled with rage, constricted by the swaddling; the next moment their limbs are free they are held in warm and strong arms and given the bountiful breast." (Quoted in Mandler, ibid. at 230, citing Geoffrey Gorer \& John Rickman, "The people of Great Russia" (1949) Margaret Mead, Geffrey Gorer \& John Rickman, Russian Culture (2001) 1-159. See also Geoffrey Gorer, "Some Aspects of the Psychology of the People of Great Russia" 8 Am. Slavic and E. European Rev. (1949), 155-66.) Gorer's approach was immediately derided as “diaperology," and Mead's defense of him did much to discredit not only herself but the entire culture and personality movement, and perhaps anthropology more generally. (Mandler, Return, supra note 5 at 234-242.)

${ }^{207}$ Lemkin, "Philosophical," supra note 104.

${ }^{208}$ Raphael Lemkin, "The Genocide Convention by Professor Raphael Lemkin, Author of the Genocide Convention" (undated) AJA, supra note 104 (Box 4, File 7). See also Lemkin, "A Memorandum on the Genocide Convention" (undated but post-1957), NYPL, supra note 191, Reel 3, File 1:

The philosophy of the Convention is very simple. It is based on the recognition that the human cosmos consists of the above-mentioned four groups. Every one of these groups is the creator of a culture of its own. If the group is destroyed, the culture is destroyed too. Since culture is of great value to mankind, and every nation borrows its cultural strength from other nations, the destruction of one of these four groups diminishes the volume of world culture. Consequently we protect these four basic groups not only because of our compassion for human life and our concern for the misery of other peoples, but also because we protect common cultural values. The totality of the groups protected by the Genocide Convention constitutes the whole human race. 
destruction of these four groups brings about, not only a deep deterioration of the moral feelings of society, but also a loss of the cultural contributions of every one of these groups." 209

While the right of groups to exist "as such" was central to Lemkin's idea of genocide, ${ }^{210}$ these groups had no innate right to exist. Instead, their rights derived from those of humanity, which had a right to the riches developed by each component nation:211 "Every type of genocide, whether directed against a religious, racial, ethnical or national group, is detrimental to humanity, not only because it Shocks $[$ sic] the human conscience but also because it deprives the world of . . the potential moral and cultural contributions of the human group slated for annihilation."212 In a 1946 American Scholar article, he argued that cultural considerations speak for international protection of national, religious and racial groups. Our whole cultural heritage is a product of the contributions of all nations. We can best understand this when we realize how impoverished our culture

${ }^{209}$ Lemkin, “The Genocide Convention by Professor Raphael Lemkin,” ibid.

${ }^{210}$ Lemkin, "Philosophical," supra note 104. Lemkin's support for the right of group existence was unambiguous. See Raphael Lemkin, "Genocide" 15:2 The American Scholar (1946), 227 at 229 [Lemkin, "Genocide"]: "[A]s in the case of homicide, the natural right of existence for individuals is implied; by the formulation of genocide as a crime, the principle that every national, racial and religious group has a natural right to existence is proclaimed." See also Raphael Lemkin, "Genocide as Crime under International Law," 4 United Nations Bulletin (15 January 1948) at 70: "A birthright, the right of entire human groups to exist, has been put under international protection by [UNGA Resolution 96(1)]." Contra Irvin-Erickson, supra note 48 at 12, arguing, "Lemkin's goal was not to use the law to create a world that would give groups a right to exist."

${ }^{211}$ Lemkin, Axis Rule, supra note 23 at 91 . He believed that

the respect for and appreciation of the national characteristics and qualities contributed to world culture by the different nations - characteristics and qualities which, as illustrated in the contributions weak in defense and poor in economic resources, are not to be measured in terms of national power and wealth.

${ }^{212}$ Lemkin, "GE VCIDE" [sic] (undated), AJHS, supra note 105 (Box 6, File 2). He continued, "We should never have had a Bible if the Jews had been exterminated before creating it. We should never have had the philosophy of the French Enlightenment, which lad [sic] the foundation for modern democracy, if the French nation had been slaughtered through an act of genocide. Such examples could be repeated." See also Lemkin, "On the Need for a Genocide Convention, Introduction" (undated, no pagination), AJHS, supra note 105 (Box 7, File 2), giving a further example: "Genocide committed on the Incas destroyed and interrupted the magnificent development of the art and science of astronomy. ... Similarly, genocide committed by Tamerlane in Persia inflicted great losses on Persian culture, from which this country has never recuperated fully." And "[t]he recent case of genocide against the Jews resulted in the disappearance of entire cultures. This is especially true of the original culture of the Polish Jews, who have developed original Yiddish literature and art." 
would be if the peoples doomed by Germany, such as the Jews, had not been permitted to create the Bible, or to give birth to an Einstein, a Spinoza; if the Poles had not had the opportunity to give the world a Copernicus, a Chopin, a Curie; the Czechs a Huss, a Dvorak; the Greeks, a Plato and a Socrates; the Russians, a Tolstoy and a Shostakovich. ${ }^{213}$

Thus, Lemkin based the Genocide Convention not on the rights of groups themselves, but on the right of humanity to benefit from the culture nurtured within those groups.

Because the culture-generating capacity of groups grounded their protection, Lemkin warned against including protections for "groups" more generally. He insisted that the word "group" in Article 2 of the Genocide Convention must always be modified by "national, racial, or religious." For, he declared, "[t]he law is like poetry. It can lose its meaning with the loss of a single word."214

\section{Lemkin's Diversity}

The role of cultural difference in maintaining the human cosmos led Lemkin to a core value: diversity. To Lemkin, diversity was not something to be tolerated; it was to be esteemed, cultivated, and above all protected. He argued that "the diversity of cultures is the basic condition of the existence and development of world culture," 215 for "[d]iversity serves

\footnotetext{
${ }^{213}$ Lemkin, "Genocide," supra note 211 at 228. See also Lemkin, Part 1, Ch. 2, Sec. 1, "International Collective Responsibility for the Survival of National, Racial, Religious, and Ethnical Groups" AJA, supra note 104 (Box 7, File 2): "Culture bearing groups: National, ethnical, and religious groups are the bearers of specific cultures. These cultures find expression in specific creations in the fields of music, literature, scientific achievements, linguistics, religious concepts, and so forth."

${ }^{214}$ See document attached to letter, Edith S. Besser to Lemkin, "Draft Paper" (2 February 1951) AJHS, supra note 104 (Box 7, File 3, at 3-4).

${ }^{215}$ Lemkin, "Nature of Groups," supra note 107. See also Lemkin (untitled and undated, but post November 1953), NYPL, supra note 191 (Reel 3, File 1):

The concept of genocide will help the world in its philosophereal [sic] and ethereal thinking and will enrich greatly the field of poetry, literature and the arts. Here we have a basic concept which reconciles the natural principle of diversity of nations, races and religious groups with the concept of universal unity in the sense of protecting the integrity of the component parts of mankind.

We want unity, but not uniformity. One nation, one race, one religion, one culture for all mankind would make our world a very dull and non-inspiring place. Because we recognize the equal value of
} 
the basic idea of the unity of the world and its civilization. This unity should not be mistaken

for uniformity. Uniformity is death while unity is an ideal of common responsibility for life, for all." ${ }^{216}$ He believed that "national and religious groups have a special place in the history of mankind. They produce mild moral values of very great importance. They enrich civilization through their contribution." ${ }^{217}$ He continued, "One can easily imagine how impoverished our culture would be if nations and races and religious groups slated for destruction would have been destroyed before they had made their great contributions to mankind." 218 Elsewhere, he argued,

It is easy to see that our world would be gradually converted in[to] a physical and cultural desert if we would allow these human groups to be exterminated and their spiritual heritage obliterated. Our world and our culture is based on natural diversity and at the same time on moral unity. We must seek to preserve various races, creeds and nationalities for the common purpose of cooperation, but not subordination. ${ }^{219}$

cultural contributions of all nations, races and religious groups the United Nations are united now through the Genocide Convention to protect diversity.

See also Lemkin, “A Memorandum on the Genocide Convention" (undated but post-1957), NYPL, supra note 191 (Reel 3, File 1).

${ }^{216}$ Lemkin, "Nature of Groups," supra note 107 at 3.

${ }^{217}$ Ibid. at 17-18.

218 Ibid. at 18.

${ }^{219}$ Lemkin, "Genocide" (undated, but post conclusion of the Genocide Convention), AJHS, (Box 6, File 2). See also Pearl S. Buck, letter to Lemkin (undated), AJHS, supra note 105 (Box 1, File 17). A "Manifesto" written by the Nobel-winning novelist Pearl Buck, with Lemkin's guidance, argued "that life in our world is enriched by the diversity of cultures and ideas which proceed from variety in racial, national, and religious groups, whatever their size and strength, ... as any community is the better for variety in its citizens." And she argued, "The destruction of variety would be an intolerable loss to mankind, and there is no guarantee, moreover, that the stronger group or groups would be the best ones, did they survive alone." See also Lemkin, "Nature of Groups,"supra note 107:

Obviously, mutual borrowing is natural. Some cultures have borrowed more, and some have borrowed less. At different stages of history some cultures have been stronger, some have been weaker, but the diversity of cultures in the world has been aspired to from earliest times. And onece a tendency was felt to impose one culture upon the rest of the world, like in the case of Greece, Rome, Assyria, France, ... . Nazi Germany ...., this tendency was always broken up by counter-forces which ultimately secure the principle of diversity.

See also, Lemkin "Stop Genocide Now” (undated), AJHS, supra note 105 (Box 7, File 3): 
To Lemkin, human groups were reservoirs of cultural genius. This genius not only enriches the group that produced it - it enriches humanity. ${ }^{220}$

In elevating the concept of diversity to a basic value, Lemkin appeared to echo other prominent mid-century thinkers. For instance, at mid-century, Lemkin's use of the term "genuine culture" (in the inset quote above) would have been read as a reference to Edward Sapir's article "Culture, Genuine and Spurious." ${ }^{" 21}$ Writing in 1932, Sapir adumbrated much of Lemkin's thinking on diversity, writing, "A culture may well be quickened from without,

Our whole cultural heritage is the product of the contributions of all peoples, races and creeds. We can best understand how impoverished our culture would be if the peoples doomed by the Nazis such as the Jews, and had not been permitted to create the Bible, or to give birth to a Brandeis, a Spinoza; if the Poles had not the opportunity to give the world a Copernicus, a Chopin, a Curie; the Czechs a Huss, a Dvorak; the Greeks a Plato and a Socrates; the Russians a Tolstoy and a Rimsky Korsakoff.

${ }^{220}$ Lemkin, "GE VCIDE" [sic] (undated), AJHS, supra note 105 (Box 6, File 2). In basing the group right of existence on humanity's right to enjoy the cultural contributions of all groups, Lemkin was embracing a pluralistic theory of cultural diversity that had long roots in the German tradition. Herder wrote, "Men of all quarters of the globe who have perished over the ages, you have not lived solely to manure the earth with your ashes so that at the end of time your posterity should be made happy by European culture. The very thought of a superior European culture is a blatant insult to the majesty of nature." (Williams, Keywords, supra note 138 at 89.) See also Berlin, Against, supra note 113 at 11. As Berlin put it to Herder,

nothing is more barbarous than to ignore or trample on a cultural heritage. Hence Herder's condemnation of the Romans for crushing native civilizations, of the church (despite the fact that he was himself a Lutheran clergyman) for forcibly baptizing the Balts, and so forcing them into a Christian mould alien to their natural traditions, or of British missionaries for doing this to the Indians and other inhabitants of Asia, whose exquisite native cultures were being ruthlessly destroyed by the imposition of alien social systems, religions, forms of education that were not theirs and could only warp their natural development.

See also Dumont, German Ideology, supra note 15 at 120-21. Wilhelm von Humboldt, drawing on Herder, had applied the notion of Bildung to cultures, strengthening the argument for the protection of diversity. Humboldt argued that as individuals cultivate themselves, reaching for the internal perfection of Bildung, so a culture cultivates itself, reaching for its best self. Because, as with individuals, development happens internally, within the culture, the development of any one culture will be unique. Humboldt saw in these particularities an opportunity for the improvement of the species as each culture had the potential to contribute its unique gifts to the whole of humanity. But as Dumont argues, Humboldt lacked Herder's robust egalitarianism, so that "[t]here are blamable varieties [of culture], 'indeed not every difference deserves to be preserved." (Ibid. quoting Humboldt.)

${ }^{221}$ Edward Sapir, "Culture, Genuine and Spurious," 29 Am. J. Sociology (1924) 401-429, cited here as Sapir, "Genuine," supra note 172. 
but its suppression by another, whether superior or not, is not cultural gain":222 "[T]he deliberate attempt to impose a culture directly and speedily, no matter how backed by good will, is an affront to the human spirit. When such an attempt is backed, not by good will, but by military ruthlessness, it is the greatest conceivable crime against the human spirit, it is the very denial of culture." 223 Sapir also argued against "the prevalent fallacy that internationalism is in spirit opposed to the intensive development of autonomous cultures."224

Similarly, Lemkin cautioned that protecting nations should be based not on "subjugation" but on the search for a common ground for cooperation." 225 He argued,

There must be a unity in the ideal of protection while guarding against this protection from becoming overzealous so as to destroy the very values which are protected. Unity is required to carry out the ideal of protection but by no means should this unity be confused with uniformity which stems from a misinterpreted tendency to mold human values in every nation in the same fashion. Unity should not lead to uniformity nor to universal dullness. ${ }^{226}$

Likewise, T. S. Eliot wrote that " $[\mathrm{t}]$ he absolute value is that each area should have its characteristic culture, which should also harmonise with, and enrich, the cultures of the neighboring areas." 227 And if it is to be a healthy culture, it must be "part of a larger culture, which requires the ultimate idea, however unrealizable, of a 'world culture' in a sense

\footnotetext{
${ }^{222}$ Sapir, "Genuine," supra note 172 at 328.

${ }^{223}$ Ibid.

${ }^{224} \mathrm{Ibid}$. at 329 . However, "[u]nfortunately we are so obsessed by the idea of subordinating all forms of human association to the state and of regarding the range of all types of activity as conterminous with political boundaries, that it is difficult for us to reconcile the idea of a local restrictedly national autonomy of culture with a purely political state-sovereignty and with an economic-political internationalism.

${ }^{225}$ Lemkin, "Philosophical," supra note 105.

${ }^{226}$ Ibid.

${ }^{227}$ Eliot, Notes, supra note 160 at 53 [emphasis in original].
} 
different from that implicit in the schemes of the world-federationists." 228 Thus, Lemkin held

culture precious, as did these other commentators - so much so that he would protect it not

only from inter-group aggression, but from the "world-federationists" and others involved

universalistic schemes of international governance.

\title{
Lemkin's Relativism
}

Valuing cultural difference as deeply as he did led Lemkin to engage with the far

\author{
more controversial theory of cultural relativism. ${ }^{229}$ Citing Ruth Benedict's Patterns of
}

\begin{abstract}
${ }^{228} \mathrm{Ibid}$. at 83. He believed "it is of great advantage for English culture to be constantly influenced from Scotland, Ireland, and Wales," and implied that the real value of these "satellite cultures" inhered in their ability to revitalize the dominant, English culture. For, "[a] people is judged by history according to its contribution to the culture of other peoples flourishing at the same time and according to its contribution to the cultures which arise afterwards." (Ibid. at 53.) For this reason, "[w]e can also learn to respect every other culture as a whole, however inferior to our own it may appear, or however justly we may disapprove of some features of it: the deliberate destruction of another culture as a whole is an irreparable wrong, almost as evil as to treat human beings like animals." (Ibid. at 65-66.)

${ }^{229}$ David A Hollinger, "Cultural Relativism," supra note 145 at 710. Melville J. Herskovits, Cultural Relativism: Perspectives in Cultural Pluralism (New York: Random House, 1972) at 31, described cultural relativism as "a philosophy that recognizes that the values set up by every society to guide its own life that understands their worth to those who live by them, though they may differ from one's own." Herskovits described cultural relativism as having "three quite different aspects," methodological, philosophical, and practical. Methodologically, the anthropologists' notion of cultural relativism foreshadowed the postphenomenological hermeneutic approach that I outlined in a previous chapter 2. (Ibid. at 32.) Later he declared that cultural relativism "holds that there is no absolutely valid moral system, any more than there is an absolutely valid mode of perceiving the natural world. The traditions of a people dictate what for them is right and wrong, how they are to interpret what they see and feel and hear, and they live according to these imperatives." (Ibid. at 101.) See also, Kroeber \& Kluckhohn, supra note 136 at 174:
\end{abstract}

[S]incere comparison of cultures leads quickly to recognition of their "relativity." What this means is that cultures are differently weighted in their values, hence are differently structured, and differ both in part-functioning and in total-functioning; and that true understanding of cultures therefore involves recognition of their particular value systems. Comparison of cultures must not be simplistic in term of an arbitrary or preconceived universal value system, but must be multiple, with each culture first understood in terms of its own particular value system and therefore its own idiosyncratic structure.

See Benedict, Patterns, supra note 144 at 2, declaring, "No man ever looks at the world with pristine eyes. He sees it edited by a definite set of customs and institutions and ways of thinking. Even in his philosophical probings he cannot go behind these stereotypes; his very concepts of the true and the false will still have reference to his particular traditional customs." Notably, relativism was not unique to the anthropologists. Eliot, who had previously achieved renown for espousing the virtues of "Christian society," cautioned that "[e]very nation, every race, has not only its own creative, but its own critical turn of mind; and is even more oblivious of the shortcomings and limitations of its critical habits than those of its creative genius." (T. S. Eliot, "Tradition and the Individual Talent" in Peter Washington, ed, Eliot: Poems and Prose (Knopf, 1998) at 117. See also David Hollinger, "Science as a Weapon in Kulturkampfe in the United States During and After World War II," 86 Isis (1995) 440 at 443 (discussing Eliot's anti-Semitism). Notably, cultural relativism is also traced back to 
Culture, Lemkin lauded cultural relativism, writing, "It can be a doctrine of hope rather than despair. In our present endeavors at unifying the world for peace, this doctrine has a two-fold significance. It means that we must respect every culture for its own sake. It also means that we must probe between specific cultural differences in our search for a unified conception of human values and human rights. We know that this can be done."230

In the cultural moment, the theory of cultural relativism was seen as a crucial insight that would allow policymakers to shape a more harmonious world. Kluckhohn and Kelly argued that

those who have the cultural outlook are more likely to look beneath the surface and bring the culturally determined premises to the light of day. This may not bring about immediate agreement and harmony, but it will at least facilitate a more rational approach to the problem of "international understanding" and to diminishing the friction between groups within a nation. ${ }^{231}$

Cultural relativists recognized "the pluralistic nature of the value systems of the world's cultures, and that the ways of the many different peoples of the world cannot be judged on the basis of any single system." ${ }^{232}$ This implied a cautionary stance against what Herskovits termed "cultural evangelism," "where an exercise of power is accompanied by a

Herder and the Romantics. See Isaiah Berlin, Vico and Herder, supra note 58 at 153. Berlin sums up Herder's pluralism as "the belief not merely in the multiplicity, but in the incommensurability, of the values of different cultures and societies and, in addition, the incompatibility of equally valid ideals, ..." See also Terry Eagleton, The Idea of Culture (Malden, MA: Blackwell, 2013) at 14. With the Romanticists, "there is something intrinsically precious about a whole way of life, ... [s]imply being a culture of some kind was a value in itself."

${ }^{230}$ Lemkin, Lemkin on Genocide, supra note 22 at 42. Note that Jacobs uses "prove" where Lemkin's original manuscript says "we must probe." See Lemkin, "Anthropology," NYPL, supra note 191 (Reel 3, folder 1/4).

${ }^{231}$ Kluckhohn \& Kelly, supra note 179 at 104.

${ }^{232}$ Herskovits, supra note 230 at 109 . Herskovits argued that the concept of cultural relativism "holds that there is no absolutely valid moral system, any more than there is an absolutely valid mode of perceiving the natural world. The traditions of a people dictate what for them is right and wrong, how they are to interpret what they see and feel and hear, and they live according to these imperatives." (Ibid. at 101.) 
claim of total cultural superiority." 233 "Above all," it demanded "a reorientation of thought that, by giving full weight to the cross-cultural factor, will grant to all peoples their right to identify their future with the continuities of their ancestral heritage."234

Ultimately, Cold War exigencies cut short the relativists' run. The world would be divided between two superpowers with little interest in recognizing, much less valuing, particular cultures. But this was not apparent in the cultural moment. In invoking the idea of cultural relativism, Lemkin was not only expressing his culturalist views; he was also aligning himself with the most influential thinkers on international governance.

\section{Lemkin's Destruction}

This abiding awareness of the fragility of group life led Lemkin to develop an elaborate typology of genocidal destruction. In Axis Rule, he first outlined nine distinct techniques of genocide: political (forced name changes of individuals and landmarks, expulsions), social (imposing foreign law, altering social structures and targeting intelligentsia), cultural (forbidding the use of targeted languages, requiring education in the dominant culture, limiting access to libraries or other cultural centres), economic ("lowering ... the standard of living creates difficulties in fulfilling cultural-spiritual requirements"), biological (discriminatory undernourishment, encouragement of illegitimate children, separation of the sexes, marriage restriction, and other steps to decrease birthrates), physical (depriving the targeted group of calories or endangering health by withholding blankets and firewood, mass killings), religious (allowing children to renounce their religion, destruction

\footnotetext{
${ }^{233} \mathrm{Ibid}$. at 82 .

${ }^{234} \mathrm{Ibid}$. at 75.
} 
of churches), and moral ("weaken[ing] the spiritual resistance of the national group" through pornography, alcohol, and gambling). ${ }^{235}$

Each of Lemkin's techniques of genocide, even physical genocide, operated culturally by destroying the cohesiveness of the group. These techniques are not genocide in and of themselves; they are the means of committing genocide, which is the destruction of the group. Key to understanding this is Lemkin's assertion that “[g]enocide is directed against the national group as an entity, and the actions involved are directed against individuals, not in their individual capacity, but as members of the national group." ${ }^{236}$ This statement unearths the syllogism at the heart of Lemkin's idea of the group: because groups can only coalesce through culture, techniques of genocide, even mass killings, must destroy the group by attacking its cultural functioning. That is, while man is a biological entity and killing him requires a biological attack, a group is a cultural entity so that killing it requires an attack on its culture, even when the attack involves "physical" means such as mass killings.

Lemkin explains that "genocide does not necessarily mean the immediate destruction of a nation, except when accomplished by mass killings of all members of a nation."237 Instead, genocide signifies "a coordinated plan of different actions aiming at the destruction of essential foundations of the life of national groups, with the aim of annihilation of the groups themselves." 238 Thus, "[t]he objectives of such a plan would be disintegration of the

\footnotetext{
${ }^{235}$ Lemkin, Axis Rule, supra note 23 at 82-90.

${ }^{236} \mathrm{Ibid}$. at 79. See also Lemkin, "Genocide," NYPL, supra note 191 (Reel 3, File 1 at 1). "The Genocide Convention protects specifically the minds of the people because it is through the mind that the nation exists and transfers its national heritage."

${ }^{237}$ Axis Rule, ibid. [emphasis added].

${ }^{238}$ Ibid.
} 
political and social institutions, of culture, language, national feelings, religion, and the economic existence of national groups, and the destruction of the personal security, liberty, health, dignity, and even the lives of the individuals belonging to such groups." 239 Any attack that does not kill all of its members leaves the group able to function so long as its culture remains intact. Only when the attack ruptures its culture to the point that the group can no longer function as an entity has genocide been achieved. ${ }^{240}$

Lemkin believed a group's cultural leaders were crucial to its continuity. He invoked "Carlyle [who] once said ... ten original thinkers within one society are able to create a national culture.” ${ }^{241}$ Again writing after the Genocide Convention had been concluded, Lemkin argued that the phrases "destruction in part" and "as such" in the chapeau of Article 2 meant that the Genocide Convention prohibited killings aimed at destroying the "elements" of a group "which provide the forces of cohesion ... and which are traditionally the residue

${ }^{239}$ Ibid.

${ }^{240}$ Lemkin, "GE VCIDE" [sic] (undated), AJHS, 105 (Box 6, File 2). After its conclusion, and despite the excision of the cultural genocide provisions, Lemkin continued to believe the Convention protected group "continuity." To him, the requirement that groups be destroyed "as such" was crucial and therefore:

[a] human group is considered an organic entity and as such can be eliminated either by acts of violence leading to the immediate death of its members or by measures designed brutally to interrupt its continuity. To the first group belong such measures as killings, mutilations, incarceration in concentration camps, in conditions endangering life, etc. This is physical genocide. To the second group belong such acts as compulsory sterilization, abortions, stealing of children.... This is biological genocide. From the point of view of genocide or the destruction of a human group, there is little difference between direct killings and such techniques which, like a time-bomb, destroy by delayed action.

See also, Lemkin, "Philosophical," AJA, supra note 104 (Box 3, File 3), discussing "the kidnapping of children," which he described as "a well-known" "technique of genocide." He argued, "Here we deal not with the destruction or mutilation of the body, but with the disintegration of the "national soul' of the children."

${ }^{241}$ Lemkin, Part 1, Ch. 2, Sec. 1, "International Collective Responsibility for the Survival of National, Racial, Religious, and Ethnical Groups," AJA 104 (Box 7, File 2). In support, Lemkin cites T. S. Eliot's Notes (supra note 160). 
of its national consciousness." 242 To determine whether an attack on a group would be considered genocide, one must look to the "sociological structure" of a specific group. He explained,

In many countries in Central and Eastern Europe the forces of cohesion of nations are provided by the intelligentsia, the clergy and the middle class. When these elements are removed, those remaining lose their source of national inspiration. They become an amorphous mass which although speaking the national language, is gradually losing its nation and cultural identity. Hence a national group can be destroyed as such when the elements of a national leadership or national inspiration have been destroyed. ${ }^{243}$

Lemkin argued consistently that "[t]hrough liquidation, for example of the national or spiritual leaders of a group, the elements of cohesion are being weakened, and the entire groups starts to disintegrate as a group. Through injuring the brain, the entire body becomes paralyzed." 244

Lemkin's apparent cultural elitism is troubling when judged by today's more egalitarian standards. His approach would differentially value the lives of cultural leaders, who would be protected because of their role in perpetuating "national culture." The rest of us, it seems, might be killed with abandon as our loss would not endanger the group. This

\footnotetext{
${ }^{242}$ Raphael Lemkin, "Philosophical," AJA, supra note 104 (Box 3, File 3).

${ }^{243}$ Raphael Lemkin, "Philosophical," ibid. See also Lemkin, "On the Need for a Genocide Convention, Introduction," AJHS supra note 105 (Box 7, File 2 at 8), arguing "the words 'in part' might also refer to the special role which the part subject to destruction plays in the entirety, as, for example, an intellectual class in a nations groups [sic] or priests in a religious groups. Through the destruction of these substantial parts, national or religious groups are most severely damaged." See also Lemkin, "Memorandum on the Genocide Convention" (undated), AJA, supra note 104 (Box 4, File 6 at 2):

For all practical purposes the concept of national groups is so broad, that it includes also the elements which actively lead the nation and provide the forces of cohesion. Such an interpretation is made plausible by the fact, that according to the Convention a national group can be destroyed also in part. ... This permits to indict the acts of the Soviet Union, consisting in the liquidation of national leaders, so that the remainder of the nation can be reduced to an amorphous mass and enslaved. It should be noted in this connection, that the Genocide Convention uses the words "to destroy a group in part," but not to exterminate a group.

${ }^{244}$ Lemkin, "The Genocide Convention" (undated but post-1951), AJA , supra note 104 (Box 4, File 7).
} 
thinking largely tracks that of other mid-century thinkers, especially those, like Eliot, who prized "high" or "literary" culture. ${ }^{245}$ At that time, even the anthropologists tended to praise high cultural achievement, so Lemkin's apparent elitism would have been unlikely to attract criticism.

\section{The Grand Conflation}

All this nuance is invisible to the lay public. In the lay imagination, genocide is simply mass murder carried out on a grand scale. The concept of a "human group" has little salience, and instead the focus turns inevitably to body counts. Among members of the public, who have not read the Genocide Convention and who save their attention for the world's bloodiest misdeeds, such misunderstandings are to be expected. However, a number of prominent scholars have also conflated genocide with mass murder. These scholars believe the term genocide should be reserved only for the most horrific incidents of mass killing, and they dismiss or deride other forms of group destruction. This rhetorical move has done much to damage understandings of the Genocide Convention and has hindered its implementation.

But the grand conflation of genocide with mass murder might well be traced to Lemkin himself. He was, it seems, all too willing to sacrifice his concept to further his law, and his contradictory impulses left a muddied wake of conflicting meanings. Axis Rule outlines Lemkin's culturalist view of genocide, which he held throughout his life. However, he was no theoretical purist and later, in his activist role, would sometimes undermine his

\footnotetext{
${ }^{245}$ See Manganaro, supra note 138 at 24-26, explaining the friction between "hierarchical" literary culture and "anthropological culture." As he points out, Sapir and Boas incorporated aspects of "hierarchical culture" into their theories of culture. (Ibid. at 26.)
} 
complex idea by conflating it with mass killings in order to garner public support for the Genocide Convention. ${ }^{246}$ This conflation became more common after 1948, when he sought ratification by the US Senate. A poster from this period by one of Lemkin's organizations, the Washington Committee for the Ratification of the Genocide Convention, screams, "Genocide is Mass Murder!"247 Yet he chastised his friend Pearl Buck, the Nobel Prizewinning author, for confusing genocide with mass murder. ${ }^{248}$ And in a 1950 letter addressing the ratification debates in the US Senate, Lemkin chided, "Mass murder was not sufficient as an expression because it does not convey the element of selecting victims, moreover a nation can be destroyed not only by depriving life but also by preventing life by such means as sterilization, breaking up of families, and stealing of children. Genocide can also be committed by torturous and insidious acts which end up in mutilization [sic] and disintegration of the mind." 249

Lemkin, it seems, offered two competing and irreconcilable definitions of genocide, one theoretical and academic, intended to elucidate a complex and terrifying problem for a literate insider class. The other, stripped down to its most evocative facet, intended to rally public support. But despite Lemkin's inconsistencies, culture emerges as the unifying factor in his idea of genocidal destruction. Any act, short of killing all the members of a group, destroys the group by weakening its culture. Acts like transferring its children or killing its

\footnotetext{
246 Perry S. Bechky, “Lemkin’s Situation: Toward a Rhetorical Understanding of Genocide” 77 Brook L Rev (2011) 551, 613 .

247 Washington Committee for the Ratification of the Genocide Convention, "Genocide is Mass Murder! And There is a Law Against it!" (1950) AJHS, supra note 105 (Box 2, File 6).

248 Pearl Buck, letter to Lemkin (11 February 1948) AJHS, supra note 105 (Box 1, File 19).

${ }^{249}$ Lemkin, "The Genocide Convention Before U.S.A. Senate" (undated but addressing events of 1950) AJHS, supra note 105 (Box 2, File 4).
} 
intelligentsia do not destroy the group's physical existence so much as they destroy its "national soul." And a group without a national soul is destined for the wasteland.

\section{Bergson's Time}

Lemkin identified "the thesis" of his never-finished work on the history of genocide as follows: "[C]ivilization is not a frozen product but rather the creation of the constant striving of individuals." ${ }^{250}$ Thus, temporality is a key, if often overlooked, element of Lemkin's conception of group life. According to him,

[a] nation or race or religious group has two basic phases of existence: a) actual existence in the present, and b) continuity. The basic difference between an individual and a nation or a race lies not only in numbers but in the latter's collective personality, which reveals itself in the form of continuity throughout ages and the will to continue as a nation, as a race, or as a religious group. These groups look to the future, one might say to eternity. ${ }^{251}$

Here, Lemkin draws on the Romantic tradition from Herder to Dubnow, but also seems to draw on a Bergsonian sense of time and to incorporate the French philosopher's concept of élan vital..$^{252}$

Lemkin acknowledged his intellectual debt to Bergson, and it is clear that Bergsonian ideas influenced him profoundly. ${ }^{253}$ While Bergson was not an anthropologist, Lemkin’s Bergsonianism clearly shaped his anthropological ideas on group life. To Bergson, time was

\footnotetext{
${ }^{250}$ Robert Merrill Bartlett, "Pioneer vs. an Ancient Crime," The Christian Century (18 July 1956) 854. Wherein he would "try to develop a concept of history through the human group, not through the state."

${ }^{251}$ Lemkin, draft manuscript (2 February 1951) AJHS, supra note 105 (Box 7, File 3).

${ }^{252}$ Leszek Kolakowski, Bergson (Oxford: Oxford University Press, 1985) at 57. According to Kolakowski, Bergson's notion of élan vital entailed "the original energy that by infinite bifurcations and wrestling with the resistance of matter produces higher and higher variations of both instinct and intelligence. Something of this original impulse is preserved in all species and all individual organisms, all of them working unconsciously in its service." To Bergson, the process of evolution, fed by "this original impulse," proliferates variation in pursuit of a common good.

${ }^{253}$ Lemkin, Unofficial, supra note 2 at 167.
} 
not primarily or in its most interesting aspects a matter of clocks and objective measurement. Time, he asserted, is the quintessence of the human experience of being, and it is this innate drive that led us to quantify it, to invent clocks. ${ }^{254}$ Bergson posited a human tendency to divide the passing of time spatially into a series of events and analogized this to a "cinematographic camera," which catalogs static cross-sections into dynamic movement. But he warned that this distorts the reality of time, as much is lost between the frames.

A group, for Lemkin, is a process of constant forward creation. A group exists not merely in its present but through its past and for its future. This durée - the subjective perception of group members of temporality - binds the group and is its reason for existence. He declared that "[i]n the present, the life of the group coincides with the life of the individual members of the group. However, the group is endowed with a historical existence, while its members enjoy only a physical existence." ${ }^{255}$ As Bergson explained, "[o]ur psychological life is a continuous duration: it is the continuous progress of the past, which gnaws at the future and swells up as it advances. ${ }^{256}$

It is unsurprising that Lemkin would have been influenced by Bergson, who was perhaps the leading philosopher and public intellectual of his era. ${ }^{257}$ But time was unkind to Bergson, who lived just long enough to see his ideas attacked and largely discredited. In part, this wound was self-inflicted, the result of his picking a very public fight with Einstein over

\footnotetext{
${ }^{254}$ Jimena Canales, The Physicist and the Philosopher: Einstein, Bergson, and Debate that Changed Our Understanding of Time (Princeton: Princeton University Press 2015) at 42.

${ }^{255}$ Lemkin, Unofficial, supra note 2 at 167.

${ }^{256}$ Canales, supra note 254 at 301, quoting Bergson.

${ }^{257}$ Canales ibid. at 12; Karl Dietrich Bracher, The Age of Ideologies: A History of Political Thought in the Twentieth Century (New York: Saint Martin's Press, 1984) at 22. See Lemkin, "Memorandum" (undated) AJA, supra note 104 (Box 4 File 7 at 7) quoting Bergson; Raphael Lemkin, "Stop Genocide Now," AJHS , supra note 105 (Box 7, File 3 at 6) citing Bergson.
} 
the nature of time. The two great men famously held an impromptu public debate in Paris on April 6, 1922, which generated decades of debate and thousands of monographs as scholars joined in the intellectual war. On Bergson's side were those arguing that science could not account for everything, that the psychological experience of time and the physicists' conception of time only explained certain aspects of the phenomenon. On the other side were those who joined Einstein in arguing that "the time of the philosophers does not exist."258

If now largely forgotten, the stakes in this intellectual war were immense, concerning the reach of scientific explanation and the remit of philosophy. In 1946 Bertrand Russell despaired that Bergson's work “exemplifies admirably the revolt against reason which, beginning with Rousseau, has gradually dominated larger and larger areas in the life and thought of the world." ${ }^{259}$ And much as Bergson's work was a "revolt against reason," logical positivism rebelled against Bergson. As Canales puts it, "[m]ost logical positivists were driven by two goals: that of building knowledge on a firm empirical foundation and that of distancing it from dangerous metaphysics. Part of the movement was shaped by a particular hatred for the work of one man-Bergson—and an intense appreciation for the work of another: Einstein." 260

\footnotetext{
${ }^{258}$ Canales, supra note 254 at 5.

${ }^{259}$ Bertrand Russell, The History of Western Philosophy (London: Routledge, [1946] 1996) at 791.

${ }^{260}$ Canales, supra note 254 at 154. See also ibid. at 192, recounting the work of Herbert Dingle, who linked relativity and the rise of logical positivism. See also Kolakowski, supra note 252 at 9, arguing that aspects of Bergson's philosophy epitomized

a cultural trend which swept through Europe from the 1890's onwards and which is sometimes labeled "modernism" or "neo-romanticism." ... "Life" was the most powerful catchword of the age and "life" was opposed not only to inert matter, but to the supremacy of calculating reason and the monopoly of analytical spirit. ... The world it was claimed, refuses to be confined to the artificial limits that scientists had imposed on it; its mysterious and elusive facets keep haunting our experience, whatever the rationalists might decree. ... The tendency of the Zeitgeist was, on the one hand, to perceive the world as permeated by quasi-subjective energies, and, on the other to stress the unity of this all pervading sprit in which the human personality seemed to dissolve.
} 
A "Memorandum" in Lemkin's papers appears to address this controversy directly,

arguing,

Lemkin has created an original concept which finds application not only to law but also to history, philosophy, ethics, religiou [sic] and social science. Unlike Einstein who created the formula for the physical universe of mankind, Lemkin has created the formula for the human universe. According to [Lemkin] the human universe or human kind is divided into four basic groups: national, religious, ethnical, racial. The total of these groups makes up the human universe. These groups have contributed through their original cultures to world culture. The destruction of one of these groups through Genocide diminishes not only the volume of world culture but disturbs its harmony and tonality which is based on the originality of cultures.

Unlike Einstein's theory which can be misused for destruction, [Lemkin's] theory can only be used for life. ${ }^{261}$

Thus, seeming to side with Bergson, Lemkin placed his pluralistic theory of the "human

universe" in opposition to Einstein's positivism. Of course, we know which side won.

Countless posters of Einstein adorn college dorm rooms, while one would be hard pressed to

find an undergraduate who knows Bergson's name.

Kolakowski's point is vital in understanding the Genocide Convention. As the Enlightenment had been dominated by Descartes's mechanistic metaphor, of the universe as a piece of divine machinery set to run on its own, Lemkin's age, shaped by Darwin, had been dominated by a metaphor of life, a biological metaphor, wherein the thing to be understood was vested with life forces, a unique history, and therefore a destiny of its own.

${ }^{261}$ Lemkin, "Memorandum," (undated) AJA, supra note 104 (Box 4, File 7). Notably, he did not conceive originally of four human groups; "ethnical" was added by the drafters in the Sixth Committee debates.

Interestingly, the Bergson-Einstein debate centred on interpretive issues. See Kolakowski, supra note 252 at 24, explicating Bergson's interpretive approach:

We get to know a thing, Bergson says, either by circling around it or by entering into it. If we stay outside, the result depends on our standpoint and is expressed in symbols, whereas in the second kind of cognition we follow the life of the thing as an emphatic identification with it. In the first approachanalysis - I am unable to grasp, let alone express, the uniqueness of the object; I have to decompose it into elements which I describe only in terms already known to me ... The second approach also enables me to reach the reality which does not depend on my position and is, in that sense, absolute. This approach - intuition - is a sympathy whereby one carries oneself into the interior of an object to coincide with what is unique and therefore inexpressible.

Thus, Bergson fits squarely within the hermeneutic tradition in denying any Archimedean standpoint from which objective evaluation is possible. Early in his career, Einstein, by contrast, believed scientific instruments provided an unmediated view of the universe and denied interpretation any meaningful role. (Canales, supra note 254 at 232.) Lemkin, a dedicated philologist, clearly aligned with the latter view. 
Throughout Lemkin's writings, we see traces of Herder's key concepts: individual, culture, nation/Volk, and Humanität. Individuals are born into and perpetuate culture, but the group is the key to culture. ${ }^{262}$ Individuals may come and go without unduly affecting the culture, but if group function is harmed, the culture is endangered. The idea of nation is nearly synonymous with the idea of a culture-generating group and is vital to the perpetuation of culture. Culture, in turn, is vital to the continuation of humanity-so vital, in fact, that humanity, itself conceived of as a nebulous entity, has a right to protect culturegenerating groups. The capacity of cultures to foster advances that benefit humanity is the justification for protecting groups. Turning from Herder to Bergson, we see that Lemkin's culture is a process of tradition and innovation, of incorporation and bifurcation, centred on a common consciousness of duty and destiny.

\section{The World Embraces Lemkin's (Culturalist) Idea}

As World War II ended, a world struggling for language with which to make sense of the Nazis' atrocities eagerly embraced Lemkin's idea of genocide. Lemkin had outlined his idea in Chapter 9 of his 1944 book, Axis Rule in Occupied Europe. ${ }^{263}$ Comprising more than six hundred pages of mostly dry prose, including seemingly endless examples of Nazi

\footnotetext{
${ }^{262}$ Lemkin, Part 1, Ch. 2, Sec. 1, "International Collective Responsibility for the Survival of National, Racial, Religious, and Ethnical Groups," AJA, supra note 104 (Box 7, File 2). Like nearly every other mid-century thinker on culture, Lemkin posited a reciprocal relationship between and individual and her culture, wherein an individual germinated in and was nourished by a particular cultural soil. If this soil were fertile, her roots in this soil would allow her to contribute her own unique genius, in the form of art, science or other cultural contributions, back to the group. The most fertile cultural soil was capable of producing the most valuable advances in art and knowledge, which were valuable not only to the group of their generation, but to humanity as a whole. He believed that "[e]very society indeed develops in the course of ages culture bearing elements which developa [sic] supreme capacity of transforming the substrata of national ethos into great works of art, music or literature. Whether their name is Voltaire, Joyce, Hemingway, Tolstoy, or Gabriela Mistral, it is everywhere clear that they have drawn from the deepest layers of national consciousness for the purposeof [sic] creating great original works." Thus Lemkin, like Herder, was an individualist, of a sort.
}

263 Lemkin, Axis Rule, supra note 23 at $79-99$. 
decrees reproduced verbatim, his book was a decidedly odd vehicle for altering world opinion. But it hit its mark. On January 21, 1945, the New York Times Book Review featured Axis Rule on its cover, and the review within praised Lemkin's idea for helping make sense of the Nazi atrocities, which were then "seen only dimly and partially."264

It would take several years for Lemkin's conception to metamorphose into the Genocide Convention's definition. Unwilling to wait for codification, in the war's immediate aftermath activists and jurists began applying his conception to the Nazi project's vast wreckage. No defendants were convicted of genocide in the Trial of Major War Criminals conducted by the International Military Tribunal (IMT) at Nuremberg, but the idea of genocide influenced the way prosecutors organized and argued the case. ${ }^{265}$ Lemkin's word fared even better in the second round of Nuremberg trials conducted by the Americans under Control Law No. 10, during which two groups of defendants were convicted of genocide, classified as a form of crimes against humanity. ${ }^{266}$ Additionally, the Polish national courts convicted three prominent defendants of genocide. ${ }^{267}$

\footnotetext{
${ }^{264}$ Otto D. Tolischus, “Twentieth-Century Moloch: The Nazi-inspired Totalitarian State, Devourer of Progress - and of Itself," Book Review of Axis Rule in Occupied Europe by Raphael Lemkin, New York Times (21 Jan 1945) 102. See also John Q. Barrett, "Raphael Lemkin and 'Genocide' at Nuremberg" in Christoph Safferling \& Eckart Conze, eds, The Genocide Convention Sixty Years After its Adoption (TMC Asser Press, 2010) 35, 50. Lemkin developed important relationships at the New York Times and the Washington Post, which he called on to publicize his concept. These newspapers responded not only by reviewing his book, no small thing in itself, but also by running stories and editorials bringing attention to his ideas and even arguing that the word "genocide" should be used in the Nuremberg Judgment.

${ }^{265}$ See, Barret, ibid. at 45.

${ }^{266}$ Hilary Earl, "Prosecuting Genocide before the Genocide Convention: Raphael Lemkin and the Nuremberg Trials 1945-1949” 15 J. Genocide Res (2013) 317, 321-26 (documenting Lemkin's involvement with the IMT).

${ }^{267}$ Trial of Haupsturmführer Amon Leopold Goeth, Commandant of the Forced Labour Camp Near Cracow, Supreme National Tribunal of Poland $\left(27^{\text {th }}-31^{\text {st }}\right.$ Aug and $2^{\text {nd }}-5^{\text {th }}$ Sept. 1946) in United Nations War Crimes Commission, Law Reports of War Criminals, vol 7 (London: His Majesty's Stationary Office, 1948) 1 [Goeth]. In re Greiser the Supreme National Tribunal of Poland (7 July 1946) reprinted in Annual Digest and Reports of Public International Law Cases: Year 1946 Sir John Fisher Williams \& H. Lauterpacht, eds., (London: Butterworths \& Co., Ltd., 1951). Trial of Obersturmbannführer Rudolf Franz Ferdinand Hoess, Comandant of the Auschwitz Camp, Supreme National Tribunal of Poland (1 $11^{\text {th }}-29^{\text {th }}$ March, 1947) in United Nations War
} 
This early customary definition still matters. As the International Criminal Tribunal for the Former Yugoslavia (ICTY) has recognized, the pre-codification definition of genocide in customary international law continues to carry legal weight insofar as the Genocide Convention did not depart from it. ${ }^{268}$ Where the Convention is silent or lacks sufficient nuance, interpreters should look to this customary law for possible answers.

The Genocide Convention's drafters operated against this background of rapidly developing customary law and with each issue faced the choice of either endorsing or overriding the existing law of genocide. Endorsing existing customary law required no special effort, as it would simply carry over as before. However, where the drafters had intended to override existing customary law, we would expect them to indicate this in the text of the Convention or in the preparatory materials. Many arguments about exclusion centre on just this issue: whether the drafters sufficiently distanced their idea of genocide from earlier culturalist conceptions.

\section{Nuremberg}

The Nuremberg war crimes trials were conducted in two independent processes. The first round, conducted according the Nuremberg Charter, an international agreement between the Allies to address certain war crimes, resulted in one trial by the International Military Tribunal (IMT) of twenty-two high-ranking Nazi defendants. ${ }^{269}$ More trials had been

Crimes Commission, Law Reports of War Criminals, vol 7 (London: His Majesty's Stationary Office, 1948) 11, 24.

${ }^{268}$ See Prosecutor v. Radislav Krstić, IT-98-33-T, Judgement (2 Aug. 2001) at paras. 575-76 (International Criminal Tribunal for the former Yugoslavia, Trial Chamber), online: ICTY

$<\mathrm{http} / / /$ www.icty.org/x/cases/krstic/tjug/en/krs-tj010802e.pdf $>$.

${ }^{269}$ Trial of Major War Criminals Before the International Military Tribunal, Nuremberg (14 November 1945-1 October 1946) vols. 1-43 (Nuremberg: Secretariat of the IMT, 1947). 
contemplated under the charter, but rapid deterioration in relations with the Soviets prevented further collaboration on this issue. ${ }^{270}$

Shortly after Justice Jackson's appointment to lead the American prosecution team at Nuremberg, Lemkin wrote to alert him to Axis Rule and the concept of genocide. It seems Jackson was impressed, giving Lemkin a minor role in preparing the prosecution and integrating the concept - if not the word - into the early discussion on the form and direction of the proposed prosecutions. ${ }^{271}$ As Barret points out, although the London Agreement and Nuremberg Charter, which formed the legal foundation for the tribunal, "did not use the word 'genocide,' they ... adopted much of the substance of Lemkin's insight, legal definition and argument for the future of international law." ${ }^{272}$ In count three of the indictment, addressing war crimes, the prosecution argued the Nazis had "conducted deliberate and systematic genocide, viz., the extermination of racial and national groups, against the civilian populations of certain occupied territories in order to destroy particular races and classes of people and national, racial, or religious groups, particularly Jews, Poles, and Gypsies and

\footnotetext{
${ }^{270}$ See Kevin Jon Heller, The Nuremberg Military Tribunals and the Origins of International Law (Oxford: Oxford, 2011) 9-24.

${ }^{271}$ Robert H. Jackson, "Planning Memorandum Distributed to Delegations at Beginning of London Conference, June 1945," Report of Robert H. Jackson, United States Representative to the International Conference on Millitary Trials 68 (1945), online: Yale Law School, Avalon Project

$<$ http://avalon.law.yale.edu/subject_menus/jackson.asp>. Justice Jackson submitted a planning memorandum to the Allies detailing his proposals for the trials. Proof of the defendants' "atrocities and other crimes" was to include "[g]enocide or destruction of racial minorities and subjugated populations by such means and methods as (1) underfeeding; (2) sterilization and castration; (3) depriving them of clothing, shelter, fuel, sanitation, medical care; (4) deporting them for forced labor; (5) working them in inhumane conditions. ..." See also John Cooper, Raphael Lemkin and the Struggle for the Genocide Convention (New York: Palgrave Macmillan, 2008) at 62-66, detailing Lemkin's involvement with the prosecutions. He served in Washington and London as an advisor to Jackson.

${ }^{272}$ See Barret, supra note 264 at 42 . As Barret documents, "genocide" was added at the last minute and in an "odd location": count three, alleging war crimes, rather than count four, alleging crimes against humanity. (Ibid. at 45.) See also Earl, supra note 266 at 321-26 (documenting Lemkin's involvement with the IMT).
} 
others." ${ }^{273}$ Moreover, prosecutors mentioned the word genocide several times during trial and even referenced Lemkin's writings. ${ }^{274}$

The prosecutors' statements reveal significant divergence over the term genocide. Sir David Maxwell-Fyfe invoked the idea of genocide as he questioned Von Neurath about Nazi plans to depopulate Czechoslovakia:

Now, Defendant, you know that in the Indictment in this Trial we are charging you and your fellow defendants, among many other things, with genocide, which we say is the extermination of racial and national groups, or, as it has been put in the wellknown book of Professor Lemkin, "a co-ordinated plan of different actions aiming at the destruction of essential foundations of the life of national groups with the aim of annihilating the groups themselves." What you wanted to do was to get rid of the teachers and writers and singers of Czechoslovakia, whom you call the intelligentsia, the people who would hand down the history and traditions of the Czech people to other generations. These were the people that you wanted to destroy by what you say in that memorandum, were they not? ${ }^{275}$

Here, Maxwell-Fyfe clearly invokes Lemkin's argument that genocide could be carried out through an attack on a group's "social structure,"276 a means of attack that would be called cultural genocide under the ILC interpretation. In contrast, in his closing argument, French prosecutor Champetier de Ribes developed a definition of genocide more closely approximating the ILC's. He asserted that the Nazi crimes had been accomplished by many

${ }^{273}$ Trial of Major War Criminals Before the International Military Tribunal, Nuremberg (14 November 19451 October 1946) vol 1 (Nuremberg: Secretariat of the IMT, 1947) at $43-44$.

${ }^{274}$ See William Schabas, "Origins of the Genocide Convention: From Nuremberg to Paris" 40 Case West Res J Int'l L (2008) 35, 42.

275 Trial of Major War Criminals Before the International Military Tribunal, Nuremberg (14 November 19451 October 1946) vol 17 (Nuremberg: Secretariat of the IMT, 1947) at 61. See also Trial of Major War Criminals Before the International Military Tribunal, Nuremberg (14 November 1945-1 October 1946) vol 22 (Nuremberg: Secretariat of the IMT, 1947) at 226, comments of Maxwell-Fyfe: "We are dealing in this Trial not with the murder of 10 men here or 20 there. In this Indictment is charged not only the murder of millions but a demonic plan of genocide, of the planned murder of whole nations, peoples, and races."

${ }^{276}$ Lemkin, Axis Rule, supra note 23 at 83 : "The social structure of a nation being vital to its national development, the occupant also endeavours to bring about such changes as may weaken the national spiritual resources. The focal point of this attack has been the intelligentsia, because this group largely provides national leadership and organizes resistance against Nazification." 
means,

but, above all, by the scientific and systematic extermination of millions of human beings and more especially of certain national or religious groups whose existence hampered the hegemony of the Germanic race. This is a crime so monstrous, so undreamt of in history throughout the Christian era up to the birth of Hitlerism, that the term "genocide" has had to be coined to define it and an accumulation of documents and testimonies has been needed to make it credible. ${ }^{277}$

In this manner, de Ribes narrowed Lemkin's definition to "systematic extermination."

Listening from a hospital bed in Geneva as the judgment was read over the radio, Lemkin was disconsolate. The final judgement made no mention of genocide, nor did it address those Nazi crimes deemed unrelated to waging aggressive war. He later described this as the "blackest day of his life." ${ }^{278}$ Nevertheless, as Barret documents, while the word might have been absent, Lemkin's concept had played a powerful role in shaping the prosecution. ${ }^{279}$

\section{United Nations General Assembly Resolution 96(1)}

Lemkin hurried from Geneva to the United Nations temporary home in Long Island, New York. There he remained throughout November and December of 1946, lobbying the first session of the UN General Assembly for a resolution outlawing genocide. In a remarkable effort of single-handed and single-minded lobbying, he successfully overcame

\footnotetext{
277 Trial of Major War Criminals Before the International Military Tribunal, Nuremberg (14 November 1945-1 October 1946), vol 19 (Nuremberg: Secretariat of the IMT, 1947) at 531. He also spoke of "the greatest crime of all, genocide, the extermination of the races or people at whose expense they intended to conquer the living space they held necessary for the so-called Germanic race." (Ibid. at 561-62.)

${ }^{278}$ William Korey, An Epitaph for Raphael Lemkin (New York: Jacob Blaustein Institute for the Advancement Human Rights, of the American Jewish Committee, 2001) 26.

${ }^{279}$ See Barret, "Raphael Lemkin and 'Genocide' at Nuremberg" in The Genocide Convention Sixty Years After its Adoption (2010).
} 
British resistance ${ }^{280}$ to achieve a unanimous United Nations General Assembly vote for

Resolution 96(1), which reads in part,

Genocide is the denial of the right of existence of entire human groups, as homicide is the denial of the right to live of individual human beings; such denial of the right of existence shocks the conscience of mankind, results in great losses to humanity in the form of cultural and other contributions represented by these human groups, and is contrary to moral law and the spirit and aims of the United Nations. ${ }^{281}$

Lemkin had authored the draft resolution, so it is unsurprising to see his culturalist ideas in the text. ${ }^{282}$

In a last-minute manoeuvre by the British, political groups were added to the list of protected groups, and the list was made illustrative rather than restrictive. ${ }^{283}$ Thus, UNGA Resolution 96(1) reads, "Many instances of such crimes of genocide have occurred when racial, religious, political and other groups have been destroyed, entirely or in part." ${ }^{284}$ The inclusion of political groups represents UNGA Resolution 96(1)'s only significant departure from Lemkin's culturalism. Political groups cannot be said to generate culture and exist through culture in the same manner as national groups. While their inclusion makes sense in a materialist idea of genocide, it has always been at odds with a culturalist view, and so it is no surprise that Lemkin consistently, if oftentimes covertly, opposed their inclusion and was

\footnotetext{
${ }^{280}$ See Cooper, supra note 271 at 80-87. UNGA Sixth Committee, 1st Sess, 24th Mtg, UN Doc. A/C.6/SR.24 (29 Nov. 1946), comments of Mr. McKinnon Wood, United Kingdom.

${ }^{281}$ UNGA Res. 96(1), supra note 194.

${ }^{282}$ Compare "General Committee: The Crime of Genocide (Request from the Delegations of Cuba, India and Panama for the Inclusion of an Additional Item on the Agenda)" UNGA, 1st Sess, Annex Agenda Item 15, UNGA Doc. A/BUR/50. This draft was written by Lemkin and read, "Whereas throughout history and especially in recent times many instances have occurred when national, racial, ethnical, or religious groups have been destroyed, entirely or in part..."

${ }^{283}$ See Cooper, supra note 271 at 80-87.

${ }^{284}$ UNGA Resolution 96(1), supra note 194.
} 
happy to see them eliminated by the Sixth Committee. ${ }^{285}$ Otherwise, and much to the consternation of exclusionists, UNGA Resolution 96(1) is proudly culturalist, grounding the need to protect group existence in the potential cultural contributions those groups might make to humanity. In this early formulation, cultural concerns are not foreign or ancillary; they are the very reason genocide was to be prohibited, the very thing the new norm against genocide was meant to protect.

\section{Polish Trials}

As a 1948 commentary in the International Law Reports points out, the IMT at Nuremberg had largely ignored the crime of genocide, leaving "it to the future developments, which were soon to come and to the subsequent labours of international bodies and jurists to define the notion of this new, and already generally recognized, crime under international law." 286 The national courts of Poland were the first to take up this banner and begin using Lemkin's concept to prosecute and summarily execute notorious Nazi wrongdoers. On July 7, 1946, the national courts of Poland convicted notorious Nazi Gauleiter Arthur Greiser of "genocidal attack" "by deportation of adult Poles and Jews, germanization of Polish children racially suited to it, the new method of mass extermination of the Polish and Jewish population, and complete destruction of Polish culture and political thought - in other words, by physical and spiritual genocide." 287

\footnotetext{
${ }^{285}$ See discussion below, chapter 4, text accompanying notes 158-162.

${ }^{286}$ Goeth, supra note 268 at 8 . Note also, the Polish Tribunal also charged Dr. Joseph Buhler with genocide and other crimes, but according to commentary, "the findings of the Tribunal concerning these problems did not bring any new points of interest. . .." (Trial of Dr. Joseph Buhler, Staatssekretär and Deputy Governor-General (1 $7^{\text {th }}$ of June-10 $0^{\text {th }}$ July, 1948.) Supreme National Tribunal of Poland in United Nations War Crimes Commission, Law Reports of War Criminals, vol 14 (London: His Majesty's Stationary Office, 1948) at 40.

${ }^{287}$ Greiser, ibid. at 389. See also Catherine Epstein, Model Nazi: Arthur Greiser and the Occupation of Western Poland (Oxford: Oxford University Press, 2010) at 312-26; Mark A Drumbl, "'Germans are the Lords and
} 
Similarly, in August and September of 1964, the Supreme National Tribunal of Poland convicted Amon Leopold Goeth of committing acts of physical, biological, cultural, social, and economic genocide. ${ }^{288}$ A commentator for the Law Reports noticed the emerging schism between materialist and culturalist conceptions of genocide, observing "that the Prosecution at Nuremberg, when preferring ... the charge of genocide, adopted this term and conception in a restricted sense only, namely in their physical and biological connotations. ${ }^{" 289}$ However, in Goeth,

the Prosecution endeavored to do much more than establish only the physical and biological aspects and elements of the crime of genocide that were involved in the criminal acts actually committed by the accused. By providing the Tribunal with ample evidence as to the general background of the accused's activities ... and by fully setting out the general policy and system, and the machinery set in operation by the German authorities, for the gradual elimination and final extermination of the Jewish nation, they succeeded in establishing before the Supreme National Tribunal also other components of this new type of crime, such as its economic, social and cultural connotations. ${ }^{290}$

The Polish tribunal also used the term genocide in the trial of Rudolf Hoess, former commandant of Auschwitz. The prosecution argued that heinous acts had been committed in furtherance of "part of the Nazi scheme of exterminating whole nations."291 The prosecution focused on medical experiments performed at the camp, which "were obviously devised at finding the most appropriate means with which to lower or destroy the reproductive power of

Poles are the Servants': The Trial of Arthur Greiser in Poland, 1946" in Kevin Jon Heller \& Gerry Simpson, eds, The Hidden Histories of War Crimes Trials (Oxford: Oxford University Press, 2013) 411, 421.

${ }^{288}$ Goeth, supra note 267.

${ }^{289} \mathrm{Ibid}$. at 8: "This is evident not only from the definition of genocide as stated in the Indictment and from the inclusion of this charge under the general count of murder and ill-treatment, but also from the fact that all other aspect [sic] and elements of the defendants' activities aiming at the de-nationalization of the inhabitants of occupied territories were made the subject of a separate charge which was described as germanization of occupied countries."

${ }^{290}$ Ibid.

${ }^{291}$ Hoess, supra note 267 at 24. 
the Jews, Poles, Czechs, and other non-German nations which were considered by the Nazi $[\mathrm{sic}]$ as standing in the way of the fulfillment of German plans of world domination. Thus, they were preparatory to the carrying out of the crime of genocide." ${ }^{292}$ The prosecution described several experiments aimed at destroying biological reproduction within targeted groups, including one devised to determine the ideal dose of X-rays required to create genetic mutations. The Nazis hoped "that X-rays applied in a certain dosage to germinative cells caused hereditary injuries to the latter. Progeny born from such cells either could not survive or would carry congenital anomalies." ${ }^{293}$ In this manner, the Nazis experimented with means of editing the genetic code of targeted groups in order to destroy the group within several generations. Thus, "[ $[\mathrm{t}]$ his programme and practice of extermination of entire groups of people and of nations on specific grounds, described as the crime of genocide, the Tribunal defined as an attempt on the most organic bases of the human relationship such as the right to live and the right to existence." 294 The Polish tribunals then used a broad conception of genocide, encompassing aspects of what came to be known as cultural, biological, and physical genocide. But they also focused on what they believed was this new crime's central concern, the protection of human groups.

\section{Trials under Control Council Law No. 10}

Although Lemkin was forever disappointed with the IMT trial, he had better luck with the second round of Nuremberg trials. This round was conducted according to another international agreement, Control Council Law No. 10 (CC 10), but was staffed only by

\footnotetext{
292 Ibid. at 25.

${ }^{293}$ Ibid.

${ }^{294}$ Ibid. at 24.
} 
American judges. ${ }^{295}$ The first Nuremberg trial under the IMT is lauded as a milestone in the development of international criminal justice, while the second set of trials is largely ignored. ${ }^{296}$ But it is this second round of prosecutions that really began to develop the criminal law of genocide.

In these "subsequent Nuremberg trials," as they are sometimes known, genocide is first mentioned in the Justice Trial, where the court declared "the prime illustration of a crime against humanity under [Control Council Law No. 10], which by reason of its magnitude and international repercussions has been recognized as a violation of common international law, we cite 'genocide' . . which will receive our full consideration." ${ }^{297}$ The court moves on to point out that the UN General Assembly, in UNGA Resolution 96(1), had declared genocide to be a crime and quotes the resolution wholesale. ${ }^{298}$

The Court convicted two defendants of genocide. One defendant, Oswald Rothaug, a Nazi prosecutor, was convicted of conducting sham trials in "conformity with the policy of the Nazi State of persecution, torture, and extermination."299 Thus, the court continued, "[i]t is of the essence of the charges against him that he participated in the national programme of

\footnotetext{
${ }^{295}$ See Telford Taylor, The Anatomy of the Nuremberg Trials: A Personal Memoir (New York: Knopf, 1992) 269-276, recounting the origins of the subsequent Nuremberg Trials.

${ }^{296}$ See Peter Maguire, Law \& War: International Law and American History, revised ed (New York: Columbia University press, 2010) at 12-13.

${ }^{297}$ United States v. Josef Altstötter et al (the Justice case), Trials of War Criminals Before the Nuremberg Military Tribunals Under Control Council Law No. 10 (Washington: United States Government Printing Office, 1951) (Military Tribunal, Nuremberg, Germany, Oct 1946- Apr 1949) vol 3 at 983 [the Justice Case] citing Control Council Law No. 10, Punishment of Persons Guilty of War Crimes, Crimes Against Peace and Against Humanity in Trials of War Criminals Before the Nuremberg Military Tribunals Under Control Council Law No. 10 (Washington: United States Government Printing Office, 1951) vol 1 at XVIII, online:

$<$ http://avalon.law.yale.edu/imt/imt10.asp $>$.

${ }^{298}$ Ibid.

${ }^{299} \mathrm{Ibid}$. at 1155. See also ibid. at 1128 (Ernst Lautz, another Nazi prosecutor, also convicted of genocide). See Earl, supra note 266 at 327.
} 
racial persecution. It is of the essence of the proof that he identified himself with this national program and gave himself utterly to its accomplishment. He participated in the crime of genocide. ${ }^{300}$ Despite declaring its importance, the court was largely silent on the idea of genocide and left its definition unexplored.

The second trial, of accused Einsatzgruppen members, also never really develops the idea of genocide, but the prosecution seems to assume a physio-biological definition of genocide. This makes sense given the nature of the crimes charged. The trial focused on the Nazi military units that had become notorious for using modified trucks to gas Jews as they drove through the countryside, as well as for a vast number of executions by gunfire. The indictment argued that "[t]he acts, conduct, plans, and enterprises charged ... were carried out as part of a systematic program of genocide, aimed at the destruction of foreign nations and ethnic groups by murderous extermination."”301

Benjamin Ferencz, a twenty-seven-year-old American prosecutor who would go on to become a prominent voice in the development of international criminal law, opened his case by stating, "We shall show that these deeds of men in uniform were the methodical execution of long-range plans to destroy ethnic, national, political, and religious groups which stood condemned in the Nazi mind. Genocide, the extermination of whole categories of human

\footnotetext{
${ }^{300}$ Justice Trial, supra note 297 at 1156. See also, Trial of Josef Altstötter and Others, United Nations War Crimes Commission Law Reports of War Criminals (London: His Majesty's Stationary Office, 1948) vol 6 at 83, note 3. Commentary to the Justice Case explains "that the concept of crimes against humanity is greater than that of genocide. The latter crime is aimed against groups, whereas crimes against humanity do not necessarily involve offences against or persecutions of groups."

${ }^{301}$ Amended Indictment, Trials of War Criminals Before the Nuremberg Military Tribunals Under Control Council Law No. 10 (Washington: United States Government Printing Office, 1951) (Military Tribunal, Nuremberg, Germany, Oct 1946- Apr 1949) vol 4, 13 at 15.
} 
beings, was a foremost instrument of the Nazi doctrine." 302 Following his lead, the judgment mentions genocide several times, always in the context of mass killing. ${ }^{303}$

The American tribunal most fully developed the idea of genocide in United States $v$. Greifelt, also known as the RuSHA Trial. This trial focused, in part, on Nazi efforts to kidnap and appropriate "racially valuable children." ${ }^{304}$ In an interesting confluence of events, Greifelt bears even more indelibly the stamp of Lemkin's efforts. Although Axis Rule makes no mention of child stealing, Lemkin's ideas had apparently resonated with child tracers working with the United Nations Relief and Rehabilitation Administration (UNRRA) to return children stolen by the Nazis during the war. In July of 1946, they wrote to Lemkin, bringing his attention of the Nazi scheme to kidnap and "Germanize" "racially valuable children." 305 They documented

the most striking case . . of the small village of Lidice. ... [T] entirely destroyed, all men over 15 years were shot, the women sent to the

\footnotetext{
${ }^{302}$ United States v. Otto Ohlendorf, et al. (the Einsatzgruppen Case), Trials of War Criminals Before the Nuremberg Military Tribunals Under Control Council Law No. 10 (Washington: United States Government Printing Office, 1951) (Military Tribunal, Nuremberg, Germany, Oct 1946- Apr 1949) vol 4 at 30 [the Einsatzgruppen Case]. The prosecution argued that these acts "were carried out as part of a systematic program of genocide, aimed at the destruction of foreign nations and ethnic groups by murderous extermination." Ibid. at 15.; Benjamin Farencz, "A Prosecutor's Personal Account: From Nuremberg to Rome" 52 J. of Int'l Affairs (1999) 455 at 459.

${ }^{303}$ Ibid. at 450, 451, 469-70.

${ }^{304}$ United States v. Greifelt (the RuSHA case), Trials of War Criminals Before the Nuremberg Military Tribunals Under Control Council Law No. 10 (Washington: United States Government Printing Office, 1950) (Military Tribunal, Nuremberg, Germany, Oct 1946- Apr 1949) vols 4 - 5 [Greifelt].

${ }^{305}$ Memo J.H. Whitting, Zone Director to Raphael Lemkin, Advisor on Foreign Affairs Judge Advocate General's Office, War Dept, USA. Attaching two reports: "Reports on German Methods of Kidnapping, Denationalization and Germanization of Czechoslovak Children and Their Transport to Germany" and "Searching for Czechoslovak Children" (29 July 1946). New York City, United Nations Archives and Records Management Section [UNARMS] (Series S-0437, Box 17, File 19, ACC.PAG-4/3.0.11.3.3). See also Lemkin, letter to Mr. Len Peterson (9 August 1949) AJHS, supra note 105 (Box 2, File 2), explaining,

After the war, I was called upon by the War Department to prepare plans for war crimes trials. I worked out the plan which was later accepted, namely, to try the Germans for stealing children. Simultaneously, I helped to organize the "unscrambling of stolen children." . . This personal experience with the children prompted me to include the stealing of children as a component part of the notion of genocide.
} 
concentration camp Ravensbru eck [Ravensbrück] and the Children separated from their mothers and directed to various German families and institutions for "proper education." Seven children of less that 1 year of age were taken into the German Children's hospital and later into the infant-school in Prague, where they were found after the revolution-except one who died. ${ }^{306}$

The events at Lidice have since become a grotesque symbol of the Nazis' bloodthirsty

retribution, but it is far from the only incident in Himmler's effort to cull the Eastern lands of children racially suited to Germanization, which he believed would both weaken these dominated nations by depriving them of natural leaders and strengthen Germany by the appropriation of this valuable racial resource. Himmler explained,

The parents of such children of good blood will be given the choice to either give away their child - they will then probably produce no more children, so that the danger of this sub-human people of the East obtaining a class of leaders which, since it would be equal to us, would also be dangerous for us, will disappear-or else the parents will pledge themselves to Germany and to become loyal citizens there. The love towards their child, whose future and education depends upon the loyalty of the parents, will be a strong weapon in dealing with them. ${ }^{307}$

In October 1943, Himmler similarly declared "Either we win over any good blood that we can use for ourselves and give it a place in our people, or gentlemen-you may call this cruel, but nature is cruel—we destroy the blood." 308 To this end, the Nazis established an elaborate network of organizations to search the eastern lands in order to identify "racially valuable children," remove those children, re-educate them, and place them in German

\footnotetext{
306 Whitting memo, ibid.

${ }^{307}$ Greifelt, supra note 304, vol 4 at 626. And he explained,
}

The children suitable for this are not to be over 8 to 10 years of age because, as a rule, a genuine ethnic transformation, that is, a final Germanization, is possible only up to this age. The first condition for this is a complete prevention of all connections with their Polish relatives. The children receive German names which are ethnologically of accentuated teutonic [sic] origin. Their descendant certificate will be kept by a special department. All racially valuable children whose parents died during the war or later, will take over in German orphanages without any special regulation. [Emphasis omitted] (Ibid. at 675.)

308 Ibid. at 674. 
schools or even with the families of prominent (usually childless) Nazis as a reward for loyal service.

UNRRA officials wanted Nazi child stealing addressed at Nuremberg and reached out to the Polish and Czechoslovakian governments on whose territory the child stealing had occurred, in the hope that they would push the Allies to prosecute these crimes. The Czechs were not interested, but when UNRRA officials contacted Captain Wicenty Hein, a Polish officer serving as war crimes liaison, he "had evidently read Dr. Lemkin's book, and referred frequently to his beliefs about Nazi practices and intents," and enthusiastically supported UNRRA's effort to have child stealing addressed at Nuremberg as an aspect of genocide. ${ }^{309}$ They submitted reports to Lemkin, who at that time was helping prepare the Nuremberg prosecutions with the War Department's Judge Advocate General's office. ${ }^{310}$

The child tracers' wishes were fulfilled when child stealing featured prominently in United States v. Greifelt. ${ }^{311}$ Citing Lemkin, the prosecution described Himmler's program of

\footnotetext{
${ }^{309}$ Memo "Conferences at Wiesbaden, August 7, 1946” (7 Aug 1946). UNARMS, supra note 305 (Series S0437 Box 18 File 20, PAG-4/3.o.11.3.3).

${ }^{310}$ See Lemkin, letter to Len Peterson (9 August 1949) AJHS, supra note 105 (Box 2, File 2), recounting his involvement:
}

After the defeat of Stalingrad, the Germans hoped for a prolonged war and they had to plan for a replenishment of their manpower. For military purposes, they repudiated secretly the race theory. Hundreds of thousands of Slavic children from Russia, Poland, Czechoslovakia, and Yugoslavia were rounded up and brought into Germany where they were brought up as Germans, either in special institutions called, "Lebensborn," or in private homes. The children were beaten for speaking their own languages. After the war, I was called upon by the War Department to prepare plans for war crimes trials. I worked out the plan which was later accepted, namely, to try the Germans for stealing children. Simultaneously, I helped to organize the "unscrambling of stolen children."

${ }^{311}$ See Greifelt, supra note 304, vol 5 at 102-08. The other acts defendants were indicted for included (b) encouraging abortions among Eastern workers, (c) infanticide of Eastern workers' babies, (d) executing or imprisoning Eastern workers who had sex with Germans (potentially diluting German blood), (e) "Preventing marriages and hampering reproduction of enemy nationals," (f) acts that would now be referred to as ethnic cleansing, (g) forced labor, (h) plundering property, and (i) "Participating in the persecution and extermination of Jews." See generally Catherine Clay \& Michael Leapman, Master Race: The Lebensborn Experiment in Nazi Germany (London: Hodder and Stoughton, 1995); Lynn H. Nicholas, Cruel World: The Children of Europe in the Nazi Web 240-58, 502-13 (New York: Vintage Books, 2005); Isabel Heinemann, "Until the Last Drop of 
genocide as "a coordinated plan aimed at the destruction of the essential foundations of the life of national groups." ${ }^{312}$ The prosecution asserted that this plan was accomplished "by a number of different means, which may be broadly classified as physical, political, biological, and cultural." 313 "These techniques of genocide," they stated, "while neither so quick nor perhaps so simple as outright mass extermination, are by the very nature of things far more cruel and equally effective." 314

In the Ministries Case, the third of the subsequent Nuremberg trials to charge genocide, the prosecution

alleged that the Third Reich embarked upon a systematic program of genocide aimed at the destruction of nations and ethnic groups within the German sphere of influence in part by murderous extermination and in part by elimination and suppression of

Good Blood": The Kidnapping of "Racially Valuable" Children and Nazi Racial Policy in Occupied Eastern Europe, in A. Dirk Moses, ed, translated by Andrew H. Beattie, Genocide and Settler Society: Frontier Violence and Stolen Indigenous Children in Australian History (New York: Berghahn Books, 2004) 244.

${ }^{312}$ Greifelt, supra note 304, vol 4 at 626.

${ }^{313}$ Ibid. The prosecution also stated,

In this very same courtroom crimes have been revealed which were so revolting and marked with such bestiality that the civilized world has been shocked at the extent of "man's inhumanity to man." The outrages committed by the Nazis against the inhabitants of the occupied countries would be considered incredible except for captured orders and reports showing the fidelity with which these crimes were executed. All who cared to read have been informed of the mass killing of the Jews, the atrocities in concentration camps, the savage medical experiments, and many more ruthless forms of torture and extermination practiced by the Nazi fanatics. But now we turn to a crime which in many respects transcends them all ... the crime of kidnapping children. (Ibid. at 674.)

Strikingly, in this first conviction for genocide, child stealing was not considered peripheral or de minimis but was central to the prosecution and was even considered to transcend all other crimes.

${ }^{314} \mathrm{Ibid}$. at 627. Interestingly, the counsel for defendant Brueckner also cited Axis Rule, pointing out that Lemkin argued there that genocide was not illegal. Therefore, charging Brueckner would be an imposition of ex post facto law. His defense also argued that "Lemkin does not mention the resettlement or repatriation of groups of ethnic Germans residing outside the borders of the Reich as being 'genocide.' This would make also his train of thought entirely inconsistent as the very aim of his work is the rescue of ethnic groups." (Greifelt, supra note 304 , vol 5 at 4.) 
national characteristics with intent to strengthen the German nation and the so-called "Aryan" race at the expense of such other nations and groups. . . 315

Finally, in United States $v$ Pohl, the tribunal declared, "The trend of modernity toward mechanization and assembly line methods was not overlooked even in this most modern of achievements - genocide — a business so novel that a new name had to be coined for it. Genocide, the scientific extermination of a race." 316

At this point, the concept of genocide remained fluid. However, even in this early formulation, it denotes something specific: an attack aimed at destroying a group's cohesion. In each case, any consideration of the means by which the Nazis attempted to destroy targeted groups is secondary to their attempt to destroy these groups as such. Where the Einsatzgruppen Case understandably focused on "extermination," Greifelt addressed "a number of different means, which may be broadly classified as physical, political, biological, and cultural," 317 and the Ministries Case drew attention to "the suppression of national characteristics." 318 Taken together, these early cases illustrate both the specificity and ecumenicity of the concept of genocide as it existed from 1946 to 1948 . It was specific in

\footnotetext{
${ }^{315}$ United States v. Ernst von Weizsaecker, et al. (the Ministries Case), Trials of War Criminals Before the Nuremberg Military Tribunals Under Control Council Law No. 10 (Washington: United States Government Printing Office, 1951) (Military Tribunal, Nuremberg, Germany, Oct 1946- Apr 1949) vol 14 at 468.

${ }^{316}$ United States v. Pohl et. Al, Trials of War Criminals Before the Nuremberg Military Tribunals Under Control Council Law No. 10 (Washington: United States Government Printing Office, 1951) (Military Tribunal, Nuremberg, Germany, Oct 1946- Apr 1949) vol 5 at 1135. Genocide was also mentioned in the Flick Trial "as 'the prime illustration of a crime against humanity under Control Council law No. 10.'" United States v. Flick et. al, Trials of War Criminals Before the Nuremberg Military Tribunals Under Control Council Law No. 10 (Washington: United States Government Printing Office, 1951) (Military Tribunal, Nuremberg, Germany, Oct 1946- Apr 1949) vol 9 at 35.

${ }^{317}$ Greifelt, supra note 304, vol 4 at 626.

318 Ministries Case, supra note 315, at 468.
} 
denoting only one thing: the destruction of groups. But it was ecumenical in considering nearly any act directed at group destruction to be an act of genocide.

When the United Nations General Assembly voted unanimously on December 9, 1948, to adopt the Genocide Convention, there already existed a customary law of genocide. This fact was recognized in the Convention's preamble, which references UNGA Resolution 96(1). ${ }^{319}$ In addition, article 1 states, "The Contracting Parties confirm that genocide . . is a crime under international law." 320 As Shabtai Rosene said in 1951,

[t] he existence of genocide as a crime under international law is clear from the past history of the notion, and not from the formal definitions in the Convention, or in Resolution 96(1). The conventional definition is so to speak superimposed upon the definition of the customary law, just as a statutory definition of a crime under municipal law may be superimposed upon the common law definition, without necessarily doing away with the common law crimes. ... In other words, the text has a profound influence upon the future development of the law, which in one sense it fetters and in another diverts into new channels. ${ }^{321}$

Thus, the IMT trial, the Polish Trials, and the subsequent Nuremberg Trials each contributed, however haltingly, to an emerging definition of the crime of genocide. By today's standards, that law appears strikingly culture-centric.

This is not to say that the drafters were in any meaningful way constrained by genocide's early culturism. To the contrary, as evidenced by their excision of political groups, they clearly felt empowered to make significant departures. However, as with the excision of political groups, one would expect them to make such departures clear either in

\footnotetext{
${ }^{319}$ Genocide Convention, preamble, supra note 7. Josef L. Kunz, Editorial Comment, "The Genocide Convention" 43 AJIL (1949) 732 at 741.

${ }^{320}$ Genocide Convention, art. 1, ibid..

${ }^{321}$ Reservations to the Convention on the Prevention and Punishment of the Crime of Genocide, Advisory Opinion of 28 May 1951, "Statement of Mr. Shabtai Rosenne (11 April 1951) [1951] ICJ Pleadings, Oral Arguments, Documents (vol 2) 328 at 337 He continued, "Time and experience are needed before such a written text can be fully 'declaratory' of existing law. Both these are lacking in regard to the Genocide Convention."
} 
the debates or the text itself. As I discuss in subsequent chapters, the text and debates leave little indication that the drafters intended to abandon the cultural conception of groups.

\section{Conclusion}

Throughout the nineteenth century and well into the twentieth, the idea of nationalism had been invoked to explain, as well as to navigate, inter-group differences. But by midcentury, nationalism had grown threadbare, sullied by the Nazi embrace and tarnished—in the eyes of most Western thinkers-by Third-World anti-colonialists who sought to harness its power. By contrast, the concept of culture could account for group difference yet appeared relatively unencumbered by political baggage.

In the immediate postwar period, the perceived felicitousness of the culture concept motivated the Washington defense and foreign policy establishment to invest heavily in it, directing massive sums to research and bringing anthropologists into newly formed defense research institutions. ${ }^{322}$ During this brief moment, culture appeared poised to dominate foreign and military policy, much the way the "principle of nationalities" and selfdetermination had dominated the preceding century. As it turns out, there would be no century of culture, but this was not apparent in 1948. At that time, the idea of culture was seen as providing answers to the world's most pressing questions.

Arriving in America, Lemkin found himself at home intellectually in the cultural moment. Like Lemkin, the idea of culture developed by Franz Boas and his students was rooted in the tradition of Central European thought. Because of this common lineage, Lemkin would have found anthropological insights on the importance of culture to group life less revolutionary than familiar. Thus, it is unsurprising that Lemkin engaged with the leading

\footnotetext{
322 See Mandler, Return, supra note 5 at 193-94.
} 
works of anthropology at that time and used those works to buttress his argument in favor of a convention on genocide.

The influence of the idea of culture on Lemkin's idea of genocide was profound. In his conception, it is culture - the culture generated within human groups - that justifies intervention by international society into the sovereign realm of states. Humanity, he asserted, had a right to benefit from these cultural riches, a right that trumps state sovereignty. Therefore, culture is also the very thing the Genocide Convention is meant to protect. In Lemkin's view, group destruction is measured not by the number of individuals killed, maimed, or otherwise harmed, but by the impact the loss of those individuals has on the group's cultural functioning. In Lemkin's idea of genocide, culture is everything.

Inasmuch as Lemkin found Boasian ideas on culture comfortable and familiar, it is also true that foreign policy leaders were well disposed to receive Lemkin's arguments. And indeed, they embraced Lemkin's argument and implemented his plan. Not awaiting codification, those dealing with the aftermath of the Nazi atrocities used Lemkin's idea heuristically, to help them understand the Nazis' aims, and legally, to charge some of the most egregious offenders. They endorsed the culturalism inherent in Lemkin's concept, because it seemed to capture the type of carnage they had witnessed and because, in the cultural moment, a cultural perspective was common.

Lemkin achieved his success not by converting the world to an atavistic, antique, and idiosyncratic worldview, as some scholars have suggested. And neither did the world's foreign policy establishment misrecognize Lemkin's culturalist ideas as it sought to enshrine an individualist solution to the problem of group relations, as other scholars have implied. Rather, Lemkin's ideas were well received simply because they reflected the intellectual 
tenor of that time, a time obsessed with inter-group difference, a time in which the concept of culture appeared to provide vital insight.

In its earliest, pre-codification form, the concept of genocide was unapologetically culturalist. Lemkin's seminal work Axis Rule defined genocide as the destruction of whole groups of people, and the UN General Assembly declared genocide a crime precisely because of the loss that befalls the world community when one of its constituent cultures is destroyed. Early genocide prosecutions, by the Americans in Nuremberg under Control Council Law No. 10 and in the Polish national courts, also emphasized the role of culture in perpetuating group life. But genocide's original culturalism was unlikely to survive the demise of the more robust, mid-century idea of culture.

Culture's moment would end with the Cold War's onset. Scholarly voices began to see Stalin and Hitler as the Janus face of a single phenomenon, which they labeled "totalitarianism." ${ }^{323}$ A gathering Western consensus held that universal rights - to democracy and freedom of speech, primarily — represented the best means of combating totalitarianism. Therefore, any approach that emphasized cultural difference was suspect for implying that different cultures might require different social and political structures. Increasingly, the right embraced a return to "economistic thinking" enabled by Popperian science, methodological individualism, and ultimately rational choice theory. The left, too, embraced individualism, lauding its capacity for enabling personal freedom and growing suspicious of the tyrannies

\footnotetext{
${ }^{323}$ See Mandler, Return, supra note 5 at 226-28: "Ironically, this began as a psycho-cultural approach. . . . Since the 1930s Erich Fromm and other neo-Freudian émigrés of the so-called 'Frankfurt School' had been blaming the rise of the 'authoritarian character' on the forces of capitalism and modernity." (Ibid. at 226.) But soon "“ totalitarianism' could shift emphasis to the mechanisms of control from above, and away from the susceptibilities of the people." As Mandler explains, "this view of other people 'just like us,' awaiting and needing American-style democracy, was increasingly prevalent on the Left as well as on the Right." (Ibid. at 227.)
} 
that lurk within traditional social structures. In this changing intellectual climate, the midtwentieth century idea of culture, which celebrated the local, the traditional, and the particular, never stood a chance. And although radical change is once again afoot, it bears remembering that our world is the product of the resurgent individualism and universalism of the Cold War years. The Genocide Convention hails from a different world. 


\section{Chapter 3-The Tedious Crucible: A Hermeneutic Inquiry Into Culture's Place in the Genocide Convention According to the Vienna Convention on the Law of Treaties, Article 31}

And where should an austere philologist

Relax but in the very world of shade

From which the matter of his field was made.

$\cdots$

(W. H. Auden, from “Woods (for Nicolas Nabokov),” August 1952)

This chapter conducts a thorough interpretation of article 2 of the Convention on the Prevention and Punishment of the Crime of Genocide (Genocide Convention), as regards the issue of cultural genocide, according to the rules of treaty interpretation outlined in article 31 of the Vienna Convention on the Law of Treaties (VCLT article 31). ${ }^{2}$ Richard Gardiner admits that the application of the VCLT rules can be "tedious,"3 and this analysis will likely prove him right. A thoroughgoing application of the VCLT article 31 requires a contested provision to be read in relation to the treaty's context, subsequent agreements on interpretation of the treaty, subsequent practice, and relevant rules of international law. Additionally, these factors are to be considered while reading the treaty's terms in "good faith," according to their "ordinary meaning" and in light of the treaty's "object and purpose." Moreover, because article 31 is thought to enshrine a "single rule of

\footnotetext{
${ }^{1}$ W. H. Auden, Collected Poems, Edward Mendelson, ed, (Random House: New York, 1976) at 428.

${ }^{2}$ Convention on the Prevention and Punishment of the Crime of Genocide, 9 December 1948, 78 U.N.T.S. 277, 102 Stat. 3045 (entered into force 12 January 1951) [Genocide Convention]. Vienna Convention on the Law of Treaties 23 May 1969, 1155 U.N.T.S. 331 (entered into force 27 January 1980) [VCLT].

${ }^{3}$ Richard K. Gardiner, Treaty Interpretation (Oxford: Oxford University Press, 2008) at 35.

${ }^{4}$ VCLT, supra note 2 at art 31.
} 
interpretation," none of these considerations takes precedence, each is accorded equal interpretive weight, and, in true hermeneutic fashion, each is evaluated in the light of every other consideration, resulting in a refractory whirlwind of competing considerations. ${ }^{5}$

In this light, Sir Humphrey Waldock's analogy of VCLT article 31 to a "crucible"" seems apt in that it implies "a vessel or pot ... so baked or tempered as to resist extreme heat ..., used for melting ores, metal etc., [or] a severe test; a hard trial." ${ }^{\text {7 }}$ Indeed, VCLT article 31 is both a vessel to alloy interpretive material and a "severe test," so it is unsurprising that, in Gardiner's understated assessment, "[e]xamination of the growing case law suggests that systematic use of the rules as a practical means of treaty interpretation still has scope for improvement." Typically, courts nod to the VCLT but invoke its rules haphazardly, citing "a particular rule to bolster an argument" while ignoring the obligation to apply the rules as a whole. ${ }^{9}$

\footnotetext{
5 "Reports of the International Law Commission on the Second part of its Seventeenth and on its Eighteenth Session" (UN Doc A/6309/Rev1) in Yearbook of the International Law Commission 1966 vol. II (New York: UN, 1967) 169 at 219-20 (UNDOC, A/CN.4/SER.A/1966/Add.1):
}

The Commission ... intended to indicate that the application of the means of interpretation in the article would be a single combined operation. All the various elements, as they were present in any given case would be thrown into the crucible and their interaction would give the legally relevant interpretation. Thus [article 31] is entitled "General rule of interpretation" in the singular, not "General rules" in the plural, because the Commission desired to emphasize that the process of interpretation is a unity and that the provisions of the article form a single, closely integrated rule. (Emphasis in original.)

${ }^{6}$ Ibid.

${ }^{7}$ Webster's Deluxe Unabridged Dictionary 2nd ed, sub verbo "crucible."

${ }^{8}$ Gardiner, supra note 3 at 7. Isabelle Van Damme, Treaty Interpretation by the WTO Appellate Body (Oxford: Oxford University Press, 2009) at 34, similarly observes,

Discrepancies exist in the manner in which courts and tribunals explain and justify how they interpret the treaty language. But even if they articulate in clear terms their interpretive practice, it is less common for adjudicators to specify the reasons for preferring certain principles of interpretation to others. An analysis of any court's interpretive practices relies on a degree of pragmatism shown in its decisions. There is no guarantee that a judgment discloses all the principles applied, all the elements of interpretation taken into account, and the weight given to the latter.

${ }^{9}$ Gardiner, ibid. at 7. 
But the VCLT does not provide a menu from which interpreters are permitted to select the most attractive choices. Instead, the VCLT demands a full application of the rules laid out in articles 31 and 32. Moreover, a truly good faith interpretation requires interpreters to "show their work" by making transparent the bases of their decision. Anything less will fall short of being "virtuous" or "persuasive" and will remain unconvincing. This chapter will address each of VCLT article 31 's provisions and apply them to article 2 of the Genocide Convention, inquiring whether the Genocide Convention's text supports exclusion. Because the VCLT mandates a refractory process, by which each provision is measured against all relevant evidence and all this evidence is measured against the whole, a virtuous interpretation implies a certain amount of repetition; the same interpretive ground may be repeatedly ploughed with each new issue raised.

\section{VCLT Article 31(1)}

Article 31(1) of the VCLT requires interpretation to be conducted "in good faith in accordance with the ordinary meaning to be given to the terms of the treaty in their context and in the light of its object and purpose."10 This section explores the controversial idea of ordinary meaning and asks whether it is permissible to imply a term restricting the Genocide Convention to physio-biological genocide. It then addresses good faith and the two branches of effective interpretation: textual and teleological.

\footnotetext{
${ }^{10}$ VCLT, supra note 2 at $31(1)$.
} 


\section{Ordinary Meaning}

The idea of ordinary meaning holds an understandable allure to courts, which cite "the wording of paragraphs" or conduct "a simple reading of the text"11 or declare that "the words ... must be read in their natural and ordinary meaning, in the sense which they would normally have in their context."12 According to the International Court of Justice (ICJ), "the first duty of a tribunal which is called upon to interpret and apply the provisions of a treaty, is to endeavour to give effect to them in their natural and ordinary meaning in the context in which they occur. If the relevant words in their natural and ordinary meaning make sense in their context, that is an end of the matter." ${ }^{13}$ Fitzmaurice explained this tenet by stating that "particular words and phrases are to be given their normal, natural, and unrestrained meaning in the context in which they occur. This meaning can only be displaced by direct evidence that the terms used are to be understood in another sense than the natural and ordinary one, or if such an interpretation would lead to an unreasonable or absurd result." ${ }^{14}$ Oftentimes, this is referred to as a "grammatical" or "literal" reading of the text. ${ }^{15}$

\footnotetext{
${ }^{11}$ Case Concerning Pulp Mills on the River Uruguay Judgment (Argentina v Uruguay), (20 April 2010) [2010] ICJ Rep 14 at 79.

${ }^{12}$ Constitution of the Maritime Safety Committee of the Inter-Governmental Maritime Consultative Organization, Advisory Opinion (8 June 1960), ICJ Reports [1960] 150 at 159-60. See also, Ambatielos Case (Merits Obligation to Arbitrate, (19 May 1953) Joint dissent of Judges McNair, Basdevant, Klavestad, and Read [1953] ICJ Rep 25 at 30: "These words should be construed in their natural and ordinary meaning, as has been said over and over again ... ." Cited in Sir Gerald Fitzmaurice, "The Law and Procedure of the International Court of Justice 1951-4: Treaty Interpretation and Other Treaty Points" 33 Brit Y.B. Int'l L (1957) 203 at 214.

${ }^{13}$ Competence of the General Assembly for the Admission of a State to the United Nations, Advisory Opinion, [1950] ICJ Rep 4 at 8.

${ }^{14}$ Fitzmaurice, "The Law and Procedure 1951-4," supra note 12 at 211.

${ }^{15}$ See Ulf Linderfalk, On the Interpretation of Treaties: The Modern International Law as Expressed in the 1969 Vienna Convention on the Law of Treaties (Dordrecht: Springer, 2007) at 96, note 7.
} 
Of course, "ordinary meaning" is itself a phrase that is susceptible to many different meanings. ${ }^{16}$ Interpreting a phrase according to its ordinary meaning may also yield differential results depending on whether it is understood through a lay, legal, or technical prism. ${ }^{17}$ Temporal change in language usage can also alter a term's ordinary meaning. ${ }^{18}$ And de-contextualized terms are often simply meaningless. ${ }^{19}$

For these reasons, ordinary meaning is not discerned semiotically, by isolating a word and defining it in "opposition to the other lexical units of the same system," but rather semantically and discursively, by reading words within sentences and sentences within texts. ${ }^{20}$ In this light, fears of indeterminacy seem somewhat overblown. The contextualized approach enshrined in VCLT article 31 filters textual polysemy, winnowing possible meanings and mitigating the ambiguity of discourse. ${ }^{21}$ Fitzmaurice referred to this as the

\footnotetext{
${ }^{16}$ Georg Schwarzenberger, "Myths and Realities of Treaty Interpretation: articles 27-29 of the Vienna Draft Convention on the Law of Treaties" 9 Va J Int'l L (1968) 1 at 13. According to Schwarzenberger: "The difficulty about this approach to the issue is that almost any word has more than one meaning. The word 'meaning' itself, has at least sixteen different meanings." (Footnotes omitted.) See also Georg Schwarzenberger, International Law 3rd ed, vol 1 (London: Stevens, 1957) 501. Schwarzenberger famously slammed the "technique" of literal interpretation, stating,

The most unsatisfactory features of this technique are its presumptuousness, inarticulateness and illogicality. The technique is presumptuous, for once parties have argued a case at length, and a Court is divided, it is hard to believe that the vision of the "clear," "natural," or "ordinary" meaning of a clause has descended on a supernaturally enlightened majority. To make such categorical statements appears to lack awareness of the fallibility which even international judges and arbitrators may be condemned to share with other human beings. The technique is inarticulate because it hides what may be the most, or least, convincing links in the chain process which leads to such an apodictic conclusion. The technique is illogical because "it postulates as an established fact that which remains to be proved: it takes as a starting point of the research that which, normally, should be the result thereof.

${ }^{17}$ Gardiner, supra note 3 at 173-74.

${ }^{18}$ Linderfalk, supra note 15 at 73-94.

${ }^{19}$ Gardiner, supra note 3 at 178 .

${ }^{20}$ Paul Ricoeur, Interpretation Theory: Discourse and the Surplus of Meaning (Fort Worth: Texas Christian University, 1976) at 5. See also Aegean Sea Continental Shelf Case (Greece v Turkey), [1978] ICJ Rep 3 at 22 [Aegean Sea], rejecting grammatical arguments in favour of a contextual approach.

${ }^{21}$ Ricoeur, ibid. at 17.
} 
"principle of integration," which rejects "a narrow and quasi-literal interpretation of words, phrases, or articles, taken in isolation ..." in favour of an interpretation "related to the treaty as a whole."22

Despite the precedence that courts grant to "ordinary meaning," interpreters have not been hung up by the notion and are quick to abandon it when faced with contradictory evidence. Gardiner argues that, to the extent ordinary meaning serves as a starting point for interpretation, it is "a very fleeting starting point" quickly bypassed for consideration of the term's context and other interpretive factors outlined in the VCLT. ${ }^{23}$ And when treaty text has proved troublesome, the ICJ has declared that "the Court cannot base itself on a purely grammatical interpretation of the text" 24 and has downplayed "actual language" in favour of interpretations that incorporate a treaty's historical context and those reading terms "in a figurative sense. ..."25

Whether ordinary meaning restrains interpreters or, as Gardiner claims, merely serves as a jumping-off point, it is noteworthy that the Genocide Convention's ordinary language is nearly silent on the matter of genocidal destruction and contains no language excluding acts of cultural genocide. But could such a restrictive term be implied? In its 1951 advisory

\footnotetext{
${ }^{22}$ Sir Gerald Fitzmaurice, "The Law and Procedure of the International Court of Justice: Treaty Interpretation and Other Treaty Points" 28 Brit. YB Intl L (1951) 1 at 11 [Fitzmaurice, "Law and Procedure," 1951].

${ }^{23}$ Gardiner, supra note 3 at 161-62.

${ }^{24}$ Aegean Sea, supra note 20 at 23, quoting Anglo-Iranian Oil Co. (United Kingdom v/Iran), Preliminary Objections, [1952] ICJ Rep 93 at 104.

${ }^{25}$ Barcelona Traction, Light and Power Company, Limited (Belgium v Spain), Preliminary Objections [1964] ICJ Reports 6 at 33. See also Interpretation of Peace Treaties with Bulgaria, Hungary and Romania (Second Phase), Advisory Opinion, [1950] ICJ Rep 221 at 227 [Peace Treaties, Second Phase] ("natural and ordinary meaning" "strictly construed" to override the "literal sense" of a clause); Case Concerning the Temple of Preah Vihear (Cambodia $v$ Thailand), Preliminary Objections, [1961] ICJ Rep 17 at 33 (rejecting interpretation in a "purely literal way").
} 
opinion on Reservations to the Convention on Genocide, the ICJ implied a term in the

Genocide Convention allowing reservations where the Convention was silent on that issue. ${ }^{26}$

According to the court, "it could certainly not be inferred from the absence of an article

providing for reservations in a multilateral convention that the contracting States are

prohibited from making certain reservations." 27

On the other hand, where contextual factors militate against inference, the ICJ has

refused to overturn "actual terms used." ${ }^{28}$ Or, as the ICJ declared in Conditions of Admission, where the court addressed conditions for admission to the UN and reasons for which admission may be refused, "the text does not differentiate between these two cases and any attempt to restrict it to one of them would be purely arbitrary." 29 Thus, whether it is permissible to infer a term largely depends upon whether an interpreter finds the logic of the

\footnotetext{
${ }^{26}$ Reservations to the convention on the Prevention and Punishment of the Crime of Genocide, Advisory Opinion, [1951] ICJ Reports 15 at 22 [Reservations].

${ }^{27} \mathrm{Ibid}$. See also Case Concerning the Application of the Convention on the Prevention and Punishment of the Crime of Genocide (Bosnia and Herzegovina v Serbia and Montenegro) [2007] ICJ Rep 45 at 63 [Bosnia v Serbia], where the court, hardly going out on a limb, implies a term forbidding states from committing genocide. See also Dispute Regarding Navigation and Related Rights (Costa Rica v Nicaragua) [2009] ICJ Rep 213 at 246 [Costa Rica v Nicaragua], where the ICJ considered "that while [a right to river access] cannot be derived from the express language ... it can be inferred from the provisions of the Treaty as a whole ..." Therefore, it implied an obligation of notification, "[d]espite the lack of any specific provision in the Treaty relating to notification." (Ibid. at 251-52.). Reparation for Injuries Suffered in the Service of the United Nations, Advisory Opinion, [1949] ICJ Rep 174 at 184 (implying terms from the "necessary intendment of the Charter"); International Status of South West Africa (Advisory Opinion), [1950] ICJ Rep 128 at 142 (terms inferred "by analogy").

${ }^{28}$ International Status of South West Africa, ibid. at 140 (obligation to negotiate or conclude an agreement was not inferable by treaty terms or context); Peace Treaties, Second Phase, supra note 25 at 229:
}

It is the duty of the Court to interpret the Treaties, not revise them.

The principle of interpretation expressed in the maxim: Ut res magis valeat quam pereat, often referred to as the rule of effectiveness, cannot justify the Court in attributing to the provisions for the settlement of disputes in the Peace Treaties a meaning which, as stated above, would be contrary to their letter and spirit.

${ }^{29}$ Conditions of Admission of a State to Membership in the United Nations, Advisory Opinion, [1948] ICJ Rep 57 at 62 [Conditions of Admission]. 
agreement supports such an inference. ${ }^{30}$ In this instance, interpreters must consider whether the logic of the Genocide Convention would permit an inferred provision restricting genocide to instances of physio-biological genocide.

Neither the terms nor logic of the agreement support such an inference. In fact, the absence of any term restricting the Genocide Convention from reaching cultural matters should be considered evidence that no such restriction had been intended. As Thirlway explains in his review of ICJ practice, "the Court has felt entitled also to take into account the absence of words which might have been used, but were not." ${ }^{31}$ In Military and Paramilitary Activities, the ICJ declared that "if the highly experienced drafters of the Statute had had a restrictive intention on this point, in contrast to their overall concern, they would certainly have translated it into a very different formula from the one which they in fact adopted." 32

${ }^{30}$ Costa Rica v Nicaragua, supra note 27 at 251-52.

${ }^{31}$ Hugh Thirlway, "The Law and Procedure of the International Court of Justice, 1960-1989, Part Three" 62:1 Brit YB Int'l L (1992) at 26 [footnotes omitted]. Thirlway refers to this as "a sort of negative context." See also Case Concerning Right of Passage Over Indian Territory [1960], ICJ Rep 6 at 38:

From an examination of the various texts of that article placed before it, the Court is unable to conclude that the language employed therein was intended to transfer sovereignty over the villages to the Portuguese. There are several instances on the record of treaties concluded by the Marathas which show that, where a transfer of sovereignty was intended, appropriate and adequate expressions like cession "in perpetuity" or "in perpetual sovereignty" were used.

See also Aegean Sea, supra note 20 at 23:

If that had been the intention at the time, it would have been natural for those who drafted Greece's instrument of accession to put the words y compris (including) where the words et, notamment, (and in particular) in fact appear in the reservation (b) and the words et, notamment, where the words y compris are now found. That is not how the reservation (b) was drafted.

See also Antonin Scalia \& Bryan Garner, Reading Law: The Interpretation of Legal Texts (Thompson/West, 2012) at 93, describing the "Omitted-Case Canon (casus omissus pro omisso habendus est) . . . a matter not covered is to be treated as not covered." "The principle that a mater not covered is not covered is so obvious that it seems absurd to recite it. (Ibid.)

${ }^{32}$ Case Concerning Military and Paramilitary Activities in and Against Nicaragua (Nicaragua v United States), Jurisdiction and Admissibility, [1984] ICJ 392 at 408. International Status of South West Africa, supra note 27 at 140: "Had the parties to the Charter intended to create an obligation of this kind for a mandatory State, such intention would necessarily have been expressed in positive terms." See also India-Patent, Protection for Pharmaceutical and Agricultural Chemical Products, AB-1997-5 (1997), WT/DS 50/AB/R at para 45 (Report 
Similarly, if the Genocide Convention's highly experienced drafters ${ }^{33}$ had intended to restrict genocide to its physio-biological variants, we would expect them to have included restrictive language. Certainly, the parties to the Genocide Convention had many opportunities to further restrict genocide's definition — had they so intended. That they did not should be considered one more factor indicating they did not intend, or could not agree, to this limit. This seems to be an instance where, as the WTO Appellate Body said, "[s]ometimes the absence of something means simply that it is not there." ${ }^{34}$

\section{Good Faith}

VCLT article 31 requires interpretation to be conducted in "good faith," 35 an impossibly vague term which has been understood to imply an overall approach to interpretation and to incorporate well-established principles of treaty interpretation. ${ }^{36}$

of the Appellate Body), online: WTO < docsonline.wto.org>: The Vienna Convention rules "neither require nor condone the imputation into a treaty of words that are not there or the importation into a treaty of concepts that were not intended." And Conditions of Admission, supra note 29 at 63: "If the authors of the Charter had meant to leave Members free to import into the application of this provision considerations extraneous to the conditions laid down therein, they would undoubtedly have adopted a different wording."

${ }^{33}$ State Department Memo, Gross to Sandifer: "Trip to New York" (14 April 1948), College Park, MD, United States National Archives (RG59 Box 8, Sandifer File). Ernest Gross, United States delegate to the Sixth Committee, described his fellow delegates as "unusually qualified."

${ }^{34}$ Canada-Term of Patent Protection (2000) WT/DS170/AB/R at para 78 (Appellate Body Report), online: WTO $<$ docsonline.wto.org $>$.

${ }^{35}$ VCLT, supra note 2 at art 31 (1). As a multilateral treaty addressing humanitarian and human rights law, the Genocide Convention has been said to be subject to other principles of interpretation. Dissenters in Reservations felt that "the enormity of the crime of genocide can hardly be exaggerated, and any treaty for its repression deserves the most generous interpretation ..." (See Reservations, supra note 26, (Dissenting Opinion of Judges Guerrero, Sir Arnold McNair, Read, Hsu Mo) at 47. The majority (Reservations, supra note 26 at 23) declared, "The high ideals which inspired the Convention provide, by virtue of the common will of the parties, the foundation and measure of all its provisions." Conversely, the ICTY and ICTR have followed a policy of "strict construction," according to which any ambiguity in the Genocide Convention must be resolved in favour of the accused. See William A. Schabas, Genocide in International Law: The Crime of Crimes 2nd ed (Cambridge: Cambridge University Press, 2009) at 638-39 [Schabas, Genocide 2d].

${ }^{36}$ Linderfalk, supra note 15 at 105-10, identifies five (seemingly overlapping) rules of interpretation. 
Gardiner identifies "two limbs" of good faith interpretation: textual and teleological. ${ }^{37}$ The first limb requires textual effectiveness and demands that an interpretation give meaning to every term by avoiding nugatory or redundant statements. ${ }^{38}$ The second limb concerns a treaty's "object and purpose" and is meant to ensure its teleological effectiveness. As Thirlway explains,

The first [principle] is the rule that all provisions of the treaty or other instrument must be supposed to have been intended to have significance and to be necessary to convey the intended meaning; that an interpretation which reduces some part of the text to the status of a pleonasm, or mere surplussage, is prima facie suspect. The second is the rule that the instrument as a whole, and each of its provisions, must be taken to have been intended to achieve some end, and that an interpretation which would make the text ineffective to achieve the object in view is, again, prima facie suspect. $^{39}$

Underlying the principle of effectiveness is an assumption that treaties are intended to be "linguistically, normatively and teleologically effective. ..."40 However, as Thirlway points out, effectiveness may rule out "any interpretation of the text which would make it a dead letter, but does not of itself necessarily supply or point to the correct interpretation." ${ }^{41}$

Hersch Lauterpacht, a leading voice of the intentionalist school of treaty interpretation, recognized that the principle of effectiveness could conflict with the parties' intentions "If the intentions of the parties was that the treaty should not be fully effective- if

\footnotetext{
${ }^{37}$ Richard K. Gardiner, supra note 3 at 159-60. But see Linderfalk, ibid at 219-20 (identifying three strands of the effectiveness principle). See also Fitzmaurice, "Law and Procedure 1951-4" supra note 12 at 222.

${ }^{38}$ I. M. Sinclair, The Vienna Convention on the Law of Treaties (Manchester: Manchester University Press, 1973) at 75; Gardiner, supra note 3 at 159-61, surveying the doctrine of ut res and its application in international courts. See also Cayuga Indians (Great Britain) v United States (1926) 6 Rep Int'l Arbitral Awards 173 at 184: "Nothing is better settled, as a canon of interpretation in all systems of law, than that a clause must be so interpreted as to give it a meaning rather than so as to deprive it of meaning."

${ }^{39}$ Thirlway, supra note 31 at 44 .

${ }^{40}$ Linderfalk, supra note 15 at 220.

${ }^{41}$ Thirlway, supra note 31 at 47.
} 
they intended that its clauses should be limited in their scope and operation. . .."42 Yet he argued,

In interpreting treaties it seems legitimate to act on the view that in availing themselves of the faculty of entering into treaties Governments intend to pursue a purpose which, in accordance with the requirement of good faith, treaties must be considered to fulfill. If parties - or a party - abuse that faculty by reducing it to the level of a device calculated to deceive one another, or to mislead others, they cannot rule out the contingency that the judge will attach to words a meaning usually associated with them. Nothing save explicit language will reduce the incidence of that risk. Once an instrument has assumed the form of a treaty, signed and ratified, good faith requires that, in the absence of compelling reasons to the contrary, it should not be treated as a non-committal enunciation of principle. ${ }^{43}$

Thus, in assenting to treaty language, states assume the "risk" that they will be held to the standards outlined in that language, no matter how desperately they may have sought to undermine it throughout the drafting process.

Good faith textual effectiveness is said to embody closely related and often overlapping interpretive principles: first, a presumption against surplusage; and second, the principle expressed in the maxim ut res magis valet quam pereat, which simply requires that the matter may have effect rather than fail. ${ }^{44}$ As the World Trade Organization (WTO) Appellate Body put it, interpreters are "not free to adopt a reading that should result in reducing whole clauses or paragraphs of a treaty to redundancy or inutility."45 Judge

\footnotetext{
${ }^{42}$ Hersch Lauterpacht, "Restrictive Interpretation and the Principle of Effectiveness in the Interpretation of Treaties” (1949) 26 Brit YB Int'l L 48, 69.

${ }^{43} \mathrm{Ibid}$. at 73 .

${ }^{44}$ ILC Reports 1966, supra note 5 at 219. Arnold McNair, The Law of Treaties (Gloucestershire: Clarendon Press, 1961) 383, addressing the principle of effectiveness, despite his skepticism "as to the value of [this] socalled [rule]" because it has been "so frequently invoked [as to] require examination." See also Scalia \& Garner, supra note 31 at 66, criticizing as "imprecise" the application of ut res "to interpretations that do not render a provision void, but merely make it ineffective" and those "that render a provision superfluous or nugatory."

${ }^{45}$ Korea-Definitive Safeguard Measures on Imports of Certain Dairy Products (1999), WTO Doc WT/DS98/AB/R at para 80, quoting United States - Standards for Reformulated and Conventional Gasoline (1996) WTO Doc WT/DS2/AB/R.
} 
Anzilotti of the Permanent Court of International Justice (PCIJ) argued in 1934 that "it is a fundamental rule in interpreting legal texts that one should not lightly admit that they contain superfluous words: the right course, whenever possible, is to seek for an interpretation which allows a reason and a meaning to every word in the text." ${ }^{\prime 6}$ Similarly, in 1951 Gerald Fitzmaurice summed up the principle of effectiveness as reflected in the ICJ's case law, stating, "Particular provisions are to be interpreted so as to give them the fullest weight and effect consistent with the normal meaning of the words and with other parts of the text."47

A UN Commission of Experts applied the principle of semantic effectiveness to the Genocide Convention, stating that "the text of the [Genocide] Convention should be interpreted in such a way that a reason and a meaning can be attributed to every word. No word or provision may be disregarded or treated as superfluous, unless this is absolutely necessary to give effect to the terms read as a whole." 48

Interpreting article 2 according to the principle of textual effectiveness requires reading each provision in a manner that gives it independent effect, so that each reaches a distinct sphere of behaviours. Read in this light, article 2(e) appears to be exclusionists' most significant obstacle. Article 2(e) must encompass acts intended to destroy a group culturally if it is to have an effect beyond article 2's other prohibitions. As Lemkin recognized, the practice of removing a group's children in order to destroy it by denying its future has a long

\footnotetext{
${ }^{46}$ Lighthouses Case Between France and Greece, Separate Opinion of Judge Anzilotti, (1938) PCIJ (Ser A/B) No. 59 at 31.

${ }^{47}$ Fitzmaurice, "Law and Procedure, 1951," supra note 22 at 9.

${ }^{48}$ Letter Dated 24 May 1994 From the Secretary-General to The President of the Security Council: Final Report of the Commission of Experts Established Pursuant to United Nations Security Council Resolution 780 (1992) UNSC, UN Doc S/1994/674 (1994) at 24.
} 
and sordid history ${ }^{49}$ Most often, this involves plans to place children in boarding schools where they are stripped of their culture. Of course, it is common for children to be disproportionately removed from a protected group for the children's welfare. However, in such cases there would be no intent to destroy the group and hence no genocide. If one intends to destroy a group by removing its children, such an act, by definition, will be intended to cause the group's cultural or biological destruction. ${ }^{50}$ If removals are intended to destroy the group biologically by scattering children and preventing intra-group reproduction, those acts fall under article 2(d). In order to read article 2(e) to give it a meaning beyond the scope of article 2(d), it must be allowed to encompass instances of nonpermanent removal intended to destroy group culture.

Ulf Linderfalk argues that the principle of teleological effectiveness does not require interpreters to "attempt to interpret a treaty to make it as effective as possible, but [only] that appliers shall attempt to make sure that the treaty is not ineffective." ${ }^{51}$ In the South West Africa cases of 1966, the ICJ encountered the limits of teleological effectiveness, declaring,

It may be urged that the Court is entitled to engage in a process of "filling in the gaps", in the application of a teleological principle of interpretation, according to which instruments must be given their maximum effect in order to ensure the achievement of their underlying purposes. The Court need not here enquire into the scope of a principle the exact bearing of which is highly controversial, for it is clear that it can have no application in circumstances in which the Court would have to go beyond what can reasonably be regarded as being a process of interpretation, and

\footnotetext{
${ }^{49}$ Donna-Lee Frieze, Introduction, "New Approaches to Raphael Lemkin" 15 J Genocide resolution (2013) 247 at 248. After reviewing Lemkin's writings and papers, Frieze determined that "[t]he act of genocide that Lemkin found to be the cruelest was the forcible removal of children from the group."

${ }^{50}$ If the removed children are subjected to especially harsh conditions causing high mortality or disability rates, these actions would be covered by article 2(a), which prohibits "killing members of the group," or by article (c), which prohibits "deliberately inflicting on the group conditions of life calculated to bring about its physical destruction in whole or in part."

${ }^{51}$ Linderfalk, supra note 15 at 219 [emphasis in original].
} 
would have to engage in a process of rectification or revision. Rights cannot be presumed to exist merely because it might seem desirable that they should. ${ }^{52}$

According to the court, teleological effectiveness cannot outweigh treaty terms, no matter how noble or commonsense that purpose might be. ${ }^{53}$

As I will point out, the Genocide Convention was intended in part to safeguard the potential cultural achievements of certain groups. Limiting the Convention to exclude cultural destruction therefore renders the Convention ineffective regarding this central purpose. The exclusionist stance will generally protect culture as a byproduct of protecting against physical and biological genocide. However, an exclusionist interpretation permits otherwise prohibited acts so long as they are intended to destroy a group by attacking its cultural existence.

The flipside of textual and teleological effectiveness is embodied in the long-reviled principle of restrictive interpretation, which posits that when a provision permits more than one meaning, interpreters should choose the one least restricting state action. ${ }^{54}$ Explicit references to the principle of restrictive interpretation have long since vanished from the case law, but it retains a sub rosa influence on interpretation nonetheless. Restrictive interpretation finds expression in stubborn sovereigntist conceptions, which clearly provide normative direction to the VCLT and international law more generally. VCLT article 31

\footnotetext{
${ }^{52}$ South West Africa Cases (Ethiopia v South Africa; Liberia v South Africa) Second Phase, [1966] ICJ Rep 6 at 48.

${ }^{53}$ See also Peace Treaties, Second Phase, supra note 25 at 229: ut res "cannot justify the Court in attributing to the provisions for the settlement of disputes in the Peace Treaties a meaning which, as stated above, would be contrary to their letter and spirit."

${ }^{54}$ Award in the Arbitration Regarding the Iron Rhine ("Ijzeren Rijn") Railway Between the Kingdom of Belgium and the Kingdom of the Netherlands (2005) 28 UNRIAA 35 at 65 (Permanent Court of Arbitration): "Restrictive interpretation thus has particularly little role to play in certain types of treaties - such as, for example, human rights treaties."
} 
owes much to "bilateralism," which, according to Koskenniemi, "means that international law obliges States reciprocally in their relations inter se and not towards each other as members of some more or less general idea of an international public realm." ${ }^{\circ 5}$ And bilateralism is nearly co-extensive with the positivist view of international law, which asserts "that international law is the sum of the rules by which states have consented to be bound, and that nothing can be law to which they have not consented."56 Although generally unacknowledged, these sovereignty-protecting background understandings colour interpreters' ideas of international law and so shape the outcomes of many interpretations. But these realist principles are in tension with utopian notions of human rights and international governance. ${ }^{57}$ In this instance, any residual interest states retain in destroying groups through cultural means (or in standing by while others destroy groups) is outweighed by more utopian goals of forging a system of international governance based on the protection of individuals and groups.

The European Court of Human Rights and other regional international courts and treaty bodies have established a long-standing practice of dynamically or evolutively interpreting human rights treaties. ${ }^{58}$ Judge Higgins asserts "that the inter-temporal principle

\footnotetext{
${ }^{55}$ GA, International Law Commission, Martti Koskenniemi, "Difficulties Arising From the Diversification and Expansion of International Law: Report From the Study Group pf the International Law Commission: Fragmentation of International Law" UN Doc A/CN.4/L.682 (13 April 2006) at 194 [Koskenniemi, Fragmentation"].

${ }^{56} \mathrm{JL}$ Brierly, The Law of Nations: An Introduction to the International Law of Peace, 6th ed (Oxford: Oxford University Press, 1963) at 51, [emphasis in original].

${ }^{57}$ Edward Hallett Carr, The Twenty Years Crisis, 1919-1939: An Introduction to the Study of International Relations (New York: St. Martin's Press, 1939) at 93, laying out the dynamic and interdependent relation between realism and utopianism in international relations.

${ }^{58}$ Tyrer $v$ United Kingdom (1978), 26A ECHR (Ser A) 15, 2 EHRR 1, stated that the European Convention on Human Rights "is a living instrument which ... must be interpreted in the light of present day conditions. In the case now before it the Court cannot but be influenced by the developments and commonly accepted standards in the penal policy of the member states of the Council of Europe in this field." See also Pierre-Marie Dupuy,
} 
of international law, as it is commonly understood [as grounding meaning in understandings at the time of drafting], does not apply in the interpretation of human rights obligations .... ${ }^{59}$ In ICJ practice, the signal case illustrating evolutive interpretation remains its advisory opinion on the Legal Consequences of States of the Continued Presence of South Africa in Namibia Notwithstanding Security Council Resolution 276 (1970), where the court declared that the parties had intended key terms to change over time and that "subsequent development[s] of law" had indeed forced changes in those terms. ${ }^{60}$

But beyond merely allowing the content of international law to change to fit evolving international norms, some have argued that we are witnessing a broad reconceptualization of the role of multilateral instruments like the Genocide Convention. Luigi Crema discerns "a new interpretive attitude emerging: in case of doubt, the interpretation more favourable to the

\footnotetext{
"Evolutionary Interpretation of Treaties: Between Memory and Prophecy" in Enzo Cannizzaro ed., The Law of Treaties Beyond the Vienna Convention (Oxford: Oxford University press, 2011) 123 at 133-136, surveying ECHR case law on evolutive interpretation.

${ }^{59}$ Rosalyn Higgins, "Time and the Law: International Perspectives on an Old Problem" 46 ICLQ (1997) 501 at 517. See also, VCLT, supra note 2 at article 64: "[I]f a new peremptory norm of general international law emerges, any existing treaty which is in conflict with that norm becomes void and terminates."

${ }^{60}$ Legal Consequences for States of the Continued Presence of South Africa in Namibia (South West Africa) Notwithstanding Security Council Resolution 276, (1970) Advisory Opinion, [1971] ICJ Rep 16 at 31:

Mindful as it is of the primary necessity of interpreting an instrument in accordance with the intentions of the parties at the time of its conclusion, the Court is bound to take into account the fact that the concepts embodied in article 22 of the Covenant- "the strenuous conditions of the modern world" and the "well-being and development" of the peoples concerned - were not static, but were by definition evolutionary, as also, therefore, was the concept of the "sacred trust." The parties to the Covenant must consequently be deemed to have accepted them as such. That is why, viewing the institutions of 1919, the Court must take into consideration the changes which have occurred in the supervening half-century, and its interpretation cannot remain unaffected by the subsequent development of law.... These developments leave little doubt that the ultimate objective of the sacred trust was the self-determination and independence of the peoples concerned. In this domain, as elsewhere, the corpus iuris gentium has been considerably enriched, and this Court, if it is faithfully to discharge its functions, may not ignore.

Notably, the court refused to move beyond the fiction of the parties' intent. It is not that the right of selfdetermination overrides the terms of the Covenant, only that the parties had intended these terms to track the development of international law in an "evolutionary" manner. According to this positivist argument, if the parties had expressed a clear intent that the mandate should continue to exist regardless of broader developments of international law, Namibia would have no legal recourse.
} 
private party must be preferred, and, moreover, in case of doubt the interpretation favourable to international jurisdiction and regulation against national ones must be preferred." ${ }^{61}$ According to this interpretive attitude, where the previous default position had favoured the interpretation least impinging state sovereignty, the current default position favours an interpretation giving treaty-based individual rights the broadest possible scope. ${ }^{62}$ As the Inter-American Court of Human Rights (I/ACHR) explained,

Modern human rights treaties in general ... are not multilateral treaties of the traditional type concluded to accomplish the reciprocal exchange of rights for the mutual benefit of the contracting States. Their object and purpose is the protection of the basic rights of individual human beings irrespective of their nationality, both against the State of their nationality and all other contracting states. In concluding these human rights treaties, the States can be deemed to submit themselves to a legal order within which they, for the common good, assume various obligations, not in relation to other States, but towards all individuals within their jurisdiction. ${ }^{63}$

This makes sense as a normative proposition. After all, multilateral humanitarian treaties such as the Genocide Convention are intended to provide protection against state malfeasance, and therefore in these instances a traditional restrictive interpretation simply empowers atrocity.

All considerations of teleological effectiveness line up against reading article 2 of the Genocide Convention restrictively to imply exclusion. As the ICJ recognized in 1951, with an agreement like the Genocide Convention, "[s]tates do not have any interests of their own," ${ }^{64}$ so it is nonsensical to restrictively interpret it to safeguard state interests. Instead, the

\footnotetext{
${ }^{61}$ Luigi Crema, "Disappearance and New Sightings of Restrictive Interpretation(s)" 21 Eur J Intl L (2010) 681, 691.

${ }^{62} \mathrm{Ibid}$. at 694.

${ }^{63}$ Effect of Reservations on the Entry Into Force of the American Convention on Human Rights (Arts 74 and 75) (1982) Advisory Opinion OC-2/82, Inter-Am Ct HR (Ser A) No 2, at para 29.

${ }^{64}$ Reservations, supra note 26 at 23.
} 
Genocide Convention should be read effectively in accord with its object and purpose to "safeguard the very existence of certain human groups." ${ }^{95}$ Because group existence depends on the perpetuation of culture, where treaty terms allow flexibility, interpreters should favour interpretations that expand rather than restrict the protection of culture.

\section{Object and Purpose}

As I have discussed, VCLT article 31(1) requires interpreters to read treaty text in a manner that makes it effective in relation to its teleology. This in turn is determined by inquiring into the treaty's “object and purpose." A treaty's object and purpose is understood as "the reasons for which the interpreted treaty exists." ${ }^{\prime \prime 6}$ The terms object and purpose are not ascribed individual meanings, and instead the term object and purpose is taken as signifying a single concept. ${ }^{67}$ However, because there may be several reasons for which a treaty exists, "object and purpose" is typically read in the plural, as "objects and purposes."68 Like treaty language more generally, object and purpose is determined hermeneutically by measuring various provisions against the whole of the treaty and the whole of the treaty against these parts. An object and purpose may be attributed to individual provisions as well as to the treaty as a whole, and where these conflict, the latter is said to prevail. ${ }^{69}$

\footnotetext{
${ }^{65} \mathrm{Ibid}$.

${ }^{66}$ Linderfalk, supra note 15 at 206.

${ }^{67}$ But see Gardiner, supra note 3 at 192, explaining that "object and purpose" originate in translation from French Public Law, where they are less co-extensive.

${ }^{68}$ See Reservations, supra note 26, at 23-24, finding several objects and purposes. See also Gardiner, supra note 3 at 194-96 (an overview of intonational case law on object and purpose).

${ }^{69}$ Van Damme, supra note 8 at 258.
} 
The VCLT uses teleological interpretation "to shed light on the terms actually used in their context, rather [than to] introduce an alternative option for finding the meaning."70 Teleological interpretation is an inquiry into the objects and purposes the parties mutually intended. Moreover, in accordance with the intertemporal rule, the mutual intent attributed to the parties is generally reconstructed based on intentions and assumptions held at the time of the treaty's conclusion rather than at the time of its interpretation. ${ }^{71}$ Finally, international practice allows recourse to preparatory work to "identify or confirm object and purpose."72

A mere three years after its conclusion, the Reservations Case addressed the Genocide Convention's objects and purposes, stating,

The objects of such a convention must also be considered. The [Genocide] Convention was manifestly adopted for a purely humanitarian and civilizing purpose. It is indeed difficult to imagine a convention that might have this dual character to a greater degree, since its object on the one hand is to safeguard the very existence of certain human groups and on the other to confirm and endorse the most elementary principles of morality. In such a convention the contracting States do not have any interests of their own; they merely have, one and all, a common interest, namely, the accomplishment of those high purposes which are the raison d'etre of the convention. Consequently, in a convention of this type one cannot speak of individual advantages or disadvantages to States, or of the maintenance of a perfect contractual balance between rights and duties. The high ideals which inspired the Convention provide, by virtue of the common will of the parties, the foundation and measure of all its provisions. $^{73}$

As the court argues, the high ideals that originally animated the Genocide Convention are the best measure of its provisions. The difficulty lies in determining what these ideals might be and how to balance them.

\footnotetext{
${ }^{70}$ Gardiner, supra note 3 at 192.

${ }^{71}$ Linderfalk, supra note 15 at 211.

${ }^{72}$ Gardiner, supra note 3 at 340-41, citing Border and Transborder Armed Action (Nicaragua v Honduras) (Jurisdiction and Admissibility) [1988] ICJ Rep 69.

${ }^{73}$ Reservations, supra note 26 at 23.
} 
Although there may be several objects and purposes for which the Genocide Convention exists, it is also clear from its text, context, preparatory work and the circumstances of its conclusion that it possesses one overriding goal: the protection of certain types of human groups. While the Genocide Convention was intended to prevent and punish genocide, these goals are only relevant insofar as they safeguard human groups. Similarly, while the Genocide Convention's civilizing purpose is undeniable, the Convention was meant to civilize by protecting "national" groups whose maltreatment had engendered so much interstate strife and was blamed in part for starting two world wars. The object and purpose analysis often plays a decisive role in treaty interpretation. For this reason, this section will confront two potent myths concerning the Convention's teleology: that it primarily protects individual rights and that the parties had meant to place genocide at "the apex" of international criminality, as the "crime of crimes."

\section{Group Protection: "Safeguard the Very Existence of Certain Human Groups"74}

Article 2's chapeau defines genocide as "any of the following acts committed with intent to destroy in whole or in part, a . . group, as such.” Thus, only those acts intended to destroy a protected group amount to genocide; acts committed against individuals without this greater aim, no matter how horrific those acts might be, are not genocide. The Genocide Convention addresses mass killings but does not stigmatize this act beyond any other act of genocide and in fact lists killing co-equally with the forcible transfer of children. Within the Genocide Convention's internal morality, these acts are equivalent; both destroy a protected group.

\footnotetext{
${ }^{74}$ Reservations, supra note 26 at 23, affirmed in Bosnia v Serbia, supra note 27 at 110-11.
} 
Protecting group existence could be considered an indirect means of condemning large-scale atrocity. It is certainly true that mass atrocities like the Armenian tragedy, the Holocaust, and the events in Rwanda stain our collective existence and demand response. Many of the most horrific acts of violence in our species's history have been directed at the types of groups protected by the Genocide Convention. The international community is therefore justified in declaring its opposition to acts of mass killings like these. However, if it had been the parties' aim merely to declare their abhorrence to mass atrocity, it is unclear why mass killing is listed co-equally with non-lethal means of genocide including the forcible transfer of children. The very structure of article 2 points not toward an attempt to outlaw particularly egregious incidents of mass killing but rather to an overriding concern with group protection.

As I have shown, the reasons behind the Genocide Convention's group protections are far from obscure. The United Nations General Assembly explained these group protections in UNGA Resolution 96(1), which states that "denial of the right of existence shocks the conscience of mankind, [and] results in great losses to humanity in the form of cultural and other contributions represented by these human groups ...."75 This indicates that group protection is based on two factors. First, these groups have inherent worth and so deserve protection. Second, the continued existence of these groups is not only valuable to the groups themselves but valuable also "to humanity" because of their "cultural and other contributions." ${ }^{.76}$

\footnotetext{
${ }^{75}$ The Crime of Genocide GA resolution 96(1) UN GAOR. ${ }^{\text {st }}$ Sess, UN Doc. A/BUR 5.50 (1946) [Resolution 96(I)].

${ }^{76}$ Ibid.
} 
However, commentators have been reluctant to recognize the Genocide Convention's cultural imperatives. David Nersessian, who has written the most competent and comprehensive account of groups in genocide law, catalogues the reasons for protecting certain types of groups but fails to include among those reasons the view that certain groups foster culture or that this culture has value to humanity. ${ }^{77} \mathrm{He}$ believes that " $[\mathrm{a}] \mathrm{t}$ the deepest level, 'protected groups' under the Convention are abstract proxies for individual rights to certain forms of collective existence that cannot be infringed through physical and biological destruction." ${ }^{78} \mathrm{He}$ bases this stance in his observation that "[in] the overall structure of international human rights law, the protection of the individual is paramount. This reflects an underlying philosophy 'that group rights would be taken care of automatically as the result of the protection of the rights of individuals." ${ }^{79} \mathrm{He}$ writes, "The legal prohibition on harming a 'protected group' essentially preserves the individual rights to exist or to practice certain belief systems in community with others." ${ }^{" 80}$ Similarly, Claudia Card focuses not on the group itself but on "the harm inflicted [by genocide] on its victims' social vitality," on what she terms the victims" "social death." ${ }^{11}$ Social death occurs "[w]hen a group with its own cultural

\footnotetext{
${ }^{77}$ David Nersessian, Genocide and Political Groups (Oxford: Oxford University Press, 2010) at 62-69 [Nersessian, Political Groups].

${ }^{78} \mathrm{Ibid}$. at 74 .

${ }^{79}$ Ibid.

${ }^{80} \mathrm{Ibid}$. Nersessian, who has been sympathetic to the harm of cultural genocide, does acknowledge that " $[\mathrm{t}] \mathrm{he}$ rights to life, bodily integrity, etc of individual group members are protected already. Genocide is a special crime that protects the separate physical and biological existence of the group." (Ibid. at 60.) Of course, one wonders how the group is to maintain a separate physio-biological existence, if not through its culture. See also David Nersessian, "Rethinking Cultural Genocide Under International Law" 2:12 Hum Rts Dialog (2 April 2005) 7-8: "By limiting genocide to its physical and biological manifestations, a group can be kept physically and biologically intact even as its collective identity suffers in a fundamental and irremediable manner. Put another way, the present understanding of genocide preserves the body of the group but allows its very soul to be destroyed."

${ }^{81}$ Claudia Card, "Genocide and Social Death” 18 Hypatia (2003) 63 at 73.
} 
identity is destroyed, [and] its survivors lose their cultural heritage and may even lose their intergenerational connections ... producing a consequent meaninglessness of [their] life and even of its termination." ${ }^{82}$

These opinions reveal an important shift over the past several decades. Where in the mid-twentieth century individuals were protected as a means of safeguarding the group, now groups are protected as a means of safeguarding the rights of individuals. In this conception, the group has no right to existence, but individuals have a right to group identity; there is no consideration of the value of group culture to humanity as a whole, only to its value to the individual group members.

Protecting the individual right of group affiliation or identity will not adequately protect the group itself. After all, there are important differences between a child's right not to be subjected to "social death" by being forcibly transferred out of her group, and the right of her group to retain its children. The former speaks to the child's right to retain important social connections while the latter addresses the ability of the group to continue its existence through procreation and acculturation. If the perpetrator places the removed children in a circumstance where they can develop social connections equivalent to, or perhaps even better than, those they enjoyed with the targeted group, then there is in theory no harm to the child, no "social death." The child may even receive substantial benefit in economic and social status by being removed from a historically marginalized group. But while the child might

\footnotetext{
${ }^{82} \mathrm{Ibid}$. at 73 . See also Bosnia $v$ Serbia, supra note 27 at 124-25, where the ICJ apparently endorsed this atomistic conception of group existence, stating that a protected group "must have particular positive characteristics - national, ethnical, racial or religious ..." But it seems the court actually meant not that the "group" must have these characteristics, only that individual members must possess them. In the follow-on sentence, the court states that "[t]he intent [to commit genocide] must also relate to the group 'as such.' That means that the crime requires an intent to destroy a collection of people who have a particular group identity."
} 
benefit, because its ability to self-perpetuate is destroyed, the group is clearly harmed. The individualist focus on the child obscures the group's right to exist as a "group, as such."

The Genocide Convention does protect individuals against the acts prohibited in article 2, but not for the reasons Nersessian and Card suppose. The Genocide Convention protects individuals only as a means of protecting the group to which they belong. Like beads on an abacus, individuals in the Genocide Convention amount to little more than a means of measuring the harm accruing to their group. ${ }^{83}$ Acts like killing, forced sterilization, and the forcible removal of children from a group are only prohibited under the Genocide Convention when they are committed "with intent to destroy, in whole or in part a [protected] group, as such." ${ }^{" 84}$ In the absence of group-destroying intent, the Genocide Convention is mute on these acts. For this reason, the Genocide Convention should not be read to harmonize with the individualism of today's human rights, as Nersessian asserts. Instead, it should be read against this doctrine, as a stubborn collectivist holdout in today's hyperindividualized world.

Given their divergent views on most subjects, the drafters displayed remarkable unity around the idea that the Genocide Convention's central object and purpose is the protection of human groups. As I will discuss in the next chapter, the issue of group protection became most apparent as the drafters considered which types of groups to include and whether to exclude certain acts considered to be cultural genocide. Overall, the preparatory work and

\footnotetext{
${ }^{83}$ But see Gerhard Werle, Principles of International Criminal Law (The Hague: T M C Asser Press, 2005) at 193. Werle asserts that the Genocide Convention protects two rights: the right of the group to continued existence and the right of individuals of protected groups to be free from genocidal attacks, which are "serious violations of . . . human dignity" that depersonalize the individual, reducing him or her "to a mere object." There is little in the Convention's text or context to support Werle's moralizing on human dignity. Though this is a now a common approach to the Genocide Convention, it is primarily a scholarly gloss.

${ }^{84}$ Genocide Convention, supra note 2 at art 2.
} 
other supplementary means of interpretation reveal overwhelming support for the idea that the crime of genocide's defining characteristic, the thing that set it apart from all other national and international crimes, was its protection not of individuals but of groups.

As it turned out, Lemkin's proposal to protect groups "as such" was valuable to the major powers interested in doing something to outlaw and condemn Nazi atrocities while leaving their own misdeeds free from scrutiny. This is most obvious with the United States, where State Department officials weighed the Genocide Convention's provisions against the possibility they might implicate the American South's juridified racial hierarchy and the pervasive violence used to maintain it. ${ }^{85}$ They would spend the next decade unsuccessfully reassuring southern senators that the Convention's group focus prevented it from implicating the South's longstanding - and at that time, continuing - tradition of lynching African Americans. ${ }^{86}$ Clearly, the Genocide Convention would not have garnered crucial American

\footnotetext{
${ }^{85}$ State Department Memo: Gross to Sandifer, "Cultural Genocide" (22 April 1948) College Park, MD, United States National Archives, (RG59 Box 8, Sandifer File), stating that US delegates to the Sixth Committee were unconcerned about lynching because they believed the convention was too clear to permit abuse. See also LeBlanc, Lawrence J., The United States and the Genocide Convention (Durham, NC: Duke University Press, 1991) 35, claiming that the issues of lynching and the Genocide Convention "were first raised" in senate hearings of 1950. But I believe, as the Sandifer memo indicates, that the State Department had anticipated these concerns and had worked to shape the Genocide Convention accordingly. See also State Dept. Confidential Memo: Sandifer to Gross "Trip to New York on Genocide" (14 April 1948) College Park, MD, United States National Archives, (RG59 Box 8, Sandifer File), discussing the problem of state complicity for genocide in "lynching cases in which there is an acquittal in the face of convincing evidence of guilt": "It was agreed that [the complicity language] was satisfactory so long as the point is kept uppermost that the thing we are talking about in all of this discussion is the physical elimination of the group." Rowland Brucken, A Most Uncertain Crusade: The United States, the United Nations, and Human Rights, 1941-1953 (Northern Illinois University Press, 2013) also documents the pervasive effect America's concern about its lynching problem had on the early shape of human rights. According to Brucken, State Department officials Ernest Gross and Dean Rusk "believed that ... those who participated in vigilantism [lynching] did not have the prerequisite intent to destroy the whole African American race." (Ibid. at 180, 202.)

${ }^{86}$ See Carol Anderson, Eyes off the Prize: The United Nations and the African American Struggle for Human Rights, 1944-1955 (Cambridge: Cambridge University Press, 2003) 180, documenting State Department efforts to assuage Southern senators following the publication of "We Charge Genocide." See also LeBlanc, ibid. at 35, quoting William Rehnquist's testimony at a 1970 Senate hearing:
} 
support had it lacked a robust group element. But the United States' concerns were far from unique; none of the Allied Powers came to the drafting table with clean hands. Hiroshima, Nagasaki, and the firebombing of Tokyo; Dresden, the nighttime bombing of civilian populations, and the starvation of India; Katyn and the parade of systematic rape that accompanied the Soviet advance into Germany_all these tainted the Allies with moral if not legal guilt.

And World War II, the bloodiest of wars, was followed by a similarly bloody peace. Following the war, Central Europe shed itself of unwanted populations in a massive campaign of ethnic cleansing, ${ }^{87}$ the colonial powers used all necessary means to re-secure their foreign holdings, and soldiers continued raping. ${ }^{88}$ But the victors reassured themselves

In my opinion, as I understand the sort of lynchings that have taken place in this country in past times, they have not been accompanied by the intent to destroy in whole or in part an ethnical, racial, or religious group. I think genocide, as defined in the treaty, does require that specific intent.

${ }^{87}$ R. M. Douglas, Orderly and Humane: The Expulsion of the Germans after the Second World War (New Haven: Yale University Press, 2012) 364, summarizes the results of Eastern Europe's postwar ethnic cleansing, which the Allies abetted, despite their general disapproval:

While the supposed benefits of mass expulsions remained nebulous, the costs were all too apparent. On the most conservative of estimates, hundreds of thousands of expellees - most of whom, if they conformed to the demographic profile of the transferred population as a whole, were women and children — had lost their lives. Millions more were reduced to penury, without the assets they had lost necessarily enriching those who had taken possession of them.

As Douglas rightly points out, this issue arose during drafting when a Sixth Committee delegate argued that a proposed Syrian Amendment to article 2 the Genocide Convention (Syria: Amendment to article II, UN GAOR Sixth Committee, 3rd Sess, UN Doc A/C.6/234, 15 October 1948), which would have outlawed what we now refer to as "ethnic cleansing," would implicate many of the states involved in drafting the convention, which had either condoned or conducted these expulsions. (Douglas, ibid. at 335.)

${ }^{88}$ Ian Buruma, Year Zero: A History of 1945 (New York: Penguin Books, 2013) at 83-84, discussing Soviet mass rape of German women; ibid. at 111-26, on actions taken to subdue anti-colonialists in Indonesia and Vietnam; and ibid. at 315: "The Algerian protesters in Sétif, who were gunned down on May 8 [1945] . . for demanding equality, carried banners that read: 'Long Live the Atlantic Charter!'” See also Telford Taylor, "When a People Kill a People," Book Review of Genocide: Its Political Uses in the Twentieth Century by Leo Kuper, (28 March, 1982) New York Times Book Review at 9. In discussing the bombing of Dresden, Tokyo, Nagasaki, and Hiroshima, Taylor uses just this defense, stating that

it is difficult to perceive the bombings of World War II as violations of the laws of war. But however that question might be resolved, they were certainly not "genocidal" within the meaning of the Convention, which limits genocide to "acts committed with intent to destroy ... a national, ethnical, 
that these acts had been carried out for reasons of military expediency or were simple

byproducts of occupation in difficult circumstances and were not intended to destroy groups

as such. ${ }^{89}$ The Nazis, on the other hand, had loudly declared their intent to destroy groups

and then worked to fulfill this promise. Grounding the Genocide Convention in the protection

of groups was pivotal in allowing states to sign on without fear of implicating themselves.

There would have been no Genocide Convention had it not been made safe in this manner.

“Civilizing Purpose": "[T]o Confirm and Endorse the Most Elementary

Principles of Morality"90

One of the Genocide Convention's most obvious aims lies in stigmatizing genocidal

acts: UNGA Resolution 96(1) declares genocide "contrary to moral law and to the spirit and

aims of the United Nations." 91 And the preamble seeks to place these acts firmly beyond the

racial or religious group, as such." Berlin, London and Tokyo were not bombed because their inhabitants were German, English or Japanese, but because they were enemy strongholds. Accordingly, the killing ceased when the war ended and there was no longer any enemy.

${ }^{89}$ Peter Maguire, Law \& War: International Law and American History, revised ed (New York: Columbia University press, 2010) at 79, makes a similar point. He ties US enthusiasm for postwar war crimes prosecutions to the fact that "[a]lthough the United States waged total war against the Axis Powers, the extermination of entire ethnic, racial, religious, and economic groups was never among its wartime goals." But see Timothy Snyder, Bloodlands: Europe Between Hitler and Stalin (New York: Basic Books, 2010) 89-154. As Snyder documents, the Soviet Union under Stalin had targeted national groups for destruction and in so doing had employed each of the acts prohibited by article 2 of the Genocide Convention, so there is little chance that the Soviets believed the group element would protect them. Of course, as Lemkin often argued, the USSR was deeply opposed to the Genocide Convention and sought constantly to sabotage the drafting process. As I will point out in chapter 4, the Soviets attempted to insert language into the convention's preamble restricting genocide to only those acts motivated by racism or fascist ideology. See also Keith Lowe, Savage Continent: Europe in the Aftermath of World War II (New York: Saint Martin's Press, 2012), cataloguing the many violent anti-group acts committed in the war's aftermath, including Polish and Hungarian anti-Semitism culminating in pogroms that forced Jews to seek safety in Germany (ibid. 203-211). According to Lowe, the Soviets harnessed nationalist tension to ethically cleanse Eastern Europe, resulting in today's much more ethnically homogenous nations. (Ibid. at 214).

${ }^{90}$ Reservations Case, supra note 26 at 23; affirmed in Bosnia v Serbia, supra note 27 at 110-11. See also U.N. Sec. Council, Final Report of the United Nations Commission of Experts Established Pursuant to Security Council Resolution 780 (1992), 988 , U.N. Doc. S/1994/674 (May 27, 1994): "to affirm and emphasize the most elementary principles of humanity and morality."

${ }^{91}$ Res. 96(I), supra note 75. 
moral boundary when it asserts that genocide is "an odious scourge" and declares it "a crime under international law, contrary to the spirit and aims of the United Nations and condemned by the civilized world," which has "inflicted great losses on humanity. . .."92

The revelations of Nazi atrocity at Nuremberg weighed heavily in the formulation of the Genocide Convention. ${ }^{93}$ Nazi sadism had exposed a previously unacknowledged capacity for human brutality and this new reality demanded action. Behind the countless stories of tragedy, of children ripped from their mothers' arms to die alone and naked on the concrete floors of gas chambers, postwar observers were also left to contemplate the lost potential in this vast human wastage. How many composers, scientists, novelists, artists, and thinkers fed this inferno?

But again, the group element of this crime must be taken into account. Certainly many would have regarded the Nazi crimes in the manner I have expressed it above, as a story of aggregate tragedies and the lost human potential represented by millions of slaughtered individuals. And above all, it was that. But in the drafters' hybrid intellectual era, many were guided by the "idea that a given group possessed an enduring cultural essence grounded in blood and history, implanted in each of its individual members and capable of having an unmediated impact on any object it encountered." 94 In fact, most delegates seemed

\footnotetext{
92 Genocide Convention, supra note 2.

93 The legal specialists who drafted the Genocide convention and formulated the early direction of the human rights movement were aware of the disproportionate Jewish role as victims of Nazi atrocities. In the UN Sixth (legal) Committee, which debated drafts of UNGA Resolution 96(1) (supra note 75), Sir Hartley Shawcross referenced the "six million human beings [who] had been coldly and deliberately exterminated with a view to destroying the Jewish race." (UN GAOR, Sixth Committee, 1st Sess, 1st Mtg, UN Doc. A/C.6/SR.22 (1946) at 102). Similarly, John Maktos, US representative to the General Assembly's Ad Hoc Committee on Genocide, declared "[ $\mathrm{t}]$ he fact which initiated the General Assembly resolution [96(1)] had been the systematic massacre of Jews by nazi $[\mathrm{sic}]$ authorities during the course of the last war." (UNESCOR, Ad Hoc Committee on Genocide, 3rd Sess, 5th Mtg, UN Doc E/AC.25/SR.5 (1948) at 3 [Ad Hoc Committee].

${ }^{94}$ David Hollinger, Science, Jews, and Secular Culture: Studies in Mid-Twentieth Century American Intellectual History (New Brunswick: Princeton University Press, 1996) at 13.
} 
able to accommodate both individualistic and groupist conceptions simultaneously, without apparent dissonance. In the cultural moment, many believed that individuals were nurtured by and arose from group-based culture and rued the irreparable loss to humanity when those reservoirs of unique culture were destroyed.

\section{The Apex of Apoplexy}

Some have proposed a hierarchy of international crimes and have attempted to install genocide at its "apex." 95 According to these sources, genocide should be regarded as a crime beyond all others, as "the crime of crimes." ${ }^{\text {" How }}$ Hower, there is no support for this hierarchy in the Genocide Convention's text and little in its drafting history. And far from harmonizing the Genocide Convention with other aspects of international law, hierarchy has led to division and derision. ${ }^{97}$ The status of genocide as the international community's crime of crimes fosters competition between victimized groups as they seek the symbolic capital inherent in being designated victims of genocide, and there is tremendous outcry from victim groups when an incident is deemed to fall short of genocide, constituting "only" a war crime

\footnotetext{
${ }^{95}$ Prosecutor v Jelisić, Partial Dissenting Opinion of Judge Wald, IT-95-10-A, Judgment (5 July 2001) at para 13 (International Criminal Tribunal for the former Yugoslavia, Appeals Chamber) online: ICTY $<$ www.icty.org>. See also Nersessian, Political Groups, supra note 77 at 178, arguing the distinct elements of the crime of genocide set it above all other international crimes.

${ }^{96}$ Prosecutor v Kambanda, ICTR-97-23-S, Judgment and Sentence (4 September 1998) At para 16 (International Criminal Tribunal for Rwanda) online: ICTR $<$ ictr.org $>$; Prosecutor $v$ Rutaganda, ICTR-96-3-T Judgment and Sentence, (6 December 1999) at para 451 (International Criminal Tribunal for Rwanda, Trial Chamber) online: ICTR <ictr.org>; Prosecutor v Serushago, ICTR-98-39-S, Sentence (5 February, 1999) at para 15 (International Criminal Tribunal for Rwanda, Trial Chamber) online: ICTR <ictr.org >; Prosecutor $v$ Musema, ICTR-96-13-T, Judgment and Sentence (27 January 2000) at para 981 (International Criminal Tribunal for Rwanda, Trial Chamber) online: ICTR <ictr.org>.

${ }^{97}$ This was especially evident in the controversy following the release of the Report of the International Commission of Inquiry on Darfur to the United Nations Secretary-General Pursuant to Security Council Resolution 1564 of 18 September 2004 (Geneva: Office of the High Commissioner for Human Rights, 25 January 2005) online: un.org < http://www.un.org/news/dh/sudan/com_inq_darfur.pdf $>$. See also discussion in Payam Akhavan, Reducing Genocide to Law: Definition, Meaning, and the Ultimate Crime (Cambridge: Cambridge University Press, 2012) at 135-36.
} 
or a crime against humanity. For these reasons, international tribunals and other bodies have abandoned the effort to establish a hierarchy of international crimes, and genocide is increasingly regarded as on par with, rather than beyond, the worst criminal acts. ${ }^{98}$

Notably, the Convention's ordinary meaning contradicts hierarchy. After all, how can we consider the forcible transfer of children as prohibited by article 2(e) of the Genocide Convention more morally abhorrent than discriminatory mass slaughter, which is forbidden as a crime against humanity? The efforts of courts and scholars to enshrine genocide at the apex of international criminality reveal the stubbornness of "fore-understanding." 99 The ability of interpreters to avoid being caught short by the juxtaposition of transferring children and mass killing speaks to their capacity — and the capacity of the interpretive communities to which they belong - to impose a meaning on the text, even where the text so obviously works against their fore-meaning.

\section{Prevention and Punishment}

The emphasis on prevention and punishment is evident in its title: Convention on the Prevention and Punishment of the Crime of Genocide. In article 1, the parties confirm that genocide "is a crime under international law which they undertake to prevent and punish."100 After conducting a detailed examination of the Genocide Convention's preparatory work, the ICJ "confirm[ed] that Article 1 does impose distinct obligations over and above those

\footnotetext{
${ }^{98}$ Schabas, Genocide $2 d$, supra note 35 at 642.

${ }^{99}$ Hans-Georg Gadamer, Truth and Method, translated by Joel Weisheimer \& Donald G. Marshall (London: Bloomsbury, 1975) at 327. Foreunderstanding is "clearly not something to be attained through the process of understanding but is already presupposed."

${ }^{100}$ Genocide Convention, supra note 2 at art. 1. See also Bosnia v Serbia, supra note 27 at 113, discussing the binding, non-preambular nature of article 1.
} 
imposed by other Articles of the Convention. In particular, the Contracting Parties have a direct obligation to prevent genocide." 101

This discussion of the Genocide Convention's teleology has revealed its overriding concern: to protect certain human groups because of the culture they nurture. As I have shown, it is embedded in article 2 itself, which protects only those groups that self-perpetuate through culture and which prohibits not just mass killing but a host of group-destroying acts. It is apparent in the Genocide Convention's broader context, where UNGA Resolution 96(1) declares that genocide is group destruction and a matter of international concern because of the cultural losses it inflicts on the whole of humanity. And as I will discuss in Chapter 4, supplementary means of interpretation, including the preparatory work, also document the parties' intent to protect these types of human groups. With its object and purpose in mind, I now move on to a textual analysis of article 2 of the Genocide Convention.

\section{Article 2: An Ordinary Reading}

The text of article 2 simply does not include any language restricting genocide to physio-biological acts or to instances of physio-biological destruction. It alludes to typologies of destruction only once, in subparagraph (c), where it prohibits "deliberately inflicting on the group conditions of life calculated to bring about its physical destruction in whole or in part." ${ }^{102}$

\footnotetext{
${ }^{101}$ Bosnia v Serbia, ibid.

102 Genocide Convention, supra note 2, art. 2 [emphasis added].
} 
Article 2 Chapeau: "In the present convention, genocide means any of the following acts committed with intent to destroy, in whole or in part, a national, ethnical, racial or religious group, as such."103

The chapeau defines genocide as "any of the following acts committed with intent to destroy" a protected group, thereby stating the elements of the crime of genocide, the prohibited act, and the requisite intent. "Destruction" is unmodified, and the text lacks any indication that cultural destruction is excluded. Indeed, the chapeau provides no indication that distinctions should or could be drawn between differing types of intended destruction. Moreover, destruction is purely a matter of intent; actual destruction of the group "in whole or in part" is not required to establish genocide. ${ }^{104}$

The doctrine of exclusion feeds on the constant conflation of two discrete elements of the crime of genocide: the prohibited act and the destruction that act is intended to achieve. ${ }^{105}$ In disentangling this issue, it is helpful to consider the prohibited acts as concerning individual members of the group, and the intended destruction as concerning the group as an entity. This interpretation finds some support in the structure of article 2, which addresses destruction in the chapeau while addressing the prohibited acts separately in subparagraphs (a) through (e). The language of those subparagraphs also supports it. Subparagraph (a) prohibits "killing members of the group" and subparagraph (b) prohibits "causing serious bodily or mental harm to members of the group." ${ }^{106}$ Similarly, while subparagraph (d)

\footnotetext{
${ }^{103}$ Genocide Convention, supra note 2, art. 2.

${ }^{104}$ Prosecutor v Akayesu, ICTR-96-4-T, Judgment (2 September 1998) at para 497 (International Criminal Tribunal for Rwanda, Trial Chamber) online: <ictr.org>. See Akhavan, supra note 97 at 45.

105 See below, chapter 5 text accompanying notes 127-134.

106 Genocide Convention, supra note 2, art. 2 [emphasis added].
} 
prohibits "measures intended to prevent births within the group" and subparagraph (e) prohibits "forcibly transferring children of the group, ..." these acts clearly involve individual children. The only ambiguity is found in subparagraph (c), which prohibits "inflicting on the group conditions of life calculated to bring about its physical destruction. ..."But even this provision makes more sense if it is read as concerning individual group members. After all, as exclusionists point out, the group itself does not possess a "physical" existence, only its members do. ${ }^{107}$ Finally, the only mention of destruction occurs in the chapeau, which defines genocide as certain acts "committed with intent to destroy . . a . . group, as such.” As Judge Shahabuddeen argues, even if one believes, as he does, that "the listed (or initial) acts must indeed take a physical or biological form, . . . the accompanying intent, by those acts, to destroy the group in whole or in part need not always lead to a destruction of the same character." ${ }^{108}$ Under this interpretation, if a perpetrator intends to destroy a group by any of acts listed in subparagraphs (a) through (e), then genocide has occurred regardless of whether that destruction was intended to be of a physical, biological, or cultural character.

Article 2's chapeau prohibits destruction of a group "in whole or in part," which has generated some confusion. Early on, many in the United States Senate and the American Bar Association fretted this phrase might encompass instances in which a single individual had been killed based on membership in a protected group, a circumstance which would thereby

\footnotetext{
${ }^{107}$ This has been the approach of several international courts. See e.g. Akayesu, supra note 104 at para 505: article 2(c) "should be construed as the methods of destruction by which the perpetrator does not immediately kill the members of the group, but which ultimately seek their physical destruction."

${ }^{108}$ Prosecutor v Radislav Krstić, IT-98-33-A, Judgment, Partial Dissenting Opinion of Judge Shahabuddeen (19 April 2004) at paras 48-54 (International Tribunal for the former Yugoslavia, Appeals Chamber) online: ICTY $<$ www.icty.org> [Krstić, Appeals].
} 
implicate lynching. ${ }^{109}$ The southern segregationists' fears have not been realized, as courts have read this phrase to mean "a substantial part of the particular group." Applying this substantiality requirement, courts will declare an act genocide only where perpetrators target a significant percentage of a group's members or when they target a significant component of the group, such as its religious or cultural leaders or men of military age. ${ }^{110}$

Finally, the chapeau prohibits the destruction of a group "as such," which has also generated significant confusion, some of it genuine. For instance, some have asserted that "as such" implies a motive element and that it is therefore reasonable to require that a perpetrator has "hatred" toward the targeted group as a condition of finding genocide, but this is absurd. ${ }^{111}$ To be sure, the "as such" language was included to placate several drafters who argued for a motive element. However, as I discuss in chapter 4, the drafters never achieved

${ }^{109}$ See LeBlanc, supra note 85 at 35.

${ }^{110}$ Bosnia v Serbia, supra note 27 at 126.

${ }^{111}$ Schabas, Genocide 2d, supra note 35 at 306. See also Lemkin, "Philosophical and Legal aspects of the Word Genocide" (undated, but post 1948), Cincinnati, The Jacob Rader Marcus Center of the American Jewish Archives, Raphael Lemkin Papers (Box 3, File 3). Notably, Lemkin had little tolerance for those who would read this language as implying a motive element:

Genocide being a crime, its legal structure is based on intent and not on motivation of the act. Intent is what the perpetrator desires to achieve, namely to destroy the group. The motivations of the act or why such intent is being conceived by the perpetrator is immaterial. The motives might be political, economic, strategic and so forth. Because of the inability of laymen to distinguish between intent and motivation, erroneous statements are often made, for example, that to destroy a national group for political reasons is not a crime under the Genocide Convention.

See also Raphael Lemkin, "The Truth About the Genocide Convention" (undated at 2) New York, New York Public Library, Archives and Manuscripts, Raphael Lemkin Papers [NYPL] (Reel 3, File 1): "The motivations on the side of the offenders are of no importance. To destroy the above groups for political, economic, or strategic reasons is genocide." He continued, "In genocide, like homicide, the motives are of no importance. However, motives must be distinguished from intent. The intent to destroy the group is basic to the concept of genocide. Killing people or mutilating them will not be genocide unless it can be proved that these acts are undertaken with the intent to destroy the group." As I have argued elsewhere, genocidal attacks on groups have been motivated by a number of factors including profit or even a desire to "save" individual group members from the corrupting influence on the group. See Kurt Mundorff, "Other Peoples' Children: A Textual and Contextual Interpretation of the Genocide Convention, Article 2(e)," 50 Harv Int'l L J (2009) 61 at 108-110. 
consensus or even a majority view on the meaning of this phrase. ${ }^{112}$ In an attempt to

overcome this obscurity, the Venezuelan delegation proposed a subcommittee to determine

what the committee had intended by this language, but no such committee was formed. ${ }^{113}$ In

fact, the "as such" language seems to be an instance of drafters adopting deliberately vague

language to placate parties pursuing a number of diverse interests. Lacking evidence that the

drafters achieved a majority view on the meaning of "as such," it should be read according to

its ordinary meaning. According to ordinary usage, "as such" modifies "group" and restricts

culpability to those acts aimed to destroy the group qua group. ${ }^{114}$

At the time of drafting, the idea of protecting groups as such was not seen as

especially problematic. During the Convention's drafting, the Secretariat commented that

"[t]he victim of the crime of genocide is a human group. It is not a greater or smaller number

of individuals who are affected for a particular reason . . . but a group as such. ..."115 In 1951

\footnotetext{
${ }^{112}$ See below, chapter 4, text accompanying notes 223-233.

${ }^{113}$ UN GAOR, Sixth Committee, 3rd Sess, 78th Mtg, UN Doc A/C.6/SR.78 (1948) at 139 [Sixth Committee 3rd Sess]. Proposal of Mr. Manini y Ríos. The working group proposal was voted down "30 votes to 15 with 3 abstentions." Ibid. at 142. See also Mr. Morozov USSR stating "the majority had adopted an ambiguous definition of genocide which judges would be able to interpret only with the aid of voluminous documentation." (Ibid. at 77th Mtg at 137).
}

114 The Shorter Oxford English Dictionary, 5th ed, sub verbo says that "as such" means "being what has just been named." Bryan A. Garner, Garner's American Usage 2nd ed (Oxford: Oxford University Press, 2003) sub verbo "as such," points out that "[i]n this phrase, "such' is a pronoun requiring an antecedent" but admits that "sometimes [it] causes ambiguity when the referent isn't clear" and that writers use it "faddishly" where they mean thus or therefore. H. W. Fowler, New Fowler's Modern English Usage revised 3rd ed, revised by R. W. Burchfield (Oxford: Oxford University Press, 1998) sub verbo "as such" finds it useful in "the spoken language" as a means of removing ambiguity by adding emphasis. But even there, he prefers substitution of "a synonymous expression." However, according to VCLT (supra note 2), article 31's hermeneutic approach, "as such" is not read alone but in relation to the other elements of the treaty's text and context. Because the other elements of the Genocide Convention's text and context emphasize collective group existence, I think the proper and relatively clear reading of "as such" would consider it nearly synonymous with per se, emphasizing the group's group-ness, collective identity, or culture. (See Thesaurus.com, online:

$<\mathrm{http}$ ://thesaurus.com/browse/as+such $>$ ).

${ }^{115}$ Note by the Secretariat, Relations Between the Convention on Genocide on the One Hand and the Formulation of the Nurnberg Principles and Preparation of a Draft Code of Offences Against Peace and 
the International Court of Justice similarly commented that the Genocide Convention was intended "to safeguard the very existence of certain human groups." 116 Writing in 1960, Nehemiah Robinson surveyed the various controversies surrounding the Genocide Convention and offered only this on the concept of "group":

The main characteristic of Genocide is its object: the act must be directed toward the destruction of a group. Groups consist of individuals, and therefore destructive action must, in the last analysis, be taken against individuals. However, these individuals are important not per se but only as members of the group to which they belong. ${ }^{117}$

By contrast, how much of a group a perpetrator would need to intend to destroy to trigger the Genocide Convention, and whether political or other types of groups should have been included, continues to generate controversy. Notably absent, from today's perspective, is any philosophical rumination on human groups. Instead, Robinson, like his contemporaries, appears to assume that groups exist and that it is proper to protect them as such. $^{118}$

Article 2 spells out protections for national, ethnic, racial, and religious groups, and this list also emphasizes culture, since each of these types of group coheres through cultural practices. Even by today's atomistic standard, ethnic, national, and religious groups are considered cultural entities, cohering through overtly cultural processes. Of the protected groups, only racial groups might be considered to have the ability to self-perpetuate through

Security on the Other, UNESCOR, Ad Hoc Committee on Genocide, 3rd Sess UN Doc, E/AC.25/3/Rev1 (1948) at 6.

${ }^{116}$ Reservations Case, supra note 26 at 23.

${ }^{117}$ Nehemiah Robinson, The Genocide Convention: A Commentary (Institute of Jewish Affairs, 1960) at 58 [emphasis in original].

${ }^{118}$ But see Schabas, Genocide $2 d$, supra note 35 at 121 . Schabas misleadingly quotes a portion of Robinson's commentary: "Nehemiah Robinson, in his study of the Genocide Convention, proposed an obvious and succinct formulation: 'groups consist of individuals."'[footnotes omitted.] It seems the point Robinson intended differs substantially from the one Schabas ascribes to him. 
non-cultural processes because racial characteristics can be passed on independent of any process of acculturation. But our ideas on race have narrowed over the intervening decades. Where it had been common to use the terms "race" and "nationality" interchangeably, race is gradually losing many of its ethnic connotations and is increasingly thought of as a social construction based around arbitrarily selected phenotypical traits.

William Schabas is correct when he argues, "The four terms in the Convention not only overlap, they also help to define each other, operating much as four corner posts that delimit an area within which a myriad of groups covered by the Convention find protection. This was certainly the perception of the drafters." ${ }^{119}$ The protection of groups in the Secretariat's draft, he argues, was grounded in the idea of "national minorities"; the specific enumeration "merely fleshed out the idea, without at all changing its essential content."120 The International Criminal Tribunal for the Former Yugoslavia (ICTY) picked up this analysis in Kristić, concluding,

The preparatory work of the Convention shows that setting out such a list was designed more to describe a single phenomenon, roughly corresponding to what was recognized, before the second world war, as "national minorities", rather than to refer to several distinct prototypes of human groups. To attempt to differentiate each of the named groups on the basis of scientifically objective criteria would thus be inconsistent with the object and purpose of the convention. ${ }^{121}$

\footnotetext{
119 Schabas, Genocide 2d, supra note 35 at 129 [footnotes omitted]. See also Diane Marie Amann, "Group Mentality, Expressivism, and Genocide" 2:2 Intl Crim L Rev (2002) 93 at 112, crediting Schabas with influencing the Krstić court's move to an "ensemble" conception of protected groups. See also Jill C. Anderson, "Misreading like a Lawyer: Cognitive Bias in Statutory Interpretation" 127 Harv L Rev (2014) 1 at 33-44, reaching the same conclusion by applying an linguistic analysis to the text of article 2 . She "argue[s] that the essence of a genocide is not its group-based targeting of what just happens to be a racial, ethnic, religious or national group . . . but its targeting of a group as a people." (Emphasis in original.)

120 Schabas, Genocide 2d, supra note 35 at 120.

${ }^{121}$ Prosecutor v Radislav Krstić, IT-98-33-T, Judgment (2 August 2001) at para 556 (International Criminal Tribunal for the Former Yugoslavia, Trial Chamber) online: ICTY <www.icty.org > [Krstić, Trial].
} 
At the time of drafting, the term "national minorities" was used widely but was notoriously difficult to pin down. ${ }^{122}$ Writing as World War II ended, P. De Azcárate observed "that what in the last resort constitutes the distinctive and characteristic features of a national minority is the existence of a national consciousness, accompanied by linguistic and cultural differences." 123 His definition mirrored the majority view that whatever a "national minority" might be, it necessarily encompassed aspects of a distinct cultural existence and a "national consciousness," meaning a group's awareness that it possessed a distinct nationality or culture.

\section{Article 2(a): Killing Members of the Group}

Article 2(a) prohibits "killing members of the group," which is understood to mean an indeterminate number of individual group members. It is not necessary for the perpetrator to intend to kill all group members.

Article 2(a) appears to be the one article squarely addressing physical genocide. However, even this seemingly unambiguous provision can also implicate cultural considerations, as when perpetrators target specific elements within a group, such as its intelligentsia, or religious, or political leaders, in order to destroy group cohesion. ${ }^{124}$ In this way killing, a physical act, is used to destroy the group culturally.

\footnotetext{
122 Pablo De Azcárate, The League of Nations and National Minorities: An experiment (Carnegie Endowment for International Peace, 1945) at 3.

${ }^{123}$ Ibid. at 4 [emphasis in original]. See also Inis Claude, National Minorities: An International Problem (Cambridge, MA: Harvard University Press, 1955) at 2: "We can only say that a national minority exists when a group of people within a state exhibits the conviction that it constitutes a nation, or a part of a nation, which is distinct from the national body to which the majority of the population of that state belongs, or when the majority element of the population of a state feels that it possesses a national character in which minority groups do not, and perhaps cannot, share."

${ }^{124}$ Prosecutor v Jelisić, IT-95-10-T, Judgment (14 December 1999) at para 82 (International Criminal Tribunal for the Former Yugoslavia, Trial Chamber) online: ICTY <www.icty.org> [Jelisić]; Prosecutor v Sikirica et al., IT-95-8-T, Judgment on Defense Motions to Acquit (3 September 2001) at para 77 (International Criminal
} 
Courts have recognized this as genocide. The Kristic Trial Chamber found that "the

Bosnian Serb forces had to be aware of the catastrophic impact that the disappearance of two or three generations of men would have on the survival of a traditionally patriarchal society .

..."125 And in Jelisić, the ICTY declared,

Genocidal intent may ... manifest in two forms. It may consist of desiring the extermination of a very large number of the members of the group, in which case it would constitute an intention to destroy a group en masse. However, it may also consist of the desired destruction of a more limited number of persons selected for the impact that their disappearance would have upon the survival of the group as such. This would then constitute an intention to destroy the group "selectively." 126

A rigid application of the International Law Commission's (ILC) exclusion stance would excuse these instances from amounting to genocide because they result in the group's cultural destruction. ${ }^{127}$ The perpetrator intends to leave the group physically and biologically intact; the group is destroyed as the degradation of its cultural cohesion causes it to disperse.

\section{Article 2(b): Causing Serious Bodily or Mental Harm to Members of the Group}

The prohibition against inflicting "mental harm" on group members was added to article 2 to appease members of the Chinese delegation who were concerned about the

\footnotetext{
Tribunal for the Former Yugoslavia, Trial Chamber) online: ICTY <www.icty.org>: "The important element here is the targeting of a selective number of persons who, by reason of their special qualities of leadership within the group as a whole, are of such importance that their victimization ... would impact upon the survival of the group, as such.") See also Prosecutor v Radoslav Brđanin, IT-99-36-T, Judgment (1 September 2004) at para 703 (International Criminal Tribunal for the Former Yugoslavia, Trial Chamber) online: ICTY

$<$ www.icty.org $>$.

${ }^{125}$ Krstić, Trial, supra note 121 at para 595.

${ }^{126}$ Jelisić, Trial, supra note 124 at para 82.

${ }^{127}$ Report of the International Law Commission on the Work of Its Forty-Eighth Session, [1996] 2 YB Intl L Comm'n 17, 45, UN Doc A/CN.4/SER.A/1996/Add.1 (Part 2) [ILC, [1996] Draft Code]. According to the ILC,

the destruction in question is the material destruction of a group either by physical or by biological means, not the destruction of the national, linguistic, religious, cultural or other identity of a particular group. The national or religious element and the racial or ethnic element are not taken into consideration in the definition of the word "destruction," which must be taken only in its material sense, its physical or biological sense.
} 
potential use of narcotic drugs to destroy groups. ${ }^{128} \mathrm{Mr}$. Lin Mousheng first raised the issue in the Ad Hoc Committee where he "requested that the systematic distribution of narcotic drugs for the purpose of bringing about the physical debilitation of a human group be included in the list of measures or acts aimed against a national culture." ${ }^{129}$ In the Sixth Committee, Mr. Fitzmaurice (Britain) argued against adding "mental harm" to article 2 of the draft convention, which at that point included only physio-biological acts, because "if such impairment produced repercussions on physical health the case would be covered by the present text. If there were no repercussions on physical health, it could not be said that a group had been physically destroyed, that was to say that the crime of genocide had been committed in the sense of article II."130

As Fitzmaurice pointed out, "mental harm" is not intended to kill group members or prevent them from reproducing within the group but appears to operate culturally, by attacking the ability of individuals to fulfill social roles. ${ }^{131}$ If this harm is widespread, the group will be destroyed as its members become unable to fulfill the social functions that allow the group to survive.

In accordance with the ILC stance, subparagraph 2(b) could be read as encompassing only those acts intended to kill group members or render them incapable of reproduction, but this would make the term redundant and violate good faith textual effectiveness. If the infliction of serious mental harm causes the death of the targeted individuals, these acts

\footnotetext{
${ }^{128}$ Sixth Committee 3rd Sess, supra note 113, 81st Mtg UN Doc A/C.6/SR.81 (1948) at 177-79

${ }^{129}$ UN Doc. E/AC.25/SR.5 at 9 [emphasis added].

${ }^{130}$ Sixth Committee 3rd Sess, supra note 113, 81st Mtg UN Doc A/C.6/SR.81 (1948) at 178.

${ }^{131}$ See Stephen Grove, “The problem of 'Mental Harm' in the Genocide Convention” Wash. U. L. Q. (1951) 174 at 178 , discussing this argument.
} 
would be covered by subparagraph 2(a), which prohibits killing. If the infliction of serious mental harm causes the physical incapacitation of the targeted, these acts would be covered by subparagraph 2(c), which prohibits conditions of life calculated to cause the group's physical destruction. Finally, if the infliction of serious mental harm prevents group members from reproducing, these acts would be covered by subparagraph 2(d), which prohibits preventing births. As Fitzmaurice argued, if it is not to overlap with the other prohibitions in article 2, subparagraph (b) must be read as encompassing cultural destruction.

\section{Article 2(c): Deliberately Inflicting on the Group Conditions of Life Calculated to Bring About Its Physical Destruction in Whole or in Part}

The only mention of "physical destruction" occurs in subparagraph (c), which prohibits "[d]liberately inflicting on the group conditions of life calculated to bring about its physical destruction ...."132 This provision was included to address the deliberate infliction of starvation and other measures intended to destroy the group by degrading its members' physical condition, even though these acts might not be intended to cause their deaths. Mr. Ordonneau, French delegate to the Ad Hoc Committee, provided as "an historical example, the ghetto, where the Jews were confined in conditions which, either by starvation or by illness accompanied by the absence of medical care, led to their extinction, [which] must certainly be regarded as an instrument of genocide."133

The authors of a $2008 \mathrm{UN}$ report on indigenous education argue that limiting subparagraph (c) to "physical" destruction indicates that the Convention covers more than just physical destruction. According to these authors,

\footnotetext{
132 Genocide Convention, supra note 2, art. 2(c).

${ }^{133}$ Ad Hoc Committee, supra note 93, 4th Mtg, UN Doc E/AC.25/SR.4 at 14.
} 
[b]y qualifying the concept of destruction in paragraph (c) with the word "physical," the Genocide Convention implies that the concept of "destruction" must be wider than mere physical destruction. If "destruction" was intended to be limited to physical destruction, then there would be no need to qualify the word "destruction" in this way in paragraph 2(e). Thus, the terms of article 2 of the Genocide Convention itself require that the concept of "destruction," as used in the chapeau in that article, is wider than mere physical destruction. ${ }^{134}$

The authors are correct in that an interpretation per argumentum e contrario of subparagraph (c) indicates that inflicting conditions of life to bring about non-physical destruction is excluded. ${ }^{135}$ But "physical" might be read as merely foreclosing culpability for "biological" destruction. According to this reading, article 2's other listed acts might address both physical and biological genocide while article 2(c) is restricted to instances when it is intended to cause physical, as opposed to biological, genocide.

However, if the principle of effectiveness is applied, "inflicting on the group conditions of life calculated to bring about its" ${ }^{136}$ biological destruction is already covered in subparagraph (d), which prohibits measures intended to prevent births within the group. Therefore, in order to give meaning to the exclusion implied in subparagraph (c), "physical" should be taken to exclude culpability for "[d]eliberately inflicting on the group conditions of life calculated to bring about its" cultural destruction. Accordingly, the restriction of "physical" found in subparagraph (c) indicates that the Convention's other provisions encompass other forms of destruction, including cultural destruction.

However, this attenuated argument seems more virtuoso than virtuous and is far from convincing. In fact, the vote for article 2(c) occurred before the delegates voted to eliminate

\footnotetext{
${ }^{134}$ Permanent Forum on Indigenous Issues, Forms of Education of Indigenous Children as Crimes Against Humanity? UNESCOR, 7th Sess, UN Doc E/C.19/2008/7 (2008) at 14-15.

${ }^{135}$ See Linderfalk, supra note 15 at 299 , addressing interpretation per argumentum e contrario.

${ }^{136}$ Genocide Convention, supra note 2, art. 2(c).
} 
draft article 3, which addressed acts of cultural genocide. In this light, it was reasonable to restrict the application of article 2(c) as against both biological and cultural destruction, and we should probably not read too much — one way or another-into the qualifying term "physical."

\section{Article 2(d): Imposing Measures Intended to Prevent Births Within the Group}

Subparagraph (d) appears limited to biological genocide but like subparagraph (a) has also been found to operate culturally. The original draft of the Genocide Convention addressed biological genocide in a provision prohibiting "sterilization and/or compulsory abortion; or segregation of the sexes; or obstacles to marriage." ${ }^{137}$ Clearly, the prohibition on “obstacles to marriage” operates culturally. The Ad Hoc Committee, which produced the second draft, drew more distinct lines, omitting obstructions to marriage from their draft, and the Sixth Committee accepted the ad hoc formulation into the final draft with little debate.

However, the Akayesu court, the first court to issue a judgment on the Rwandan genocide, blurred this line when it linked systematic rape to article 2(d), pointing out that widespread rape can inhibit births within a group, causing the group's biological destruction. In doing so, it moved beyond arguments that genocidal rape physically or psychologically disables victims, rendering them incapable of childbearing, and instead highlighted cultural processes, pointing out that widespread rape is particularly effective:

In patriarchal societies, where membership of a group is determined by the identity of the father, an example of a measure intended to prevent births within a group is the case where, during rape, a woman of the said group is deliberately impregnated by a man of another group, with the intent to have her give birth to a child who will consequently not belong to its mother's group. ${ }^{138}$

\footnotetext{
${ }^{137}$ Draft Convention on the Crime of Genocide, UNESCOR, 3rd Sess, UN Doc E/447 (1948) at 6.

${ }^{138}$ Akayesu, supra note 104 at para 507.
} 
And the court argued,

These rapes resulted in physical and psychological destruction of Tutsi women, their families and their communities. Sexual violence was an integral part of the process of destruction, specifically targeting Tutsi women and specifically contributing to their destruction and to the destruction of the Tutsi group as a whole. ${ }^{139}$

As the court recognized, rape is most effective as a genocidal weapon when it is intended to attack the group culturally.

\section{Article 2(e): Forcibly Transferring Children of the Group to Another Group}

Article 2(e), which prohibits forcibly transferring children of a protected group to another group, presents the paradigmatic situation in which a specifically prohibited action is likely to cause cultural destruction. ${ }^{140}$ History provides many examples of children temporarily removed from protected groups for education and re-acculturation. ${ }^{141}$ These programs were intended to destroy the targeted groups by estranging successive generations from cultural practices. Turning a group's young against the group itself in this manner is commonly understood to cause cultural destruction; the group disintegrates because the intergenerational transmission of cultural practices has been severed. Under these all-toocommon circumstances, individual group members may not be maimed or killed, nor are they prevented from reproducing with fellow group members and so there is no physiobiological genocide. Therefore, the ILC stance excuses these child removal programs even when perpetrators intend to destroy, and actually do destroy, a protected group. ${ }^{142}$

\footnotetext{
139 Ibid. at para 731.

${ }^{140}$ Mundorff, supra note 111 at 63-65. See also David Moshman, "Conceptions of Genocide and Perceptions of History” in Dan Stone, ed, The Historiography of Genocide (Palgrave Macmillan, 2008) 71 at 87.

${ }^{141}$ See Mundorff, ibid. at 63-65.

142 Robert van Krieken, Rethinking Cultural Genocide: Aboriginal Child Removal and Settler-Colonial State Formation, 75 Oceania (2004) 125 at 144. Regarding Australia's forcible child transfers, van Krieken says these acts were “actually alien to [the Genocide Convention's] overall intent, particularly its concern to exclude
} 
The ILC stance would allow a finding of genocide when the perpetrator intends to permanently remove children from their group, as the Australian government did to many Aboriginal groups into the $1960 \mathrm{~s} .{ }^{143}$ In such a case, the forcible transfer of children would be considered to cause biological genocide because it disperses members of the group, preventing them from reproducing within the group.

In his separate decision in Bosnia and Herzegovina v. Serbia and Montenegro, Judge Kreca, (ad hoc) recognized the difficulties presented by article 2(e), providing what is still the most comprehensive judicial consideration of this issue. He pointed out that

Prima facie only the act of forcible transfer of children of the group to another group does not fit into the concept of physical/biological genocide as defined in the Convention. However, it should be emphasized that the act of forcible transfer of children has been included in acts constituting genocide with the explanation that it has physical and biological effects since it imposes on young persons conditions of life likely to cause them serious harm, or even death. ${ }^{144}$ In that sense, it is of considerable importance that the proposal to include cultural genocide in the Convention also has been understood to cover a number of acts which spiritually destroy the vital characteristics of a group, as observed in particular in forcible assimilation. The proposal was rejected on a vote of 26 against and 16 in favour with 4 abstentions. ${ }^{145}$ Hence, it appears reasonable to assume that the underlying rationale of sub paragraph (e) is "to condemn measures intended to destroy a new generation, such action being connected with the destruction of a group that is to say with

\footnotetext{
the question of 'cultural' genocide. In this sense, then, it is clear that 'genocide' has only restricted range of application of law."

${ }^{143}$ Meredith Wilkie, Bringing Them Home: Report of the National Inquiry into the Separation of Aboriginal and Torres Strait Islander Children from Their Families, Human Rights and Equal Opportunity Commission (1997) at 275 .

${ }^{144}$ Bosnia v Serbia, supra note 27, Separate Opinion of Judge ad hoc Kreca, 457 at 512-13, citing UN Doc $\mathrm{A} / \mathrm{C} / .6 / 242$. Strangely, this document lends no support to his assertion. It simply states,

GENOCIDE: DRAFT CONVENTION AND REPORT OF THE ECONOMIC AND SOCIAL COUNCIL

Greece: Amendment to the Enumeration in article II of the Draft Convention (E/794)Add a final paragraph worded as follows: "5. Forced transfer of children to another human group."

${ }^{145}$ Sixth Committee 3rd Sess, supra note 113, 83rd Mtg, UN Doc A/C.6/SR.83 (1948) at 206.
} 
physical genocide." ${ }^{146}$ Even if it is accepted that the act covered by subparagraph (e) constitutes "cultural" or "sociological" genocide, its meaning is in concreto of limited importance ... As such it would be an exception to the rule regarding material genocide embodied in Article II of the Convention and, therefore, would be subject to restrictive interpretation. ${ }^{147}$

Despite Kreca's claims, neither article 2 (e)'s ordinary language nor its drafting history limit it to instances when it causes biological destruction. Several drafters, those both for and against article 2(e), argued that the forcible removal of children is primarily a cultural act likely to cause cultural destruction. ${ }^{148}$ (Kreca is also on unstable ground in asserting that a treaty provision with such a manifestly humanitarian purpose ought to be interpreted restrictively.)

Parsing article 2(e) in this manner illuminates exclusion's conceptual instability. In order to transform article 2(e) into a biological act, Judge Kreca must invoke exclusion to limit culpability to instances where forcible child transfers cause biological destruction. Otherwise, article 2(e) has clear cultural implications and it cannot be true that the Genocide Convention excludes all acts of cultural genocide. However, the move to characterize article 2(e) as an act of biological genocide makes it necessary to engage in the messy business of categorizing genocidal destruction. Conversely, if article 2(e) is read according to its ordinary meaning, to encompass an act of cultural destruction, then it cannot be true that the Genocide Convention excludes all cultural matters.

\footnotetext{
${ }^{146}$ Study of the Question of the Prevention and Punishment of the Crime of Genocide, Prepared by Nicodéme Ruhashyankiko, Special Rapporteur Commission on Human Rights, UNESCOR, 31st Sess, UN Doc E/CN.4/Sub.2/416 at 23 .

${ }^{147}$ Bosnia v Serbia, supra note 27, Separate Opinion of Judge ad hoc Kreca 457 at 512-513.

${ }^{148}$ Sixth Committee 3rd Sess, supra note 113, 83rd Mtg UN Doc A/C.6/SR.83 (1948) at 193 (statement of Mr. Perez Perozo. See also ibid., 82nd Mtg, U.N. Doc. A/C.6/SR.82 (1948) (statements of Mr. Bartos, Mr. Morozov; Mr. Raafat, Mr. Zourek, Mr. Kackenbeeck).
} 
Thus, article 2 contains no language limiting it to physical or biological genocide. Of its provisions, only article (c) is restricted to instances "calculated to bring about [the group's] physical destruction." When applied, the other unrestricted provisions seem to blur the artificial lines exclusionists have drawn between physical, biological, and cultural destruction. Moreover, in protecting only those types of groups that self-perpetuate through child rearing, the ordinary meaning of article 2 seems to imply an overriding concern with culture.

\section{VCLT article 31(2): Context (More Text)}

Myres McDougal attacked “the International Law Commission's final recommendations about the interpretation of treaties [for] their insistent emphasis on an impossible, conformity-imposing textuality." ${ }^{149}$ Addressing article 31(2), he stated, "Lest it be thought that the references to 'context' and 'object and purpose' are intended to remedy the blindness and arbitrariness of 'ordinary meaning,' context is immediately defined as including mere text ...." 150 Indeed, although article 31(1) demands that "ordinary meaning" be determined contextually, that context is narrowly defined to include only additional textual sources. These include its preamble and annexes as well as "any agreement relating to the treaty which was made between all the parties in connexion with the conclusion of the

\footnotetext{
${ }^{149}$ Myres McDougal, “The International Law Commission's Draft articles Upon Interpretations: Textuality Redivivus" 61 AJIL (1967) 922 at 992 [footnotes omitted].

${ }^{150} \mathrm{Ibid}$. at 998. See also Myres McDougal, Harold Laswell \& James Miller, The Interpretation of Agreements and World Public Order: Principles of Content and Procedure (New Haven: New Haven Press, 1967) at 50, proposing a broad conception of "context," including "all relevant signs and deeds occurring at any time prior to, at the time of, or subsequent to outcome. Beyond this, it requires consideration also of the entire process of agreement and its context of conditioning factors, as well as of the process of claim and decision and of possible future impacts upon various expectations of the current decision process ..." Contra Alexander Orakhelashvili, Interpretation of Acts and Rules in Public International Law (Oxford: Oxford University Press, 2008) at 313, criticizing the New Haven Approach for "introduc[ing] extra superfluous elements which are not essential or necessary for the governing legal framework..."
} 
treaty" 151 and "any instrument which was made by one or more parties in connexion with the conclusion of the treaty and accepted by the other parties as an instrument related to the treaty." "152 Additionally, interpreters may look to its immediate context, including titles, headings, subheadings, the chapeau, "grammar and syntax," other provisions, and "any structure or scheme underlying a provision or the treaty as a whole." ${ }^{\prime 53}$ In this section I address the Convention's preamble and UNGA Resolution 96(1), considering whether these and other relevant aspects of the Genocide Convention's context support exclusion.

\section{Preamble}

Article 31(2) of the VCLT specifies that a treaty's preamble is part of its interpretive context. ${ }^{154}$ According to Judge Weeramantry, "[ $\left.\mathrm{t}\right]$ he preamble is a principle and natural source from which indications can be gathered on a treaty's objects and purposes even though the preamble does not contain substantive provisions." ${ }^{155}$ Given their generally vague and lofty language, preambles are unlikely to add terms to a treaty but can be used to clarify a substantive term. ${ }^{156}$ The Genocide Convention's preamble reads,

The Contracting Parties,

\footnotetext{
${ }^{151}$ VCLT, supra note 2 at art 31(2)(a).

${ }^{152}$ VCLT, supra note 2 at art 31(2)(b).

${ }^{153}$ Gardiner, supra note 3 at 178, 182 [footnotes omitted]. See also Land, Island, and Maritime Frontier Dispute (El Salvador/Honduras: Nicaragua intervening) [1992] ICJ Rep 351 at 583: "But the word must be read in its context; the object of the verb 'determine' is not the maritime spaces themselves but the legal situation of these spaces."

${ }^{154}$ VCLT, supra note 2 at art 31(2).

155 Case Concerning the Arbitral Award of 31 July 1989 (Guinea-Bissau v Senegal), Dissenting Opinion of Judge Weeramantry [1991] ICJ Rep 130 at 142, canvassing the international case law on the interpretive value of preambles. See also Case Concerning Oil Platforms (Islamic Republic of Iran v United States of America), Preliminary Objection, Judgment [1996] ICJ Rep 803 at 813 (object of the treaty determined by reference to preamble).

${ }^{156}$ Gardiner, supra note 3 at 186-87.
} 
Having considered the declaration made by the General Assembly of the United Nations in its resolution 96(1) dated 11 December 1946 that genocide is a crime under international law, contrary to the spirit and aims of the United Nations and condemned by the civilized world, Recognizing that at all periods of history genocide has inflicted great losses on humanity, and

Being convinced that, in order to liberate mankind from such an odious scourge, international co-operation is required,

Hereby agree as hereinafter provided: . . ${ }^{157}$

Thus, the preamble forms the broad outlines of the crime of genocide and enunciates a norm against it. It asserts that genocide is "contrary to the spirit and aims" of the UN and is "condemned by the civilized world," thereby cementing its status as a crime against customary international law. It decouples genocide from the Nazis' crimes by declaring that genocide has occurred in "all periods of history" and demands international cooperation against genocide. The preamble declares genocide an "odious scourge," but it does not indicate that genocide is "the crime of crimes" or that it should sit at "the apex of international criminality" as the worst or most stigmatized international crime, as some courts and commentators have urged.

Finally, the preamble states that in agreeing to the terms of the Genocide Convention, parties have “considered” UNGA Resolution 96(1), which first declared genocide an international crime. This reference brings UNGA Resolution 96(1) into the context of the Genocide Convention. ${ }^{158}$

\footnotetext{
${ }^{157}$ Genocide Convention, supra note 2 at preamble.

158 Thirlway, supra note 31 at 31: "Where the text to be interpreted specifically refers to another document, from which the expression to be interpreted is taken, it is evident that that other document should form part of the 'context' for interpretation purposes." [Footnotes omitted.] See also ibid. at 67.
} 


\section{UNGA Resolution 96(1)}

On December 11, 1946, the UN General Assembly unanimously adopted UNGA

Resolution 96(1), which reads in relevant part,

Genocide is a denial of the right of existence of entire human groups, as homicide is the denial of the right to live of individual human beings; such denial of the right of existence shocks the conscience of mankind, results in great losses to humanity in the form of cultural and other contributions represented by these human groups, and is contrary to moral law and to the spirit and aims of the United Nations.

Many instances of such crimes of genocide have occurred when racial, religious, political, and other groups have been destroyed, entirely or in part . . . ${ }^{159}$

The ICJ has affirmed the importance of UNGA Resolution 96(1) in determining the

Genocide Convention's object and purpose, first in Reservations ${ }^{160}$ and again, thirty-six years later, in Bosnia v. Serbia. ${ }^{161}$ Therefore, the terms of UNGA Resolution 96(1) should guide interpretation of the Genocide Convention - at least to the extent the latter does not explicitly contradict the former.

On November 7, 1946, five days after UNGA Resolution 96(1) had been proposed and a month before the General Assembly adopted it, Lemkin penned a letter to the New York Times supporting the resolution and assuring potential signatories that it was not overbroad. ${ }^{162}$ He argued "that genocide is directed against a human group as an entity and the

\footnotetext{
${ }^{159}$ Resolution 96(1), supra note 75. See also Legality of the Threat or Use of Nuclear Weapons, Advisory Opinion [1996] ICJ Rep 226 at 254-55: UN General Assembly resolutions are not generally a source of binding law but some "have normative value ... [and] in certain circumstances, provide evidence important for establishing the existence of a rule or the emergence of an opinio juris."

${ }^{160}$ Reservations Case, supra note 26 at 23.

161 Bosnia v Serbia, supra note 27 at 110.

162 Raphael Lemkin, "Genocide Before the U.N.: Importance of Resolution Declaring Crime International is Stressed," Letter to the Editor, The New York Times (8 November 1946). See Draft resolution on the Crime of Genocide (Request from the Delegations for Cuba, Indian and Panama for the Inclusion of an Additional Item in the Agenda) UN GAOR 1st Sess, UN Doc A/BUR/50 (2 Nov 1946).
} 
actions involved affect individuals not in their individual capacity but as members of the group. A human group can be destroyed through different means ranging from mass killings to the disintegration of its spiritual resources." ${ }^{163} \mathrm{He}$ continued, stating that "for purposes of international legislation the definition must be limited to more basic elements, such as killings, mayhem, and biological devices, as, for example, sterilization. One should limit oneself to such acts which are serious enough to be of international concern." ${ }^{164}$ And in the next paragraph he stated that "genocide as an international crime boils down to the physical and biological destruction of the [sic] national, racial, ethnical and religious groups."165

This initial statement on 96(1) is best read as a strategic attempt by Lemkin to assure states that the resolution would not be too far-reaching. He later argued that UNGA Resolution 96(1) "stresses especially the losses in culture which have occurred because of past cases of Genocide. Not only the solidarity of nations in preserving human life, but also the interdependence and mutual borrowing among national cultures is at stake."166

Despite Lemkin's spin, UNGA Resolution 96(1) evidences the centrality of cultural concerns in any interpretation of the Genocide Convention. It begins by drawing an analogy between the murder of an individual and the destruction of a human group. By one interpretation, "[t]his association between genocide and homicide focused on the physical

\footnotetext{
${ }^{163}$ Lemkin, ibid.

${ }^{164}$ Ibid.

${ }^{165}$ Ibid.

${ }^{166}$ Raphael Lemkin, "The Effectiveness of the Genocide Convention” (undated) NYPL, supra note 111 (Reel 3, File 1).
} 
dimension" of genocide. ${ }^{167}$ This materialist interpretation received some support during the drafting of the Genocide Convention, which Mr. Azkoul, delegate of Lebanon, summed up:

The connexion made in [UNGA Resolution 96(1)] between genocide and homicide had been interpreted by certain delegations, among them the Canadian delegation, as excluding cultural genocide. Mr. Azkoul did not consider that that argument could be upheld if consideration were given to the motives which had led the Assembly to condemn genocide and which were outlined in the first paragraph of that resolution. One of the reasons which had led the Assembly to condemn genocide was the cultural loss it inflicted upon humanity. ${ }^{168}$

The Canadian delegation opposed the inclusion of cultural genocide and let it be known that Canada would refuse to sign a convention containing such provisions. ${ }^{169}$ Notably, Canada's instrumental interpretation of UNGA Resolution 96(1) garnered little support among the other delegates.

Mr. Azkoul argued just the opposite, that analogizing an individual to a group seemed intended to highlight the group's existence as an entity. As he pointed out, UNGA Resolution 96(1) supports this culturalist interpretation with follow-on statements highlighting the right of group existence and declaring that the loss of group culture "results in great losses to humanity in the form of cultural and other contributions represented by these human

\footnotetext{
${ }^{167}$ Schabas, Genocide 2d, supra note 35 at 173.

${ }^{168}$ Sixth Committee 3rd Sess, supra note 113, 66th Mtg, UN Doc A/C.6/SR.66 (1948) at 33. See also Mr. Azkoul's remarks in the Ad Hoc Committee, supra note 93, 5th Mtg, UN Doc E/AC.25/SR. 5 at 6:
}

[I]n reply to the remarks of the representative of the United States, read the preamble of the General Assembly resolution calling attention to the losses genocide inflicted upon humanity which, by the destruction of a human group, found itself deprived of the cultural contribution of that group. Contrary to the opinion voiced by the United States delegation, that resolution made it a duty for the Committee to mention cultural genocide and not to restrict the convention to the physical destruction of human groups.

Mr. Maktos (United States) replied that "[h]e felt the General Assembly had had in view only the physical aspect of genocide and that if, as stated by the representative of Lebanon, its Members had meant to include in the resolution other forms of that crime, such as cultural genocide, the resolution would not have received so many votes." (Ibid. at 7.)

${ }^{169}$ Schabas, Genocide 2d, supra note 35 at 212, note 239. 
groups." ${ }^{" 170}$ Implicit in this statement is an understanding that groups generate cultures and therefore attacks that leave groups "destroyed, entirely or in part," deprive humanity of the unique cultural resources generated by such groups. In the final analysis, UNGA Resolution 96(1)'s finely wrought homicide analogy appears deliberately vague, allowing parties to invest it with either a materialist or a culturalist interpretation. ${ }^{171}$ However, terms are not read insolation, and UNGA Resolution 96(1)'s imploration to protect groups in order to prevent cultural losses weights the scale in favour of the culturalist argument. Either way, this is diplomatic draftsmanship at its most pernicious.

There are important differences between UNGA Resolution 96(1) and the Genocide Convention. For instance, the Genocide Convention provides an exhaustive list of protected groups, while UNGA Resolution 96(1)'s list is illustrative. In addition, while UNGA Resolution 96(1) lists political groups, they were left out of the Genocide Convention. On these issues, the Convention's drafters explicitly shifted away from the language of UNGA

\footnotetext{
${ }^{170}$ Res 96(1), supra note 75. See also Schabas, Genocide $2 d$, supra note 35 at 173 . Schabas splits the difference, explaining the cultural emphasis thusly:

The resolution noted that genocide had resulted "in great losses to humanity in the form of cultural and other contributions represented by these human groups." But the reference to culture did not have the same connotation as in Lemkin's writings. It merely lamented cultural loss occasioned by physical genocide, without necessarily suggesting that the destruction of culture, in the absence of violence against the person, might also amount to the crime of genocide. [Footnotes omitted.]
}

Thus, Schabas appears close to adopting the argument I've pursued in this project. According to this argument, groups are protected because of their potential cultural contributions-yet acts against language, edifices, and rituals were indeed excluded. However, any of the prohibited acts are necessarily violent to the person. Therefore, it would be exceedingly strange to allow a perpetrator to use one of the violent acts prohibited by article 2 to destroy the group's existence by attacking its cultural cohesion.

${ }^{171}$ See Draft resolution on the Crime of Genocide (Request from the Delegations for Cuba, Indian and Panama for the Inclusion of an Additional Item in the Agenda) UN GAOR 1st Sess, UN Doc A/BUR/50 (2 Nov 1946). Notably, the analogy with homicide, present in Lemkin's draft as initially proposed by Cuba, India, and Panama, was not remarked on and remained unaltered throughout the process of drafting and passed into UNGA Resolution 96(1) (supra note 75). See also Raphael Lemkin, Totally Unofficial: The Autobiography of Raphael Lemkin, Donna-Lee Frieze, ed, (New Haven: Yale University Press, 2013) at 122 [Lemkin, Totally Unofficial], where Lemkin claims sole authorship of the first draft of UNGA Resolution 96(1) and states that he "stressed that genocide had happened throughout history and inflicted great losses on mankind and culture." 
Resolution 96(1). If the Genocide Convention's drafters had sought distance from UNGA Resolution 96(1)'s group orientation, it is likely that they would have made this explicit as well. Notably, nothing in the Genocide Convention appears to override UNGA Resolution 96(1)'s group orientation.

\section{VCLT Articles 31(2)(a)(b) and 31(3)(a)(b): Subsequent Agreement/Practice}

It is generally said that the terms of a treaty may be altered if the parties' subsequent agreements or practices evidence a shared intent favouring the change. As VCLT article 31(3) states, "[t]here shall be taken into account, together with the context; a.) any subsequent agreement between the parties regarding the interpretation of the treaty or the application of its provisions; b.) any subsequent practice in the application of the treaty which establishes the agreement of the parties regarding its interpretation; ...." Schabas points out that the parties have reached no subsequent agreements regarding the interpretation or application of the Genocide Convention and subsequent practice is notable only in declaring that the obligation of states to prevent genocide does not imply an obligation to intervene militarily. ${ }^{172}$

It would be exceedingly difficult to alter the Genocide Convention through subsequent agreement or practice. ${ }^{173}$ First, modification is said to require the assent of all the

\footnotetext{
${ }^{172}$ Schabas, Genocide 2d, supra note 35 at 636.

${ }^{173}$ But see Akhavan, supra note 97 at 46, arguing that "the ICC Elements of Crimes thus amends and restricts the scope of genocide as envisaged in both international conventional and customary law." Notably, this restriction has proved controversial. See Prosecutor v Jelisić, Case No. IT-95-10-A, Judgment (July 5, 2001) at para 48 (International Criminal Tribunal for the Former Yugoslavia, Appeals Chamber), online: ICTR $<$ www.ictr.org $>$ (rejecting the Rome Statute's contextual element); Prosecutor v Omar Hassan Ahmad Al Bashir, ICC-02/05-01/09 Decision on the Prosecution's Application for a Warrant of Arrest Against Omar Hassan Ahmad Al Bashir(4 March 2009) at para 125 (International Criminal Court), 4 March 2009) online: ICC $<$ icc-cpi.int> acknowledging "that there is certain controversy as to whether this contextual element should be recognized." Genocide Convention, supra note 2, art 15, states that " A request for the revision of the present Convention may be made at any time by any Contracting Party ..." and that " [ $t$ ]he General Assembly shall
} 
parties and this is unlikely for an instrument such as the Genocide Convention, with 146 current parties. Next, the prohibition against genocide is widely regarded as a peremptory norm in international law and any subsequent agreement or customary law that violates it is said to be void. ${ }^{174}$

\section{VCLT Article 31(3)(c): Relevant Rules of International Law}

VCLT article 31(3)(c) prods interpreters to take into account "any relevant rules of international law applicable between the parties." Following the ICJ decision in Oil Platforms, this provision has been regarded as “a 'master key' to the house of international law," allowing courts to reconcile treaties with broader aspects of international law to avoid contradictory results. ${ }^{175}$ The ILC commented that article 31(c) embodies the "“principle of systemic integration,' that is to say, a guideline according to which treaties should be interpreted against the background of all the rules and principles of international law-in other words, international law understood as a system." $" 176$

decide upon the steps, if any, to be taken in respect of such a request." This procedure has never been utilized. Lemkin, Totally Unofficial, supra note 171 at 176, worried it was "a Trojan horse" that threatened to destroy the Convention.

${ }^{174}$ Case Concerning Armed Activities in the Territory of the Congo (New Application 2002) (Democratic Republic of the Congo v Rwanda), Jurisdiction and Admissibility, [2006] ICJ Rep 6 at 31, affirming Reservations Case, supra note 26 at 23. See also Case Concerning Application of the Convention on the Prevention and Punishment of the Crime of Genocide (Bosnia and Herzegovina v Yugoslavia), Preliminary Objections, [1996] ICJ Rep 595 at 616.

${ }^{175}$ Koskenniemi, Fragmentation," supra note 55 at 211, quoting Ms. Xue Haquin during ILC debate. Other commentators have been far more skeptical of VCLT art 31(3)(c)'s unifying power. See Mélanie Samson, "High Hopes, Scant Resources: A Word of Skepticism About the Anti-Fragmentation Function of article 31(3)(c) of the Vienna Convention on the Law of Treaties" 24 Leiden J Int'l Law (2011) 701 at 701: "As the travaux préparatoires ... unambiguously show, this provision has little to do with the concern for the unity of international law. As Thirlway put it, Article 31(3)(c) 'is a survival in the final text of the Convention of what was originally proposed as a provision concerning the intertemporal principle." (Citing Hugh Thirlway, supra note 31 at 70.) See also Jan Klabbers, "Reluctant Grundnorm" in M. Craven, Malgosia Fitzmaurice, \& Maria Vogiatzi, eds, Time History and International Law (Leiden: Martin Nijhoff, 2007) 141 at 157.

${ }^{176}$ International Law Commission, "Report of the Study Group on Fragmentation of International Law: Difficulties Arising From the Diversification and Expansion of International Law" UNGA, UN Doc A/CN.4/L.676 (2005) at 11.See also Phillipe Sands \& Jeffery Commission, "Treaty, Custom and Time: 
In determining the outlines of international law, lawyers generally turn to article 38 of the Statute of the International Court of Justice, which lists the sources of international law from which the ICJ may draw:

a) international conventions, whether general or particular, establishing rules expressly recognized by the contesting states;

b) international custom, as evidence of a general practice accepted as law;

c) the general principles of law recognized by civilized nations;

d) subject to the provisions of article 59, judicial decisions and the teachings of the most highly qualified publicists of the various nations, as subsidiary means for the determination of rules of law. ${ }^{177}$

Facing this open door, many interpreters have attempted to harmonize the Genocide Convention with related areas of international law, especially the rapidly developing fields of human rights and international criminal law. These moves are permissible so long as they do not interfere with the Genocide Convention's object and purpose.

Harmonization may occur overtly, as when Schabas argues that the Genocide Convention should be interpreted in tandem with the doctrine of crimes against humanity in order to reduce gaps in international law. ${ }^{178}$ However, most harmonization happens through the surreptitious influence of Gadamerian fore-conceptions, as when Nersessian atomizes the Genocide Convention's group protections to accord better with the individualism that dominates current ideas of human rights. ${ }^{179}$

The Genocide Convention is interpreted according to a growing body of customary international law consisting of limited state practice, judicial decisions, and a sea of scholarly

\footnotetext{
Interpretation/Application?" in Malgosia Fitzmaurice, Olufemi Elias \& Panos Merkouris eds, Treaty Interpretation and the Vienna Convention on the Law of Treaties: 30 Years On (Leiden: Martinus Nijhoff, 2010) 39 at 49.

177 Statute of the International Court of Justice, 26 June 1945, 59 Stat. 1055, 33 U.N.T.S. 993, article 38(1).

178 William A. Schabas, “Genocide, Crimes Against Humanity, and Darfur: The Commission of Inquiry’s Findings on Genocide” 27 Cardozo L Rev (2005) 1703, 1720 [Schabas, “Darfur”].

${ }^{179}$ Nersessian, Political Groups, supra note 77 at 74.
} 
opinion. On the surface, opinion appears to unite solidly behind exclusion. As I discuss below, the ICJ, the ICC, national courts, and several ad hoc tribunals have generated a substantial body of case law on genocide, which exerts an undeniable influence understandings of genocide. And Schabas points to state practice in his assertion that "it would be implausible to argue that there was some customary norm to fill the void in the Convention on this issue" of cultural genocide. ${ }^{180}$ Similarly, scholarly opinion has been nearly unanimous in accepting the exclusionist interpretation. Therefore, inasmuch as VCLT article 31(3)(c) grants interpreters permission to consult these broader sources, some might argue they should follow this apparent exclusionist consensus.

But this argument strikes me as disingenuous. In fact, this issue has been addressed only glancingly; there has never been a substantial critique of the ILC's exclusion stance. As I discuss below, the case law on exclusion provides the best evidence of its unsettled character. The early case law on genocide had embraced several divergent approaches to cultural genocide. Many point to the ICJ's 2007 judgment in Bosnia v. Serbia, as marking a definitive end to the controversy. However, the ICJ decision was not the ironclad statement that some exclusionists believe, and judges at the national and international levels have criticized exclusion. ${ }^{181}$ Moreover, the ICJ relied on the same flawed readings of the Convention's preparatory work that have plagued previous considerations of this issue. In fact, all exclusionist interpretations over the last twenty years have relied upon either the ILC's or Schabas's reading of the Convention's preparatory work, both of which are deeply

\footnotetext{
${ }^{180}$ Schabas, Genocide 2d, supra note 35 at 220-21.

${ }^{181}$ See below chapter 5, text accompanying notes 193-198.
} 
flawed. ${ }^{182}$ Exclusion cannot seem to exist outside the self-referential circle wherein one authority cites another and they all refer back to the ILC's misinterpretation of the preparatory work. Finally, as I pointed out above, important norms have emerged in international law over the past sixty years that indicate that humanitarian agreements like the Genocide Convention should not be read restrictively, as exclusionists do, to the benefit of state power, but evolutively, to carve out rights against the state.

\section{VCLT Article 31(4): Special Meaning}

VCLT article 31(4) declares that "[a] special meaning shall be given to a term if it is established that the parties so intended." 183 According to the ILC, this provision "provides for the somewhat exceptional case where, notwithstanding the apparent meaning of a term in its context, it is established that the parties intended it to have a special meaning." ${ }^{184}$ This provision is unlikely to offer cover to exclusionists. First, the drafters were self-consciously defining the term "genocide," so it is a logical impossibility that the parties had assumed a special meaning for this term. Next, "the burden of proof lies on the party invoking the special meaning." 185 There is simply no evidence in the treaty's terms or context to support exclusion, and as I will document, the preparatory work also fails to reach this evidentiary threshold.

\footnotetext{
${ }^{182}$ See eg. Krstić, Appeals, supra note 108 at note 39, citing both Schabas, Genocide 2d, supra note 35, and the ILC Report, ILC, [1996] Draft Code, supra note 127.

${ }^{183}$ VCLT, supra note 2 at art 31(4).

${ }^{184}$ ILC Reports 1966, supra note 5 at 222.

${ }^{185}$ Ibid.
} 


\section{Conclusion}

The ICJ has stated that, "When the Court can give effect to a provision of a treaty by giving to the words used in it their natural and ordinary meaning, it may not interpret the words by seeking to give them some other meaning." ${ }^{186}$ The natural and ordinary meaning of the Genocide Convention's article 2 contains no terms excluding cultural genocide.

The ILC exclusion stance rests on two distinct yet interdependent assertions. First, it asserts that the delegates had excluded all acts of cultural genocide. Of course, there is no language restricting culpability for these acts to instances when they operate through physical or biological means. In fact, the ordinary meaning of article 2(e), prohibiting "forcibly transferring children of the group to another group," directly implicates cultural processes. Second, the ILC asserts that the proscribed acts only amount to genocide insofar as they are intended to cause physical or biological destruction. With the exception of article 2(c), the Convention contains no language distinguishing typologies of group destruction, and as the international case law on genocide demonstrates, any of article 2's proscribed acts can cause group destruction through cultural processes.

In fact, article 2's ordinary meaning implies strong support for the idea that the protection of group cultural existence is a central object and purpose of the Genocide Convention. First, the Genocide Convention protects groups "as such," as entities, which can only cohere through culture. Next, it specifically protects only "national, ethnical, racial, or religious groups," each of which assures its continued existence as a group through instilling cultural practices in its children.

${ }^{186}$ Competence, supra note 13 at 8. 
Looking to the Genocide Convention's context, the same pattern is apparent; not only is there a lack of evidence indicating exclusion, but in fact this evidence seems to favour the protection of group culture. Certainly, the preamble and other articles of the Genocide Convention contain nothing to indicate an exclusionary intent. And UNGA Resolution 96(1) declares that the international community is concerned with genocide precisely because it "results in great losses to humanity in the form of cultural and other contributions represented by these human groups...."187

Moreover, a host of more intangible factors support the Convention's inclusion of cultural considerations. Principles of good faith and effectiveness indicate that the Genocide Convention should be interpreted "generously" in accord with its object and purpose of protecting certain types of human groups. By contrast, exclusion relies on a deliberately narrow interpretation that endangers groups by making them vulnerable to destructive acts that operate through cultural mechanisms. Finally, the broader reconceptualization of international law as a force serving not just state interests but also the interests of groups and individuals militates in favour of a broader interpretation that recognizes not the right of states to destroy groups through cultural means, but the right of groups to exist free from culturally mediated attack.

Thus, the text of the Genocide Convention provides no support to exclusionists and actually appears to support inclusion. To bolster their argument, exclusionists must look beyond the Convention's text and context to its preparatory work and other supplementary means of interpretation. But as I will show, these materials are similarly unsupportive of exclusion and instead appear to imply protections for group culture.

\footnotetext{
${ }^{187}$ Resolution 96(1), supra note 75.
} 


\section{Chapter 4-The Trouble with Travaux}

People who are always praising the past And especially the times of faith as best Ought to go and live in the Middle Ages

And be burnt at the stake as witches and sages. (Stevie Smith, 1957 ${ }^{188}$ )

This dissertation has historicized the Convention on the Prevention and Punishment of the Crime of Genocide (Genocide Convention) by locating it within the political and intellectual context of the immediate postwar period and has offered an interpretation of the Genocide Convention's text. ${ }^{189}$ Notably, the discussion thus far indicates that rather than being alien or somehow out of place as exclusionists claim, cultural considerations are central to the Genocide Convention. This chapter continues by addressing the Genocide Convention's preparatory work, commonly understood to encompass those documents compiled in connection with a treaty's drafting and conclusion. I argue that these materials, too, support a more culturalist interpretation of the Genocide Convention.

As I discussed in the preceding chapter, the Genocide Convention's text contains no language excluding cultural genocide. ${ }^{190}$ Lacking textual support, exclusionists commonly invoke its preparatory work, claiming these materials evidence the parties' intent to exclude cultural genocide. However, I will argue that recourse to preparatory work and other supplementary means of interpretation in this instance raises significant legal and theoretical problems. First, I will argue that because the language of the Genocide Convention is clear

\footnotetext{
188 Stevie Smith, “The Past” in Hermione Lee, ed, Stevie Smith: A Selection (London: Faber, 1983 ) at 147.

189 Convention on the Prevention and Punishment of the Crime of Genocide, 9 December 1948, 78 UNT.S. 277 (entered into force 12 January 1951) [Genocide Convention].

190 Ibid.
} 
on the issue of cultural genocide, The Vienna Convention on the Law of Treaties (VCLT), article 32, should bar recourse to these materials. ${ }^{191}$ However, I will also acknowledge that, given current practice, interpretive use of preparatory work is probably inevitable. Therefore, I will discuss certain theoretical and practical problems posed by the use of these materials. The major portion of this chapter addresses the Genocide Convention's preparatory work through its three successive stages of drafting. Finally, I conclude by pointing out that not only does the Genocide Convention's preparatory work fail to offer evidence of exclusionary intent, it actually indicates that culture played a significant role in the parties' conception of genocide.

Lemkin was not shy in his efforts to manipulate the debate, and his behind-the-scenes presence was felt, and resented, through each stage of drafting. ${ }^{192}$ Near the end of the Sixth Committee debates, John Hohenberg, a reporter covering the early UN for the New York Post, recounted how another

correspondent came into the press section at Lake Success on a bitterly cold day and told of having seen Lemkin walking along the Grand Central Parkway toward the building. Thus, the legend spread that he had to walk between sessions at Flushing Meadow and Lake Success (although considerable help came from kindly souls who gave him a lift). As the fall became ever more brisk, Lemkin seemed to grow thinner and paler and shabbier. His cause seemed almost hopeless, for now it was only an extraordinary delegate who would bother to speak to him in the Delegates' Lounge. ${ }^{193}$

Lemkin, who was by this time becoming increasingly threadbare, went on despite the resentments mounting against him, despite his tenuous health, and despite the fact that he

\footnotetext{
${ }^{191}$ Vienna Convention on the Law of Treaties 23 May 1969, 1155 UNT.S. 331 (entered into force 27 January 1980) [VCLT].

${ }^{192}$ See Raphael Lemkin, Totally Unofficial: the Autobiography of Raphael Lemkin, Donna-Lee Frieze, ed, (New Haven: Yale University Press, 2013) at 133-79 [Lemkin, Totally Unofficial]; John Cooper, Raphael Lemkin and the Struggle for the Genocide Convention (New York: Palgrave Macmillan, 2008) at 122-72.

193 John Hohenberg, “The Crusade that Changed the UN,” Saturday Review (9 November 1968) 86.
} 
was always on the verge of financial destitution. Hohenberg reported that "most of the professional diplomats long since had given up on him as an unmitigated nuisance. . .."194 Beginning in 1947, the Genocide Convention was written in a series of three major drafts. The first was compiled by a committee of three experts appointed by the UN Secretary-General: Lemkin, Donnedieu de Vabres, and Vespian Pella, with significant help from John Humphrey and the staff of the UN Division of Human Rights. ${ }^{195}$ In the spring of 1948, an Ad Hoc Committee of the United Nations Economic and Social Council (ECOSOC) — set up for the purpose — completed a second draft. ${ }^{196}$ In September 1948, the General Assembly's Sixth (Legal) Committee began deliberations on the final draft, ${ }^{197}$ which received the General Assembly’s unanimous approval on December 9, $1948 .{ }^{198}$

In order to understand the preparatory work, it is necessary to understand the tensions that existed just beneath the surface of the drafting process. To be sure, many delegations were motivated by a humanitarian impulse to redress recent atrocities. However, what form that redress should take, and how potent it should be, were questions that exposed the

\footnotetext{
${ }^{194}$ Ibid.

${ }^{195}$ See Draft Convention on the Crime of Genocide, UNESCOR, 3rd Sess, UN Doc E/447 (1948) at 15 ["Secretariat's Draft"]; Lemkin, "Summary and History of the Genocide Convention" (undated, but likely MayAug 1948) New York, American Jewish Historical Society, Raphael Lemkin Collection [AJHS] (Box 7, File 3). According to Lemkin, the three experts were assisted by "Professor Humphrey, Director of the Division of Human Rights, Professor Girand, Chief of the Division and Mr. Klivava, representing the Legal Department of the Secretariat. Together, they amended and expanded the original draft into the Secretarial Draft ...."

${ }^{196}$ Note by the Secretary General: Ad Hoc Committee's Terms of Reference, UNESCOR, 3rd Sess, UN Doc E/AC.25/2 (1948) [Secretariat, Terms].

${ }^{197}$ Report of the Sixth Committee: Genocide: Draft Convention and Report of the Economic and Social Council UN GAOR, 3rd Sess, UN Doc. A/760/Corr.2 at paras 7-9, recounting the Sixth Committee drafting process.

198 See Adoption of the Convention on the Prevention and Punishment of the Crime of Genocide, GA Res 260 (III), UN GAOR, 3rd Sess, UN Doc A/Res/3/260 (1948).
} 
competing beliefs and instrumental political concerns of the participating states. These underlying tensions affected every aspect of the convention's drafting.

During the drafting process, when reporters asked Lemkin how it was going, "[h]e would wave his hands. 'Plots, plots against genocide' he would say and grit his teeth and shake his head. But, [he asserted,] I will win in spite of all their plots." ${ }^{199}$ And, when asked who was plotting against him, he answered "The British, the Russians . . Plots . . Plots . . "200 As Lemkin explained in July 1948, "The danger is . . that the whole subject may be referred to a committee of lawyers, or to the Human Rights Commission, or to some voluntary world conference, and any such course would shelve the matter and indefinitely postpone the convention for years."201 Although Lemkin's vivid imagination could sometimes lead him down dark corridors to places of "paranoia," he was correct in recognizing that the Genocide Convention had many enemies, enemies he would need to vanquish in order to "win."

Lemkin waged diplomatic warfare against the British, who consistently but often covertly opposed any convention on genocide. ${ }^{202}$ As he explained, "[B]ecause of its inherent

\footnotetext{
${ }^{199}$ Hohenberg, supra note 193.

${ }^{200}$ Ibid.

${ }^{201}$ Raphael Lemkin, letter to Major John Ennals, World Federation of United Nations Associations (23 July 1948) AJHS, supra note 195 (Box 2, File 9).

${ }^{202}$ See Cooper, supra note 192 at 140, quoting Lemkin: "I was told on good authority that the British delegation will fight Genocide to the bitter end." See also Lemkin, Totally Unofficial, supra note 192 at 143-45 (early British opposition) and ibid. at 162 (British advocated inclusion of political groups as poison pill meant to doom the convention). A. W. Brian Simpson, "Britain and the Genocide Convention" 73:1 Brit YB Intl L (2003) 5 [Simpson, "Britain"]. Britain's initial opposition centered on the inclusion of Lemkin's cultural genocide provisions and the creation of an international criminal court (ibid. at 9): "The British delegation was now authorized to collaborate in trying to produce an improved text of a Convention which the UK government claimed was unnecessary and valueless.... This meant that the delegation was to pursue two essentially inconsistent policies." (Ibid. at 19.) See also British House of Lords Debate, HL Deb 10 February 1948 vol 153 cc909-11 (the Lord Chancellor, Viscount Jowitt, responding to a question from the Lord Archbishop of Canterbury):
} 
high moral values, [the Genocide Convention] cannot be fought against openly and only procedural tactics will be used in the future." ${ }^{203}$ Lemkin fought back, sending out twentyeight telegrams to organizations in Britain that had signed an earlier petition favouring a Genocide Convention. According to Lemkin, "the result was very good" as "[a]11 these organizations urged the British Foreign Office and the British delegation in Paris to change their attitude." 204 Yet, even when the Foreign Office began to change its public stance toward the convention, he complained, "Great-Britain is cooperating formally only, [and] this is even more dangerous." 205

In particular, Lemkin worried the British would insist on protecting political groups. In the course of the drafting process, the British had argued that it was impossible to imagine a convention on genocide that did not protect political groups. ${ }^{206}$ However, the British, like everyone else, realized that including protections for political groups meant the Soviet bloc

[T] he fact that His Majesty's Government were in a minority on this question at the last Assembly meeting has not persuaded them that their view was wrong. On the contrary, they hope that it will become more widely held. An honest difference of opinion as to the best means of moving towards a goal common to all of them divided Governments on that occasion. . . . In His Majesty's Government's view, based on the deficiencies and difficulties of the first Draft Convention prepared, it is unlikely to prove possible to draft a comprehensive Convention on this subject to which the majority of Governments will be prepared to adhere.

${ }^{203}$ Raphael Lemkin, letter to Dr. Henry Noble MacCracken, National Conference of Christians and Jews (30 August 1948) AJHS, supra note 195 (Box 1, File 19).

${ }^{204}$ Raphael Lemkin, letter to Mme. M. Romme, Union Internationale des Ligues Feminies Catholiques (14 December 1948) AJHS, supra note 195 (Box 1, File 19). See also Cooper, supra note 192 at 104, on the British underestimating the breadth and depth of Lemkin's coalition.

${ }^{205}$ Raphael Lemkin, letter to Mr. T. Thackery (23 November 1948) AJHS, supra note 195 (Box 1, File 19).

${ }^{206}$ Raphael Lemkin, "Memorandum on the Genocide Convention" (undated), Cincinnati, The Jacob Rader Marcus Center of the American Jewish Archives, Raphael Lemkin Papers [AJA] (Box 4, File 6), summing up British opposition:

Sir Hartley Shawcross, who was the main spokesman against adopting a Genocide Convention, used the argument of the political groups literally in the following way; -- "A Genocide Convention without political groups is meaningless - but, if it should contain political groups, this would make international life unbearable, because of constant intervention in the internal affairs of other countries." 
and most Latin American countries would oppose the convention. Lemkin accused the

British of using the issue as a poison pill to doom the entire convention. ${ }^{207}$ Lemkin ultimately outmanoeuvred the British, who grudgingly responded to popular opinion by voting for the final draft of the Genocide Convention, which omitted political groups. ${ }^{208}$

Given Stalin's proclivity for destroying human groups and for killing on a truly mass scale, Soviet opposition to the Genocide Convention was widely anticipated. And, early on, they did oppose the convention, arguing that genocide was a matter better addressed by other means and by other committees. However, they quickly realized that open opposition to a convention on genocide would cede the moral high ground to the Western democracies. Beyond this, the Soviets began to see that the Genocide Convention might be used for propaganda purposes against the United States. A State Department telegram dated April 13, 1948, complained about

the situation created by Soviet action in coming forward in support of a Genocide Convention and with a set of principles which it succeeded in having adopted as a basis of a general discussion. Soviet representation has shown usual tendency to make

\footnotetext{
${ }^{207}$ Cooper, supra note 192 at 168.

208 See Simpson, "Britain," supra note 202 at 11, on the growing embarrassment over British recalcitrance. Lemkin was certainly suspicious of the Soviets. He had been captured and interrogated by Soviet forces during his flight from the Nazis and escaped death at their hands only by pretending to be a peasant. (Cooper, ibid. at 28-29.) In the years after 1948, Lemkin's writings would grow even more anti-communist. In part, he was attempting to harness the virulent anti-communism of American Republicans in service to getting the Genocide Convention ratified by the US Senate, but this instinct also would have come to him naturally as someone who had grown up in the Bloodlands between Germany and Russia. See Anton Weiss-Wendt, "Hostage of Politics: Raphael Lemkin on 'Soviet Genocide"” 7 J Genocide Res (2005) at 551; Timothy Snyder, Bloodlands: Europe Between Hitler and Stalin (Basic Books: New York, 2010) at 141. Jews fleeing the Nazi advance landed in Soviet detention camps and were often sent to labour camps in Kazakhstan or Siberia: "Unlike the Germans, who wrongly believed that they had eliminated the Polish educated classes in their part of Poland, the Soviets in considerable measure actually had." (Ibid. at 150.) Lemkin, it seems, was doubly damned as both a Jew and a member of the Polish intelligentsia.
} 
propaganda use of this situation, and seems to have received considerable support on a number of points from other members of Committee. ${ }^{209}$

The telegram went on to declare that the "US will not find itself in a minority with a loss of moral leadership on this question. ..” and authorized the US negotiators to make "adjustments" to the draft articles, ones more likely to garner support in the Ad Hoc Committee, including the creation of an international criminal court, "a step which USSR is apparently unwilling to take." 210

The Soviets saw the Genocide Convention's propaganda potential but desired a weak and unenforceable law. ${ }^{211}$ They attempted to insert language in the preamble linking genocide to "Fascism-Nazism" and tying it to theories of racial hierarchy, which would limit its scope to exclude Communist atrocities and instead implicate the official racial caste system in parts of the United States. ${ }^{212}$ They opposed an international criminal court ${ }^{213}$ and the inclusion of political groups, ${ }^{214}$ but favoured broad prohibitions on acts of cultural

\footnotetext{
${ }^{209}$ Lovett to Maktos: State Department Outgoing Telegram (13 APRIL 1948), National Archives at College Park, College Park, MD. [NACP] (Box 2186, "501.BD Freedom of Information/1-49 to 501. BD Human Rights/12-346," General Records of the Department of State Central Files Record Group 59).

${ }^{210} \mathrm{Ibid}$.

${ }^{211}$ Cooper, supra note 192 at 102.

${ }^{212}$ See Union of Socialist Soviet Republics: Amendments to the Draft Convention (E794), UN GAOR, 3rd Sess, UN Doc. A/C.6/215/Rev.1 (1948) at 1, proposing

after the words: "having been profoundly shocked by many recent instances of genocide," add the words: "which is organically bound up with Fascism-Nazism and other similar race 'theories' which preach racial and national hatred, the domination of so-called higher races and the extermination of the so-called lower-races."

But see Mark Lewis, The Birth of the New Justice: The Internationalization of Crime and Punishment, 1919-1950 (Oxford: Oxford University Press, 2014) at 185-86: "The Soviet Union had complex goals. It sought an international legal document that would validate the belief that genocide was 'scientifically' connected to Nazi racism, with the implication that the Soviets had defeated that doctrine. This was supposed to demonstrate the superiority of Soviet ideology, and the doctrine of the classless society."

${ }^{213}$ USSR Amendments, ibid.

${ }^{214}$ Ibid. at 2.
} 
genocide, which they hoped to use against the United States and the colonial powers. ${ }^{215}$ Considering their losses throughout the drafting process, many doubted the Soviets would vote for the final draft, but not even Stalin was immune to the power of public opinion, and in the end the Soviets, along with the rest of the Soviet Bloc, joined the unanimous vote for the convention.

Britain and the USSR had aligned early in the drafting process in an effort to foist the matter of genocide off on other UN organs, including the not-yet-formed International Law Commission. ${ }^{216}$ Lemkin believed that, as a part of this agenda, the British, the French, and the Soviets were engaged in a loosely concerted effort to conflate his concept of genocide with the concept of crimes against humanity, which had been developed at the Nuremberg Tribunal, where genocide had been considered one sub-type of this broader crime. ${ }^{217} \mathrm{He}$ argued "that this sort of opposition is supported independently by those lawyers who have identified themselves with the Nuremberg trials and would like to treat the Nuremberg law as the only source of new ideas in law." ${ }^{218}$ Rendering genocide synonymous with crimes against humanity, he believed, would allow these forces to push the matter of genocide into the ILC, which was to be tasked with enunciating the Nuremberg principles and developing a draft code of crimes against the peace and security of mankind. ${ }^{219}$ He feared there would be no

${ }^{215}$ Basic Principles of a Convention on Genocide (Submitted by the Delegation of the Union of Soviet Socialist Republics on 5 April 1948), UNESCOR, Ad Hoc Committee on Genocide, UN Doc. E/AC.25/7 (1948) at 2.

216 Simpson, "Britain," supra note 202 at 10-11 (British were early advocates of allocating the matter to the ILC).

${ }^{217}$ Lemkin, "Memorandum on Genocide” (undated) AJHS, supra note 195 (Box 7, File 3) at $5 .$.

218 Ibid.

${ }^{219}$ Formulation of the Principles Recognized in the Charter of the Nürnberg Tribunal and in the Judgment of the Tribunal, GA Res. 177(II), UN GAOR, 2nd Sess, UN Doc A/RES/177(II) (1947). The ILC was directed to

(a) Formulate the principles of international law recognized in the Charter of the Nürnberg Tribunal and in the judgment of the Tribunals, and 
need for a separate convention on genocide, as the matter would have been considered adequately addressed in the draft code.

Lemkin also had to ward off human rights activists who would have been only too happy to defeat the convention-which many saw as an unwelcome competitor to the early human rights movement — or to incorporate and domesticate his evocative concept into their larger project. ${ }^{220}$ The British had been eager to consider genocide a human rights matter and to shunt it off to the ECOSOC's newly formed Human Rights Commission. However, the Human Rights Commission was busily divesting itself of any potential power, abdicating the right to consider petitions that alleged human rights abuses and denying itself the power of effective intervention. ${ }^{221}$ It would restrict itself to drafting the United Nations Declaration of

(b) Prepare a draft code of offences against the peace and security of mankind, indicating clearly the place to be accorded to the principles mentioned in sub-paragraph (a) above.

See also, United States Committee for a United Nations Genocide Convention, "Genocide" pamphlet (June 1948 ) at 2, arguing against considering the convention together with the draft code, because

the Nuremberg law is only a law of war and therefore not applicable in time of peace. It envisaged the relationship between a conqueror and a conquered country and to the relationship among sovereign states. Moreover, it is historical fact that genocide occurs most often in times of peace. A few have argued also that the Genocide Convention should be considered in conjunction with a general codification of international law. Such an argument would shelve the matter for decades. The efforts of almost twenty years of League of Nations codification were without noticeable result.

220 170-72; Cooper, supra note 192 at 165.

${ }^{221}$ Hersch Lauterpacht, International Law and Human Rights (FA Praeger, 1950) at 228-31 [Lauterpacht, IL and HR]; Roger Normand \& Sarah Zaidi, Human Rights at the UN: The Political History of Universal Justice (Bloomington: Indiana University Press, 2008) at 157-162; Carol Anderson, Eyes Off the Prize: The United Nations and the African American Struggle for Human Rights, 1944-1955 (Cambridge: Cambridge University Press, 2003) at 96-98. See also Lemkin "Memorandum on the Convention for the Prevention and Punishment of the Crime of Genocide" AJHS, supra note 195 (Box 6, File 2):

No other international instrument is available now for such protections. The prewar minorities treaties do not exist and besides that they always had a limited application to a small number of states. The International Bill of Rights now being prepared will have rather the significance of a moral political instrument since the enforcement of human rights in a politically divided world presents considerable difficulties. Mrs. Roosevelt, in her last broadcast on the International Bill of Rights stated the other day that the enforcement of such a bill will be impossible so long as the world does not agree on a common concept of democracy. 
Human Rights, which everybody understood would be merely hortatory, and to the more distant and uncertain project of drafting an "International Bill of Rights." If the Human Rights Commission of 1946-1948 is now regarded as the progenitor of a new age of international rights, at that time Lemkin and many of his contemporaries regarded it as a dumping ground where utopian ideas were stripped of any emancipatory potential. ${ }^{222}$

Everyone recognized the British move for what it was: a cynical ploy to send the matter of genocide to a place where it could be quietly sidelined.

There was also a fundamental incommensurability between the group-centric ideas that ground the Genocide Convention and the individualism that animated the early postwar human rights movement. Hersch Lauterpacht, who had coined the term "crimes against humanity," was skeptical of the Genocide Convention, arguing that "if one emphasizes too much that it is a crime to kill a whole people, it may weaken the conviction that it is already a crime to kill one individual." ${ }^{223}$ In the first session of the Human Rights Commission,

\footnotetext{
${ }^{222}$ For laudatory assessments of the early HR Commission see Mary Ann Glendon, A World Made New: Eleanor Roosevelt and the Universal Declaration of Human Rights (New York: Random House, 2001); Johannes Morsink, The Universal Declaration of Human Rights: Origins, Drafting and Intent (Philadelphia: University of Pennsylvania Press, 1999). Contra A.W. Brian Simpson, Human Rights and the End of Empire: Britain and the Genesis of the European Convention (Oxford: Oxford University Press, 2001) at 347-48; Samuel Moyn, The Last Utopia: Human Rights in History (Cambridge, MA: Belknap Press, 2010) at 46-47.

${ }^{223}$ Quoted in Anna Filipa Vrdoljak, "Human Rights and Genocide: The Work of Lauterpacht and Lemkin in Modern International Law" 20 EJIL (2009) 1163 at 1184. See also Lauterpacht, IL and HR, ibid. at 103:

[Iit is] indisputable that man's claim to recognition of inalienable rights is part of his moral constitution as a rational being endowed with conscience. To that extent they are manifestly part of nature. There is nothing fanciful in Kant's affirmative comparison of the absolute reality of man's sense of duty with the awful magnificence of the starry heavens above. Inasmuch as that sense of duty expresses itself in the recognition of the absolute value of man and in the prohibition of treating him otherwise than as an end in himself - and this is one of the central aspects of Kant's ethics - it amounts to an affirmation, in a different sphere, of the natural rights of man.
}

But see Samuel Moyn, "Personalism, Community, and the Origins of Human Rights" in Stefan LudwigHoffmann, ed., Human Rights in the Twentieth Century (Cambridge: Cambridge University Press, 2011) 85 at 105, arguing that "Kantians were few and far between in the 1940s." Instead, Moyn argues that the early postwar human rights movement was influenced by the Catholic doctrine of personalism and that the UDHR is a "profoundly communitarian document." (Ibid.) Moyn is right to point out that from today's hyper- 
Charles Malik, the influential Lebanese delegate and philosopher who had studied with Heidegger,

urged the Commission to adopt the following four principles, which were in danger of being repudiated:

1. The human person is more important than the racial, national, or other group to which he may belong;

2. The human person's most sacred and inviolable possessions are his mind and his conscience, enabling him to perceive the truth, to choose freely, and to exist;

3. Any social pressure on the part of the State, religion or race, involving automatic consent of the human person is reprehensible;

4. The social group to which the individual belongs, may, like the human person himself, be wrong or right: the person alone is the judge. ${ }^{224}$

Malik's four principles were self-evidently at odds with the group-centric approach of the Genocide Convention. The human rights movement of the early postwar period was motivated above all else to free the individual from the state and to "constitute the individual [as] a subject of the law of nations," 225 and Lemkin's groupism would have fared poorly in its hands.

Lemkin was determined to guide the Genocide Convention through these dangerous shoals, but time was running short. By 1948, as the Cold War set in and the immediacy of Nazi crimes retreated, everyone recognized that the window to act against genocide was closing rapidly. Just as the convention's advocates tried desperately to push it forward, its

individualistic perspective, the early postwar human rights movement appears steeped in collectivist concerns. Even the most committed individualists of that time held collectivist presuppositions. However, Lemkin and his contemporaries clearly recognized human rights as an individualistic credo. See Executive Board of the American Anthropological Association "Statement on Human Rights" 49 American Anthropologist (1947) 539 at 540, criticizing the proposed declaration for enshrining individualism at the expense of collective life and for perpetuating Western colonialism; Karen Engle, "From Skepticism to Embrace: Human Rights and the American Anthropological Association From 1947-1999" 23 Hum. Rts Q (2001) 536 at 540-41, explaining the AAA stance. See also Mahatma Gandhi, "A Letter Addressed to the Director-General of UNESCO" in UNESCO, ed, Human Rights: Comments and Interpretations (1949) 89, criticizing the developing human rights doctrine for placing individual rights before "the duty of citizenship to the world."

${ }^{224}$ UN ECOSOC, Commission on Human Rights, 1st Sess, 14th Mtg, UN Doc E/CN.4/SR.14 (1947) at 3-4.

${ }^{225}$ Lauterpacht, IL and HR, supra note 221 at 4. 
enemies stalled, hoping to run out the clock. That the Genocide Convention was approved against these long odds is testament above all to Lemkin's skill and determination; to the support of the United States, which took a leading role in drafting and advocating for the convention; and to massive support by an activist public.

\section{Uses and Misuses of Preparatory Work}

The use of preparatory work taps into an age-old controversy between textualists, who believe the text is the only material properly used in interpretation, and intentionalists, who accord authorial intent a role in interpreting ambiguous text and would consult a range of materials in doing so. Antonin Scalia and Bryan Garner ridicule the use of legislative history to discern drafter intent, but they "do not object to using legislative history for the same purpose as one might use a dictionary or a treatise." ${ }^{226}$ According to these archtextualists, preparatory work can be useful in ascertaining the drafters' background assumptions and the meaning of key terms. They draw a distinction between the instrumental use of legislative history to determine a legislature's intent and background use that merely aids in understanding the disputed text. Pushed too far, this distinction disintegrates. ${ }^{227}$ Using this distinction heuristically, however, one could argue that I use the drafting debates in two distinct (if often overlapping) ways. On the one hand, I use the debates to reveal the importance that delegates attached to keywords like "group" and "culture." On the other, I

\footnotetext{
${ }^{226}$ Antonin Scalia \& Bryan Garner, Reading Law: The Interpretation of Legal Texts (Thompson/West, 2012) at 382. See also, Antonin Scalia, A Matter of Interpretation: Federal Courts and the Law, ed. by Amy Gutman (Princeton University Press, 1997) at 38 [Scalia, A Matter].

${ }^{227}$ Here, I find myself agreeing with Stanley Fish, "Play of Surfaces: Theory and the Law" in Gregory Leyh ed., Legal Hermeneutics: History, Theory, and Practice (Berkeley: University of California Press, 1992) 297 at 301, who argues that "everyone who is an interpreter is in the intention business, and there is no methodological cash value to declaring yourself (or even thinking yourself) to be an intentionalist because you couldn't be anything else."
} 
conduct a more instrumental review to debunk the notion that votes in the Sixth Committee or the General Assembly reveal the delegates' intention to exclude all acts of cultural genocide or all cultural considerations from the Genocide Convention.

In the interest of transparent interpretation, I have quoted many of the delegates' statements at some length, and have abridged others. These statements are from the summary records and often reflect not the delegate's actual language but the rapporteur's account of those words, so that often what is left is a stylized account that plasters over some of the conflict. Nonetheless, recounting these statements makes apparent the bases for my conclusions and at the same time exposes the reader to the language of that time, fostering some overlap of interpretive horizons.

I have highlighted what I feel are the most persuasive statements on all sides of the pertinent questions, banishing to the footnotes lesser statements to the same effect and bypassing those that appear obscure, ambiguous, or otherwise inscrutable. This is the business of lawyers and historians: to compile data in narrative form in pursuit of an argument. ${ }^{228}$ Ronald Dworkin lauded this move to narrativity, insisting that the interpreter must always strive "to make the legislative story as a whole as good as it can be. ..."229 He advocated working under the assumption that lawmakers should not be shown "doing one thing while saying another." Therefore, the interpreter must work toward coherence. But of course, extracting and arranging these statements distorts their meaning by imbuing them with false coherence. UN delegates have often been masters of doing one thing while saying

\footnotetext{
${ }^{228}$ Hayden White, The Content of the Form: Narrative Discourse and Historical Representation (Baltimore: The Johns Hopkins University Press, 1987) at 14. As Hayden White points out, it may be "that every historical narrative has as its latent or manifest purpose the desire to moralize the events of which it treats."

${ }^{229}$ Ronald Dworkin, Law's Empire (Cambridge, MA: Belknap Press, 1986) at 343.
} 
another, and any attempt to obscure this unseemly reality may bestow unwarranted legitimacy. ${ }^{230}$ Delegate statements were often evasive and self-serving, and sometimes contradictory or incomprehensible. To add to the incoherence, the final draft convention was compiled in a stepwise fashion as the committee simply worked its way down the draft provision by provision, mostly ignoring their interconnectedness. For instance, many questioned whether a convention that protected political groups could also contain cultural protections: wouldn't granting untoward political groups protections for speech and publications pose an undue danger to the state? Because the cultural genocide vote was taken before the excision of political groups, it is impossible to know how the absence of political groups might have changed their positions on cultural protections.

I think it is a mistake to view the drafting of the Genocide Convention as the construction of a puzzle wherein each piece has been rationally sculpted to fit into a logical whole. Instead, its drafting was more like building an unwieldy edifice with many moving but interlocking parts, while it travels down a steep slope, steadily gaining momentum. ${ }^{231}$ This event ended in codification, but it could have just as easily collapsed. While I have saved readers from much of this mess, I do attempt to highlight the tensions and contradictions.

\footnotetext{
${ }^{230}$ In fact, Dworkin's coherence principle is nothing more than a latter-day restatement of the Augustinian "rule of faith" whereby scriptural text that apparently comports with Augustine's notion of a beneficent God is taken as it is found, while text that contradicts this principle is read figuratively. See Gerald Bruns, "The Problem of Figuration in Antiquity" in Gary Shapiro \& Alan Sica, eds., Hermeneutics: Questions and Perspectives (Amherst: University of Massachusetts Press, 1984) 167 at 158-59, discussing the Augustinian "rule of faith." A true liberal, Dworkin endows the state with godly virtues of benevolence and consistency.

${ }^{231}$ Paul Ricoeur, "The Hermeneutical Function of Distanciation" in Paul Ricoeur, From Text to Action: Essays in Hermeneutics, II, translated by Kathleen Blarmey (Continuum, 1991) 75 at 81 . Conceiving of the Genocide Convention in this way rebels against what Ricoeur identifies as "the initial paradox of event and meaning: discourse ... is realized as event but understood as meaning."
} 


\section{The Controversy Over Preparatory Work}

The question of how easily recourse to "supplementary means of interpretation" should be granted has fuelled more than a century of controversy. ${ }^{232}$ Read literally, VCLT article 32 establishes a rigid hierarchy in which supplementary means of interpretation are granted only a limited and secondary role. ${ }^{233}$ It reads,

Recourse may be had to supplementary means of interpretation, including the preparatory work of the treaty and the circumstances of its conclusion, in order to confirm the meaning resulting from the application of article 31 , or to determine the meaning when the interpretation according to article 31 :

(a) leaves the meaning ambiguous or obscure; or

(b) leads to a result which is manifestly absurd or unreasonable. ${ }^{234}$

As I discussed in a previous chapter, the VCLT is regarded not as establishing new law but as codifying the existing customary law of treaty interpretation. In its early jurisprudence, which predates the VCLT's conclusion, the ICJ explicitly refused to consult preparatory work where terms were deemed sufficiently clear and reasonable. ${ }^{235}$ Accordingly, in a 1950 advisory opinion, the court said that

the first duty of a tribunal which is called upon to interpret and apply the provisions of a treaty, is to endeavour to give effect to them in their natural and ordinary meaning in the context in which they occur. If the relevant words in their natural and ordinary meaning make sense in their context, that is an end of the matter. If on the

\footnotetext{
${ }^{232}$ Luigi Sbolci, "Supplementary Means of Interpretation" in Enzo Cannizzaro, ed., The Law of Treaties Beyond the Vienna Convention (Oxford: Oxford University Press, 2011) 145 at 152, summarizing prominent objections.

${ }^{233}$ George Schwarzenberger, "Myths and Realities of Treaty Interpretation: Articles 27-29 of the Vienna Draft Convention on the Law of Treaties" 9 Va J Int'l L (1968) 1 at 4, commenting that "[t]he relation between Articles [31 and [32] was ... meant to be strictly hierarchical. While the items mentioned in Article [31] were considered to be 'authentic,' those enumerated in Article [32] were reduced to a category of 'subsidiary' or 'supplementary' — and by implication, non-authentic - means of interpretation." Contra Mark E. Villiger, "The Rules on Interpretation: Misgivings, Misunderstandings, Miscarriage? The 'Crucible' Intended by the International Law Commission" in Cannizzaro, supra note 232, 105 at 118-19, asserting, "As regards Article 32, the ILC envisaged automatic resort to the supplementary means."

${ }^{234}$ VCLT, supra note 191, article 32.

${ }^{235}$ Conditions of Admission of a State to Membership in the United Nations, Advisory Opinion, [1948] ICJ Rep 57 at 63; Competence of the General Assembly for the Admission of a State to the United Nations, Advisory Opinion, [1950] ICJ Rep 4 at 8 [Competence].
} 
other hand, the words in their natural and ordinary meaning are ambiguous or lead to an unreasonable result, then, and then only, must the Court, by other methods of interpretation, seek to ascertain what the parties really did mean when they used these words. ${ }^{236}$

And the ILC has noted that the treaty itself "must be presumed to be the authentic expression of the intentions of the parties, and that the elucidation of the meaning of the text rather than an investigation $a b$ initio of the supposed intentions of the parties constitutes the object of interpretation." 237

However, scholars have long noted that these restrictions are not interpreted "literally" and are unlikely to restrain courts interested in reviewing these materials. ${ }^{238}$ Gardiner, with typical understatement, points out that there is "plenty of evidence that a literal approach to treaty interpretation has not been applied to this element of the Vienna

\footnotetext{
${ }^{236}$ Competence, ibid.

237 "Reports of the International Law Commission on the second part of its seventeenth and on its eighteenth session" (UN Doc A/6309/Rev1) in Yearbook of the International Law Commission 1966 vol. II (New York: UN, 1967) 169 at 223 (UNDOC, A/CN.4/SER.A/1966/Add.1). See also ibid.:
}

"[S]upplementary" emphasizes that article [32] does not provide for alternative, autonomous, means of interpretation but only for means to aid an interpretation governed by the principles contained in article [31]... The Court has recognized this exception to the rule that the ordinary meaning of the terms must prevail. On the other hand, the comparative rarity of the cases in which it has done so suggest that it regards this exception as limited to cases where the absurd or unreasonable character of the "ordinary" meaning is manifest. The Commission considered that the exception must be strictly limited, if it is not to weaken unduly the authority of the ordinary meaning of the terms. Sub-paragraph (b) is accordingly confined to cases where interpretation under article [31] gives a result which is manifestly absurd or unreasonable.

${ }^{238}$ See Jan Klabbers, "Virtuous Interpretation" in Malgosia Fitzmaurice, Olufemi Elias \& Panos Merkouris eds, Treaty Interpretation and the Vienna Convention on the Law of Treaties: 30 Years On (Leiden: Martinus Nijhoff, 2010) 20 at 28: "[T] hrough out the 20th century, the main debate [on treaty interpretation] turned around the evidential question: which documents can be admitted before a court ... to shed light on the intention of the parties, and which should be excluded?" See also Richard K. Gardiner, Treaty Interpretation (Oxford: Oxford University Press, 2008 at 312-39, documenting the myriad reasons courts invoke to justify recourse to preparatory work. 
Rules ...."239 Special Rapporteur Waldock best expressed the prevailing ambivalence to supplementary means when he wrote,

This formulation [of the precursor to article 32] seemed to the Commission to be about as near as it is possible to get to reconciling the principle of the primacy of the text ... with the frequent and quite normal recourse to travaux préparatoires without any too nice regard for the question whether the text itself is clear. Moreover, the rule ... is inherently flexible, since the question whether the text can be said to be "clear" is in some degree subjective. ${ }^{240}$

Given this ambivalence, it should be unsurprising that judicial practice on recourse has been inconsistent and obscure. As Gardiner points out, courts rarely indicate whether they are using preparatory work to confirm language they have found sufficiently clear, or if they are using it to correct language that they have found lacking. And, in the latter case, they rarely indicate which one or more "of the circumstances" (obscurity, absurdity, ambiguity) is present to trigger recourse. ${ }^{241}$ As he puts it, "[O]nly sometimes do courts and tribunals identify which of these gateways they are using. In other instances their use is not explicit or there is no sign of them being used at all."242

\footnotetext{
${ }^{239}$ Gardiner, ibid. at 303. See Hersch Lauterpacht, "Some Observations on Preparatory Work in the Interpretation of Treaties" 48 Harv. L. Rev. (1934-1935) 549 at 549 [Lauterpacht, "Some Observations"]. Lauterpacht goaded his fellow scholars, asserting, "It can safely be said that the admissibility of preparatory work has now become a well-established rule of international jurisprudence. But in the literature of international law the question is frequently discussed as if it were still controversial. ..." See also Ulf Linderfalk, "Is the Hierarchical Structure of Articles 31 and 32 of the Vienna Convention Real or Not? Interpreting the Rules of Interpretation" 54:1 Netherlands Intl L Rev. (2007) 133 at 137-40, summarizing the current state of the ongoing controversy. Of course, this problem is not unique to legal interpretation. See Georgia Warnke, Gadamer, Hermeneutics, Tradition and Reason (Cambridge, UK: Polity Press, 1987) at 85, discussing the same issue as it emerges in literary criticism.

${ }^{240}$ Sir Humphrey Waldock, Special Rapporteur, "Sixth Report on the Law of Treaties" (UN Doc. A/CN.4/186 and Add.1, 2/Rev.1, 3-7) in Yearbook of the International Law Commission 1966 vol. II (New York: UN, 1967) 51 at 99-100 (UNDOC, A/CN.4/SER.A/1966/Add.1).

${ }^{241}$ Gardiner, supra note 238 at 313.

${ }^{242} \mathrm{Ibid}$. at 312 . This matters because differential evidentiary standards apply when a statement is used to correct rather than merely confirm treaty terms. When using preparatory work to confirm treaty terms, interpreters are generally accorded some leeway in locating supportive statements. However, when the preparatory work is used to determine meaning, interpreters are expected to produce direct evidence to support the proposed meaning. (Ibid. at xl-xli, xlvi.) The burden rests squarely on those asserting an alternative meaning. See Panos Merkouris,
} 
The issue of exclusion may represent one of the few instances of treaty language that is clear enough to bar recourse to supplementary means of interpretation. Article 32 of the VCLT allows interpreters free recourse to confirm an interpretation made through the application of article 31 but allows use of the preparatory work to amend conventional text only in those instances when the interpreted text is vague or unreasonable. ${ }^{243}$ Because exclusionists invoke the preparatory work not to confirm but to amend the Genocide Convention's text, they must meet this higher threshold, and it is not at all clear that they have. $^{244}$

Perhaps the best way to test this is by phrasing it as a series of threshold questions. First, can we say the Genocide Convention's silence on cultural genocide is ambiguous or obscure, or that it leads to a manifestly absurd or unreasonable result? Ambiguity refers to language that permits more than one interpretation, while obscurity entails language that is

\footnotetext{
“"Third Party' Considerations” in Fitzmaurice, Elias \& Merkouris eds., supra note 238, 75 at 86-95 [Merkouris, "Third Party"]. Because the object is to discern the parties' concordance, interpreters cannot cherry-pick supporting statements from the preparatory work. Instead, they must conduct a searching inquiry encompassing the entire body of preparatory work and weigh evidence according to its ability to reflect common intent. (Lauterpacht, "Some Observations," supra note 239 at 590.) Delegate statements for which there was no meaningful opportunity to reply and statements that were contradicted by other delegates do not establish concordance and cannot be relied on.

${ }^{243}$ VCLT, supra note 191, article 31. See also, Case of the S.S. "Lotus" (France v Turkey), (1927) PCIJ (Ser A) No 10 at 16: "[T] here is no occasion to have regard to preparatory work if the text of a convention is sufficiently clear in itself," and the preparatory work "would not furnish anything calculated to overrule the construction indicated by the actual terms ..." of the convention (ibid. at 17). See also LaGrand Case (Germany v United States of America), [2001] ICJ Rep 466 at 503-506, using preparatory work to confirm treaty terms; Fisheries Jurisdiction Case (United Kingdom v Iceland) [1973] ICJ Rep 3 at 9-14, on how "peculiar circumstances" require review of preparatory work; Constitution of the Maritime Safety Committee of the Inter-Governmental Maritime Consultative Organization, Advisory Opinion, [1960] ICJ Rep 150 at 159-60, laying out the standard for recourse to preparatory work, and at 161-64, reviewing successive drafts.

${ }^{244}$ Prosecutor v. Krstić, IT-98-33-A, Judgment, Partial Dissenting Opinion of Judge Shahabuddeen, (Apr. 19, 2004) at paras 48-54 (International Criminal tribunal for the former Yugoslavia, Appeals Chamber) online:

ICTY $<$ wwwicty.org $>$.
} 
"[n]ot plain or clear to the mind; vague; uncertain; not easily understood." 245 As I argued in the previous chapter, applying VCLT article 31 to the Genocide Convention produces a clear and unambiguous interpretation as regards the issue of cultural genocide. Article 2 of the Genocide Convention states simply that "genocide means any of the following acts committed with intent to destroy ..." certain "group[s], as such" and lists five prohibited acts. $^{246}$ With the exception of article 2(c), it contains no language limiting the scope of these provisions to encompass only physio-biological acts. Moreover, it is apparent that the convention's underlying object and purpose is the protection of group existence, meaning the group's continuing collective existence through cultural practice. This seems obvious and uncontroversial—far from ambiguous or obscure.

Next, VCLT article 32(b) allows recourse to supplementary interpretive means when the application of VCLT article 31 "leads to a result which is manifestly absurd or unreasonable." 247 Absurd means "[o]ut of harmony with reason or propriety; incongruous; inappropriate; unreasonable; ridiculous, silly." 248 By unreasonable, we mean "[n]ot based on or acting in accordance with reason or good sense" or that which goes "beyond what is reasonable or equitable; excessive."249 "Manifest" requires these defects to be "[c]learly

\footnotetext{
245 The Shorter Oxford English Dictionary, 5th ed, sub verbo “obscure." See also Webster's Deluxe Unabridged Dictionary 2nd ed, sub verbo "obscure":

1. dark; destitute of light; dim; gloomy.

2. living in darkness; as the obscure bird.

3. not easily understood; not obviously intelligible; vague; ambiguous; as an obscure passage in writing ....

6. not clear or distinct; as an obscure idea ... .

${ }^{246}$ Genocide Convention, supra note 189, art 2.

247 VCLT, supra note 191, article 32 (b).

248 The Shorter Oxford English Dictionary, 5th ed, sub verbo "absurd."

249 Ibid., sub verbo "unreasonable."
} 
revealed to the eye, mind, or judgment; open to view or comprehension; [or] obvious."250 Remembering that the Genocide Convention's purpose is to safeguard group existence, we must ask: is it ridiculous or incongruous to protect groups from the acts specifically proscribed in article 2 when those acts are intended to destroy groups through cultural mechanisms? Do we cross the line into manifest unreasonableness by protecting groups from these acts when they are intended to cause cultural destruction? Put differently, we might ask whether it is manifestly excessive to prohibit the targeted killing of a group's intellectual or cultural leaders when those killings are intended to destroy the group's cultural functioning. Is it manifestly incongruous to prohibit removing a group's children for purposes of destroying the group by acculturating its children to the life of another group? Is it manifestly ridiculous to prohibit systematic rape when those rapes are intended to alienate victims from their groups, thereby destroying the group through cultural disintegration? (A consistent application of the ILC's exclusion stance would place each of these acts outside the Genocide Convention's scope.) A virtuous application of the VCLT's interpretive scheme would require confronting these questions, but as I discussed in previous chapters, rarely are VCLT articles 31 and 32 applied fully. Exclusionists' neglect of these rules has allowed these difficult questions to remain unanswered.

\section{Problems of the Preparatory Work}

Proponents of preparatory work often treat it as a miracle salve that, when vigorously applied to treaty text, magically dissolves troublesome opacity. They tend to ignore the fact

${ }^{250}$ Ibid., sub verbo "manifest." 
that interpreting preparatory work is itself damnably difficult. ${ }^{251}$ More often than anyone likes, drafters settle on compromise language to bridge an otherwise irreconcilable gap, and so the ambivalence of treaty text wends its way through the preparatory work as well. Too many times a treaty is simply a "disagreement reduced to writing" 252 and rarely is there reason to believe the preparatory work capable of resolving that disagreement. In effect, when they turn to the preparatory work, interpreters abandon a narrow but ambiguous text in favour of a much larger but still ambiguous text.

How often the preparatory work actually reflects anyone's intent is an issue open to question. Most of the action in treaty drafting occurs unofficially, in the corridors, away from the rapporteurs, and therefore is never included the preparatory work. Statements are frequently strategic or insincere, and as interpreters increasingly turn to preparatory work rather than treaty terms, drafters respond by being even more strategic in their remarks, rendering these materials only more sterile..$^{253}$

\footnotetext{
${ }^{251}$ Lemkin, Totally Unofficial, supra note 192 at 203, captured the difficulty of interpreting preparatory work, complaining, "I never like to read U.N. legal documents. They are always written in a way that hides their real meaning. Their intent emerges only gradually, when one watches the interested delegate discussing them. Then one can see how from behind the corner of every ambiguity crawls a snake, first slowly, then faster and faster ...." Lauterpacht, "Some Observations," supra note 239 at 579:

A not altogether groundless objection to admissibility of preparatory work is that recourse to it may be abused for the purpose of disintegrating the work of interpretation by diverting the attention of the judge from the consideration of the final text of the treaty and by compelling him to study and disentangle a bulky and confusing mass of evidence. There is no doubt that a consideration of preparatory work, although it may relieve on occasion the burden of responsibility, imposes a considerable strain upon judicial activity.

${ }^{252}$ Philip Allott, "The Concept of International Law" 10 EJIL (1999) 31 at 43.

${ }^{253}$ Jan Klabbers, "International Legal Histories: The Declining Importance of Travaux Préparatoires in Treaty Interpretation," 50:1 Netherlands Intl L Rev 267 at 281 [Klabbers, "Legal Histories"], argues that reliance on travaux préparatoires creates a "risk that states will end up negotiating not just the contents of the treaty, but also, additionally, the contents of the travaux préparatoires: it would be as difficult to agree on what the records would contain as it would be to agree on the text of the treaty itself." See also Scalia, A Matter, supra note 226 at 34 .
} 
The very notion of the "parties" to a convention presents certain problems. In a multilateral treaty like the Genocide Convention - which involved dozens of individuals in several drafting committees, a General Assembly vote, and numerous ratifications - whose intentions count? ${ }^{254}$ For the most part, preparatory work reveals not the parties' but only the drafters' intentions. Additionally, a multilateral convention such as the Genocide Convention attracts parties throughout its existence, and many of these parties may not have existed at the time of drafting, so it is impossible that their intent would be made clear in the preparatory work. ${ }^{255}$ Moreover, as Jan Klabbers rightly emphasizes, "many treaties were concluded when the world comprised a small number of states. To insist on a significant role for historical interpretation is to deny a voice to roughly three quarters of today's states, simply for not existing independently at the time of the drafting of a great number of treaties." 256 Finally, excessive reliance on preparatory work can only render international law more disillusioning to those who may lack the resources or expertise to investigate these materials. ${ }^{257}$

For all these reasons, we would expect interpreters to shy away from preparatory work. However, an interpretation is unlikely to be virtuous, persuasive, or authoritative unless it has addressed the preparatory work. ${ }^{258}$ Leaving these materials unexamined will

\footnotetext{
${ }^{254}$ See Jack N. Rakove, Original Meanings: Politics and Ideas in the Making of the Constitution (New York: Knopf, 1996) at 6 (discussing the problem of determining intent in multi-stage collective decision making).

${ }^{255}$ Case Relating to Jurisdiction of the International Commission of the River Oder (United Kingdom, Czechoslovakia, Denmark, France, Germany, Sweden v Poland), Order of 15 August 1929, PCIJ (Ser A) No 23 at 41 , on avoiding preparatory work because some parties to the litigation had not been involved in drafting. See also Sbolci, supra note 232 at 155-56, documenting the ILC response, which is to assert that later assenting parties are entitled to review the preparatory work.

${ }^{256}$ Klabbers, "Legal Histories," supra note 253 at 280.

${ }^{257}$ See Merkouris, "Third Party," supra note 242 at 82.

${ }^{258}$ Lauterpacht, "Some Observations," supra note 239 at 574 . This problem is more pronounced with international courts, which cannot fall back on the institutional authority more readily available to most national courts:
} 
always beg the question of whether they contain some kind of contradictory evidence.

Moreover, as Judge Shahabuddeen intimates, these materials really are interesting and for this reason alone are likely to attract the attention of courts. ${ }^{259}$

\section{Guidelines for Interpreting the Preparatory Work}

There "are no ready-made rules" to guide interpreters when they turn to the preparatory work. ${ }^{260}$ Lauterpacht applauded this state of events, asserting that it provides interpreters the leeway necessary for a thoroughgoing analysis of the preparatory work. But, as illustrated by ICJ practice especially in citing but not discussing these materials, unguided recourse may allow interpreters to justify textually tenuous positions by mindlessly invoking the moral weight of the preparatory work. Oftentimes, interpreters simply cherry-pick supportive statements, conveniently ignoring those that fail to accord with the desired interpretation. As David Bederman puts it, "The use of travaux préparatoires . . can thus be described 'as the equivalent of entering a crowded cocktail party and looking over the heads of the guests for one's friends.",261

Therefore, although there may be no rules for using the preparatory work, adhering to a few commonsense guidelines could improve its use. Lauterpacht, who was otherwise a

In international relations the position of the judiciary is not yet so exalted as to rely entirely on the authority of the bench. It is imperative that the decision of an international court should be based on as many factors independent of the subjective reasoning of the judge as circumstances allow.... The question of preparatory work is yet another illustration of the view that in international relations it is as important that justice should appear to be done as that it should be done in fact.

${ }^{259}$ Krstić, Appeals, supra note 244, Partial Dissenting Opinion of Judge Shahabuddeen, at paras 48-54.

${ }^{260}$ Lauterpacht, "Some Observations," supra note 239 at 583: "There are no ready-made rules—and there ought not to be-for dealing with the various problems raised by an appeal to preparatory work."

261 David J Bederman, "Foreign Office International Legal History" in M. Craven, Malgosia Fitzmaurice, \& Maria Vogiatzi, eds, Time History and International Law (Leiden: Martin Nijhoff, 2007) 43 at 59. The reference originated in Patricia M. Wald, "Some observations on the Use of Legislative History in the 1981 Supreme Court Term” 68 Iowa L Rev (1983) 195 at 214, as cited in Scalia \& Garner, supra note 226 at 377 note 36 . 
proponent of recourse to preparatory work, nonetheless urged caution when using these

materials. According to him,

The object of interpretation is to elicit the common intention of both parties, and not only of one party only. Unless the declaration of intention of a party is instrumental in disclosing the common intention of all signatories, its value is limited. What one party understood by the treaty is of little importance if the other party disagreed with that interpretation, or if circumstances show that it could not be expected, or that there was no opportunity to repudiate it expressly. For in the atmosphere of international conferences an unpalatable proposal or interpretation is not always expressly rejected. Frequently they are merely ignored by others; at times the delegates are not sufficiently acquainted with the intricacies of the situation to grasp and to reply to the implications of a subtle declaration. In such cases it would be unreasonable to attach to the unilateral proposal much evidential value. ${ }^{262}$

Lauterpacht's cautionary statement illustrates a commonsense norm. When using the preparatory work to demonstrate the parties' common intention, statements that cannot demonstrate such intent hold little value. With these caveats in mind, I move now to examine the preparatory work, asking whether it evidences an exclusionist intent by the parties that is sufficiently strong and clear to overturn articles 2's ordinary meaning.

\section{The Secretariat's Draft}

Following passage of UN resolution 96(1), which requested the ECOSOC "to undertake the necessary studies, with a view to drawing up a draft convention," 263 the Secretary-General referred the matter to John P. Humphreys, Director of the United Nations Division of Human Rights, who consulted with a committee of three experts, including

\footnotetext{
${ }^{262}$ Lauterpacht, "Some Observations," supra note 239 at 582 [footnotes omitted].

${ }^{263}$ The Crime of Genocide GA Res. 96(1) UN GAOR. $1^{\text {st }}$ Sess, UN Doc. A/BUR 5.50 (1946). For an overview of the drafting process see Pieter N. Drost, The Crime of State: Genocide: United Nations Legislation on International Criminal Law (A.W. Sythoff, 1959) at 1-7; William A. Schabas, Genocide in International Law: The Crime of Crimes 2nd ed (Cambridge: Cambridge University Press, 2009) at 59-116, 207 - 213 [Schabas, Genocide 2d]; Matthew Lippman, "The Drafting of the 1948 Convention on the Prevention and Punishment of the Crime of Genocide" 3 BU ILJ 1 (1985).
} 
Lemkin. ${ }^{264}$ In his instructions, the Secretary-General indicated that he did not intend to "recommend one political solution rather than another...."265 Instead, these experts were to generate a broad draft convention that "ought, as far as possible, to embrace all the points likely to be adopted, it being left to [the organs of the UN] to eliminate what they wished."266 The experts responded with an inclusive draft that segregated acts of genocide into three broad categories: "physical" (killing or injuring group members), "biological" (restricting births), and "cultural" (destroying group characteristics). ${ }^{267}$ While Lemkin argued that cultural genocide was central to the practice of genocide, the other two experts, Professors De Vabres and Pella, opposed most of the cultural genocide provisions, feeling these provisions would unduly expand the definition of genocide. ${ }^{268}$ De Vabres, a professor at the Sorbonne, had been a judge at Nuremberg. ${ }^{269}$ Pella was head of the International Penal

\footnotetext{
${ }^{264}$ Secretariat's Draft, supra note 195 at 15 . Lemkin, in his "Summary and History of the Genocide Convention" AJHS, supra note 195 (Box 7, File 3) (undated) also lists as authors of the Secretariat's Draft, Humphrey, Professor Girand (Chief of the Division on Human Rights) and Mr. Kliava (of the Legal Secretariat's Legal Department).

${ }^{265}$ Secretariat's Draft, ibid. at 16.

${ }^{266} \mathrm{Ibid}$. See also UN GAOR. Committee on the Progressive Development on International Law and its Codification, 28th Mtg, UN Doc A/AC.10/SR.28 (1947). After completion of the Secretariat's Draft, Donnedieu de Vabres described it as "[a]ctually ... not a draft, but at the utmost, a preliminary draft or, even more exactly, a programme in which the experts had tried to collate all the possible solutions as regards the crime of genocide, including the worst excesses. It was, so to speak, a maximum programme and the authors of the Convention would be able to draw from it as they considered appropriate, in view of the fact that controversial questions had been raised."

${ }^{267}$ Secretariat's Draft, supra note 195 at 5-7.

${ }^{268}$ Ibid. at 26-28. See also, Cooper, supra note 192 at 90, discussing the "clash" between Lemkin and his colleagues over issues of cultural genocide and the inclusion of political groups.

${ }^{269}$ See Philippe Sands, East West Street: On the Origins of "Genocide" and "Crimes Against Humanity" (New York: Vintage Books, 2017) at 212-13, 301. Sands documents that De Vabres was an acquaintance of two prominent Nazis, Julius Streicher and Hans Frank. Frank was one of those charged in the Nuremberg Trial, over which De Vabres presided.
} 
Law Association and had championed Lemkin's ideas and career, though the two men would soon fall out in a public and particularly nasty way. ${ }^{270}$

Fulfilling the Secretary-General's direction to err on the side of inclusiveness, the committee's draft included a broad array of cultural genocide provisions. ${ }^{271}$ They left it to UN delegates to eliminate unwanted provisions. The cultural genocide provision read,

In this Convention, the word "genocide" means a criminal act directed against any one of the aforesaid groups of human beings, with the purpose of destroying it in whole or in part, or of preventing its preservation or development. Such acts consist of: ...

(3) Destroying the specific characteristics of the group by:

(a) forced transfer of children to another human group; or

(b) forced and systematic exile of individuals representing the culture of a group; or

(c) prohibition of the use of the national language even in private intercourse; or

(d) systematic destruction of books printed in the national language or of religious works or prohibition of new publications; or

(e) systematic destruction of historical or religious monuments or their diversion to alien uses, destruction or dispersion of documents and objects of historical, artistic, or religious value and of objects used in religious worship. ${ }^{272}$

This draft was quite broad and exhibited some of the conceptual confusion that continues to haunt the Genocide Convention. For instance, marriage restrictions, a cultural issue, were included in the section addressing biological genocide. ${ }^{273}$ Similarly, deprivation of livelihood was included in the section addressing physical genocide, though this act also appears to

\footnotetext{
${ }^{270}$ Cooper, ibid. at 90; Lewis, supra note 212 at 281-82.

${ }^{271}$ Secretariat's Draft, supra note 195.

${ }^{272} \mathrm{Ibid}$. at art. 1(3. a-e ) at 6-7.

${ }^{273} \mathrm{Ibid}$. at 6 art 1(ii)(2) "Restricting births by":(c) "obstacles to marriage."
} 
operate culturally. ${ }^{274}$ And the forcible transfer of children, which some delegates later tried to characterize as a biological measure, was included in the cultural genocide section. ${ }^{275}$

Commentary to the Secretariat's Draft Convention revealed sharp disagreement

between Lemkin and his fellow drafters on the matter of cultural genocide:

"Cultural" genocide This consists not in the destruction of members of a group nor in restrictions on birth, but in the destruction by brutal means of the specific characteristics of a group; this section gave rise to divergent views among the experts.

Professor Donnedieu de Vabres and Professor Pella held that cultural genocide represented an undue extension of the notion of genocide and amounted to reconstituting the former protection of minorities (which was based on other conceptions) under cover of the term genocide.

Professor Lemkin, on the contrary, argued that a racial, national, or religious group cannot continue to exist unless it preserves its spirit and moral unity. Such a group's right to existence was justified not only from the moral point of view, but also from the point of view of the value of the contribution made by such a group to civilization generally. If the diversity of cultures were destroyed, it would be as disastrous for civilization as the physical destruction of nations. ${ }^{276}$

Thus, De Vabres and Pella believed the "forced and systematic exile of individuals representing the culture of a group," as well as protections for group language, publications, and for culturally valuable objects, monuments, and documents, were either de minimis when placed alongside the other acts to be prohibited as genocide, or were akin to the League of Nations' minorities protections and therefore more properly addressed elsewhere. ${ }^{277}$

\footnotetext{
${ }^{274} \mathrm{Ibid}$. at 6. art I(ii)(1)(d): “. . . deprivation of all means of livelihood, by confiscation of property, looting, curtailment of work, denial of housing and of supplies otherwise available to the other inhabitants of the territory concerned."

${ }^{275} \mathrm{Ibid}$. at 6. Despite their general disagreement on cultural genocide, the three experts agreed to retain the provision prohibiting the forcible transfer of children. (Ibid. at 27.)

${ }^{276} \mathrm{Ibid}$. at 26-27.

${ }^{277}$ Mark Mazower, No Enchanted Palace: The End of Empire and the Ideological Origins of the United Nations (Princeton: Princeton University Press, 2009) at 130, considers the excision of the cultural genocide provisions to signify the United Nations' abandonment of minority rights, but this was unclear in the postwar moment, when many continued to believe minority rights would play an important role in the emerging international order. According to Mazower, "[t]he retreat from minority rights [was part of a broader rejection of international law and interference in sovereignty] - the scrapping of the minorities treaties and the evisceration of the Genocide Convention. Minorities were now seen as sources of destabilization, and liberals and socialists
} 
Lemkin argued, to the contrary, that these issues got to the heart of group protection.

\section{He asserted that}

cultural genocide was much more than just a policy of forced assimilation by moderate coercion - involving for example, prohibition of the opening of schools for teaching the language of the group concerned, of the publication of newspapers printed in that language, of the use of that language in official documents and in court, and so on. It was a policy which by drastic methods, aimed at the rapid and complete disappearance of the cultural, moral and religious life of a group of human beings. ${ }^{278}$

were as passionate in demanding their eradication as fascists." (Ibid. at 143.) See Normand \& Zaidi, supra note 221 at 253, arguing that "the genocide convention [sic] set back the framework of protection of group rights of minorities." See also Inis Claude, National Minorities: An International Problem (Cambridge, Harvard University Press, 1955) at 155. According to Claude, in rejecting the cultural genocide provisions, "the United Nations declined its first invitation to give official support to the concept of positive minority rights." He also argued,

The final rejection [of minorities protections] has not occurred; if it does occur, it may be masked as an acceptance. The favourite tactic in the United Nations has been neither to accept nor to reject proposals for minority rights, but to "postpone" them. The classic example of this tactic occurred in 1948, when the United States led a group of states in deleting the cultural genocide clauses from the draft Genocide Convention, on the ground that the cultural rights of minorities should be safeguarded in the human rights documents, and simultaneously fought to eliminate reference to those rights in the draft Declaration of Human Rights, on the ground that they were out of place there. In general, this attitude has prevailed: wherever the issue is presented, it is out of place; whenever it is presented, it is premature. (Ibid. at 164-65.)

See also Jennifer Jackson Preece, "Minority Rights in Europe: From Westphalia to Helsinki” 23 Rev Intl Stud (1997) 75 at 83-84, emphasizing the role of the League's failure in shaping the postwar international order. In her reading, "the League of Nations System of Minority Guarantees, with few exceptions, ultimately became an instrument for fomenting international rivalry and discontent." "The failure of the League of Nations discredited minority rights and the minorities themselves tended to be viewed with suspicion ..." "Consequently, unlike in previous eras, minority rights were considered contrary to international peace and security." (Footnotes omitted.) But see Claude, ibid. at 153-54: "[I]t was not true that the United Nations had clearly and firmly rejected the view that national minorities needed and were entitled to a special regime of rights and safeguards, in favour of the complete identification of the minority problem with the general problem of human rights." See Nathaniel Berman, "The International Law of Nationalism: Group Identity and Legal History” in Robert J. Beck \& Thomas Ambrosio, eds., International Law and the Rise of Nations (Seven Bridges, 2002) 106 at 129 , describing the postwar period as a "transitional period" that "combined new ideas about human rights and democracy with interwar ideas about cultural difference and internationalist supremacy." See also Jacob Robinson, Oscar Karbach, Max M. Laserson, Nehemiah Robinson \& Marc Vichniak, Were the Minorities Treaties a Failure? (New York: Institute of Jewish Affairs, 1943) at 265, arguing that "the experience of twenty years does not justify the condemnation of a most remarkable experiment; an experiment that could not but share the fate of the political organism in which it lived - the League of Nations itself." And see Pablo De Azcárate, The League of Nations and National Minorities: An experiment (Carnegie Endowment for International Peace, 1945) at 61: the former Director of the Minorities Questions Section of the League of Nations, providing advice on minority issues that "could well be used in any future international organization ..."

278 Secretariat's Draft, supra note 195 at 27. 
Throughout the drafting process, exclusionists would continue to raise what they asserted were cultural genocide's similarities to the minorities protections under the League of Nations system. Lemkin saw the danger of this and attempted to distinguish the two. The League of Nations minorities system remained quite controversial at the time of drafting and the cultural genocide provision was informed by, and overlapped significantly with, the League protections. So it is understandable that some would continue to oppose the cultural genocide provisions on these grounds. After all, whether one felt the League system was too much or too little, no one wanted to relive the dark days of German irredentism. On the other hand, many who opposed the cultural genocide provisions for more self-serving reasons also sought advantage by tarring it with the League brush.

\section{The Ad Hoc Committee Draft}

Nearly a year after the Secretariat's draft had been proffered, the task of drafting a convention on genocide was taken up by the Economic and Social Council, which turned the task over to an ad hoc drafting committee. ${ }^{279}$ In the interim, opponents of the Genocide Convention had employed theoretical arguments and furious diplomatic manoeuvring in an attempt to derail the convention. ${ }^{280}$ Lemkin adeptly outmanoeuvred his opponents, gaining the growing support of the United States UN delegation and rallying a groundswell of international public opinion.

\footnotetext{
${ }^{279}$ Draft Convention on Genocide, GA Res 180(II), UN GAOR, 2nd Sess, UN Doc A/Res/180(II) (1947), had directed the ECOSOC to continue work on a genocide convention and not to wait on member comments on the Secretariat's Draft. See also Secretariat, Terms, supra note 196 (UN Doc. E/AC.25/2).

${ }^{280}$ See especially Rowland Brucken, A Most Uncertain Crusade: The United States, the United Nations, and Human Rights, 1941-1953 (Northern Illinois University Press, 2013) at 176-82.
} 
On April 5, 1948, the Ad Hoc Committee on Genocide convened at the United Nations' temporary home in a re-purposed warehouse at Lake Success on Long Island, New York. The committee was comprised of delegates from China, France, Lebanon, Poland, the Soviet Union, the United States, and Venezuela, ${ }^{281}$ with Lemkin ever-present "behind the scenes." 282

The Ad Hoc Committee completed a draft convention on genocide over the course of twenty-eight meetings. The Secretary-General had requested the committee deal with several questions raised by the committee of experts. ${ }^{283}$ Among these was the question of what "forms of genocide" the convention should prohibit, specifically whether "the idea of cultural genocide should be excluded and consideration given only to physical and biological genocide." 284 The Ad Hoc Committee did little to answer the Secretary-General's questions and largely ignored the Secretariat's draft, preferring instead to rely on drafts submitted by China, France, the Soviet Union, and the United States. ${ }^{285}$ Because it could not achieve agreement on several key issues, including cultural genocide and the inclusion of political

\footnotetext{
${ }^{281}$ Secretariat, Terms, supra note 196, UN Doc E/AC.25/2.

${ }^{282}$ Lemkin, Totally Unofficial, supra note 192 at 152.

${ }^{283}$ Secretariat, Terms, supra note 196, UN Doc E/AC.25/2.

${ }^{284} \mathrm{Ibid}$. at 4 . He defined cultural genocide as "the destruction by brutal means of the specific characteristics of a human group, that is to say, its moral and sociological characteristics." (Ibid. at 4.) According the SecretaryGeneral, "'Physical' genocide involves acts intended to cause the death of members of a human group" and “'[b]iological' genocide consists in placing restrictions upon births."

${ }^{285}$ Ad Hoc Committee on Genocide, Report to the Economic and Social Council on the Meetings of the Committee Held at Lake Success, New York, From 5 April to 10 May 1948, UNESCOR (1948) UN Doc E/794 at 2:
}

Although the Committee had previously decided on the proposal of the representative of Venezuela to take the Secretariat draft as the basis of the actual drafting of the Convention which followed the discussion of general principles, it eventually reversed its decision and it resolved not take as a basis any of the drafts before it, namely the Secretariat draft (UN Doc E/447), the draft of the United States of America (UN Doc E/623), and the French draft (UN Do E/623/Add.1), but to take them into account in its work. 
groups, the Ad Hoc Committee draft was also broad, leaving resolution of these most contentious issues to a subsequent stage of drafting.

The committee appointed a young State Department lawyer, John Maktos, to be chairman. ${ }^{286}$ Honouring a "gentlemen's agreement" between the five powers (China, France, the USSR, the UK, and the US) not to seek leadership of UN organs, Maktos had initially avoided any formal leadership role in the committee. ${ }^{287}$ However, when the Polish delegate nominated Mr. Morozov (USSR), Maktos requested State Department permission to serve as chairman. Maktos was a strong advocate for a convention on genocide and used this position to shepherd the convention through this difficult stage. ${ }^{288}$ However, reflecting the State Department position, ${ }^{289} \mathrm{Mr}$. Maktos was a committed opponent of the cultural genocide provisions, which he succeeded in placing in a separate article, a move calculated to facilitate its excision in the subsequent round of drafting. Because they were opposed to the entire endeavour, the British declined committee membership, hoping their neglect would contribute to the convention's foundering. ${ }^{290}$

As they set about the difficult task of drafting, the delegates quickly confronted deep philosophical disagreements on the nature of human groups. Though UNGA Resolution 96(1) had declared that "[g]enocide is a denial of the right of existence of entire human

\footnotetext{
${ }^{286}$ UN ECOSOC, Ad Hoc Committee on Genocide, 3rd Sess, 14th Mtg, UN Doc E/AC.25/SR.14 (1948) at 4 [Ad Hoc Committee Mtgs.].

287 John Maktos, Oral History Interview, 28 May 1973, by Richard D. McKinzie, Independence, MO, Truman Library at 3 online: Truman Library <http:www.trumanlibrary.org/oralhist/maktosj.htm\#transcript>.

${ }^{288} \mathrm{Ibid}$. at 32. As he put it, "I'm not accusing anybody in particular, but there is no doubt that a chairman may be able to recognize a delegate ahead of another, put a resolution ahead of another, and so forth."

289 "Report of the United States Representative on the Ad Hoc Committee on Genocide of the Economic and Social Council" NACP, supra note 209, Lot File D 429, Box 8 (box 2 of 11) Sandifer Files, "Human Rights General - 1947-1956," General Records of the Department of State Central Files Record Group 59 at 6.

${ }^{290}$ Simpson, "Britain," supra note 202 at 11.
} 
groups, ..." what exactly was a human group? Mr. Azkoul (Lebanon) seemed to voice many

of the delegates' anxieties when he stated that the

[e]xisting definitions stressed only certain characteristic features of the crime of genocide, the existence of which was based on the actual and intentional destruction of a human group as such. If that argument were taken as a basis, it would entail giving any group an absolute entity which it would be criminal to attack.

It was not certain that the conscience of mankind was prepared to consider such a group from that angle and to react spontaneously against any attempt to cut short its existence or development. World conscience seemed to take offence only at physical destruction which eliminated, either suddenly or gradually, a certain number of individuals. Therefore, it was the destruction of individuals which had an effect, rather than the destruction of a group. Nevertheless, certain higher considerations led world conscience also to revolt at the thought of the destruction of a group, even though the individual members survived. One of these considerations was the loss likely to be suffered by humanity if it were deprived of the possible or actual cultural contribution of the group destroyed. In the General Assembly resolution on the subject, that argument was used to condemn genocide.

Such consideration might, however, succumb either to more urgent issues, such as national or international security, which might be endangered by the activities of a group, or to more positive interests, as for example, the interest of the human group in question. The case might also arise of a group which itself habitually committed the crime of genocide, or which endangered the fundamental rights and essential liberties of its own members; such a group should not be permitted to exist, whatever the cultural benefit that might be expected from it.

$\cdots$

The convention should safeguard the right of the group to exist and to develop without let or hindrance, while it should also protect the freedom of its members both as individuals and as part of the group. If the convention failed to guarantee such freedom, it would become an instrument of reaction, an obstacle to the progress of humanity towards the complete freedom of groups and, more especially, of the individual. $^{291}$

He submitted the question: "Should the crime of genocide be defined as the physical

extermination of individuals, or as the extermination of a group as such, without regard to the massacre of individuals?" 292 To which Mr. Pérez Perozo (Venezuela) responded, "The idea of genocide was very clear in his mind: from the etymological standpoint, its roots were

\footnotetext{
${ }^{291}$ Ad Hoc Committee Mtgs, supra note 286, UN Doc. E/AC.25/SR.2 at 3-5.

${ }^{292}$ Ad Hoc Committee Mtgs, supra note 286, UN Doc E/AC.25/SR.4 at 3.
} 
'group' and 'kill'. When these two ideas were combined, the crime of genocide appeared."293 He argued, "It would be a mistake to think that genocide was bound up with the physical disappearance of members of the group. The life of individuals could continue after the group as such had been killed off." 294 Finally, Mr. Ordonneau (France), a fierce opponent of the cultural genocide provision, nonetheless declared that he "thought that a definition of genocide should cover all violent measures used to destroy the cultural elements of a group, whether such group were of a national, racial, or religious character." $295 \mathrm{Mr}$. Ordonneau argued presciently that the draft did not sufficiently distinguish "between the aim- the physical destruction of a group - and the material means, whatever they might be, used to achieve that aim." ${ }^{296} \mathrm{He}$ argued that "[b]ehind the physical act which was its outcome (assassination, violence or some other form of crime) there was a deliberate intention, directed not against the victims but against the group to which they belonged."297

Mr. Maktos (United States) asserted "that it was the repression of barbarous acts against individuals forming a group which above all shocked the conscience of mankind, and it was, therefore, on the condemnation of physical genocide that agreement would be most

\footnotetext{
${ }^{293}$ Ad Hoc Committee Mtgs, supra note 286, UN Doc E/AC.25/SR.4 at 7.

${ }^{294}$ Ibid. Similarly, Mr. Rudzinski asserted that "[n]ot only murder but also the extinction of a group not involving the death of all its members might constitute a case of genocide." Mr. Lin Moushen (China) "agreed with the representative of Lebanon that the cultural destruction of a group was tantamount in effect to destruction of the group." (Ibid. UN Doc. E/AC.25/SR.14 at 5.) He believed "genocide was defined as a criminal act directed against a group with the purpose of destroying it, and not as the destruction of the 'physical existence' of that group. Moreover, as the Lebanese representative had very truly observed, the destruction of a group did not necessarily involve the destruction of the individuals who composed it." (Ibid. at 2-3.)

${ }^{295}$ Ad Hoc Committee Mtgs, supra note 286, UN Doc E/AC.25/SR.5 at 8. He continued, asking "the Representative of the USSR if he really agreed on that point. ..." Mr. Morozov . . "expressed his agreement with the opinion put forward by Mr. Ordonneau."

${ }^{296}$ Ad Hoc Committee Mtgs, supra note 286, UN Doc E/AC.25/SR.10 at 10.

${ }^{297}$ Ad Hoc Committee Mtgs, supra note 286, UN Doc E/AC.25/SR.7 at 8 [emphasis omitted].
} 
easily reached ...." ${ }^{298}$ Acting as Committee Chairman, Maktos proposed a definition of genocide which read, "Genocide is the extermination or attempted extermination of racial, national and religious groups of human beings. ${ }^{.299}$ Mr. Azkoul asked whether “'extermination' was to be taken to mean the physical destruction of individuals composing a group or the elimination of the group as such," to which Maktos replied "that for the time being, he was referring only to physical extermination. To lay down a very precise distinction between extermination of individuals comprised in a group and that of a group as such would raise very delicate questions of law and would involve the committee too deeply." ${ }^{300}$ Thus, Maktos recognized that the issue of group ontology was one on which the delegates would not agree and which, if engaged too deeply, might cause the committee to founder. Under his stewardship, they would draft a convention without explicitly addressing the nature of the thing that the convention was intended to protect: human groups. ${ }^{301}$

\section{Nuremberg Reference in the Preamble}

In January 1948, as the UN geared up to formulate a second draft of the convention, Lemkin warned that "[a] great deal of deliberate confusion has been created by an ill-advised tendency from a small group of influencial $[s i c]$ lawyers to mix the genocide issue with the

\footnotetext{
${ }^{298}$ Ad Hoc Committee Mtgs, supra note 286, UN Doc E/AC.25/SR.5 at 3.

${ }^{299}$ Ad Hoc Committee Mtgs, supra note 286, UN Doc E/AC.25/SR.3 at 11.

${ }^{300}$ Ibid.

${ }^{301}$ But the issue would not go quietly. Later, during the thirteenth debate, Mr. Ordonneau pointed out a difference between the Soviet draft, "which covered the destruction of a group, and the United States delegation's text, which covered the destruction of individuals constituting a group." (Ad Hoc Committee Mtgs, supra note 286, UN Doc E/AC.25/SR.13 at 12-13). To which Mr. Pérez Perozo replied that "he preferred the text proposed by the United States of America, which protected the members of a group, to that of the USSR which in effect protected only the group as such." (Ibid. at 13.) Mr. Rudzinski "remarked that it was possible to destroy a group without destroying its members. For instance, it was sufficient to enforce measures such as the prolonged segregation of sexes." (Ibid. at 12-13.)
} 
larger projects of the codification of international law. They wanted jobs, honors and Mandarin ceremonies to go on for decades in the international law committees." ${ }^{302}$ One prominent instance of this program of mixing genocide with larger codification projects came early, when the Ad Hoc Committee on Genocide included in their draft's preamble language "taking note of the fact that the International Military Tribunal at Nurnberg in its judgment of 30 September-1 October 1946 has punished under a different legal description certain persons who have committed acts similar to those which the present convention aims at punishing ...."303

Like the draft code, Lemkin believed the reference endangered the Genocide Convention's reach and independence. He argued that the General Assembly "felt that international law of the type proposed by the Genocide Convention should be based on free assumption of responsibilities by sovereign states rather than on a measure imposed by occupying armies on a conquered nation." ${ }^{304}$ In addition, "one case of Genocide is not enough to justify the necessity for such a Convention, but that the sufferings of all mankind should be remembered." ${ }^{305}$ Finally, he asserted that in response to the Nuremberg Judgment, "the Assembly felt that national, racial and religious groups should be protected at all times irrespective of conditions of war or peace."”306

\footnotetext{
${ }^{302}$ Letter: Raphael Lemkin to Gertrude Samuels, New York Times (12 January 1948) AJHS, supra note 195 (Box 1, File 19).

${ }^{303}$ Ad Hoc Committee on Genocide, Draft Convention on Prevention and Punishment of the Crime of Genocide, UNESCOR, (1948) UN Doc E/794 at 6 [Ad Hoc Committee Draft].

${ }^{304}$ Raphael Lemkin, “The Genocide Convention” (undated) New York, New York Public Library, Archives and Manuscripts, Raphael Lemkin Papers (Reel 3, File 1) [NYPL] at 2.

${ }^{305}$ Ibid.

${ }^{306} \mathrm{Ibid}$. See also Raphael Lemkin, untitled, but beginning, "Is genocide punishable already now as an international crime?" (undated but post November 1947) AJHS, supra note 195 (Box 6, File 9), where Lemkin argues "another point" that distinguishes genocide from the Nuremberg Principles:
} 
Lemkin's interventions in the Ad Hoc Committee discussion angered the French delegate, Mr. Ordonneau, so "that he immediately rose to depart" from the deliberations and threatened to "retire" from the committee ${ }^{307}$ A confidential State Department memo was dismissive, explaining that Lemkin, "who coined the word 'genocide' considers that the concept is his child." 308

His basic objection to a reference to the Nuremberg Tribunal arises from his desire to be known as the one responsible for the Convention and from his fear that any reference to the Nuremberg Tribunal may imply that the Convention grew out of the Nuremberg Trial. ${ }^{309}$

As a result of Maktos's personal entreaties the controversial language was retained, and Ordonneau remained, but the controversy continued.

The Secretary-General responded to the controversy by addressing a "Note" to the Ad Hoc Committee addressing the "Relation between the Convention on Genocide on the one hand and the Formulation of the Nurnberg Principles and the Preparation of a Draft Code of Offences Against the Peace and Security on the Other." ${ }^{310}$ The note, reflecting Lemkin's

Genocide is a specific crime directed not against any human groups, but against specific human groups, based upon race, religion, nationality or political belief. These groups are not casual gathering of people, but groups which occupy a special place in the world. Just because of their specific nature, these groups throughout history have been subjected to destruction. Therefore, the United Nations took action in order to protect these specific groups.

The Nuremberg law which was concerned with civilian population as such in time of war could not and did not single out these particular groups for protection. It protects masses of individuals.

${ }^{307}$ United States Department of State, "Position on Genocide Convention Prepared by the Ad Hoc Committee on Genocide" (undated) NACP, supra note 209, Lot File D 429, Box 8 (box 2 of 11) Sandifer Files, "Human Rights - General - 1947-1956," General Records of the Department of State Central Files Record Group 59. See also Ad Hoc Committee Mtgs, supra note 286, UN Doc. E/AC.25/SR. 23 at 3-5, documenting the debate on the Nuremberg reference, while avoiding any mention of the conflict between Lemkin and Ordonneau.

${ }^{308}$ State Dept., ibid.

${ }^{309}$ Ibid.

${ }^{310}$ Note by the Secretariat, Ad-Hoc Committee on Genocide, Relation between the Convention on Genocide on the one hand and the Formulation of the Nurnberg Principles and the Preparation of a Draft Code of Offences Against the Peace and Security on the Other UNESCOR (1948) UN Doc E/A.25/3/Rev.1. 
influence, acknowledged the overlap between genocide and certain of the crimes against humanity that had been addressed at Nuremberg, but went on to outline important differences between them. It pointed out that unlike crimes against humanity, which were only punishable in connection with war, genocide was also punishable in times of peace. ${ }^{311}$ It also argued that unlike the doctrine of crimes against humanity, which merely empowered states to punish such crimes, the Genocide Convention would compel them to punish and prevent genocide. ${ }^{312}$ Finally, it pointed out important conceptual distinctions between the two doctrines:

1. The victim of the crime of genocide is a human group. It is not a greater or smaller number of individuals who are affected for a particular reason (execution of hostages) but a group as such;

2. It refers to the actual destruction of a human group and not to a policy of vexations, ill-treatment or oppression of that group;

3. The destruction of the human group is the actual aim in view. In the case of foreign or civil war, one side may inflict extremely heavy losses on the other but its purpose is to impose its will on the other and not to destroy it. ${ }^{313}$

\footnotetext{
${ }^{311} \mathrm{Ibid}$. at 5.
}

312 Ibid. at 7-8.

${ }^{313} \mathrm{Ibid}$. at 6 . This view was shared widely by informed legal scholars at the time. See e.g., Trial of Josef Altstötter and Others, United Nations War Crimes Commission, Law Reports of War Criminals (London: His Majesty's Stationery Office, 1948) vol 6 at 83, note 3, explaining "that the concept of crimes against humanity is greater than that of genocide. The latter crime is aimed against groups, whereas crimes against humanity do not necessarily involve offences of persecutions of groups." See also ibid. vol 15 at 138:

The crime of genocide, which received recognition by the Tribunal which conducted the Justice Trial, bears similarity to certain types of crimes against humanity but also certain dissimilarities . . . while the two concepts may overlap, genocide is different from crimes against humanity in that, to prove it, no connection with war need be shown, and on the other, hand, genocide is aimed against groups, whereas crimes against humanity do not necessarily involve offences against or persecutions of groups. The inference may be justified that deeds are crimes against humanity ... if the political, or racial or religious background of the wronged person is the main reason for the wrong done to him, and if the wrong done to him as an individual is done as part of a policy or trend directed against persons of his political, racial or religious background; but it is not necessary that the wronged person belong to an organized or well-defined group. (Footnotes omitted, emphasis in original.) 
Thus, as the Secretariat noted, the sine qua non of genocide is its focus on group destruction, and this provides the justification for a separate treaty.

The Secretariat note did little to quiet the Nuremberg discussion, which continued throughout the drafting process. In the end, the Ad Hoc Committee did not bend, ${ }^{314}$ but Lemkin had better luck in the Sixth Committee's final draft, where references to Nuremberg and the draft code were finally abandoned. ${ }^{315}$

\section{Ad Hoc Approaches to Cultural Genocide}

The delegates also struggled to draw any firm boundaries between physical and biological genocide on the one hand and cultural genocide on the other. ${ }^{316}$ If the Genocide Convention was to protect certain types of human groups, which were understood to cohere through cultural processes, could it really matter that a group had been destroyed culturally

\footnotetext{
${ }^{314}$ Ad Hoc Committee Mtgs, supra note 286, UN Doc. E/AC.25/SR. 23 at 5. Mr. Azkoul (Lebanon) opposed it "because the acts punished by that tribunal had not been regarded as cases of genocide but as constituting crimes against humanity," and Mr. Pérez Perozo objected because he felt there was no reason to mention the judgment. (Ibid. at 4-5.) See also Lemkin letter to Fahy (9 November 1947) AJHS, supra note 195 (Box 1, File 18). Lemkin wrote to Fahy, the State Department legal advisor, arguing, "If the French suggestion would be followed it would 'internationalize' even individual crimes of the murder type like lynching. This was certainly not the intention of the authors of [UNGA Resolution 96(I)] and of the draft convention prepared by the Secretary General."

${ }^{315}$ UN GAOR, Sixth Committee, 3rd Sess, 127th Mtg, UN Doc A/C.6/SR.127 (1948) at 509 [Sixth Committee Mtgs]; UN GAOR, Sixth Comm., 3rd Sess, "Venezuela: Proposed Text for the Preamble to the Draft Convention," UN Doc E/794 (1948).

${ }^{316}$ See especially discussion in Ad Hoc Committee Mtgs, supra note 286 (UN Doc. E/AC.25/SR.13) at 12-15. Mr. Maktos proposed language that could have adequately addressed many of these difficulties. See Ad Hoc Committee Mtgs, supra note 286 (UN Doc. E/AC.25/SR.12) at 2:

In this convention, genocide means any of the following acts directed against a national, racial, religious or political group as such:

1. With the intent to destroy the physical existence of the group, killing members thereof;

2. With the intent to destroy the physical existence of the group, subjecting members of the group to such conditions or measures as will cause their deaths or prevent the propagation of the group;

3. With the intent (cultural genocide).

Subparagraph 2 of the Maktos proposal appears broad enough to encompass targeted killings, the forcible transfer of children, and systematic rape and seems to indicate that the United States assumed a group could be physically destroyed through acts like these.
} 
rather than physically or biologically? Mr. Pérez Perozo, Venezuela's UN Ambassador and an important Lemkin ally, "criticized the use of the expression 'physical existence' because it seemed to lead to confusion by introducing a metaphysical concept." ${ }^{317}$ Mr. Ordonneau pointed out difficulties with the concept of "destruction," as this term "was difficult to translate into French.... '[D]estruction' in French was not the criminal act but the means to achieve it ... A word would have to be found which meant a series of acts which would bring about destruction as a final result." ${ }^{318}$ And Mr. Pérez Perozo reminded the committee that UNGA Resolution 96(1) "stressed the fact that genocide deprived humanity of the cultural contributions of certain human groups." He reaffirmed his view that

the cultural bond was one of the most important factors among those which united a national group, and that was so true that it was possible to wipe out a human group, as such, by destroying its cultural heritage, while allowing the individual members of the group to survive. The physical destruction of individuals was not the only possible form of genocide; it was not the indispensable condition of that crime. ${ }^{319}$

In addition to these confusions over the basic nature of human groups and the concept of "destruction" (as distinct from the means used to achieve it), delegations also struggled to find an acceptable definition of cultural genocide. ${ }^{320} \mathrm{Mr}$. Pérez Perozo advocated

\footnotetext{
${ }^{317}$ Ad Hoc Committee Mtgs, supra note 286, UN Doc. E/AC.25/SR.13 at 5.

${ }^{318}$ Ad Hoc Committee Mtgs, supra note 286, UN Doc. E/AC.25/SR.11 at 4; ibid. at 2. Mr Ordonneau "said that the word 'destruction' could be misinterpreted. From the technical point of view, genocide qualified the means of achieving destruction and not the destruction of the group itself, just as murder was the act causing death, not death itself. ... There was confusion between the final result and the means employed to obtain the result." See ibid. (UN Doc E/AC/SR.10 at 10.) comments of Mr. Ordonneau, who "considered that a distinction must be made between the aim - the physical destruction of a group - and the material means, whatever they might be, used to achieve that aim." See also, Mr. Lin Mousheng (China) argued that "the destruction of a group did not necessarily involve the destruction of the individuals who composed it." (Ibid. UN Doc E/AC.25/SR.14 at 2-3.) Mr. Rudzinski (Poland) concurred, stating, "It was thus important to recognize that genocide was a crime resulting from persecution directed against a group, and that it could assume a physical character and a cultural character. To draw that distinction was not to place the two forms of the crime on an equality; the fact that the acts of genocide were placed in separate paragraphs should suffice to allay the fear of certain representatives." (Ibid. UN Doc E/AC.25/SR.14 at 4.)

${ }^{319}$ Ad Hoc Committee Mtgs, supra note 286, UN Doc E/AC.25/SR.5 at 2-3.

${ }^{320}$ It is impossible to completely disentangle the issue of cultural genocide from other issues debated by the
} 
continuously for the inclusion of cultural genocide but remained dissatisfied with successive draft proposals, which he criticized as overbroad and vague. He indicated he "would prefer the following wording: 'Preventing or restricting the licit use of its own language in daily intercourse, in education and publications, and destroying cultural and religious means and objects, or hindering the use thereof." ${ }^{321}$ Mr. Morozov (USSR) proposed a general definition of cultural genocide, which would precede the enumeration of individual acts of cultural genocide, reading, "Genocide means any measures and any actions directed against the use of the national language or against the national culture." $322 \mathrm{Mr}$. Azkoul (Lebanon) "thought

committee, for as the delegates realized, these issues interact so that tweaking one would have an effect on the others. For instance, the Ad Hoc Committee had included a motive element, which prohibited only those acts committed "on grounds of the national or racial origin, religious belief, or political opinion of its members" (Ad Hoc Committee Draft, supra note 303, art. 1) and Mr. Azkoul believed that "[w] hile it was relatively easy to determine the motive for the massacre of a human group, it was much harder to prove the intention behind genocide which, for example, consisted of forbidding a group to use its own language." (Ibid. UN Doc E/AC.25/SR.14 at 11.) Some delegates also believed the inclusion of cultural genocide made it difficult to protect political groups. Would not protecting a political group's culture make it unduly difficult to challenge that group's dangerous political beliefs? Along the way, delegates proposed various alternative definitions of cultural genocide. Mr. Azkoul "proposed the following wording: 'Destroying the cultural institutions and achievements and other cultural ties which serve to make the group homogenous." (Ibid. UN Doc E/AC.25/SR.11 at 5.) Morozov proposed defining cultural genocide as "the prohibition of the use of the national tongue; the prohibition of teaching in schools given in the national tongues; destruction of and prohibition of the printing of books and circulation of printed publications in the national tongues; destruction of historical or religious monuments, museums, documents, libraries and other landmarks and objects of national culture or religious worship." (Ibid. UN Doc E/AC.25/SR.12 at 3.) The Committee consistently rejected moves to establish gradations of genocide, with cultural genocide considered a lesser form. At one point Mr. Azkoul sought to distinguish direct from indirect genocide. Direct genocide would be those "acts which are intended to destroy directly, totally or partially, the physical existence of the group," by which he intended acts of mass killing. Other acts would "[d]estroy the group indirectly, totally or partially: (a) By stopping or preventing its reproduction; (b) By subjecting it to conditions likely to destroy its physical existence." (Ibid. UN Doc E/AC.25/SR.13 at 5.) At a later moment, he would propose a new wording of "the cultural genocide provision." (Ibid.)

${ }^{321}$ Ad Hoc Committee Mtgs, supra note 286, UN Doc E/AC.25/SR.14 at 5. He explained "that his reason for using the word 'lawful' had been that a Government might conceivably forbid teaching to be carried on in a language other than that of the country, without having any intention of committing genocide." (Ibid.)

${ }^{322} \mathrm{Ibid}$. at 5 . He pointed out that " $[\mathrm{t}] \mathrm{o}$ establish cultural genocide, evidence would have to be adduced to prove that there had been destruction of the cultural and religious monuments of the country, motivated by a desire to exterminate the national culture." "If that were not the case, it might simply be a matter of a threat to human rights or to minority rights which nobody proposed to include in the scope of international criminal law of genocide." (Ibid. UN Doc E/AC.25/SR.8 at 21). 
that the only acts ... which should be included in the convention were those which could cause the complete and rapid disappearance of the culture, language or religion of a group." ${ }^{323} \mathrm{He}$ offered this definition of cultural genocide: "In this convention, genocide also means acts or measures directed against a national, racial or religious group on grounds of national or racial origin or religious beliefs, which will cause the rapid and complete disappearance of the language, culture or religion of the group." 324

While supporters of inclusion continued to grasp for a workable definition, the United States and, increasingly, France opposed any provision on cultural genocide. Mr. Maktos also argued that "[i]t would be child's play for any clever lawyer to find a large number of new definitions of genocide: it was precisely that profusion which had to be avoided." ${ }^{325} \mathrm{Mr}$. Ordonneau provided a laundry list of reasons why "the French delegation would oppose any definition of cultural genocide in the proposed convention." ${ }^{326} \mathrm{He}$ argued, "The Committee should avoid stating the problem of genocide in such a way as to incriminate States exercising their powers in a normal way" 327 and rather than protecting groups, cultural protection could cause conflict between the group and the state, thereby endangering the

\footnotetext{
${ }^{323}$ Ad Hoc Committee Mtgs, supra note 286, UN Doc E/AC.25/SR.14 at 11.

${ }^{324}$ Ibid. at 12-13.

${ }^{325}$ Ad Hoc Committee Mtgs, supra note 286, UN Doc E/AC.25/SR.5 at 7.

${ }^{326}$ Ad Hoc Committee Mtgs, supra note 286, UN Doc E/AC.25/SR.14 at 3.

${ }^{327}$ Ibid. at 9. See also comments of Mr. Ordonneau (ibid. at 7):
}

stated that his delegation attached great importance to the concept of cultural genocide, and regarded as essential the protection of the cultural life of groups. Nevertheless, it considered that the matter could not be settled as easily as was desired by some members of the Committee. One of the most delicate aspects of the question of genocide was that it raised the general problem of the rights of the State with respect to minority groups and the rights of minority groups with respect to the State. The French delegation had unhesitatingly declared itself in favour of the adoption of a convention on physical genocide dealing with such serious crimes as murder and assassination; its attitude was more reserved where actions which were not necessarily criminal were concerned. 
group. ${ }^{328} \mathrm{He}$ also questioned "the value of the culture to be preserved. Speaking theoretically, genocide would only take place when valuable growing culture was destroyed. ${ }^{329} \mathrm{He}$ clarified that "France did not oppose the suppression of cultural genocide; she was ready to co-operate with the Commission on Human Rights and the Sub-Commission on the Prevention of Discrimination and the Protection of Minorities when they considered the problem." ${ }^{330}$ Mr. Maktos offered the support of the United States for the French position, especially the move to foist the issue off on the Commission on Human Rights. According to Maktos,

[t]hose who advocated the inclusion of cultural genocide in the convention defined it as inter alia the prohibition of the use of language, systematic destruction of books, and destruction or dispersion of documents and objects of historical value.... The United States government believed that the crime should be limited to barbarous acts committed against individuals, which in the eyes of the public, constituted the basic concept of genocide. ${ }^{331}$

${ }^{328}$ Ad Hoc Committee Mtgs, supra note 286, UN Doc E/AC.25/SR.14 at 9.

${ }^{329}$ Ibid. at 5.

${ }^{330}$ Ad Hoc Committee Mtgs, supra note 286, UN Doc E/AC.25/SR.14 at 10. He continued, "It was only after the question of cultural genocide had been thoroughly studied, however, that an international convention on the subject should be drawn up."

${ }^{331}$ Ibid. at 10. See also Foreign Relations of the United States, 1948, General, The United Nations, vol 1, part 1, (Washington: Government Printing Office, 1948), Document 185 ("Minutes of the Ninth Meeting of the United States Delegation, Paris, Hotel d'léna, 30 September 1948”), online: US State Department, Office of the Historian $<$ https://history.state.gov/historicaldocuments/frus1948v01p1/d185> (conveying the State Department's idea of and stance on cultural genocide in the Ad Hoc Committee); Foreign Relations of the United States 1948: General; the United Nations vol 1, part 1, (Washington: Government Printing Office, 1948) Document 183 ("Minutes of the Fourth Meeting of the United States Delegation to the Third Regular Session of the General Assembly, Paris, Hotel d Iéna, 24 September 1948, 9:15 am,") online: US State Department, Office of the Historian $<\mathrm{https} / /$ history.state.gov/historicaldocuments/frus1948v01p1/d183>, providing the American view on the proposed cultural genocide provisions:

Mr. Thorp observed that the real question was whether the convention should be limited to the right of a minority to survive, or whether it should also describe their rights and privileges. He thought these latter principles could be developed elsewhere. Mr. Jessup thought it might be undesirable to oppose Article 3 in terms of the general American position on the protection of minority rights. It should be made clear that our opposition to this article did not indicate any lack of support for the rights of minorities. Mr. Gross thought that, in discussion, it would be important to emphasize the relationship of the convention on genocide to the Declaration on Human Rights. In his opinion, it was better to preserve the integrity of 
Mr. Ordonneau was not alone in his concern that a cultural genocide provision might adversely affect state interactions with minority groups. Proponents and opponents of the cultural genocide provision struggled with the boundary between justified state intervention and the right of a group to maintain a separate cultural identity. For instance, even Mr. Pérez Perozo was concerned by a proposal against "suppressing language." He pointed out that "[f]oreign groups settling in a country might be a danger to the culture of the country itself if their languages were not suppressed in order to defend the national language of the country in which they lived." 332 Mr. Rudzinski (Poland) "said that the purpose of the proposed convention was not to interfere with the natural evolution of humanity, or the inevitable absorption of certain minority groups into the national whole, but rather to prevent the violence, persecutions and excesses which aroused the conscience of mankind." 333 Similarities with the League minorities system continued to haunt the cultural genocide provision. Mr. Rudzinski (Poland) "considered that the acts constituting genocide were acts aimed at the physical extermination of a human group or acts leading to its progressive extermination, called biological genocide, ... He said cultural genocide was

this convention to the issue of life and death. The Secretary pointed out that if the term "cultural" was used, it would lead to endless debates on its definition.

${ }^{332}$ Ad Hoc Committee Mtgs, supra note 286, UN Doc E/AC.25/SR.11 at 5. Mr. Pérez Perozo (Venezuela) asked for this statement to be included in the final report: "The representative of Venezuela expressed the fear that subparagraph 1 of Article 3 does not protect the parties against accusations when they take measures with a view to protecting their own language." (Ibid. UN Doc E/AC.25/SR.26 at 12.) Mr. Azkoul, who had so adeptly framed the issue of group protection, asserted that " $[\mathrm{t}]$ he physical destruction of a human group was certainly not the only form which genocide could take, but immediately the question of cultural genocide was mooted, confusion with certain measures of national or state interest might arise. For example, it had been necessary, in the interests of world peace, to introduce re-education of Japan's youth, in order to destroy the idea of the Emperor's divinity." (Ibid. UN Doc E/AC.25/SR.5 at 3-4.)

${ }^{333}$ Ad Hoc Committee Mtgs, supra note 286, UN Doc E/AC.25/SR.14 at 9. 
closely related to the problem of the protection of minorities." ${ }^{334}$ Maktos concurred, asserting the United States belief that "cultural genocide would be more appropriately dealt with in connection with the question of the protection of minorities." ${ }^{335}$ Ordonneau emphasized that "it was necessary to succeed in drafting a convention concerning physical genocide" and argued that the complexities inherent in defining cultural genocide could endanger this greater aim. ${ }^{336}$

Despite opposition by France and the United States, the committee voted six to one to include article 3, a cultural genocide provision, in its draft convention. ${ }^{337}$ It read,

In this Convention genocide also means any deliberate act committed with the intent to destroy the language, religion or culture of a national, racial, or religious group on grounds of national or racial origin or religious belief such as:

1. Prohibiting the use of the language of the group in daily intercourse or in schools, or the printing and circulation of publications in the language of the group;

2. Destroying or preventing the use of, libraries, museums, schools, historical monuments, places of worship or other cultural institutions and objects of the group. ${ }^{338}$

\footnotetext{
${ }^{334}$ Ad Hoc Committee Mtgs, supra note 286, UN Doc E/AC.25/SR.3 at 3. He continued, "His country would willingly sign and ratify any convention aimed at the protection of minority groups, but this idea should not be enclosed in a proper convention on genocide."

${ }^{335}$ Ad Hoc Committee Mtgs, supra note 286, UN Doc E/AC.25/SR.14 at 10-11.

${ }^{336}$ Ad Hoc Committee Mtgs, supra note 286, UN Doc E/AC.25/SR.5 at 4-5.

${ }^{337}$ Ad Hoc Committee Mtgs, supra note 286, UN Doc E/AC.25/SR.5 at 8: "The Committee decided by six votes to one that the principle of the suppression of cultural genocide should be inscribed in the draft convention." Mr. Maktos, the United States, spoke against inclusion. (Ibid. at 3) Mr. Ordonneau, France, criticized the proposed provision as vague and suggested it would be better addressed in the then forthcoming covenant on human rights. (Ibid. at 4-5) Nevertheless, Mr. Ordonneau "voted in favour ... in the hope that a fully comprehensive definition of genocide would be found later." (Ibid.at 8.)

${ }^{338}$ Ad Hoc Committee Draft, supra note 303 at 6. Article 2 read,

In this Convention genocide means any of the following deliberate acts committed with the intent to destroy a national, racial, religious or political group, on grounds of the national or racial origin, religious belief, or political opinion of its members;

(1) killing members of the group;

(2) impairing the physical integrity of members of the group;

(3) inflicting on members of the group measures or conditions of life aimed at causing their deaths;

(4) imposing measures intended to prevent births within the group. (Ibid. at 13.)
} 
This provision is both broad and shallow. It is broad because the list of prohibited acts is illustrative rather than restrictive; the "such as" language would allow any analogous act conducted with intent to destroy a protected group's language, religion, or culture to be considered genocide. It is shallow in that the acts listed do appear minor when compared with mass murder and the other acts prohibited in article 2 of the Ad Hoc Committee's draft. Mr. Ordonneau argued, "While the factor of intention was present in both cases, the means of action were different. These, in the case of physical genocide, consisted in attacks on life (murder), whereas cultural genocide involved various acts which might be directed against objects and things, such as the 'culture' of a group."339

According to the Secretariat, opponents of the cultural genocide provision emphasized that acts of cultural genocide were not as serious as physical genocide, that it was difficult to fix "the limits of 'cultural' genocide, which impinged upon the violation of human rights and the rights of minorities," and that the inclusion of this provision would “prevent many parties from becoming parties to the Convention and jeopardize its success." 340 On the other hand,

[t]hose who supported the inclusion in the Convention of "cultural" genocide emphasized that there were two ways of suppressing a human group, the first by causing its members to disappear, and the second by abolishing, without making any attempts on the lives of the members of the group, their specific traits. According to this opinion, the Convention would fail fully to achieve its object if it left out "cultural" genocide. ${ }^{341}$

\footnotetext{
${ }^{339}$ Ad Hoc Committee Mtgs, supra note 286, UN Doc E/AC.25/SR.10 at 8. Notably, although article 2, which addressed physio-biological genocide, protected political groups, article 3 of the Ad Hoc Draft did not. The Secretariat explained that "the idea of "cultural' genocide could not be applied in practice to political groups." (Ad Hoc Committee Draft, supra note 303 at 7).

${ }^{340}$ Ad Hoc Committee Draft, supra note 303 at 17.

${ }^{341}$ Ibid.
} 
Despite majority support for the provision, the committee voted to separate cultural genocide from physio-biological genocide by placing it in a separate article, making it easier to cut at some later point. ${ }^{342}$ Importantly, the delegates "agreed that titles, such as 'cultural genocide' would be omitted from the Convention, although such terms might be used in quotations in the report." 343 By this move the delegates began to show skepticism toward Lemkin's increasingly unworkable typologies of genocidal destruction. Notably, this skepticism carried through to the final draft, which also avoided any attempt to categorize genocidal destruction.

\section{The Ad Hoc Committee Retains Political Groups}

Whether the convention should protect political groups turned out to be as contentious as the inclusion of cultural genocide, and in fact both issues raise some of the same concerns about the role culture plays in the perpetuation of group life. Throughout history, political groups have been the target of massive violence, but many delegates believed they did not possess the durable culture of the other protected groups, and it was the protection of culture that in their minds provided the conceptual framework and justification for the Genocide Convention.

\footnotetext{
${ }^{342}$ Ad Hoc Committee Mtgs, supra note 286, UN Doc E/AC.25/SR.10 at 5, 12. Maktos argued that "this would make it easier for the various countries to notify the Convention. If the crime of cultural genocide was dealt with in a separate article, this would enable Governments to make reservations on a particular point of the Convention." Mr. Lin Mousheng replied "that legislative bodies could as easily make reservations on part of an article as on a whole one." (Ibid. at 6.) And Morozov argued against separation, asserting that

it would not be possible to isolate one of the elements constituting the crime in order to specify it in a separate article. In that way, the notion of cultural genocide, instead of being put rather in the background, would only be given greater importance. It was essential to bear in mind that any prohibition of the use of a language, any destruction of cultural monuments, etc., did not necessarily constitute an act of genocide. They could only be so described if the acts were the result of a persecution carried out on racial, national, or religious grounds.

${ }^{343}$ Ad Hoc Committee Mtgs, supra note 286, UN Doc E/AC.25/SR.24 at 7.
} 
The inclusion of political groups drew sharp opposition, especially from the Soviet Bloc. Payam Akhavan argues that the decision to exclude them "was therefore primarily a practical one and not necessarily based on theoretical or moral imperatives." 344 However, this explanation misses the nuance of the debate and does a disservice to those who raised substantive questions about their inclusion.

Lemkin had opposed protecting political groups in the Genocide Convention, arguing that their inclusion would attract fierce opposition while "the omission of political groups is possible without destroying the basic value of the Convention." 345 Early on, as he assisted the UN Secretariat in compiling the convention's first draft, he made his opposition clear. The comments to that draft indicate that

Professor Lemkin, voiced some doubts . . . on the advisability of including political groups. He pointed out, on the one hand, that political groups have not the permanency and the specific characteristics of the other groups referred to and, on the other hand, that the Convention on Genocide being of general interest, it should not run the risk of failure by introducing ideas on which the world is deeply divided. ${ }^{346}$

As this statement indicates, Lemkin believed that political groups lacked the permanency and culture-generating characteristics that would warrant protection. ${ }^{347}$ But because the

\footnotetext{
${ }^{344}$ Payam Akhavan, Reducing Genocide to Law: Definition, Meaning, and the Ultimate Crime (Cambridge: Cambridge University Press, 2012) at146. He continues, "It also does not take much imagination to see why the Soviets were so insistent on excluding political and social groups from the definition of genocide."

${ }^{345}$ Lemkin, "Memorandum on the Convention for the Prevention and Punishment of the Crime of Genocide" AJHS, supra note 195 (Box 6, File 2).

${ }^{346}$ Secretariat's Draft, supra note 195 at 22.

${ }^{347}$ Raphael Lemkin, "Definition: Nature of Genocide" (undated) AJHS, supra note 195 (Box 7, File 2) at 20. Lemkin argued that the fluid membership of political groups would make it difficult to determine which individuals deserved protection. He argued that "the destruction of a political party is not the same as the destruction of a political group conceived as a conglomeration of human beings affiliated with the party." And he continued, "Genocide of a political group will normally start with outlawing the party. The members will go underground, will forge their papers, will comaflouge [sic] themselves by joining other parties," which might make it "more difficult to define the political group." Notably, it is difficult to square this argument with his earlier subjectivist stance on group membership criteria. Elsewhere (Lemkin, "Philosophical and Legal Aspects of the Word Genocide," AJA, supra note 206, Box 3, File 3), he argued that although the General Assembly did
} 
Americans and other important allies supported including political groups, and because their support for his project was crucial, Lemkin couched his opposition in practical terms, arguing that opposition to including political groups was so strong as to doom the entire convention. ${ }^{348} \mathrm{He}$ would also demur at times that in a more stable and civilized world, it would be nice to protect political and other social groups, such as, for instance, "those who play cards." ${ }^{349}$ But protections for card players, political groups, and other non-culture-

not include political groups, "it was felt that the political parties which identify themselves with the aims and ideals of their nations as such can be protected under the all-embracing concept of national groups."

${ }^{348}$ See Lemkin, "Memorandum on the Convention for the Prevention and Punishment of the Crime of Genocide" (undated, but likely 1947) AJHS, supra note 195 (Box 6, File 2): "People might feel that the protection of political groups might interfere with unanimous acceptance of the Convention. In this particular case, the omission of the political groups is possible without destroying the basic values of the Convention."

Contra, Raphael Lemkin, Lemkin on Genocide, Steven Leonard Jacobs, ed, (Lanham: Lexington Books, 2012) at 34. Later, as he sought ratification in the US Senate, Lemkin would appeal to conservative anti-communist sentiment by arguing for the protection of political groups:

As the concept of a social groups is being used repeatedly in this volume, it will be useful to analyze it sociologically at this point. The social group as such is a meaningless concept. Any two or more persons who stand in any social relationship to one another form a social group. We are here concerned with particular types of social groups, namely racial, religious, national, linguistic, and political groups. We have also pointed out that such groups are exposed to genocide only when they constitute a minority or subjected majority within the community or sphere of control in which they are destroyed. If this is not the case, we are dealing with manifestations of war or revolution rather than genocide.

${ }^{349}$ Raphael Lemkin, "Definition: Nature of Genocide" (undated) AJHS, supra note 195 (Box 7, File 2) at 14, 21, 23. Lemkin explained,

[O]bviously also political groups might be and have been destroyed in the past. However, for the purposes of international legislation not every human group could be included in this definition. The following reasons for selection of the protected groups prevailed. (a) the protected groups must be easily recognizable; (b) it must be in the $[$ sic $]$ with its surroundings so as to warrant the presumption that it needs special protection. (c) This conflict must be of a serious nature with certain characteristics of permanency. (d) the conflict between the group and the majority society must be easily recognizable to the effect that the reasons for this conflict are unjust and the majority is guilty. (e) The moral values and the acts, as well as the way of life, of the group involved must be unimpeachable. For obvious reason only racial, religious, national and ethnical groups meet these requirements. (Ibid. at 15-16.)

Lemkin's concern with group innocence was also apparent in his unfinished history of genocide (Lemkin, "Part I, Ch. II, Sec I: International Collective Responsibility for the Survival of National Racial, Religious, and Ethnical Groups" (AJA, supra note 206, Box 7, Folder 2 at 6), where he wrote, "The group which is subject to genocide is basically innocent. We can hardly find a reason for blame in the fact that people belong to a different nationality, that they cherish the idea of a different culture, that they worship a different God, or that the color of their skin is different from that of the oppressor." And he continued, "The problem of innocence has further implications. It dramatizes to the highest degree the injustice of genocide. Punishment without guilt is beyond reason and beyond intelligence, is it beyond 
generating entities should wait until the world had secured the basic right of existence for cultural groups, which formed the fabric of Lemkin's "human cosmos."

logic and constructive living. It is wanton destructiveness and sheer atrocity." He finished this passage quoting Jacques Maritain: "It is only the cross of Christ which explains to us a little bit of the mystery of evil." See also Lemkin, "Memorandum on the Genocide Convention" (undated) NYPL, supra note 117 (Reel 3, File 1): "The important words 'as such' limit the concept of the crime to situations when it is committed on innocent people. Should a group act as rebels then a government is entitled to self-defense like an individual has the right to defend himself when he is attacked." See also Lemkin, "Definition: Nature of Genocide" (undated) AJHS, supra note 195 (Box 7, File 2) at 22-23:

Moreover, a political group is not always a defenceless victim. Very often it takes the initiative and becomes the aggressive part in a state. In such a way, most of the revolutions started. Revolution is very close to civil war. It is civil war. This problem of how to control political passions in civil war is very difficult and complicated. Should the state allow a revolutionary group to overthrow by violence its constitution, to burn its parliament, to destroy its courts, even of the sake of a higher better form of government? On the other hand, should we allow a government which fights a revolution to exterminate its political opponents?

The matter would then amount to establishing and defining a borderline which will bar a government from excessive zeal in quashing down a revolution. One should, however, be aware of the fact that the government would have to make a decision on its own risk. One should not overlook the fact that the desire of governments and political parties for survival might lead them to excessive action and to disregard any international obligations in this respect. One should also count with the possibility that a government might be accused of excessive zeal in quashing a revolution would challenge other governments with the question Would you act differently in my situation when your very existence is at stake?

$\cdots$

This does not necessarily mean that such controls will never be established. They will, in theproper [sic] time. One should allow international life to grow and develop to such an extent that the feeling of solidarity in preserving humanitarian values will be stronger that the desire for political domination.

He also argued that protecting political groups would become too "political," because new factions gaining control of a government could use the Genocide Convention to unfairly target the opposition, thereby sullying the convention. See Raphael Lemkin, letter to Maynard Gertler (7 December 1946) AJHS, supra note 195 (Box 1, file 18), discussing the original genocide resolution, written by Lemkin and sponsored by Cuba, India, and Panama:

The resolution excludes rightly political parties, or similar groups. As much as everyone of us is longing for a stabilization and humanization of political life on a world scale, it is felt, however, that the differences existing now in political ideologies do not make it possible that such an enormous task could be achieved by international law alone. Governments might negotiate an international treaty containing political "dynamite," but such treaties as a rule are not ratified. The best example is served to this effect by the draft convention on international rerrorism $[\mathrm{sic}]$ which was prepared several years before the war but which was forgotten completely. International law did not reach yet the stage when it can successfully carry the burden of too great political and ideological differences. And if one gives too much food to small chickens they die. 
Several delegations similarly objected to the inclusion of political groups on philosophical grounds. ${ }^{350} \mathrm{Mr}$. Azkoul pointed out "the essential difference between racial, national, and religious groups, all of which bore an inalienable character, on the one hand and political groups, far less stable in character, on the other." ${ }^{351} \mathrm{He}$ believed that "[t]he political group was not permanent; it was based on a body of theoretical concepts whereas sentiment or tradition bound the members of a national, racial or religious group." ${ }^{352}$ And he added "that the period of history when racial and national hatred had been the thing to be most greatly feared had been succeeded by a period in which political opinion had become the greatest cause of hatred." ${ }^{353}$ Morzov objected to the inclusion of political groups because “[c]rimes committed for political motives belonged to a special type of crime and had nothing in common with crimes of genocide, the very name of which, derived as it was from the word genus - race, tribe, referred to the destruction of nations or races as such for reasons of racial or national persecution, and not for political opinions of those groups. ${ }^{354} \mathrm{He}$ argued that the inclusion of political groups "would signify such a broadening of the concept of genocide as to contradict the basic, scientifically recognized meaning of that word." 355

\footnotetext{
${ }^{350}$ See Lawrence J LeBlanc, The United States and the Genocide Convention (Durham, NC: Duke University Press, 1991) at 74-75.

${ }^{351}$ Ad Hoc Committee Mtgs, supra note 286, UN Doc E/AC.25/SR.4 at 10.

352 Ad Hoc Committee Mtgs, supra note 286, UN Doc E/AC.25/SR.13 at 2. He followed this statement with one in favour of including political groups: "It was the political group that was most often attacked, most exposed to genocide. Finally, it might be dangerous for the convention not to condemn the persecution of a group for political reasons while providing for punishment of all other forms of genocide." (Ibid. at 3.)

${ }^{353}$ Ad Hoc Committee Mtgs, supra note 286, UN Doc E/AC.25/SR.4 at 13.

${ }^{354}$ Ibid.

${ }^{355} \mathrm{Ibid}$. at 5 . Mr. Pérez Perozo worried that political groups would cause mischief by "inundating the competent organs with complaints." (Ibid. UN Doc. E/AC.25/SR.4 at 12.)
} 
The United States and France argued just as fervently for the inclusion of political groups. On a strategic level, including political groups could prove useful in using the convention against the Soviets in the Cold War. On a humanitarian level, it was clear that political groups were - and would remain — vulnerable to the type of violence the Genocide Convention was intended to prohibit. ${ }^{356} \mathrm{Mr}$. Lin (China) stated his comfort with including political groups, but also argued, "There was, in fact, no good reason why social, economic and other groups should not be included, or even why no mention of sex distinction should be made, because there again it was possible to envisage separate groups." ${ }^{357}$ By a vote of four to three, the Ad Hoc Committee voted to retain political groups, effectively leaving to the following round of drafting the difficult task of excision. ${ }^{358}$

In congratulating the delegates for completing a draft convention, Maktos added, The importance of the new convention lies not in the fact that it established a new legal relationship between individuals and their governments, which, when the convention would come into force, would no longer be able to deal with their nationals as they pleased, but would be answerable for their actions under international law. The extermination of human beings because of their race, nationality, religion or political beliefs would be punishable, regardless of who the perpetrators might be..$^{359}$

On this issue at least, Maktos reflected the consensus view of the delegates. Whatever disagreements they might hold over the meaning of their draft convention, all understood it as a radical departure from the status quo ante in international law.

\footnotetext{
${ }^{356}$ For instance, Mr. Ordonneau "stated that in Hitler Germany it had been equally dangerous for a member of a political group, such as the social democrats or the communists to declare his membership as it was to announce that he was a Jew." (Ad Hoc Committee Mtgs, supra note 286, UN Doc E/AC.25/SR.4 at 12.)

${ }^{357} \mathrm{Ibid}$. at 11-12.

${ }^{358}$ Ad Hoc Committee Mtgs, supra note 286, UN Doc E/AC.25/SR.13 at 4.

${ }^{359}$ Ad Hoc Committee Mtgs, supra note 286, UN Doc E/AC.25/SR.24 at 16.
} 


\section{The Sixth Committee Debates}

On September 21, 1948, when the United Nations General Assembly's Sixth (Legal) Committee took up the Ad Hoc Committee draft at the Palais de Chaillot in Paris, cultural genocide was just one among many contentious issues the committee faced.

The United States delegation reported back to Washington that, on the whole, the committee members appeared very well qualified. ${ }^{360}$ Nevertheless, debates began slowly, so much so that Mr. Kerno, the Assistant Secretary-General in charge of the Legal Department, “drew the Committee's attention to the fact that the President of the General Assembly and the Secretary-General were deeply concerned about" the slow progress of its work. ${ }^{361}$ Lemkin worried about the convention's prospects if the Sixth Committee missed its target and could not deliver a draft before the closure of the third General Assembly session. ${ }^{362}$ The drafters began meeting twice daily to make up lost ground, and Chairman Alfaro increasingly enforced time limits on delegate speeches. ${ }^{363}$

Lemkin was well aware of the continuing opposition to the Genocide Convention in general and the cultural genocide provisions in particular, and from the outset appeared willing to trade the latter for the former. As he wrote in a letter to James N. Rosenberg, Chairman of the United States Committee on a Genocide Convention, "In the [Sixth Committee] there will be bargaining about points. One point will be exchanged for another.

\footnotetext{
${ }^{360}$ Ernest Gross to Durward Sandifer, Memo: "Trip to New York" (14 April 1948) NACP, supra note 209, Lot File D 429, Box 8 (box 2 of 11) Sandifer Files, "Human Rights - General - 1947-1956," General Records of the Department of State Central Files Record Group 59.

${ }^{361}$ Sixth Committee Mtgs., supra note 315, 78th Mtg, UN Doc A/C.6/SR.78 at 142. See also ibid. 88th Mtg, UN Doc A/C.6/SR.88 at 299.

${ }^{362}$ See Cooper, supra note 192 at 155-56.

${ }^{363} \mathrm{Ibid}$. at $155-56$.
} 
Those delegations which are opposed to particular points of the convention should not be encouraged in their stubbornness." ${ }^{364} \mathrm{He}$ warned that "if you will fight now cultural genocide, you will play into the hands of the British delegation. They will fight cultural genocide not in order to have a convention, but in order to be able to bury it." ${ }^{365}$ And, he counselled, "we must not be dogmatic about points. We might have to give up one or two ... points, but let us do it in time, coldly, through bargaining and certainly not through giving arguments to our skillful opponents." ${ }^{366}$

Even at this rather late stage in the drafting process, the delegates struggled with the basic contours of genocide. It was often stated that genocide was "homicide committed against a group of human beings." ${ }^{367}$ But because they had reached no agreement on what constituted "a group," this statement was entirely question begging. Some delegates, like Mr. Chaumont, who viewed groups as a collection of individuals might have considered "homicide" against the group to entail only the killing of individual group members. On the other hand, delegates who held a substantialist view of human groups would have been

\footnotetext{
${ }^{364}$ Letter, Lemkin to Rosenberg, (I3st [sic] September 1948) AJHS, supra note 195 (Box 1, File 19) at 2. ${ }^{365} \mathrm{Ibid}$. at 3.

${ }^{366} \mathrm{Ibid}$. See also Lemkin, Totally Unofficial, supra note 192 at 173:
}

A long discussion on cultural genocide would undoubtedly have prevented the committee from finishing the drafting of the convention at the Paris Assembly. I wanted to get the convention through the Paris Assembly at any cost, because I could never hope to have the president of the Assembly and the president Drafting Committee on my side at another Assembly. Indeed the Paris Assembly was the end of the golden age for humanitarian treaties at the UN.

But see Raphael Lemkin, "Genocide Before the U.N.: Importance of Resolution Declaring Crime International is Stressed," Letter to the Editor, The New York Times (8 November 1946) C22, arguing that the recently proposed UNGA Resolution 96(1) only addressed physical and biological genocide. This letter lends some support to the idea that Lemkin never believed the cultural genocide provisions would survive the drafting process and that he likely considered them a chip to be bargained away when the time was right.

${ }^{367}$ Sixth Committee Mtgs, supra note 315, 63rd Mtg, UN Doc A/C.6/SR.63 at 6, comments of Mr. Amado. 
inclined to think that homicide could be committed against a group merely by attacking the means through which the group cohered.

As it had in the Ad Hoc Committee, the question of how to conceive of human groups became a recurring topic in the Sixth Committee. Mr. Azkoul (Lebanon) argued that genocide constituted "a new legal category, that of collective crime. Hence it was indisputable that genocide differed, in law, from other crimes with which it had so far been confused; for while genocide, like the other crimes, resulted in the physical destruction of one or several individuals, it involved a new factor, namely, the intention to destroy a group as such." ${ }^{368} \mathrm{He}$ continued,

The inherent value of the human group had at last been recognized as well as its contribution to the cultural heritage of the human race. The relation between cultural and physical genocide was thus demonstrated; they were but two facets of one and the same act having the same origin and the same purpose, namely the destruction of a group, whether by the extermination of its members or by the eradication of its distinctive characteristics. ${ }^{369}$

And Mr. Maúrtua (Peru) "believed that, as the concept of genocide was new, it would be well to define it. Its characteristic feature was the destruction of groups." ${ }^{\text {370 }}$ However, Mr.

Chaumont argued that "group was an abstract concept; it was an aggregate of individuals; it had no independent life of its own; it was harmed when the individuals composing it were harmed." 371 Mr. Manini y Ríos (Uruguay) argued that “[t]he word 'group' in article II should

\footnotetext{
${ }^{368}$ Sixth Committee Mtgs, supra note 315, 66th Mtg, UN Doc A/C.6/SR.66 at 32.

${ }^{369} \mathrm{Ibid}$. at 32-33. Similarly, Mr. Alemán (Panama) asserted, "The characteristic which distinguished genocide from the common crime of murder was the intention to destroy a group." (Ibid. 69th Mtg, UN Doc A/C.6/SR.69 at 62.) See also comment by Mr. Paredes (Philippines) (Ibid. 80th Mtg, UN Doc A/C.6/SR.80 at 166): "[I]ntent to destroy a particular group ... constituted the criterion for the crime of genocide which the convention sought to prevent and punish.”

${ }^{370}$ Sixth Committee Mtgs, supra note 315, 71st Mtg, UN Doc A/C.6/SR.71 at 78.

${ }^{371}$ Sixth Committee Mtgs, supra note 315, 73rd Mtg, UN/Doc A/C.6/SR.73 at 91.
} 
be defined more precisely ..."372 while Mr. Bartos (Yugoslavia) argued "Neither the

preamble nor article 1 of the draft convention defined the group of human beings, the genus, to which the concept of genocide should apply."373

Many delegates argued that safeguarding culture was integral to group protection. The "Venezuelan delegation felt in principle, that [cultural genocide] should be suppressed, since it was possible to destroy a human group ethnically without exterminating it physically."374 Mr. Kovalenko (Ukrainian Soviet Socialist Republic) asserted that "[i]t was generally recognized that genocide aimed at the extermination of a group of people. That aim could be attained either by exterminating all the members of the group or by destroying its characteristics. " $375 \mathrm{Mr}$. Correa of Ecuador believed that "[a] group consisted of individuals and possessed a culture of its own. The destruction of that culture was normally effected with less violence than the extermination of the members of the group, but the result was the same - the disappearance of the group." 376 And, Mr. Tsien Tai (China) argued that

\footnotetext{
${ }^{372}$ Sixth Committee Mtgs, supra note 315, 64th Mtg, UN Doc A/C.6/SR64 at 16.

${ }^{373}$ Sixth Committee Mtgs, supra note 315, 63rd Mtg, UN Doc A/C.6/SR63 at 9.

${ }^{374}$ Sixth Committee Mtgs, supra note 315, 64th Mtg, UN Doc A/C.6/SR64 at 22, comments of Mr. Pérez
} Perozo. He continued, "Care should be taken however, to use the term cultural genocide with great accuracy; it should be used with reference only to violent and brutal acts which were repugnant to the human conscience, and which caused losses of particular importance to humanity, such as the destruction of religious sanctuaries, libraries, etc."

${ }^{375}$ Sixth Committee Mtgs, supra note 315, 65th Mtg, UN Doc A/C.6/SR65 at 27. Mr. Kovalenko continued, stating that "[i]n the opinion of the Ukrainian delegation, no country which was genuinely anxious to combat the crime of genocide and to prevent it as well as punish it, could oppose the inclusion of cultural genocide. ..."

${ }^{376}$ Sixth Committee Mtgs, supra note 315, 108th Mtg, UN Doc A/C.6/SR. 108 at 203-04. He continued. "If attacks against the culture of a group remained unpunished for the want of appropriate provisions in the convention, that would facilitate the perpetration of physical genocide, in which such attacks normally culminated." Mr. Zourek (Czechoslovakia) "wished to draw the Committee's attention to the fact that a group might disappear either as a result of the physical extermination of its members or as a result of the forcible destruction of its distinctive and permanent characteristics. The ensuing loss to humanity was no less in the second case than in the first." (Ibid. at 205.) Morozov (USSR) asserted that "the important element was the intent to destroy a given group in whole or in part. The physical destruction of members of the group was one way of carrying out that intention, and the destruction of the culture of the group was another." (Ibid. at 205.) 
"[a]lthough it seemed less brutal, that aspect of the crime against the human group might be even more harmful than physical or biological genocide, since it worked below the surface and attacked a whole population, attempting to deprive it of its ancestral culture and to destroy its very language." ${ }^{377}$ On the other hand, Mr. Setalvad (India), after reassuring Pakistan's' delegate that Indian Muslims would be treated respectfully, asserted that "the measures for the protection of the cultural rights of a group, however desirable they might be, were not related to the idea of genocide, which was clearly defined in resolution 96(I) of the General Assembly as the denial of the right of existence of a group." ${ }^{378}$ And Mr. Amado argued that "[t]he concept of genocide implied only the physical destruction of a group. Cultural genocide was as yet too indefinite a concept to be included in a convention."379 The debate over which types of groups to protect, especially whether to extend protection to political groups, provides important insights into the delegates' thinking on issues of group life and culture. Mr. Shawcross, a prosecutor at Nuremberg, made a

\footnotetext{
377 Ibid. at 198.

${ }^{378}$ Ibid. at 201. Similarly, Mr. Lapointe (Canada) (ibid. at 199-200) declared that the
}

people of Canada were horrified at the idea of cultural genocide and hoped that effective action would be taken to suppress it. The people of his country were deeply attached to their cultural heritage, which was made up mainly of a combination of Anglo-Saxon and French elements, and they would strongly oppose any attempt to undermine the influence of those two cultures in Canada, as they would oppose any similar attempt in any other part of the world. . . . His delegation was not, therefore, opposed to the idea of cultural genocide, only to the inclusion in the convention of measures to suppress it."

See also Claude, supra note 277 at 155, stating that

the battle to retain the cultural genocide provision was waged by a group of states which included prominently the Soviet Bloc and a number of Asian-Arab states, against a determined opposition which was conspicuously representative of European and European-derived peoples. One interesting deviation from the pattern suggested above was the position of India, whose objection to the inclusion of cultural genocide was clearly related to the fact that Pakistan, and ardent supporter of the provision, proclaimed that is could hardly wait to haul its neighbor before a tribunal as a violator of the cultural rights of its Moslem minority.

${ }^{379}$ Sixth Committee Mtgs, supra note 315, 108th Mtg, UN Doc A/C.6/SR. 108 at 197-98. 
controversial statement in favour of political groups that would frame the subsequent debate

and generate significant pushback. He argued,

There was no doubt that racial groups should be included. No one should be persecuted because of the accident of his birth within a certain group. The question arose, however whether the convention should also provide protection to groups the members of which were as free to leave them as they were to join them. National or religious groups were obvious instances of that kind. If the committee favoured international legislation to prevent the destruction of national, racial or religious groups, he wondered if protection should be withheld from political groups. He asked whether a fascist State, for instance, should be entitled to destroy the lives of persons because they happened to be members of a communist group, or vice versa. There was as much persecution on political grounds as there was on racial grounds, and the question of political persecution was a practical problem in Europe. Concentration camps, sometimes known as labour camps, might still be in existence or make their appearance in the future. It was true that political groups did not have the same stable characteristics as racial or national groups, but in certain States the ruling political parties would insist that they possessed an existence as stable as some religious or racial groups. ${ }^{380}$

Thus, Shawcross argued, political groups could not be distinguished on logical grounds, and there were important practical reasons for their inclusion.

Mr. Gross (United States) scolded the other delegates for turning their backs on UNGA Resolution 96(1), which had protected political groups. He "wondered what had caused the change in attitude on the part of those delegations which were now requesting the deletion of the political group from article II." 381 And, he argued, it was not difficult to define political groups. The Germans had done so when they outlawed communist and social democratic parties, and the Allies had done so in outlawing the Nazi party. ${ }^{382} \mathrm{Mr}$. Medeiros

\footnotetext{
${ }^{380}$ Sixth Committee Mtgs, supra note 315, 69th Mtg, UN Doc A/C.6/SR.69 at 60.

${ }^{381}$ Sixth Committee Mtgs, supra note 315, 74th Mtg, UN Doc A/C.6/SR.74 at 101.

${ }^{382}$ Ibid. at 102. See also Sixth Committee Mtgs, supra note 315, 75th Mtg, UN Doc A/C.6/SR.75 at 110. Mr. Lachs (Poland) responded that as a member of the committee that had drafted UNGA Resolution 96(1), "he felt he had the right to state that its only aim had been to give a general indication of the General Assembly's attitude towards genocide. Genocide had not yet been defined; it was the task of the Committee to define it." And Mr. Pérez Perozo added that UNGA Resolution 96(1) "stated that genocide 'results in great cultural losses to humanity in the form of cultural and other contributions represented by . . . human groups.' The question
} 
(Bolivia) spoke in favour of including political groups, arguing that, "[f]rom a theoretical point of view, genocide meant the physical destruction of a group which was held together by common origin or a common ideology. There was no valid reason for restricting the concept of genocide by excluding political groups," or for that matter, economic groups. ${ }^{383} \mathrm{Mr}$. Correa (Ecuador) and Mr. de Beus (Netherlands) both admitted that political groups were difficult to define but argued that because of the nature of the crimes committed against them, political groups deserved protection nonetheless. ${ }^{384} \mathrm{Mr}$. Demesmin (Haiti) argued that one must "realize that strife between nations had now been superseded by strife between ideologies. Men no longer destroyed for reasons of national, racial or religious hatred, but in the name of ideas and the faith to which they gave birth." ${ }^{385}$ Mr. Petren (Sweden) argued that the conceptual foundations of religious groups could not be readily distinguished from political groups. He asserted that "[t]he profession of a faith did not result only from arose, therefore, why some delegations which had voted for that resolution were now against the inclusion of cultural genocide." (Ibid. at 113.)

${ }^{383}$ Sixth Committee Mtgs, supra note 315, 74th Mtg, UN Doc A/C.6/SR.74 at 98-99. He argued that

it should not be forgotten that current political strife had become so violent that parties sought to destroy each other by all possible means. It was therefore very important that political groups should be protected by the convention. The point at issue was not to protect freedom of opinion (that question came within the scope of the protection of human rights) nor was it to prevent States from maintaining internal order in the political field. The issue was to protect political groups against violence, followed by destruction.

${ }^{384}$ Ibid. at 100.

${ }^{385} \mathrm{Ibid}$. at 103. See also comments of Mr. Dihigo (Cuba), who argued that "[i]n the past, passion and fanaticism, which were the basis for all acts of genocide committed against national, racial or religious groups, were not to be found in the political struggle between rival parties. But the situation was no longer the same. Passions were more and more apparent in political struggles, and it could be said that political groups were in danger just as other groups, perhaps even in greater danger." (Ibid. at 108.) See also comments of Mr. Camey Herrera (Guatemala), pointing out that "not only that the Nazis had persecuted groups on the grounds of their nationality, race or religion, but that they had also persecuted Germans solely on political grounds. The same could be said of the Fascists, and similar examples could still be found in Spain." (Ibid. at 108.). And the comments of Mr. Petren (Sweden): "[T]he historical examples which had been given showed that the political group really stood in need of protection, for political hatred was now tending to replace religious hatred." (Sixth Committee Mtgs, supra note 315, 75th Mtg, UN Doc A/C.6/SR.75 at 114.) 
ancestral habit; it was a question to which each person gave a personal answer. That fact established a bond between the religious group and the groups based on community of opinion, such as political groups."386

Those opposing the inclusion of political groups also presented an array of compelling arguments. Mr. Abdoh (Iran) argued against the inclusion of political groups because

[i]f it were recognized that there was a distinction between those groups, membership of which was inevitable, such as racial, religious or national groups, whose distinctive features were permanent; and those, membership of which was voluntary, such as political groups, whose distinctive features were not permanent, it must be admitted that the destruction of the fist type appeared most heinous in the light of the conscience of humanity, since it was directed against human beings whom chance alone had grouped together. Those persons should therefore be given a larger measure of protection. Although it was true that people could change their nationality or their religion, such changes did not in fact happen very often; national and religious groups therefore belonged to the same category of groups, membership of which was inevitable. ${ }^{387}$

Mr. Kaeckenbeeck (Belgium) believed, "If the etymology of the word 'genocide' were borne in mind, the conclusion would have to be that the crime could be committed only against ethnical groups. The addition of religious groups constituted an extension of the concept of genocide, but that extension had been sanctioned by international law. The extension of genocide to political groups, however, would be an arbitrary measure scarcely likely to lead to success." ${ }^{388} \mathrm{Mr}$. Amado (Brazil) also weighed in against political groups, arguing that "the

\footnotetext{
${ }^{386}$ Sixth Committee Mtgs, supra note 315, 75th Mtg, UN Doc A/C.6/SR.75 at 113-14. He went on to point out that "Article II of the draft applied only to the most horrible form of the crime against a group, that of its physical destruction. It seemed that all States could guarantee that limited measure of protection to political groups." Mr. Manni y Rios (Uruguay) also wished to protect all groups. (Sixth Committee Mtgs, supra note 315, 74th Mtg, UN Doc A/C.6/SR.74 at 101.)

387 Sixth Committee Mtgs, supra note 315, 74th Mtg, UN Doc A/C.6/SR.74 at 99.

388 Ibid. at 107: "It was not [he argued] for the convention to combat all violence resulting from every kind of intolerance." See also Sixth Committee Mtgs, supra note 315, 75th Mtg, UN Doc A/C.6SR.75 at 122, where Mr. Kaeckenbeeck stated, "The concept of protected groups had also been broadened by including, first,
} 
reasons given by a number of representatives against the protection of political groups were in his opinion incontrovertible. That crime was unknown in the countries of Latin America, since in those countries there did not exist that deep-rooted hatred which in due course led to genocide."389

Mr. Lachs (Poland) argued that genocide "was the crime consisting in the destruction of those groups of human beings which were the product of circumstances beyond the control of their members". ... He believed, "The United Nations . . . should protect the individual where he was most vulnerable, which was within the group of which he was a member in spite of himself." "Those who needed protection most were those who could not alter their status." 390 While his delegation did not want political groups left without protection, "in view of their flexibility and their lack of homogeneity they should not be treated in the same way

political groups, whose membership depended upon variable subjective factors difficult to establish, and then ethnical groups, which were difficult to distinguish from racial groups."

389 Sixth Committee Mtgs, supra note 315, 69th Mtg, UN Doc A/C.6/SR.69 at 56-57. He stressed again "that the crime of genocide could only be perpetrated against groups which were stable and permanent." Mr. Amado went on to say,

Political struggle in Latin America was sometimes violent, sometimes emotional, but it was above all ephemeral. It was impossible in that part of the world to envisage such an intensification of political animosity as would lead to movements of a pogrom-like character. ... A crime committed for political motives did not contain a moral element, it was free from the intention of destroying the opposing group. Today's enemies became the friends of tomorrow.

Mr. Pérez Perozo (ibid. at 58) argued that inclusion would endanger the convention:

He realized that certain countries where civic spirit was highly developed and the political struggle fought through electoral laws, would favour the inclusion of political groups. But there were countries where the population was still developing and where political struggle was very violent. Those countries would obviously not favour the inclusion of political groups in the convention.

And Mr. Raafat (Egypt) "was against the inclusion of political groups, which went beyond the scope of genocide proper inasmuch as those groups did not have stable characteristics" (ibid. at 59), while Mr. Wikborg (Norway) was opposed to the inclusion of political groups on the ground that such groups were never so clearcut or stable as national, racial, or religious groups.” (Ibid. at 61.) Similarly, Mr. Pérez Perozo opposed the inclusion of political groups because "those groups lacked the essential element of stability which should characterize the groups to be protected by the convention." (Ibid. at 58. )

${ }^{390}$ Sixth Committee Mtgs, supra note 315, 75th Mtg, UN Doc A/C.6SR.75 at 111. 
as national, racial or religious groups. Only the latter groups should be protected by the convention because their members were defenceless." ${ }^{391}$ Similarly, Mr. Morozov believed that the criterion by which groups were protected "must be of an objective character; thus the subjective qualities of individuals were ruled out. On the basis of that fundamental concept, the groups could easily be distinguished; they were the racial and national groups, which constituted distinct, clearly determinable communities." ${ }^{392}$ He went on to castigate the British for inconsistencies in their stance on the Genocide Convention and to impugn their motives for supporting the inclusion of political groups. Morozov insisted that he

was surprised that some delegations should have attempted to extend the application of the convention beyond the scope of the scientific definition of genocide. He recalled, in that connexion, the words used by Sir Hartley Shawcross during the general discussion on genocide; according to the representative of the United Kingdom, the convention on genocide could be no more than a scrap of paper. And the United Kingdom delegation was now asking that the scope of the convention be extended! That delegation, together with several others, did not recognize cultural genocide, nor the provision to the effect that the "command of the law or superior orders shall not justify genocide." On the other hand they were trying to extend the convention to cover questions which had not yet been examined, and which were certainly extraneous to the very concept of genocide. In the circumstances, that could be nothing but an attempt to deprive the convention of any practical significance. ${ }^{393}$

\footnotetext{
${ }^{391} \mathrm{Ibid}$. at 111. See also Pérez Perozo: "The Venezuelan delegation felt that political groups should be protected not by the convention on genocide but by respect for individual liberties under constitutions, national legislation and the declaration on human rights." (Ibid. at 112-13.)

${ }^{392}$ Sixth Committee Mtgs, supra note 315, 74th Mtg, UN Doc A/C.6/SR.74 at 105. Mr. Manini y Ríos (Uruguay) supported Morozov's comments, stating that " $[t]$ he concept of genocide was, indeed the outcome of the Nazi theories of race superiority which were at the basis of the Hitlerian ideology. If the scope of the convention were extended, some word other than 'genocide' would have to be found." (Ibid. at 106.)

${ }^{393}$ Sixth Committee Mtgs, supra note 315, 74th Mtg, UN Doc A/C.6/SR.74 at 105 [footnote omitted]. Mr. Fitzmaurice (UK) replied that "the United Kingdom delegation not only categorically rejected those accusations, but also denied the moral authority of the USSR Government to make them, or to set itself up as a model of conduct before the world." (Ibid at 107.) Later, Mr. Morozov accused the British of opposing the inclusion of a motive element in order to weaken the convention. (Sixth Committee Mtgs, supra note 315, 75th Mtg, UN Doc A/C.6/SR.75 at 119.)
} 
Both those who opposed and those who supported the inclusion of political groups often appeared to do so for instrumental rather than conceptual reasons. The United States supported their inclusion in order to score a rhetorical win against the Soviets, the British supported inclusion because they knew it would doom the entire convention, and it is little wonder that the Soviets opposed political groups given their ongoing crimes against such groups. However, it is also clear that many delegates opposed inclusion on conceptual grounds. To these delegates, political groups simply did not possess the essential characteristic of group life that would qualify them for international protection: a culture. ${ }^{394}$

It should be unsurprising that conceptual and instrumental concerns often travelled in tandem. For instance, the United States, which supported including political groups, generally approached the issue of "group" from an atomistic viewpoint and therefore devalued aspects of group life including culture. But few delegations exhibited a conceptually pure view of groups. In fact, their views were complex and by today's perspective often contradictory, and, as is common in negotiations, most were willing to sacrifice conceptual purity to political expediency. ${ }^{395}$ In the end, the United States was satisfied to trade protections for political groups in order to secure the inclusion of Article 6, a provision that envisioned the establishment of an International Criminal Court, another of their pet projects. ${ }^{396}$

\footnotetext{
${ }^{394}$ See LeBlanc, supra note 350 at 67.

${ }^{395} \mathrm{Ibid}$. at 74, concluding that "[t] $]$ he Soviet delegation did oppose listing political groups . . ., but other delegations advanced much more persuasive and widely accepted arguments than the Soviets. Many delegates were concerned about the lack of stability of political groups and about whether or not extending protection to them would undermine support for the convention as a whole."

${ }^{396}$ Ibid. at 75 .
} 


\section{Delegates Vote Down a Materialist Idea of Genocide}

Other Sixth Committee votes also evidence the delegates' determination to outlaw group-destroying acts beyond those that killed group members or prevented them from reproducing. For instance, the delegates rejected a French proposal "to replace the words 'acts committed with the intent to destroy a ... group' by the words 'an attack on life directed against a human group, or against an individual as a member of a human group." 397 Sardar Bahadur Kahn of Pakistan opposed the French proposal, arguing that "the expression 'attack on ... life' would restrict the application of article II, since genocide must be condemned, whatever form it assumed." ${ }^{398}$ Mr. Pérez Perozo believed that "[a] categorical definition in general terms [like the one proposed by France] might prove dangerous since it would run the risk of failing to include all the essential factors." He favoured the Ad Hoc Committee approach, which had confined "itself simply to indicating the acts which

\footnotetext{
397 Sixth Committee Mtgs, supra note 315, 73rd Mtg, UN Doc A/C.6/ AR. 73 at 91, comments of Mr. Chaumont, discussing, France: Amendments to the Draft Convention, UNGA, Sixth Committee, 3rd Sess, UN Doc A/C.6/224 (1948). See also Raphael Lemkin, "On the Need for a Genocide Convention, Introduction" (undated and un-paginated) AJHS, supra note 195 (Box 7, File 2), recounting this event: "Mr. Chaumont, of France, tried unsuccessfully to replace the concept of group by the concept of individuals. He used the words, 'against an individual as the member of the human race.' He was opposed by all delegations and especially by Mr. Gross of the United States."

${ }^{398}$ Sixth Committee Mtgs, supra note 315, 72nd Mtg, UN Doc A/C.6/SR.72 at 81. France attempted to clarify, stating that the provision was intended to overcome the vagueness inherent in the Ad Hoc Committee's formulation. Rather than stating that acts had to be "committed with intent to destroy a ... group," the French hoped to make clear that the killing of only a single individual could constitute genocide. (Chaumont, Sixth Committee Mtgs, supra note 315, 73rd Mtg, UN Doc A/C.6/ AR. 73 at 90-91.) See also Lemkin, "On the Need for a Genocide Convention" (undated, but post 9 Dec. 1948) AJHS, supra note 195 (Box 7, File 2). On this incident, Lemkin said,
}

In the course of the discussion of the draft convention ..., the views of two delegates, who opposed one another, threw significant light on the meaning of the words "in part." Mr. Chaumont, of France, tried unsuccessfully to replace the concept of group by the concept of individuals. He used the words, "against an individual as the member of the human race." He was opposed by all delegations and especially by Mr. Gross of the United States. Mr. Gross pointed out that [UNGA Resolution 96(1)] made a basic distinction between genocide as the destruction of human groups and homicide as the destruction of individuals. 
constituted genocide and the groups against which such acts must be directed if the resultant crime were to be termed genocide." 399 Others opposed the provision as vague ${ }^{400}$ and, facing opposition, the French withdrew the proposal. ${ }^{401}$

Mr. Reid (New Zealand) supported a Soviet "amendment that proposed [adding to draft article 2] the use of the expression 'aimed at the physical destruction"' of the group. ${ }^{402}$ He supported this language precisely because it would prevent the Convention from reaching instances where "[t]he group itself had ceased to exist, but its members survived." ${ }^{403} \mathrm{He}$ explained that

history gave examples of genocide where there had been no intent of physical destruction of the groups concerned. Thus, the older members of a group had been killed and the younger ones converted by divers [sic] means to an ideology different from their own.... Such acts would not constitute genocide according to the terms of the Soviet Union amendment. ${ }^{404}$

Mr. Chaumont approved of the Soviet proposal because he thought "the term 'physical destruction' corresponded exactly to the text of article II, which [at that point] dealt solely with biological genocide." 405 The Soviets, who supported inclusion of the cultural genocide provisions, had hoped their amendment would simply shift the emphasis away from the

\footnotetext{
${ }^{399}$ Sixth Committee Mtgs, supra note 315, 72nd Mtg, UN Doc A/C.6/SR.72 at 81. Backing up Mr. Pérez Perozo's statement, Mr. Spiropoulos (Greece) “observed that the majority of speakers had been in favour of the principle of enumeration." (Ibid. at 82.)

${ }^{400}$ Sixth Committee Mtgs, supra note 315, 72nd Mtg, UN Doc A/C.6/SR.72 at 79, comments of Mr. Bartos; Sixth Committee Mtgs, supra note 315, 73rd Mtg, UN Doc A/C.6/ AR. 73 at 83; comments of Mr. Reid: "He shared the view of the representative of Venezuela that the expression 'an attack on . . . life' would lend itself to sharply differing interpretations ...." (Ibid.)

${ }^{401}$ Sixth Committee Mtgs, supra note 315, 72nd Mtg, UN Doc A/C.6/SR.72 at 84.

402 Sixth Committee Mtgs, supra note 315, 73rd Mtg, UN Doc A/C.6/ AR. 73 at 94.

${ }^{403}$ Comments of Mr. Reid ibid. at 94; Union of Soviet Socialist Republics: Amendments to Draft Article II of the Draft Convention, UNGA, Sixth Committee, 3rd Sess, UN Doc A/C.6/223 (1948).

404 Sixth Committee Mtgs, ibid.

${ }^{405}$ Sixth Committee Mtgs, supra note 315, 72nd Mtg, UN Doc A/C.6/SR.72 at 95.
} 
perpetrator's intent to the genocidal result and further distinguish cultural from physiobiological genocide. ${ }^{406}$ It is important to remember that at this juncture the delegates had not deleted draft article 3 , nor had they added the forcible transfer of children to article 2 , so most believed that article 2 addressed only physio-biological acts. Mr. Morozov explained that the purpose of the USSR amendment was to replace the expression "committed with intent to destroy" by "aimed at the physical destruction". ... . The Soviet Union amendment introduced a new factor: article II was concerned with biological genocide; the idea of "physical destruction" should therefore be specified in the text of the definition so as to establish very clearly the difference between such acts and those covered by article III. ${ }^{407}$

Even still, the proposal to consider the acts enumerated in Article 2 as genocide only when they were "aimed at the physical destruction of the group" was rejected by a wide margin. ${ }^{408}$ In rejecting these proposals - to define genocide as "an attack on life" and to limit it to "physical destruction"- the Sixth Committee passed up the opportunity to restrict the definition of genocide to include only "material" aspects.

\section{Motive}

The debate on whether to include a motive element in article 2 also reveals some of the delegate's assumptions on the matter of groups. Unable to agree to include a motive element, much less to agree on its terms, Sixth Committee delegates agreed on compromise language proposed by Venezuela that would protect "groups as such." ${ }^{409}$ Mr. Pérez Perozo

\footnotetext{
${ }^{406}$ See Sixth Committee Mtgs, supra note 315, 73rd Mtg, UN Doc A/C.6/ AR. 73 at 95-96, comments of Mr. Morozov. See also (ibid.) comments of Mr. Gross, United States, Mr. Maurta, Peru, Mr. Kaeckenbeeck, Belgium, Mr. Chaumont, France.

${ }^{407}$ Ibid. at 95 .

${ }^{408}$ Sixth Committee Mtgs, supra note 315, 73rd Mtg, UN Doc A/C.6/ SR.73 at 97. (Rejected, 36 votes to 11, with 4 abstentions.)

${ }^{409}$ Venezuela: Amendment to article II of the Draft Convention, UN GAOR, Sixth Committee, 3rd Sess, UN Doc. A/C.6/231 (1948).
} 
explained that the purpose of his amendment "was to specify that, for genocide to be committed, a group — for instance, a racial group — must be destroyed qua group. ${ }^{410} \mathrm{Mr}$. Raafat (Egypt) observed that "“as such' added yet another description of the groups,"411 and Mr. Kaeckenbeeck (Belgium) thought it "described the intention and brought the emphasis back to the concept of groups." 412 The French delegate, who had proposed substituting the words "by reason of its nature" "asked whether the expression 'as such' applied to the description of the group rather than to the group itself." ${ }^{413}$ But Mr. Morozov (USSR), who consistently favoured a robust enumeration of culpable motives, believed these words "would mean that, in cases of genocide, the members of a group would be exterminated solely because they belonged to that group." $" 14$

Because of the wide disagreement over the meaning of "as such," Mr. Manini y Ríos (Uruguay) proposed setting up a working group to consider the problems raised by this

\footnotetext{
${ }^{410}$ Sixth Committee Mtgs, supra note 315, 77th Mtg, UN Doc A/C.6/ SR.77 at 131.

${ }^{411}$ Sixth Committee Mtgs, supra note 315, 76th Mtg, UN Doc A/C,6/SR.76 at 126. See also comments of Mr. Kaeckenbeeck (Belgium), ibid. at 130: "[T]he Venezuelan amendment omitted motives but, in the interests of clarity narrowed the concept of group, which the Committee had broadened by including intent to destroy part of a group."

${ }^{412} \mathrm{Ibid}$. at 123. See also comments of Mr. Manini y Ríos (Uruguay) and Mr. Gross (United States), approving of Mr. Kaeckenbeeck's comments. Prince Wan Waithayakon (Siam) "thought there were two possible interpretations of the words 'as such'; they might mean either 'in that the group is a national, racial, religious or political group', or 'because the group is a national, racial, religious or political group.' He himself would adopt the first of those interpretations." (Sixth Committee Mtgs, supra note 315, 77th Mtg, UN Doc A/C.6/ SR.77 at 133.)

${ }^{413}$ Sixth Committee Mtgs, supra note 315, 76th Mtg, UN Doc A/C,6/SR.76 at 127.

${ }^{414} \mathrm{Ibid}$. at 126-27. He continued, "That of course, was one of the essential characteristics of genocide. There could, however, be other interpretations of the words 'as such.' Some delegation had already pointed out that he formula was too vague." See also Union of Soviet Socialist Republics: Amendments to Article II of the Draft Convention, UN GAOR, Sixth Committee, 3rd Sess, UN Doc. A/C.6/223 (1948), which proposed the following wording for Article 2's chapeau: "For the purposes of the present Convention, genocide shall be understood to mean any of the following criminal acts aimed at the physical destruction of racial, national, (or religious) grounds."
} 
language. ${ }^{415}$ However, the proposed working group was rejected. ${ }^{416}$ Delegates of Belgium and the United States argued that "the Committee had to vote on the text of a proposal and not on the interpretation of such text, whether that interpretation were given by its author or any other delegations" and the chairman "stated that delegations could only vote on the texts submitted to them. Statements on the interpretation of those texts were of value only in respect to the history of the convention. ${ }^{.417} \mathrm{Mr}$. Spiropoulos (Greece) agreed that "interpretation of the provisions of the convention must be left to those who would have to apply them." ${ }^{\text {418 }}$ However, Mr. Morozov (USSR) "regretted that the majority had adopted an ambiguous definition of genocide which judges would be able to interpret only with the aid of voluminous documentation." ${ }^{419}$ In light of these comments, it is probably unwise to accord the delegates' intentions too prominent a role in determining the meaning of "as such." This term was left deliberately vague so that the delegates might invest it with any meaning they chose, and today's interpreters would do better to simply read it in accordance with ordinary usage.

${ }^{415}$ Sixth Committee Mtgs, supra note 315, 77th Mtg, UN Doc A/C.6/ SR.78 at 139-40.

${ }^{416}$ Ibid. at 142 .

${ }^{417}$ Ibid. at 132, comments of Mr. Kaeckenbeeck, supported by Mr. Maktos.

${ }^{418} \mathrm{Ibid}$. at 132. See also statement of Mr. Kerno:

$[I] t$ was the text of an amendment, regardless of any interpretation, which was put to the vote; the declarations of the various representatives appeared in the summary records of the meetings, and might be used by the competent organs which would have to take cognizance of "disputes between the High Contracting Parties relating to the interpretation or application of this Convention," as stated in article X of the draft convention. (Ibid. at 134.)

${ }^{419}$ Ibid. at 137. 


\section{The Sixth Committee Cultural Genocide Debate}

As the Sixth Committee commenced debate on draft article 3, the cultural genocide provision, Sardar Bahadur Kahn began a powerful speech by invoking the "thirty-five million people, bound to Pakistan by ties of religion, culture and feeling but living outside its frontiers, [who] faced cultural extinction at the hands of ruthless and hostile forces." ${ }^{\prime 20}$ Kahn's speech proved to be a signal moment in the cultural genocide debate. I am quoting the summary record at length because it reveals the breadth and strength of the culturalist argument. He argued,

Cultural genocide could not be divorced from physical and biological genocide, since the two crimes were complementary in so far as they had the same motive and the same object, namely, the destruction of a national, racial or religious group as such, either by exterminating its members or by destroying its special characteristics. The delegation of Pakistan went so far as to say that cultural genocide represented the end, whereas physical genocide was merely the means. The chief motive of genocide was a blind rage to destroy the ideas, the values and the very soul of a national, racial or religious group, rather than its physical existence. Thus the end and the means were closely linked together; cultural and physical genocide were indivisible. It would be against all reason to treat physical genocide as a crime and not to do the same for cultural genocide.

$\cdots$

Hence the deletion of article III of the convention on genocide and its inclusion in an altered form in the declaration of human rights or in a charter for the protection of minorities would not be in accordance with the requirements of resolution of 96(I), which stated that genocide whether physical, biological, or cultural, was a crime under international law....

...

Some representatives appeared to consider cultural genocide as a less hideous crime than physical or biological genocide. The representative of Pakistan emphasized that for millions of men in most Eastern countries the protection of sacred books and shrines was more important than life itself; the destruction of those sacred books or shrines might mean the extinction of spiritual life. Certain materialistic philosophies prevented some people from understanding the importance which millions of men in the world attached to the spiritual life.

$\cdots$

${ }^{420}$ Sixth Committee Mtgs, supra note 315, 83rd Mtg, UN Doc A/C.6/SR83 at 193. 
The delegation of Pakistan recalled that in article II genocide was defined as something other than the physical destruction of life, as was clearly shown in subparagraphs 2 and $3 .^{421}$

Here, he declared his belief that group existence has value and that culture is vital to group existence, though "certain materialistic philosophies" blinded some people to the importance of these things. And he drew a sharp distinction between East and West as he argued that for many, the protection of culture was more important than life itself. His statement exposes the process - already underway — whereby a faction of delegations was actively reinterpreting the Convention against the ordinary meaning of its still tentative terms to restrict its scope in pursuit of political and ideological ends. As he pointed out, the just-adopted terms of article 2 indicated that culture already played a prominent role in the Genocide Convention.

The Sixth Committee cultural genocide discussion proved much more contentious and overtly political than had the comparatively placid and largely theoretical Ad Hoc Committee debates. Opposition to the provision was led by major colonial powers, especially France and Britain, which feared its broader implications. As they had in the Ad Hoc Committee, opponents criticized cultural genocide as difficult to define, as an improper subject for the Genocide Convention, and as a matter more properly addressed by some other method. Mr. Chaumont (France) stated his belief that "[c]ultural genocide should be

${ }^{421}$ Ibid. at 193-94:

It understood perfectly that new countries desired to assimilate immigrants in order to create a powerful national unit; nevertheless if assimilation was nothing but a euphemism concealing measures of coercion designed to eliminate certain forms of culture, Pakistan formally opposed fascist methods of that kind, which emanated from philosophies that should be repudiated as contrary to the aims of the Charter of the United Nations.

In an earlier draft of his speech found in Lemkin's papers, Mr. Kahn wrote that "[t]o advance [the argument that the vote would exclude cultural genocide from the convention] is therefore to attempt to reintroduce by the backdoor, the French amendment to the first part of Article II which has been rejected by the committee." (undated) AJHS, supra note 195 (Box 2, File 13). 
excluded from the draft convention because, on the one hand, that concept was not

sufficiently well-defined and, on the other hand, that type of genocide came within the sphere of the protection of human rights." $422 \mathrm{Mr}$. Manini y Ríos argued that "the convention should restrict itself to the crime of physical genocide and not deal with other aspects of the problem; those parts dealing with cultural and political genocide should be dealt with in the field of human rights." 423

Proponents continued linking cultural genocide to events in Palestine and India. ${ }^{424}$

Mrs. Ikramullah (Pakistan) argued that

[i]n India, thirty-five million Muslims were currently living under conditions of terror. Their existence as a separate cultural group was threatened. Although the use of Urdu, a language of Muslim origin, had not been prohibited by law, it was under heavy attack.

Muslim cultural and religious monuments had been burned down or destroyed. In such circumstances it was not surprising that the Pakistan delegation believed it

${ }^{422}$ Sixth Committee Mtgs, supra note 315, 65th Mtg, UN Doc A/C.6/SR.65 at 29. He also said (UN Doc A/C.6//SR.63 at 8 ) that

the idea of physical genocide should be distinguished from that of cultural genocide. The definitions should be as precise as possible. Although physical genocide could be defined in exact legal terms, the same was not true of cultural genocide, for the conception of the latter was less precise. If that concept were broadened, it would soon lead to intervention in the domestic affairs of states.

The punishment of cultural genocide was logically related to the protection of human rights. It therefore came within the province of the Third Committee. (Ibid.)

${ }^{423}$ Sixth Committee Mtgs, supra note 315, 64th Mtg, UN Doc A/C.6/SR.64 at 16. Sir Hartley Shawcross (United Kingdom) agreed that cultural genocide "was simply one aspect of the general problem of protecting the fundamental rights of man." (Ibid. at 17.) In a similar vein, Mr. Abdoh (Iran) argued that "[t]o include cultural genocide would be to go beyond the aims of the convention. It was certainly necessary to protect the spiritual and cultural activities of an ethnic group, but the Iranian delegation advocated the adoption of a supplementary convention on the subject." (Sixth Committee Mtgs, supra note 315, 66th Mtg, UN Doc A/C.6/SR.66 at 31.)

${ }^{424}$ Sixth Committee Mtgs, supra note 315, 63rd Mtg, UN Doc A/C.6/SR.63 at 10, comments of Mrs. Ikramullah, Pakistan, citing violence against Muslims in India; Sixth Committee Mtgs, supra note 315, 83rd Mtg, UN doc A/C.6/SR.83 at 199, comments of Mr. Raafat, Egypt: "The crime of cultural genocide was at present being committed in the Holy Land and elsewhere." 
essential to include cultural genocide among the acts to which the convention applied. ${ }^{425}$

Mr. Sundaram (India) answered that

the vague concept of cultural genocide as defined in article III was on an entirely different plane from physical or biological genocide. ... His country, with its mixture of races and cultures, had fully safeguarded the rights of groups and minorities in the draft constitution which was before the Constituent Assembly; there was no discrimination against any minority in matters of education, language, religion, or culture, and any law violating such fundamental rights was automatically invalidated. Cultural genocide, which was explicitly forbidden by the constitutional laws of his country, was doubtless reprehensible but could not be linked with genocide proper and ... went beyond the terms of General Assembly resolution 96(1). It should be properly dealt with in the draft international covenant on human rights. ${ }^{426}$

And, Mr. Raafat (Egypt) argued that "[a]n international convention was the only means of allaying the fears inspired by the remarks of the representative of Pakistan and by the behaviour of certain metropolitan Powers in Non-Self-Governing Territories, [who] were attempting to substitute their own culture for the ancient one respected by the local population, and which was in no way harmful to the public order." 427

The cultural genocide provisions were criticized on a number of grounds. Mr. Parades (Philippines) asserted that the cultural genocide provision "could be interpreted as depriving nations of the right to integrate the different elements of which they were composed into a homogenous whole as, for instance, in the case of language." 428 Similarly, Mr. Amado (Brazil) thought, "Cultural genocide should be taken to denote the destruction by violence of the cultural and social characteristics of a group of human beings; care should be taken, when

\footnotetext{
${ }^{425}$ Sixth Committee Mtgs, supra note 315, 63rd Mtg, UN Doc A/C.6/SR.63 at 11.

${ }^{426}$ Sixth Committee Mtgs, supra note 315, 64th Mtg, UN Doc A/C.6/SR.64 at 15.

${ }^{427}$ Sixth Committee Mtgs, supra note 315, 108th Mtg, UN Doc A/C.6/SR.108 at 199.

${ }^{428}$ Sixth Committee Mtgs, supra note 315, 65th Mtg, UN Doc A/C.6/SR.65 at 24.
} 
dealing with new countries, not to favour minority movements which would tend to oppose the legitimate efforts made to assimilate the minorities by the countries in which they were living." ${ }^{429}$ The delegate from Sweden worried that " $[t]$ he question could arise whether, for example, the fact that Sweden had converted the Lapps to Christianity might not lay her open to the accusation that she had committed an act of cultural genocide." ${ }^{430}$ Mr. Pérez Perozo, an advocate for protections against cultural genocide, nonetheless found himself unwilling to vote for any of the cultural genocide provisions proffered in the several rounds of drafting. He criticized the Sixth Committee provision as "an ill-assorted mixture of heterogeneous elements and abstract conceptions lacking in precision. The terms used were vague and too general. ..." ${ }^{\prime 41}$ Again, opponents argued that the issues raised by that provision were more properly considered part of human rights law. A French proposal to delete draft article 3, which contained the cultural genocide provisions, also requested the "Third Committee's attention to be drawn to the need to provide for the protection of language, religion and culture within the framework of the International Declaration on Human Rights. ${ }^{232} \mathrm{Mr}$. Petren (Sweden) believed "the cultural protection of minorities" should be examined as part

\footnotetext{
${ }^{429}$ Sixth Committee Mtgs, supra note 315, 63rd Mtg, UN Doc A/C.6/SR.63 at 6. See also Sixth Committee Mtgs, supra note 315, 83rd Mtg, UN Doc A/C.6/SR.83 at 197, comments of Mr. Amado: "Given the historical evolution of civilizations, sometimes through differentiation, sometimes through the amalgamation of local cultures, a State might be justified in its endeavour to achieve by legal means a certain degree of homogeneity and culture within its boundaries."

${ }^{430}$ Sixth Committee Mtgs, supra note 315, 83rd Mtg, UN Doc A/C.6/SR.83 at 197.

${ }^{431}$ Ibid. at 196-97.

${ }^{432}$ France: Amendments, UN GAOR, Sixth Committee, 3rd Sess, UN Doc. A/C.6/216 (1948). See also Sixth Committee Mtgs, supra note 315, 83rd Mtg, UN Doc A/C.6/SR.83 at 201, comments of Mr. Setalvad (India) agreeing that "[t]he protection of the cultural rights of a group should be guaranteed not by the convention on genocide but by the declaration on human rights." See also ibid. at 200, statement of Mr. Lapointe (Canada) supporting the French proposal. Other proposals were made along these lines, though none were quite so specific. See Belgium: Amendments to the Draft Convention, UN GAOR, Sixth Committee, 3rd Sess, UN Doc A/C.6/217 (1948) at 2.
} 
of a "special convention which would prescribe different forms of international control and suppression. . . "433 Finally, Mr. Federspiel (Denmark) declared that "it would show a lack of logic and a sense of proportion to include in the same convention both mass murders in gas chambers and the closing of libraries."434 This statement clearly resonated with many delegates, as it continues to resonate today.

Lemkin's Herderian pluralism, as reflected in UNGA Resolution 96(1), was not universally embraced. For instance, the South African delegate, Mr. Egeland, declared "the horror his country felt at any attempt to destroy the cultural heritage of a group or to prevent a group from making its specific contribution to the cultural heritage of mankind." 435 However, he also wanted to point out the dangers of applying the cultural genocide provision to "primitive or backwards groups... . No one could, for example, approve the inclusion in the convention of provisions for the protection of such customs as cannibalism." ${ }^{436}$ Similarly, Mr. Abdoh (Iran) warned that if cultural genocide were included, "it would have to be decided whether all cultures, even the most barbarous, deserved protection, and whether the assimilation resulting from the civilizing action of a State also constituted genocide." ${ }^{243}$ And Mr. Reid (New Zealand) pointed out that "[ $\mathrm{t}]$ he civilization of certain tribes in Africa and the South Seas was actually based on the tribal system, which meant that that system should be

\footnotetext{
${ }^{433}$ Sixth Committee Mtgs, supra note 315, 83rd Mtg, UN Doc A/C.6/SR.83 at 197.

434 Ibid. at 199.

435 Ibid. at 202. He observed that South Africa's population "was composed of a number of groups of varying origin and he wished to emphasize the fact that each was encouraged to make the largest possible contribution to the common culture."

436 Ibid. at 202.

${ }^{437}$ Ibid. at 201. He continued, "It was even possible that the opposition of one political party to another could be described as cultural genocide."
} 
protected. Nevertheless, the Trusteeship Council, [of the UN] itself, in the part of its report dealing with the situation in certain regions of Tanganyika had expressed the opinion that the 'now existing tribal structure was an obstacle to the political and social advancement of the indigenous inhabitants." ${ }^{438} \mathrm{He}$ warned that "[i]t would be detrimental to the prestige of the United Nations to include in a convention provisions which were so confused that they might be invoked against its own organs." ${ }^{439}$

\section{Mr. Pérez Perozo's Au Contraire}

On October 25, 1948, Mr. Alfaro (Panama), speaking as Committee Chairman, "opened the discussion of article III of the draft convention, including the question as to whether or not the convention would include cultural genocide. ${ }^{\$ 440}$ Mr. Pérez Perozo stepped forward to point out that in voting to add paragraph 2(e), which prohibits the forcible transfer of children, the committee had already accepted cultural genocide into the Convention. ${ }^{441}$ Therefore, while they might vote against including certain acts deemed cultural genocide, it was impossible to say that they were voting to exclude all elements of cultural genocide. In a pivotal statement, he argued,

The convention should not restrict the concept of genocide to the physical destruction of the human groups whom it was intended to protect. The definition given in article II did not specifically lay down that the destruction of a group had to be physical destruction; it might be argued that the first four sub-paragraphs of article II referred only to concrete acts of physical destruction, but it should be borne in mind that the Committee had included a fifth point covering the "forced transfer of children to another human group"; thus the Committee implicitly recognized that a group could be destroyed although the individual members of it continued to live normally without having suffered physical harm. [Article 2(e)] had been adopted because the forced transfer of children to a group where they would be given an education

\footnotetext{
${ }^{438}$ Ibid.

${ }^{439}$ Ibid.

${ }^{440} \mathrm{Ibid}$. at 193.

${ }^{441}$ Sixth Committee Mtgs, supra note 315, 83rd Mtg, UN Doc A/C.6/SR.83 at 195.
} 
different from that of their own group, and would have new customs, a new religion and probably a new language, was in practice tantamount to the destruction of their group, whose future depended on that generation of children. Such transfer might be made from a group with a low standard of civilization and living in conditions both unhealthy and primitive, to a highly civilized group as members of which the children would suffer no physical harm, and would indeed enjoy an existence which was materially much better; in such a case there would be no question of mass murder, mutilation, torture, or malnutrition; yet if the intent of the transfer were the destruction of the group, a crime of genocide would undoubtedly have been committed. The Venezuelan delegation was aware that the human conscience was particularly shocked by those acts of genocide which constituted mass murder and those covered by sup-paragraph 3 of article II; yet less spectacular crimes should not be overlooked and the concept of genocide should extend to the inclusion of acts less terrible in themselves but resulting in "great losses to humanity in the form of cultural and other contributions," for which it was indebted to the destroyed human group. ${ }^{442}$

Then, somewhat arbitrarily, Chairman Alfaro reminded him "that . . each speaker was limited to a maximum of ten minutes," and Mr. Pérez Perozo ended his speech under protest. $^{443}$

As Mr. Pérez Perozo had explained to his fellow delegates, article 2(e) is central to our conceptions of the Genocide Convention, though the motivations in proposing it were primarily strategic. Greece had submitted the forcible transfer of children provision in the Sixth Committee's eighty-second meeting. ${ }^{444}$ Since the end of World War II, Greece had been involved in a protracted struggle to gain the return of 28,000 Greek children stolen by

442 Ibid:

He recalled that resolution 96(1) defined genocide thus: "Genocide is a denial of the right of existence of entire human groups." A group could be deprived of its existence not only through the physical destruction of its members, but also through the destruction of its specific traits, the loss of which led to the dissolution of its unity, even though no attempt had been made on the life of its members. The element of persecution, which existed in every case of genocide, had two aspects, physical destruction and the destruction of the spirit, each tending to the same end: to deprive the group of its existence.

${ }^{443} \mathrm{Ibid}$. at 197.

${ }^{444}$ Sixth Committee Mtgs, supra note 315, 82nd Mtg, UN Doc. A/C.6/SR.82 at 188. Mr. Vallindas recalled that both the Secretariat's Draft (UN Doc E/447) and the United States proposed draft (UN Doc E/623) had included measures against the removal of children. 
Communist forces, and the Greek delegation's motive in submitting this proposal was transparent. Equally transparent were the motives of the Soviet Bloc, who opposed the provision in order to protect the position of their child-stealing allies. In defending the amendment, Mr. Valindas (Greece) argued that the forcible transfer of children "was not primarily an act of cultural genocide. Although it in certain cases could be considered as such, it could be perpetrated rather with the intent to destroy or to cause serious physical harm to the members of the group." ${ }^{" 45}$ Later he modified this position, arguing "It was not connected with cultural genocide, but with the destruction of a group - with physical genocide." ${ }^{\$ 46}$ Mr. Maktos (United States), a child of Greek immigrants, observed that the cultural genocide provision was "concerned with cultural elements such as language, religion and monuments, and he found it difficult to see how the transfer of children could fit into that context." ${ }^{447} \mathrm{He}$ "ask[ed] the Committee to consider what difference there was from the point of view of the destruction of a group between measures to prevent birth half an hour before the birth and abduction half an hour after the birth. ${ }^{9448}$ In response to Mr. Pérez Perozo, he seemed to imply that by the fact of its incorporation into draft article 2, which he argued only addressed acts of physical and biological genocide, the act of forcibly transferring children had been washed of its cultural implications. However, this view was not widely shared, and

\footnotetext{
${ }^{445}$ Sixth Committee Mtgs, supra note 315, 82nd Mtg, UN Doc. A/C.6/SR.82 at 188.

${ }^{446} \mathrm{Ibid}$. at 189.

${ }^{447} \mathrm{Ibid}$. at 190. Mr. Manini Y Ríos (Uruguay), who also opposed the cultural genocide provision, reasoned that "[s]ince measures to prevent births had been condemned, there was reason also to condemn measures intended to destroy a new generation through abducting infants, forcing them to change their religion and educating them to become enemies of their own people." (Ibid. at 187.)

${ }^{448}$ Ibid. at 187.
} 
delegates on all sides of these questions expressed the view that this act had clear cultural implications. $^{449}$

Gorges Kaeckenbeeck, representing Belgium, came to the committee with substantial experience in the practical application of international law to minorities issues. From 1922 to 1937, he had played an important role in implementing the League of Nations minorities protections as President of the Arbitral Tribunal of Upper Silesia and in 1942 had published an influential book drawing on these experiences. ${ }^{450} \mathrm{Mr}$. Kackenbeeck raised some important questions about the implementation of the forcible child transfer provision and revealed fissures within the overall conception of genocide. He "feared that, although the Greek amendment covered a very important point, its inclusion would give unduly broad scope to the convention and hamper its practical application. Transfers of population did not necessarily mean the physical destruction of a group." ${ }^{451} \mathrm{He}$ abstained from voting on the provision because "[t]he text was too vague and future interpretations of it would be all the

\footnotetext{
${ }^{449} \mathrm{Ibid}$. at 189 . Maktos stated that "[e]ven if it were subsequently decided to include cultural genocide in the convention, a judge considering a case of forced transfer of children would still have to decide whether or not physical genocide were involved." Mr. de Beus (Netherlands) felt the wording was "too vague" and questioned "whether forced transfer necessarily meant mass transfer" and "whether the forcible transfer of children to schools of a different language of religion constituted genocide" (ibid.); Prince Wan Waithayakon (Siam) also "felt that the draft text was unsatisfactory; it should have been stated that the transfer of children must involve their complete absorption by a new group with the resultant loss of their former identity." (Ibid. at 190.) Mr. Bartos (Yugoslavia) voted against the provision but "agree[d] that the forced transfer of individuals with a view to their assimilation into another group constituted cultural genocide." (Ibid. at 191.) Mr. Raafat (Egypt) and Mr. Zourek (Czechoslovakia) felt the provision implicated religious belief and should be considered together with Pakistan's proposed amendment (UN GAOR, Sixth Committee, 3rd Sess, "Pakistan: Amendment to Article III of the Draft Convention (E/794)" UN Doc A/C.6/229.) to the cultural genocide provision, which was intended to address forced religious conversions. (Sixth Committee Mtgs, supra note 315, 82nd Mtg, UN Doc. A/C.6/SR.82 at 188, 190.) Mr. Morozov (USSR), who supported the inclusion of cultural genocide but nonetheless opposed this measure, argued that because it concerned cultural genocide, it was inappropriate to consider the Greek amendment during the discussion of physical destruction. (Ibid. at 190.) Mr. Abdoh (Iran) felt the "amendment concerned cultural as well as physical genocide." (Ibid. at 189-90.)

${ }^{450}$ Georges Kaeckenbeeck, The International Experiment of Upper Silesia: A Study in the Working of the Upper Silesian Settlement 1922-1937 (Oxford: Oxford University Press, 1942).

${ }^{451}$ Sixth Committee Mtgs, supra note 315, 82nd Mtg, UN Doc. A/C.6/SR.82 at 188.
} 
more difficult." He asked, "[D]id the transfer have to be permanent? Did the children have to be destroyed? Could they be transferred for purely cultural or religious reasons?" $452 \mathrm{He}$ received no substantive response to these questions, the committee again opting for agreement over clarity. Despite these lingering questions, the committee adopted the provision by twenty votes to thirteen with thirteen abstentions. ${ }^{453}$

When it came time for the cultural genocide vote, Chairman Alfaro of Panama, an important Lemkin ally who nonetheless opposed the cultural genocide provision, brushed aside an Egyptian proposal to postpone the vote in light of the large number of absent delegations and, according to the summary record, "made it clear that the vote would concern only the question as to whether or not the convention would cover cultural genocide." ${ }^{" 454}$ That is, "[h]e put to the vote the exclusion of cultural genocide from the scope of the convention." ${ }^{455}$ As described in the summary records of the debate, "the Committee decided not to include provisions relating to cultural genocide in the convention." The vote was " 25 ... to 16 , with 4 abstentions, 13 delegations being absent during the vote ...."456

However, despite the chairman's broad declaration that the vote addressed "the exclusion of cultural genocide from the convention," it actually concerned only the deletion of certain acts deemed cultural genocide. This distinction is pivotal. As Mr. Pérez Perozo,

\footnotetext{
${ }^{452} \mathrm{Ibid}$. at 191.

${ }^{453} \mathrm{Ibid}$. at 190.

${ }^{454}$ Sixth Committee Mtgs, supra note 315, 83rd Mtg, UN Doc A/C.6/SR.83 at 206.

${ }^{455}$ Ibid.

${ }^{456} \mathrm{Ibid}$. In favour: Union of South Africa, United Kingdom, United States of America, Australia, Belgium, Bolivia, Brazil, Canada, Chile, Denmark, Dominican Republic, France, Greece, India, Iran, Liberia, Luxembourg, Netherlands, New Zealand, Norway, Panama, Siam, Sweden, Turkey. Against: USSR, Yugoslavia, Byelorussian Soviet Socialist Republic, China, Czechoslovakia, Ecuador, Egypt, Ethiopia, Lebanon, Mexico, Pakistan, Philippines, Poland, Saudi Arabia, Syria, Ukrainian Soviet Socialist Republic. Abstaining: Venezuela, Afghanistan, Argentina, and Cuba.
} 
Mr. Fitzmaurice, and Sardar Bahadur Kahn had pointed out, several of the acts already

prohibited by article 2 had clear cultural implications, and the Convention contained no

limiting language. ${ }^{457}$ Certainly, this was the view of Lemkin, who, after the vote, reassured

himself that the Convention continued to protect a group's cultural existence. ${ }^{458}$

To Lemkin, the deleted article 3 of the Ad Hoc Committee draft "meant the

destruction of the cultural pattern of a group, such as the language, the traditions,

monuments, archives, libraries, and churches. In brief: the shrines of a nation's soul." 459 To

Lemkin, the loss was significant, but did not disable the Convention. The night after the

cultural genocide vote, he "talked things over with [himself] in the following way: Some

elements of cultural genocide were included, such as kidnapping of children. Moreover, the

destruction of a group entails the annihilation of its cultural heritage or the interruption to the

cultural contributions coming from the group." 460 Thus, despite the vote, Lemkin reassured

\footnotetext{
${ }^{457}$ See United Nations, Rules of Procedure of the General Assembly UN GAOR (1947) UN Doc. A/520, Rule 97. The rules do grant a committee chairman "the right to speak, put question and announce decisions," and provide that "[t]he Chairman and the Rapporteur of a committee ... may be accorded precedence for the purpose of explaining the conclusion arrived at by their committee or sub-committee." (Ibid. rule 100.) But, as Mr. Kerno pointed out in the Sixth Committee debates, votes are taken on terms used, not on an individual's interpretation of those terms. (Comments of Mr. Kerno, Assistant Secretary-General in charge of the Legal Department, Sixth Committee Mtgs, supra note 315, 77th Mtg, UN Doc A/C.6/ SR.77 at 134, discussing the Venezuelan proposal to add the words "as such" to article 2.) And, while the unopposed statement of a chairman can be accorded significant weight in the interpretation of preparatory work, the chairman's statements were not unopposed. (Lauterpacht, "Some Observations," supra note 239.) For these reasons, it cannot be said that the Sixth Committee voted to exclude "cultural genocide from the convention," as the chairman declared, but merely that it voted against including the broad and shallow prohibitions of draft article 3 , which prohibited restrictions on language use and publications, destroying cultural edifices, and other acts "committed with intent to destroy the language, religion, or culture of a" protected group. The only conclusion properly drawn from this vote is that a majority of the delegates who were present believed this provision did not belong in the Genocide Convention.

${ }^{458}$ Lemkin, Totally Unofficial, supra note 192 at 173.

${ }^{459}$ Ibid. at 172.

${ }^{460} \mathrm{Ibid}$. at 173 .
} 
himself that cultural protections were inherent to the Genocide Convention - that its other provisions guaranteeing the right to group existence would protect its soul, if not its shrines.

\section{The Sixth Committee Wraps Up}

On December 1, 1948, after two-and-a-half months of argument, the Sixth Committee voted to approve the draft convention with thirty in favour, none against, and eight abstaining. ${ }^{461}$ In sharp contrast to the final days of the Ad Hoc Committee proceedings, the Sixth Committee ended on a dour note. The delegates avoided laudatory statements and chose to focus not on their contribution to international law but on the many ways their convention fell short, especially on what they felt were its many omissions and ambiguities.

In abstaining from the vote, Britain found itself in the uncomfortable company of the Byelorussian Soviet Socialist Republic, Czechoslovakia, Poland, the Ukrainian Soviet Socialist Republic, the Union of South Africa, the USSR, and Yugoslavia. The British delegate, Mr. Fitzmaurice, explained "that the United Kingdom ... while forcibly condemning genocide as a crime, had considered it preferable not to go beyond ..." UNGA Resolution 96(1). His government "had always doubted the possibility of concluding a satisfactory convention on the matter and of effectively carrying out such a convention, if and when concluded." ${ }^{462}$ Mr. Litauer (Poland) argued that "the definition of genocide should

\footnotetext{
${ }^{461}$ Sixth Committee Mtgs, supra note 315, 132nd Mtg, UN Doc A/C.6/SR.132 at 701. Those voting in favour: Burma, Canada, Chile, China, Colombia, Cuba, Denmark, the Dominican Republic, Egypt, France, Greece, India, Luxembourg, Mexico, the Netherlands, New Zealand, Norway, Peru, Siam, Sweden, Syria, the United States, Uruguay, Venezuela, Afghanistan, Argentina, Australia, Belgium, Bolivia, Brazil.

${ }^{462} \mathrm{Ibid}$. at 701. His government believed that "the question had been approached from the wrong angle. The convention dealt almost entirely with the responsibility of individuals and the prevention and punishment of acts of genocide committed by individuals; whereas the only serious cases of genocide likely to occur would be committed by Governments themselves or with the active complicity or deliberate tolerance of Governments." Despite these concerns, he indicated there was nothing in the convention that would prevent his country from signing and ratifying it. (Ibid. at 702.)
} 
include the odious crimes aimed at the destruction of a nation's art and culture" and that in rejecting this and other provisions that Poland had supported, "the majority of the Committee had merely succeeded in reducing the scope of the convention to a considerable extent." ${ }^{\prime 463}$ Mr. Morozov (USSR) believed "there was ... no doubt that the convention was imperfect in very many respects...." ${ }^{464} \mathrm{He}$ explained that the USSR had abstained because the draft convention omitted a number of important points and indicated his delegation would "submit several amendments to the draft when it came up for debate ..." in the General Assembly. ${ }^{465}$ Mr. Gross (United States) indicated "that his delegation was deeply disturbed by the fact that the draft convention had not received the unanimous approval of the Sixth Committee." ${ }^{466} \mathrm{He}$ expressed his hope "that all the members of the Committee would unite in their efforts to ensure that the convention, which no one considered perfect, but which nevertheless represented the best possible compromise, would receive the unanimous approval of all the Members of the United Nations." ${ }^{\prime 467}$

Even among the Convention's strongest supporters, enthusiasm for their accomplishment was tempered by a realization of the draft convention's imperfections. Mr.

\footnotetext{
${ }^{463}$ Sixth Committee Mtgs, supra note 315, 133rd Mtg, UN Doc A/C.6/SR.133 at 706. See also comments of Mr. Augenthaler (Czechoslovakia). His "delegation had always been in favour of a really effective convention. It feared, however, that the text adopted by the Committee did not ensure the prevention of genocide." (Ibid. at 710.) Similarly, among his several objections to the draft, the Yugoslavian delegate "could not understand how the majority of the Committee could have refused to mention cultural genocide in the convention; cultural genocide was as much a reality as the physical annihilation of human groups, and its effects were just as destructive." (Comments of Mr. Kacijan ibid. at 707-08.)

${ }^{464}$ Sixth Committee Mtgs, supra note 315, 129th Mtg, UN Doc A/C.6/SR.129 at 481.

${ }^{465}$ Sixth Committee Mtgs, supra note 315, 133rd Mtg, UN Doc A/C.6/SR.133 at 704.

${ }^{466}$ Ibid.

${ }^{467}$ Ibid. To which Mr. Mrozov (USSR) replied "that the United States representative had acted contrary to the rules of procedure in criticizing the attitude of the USSR delegation and giving it a tendentious interpretation ...." (Ibid. at 705.)
} 
Ti-sun (China) believed the draft convention "was neither complete nor effective; it was not sufficient to ensure the punishment of the heinous crime of genocide." "For instance, it made no mention whatsoever of deliberate acts committed with the intent of destroying the language or the culture ..." of a protected group. ${ }^{468} \mathrm{He}$ found it "impossible to hope that the convention would receive the support of all fifty-eight Member States of the United Nations ...." ${ }^{469}$ Mr. Maúrtua (Peru) explained that "[h]e had voted in favour of the draft convention although it did not come up to all the expectations of the Peruvian delegation." ${ }^{470}$

Earlier, Mr. Chaumont (France) "said that the convention seemed to have become mainly theoretical, and he regretted that the articles so far adopted were not likely to prove very effective." ${ }^{\prime \prime 11}$ And Mr. Maktos (United States) argued "that what was important was not to draft a theoretically perfect document, but to secure the greatest number of accessions to the convention." ${ }^{\prime 472}$ Fittingly, the final statement made during the Sixth Committee's deliberations on genocide came from Mr. Kerno (Assistant Secretary-General in charge of the Legal Department) who reassured nervous delegates that

[i]f differences of opinion arose in respect of any provision, the International Court of Justice would be the competent organ to give an interpretation of the text. If the text were ambiguous, the Court would no doubt consult the records of the discussion which had taken place on the text concerned. He stressed the fact, however, that that was only a secondary method of arriving at an interpretation: if the text were

\footnotetext{
${ }^{468}$ Sixth Committee Mtgs, supra note 315, 133rd Mtg, UN Doc A/C.6/SR.133 at 709.

${ }^{469}$ Sixth Committee Mtgs, supra note 315, 130th Mtg, UN Doc A/C.6/SR.130 at 678.

${ }^{470}$ Sixth Committee Mtgs, supra note 315, 133rd Mtg, UN Doc A/C.6/SR.133 at 710. See also comments of Mr. Amadao (Brazil) expressing "his satisfaction with the text of the draft convention," especially the rejection of political groups and the exclusion of cultural genocide. (Ibid. at 708-09.); Mr. Raafat (Egypt) pointing out that his country had been one of the initial sponsors of the effort against genocide, but arguing that "the draft convention had certain gaps, the main ones being the absence of cultural genocide . . . and the omission of an international criminal court ...." (Ibid. at 707.)

${ }^{471}$ Sixth Committee Mtgs, supra note 315, 107th Mtg, UN Doc A/C.6/SR.107 at 476.

${ }^{472}$ Sixth Committee Mtgs, supra note 315, 105th Mtg, UN Doc A/C.6/SR.105 at 460.
} 
unambiguous, the Court would base its opinion on an interpretation of the text according to the accepted principles of international law. ${ }^{473}$

Thus, the debates ended with Mr. Kerno telling the delegates who had become anxious about the ambiguity of their work that the ICJ would sort out their convention and would do so responsibly, according to accepted principles of international law.

\section{The Plenary Sessions}

The controversy over cultural genocide emerged again as an issue in two plenary sessions during which the General Assembly debated and approved the Genocide Convention. ${ }^{474} \mathrm{Mr}$. Morozov criticized the draft convention on a number of grounds, including its lack of a provision addressing cultural genocide,

which was defined as the sum total of premeditated action to destroy the religion, culture, or language of a national, racial or religious group. It included, for example, such acts as prohibiting the use of a national language and publication of books or newspapers in that language, the destruction of libraries, museums, schools, places of worship, and, generally speaking, the destruction of every building serving a cultural purpose. $" 475$

Speaking next, Mr. Pérez Perozo (Venezuela) addressed a Venezuelan proposal that "would have added '(f) Systematic destruction of religious edifices schools or libraries of the group"” to the acts prohibited in Article 2 of the Genocide Convention. ${ }^{476} \mathrm{He}$ also "pointed out that

\footnotetext{
${ }^{473}$ Sixth Committee Mtgs, supra note 315, 134th Mtg, UN Doc A/C.6/SR.134 at 718.

${ }^{474}$ UN GAOR, 3d Sess, 178th \& 179th Plen Mtgs, UN Docs A/PV.178, A/PV.179 (1948) [UNGA Plen Mtgs]; Genocide: Draft Convention and Report of the Economic and Social Council: Report of the Sixth Committee, J. Spiropoulos, Rapporteur, UN GAOR, 3rd Sess, UN Docs. A/760 \& A/760/Corr.2 (1948).
}

${ }^{475}$ Ibid. 178th Mtg, UN Doc A/PV.178 at 813-14: "Mr. Morozov feared that unless some provision regarding cultural genocide were included in the convention, some rulers who oppressed minorities might take advantage of its absence to justify crimes of genocide." See USSR: Amendment to the Draft Convention on the Prevention and Punishment of Genocide Proposed by the Sixth Committee (A/760), UN GAOR, 3rd Sess, UN Doc A/766 (1948) (proposed Soviet amendments).

${ }^{476}$ Ibid. 178th Mtg at 815-17; Venezuela: Amendment to the Draft Convention on the Prevention and Punishment of Genocide Proposed by the Sixth Committee (A/760), UN GAOR, 3rd Sess, UN Doc A/770 (1948). He stated, "The Sixth Committee had not succeeded in finding a very satisfactory phrasing for" the cultural genocide provision. He believed "[t]he article had been made up of very varied elements and had, 
logically the Venezuelan amendment should go after the sub-paragraph on 'forcibly

transferring children ...' [which] was not physical genocide because the children were not destroyed but were torn from one group and incorporated in another." ${ }^{477}$

In a lengthy and important speech on cultural genocide, Mrs. Ikramullah (Pakistan)

expressed "her great satisfaction at the completion of the draft convention," but

expressed her regret ... that no mention had been made against crimes committed against the culture of a people of a human group. It must be realized that very often a people did not differ from its neighbours by its racial characteristics but by its spiritual heritage. To deprive a human group of its separate culture could thus destroy its individuality as completely as physical annihilation.

...

To safeguard the physical existence of a group of human beings was a considerable achievement from a humanitarian point of view. But the mere physical existence of a group was of little value from the point of view of humanity, for a group deprived of the living springs of the spirit was only a body without a soul, unable to make any contribution to the world's heritage of art and science. It was an accepted principle that diversity of spiritual endowments was of great value to the human race and that every effort should be made to safeguard it. ${ }^{478}$

moreover, been couched in terms likely to cause confusion." He continued, pointing out that UNGA Resolution 96(1) "stressed the fact that genocide resulted in great loss to the cultural and spiritual life of humanity. There had been a desire to punish all forms of the crime of genocide, not merely its physical aspect. A human group might, however, be destroyed not only by the physical extermination of its members, but also by acts which prevented it from maintaining its communal existence even if its members continued to exist physically." $\mathrm{He}$ argued that " $[\mathrm{t}]$ he problem of cultural genocide was different from that of the protection of minorities." $\mathrm{He}$ lamented that "[if] the General Assembly refused to include ... the factors mentioned in the Venezuelan amendment, it would disappoint the hopes of some delegations who wished to condemn all forms of genocide and, in particular, cultural genocide."

${ }^{477}$ UNGA Plen Mtgs, supra note 474, 178th Plen Mtg, UN Doc A/PV.178 at 816-17.

${ }^{478} \mathrm{Ibid}$. at 818 . She continued,

It was obvious that the convention on genocide should not be restricted to safeguarding the physical existence of human groups, because resolution 96(1) had declared that "denial of the right of existence of entire human groups ... results in great losses to humanity in the form of cultural and other contributions represented by these human groups and is contrary to the moral law and to the spirit and aims of the United Nations." It was clear that the resolution definitely envisaged the prevention of genocide in the cultural field, as in other fields.

The Pakistan delegation recognized that the original text of article III had provided too wide a definition of cultural genocide and that it would therefore have been difficult to bring the offences enumerated in it before the courts. The delegation had, therefore, submitted an amendment (A/C.6/229) which narrowed cultural genocide to two specific crimes - forcible mass conversion of persons and the destruction of religious edifices. 
Echoing Sardar Bahadur Kahn's statement to the Sixth Committee, ${ }^{479}$ Mrs. Ikramullah

continued,

It had been argued that such acts, heinous though they might be, were not so outrageous as physical genocide. It might be that some people regarded the destruction of religious edifices as a thing of little importance, but, for the majority of Eastern peoples, such an act was a matter of grave concern. In that part of the world, a far greater value was placed upon things of the spirit than upon mere material existence. Religious monuments were a source of inspiration to those peoples and a symbol of their spiritual personality. ${ }^{480}$

...

It had also been suggested that the problem should be dealt with either in the declaration of human rights or in a possible charter on the protection of minorities. Such a view showed a complete failure to understand the real aim of the convention on genocide. The convention was not designed to proclaim rights but to punish certain crimes.

$\cdots$

It seemed that at a certain stage of the discussion, the moral aspect of the problem had been overlooked in a welter of legal considerations. It was undoubtedly true that great legal difficulties were involved in the question of genocide. Once the gravity and heinousness of the crime of genocide had been recognized, however, efforts must be made to find a legal means of preventing it, and the difficulties which existed under the present legal systems must not be allowet [sic] to impede progress. ${ }^{481}$

${ }^{479}$ See above, text accompanying notes 234-235. Sixth Committee Mtgs, supra note 315, 83rd Mtg, UN Doc A/C.6/SR83 at 193-94.

${ }^{480} \mathrm{Ibid}$. at 818-19. She continued, stating,

It was regrettable that the peoples who had most enriched world culture belonged, in general, to small groups, and were in most cases, of no political importance. As they could not defend their spiritual heritage by force of arms, they were obliged to appeal to the community of nations to preserve that precious heritage.

The Pakistani representative wished to reassure all those who feared that such a provision would prove to be an obstacle to the normal process of assimilation into the national community. There was no question of that, but rather of the forcible and systematic suppression of a national culture, which could not be covered by the euphemistic term of assimilation.

${ }^{481} \mathrm{Ibid}$. at 817-19. See also comments of Mr. Khomoussko (BSSR) (Ibid. at 830-31.):

It was important to define any step intended to suppress a language, a culture or a religion, or to destroy libraries, museums, schools or national monuments as a crime under common law. Experience of hitlerism [sic] had shown that such barbaric acts constituted some of the elements of racial or national persecution, aimed at the extermination of certain groups of the population, and were consequently a form of the crime of genocide.

For the Bielorussion $[s i c]$ people, genocide was a not a theoretical or juridical issue. The Byelorussian people would never forget the crimes committed by the Nazis during their occupation of its 
Mr. Gross (United States) responded that UNGA Resolution 96(1) “defined the crime of genocide as the destruction of entire human groups, in contrast with homicide, which was the physical destruction of an individual. However, barbarous and unpardonable it might be, the destruction of a church, a library or a school was in an entirely different category. That was a problem that concerned the fundamental human rights of the individual." ${ }^{482}$ Gross also criticized the Soviet move to amend the draft, arguing that each of the Soviet proposals had been debated and rejected by the Sixth Committee. ${ }^{483}$

In the ensuing, increasingly acrimonious, discussion, the issue of whether to reconsider these points eclipsed any discussion of their actual merit. ${ }^{444}$ Several delegations lamented the exclusion of the cultural genocide provisions from the final convention, ${ }^{485}$ but the Soviet proposals were voted down by wide margins. ${ }^{486}$ The Venezuelan delegation

territory. It knew that the destruction of cultural and national centres accompanied the mass destruction of people, cities and villages. The Germans had burned the Academy of Sciences, the State University, the State Library, the schools of medicine and law, the Ballet Theatre, the National Library, whose books had been plundered or destroyed, and over one thousand school buildings in the region of Minsk alone. They had tried to destroy those cultural centres in order better to enslave the Byelorussian people....

${ }^{482}$ Ibid. at 820-21.

483 Ibid.

${ }^{484}$ UNGA Plen Mtgs, supra note 474.

${ }^{485}$ Mr. Raafat of Egypt (Ibid. 178th Plen Mtg, UN Doc A/PV.178 at 828-29 at 843) obliquely linked cultural genocide to occurrences in Israel/Palestine as he advocated inclusion. See also comments of Mr. Katz-Suchy of Poland (Ibid. 179th Plen Mtg, UN Doc A/PV.179 at 842), who also spoke of Nazi crimes committed in his country as he criticized the exclusion of "cultural genocide, which could be as destructive to the life of a nation as physical extermination."

${ }^{486}$ UNGA Plen Mtgs, supra note 474, 179th Plen. Mtg, UN Doc A/PV.179 at 847. Fourteen in favour, 31 against, with ten abstentions. The Soviet proposal was broad reading:

In this Convention genocide also means any deliberate act committed with intent to destroy the language, religion or culture of a national, racial or religious group on grounds of national or racial origin, or religious beliefs such as: (a) Prohibiting the use of language of the group in daily intercourse or in schools or the printing and circulation of publications in the language of the group: (b) Destroying or preventing the use of libraries, museums, schools, historical monuments, places of worship or other cultural institutions and objects of the group. (Ibid.) 
withdrew its proposal after comments from other delegations convinced them it would not pass. ${ }^{487}$ On December 9, 1948, the delegates unanimously ratified the Genocide Convention, which contained no reference to cultural genocide. ${ }^{488}$

\section{Conclusion}

The many months of feverish activity leading up to ratification left Lemkin spent. He was taken to the American Hospital in Paris, where his biographer recounts, "He . . seems to have been suffering from exhaustion and a nervous breakdown of some kind." ${ }^{489} \mathrm{He}$ was nevertheless triumphant as his concept, defined only four years prior, had been enshrined as a cornerstone of the postwar era's new international legal order.

Lemkin had had to trade the cultural genocide provision for the overall success of the treaty. In a pivotal moment, one that would undeniably shape the Genocide Convention, the Sixth Committee delegates rejected draft article 3, which prohibited acts directed against group language use, publications, and the cultural edifices of a protected group. ${ }^{490}$ Some delegates felt these acts were minor when compared to mass killing and the Genocide Convention's other prohibited acts, while others found the proposals vague or overbroad. Nevertheless, as Lemkin recognized, the Convention retained important protections for a group's existence through culture, including Article 2(e)'s prohibition on forcibly transferring children.

\footnotetext{
${ }^{487}$ Ibid.at $846-47$.

${ }^{488}$ See Adoption of the Convention on the Prevention and Punishment of the Crime of Genocide, GA Res 260 (III), UN GAOR, 3rd Sess, UN Doc A/Res/3/260 (1948).

${ }^{489}$ Cooper, supra note 192 at 172.

${ }^{490}$ Sixth Committee Mtgs, supra note 315, 83rd Mtg, UN Doc A/C.6/SR.83 at 206; Ad Hoc Committee Draft, supra note 303 , art 3.
} 
Lemkin's assessment is interesting in that it seems to reflect the duality inherent in mid-century meanings of "culture." At mid-century, the idea of culture connoted both "high culture"- a goal someone strives to develop and a group's best artistic and intellectual achievements - and culture in the anthropological sense, meaning a group's ways of life and patterns of thought and belief, which develop over time and are passed on through learning. ${ }^{491}$

This distinction helps understand how Lemkin and many of his contemporaries could believe that the deletion of the cultural genocide provisions might sacrifice a nation's shrines but still protect its soul. A nation's shrines - its libraries, places of worship, newspapers, and such — would not be protected by the Genocide Convention. However, its soul, the very stuff through which cohered a group, would still be protected both explicitly in provisions such as article 2(e) and implicitly in the protection of groups "as such." The breadth of meanings within the notion of "culture" meant that one could argue it (high culture) had been excluded from the Convention and still believe culture (a group's life ways) was the Convention's central concern.

The ILC exclusion stance relies on the preparatory work but cites only differences between the draft conventions, specifically the elimination of article 3 of the Ad Hoc Committee draft. In a passage constituting the extent of its consideration of the preparatory work on the issue of cultural genocide, the ILC stated,

It is true that the 1947 draft Convention prepared by the Secretary-General . . and the 1948 draft ... prepared by the Ad Hoc Committee on Genocide contained provisions on "cultural genocide" covering any deliberate act committed with the intent to destroy the language, religion or culture of a group.... However, the text of the Convention, as prepared by the Sixth Committee and adopted by the General

\footnotetext{
${ }^{491}$ See Marc Manganaro, Culture, 1922: The Emergence of a Concept (Princeton: Princeton University Press, 2002) at 2-3.
} 
Assembly, did not include the concept of "cultural genocide" contained in the two drafts and simply listed acts which come within the category of "physical" or "biological" genocide. The first three subparagraphs of [article 2] list acts of "physical genocide," while the last two list acts of biological genocide. ${ }^{492}$

From this difference in drafts, the ILC draws conclusions as expansive as they are unwarranted. ${ }^{493}$

The evidentiary burden falls to exclusionists, who must present evidence from the preparatory work sufficient to convincingly override the Genocide Convention's text. However, as I have shown, there is little in the preparatory work to evidence an alternative meaning. The question remains whether, as exclusionists argue, the preparatory work indicates that the delegates held some sort of background assumptions that are incompatible with a culturalist interpretation. Schabas states that " $[w]$ hile these questions were not specifically debated during the drafting of article II, the spirit of the discussions resists extending the concept of destruction beyond physical and biological acts." ${ }^{494}$ His approach, which would displace the clear and reasonable language of the Genocide Convention in favour of the "spirit of the discussions," has been persuasive with judges and scholars.

However, even when looking beyond specific votes to the discussion's "spirit," there is no overriding intent to exclude all cultural matters, nor is there evidence of an understanding among the delegates that genocide only meant material destruction. In fact, in

\footnotetext{
${ }^{492}$ Report of the International Law Commission on the Work of Its Forty-Eighth Session, [1996] 2 YB Intl L Comm'n 17, 45, UN Doc A/CN.4/SER.A/1996/Add.1 (Part 2).

${ }^{493} \mathrm{Ibid}$. at $45-46$. From the difference in drafts, the ILC has concluded that "the destruction in question is the material destruction of a group either by physical or biological means, not the destruction of the national, linguistic, religious, cultural or other identity of a particular group. The national or religious element and the racial or ethnic element are not taken into consideration in the definition of the word "destruction," which must be taken only in its material sense, its physical or biological sense." [footnotes omitted.]
}

${ }^{494}$ Schabas, Genocide 2d, supra note 263 at 271. 
voting against language that would have restricted genocide to acts "aimed at the physical destruction of the group" or that would have defined genocide as "an attack on life directed against a human group, or against an individual as a member of a human group, ${ }^{\$ 495}$ the delegates "specifically" rejected a narrow, "material" definition of genocide, choosing instead one that had clear cultural reach. Just as culturalists could not muster the support necessary to maintain specific protections against certain types of cultural attacks, materialists could not muster — nor did they necessarily desire — the complete excision of cultural considerations. As Lemkin and several of his contemporaries noted, the Sixth Committee vote cannot support exclusionist contentions that the drafters excluded all acts of cultural genocide or that they intended to exclude all instances of cultural destruction. The vote simply did not reach these matters.

In fact, the question of whether genocide should be considered only in its material form or if cultural concerns should play a role was very much a live issue throughout the debates. On one side were those like the United States and France, which mostly hewed toward individualism and generally favoured a materialistic definition of genocide. These materialistic philosophies fostered what Lemkin termed the American "belief that the Convention should proscribe only acts directed toward physical destruction of the designated groups themselves. ${ }^{~} 496$ On the other side stood those like the Pakistani delegation and Mr. Pérez Perozo (Venezuela) who took a more holistic view of human groups and generally favoured a more culturalist convention. Most delegations resided somewhere in between,

\footnotetext{
${ }^{495}$ Sixth Committee Mtgs, supra note 315, 73rd Mtg, UN Doc A/C.6/ AR. 73 at 91, comments of Mr. Chaumont, discussing France: Amendments to the Draft Convention, UNGA, Sixth Committee, 3rd Sess, UN Doc A/C.6/224 (1948).

${ }^{496}$ Anon, “Genocide: A Commentary on the Convention,” 58 Yale L. J. (1949) 1142, 45
} 
holding a hybrid conception of human groups that easily accommodated both culturalist and materialist concerns. Nonetheless, on the whole, it seems safe to say that an interpretive predisposition that obscures the Genocide Convention's ambiguity by reading its text through the materialist lens renders non-materialist voices silent. It allows the materialist viewpoint, which Lemkin had identified as the American belief, to achieve through interpretation what it could not gain through negotiation. 


\section{Chapter 5-A History of Exclusion}

See the trees lean to the wind's way of learning. See the dirt of the hills shape to the water's way of learning. See the lift of it all go the way the biggest wind and the strongest water want it. (Carl Sandburg, "Landscape"1)

The most dangerous side of the opposition is represented not by persons who fight the Convention openly, but by those who openly claim to be supporters while trying to defeat the Convention. (Raphael Lemkin²)

In December 1948, as the Convention on the Prevention and Punishment of the Crime of Genocide (Genocide Convention) was concluded, commentators noted that certain "acts of cultural genocide had been excluded from the Convention." ${ }^{3}$ This anodyne observation indicated only that certain acts intended to directly attack group cohesion— by preventing language use, destroying culturally significant edifices, and exiling important group members ${ }^{4}$ - had been voted out of the Convention. Over the intervening decades, however,

\footnotetext{
${ }^{1}$ Carl Sandburg, "Landscape," in The Complete Poems of Carl Sandburg, revised ed, (San Diego: Harcourt, 1970) at 423.

${ }^{2}$ Raphael Lemkin, untitled document beginning, "In his letter to the Times" (undated, but post-1951) New York, New York Public Library, Archives and Manuscripts, Raphael Lemkin Papers [NYPL] (Reel 3, File 3).

${ }^{3}$ Convention on the Prevention and Punishment of the Crime of Genocide, 9 December 1948, 78 U.N.T.S. 277 (entered into force 12 January 1951) [Genocide Convention]. See Louis B. Sohn, "The Development of International Law: United States Action in 1949 On Convention as to Genocide," 35:1 ABA J (1949) at 56. The Genocide Convention "does not take account of cultural genocide directed against the chief characteristics of a group, such as its distinctive language or religion, and involving the destruction of the cultural heritage of the group, of its books, arts, churches, historical monuments, etc." See also, Josef L. Kunz, "Present-Day Efforts at International Protection of Human Rights: A General Analytical and Critical Introduction" 45 Proceedings of the American Society of International Law at its Annual Meeting, 1921-1969 (26-28 April 1951) 109 at 111.
}

${ }^{4}$ See e.g. Draft Convention on the Crime of Genocide, UNESCOR, 3rd Sess, UN Doc E/447 (1948) at 27-28 [Secretariat's Draft]. In the section addressing cultural genocide, the Secretariat's Draft proposed prohibiting the following acts:

(a) Forced transfer of children to another human group;

(b) Forced and systematic exile of individuals representing the culture of a group;

(c) Prohibition of the use of national language even in private intercourse; 
this simple observation has morphed into a legal doctrine that excludes from the Genocide Convention's purview not only those original attacks on culture but any act intended to cause “cultural destruction.” Despite some significant criticism, exclusion has gained momentum and appears on the threshold of consolidating its status as customary international law.

This chapter documents the doctrine of exclusion's legal evolution, beginning with the Genocide Convention's conclusion in 1948 and continuing through the International Court of Justice's (ICJ) more recent decision in Croatia v. Serbia. ${ }^{5}$ However, even against this complex and evolving background, one intervention stands out. In its 1996 commentary on genocide, which was part of its formulation of a Draft Code of Crimes Against the Peace and Security of Mankind, the International Law Commission (ILC) commented in part that genocidal destruction is limited to "the material destruction of a group either by physical or biological means." ${ }^{16}$ Although framed as a restatement of existing law, the ILC's comments represented a significant expansion of the doctrine of exclusion, one that is contradicted by the text and history of the Genocide Convention, but one that has nevertheless found friends

(d) Systematic destruction of books printed in the national language, or of religious works, or prohibition of new publications;

(e) Systematic destruction of historical or religious monuments or their diversion to alien uses, destruction or dispersion of documents and objects of historical, artistic, or religious value, and objects used in religious worship.

${ }^{5}$ Case Concerning Application of the Convention on the Prevention and Punishment of the Crime of Genocide (Croatia v Serbia), Judgement, Preliminary Objections [2008] ICJ Rep 412 at 464-65 [Croatia v Serbia Preliminary Objections].

6 "Report of the International Law Commission on the Work of its Forty-Third Session" (UN Doc A/46/10) in Yearbook of the International Law Commission 1991, vol 2, part 2 (New York: UN, 1994) at 102 (UNDOC A/CN.4/SER.A/1991/Add.1). This language was carried over verbatim in the ILC's final formulation in Report of the International Law Commission on the Work of Its Forty-Eighth Session" (UN Doc A/51/10) in Yearbook of the International Law Commission 1996, vol 2, part 2 (New York: UN, 1998) at 45-46 (UNDOC A/CN.4/SER.A/1996/Add.1) [ILC, 1996 "Draft Code"]. The full statement can be found below, text accompanying note 120. See also, Jeffrey S. Morton, The International Law Commission of the United Nations (Columbia, SC: University of South Carolina Press, 2000) 41-53 (documenting the development of the draft code). 
among jurists and scholars. The effect of this doctrine has been to limit the Genocide Convention's scope and even the ways we think about genocide.

The doctrine of exclusion has been persuasive among those defenders of the Genocide Convention who would protect it from what they view as relatively trivial cultural matters. To them, genocide is "the crime of crimes," the most horrible act imaginable. To confuse genocide with issues of cultural protection will, they assert, rob its authority and render it ineffective against these truly horrific acts. But with friends like these, the Genocide Convention needs few enemies. By eliminating cultural concerns from the Convention, they have distorted and denuded it to the point where it has only a very limited scope and is almost never successfully prosecuted. Like Grandmother's china, they have made it too precious to be useful.

In this chapter, I chart the abandonment of the original idea of genocide in favour of the exclusion doctrine's distorted caricature. I begin by laying out Lemkin's fervent opposition to the ILC's draft code project. I track the emergence and growth of exclusion in the scholarly literature. I then point out that, as the draft code project was revived, the ILC incorporated and expanded the doctrine of exclusion. I address the ILC exclusion statement at length, revealing its inconsistencies and charting the more significant criticisms of it. Finally, I canvas the exclusion doctrine's more recent reception in national and international courts. Judicial application of exclusion has been uneven, often bordering on incoherence, and is more controversial than many commentators have recognized. 


\section{Communist Agents, Human Rights Activists, and the International Law}

\section{Commission}

Following the General Assembly's unanimous vote in favour of the Genocide Convention, Lemkin could have relented. He had achieved the type of victory many desire but few achieve. He could have used his status as father of the Genocide Convention to cement his place in legal academics or to garner a prestigious position in the rarefied field of international law. But he did not relent. Instead, he committed himself to securing the twenty ratifications required to bring the Convention into force, ${ }^{7}$ a process he called "climbing a mountain again," ${ }^{8}$ and defending the Convention from threats to its meaning and importance. These efforts left him penniless, often homeless, and increasingly friendless.

As I've documented above, Lemkin's “crusade” against genocide attracted enemies. Even its conclusion in 1948 and its entering into force on January 12, 1951, did little to dissuade these enemies. Southern United States senators and the American Bar Association threatened the Convention with irrelevance by opposing ratification. Human rights activists seemed intent on tying their project to the anti-genocide movement, thereby dooming both. ${ }^{9}$ And the Soviets and the British, eternal enemies, lurked in the background, taking any

\footnotetext{
${ }^{7}$ Genocide Convention, supra note 3, art. 13.

${ }^{8}$ Raphael Lemkin, Totally Unofficial: the Autobiography of Raphael Lemkin, Donna-Lee Frieze, ed, (New Haven: Yale University Press, 2013) at 180.

${ }^{9}$ See Eugene V. Rostow letter to Dean Acheson (23 March 1949) National Archives at College Park, College Park, MD [NACP] “501.BD Freedom of Information/1-149_501. BD Human Rights/12-346,” File No 501.BD Genocide, General Records of the Department of State Central Files Record Group 59). Rostow, a prominent legal scholar and colleague of Lemkin's at Yale Law School, warned the Secretary of State that the Senate's ratification of the Genocide Convention was "complicated . . . by the normal but petty ambitions and vanities of reformers with competing panaceas. Some of those who love the Declaration of Human Rights regard the Genocide Treaty as a rival for honor. That kind of business is always pathetic. Here it is worse."
} 
opportunity to weaken the Convention. But to Lemkin, there was no enemy more threatening than the ILC draft code project and its proponents. ${ }^{10}$

From the start, the ILC's draft code project threatened to undermine Lemkin's "crusade" against genocide. Even if the ILC were to actually produce a draft code, a task that ultimately took forty years to accomplish, Lemkin and his supporters worried the very presence of genocide in the code would doom the Convention by preempting it. Lemkin argued that "[b]y having included a mutilated definition of Genocide, the draft code will deprive the Genocide Convention of any field of application, and is meant to kill the Convention by putting it on ice."11 To Lemkin's consternation, the fates of these two documents - the draft code and the Genocide Convention-were entwined, the former used as a means of restricting the latter. Lemkin's fight to save the Genocide Convention turned into a crusade against the draft code.

Needing to put a face to the opposition, Lemkin turned on Vespasian Pella, an old friend, a co-author of the Secretariat's draft of the Genocide Convention, and an early booster of Lemkin's idea. ${ }^{12}$ According to Lemkin, the draft code project started when "Pella came on May 18, 1946 to the Nuremberg trials where he discussed with Mr. Francis Biddle and other

\footnotetext{
${ }^{10}$ See generally, Benjamin Ferencz, "An International Criminal Code and Court: Where They Stand and Where They're Going" 30 Colum. J. Transnat'l L (1992) 375. Rosemary Rayfuse, "The Draft Code of Crimes Against the Peace and Security of Mankind: Eating Disorders at the International Law Commission" 8 Crim LF (1997) 43 at 44-49, covering the draft code's drafting history.

${ }^{11}$ Letter: Raphael Lemkin to Gertrude Samuels (12 January 1948) New York, American Jewish Historical Society, Raphael Lemkin Collection [AJHS] (Box 1 folder 19).

${ }^{12}$ John Cooper, Raphael Lemkin and the Struggle for the Genocide Convention (New York: Palgrave Macmillan, 2008) at 194.
} 
judges of the International Military Tribunal, including the Soviet Judge, the question of codifying parts of the international penal law." 13

Biddle was impressed with the idea and, in his report on the tribunal to President Truman, argued that the time had come for the world to outlaw wars of aggression as part of "a general codification of offenses against the peace and security of mankind."14

Truman responded publicly that he hoped the UN would take up the task, adding that "[t]he setting up of such a code as ... you recommend is indeed an enormous undertaking, but it deserves to be studied and weighed by the best legal minds the world over."15

With US support, the draft code project commenced. ${ }^{16}$ Lemkin cautioned, "An opposition of minor importance might come from lawyers who would like now to codify all

${ }^{13}$ Lemkin, "Origin of the Draft Code of Offences Against Peace and Security of Mankind" (undated but postJune 1951) NYPL, supra note 2 (Reel 3, File 3 ) at 1.

${ }^{14}$ Francis Biddle, "Prosecution of Major Nazi War Criminals: Report to President Truman," in Department of State Bulletin vol 15 (24 November 1946) 954, 956-57. Biddle reported,

The time is . . opportune for advancing the proposal that the United Nations as a whole reaffirm the principles of the Nürnberg charter in the context of a general codification of offences against the peace and security of mankind. Such action would perpetuate the vital principle that war of aggression is the supreme crime. It would, in addition, afford an opportunity to strengthen the sanctions against lesser violations of international law and to utilize the experience of Nürnberg in the development of those permanent procedures and institutions upon which the effective enforcement of international law ultimately depends.

${ }^{15} \mathrm{Ibid}$. at 955. See also Lemkin, (untitled), which begins, "The S.U. is about to win ..." (undated) NYPL, supra note 2 (Reel 3, File 3). Lemkin complained that "Biddle opened for Pella all doors in Washington, including the State Department. Biddle soon enlisted for Pella's [project] the support [of] his colleagues at the Nuremberg Tribunal (with the exception of Justice Jackson, who remained opposed to this venture), but he won over Sir Hartley Shawcross, who was Attorney General in the Labor Government as well as the [French] judge," Donnedieu de Vabres. Lemkin continued, "All these gentlemen exercised great influence with their governments and they were [eager] to support the Pella ... proyect [sic] because in view of the criticism of the Nuremberg Judgment in certain circles they were happy to see confirmation of their work by the U.N."

${ }^{16}$ Establishment of an International Law Commission, GA Res 174 (II), UN GAOR, 2nd Sess, UN Doc A/Res/174(II) (1947); Formulation of the Principles Recognized in the Charter of Nürnberg Tribunal and in the Judgment of the Tribunal, GA Res 177 (II), UN GAOR, 2nd Sess, UN Doc A/Res/177(II) (1947). ILC was directed to

a) Formulate the principles of international law recognized in the Charter of the Nürnberg Tribunal and in the judgment of the Tribunal, and 
crimes of a certain international significance. They would prefer to play with such a job for several years and let the Genocide Convention await the result of their intellectual pursuits. Such point of view is most impractical and inacceptable." ${ }^{17}$

Lemkin was right. The British and the Soviets had already begun lobbying to have the matter of genocide addressed in the draft code as a way to obviate the need for a Genocide Convention..$^{18}$ On November 20, 1947, the UN Legal (Sixth) Committee approved a resolution incorporating a Soviet proposal requesting the General Assembly to direct the ECOSOC:

To study therewith the question of whether a convention on genocide is desirable and necessary, and if so, whether there should be a separate convention on genocide, or whether the question of genocide should be considered in connection with the drafting of a convention to include the principles of international law recognized in the Charter of the Nuremberg Tribunal and in the judgment of the Tribunal. ${ }^{19}$

To Lemkin, the proposed resolution represented a substantial step backwards: first, in questioning the need for a separate convention on genocide; and second, in proposing that genocide should be addressed in the draft code, which everyone recognized was a longer term project.

(b) Prepare a draft code of offences against the peace and security of mankind, indicating clearly the place to be accorded to the principles mentioned in sub-paragraph (a) above.

${ }^{17}$ See also Raphael Lemkin, "Memorandum on the Convention for the Prevention and Punishment of the Crime of Genocide" (undated but likely 1947) AJHS, supra note 11 (Box 6, File 2).

${ }^{18}$ See UN GAOR, Sixth Committee, 2nd Sess, 59th Mtg, UN Doc. A/C.6/SR.59 (1947), comments of Mr. Beckett (United Kingdom) at 166-67, and Mr. Durdenevsky (USSR) at 167.

${ }^{19}$ Draft Convention on Genocide: Report of the Economic and Social Council: Report of the Sixth Committee, 2nd Sess, UN Doc A/510 (1947) at 4 [emphasis added]. See also ibid. at 169-70; Draft Convention on Genocide: Amendments Submitted by the Delegation of the Union of Soviet Socialist Republics, UN GAOR, Sixth Committee, 2nd Sess, UN Do. A/C.6/201 (1947). 
Lemkin responded by organizing a firestorm of resistance during the next day's General Assembly meeting, where the British-Soviet move was widely attacked. ${ }^{20}$ Facing harsh criticism, the British delegate insisted that "genocide is so closely analogous to the crimes against humanity covered by the Nürnberg judgement that the best thing to do would be to send it to the International Law Commission, who have to codify the Nürnberg principles, and let them deal with genocide at the same time."21

The General Assembly responded to the British-Soviet initiative by adopting United Nations General Assembly (UNGA) Resolution 180(2), which requested that the ECOSOC continue the work it has begun concerning the suppression of the crime of genocide, including the study of the draft convention prepared by the Secretariat, and to proceed with the completion of a convention, taking into account that the International Law Commission, which will be set up in due course in accordance with General Assembly resolution 174(II) of 21 November 1947, has been charged with the formulation of the principles recognized in the Charter of the Nürnberg Tribunal, as well as the preparation of a draft code of offences against peace and security. ${ }^{22}$

Despite its compromise language, "taking into account" the draft code, UNGA Resolution 180(2) was a clear victory for Lemkin. Its direction "to proceed with the completion of a convention" served as an admonishment for those seeking to delay or undermine the Convention and indicated that genocide should be considered separately from the emerging concept of crimes against humanity. ${ }^{23}$ However, this skirmish had merely established the battle lines; Lemkin's war against the ILC was just beginning.

\footnotetext{
${ }^{20}$ See UN GAOR, 2nd Sess, 123rd Mtg, UN Doc. A/PV.123 (1947) at 1283-1307.

${ }^{21}$ See ibid. comments of Mr. Davies, United Kingdom at 1298-1300; ibid., comments of Mr. Durdenevsky, USSR, at 1301. The Soviet delegate responded by criticizing the Secretariat's Draft, which was then the only circulating draft of the Genocide Convention. (Secretariat's Draft, supra note 4.) He said the ECOSOC should not be bound by the Secretariat's Draft, which "was drafted by three specialists who, as is usually the case with professors, failed to reach agreement on a number of very important points."

${ }^{22}$ Draft Convention on Genocide, GA Res 180(II), 2nd Sess, UN Doc A/Res/180(II) (1947).

${ }^{23}$ Note by the Secretariat, Ad-Hoc Committee on Genocide, Relations between the Convention on Genocide on the One Hand and the Formulation of the Nurnberg Principles and the Preparation of a Draft Code of Offences
} 
In July 1948, as the Ad Hoc Committee continued its work, Lemkin warned of "a great danger that the international lawyers will try to shelve the convention to the International Law Commission which is to be created next year. They would like to use this dramatic and intellectually attractive issue in their work. We have to watch out against dangers because these gentlemen do not act openly." ${ }^{24}$ Lemkin's friend, James N. Rosenberg, Chairman of the United States Committee for a UN Convention on Genocide, argued that "[ $\mathrm{t}] \mathrm{o}$ let the genocide matter get to an International Law Commission will destroy all hopes of a convention. It will be nothing more than the repetition of the League of Nations which had an International Law Commission for something like twenty years and never

\footnotetext{
Against the Peace and Security on the Other UNESCOR (1948) UN Doc E/A.25/3/Rev.1. [Note by the Secretariat] arguing in UNGA Resolution 180(II) that the General Assembly "rejected the idea of simply considering genocide as one of the crimes against humanity mentioned by the Charter of the International Military Tribunal ...."

${ }^{24}$ Raphael Lemkin letter to Major John Ennals, Association des Nations Unies (17 July 1948) AJHS, supra note 11 (Box 1, File 19). See also Raphael Lemkin, "Memorandum on the Convention for the Prevention and Punishment of the Crime of Genocide" (undated) AJHS, supra note 11 (Box 6, File 2).
} 
accomplished anything." 25 Sending the matter of genocide to the ILC, he quipped, would doom it to death by "committeecide." 26

As the Cold War intensified and anti-communism swept the United States, Lemkin increasingly framed the draft code as a communist plot intended to defeat the Genocide

\footnotetext{
${ }^{25}$ James N. Rosenberg, to Honorable Charles Malik (15 July 1948) AJHS, supra note 11 (Box 2, File 9). See also, James N. Rosenberg to Major John A. F. Ennals, World Federation of United Nations association (23 July 1948) AJHS, supra note 11 (Box 2, File 9): "The danger is, as you know, that the whole subject may be referred to a committee of lawyers, or to the Human Rights Commission, or to some voluntary world conference, and any such course would shelve the matter and indefinitely postpone the convention for years." See also James N. Rosenberg, United States committee for a United Nations Genocide Convention, to Honorable Lewis W. Douglas (1 July 1948) NACP, supra note 9 (Box 2186 "501.BD Freedom of Information/1-149—501. BD Human Rights/12-346," File No 501.BD Genocide, General Records of the Department of State Central Files Record Group 59). See also James N. Rosenberg, The National Conference of Christians and Jews, Inc., to Honorable Robert A Lovett, Under Secretary of State, Department of State (2 June 1948) NACP, supra note 9 (Box 2186 “501.BD Freedom of Information/1-149-501. BD Human Rights/12-346,” File No 501.BD Genocide, General Records of the Department of State Central Files Record Group 59). Rosenberg wrote to the U.S. ambassador to Britain that
}

[r]eference of genocide to an International Law Commission, if is submitted, will be looked upon as spelling the doom of the Convention. Not only will no such Commission come into being until 1949 but it is clear that such a Commission cannot resolve the problems which are not on a mere legal but on a higher political level.

A like Commission existed for twenty years as part of the League of Nations. It accomplished nothing. This is bound to happen again if an international group of lawyers is empowered (as is proposed) to prepare a complete international "code of offences against peace and security." Surely if agreement cannot be formulated as to one clear-cut demand of the whole world - namely to outlaw genocide - an attempt, in a world torn by suspicions and controversies to codify all criminal law is and will be premature for many years ....

Most important of all, the drafting of a Genocide Convention is not a lawyer's but a statesman's problem,

for there are "difference[s] of political philosophies and aims which can be resolved only on a highly political level and not by lawyers or any lawyers commissions."

${ }^{26}$ Raphael Lemkin to James Rosenberg (13 September 1948) AJHS, supra note 11 (Box 1, Folder 19) at 3. 
Convention: ${ }^{27}$ "Who is doing the job for the Soviet Union?" ${ }^{28}$ Lemkin singled out

"Litvinoff- former Minister of Foreign Affairs of the Soviet Union and former delegate to

the League of Nations" whom Lemkin "credited with giving advice to his subordinates that if they could not achieve a certain goal in a political body of the League of Nations they should try a technical body which dealt with similar matters. ${ }^{29}$

Lemkin believed the Soviet plan to divert the matter of genocide to the ILC draft code was intended to dodge responsibility for recent and ongoing genocides in the USSR and in Soviet-dominated areas of Eastern Europe. By including genocide in the draft code, "the soviet delegation hoped to obtain impunity for her own crimes. Crimes against humanity ... are punishable only in execution of aggressive war." And while the Soviet Union had perpetrated acts of group destruction, "she was not technically an aggressor state."30 Therefore, according to Lemkin, under the draft code, the Soviets would escape culpability.

\footnotetext{
${ }^{27}$ Raphael Lemkin, “The Truth About the Genocide Convention” (undated) NYPL, supra note 2 (Reel 3, File 1) at 1: "The Genocide Convention became wrapped up in a spider web of misunderstanding, political intrigue and, believe it or not, communists [sic] subversion." He pegged the start of the draft code project to an infamous and incendiary speech delivered by Soviet Deputy Foreign Minister Andrei Vyshinsky to the UN General Assembly on September 23, 1947, wherein he assailed the British and United States governments for pursuing aggressive "war mongering" actions, and for failing to pursue a treaty outlawing atomic weapons. He argued that "[i]t was the duty of the United Nations, whose Charter proclaimed the determination of its Members to save succeeding generations from the scourge of war and to unite their strength to maintain international peace and security." (See UN GAOR, 4th Sess, 226th Plen Mtg, UN Doc A/PV.226 (1949) at 39.) See also Lemkin, "The Truth About the Genocide Convention" (undated) NYPL, supra note 2 (Reel 3, File 1) at 8. Lemkin believed that the fact that "the Soviet judge opposed the inclusion of genocide in the [Nuremberg] judgement" presaged the Soviet intent to displace the Genocide Convention.
}

${ }^{28}$ Raphael Lemkin, “The Truth About the Genocide Convention” (undated) NYPL, supra note 2 (Reel 3, File 1) at 9 .

${ }^{29} \mathrm{Ibid}$. at 9.

${ }^{30}$ Raphael Lemkin, "The Genocide Convention" (undated) NYPL, supra note 2 (Reel 3, File 1) at 5-6. See also Raphael Lemkin, (untitled) beginning "On January 12, 1951 . .." (undated, but post-1951) Cincinnati, The Jacob Rader Marcus Center of the American Jewish Archives, Raphael Lemkin Papers [AJA] (Box4, File 4) at 4. Lemkin argued that

[t]he Soviet Union is the only nation which now could be indicted for Genocide. She is destroying the captured nation behind the Iron Curtain by killing off national and religious leaders, by breaking up families through deportation and exile, by stealing children. The Soviet Union controls now some 
Lemkin warned that "Human Rights leaders were in touch with the proponents of the Soviet inspired Code of Offenses," and painted a "picture" in which due to

the combined efforts of Soviet agents and of Human Rights lobbyists of whom many are not aware of the implications of their attitude, the Soviet Union is winning a major battle in the United Nations and in the United States. Without interference the Soviet Union can continue to destroy nations and to exterminate religious groups. The Soviet plan of diverting attention from Soviet genocide and to concentrate the attention of the United Nations upon the negro problem in America will soon be crowned with success. ${ }^{31}$

Thus, Lemkin argued, the Soviets intended to use the draft code and the broader human rights movement both to escape liability and to indict the United States.

Lemkin believed the Soviets controlled Pella and used him to dupe human rights activists into conflating genocide and human rights and to incorporate both in the draft code.

He explained that

the Human Rights leaders were in touch with the proponents of the Soviet inspired Code of Offences. They worked hand in hand and obtained also the support of some officials of the U.N. Secretariat who were eager to promote these pllans [sic], either for political reasons, or for the purpose of increasing their sphere of activities and influence which would ensue from the eventual adoption of the Code of Offenses and the Covenant of Human Rights. ${ }^{32}$

hundred million foreign peoples which are Western-minded, profoundly religious and adhere to principles of democracy. They cannot be assimilated and therefore, they will have to be destroyed in part. Genocide thus appears to be a logical consequence of Soviet control of foreign populations, especially in Central and Northeastern Europe.

The Soviet delegation hopes that if Genocide will be included in this draft code nations will have an excuse for not ratifying the genocide convention. A considerable propaganda to this effect is carried out now by V. V. Pella through the intermediary of an international Federation of Jurists and his Association of Criminal Law which gives him contacts in many countries.

${ }^{31}$ Raphael Lemkin, "Memorandum on the Genocide Convention" (undated but post 1950) AJA, ibid. (Box 4, File 6) at 4.

${ }^{32} \mathrm{Ibid}$. at 3. See also Raphael Lemkin, "Memorandum on the Status of the Genocide Convention" (undated but post-April 1950) AJA, supra note 30 (Box 4, File 6):

Several influential persons who are identified with the United Nations Human Rights Project, tried to block the adoption of the Genocide Convention at the Paris Assembly. One of these leaders in the Human Rights movement has an especially great influence with the present Administration. The proponents of the Human Rights Covenant, which is still in the Drafting stage, are afraid that the Senate will not ratify both the Genocide Convention and the Covenant on Human Rights. They are holding up 
In a memo, Lemkin explained that because the Soviets could not scuttle the Genocide

Convention in 1947, "they turned to the help of a technical and less conspicuous body of the

$\mathrm{UN}$ - the international law commission. Their liaison man with this commission appeared to

be Professor Vespasian V. Pella."33

Lemkin's most strident attack on Pella commenced on April 20, 1948, when Drew

Pearson, a notorious muckraking columnist with the Washington Post, attacked Pella in his

syndicated column, “Washington Merry Go Round.” Pearson's column, entitled "Romanian

Wire-Puller," attacked Pella, asserting,

In a spacious house on Long Island, United Nations delegates are entertained by a mysterious Rumanian named Vespasien Palla [sic]. Dr. Palla [who] came to the United States on the Queen Elizabeth with his own car and chauffeur, now boasts two footmen.

How he does it with Rumanian currency under strict control is a mystery. Nevertheless, U.N. delegates are never without champagne and shashlik when they visit Palla's home.

Previously Dr. Palla was Rumanian Minister to Switzerland for the Fascist Antonescu Government which slaughtered 300,000 Jews, sent many of their bodies to the I. G. Farben Soap Factories.

However, Palla now serves the Communist Government of Rumania, is reported to be close to Anna Pauker, Red boss of Rumania. Despite this background, Palla obtained a visa to visit the U.S.A. and believe it or not is consulted by State Department officials on legal problems. Furthermore, he is the man believed to have engineered the sudden U.S. shift of policy regarding genocide - the massacre of human beings because of race, religion or culture.

$\cdot \cdot$

If Congress investigated, it might find some interesting backstage factors behind the operations of Rumania's Dr. Vespasien Palla. ${ }^{34}$

ratification of the Genocide Convention. The tragedy of the matter is that a citizens committee for ratification of the Genocide Convention is under control of the proponents of the Human Rights Covenant.

${ }^{33}$ Raphael Lemkin, memo (untitled, undated, but post 1951) AJA, supra note 30 (Box 4, file 4); Lemkin, "Origin of the Draft Code of Offenses Against Peace and Security of Mankind" (undated) NYPL, supra note 2 (Reel 3, File 3) at 2.

${ }^{34}$ Drew Pearson, "Mysterious Rumanian Entertains U.N. Delegates" (20 April 1948) online: American University Library Digital Research Archives < http://hdl.handle.net/1961/2041-22119>. See also letter to Drew Pearson (15 June 1949) AJHS, supra note 11 (Box 2, File 10) (unsigned but likely authored by Lemkin): "You 
The next day, Pella, apparently hurt and bewildered, pled his case to John Maktos at the State Department. ${ }^{35}$ Pella told Maktos that Lemkin had instigated the Pearson story. Pella presented a 1944 report by an organization of Rumanian Jews based in Israel detailing his efforts to save Jews during the war. He "told [Maktos] that far from being a Fascist who persecuted Jews, he saved about two million of them during the war." ${ }^{36}$

Lemkin must have realized his efforts to isolate Pella had failed when a week after the Pearson column, "[o]n April 29, at a dinner for the American Society of International Law, attended by Deputy Secretary of State Dean Rusk, diplomats and lawyers stood up and applauded when Pella was introduced." ${ }^{37}$ Coming so closely on the heels of the Pearson

may recall that you intervened once in the undercover fight over the genocide convention [sic], with great effect on our State Department. ... The issue now is ratification .... :

The fellow travelers of course are fighting it with every means at their disposal, for they know that a genocide treaty accepted as part of international law would be a powerful weapon for enquiring into the police methods of the Soviet Union and its satellites. While they do not dare oppose it openly, their technique now is to link genocide with the far more controversial human rights program, hoping to assure its defeat in the Senate. .. . Pella, Anna Panker's [sic] highly paid representative in the United States, is still active among legal groups organizing this tactic of smothering genocide with human rights.

${ }^{35}$ John Maktos, Memorandum of Conversation Subj: "Drew Pearson's article in his 'Merry-Go-Round" Regarding genocide" (21 April 1948) NACP, supra note 9 (Box 2186 "501.BD Freedom of Information/1149-501. BD Human Rights/12-346," File No 501.BD Genocide, General Records of the Department of State Central Files Record Group 59).

${ }^{36}$ John Maktos, Memorandum of Conversation Subj: "Drew Pearson's article in his 'Merry-Go-Round' Regarding genocide" (21 April 1948) NACP, supra note 9 (Box 2186 "501.BD Freedom of Information/1149-501. BD Human Rights/12-346," File No 501.BD Genocide, General Records of the Department of State Central Files Record Group 59). On Pella's actual, very mixed involvement with Nazis and Jews, see Mark Lewis, The Birth of the New Justice: The Internationalization of Crime and Punishment, 1919-1950 (Oxford: Oxford University Press, 2014) at 192-95.

${ }^{37}$ See also Drew Pearson, "Washington Merry Go Round" (22 Oct. 1949) online: American University Library Digital Research Archives < http://hdl.handle.net/1961/2041-22804>. Pearson doubled down the following year, under the heading "Strange Roumanian":

There is something peculiar about the way certain American diplomats and judicial experts have been hobnobbing with a Roumanian in New York who is the registered agent of one of Stalin's chief henchmen.

The Roumanian is Dr. Vespasien Palla [sic] who arrived in the U.S.A. with his own car and chauffeur, gives swank champagne parties on his Long Island estate, and is the official representative of Premier Pauka [sic] who runs Roumania for Stalin.

$\cdots$ 
column, this applause both affirmed Pella's place in the rarefied community of international lawyers and served as a sharp rebuke to Lemkin, who would remain on the outside.

Undeterred, Lemkin continued to blame all of the Genocide Convention's woes on Pella. ${ }^{38}$ Lemkin was "sure that the opposition to the convention has the following links. In the center is Pella who on the one hand keeps the contact with Baldwin and on the other hand with Finch. All the others are intermediate links." ${ }^{\prime 39}$ Thus, when George A. Finch, an influential international law scholar who had written the introduction to Axis Rule, turned against the Genocide Convention and influenced the American Bar Association to oppose United States ratification, Lemkin blamed Pella, because Finch "often sees Pella." Similarly, he also blamed Pella when he accused Roger Baldwin, founder of the American Civil Liberties Union, who in 1949 became Chairman of the US Committee for a Genocide Convention, ${ }^{41}$ of attempting to tie the Genocide Convention to the human rights movement in

But the amazing thing is that despite this direct hook-up with the Russian-Roumanian communists, Palla has ready access to American legal bigwigs and some diplomats.

Another amazing thing is that this mysterious gentleman is called upon for advice regarding the United Nations, though Roumania is not a member of the U.N. What information he sends back to Roumania is not known, nor would the FBI know, since he has access to the un-censored Roumaian diplomatic pouch.

${ }^{38}$ See US Department of State, Memorandum of Conversation: "Genocide Convention and Covenant of Haman Rights" (29 Jan. 1952) NACP, supra note 9 (Box 1342, 340.1-AJ/1-1452 to 340.1-AM/6-2050, General Records of the Department of State Central Files Record Group 59). Lemkin continues to blame "in particular ... Roger Baldwin and the League for the Rights of Man, Ex-minister Pella of Rumania, and Alvarez Del Vayo [whose efforts] were directed toward blocking the Genocide Convention in order to keep the way clear for a human rights covenant including genocide in its broad provisions. He intimated that Pella was subject to Communist influence...."

${ }^{39}$ Raphael Lemkin to The Reverend Edward A Conway (Associate ed., America) (19 Dec. 1949) AJHS, supra note 11 (Box 2, File 2).

${ }^{40}$ Ibid. See also George Finch, Editorial Comment “The Genocide Convention” 43 Am. J. Int'1 L. 732 (1949).

${ }^{41}$ Cooper, supra note 12 at 222. See also Robert C. Cottrell, Roger Nash Baldwin and the American Civil Liberties Union (Columbia University Press: New York, 2000) 326. Baldwin was a true impresario of the American Left. Friend to both Emma Goldman and high ranking State Department officials, he at that time headed the ACLU's international efforts, chaired the International League of the Rights of Man, was a trustee for the Robert Marshall Civil Liberties Trust, Co-Chairman of the Coordinating Committee of U.S. Agencies 
order to get "something for the civil rights program with which he is permanently

connected." 42

When the ILC's 1950 meetings began in Switzerland, Lemkin noted that its president, "Professor Manley Hudson of Harvard University, lived at that time in the apartment of Mr. Pella in Geneva." ${ }^{33}$ And he noted that "[s]ubsequently, the International Law Commission, presided over by Professor Hudson, requested Mr. Pella to prepare a memorandum on the draft code of offenses which was circulated as a document of the United Nations." ${ }^{44}$

A pioneer in the international criminal law movement, Pella had long advocated an international criminal code and an international court that could prosecute such crimes. ${ }^{45}$ Pella would have been an obvious resource for Jean Spiropoulos, who served as ILC Special Rapporteur charged with formulating the draft code, and who had previously represented Greece in the UN Sixth Committee as it compiled the Genocide Convention's final draft. Therefore, it is unsurprising that Spiropoulos and the ILC welcomed a lengthy memo by Pella outlining his thoughts on the draft code. ${ }^{46}$ To Pella, this would have seemed a long-

for Human Rights, on the national committee of the International Rescue and Relief Committee and was "for a brief spell" a member of the Overseers Committee for Harvard's Economics Department.

${ }^{42}$ Cooper, supra note 12 at 193.

${ }^{43}$ Lemkin, "Origin of the Draft Code of Offenses Against Peace and Security of Mankind" (undated but postJune 1951) NYPL, supra note 2 (Reel 3, File 3) at 2.

${ }^{44}$ Ibid.

${ }^{45}$ See Ivan S. Kerno, “In Memoriam: Vespasian V. Pella, 1897-1952” 46 Am. J. Int'1 L. (Oct., 1952) 709-10; Doudou Thiam, "First Report on the Draft Code of Offences Against the Peace and Security of Mankind" (UN Doc. A/CN.4/364) in Yearbook of the International Law Commission 1983 vol. II(1) (New York: UN, 1985) 137 at 139 (UNDOC. A/CN.4/SER.A/1983/Add.1 (part 1), documenting Pella's involvement with the movement for international criminal law beginning in 1924, including a draft international penal code published in 1935 (cited as Pella, "Plan d'un code répressif mondial," Revue international de droit penal (Paris), vol. 12 (1935), p. 348.).

${ }^{46}$ Vespasian Pella, "Mémorandum Présenté par le Secrétariat" (UN Doc. A/CN.4/39) in Yearbook of the International Law Commission 1950 vol. II (New York: UN, 1957) 281 at 351-52 (UNDOC.

A/CN.4/SER.A/Add.1) [Pella, Memo]. 
awaited fruition of his decades-long advocacy of an international criminal code, something for which he deserved accolades, not condemnation. No one but Lemkin would have found anything untoward about Pella's relationship with the ILC and its members. Moreover, such accusations seem especially hypocritical coming from Lemkin, who as a private individual had taken such an aggressive role in the Genocide Convention's drafting.

As it turns out, after years of vilification, Pella's report largely adopted Lemkin's thinking on genocide. In fact, Pella recommended that the draft code avoid incorporating the crime of genocide. ${ }^{47}$ Sounding very much like Lemkin, he argued that there were fundamental distinctions between genocide and crimes against humanity. He argued, first, that the Genocide Convention did not prohibit acts against political groups, while crimes against humanity would; second, that crimes against humanity are not necessarily directed at groups, while genocide is; and third, that genocide requires no connection with war, while crimes against humanity do. ${ }^{48}$ Moreover, he argued,

[i]t should not be forgotten that the resolution of the General Assembly on the formulation of the principles of Nuremberg and the preparation of the Code of Crimes against the peace and security of mankind, is quite independent of the resolution that was generating the Genocide Convention. That would, in our opinion, go against the decisions of the General Assembly. ${ }^{49}$

Thus, Pella argued that for substantive and procedural reasons, genocide should not be included in the draft code. It is difficult to conceive of a stance more amenable to Lemkin's arguments.

But the ILC did not heed Pella's advice on genocide. When the ILC first addressed the matter in Spiropoulos's first (1950) report, Lemkin was appalled. To Lemkin's horror,

\footnotetext{
${ }^{47} \mathrm{Ibid}$. at 351.

${ }^{48}$ Ibid.

${ }^{49} \mathrm{Ibid}$. (original in French, translated by Google).
} 
Spiropoulos had lumped genocide and crimes against humanity together under the heading

“Crime No. VII,” which read:

1. The commission of any of the following acts committed with the intent to destroy, in whole or in part, a national, ethnical, racial, or religious group as such:

(a) Killing members of the group.

(b) Causing serious bodily or mental harm to members of the group.

(c) Deliberately inflicting on the group conditions of life calculated to bring about its physical destruction in whole or in part.

(d) Imposing measures intended to prevent births within the group.

(e) Forcibly transferring children of the group to another group.

2. The commission of any of the following acts in so far as they are not covered by the foregoing paragraph:

Murder, extermination, enslavement, deportation and other inhuman acts done against a civilian population or persecutions on political, racial or religious grounds ... ${ }^{50}$

Spiropoulos pointed out that the first part of Crime VII was taken from the genocide

Convention, while the second paragraph incorporated article 6(c) (crimes against humanity)

of the Nuremberg Charter. He argued that the "distinction between these crimes is not easy to draw." 51 "That genocide cannot be omitted from the draft code should not be questioned, ..." he declared, but added that neither should crimes against humanity. ${ }^{52}$ Notably, both genocide and crimes against humanity were illegal in this first draft only, "when such acts are done or such persecutions are carried on in execution or in connexion with any crime against peace or war crimes as defined by the Charter of the International Military Tribunal." ${ }^{53}$ Thus,

\footnotetext{
${ }^{50}$ J. Spiropoulos, "Draft Code Against the Peace and Security of Mankind" (UN Doc A/CN.4/19 in Yearbook of the International Law Commission 1950 vol. II (New York: UN, 1957) 253 at 263 (UNDOC

A/CN.4/SER.A/Add.1) [Spiropoulos, First Report]. The commission was well-equipped to consider the matter of genocide. Spiropoulos had been the Greek delegate and Rapporteur to the Sixth Committee during its drafting of the Genocide Convention. He was joined on the commission by fellow Genocide Convention drafters Ricardo J. Alfaro (Panama) and Gilberto Amado (Brazil), as well as Assistant Secretary-General for legal matters, Ivan Kerno, who had also attended the Sixth Committee deliberations.

${ }^{51}$ Ibid.

${ }^{52}$ Ibid.

${ }^{53}$ Ibid.
} 
in lumping genocide together with crimes against humanity, Spriropoulos had required that, for international criminal liability to attach, the crime must be carried out in conjunction with aggressive war. Of course, this was a significant narrowing the of the Genocide Convention, which only confirmed Lemkin's darkest suspicions.

Upon receiving the report, the ILC discussed whether the draft code should incorporate the crime of genocide, mention the Genocide Convention in its preamble, or perhaps omit any mention of it. ${ }^{54}$ Spiropoulos, who seemed at times to adopt each of these positions, intimated that genocide and crimes against humanity are "to some extent interconnected ... He had tried to separate them provisionally." ${ }^{\text {55 }}$ At the end of the conversation, the Chairman "admitted that the discussion had been very confused and the Commission was still befogged." 56

Lemkin argued that the British had supported the Soviet move to introduce the definition of genocide "next to crimes against humanity from the Nuremberg judgement and the last sentence of crimes against humanity permits to consolidate these crimes with the crime of genocide and to subordinate both of them to the concept of aggression without defining the latter." ${ }^{57}$ Thus, Lemkin recognized, as Spiropoulos had intimated, that the placement of genocide and crimes against humanity in the same article of the draft code was the first step in a longer-term plot to completely incorporate the former into the latter. ${ }^{58}$

\footnotetext{
${ }^{54}$ UN GAOR, ILC, 59th Mtg, (UN Doc A/CN.4/SR.59) in in Yearbook of the International Law Commission 1951, vol 1 (New York: UN, 1958) at 139-44 (UNDOC, A/CN.4Ser.A/1950).

${ }^{55} \mathrm{Ibid}$. at 139 [emphasis added].

${ }^{56} \mathrm{Ibid}$. at 143.

${ }^{57}$ Raphael Lemkin, “The Genocide Convention" (undated) NYPL, supra note 2 (Reel 3, File 1) at 5-6.

${ }^{58}$ Raphael Lemkin, "Memorandum: On the Revision of the Genocide Convention" (undated) AJA, supra note 30 (Box 4, File 5). Lemkin identified this as part of a Soviet plan to evade responsibility for Katyn and their ongoing genocides against ethnic, religious, and national groups behind the Iron Curtain. These, after all, were
} 
Finally, Lemkin decried that the chapeau of Spiropoulos's paragraph 8 did not mention the term "genocide." It mentioned only "[a]cts committed with the intent to destroy, in whole or in part, a national, ethnical, racial or religious group as such ...." ${ }^{99}$ The ILC had omitted Lemkin's word, incurring his enduring wrath. ${ }^{60}$

In November 1950, Pella wrote Lemkin a lengthy letter pleading with him to stop attacking his reputation and threatening to sue Lemkin if he did not. He pointed to their friendship of twenty years, a time during which Pella had been Lemkin's loyal supporter. He denied serving Romania's wartime fascist government and pointed to his efforts to save Jews from Hitler. And he argued that he had always opposed including genocide in the draft code and did not share the ILC's views. He referenced Drew Pearson's column, for "whose inspiration [there] was not the shadow of a doubt." ${ }^{{ }^{61}}$ Pella ended the letter by asserting that he held documents to prove each of his points and that he intended to use them in an American court if Lemkin would not stop. ${ }^{62}$

acts of domestic oppression unrelated to warfare and so un-chargeable as either war crimes or crimes against humanity.

${ }^{59}$ Spiropoulos, First Report, supra note 50 at 263.

${ }^{60}$ Raphael Lemkin, "Memorandum on the Genocide Convention" (undated) AJA, supra note 30 (Box 4, file 6).

${ }^{61}$ Vespasian Pella to Raphael Lemkin (2 November 1950) AJA, supra note 30 (Box 2, File 11) (original in French, translation by Google).

${ }^{62}$ Ibid. See also, Paul Ginsberg to James Webb, Acting Secretary of State (13 November 1951), NACP, supra note 9 (Box 1341, 340.1-AJ/1-450 to 340.1-AJ/12-1951, General Records of the Department of State Central Files Record Group 59). Lemkin continued his public campaign against Pella and the draft code, recruiting supporters to besiege the State Department with complaints. On November 13, 1951, Paul Ginsberg, National Commander of the Jewish War Veterans of the United States of America, wrote that his members were disturbed

[t]hat much of this inspiration for the draft of this code was forthcoming from Vespasian V. Pella, former Rumanian minister to the United States. Mr. Pella's association with the Fascist Antonescu government of Rumania of World War II and his connection with the Rumanian Communist government during the post-war era are matters of record. That he has been given asylum here since a purported break with the Communist government of Rumania is deeply disturbing in light of the role he has played in the development of the code on "offenses against the peace and security of mankind." 
Although Lemkin's attack on Pella was largely dismissed, and despite the disdain with which the State Department increasingly treated him, Lemkin's efforts began to show some results. In May 1951, as the ILC met to discuss the second Spiropoulos draft, Ivan Kerno, who headed the UN Secretary-General's Legal Department, noted "that the mere fact that the Commission had, the year before, contemplated the inclusion in its Code of the crime of genocide, had given rise to criticism in certain quarters. It had been asserted that, including in the Code provisions from the Convention on Genocide, the intention had been to prejudice the Convention." ${ }^{63}$ He urged them to "consider whether it was advisable to make radical changes in the subject matter of the Convention." ${ }^{64}$ Mr. Cordova reported "that before he came to [the meeting] someone had mentioned to him that inclusion of the crime of genocide in the Code would affect the fate of the Convention. Certain countries would maintain that, since the crime of genocide had been incorporated in the Code, it was not necessary to ratify the Convention." ${ }^{95}$ Mr. Alfaro worried that even if they merely reproduced verbatim the text of the Genocide Convention, "[t]he result might be prejudicial to that instrument." Instead, he proposed that the draft code reference "[a]cts of genocide as defined in the Convention on Genocide" which "would leave the convention unimpaired." ${ }^{\prime 66}$ However, Mr. Amado argued that a criminal code must necessarily define the crimes it addresses and insisted the draft

See also Robert A. Baerwalde, Chariman, Stuben Society of America, National Council, "Brief in Reference to 'Report of the International Law Commission' of the United Nations Assembly" (19 July 1956), AJA , supra note 30 (Box 5, File 5), highlighting accusations that Pella manipulated Biddle in pursuit "of a Communist plan which has as its sole purpose the protection of their immense territorial conquests in the world."

${ }^{63}$ UN GAOR, ILC, (1951) 90th Mtg, (UN Doc A/CN.4/SR.90) in Yearbook of the International Law Commission 1951, vol 1 (New York: UN, 1957) 63 at 67 (UNDOC A/CN.4/SER.A/1951).

${ }^{64}$ Ibid.

${ }^{65}$ Ibid.

${ }^{66} \mathrm{Ibid}$. 
code should enumerate the crime of genocide. ${ }^{67}$ In the end, Mr. Amado's views carried the day, and the text of the Genocide Convention article 2 was incorporated, nearly verbatim, in the draft. ${ }^{68}$

Spiropoulos's second report separated genocide and crimes against humanity into two different subparagraphs. ${ }^{69}$ In doing so, it also freed genocide of the war nexus while loosening this element for crimes against humanity. ${ }^{70}$ Lemkin responded that the ILC had

${ }^{67}$ Ibid.

${ }^{68}$ See also ibid at 69. Interestingly, in its earliest consideration of this issue, the absence of prohibitions on acts against group culture were noted and lamented. Georges Scelle noted that the proposed draft code made no mention of cultural genocide: "If that omission was to be explained solely by the silence of the Convention on Genocide in regard to the matter, that reason was insufficient, and the Commission should not disregard one of the essential forms of genocide." He added that

[a]nyone conversant with the question of minorities would be astonished if the Commission disregarded that particular form of genocide, which was already covered in treaties on minorities and which might take the form of the prohibition of schools, the prohibition of a language or the prohibition of notices (for instance the prohibition by Italy of notices in German in the part of Tyrol annexed after the First World War). (Ibid. at 70.)

Mr. Kerno, Assistant Secretary-General replied that he

[g]athered from what Mr. Scelle had said that his desire was to safeguard the cultural heritage constituted by institutions, schools and language. It would be difficult to include the concept in paragraph 9, even with the addition of the words "or cultural" to the enumeration. Murder, extermination, enslavement etc. would still be required it the crime was to be punishable. It would not be easy even by means of a broad interpretation to bring, say, the prohibition of the posting of notices in a language other than the language of the country within the provisions of that paragraph. (Ibid.)

Notably, this discussion reveals a consensus understanding among ILC members that cultural genocide denotes only prohibitions on schools, language use, publications etc. In fact, Mr. Amado, who had participated in the Genocide Convention's drafting, "recalled that the members of the General Assembly who had voted against the inclusion of cultural genocide had based their attitude on the fact that culture was already covered to a large extent by the word 'religious.' That made punishable such things, for instance, as outrages on sacred books, religious symbols, etc." (Ibid. at 69.)

${ }^{69}$ J. Spiropoulos, "Second Report on A Draft Code of Offences Against the Peace and Security of Mankind" (UN Doc A/CN.4/44) at 43 in Yearbook of the International Law Commission 1951vol 2 (New York: UN, 1957) 43 at 59 (UNDOC A/CN.4/SER.A/1951/Add.1).

${ }^{70}$ Ibid. He explained that "[w]hile according to the Nuremberg charter, [crimes against humanity] constitute a crime under international law only if they are committed in execution of or in connexion with any crime against peace or war crime as defined by the charter, the text adopted by the International Law Commission, going further, characterizes [them as] crimes under international law ... when these acts are committed in execution of or in connexion with any of the crimes defined in Nos. 1, 2, 5, 7 and 10 [1: threat of force or force against another state; 2: preparation for aggressive war; 5: undertaking or tolerating acts of terrorism of individuals or groups in another state; 7: forcible annexation; and 10: violations of the laws or customs of war]." 
"violated its mandate in as far as it extended arbitrarily the Nuremberg law to time of peace while it is essentially a law of war." ${ }^{, 71}$ In other words, because the ILC was empowered to address the Nuremberg principles, and because the Nuremberg Tribunal had restricted itself to crimes committed in connection with aggressive war, any attempt to criminalize acts committed in peacetime would exceed the ILC's mandate. It seems nothing short of the complete excision of genocide from the draft code would have satisfied Lemkin, who redoubled his efforts against this new draft.

On January 29, 1952, with the help of Pennsylvania Congressman Daniel J. Flood— nicknamed "Dapper Dan" for his baroquely waxed moustache and penchant for flamboyant

\footnotetext{
${ }^{71}$ Raphael Lemkin, document begins: "The Draft Code is supposed to ..." (untitled, undated) NYPL, supra note 2 (Reel 3, File 3). See also Lemkin, "Memorandum on the Genocide Convention" (undated, but postAugust 1953) NYPL, supra note 2 (Reel 3, File 4) at 2:

According to Art. 6, Paragraph C of the Nuremberg Charter and the opinion of the Nuremberg Military Tribunal "crimes against humanity" are punishable only under three conditions: (a) existence of an inhuman act, (b) existence of state of aggressive war, (c) existence of a connection between the inhuman act and aggressive war. Since neither aggressive war, aggression or inhuman acts (including persecutions) have not been defined, prosecution under the concept of "crimes against humanity" is extremely difficult. It is because the Nuremberg Charter and Judgment and the crimes formulated therein contained these loopholes, that the U.N. General Assembly adopted the Genocide Convention.

The other plan of replacing the Genocide Convention by the formula of "crimes against humanity" is being implemented by the introduction of a mutilated definition of Genocide (without the term Genocide) next to "crimes against humanity" in Sec. 9 and 10 of the Draft Code of Offenses. A consolidation of the latter two concepts has been made possible by an insertion in the formula of "crimes against humanity" of a provision which makes these crimes punishable not only when they are connected with aggression but also with Genocide.
}

See also Raphael Lemkin, "The Legal Nature of Crimes Against Humanity” NYPL, supra note 2 (undated) (Reel 3, File 4) at 1: "Crimes against humanity are not an independent category of crimes, but they are subordinated to conditions of aggressive war and are connected with other crimes deriving out of war." For, he argued, "if every crime, persecution" was placed under international control, it would make international life impossible" and it would unduly restrain nations that had bene attacked from "acts in retaliation to its own citizens who might be engaged in subversive activities or in sabotaging the defense." (Ibid.) Lemkin, to Fahy (9 November 1947) AJHS , supra note 11 (Box 1, File 18), arguing this approach "would 'internationalize' even individual crimes of the murder type like lynching." Raphael Lemkin, document begins: "The Draft Code is supposed to ..." (untitled, undated) NYPL, supra note 2 (Reel 3, File 3). He "noted that the General Assembly of 1950 refused to approve the principles of the international Law of Nürnberg. Thus the Draft Code of Offences lacks the legal basis on which it is supposed to rest." Lemkin also argued that aggression was undefinable. See Lemkin, "The Problem of Aggression” (undated) NYPL, supra note 2 (Reel 3, File 4). 
suits—Lemkin secured a meeting with Secretary of State Dean Acheson. ${ }^{72}$ According to Acheson, Flood began the meeting reminding him that Polish voters held the balance of power in his district, and informed him that this constituency was upset about the Senate's failure to ratify the Genocide Convention. At that point it appears Lemkin took over the meeting, arguing the Genocide Convention was being dragged down by human rights activists, who were "sowing misinformation in the public mind regarding the extent to which the Genocide Convention actually dealt with human rights matters and impinged upon the sovereignty of the ratifying states." He then focused on Pella, intimating he "was subject to Communist influence, and remarked that the Communists were also seeking to sabotage the Genocide Convention by supporting the draft code of offenses against the peace and security of mankind." 73

When Pella died on August 24, 1952, at fifty-five years old, ${ }^{74}$ he had lived long enough to see the political winds turn again against his life's work. The General Assembly stalled, and in 1953, the ILC again took up the matter and again tasked Spiropoulos with compiling another report. The General Assembly took up the 1953 report the following year, when it "decided to postpone consideration of the draft code until the new special committee

\footnotetext{
${ }^{72}$ Department of State: Memorandum of Conversation: "Genocide Convention and Covenant of Human Rights" (29 Jan. 1952) at 1, NACP, supra note 9 (Box 1342, 340.1-AJ/1-1452 to 340.1-AM/6-2050, General Records of the Department of State Central Files Record Group 59).

${ }^{73}$ Ibid. at 2. See also, Frances Harvey, "The Raphael Lemkin Saga: An AJP Hanukkah Feature” (1956) AJA, supra note 30 (Box 5, File 7). Lemkin continued to warn that

the Genocide Convention faces at the next General Assembly ... a grave danger. The opposition succeeded in drafting another document called "draft code of offenses against peace and security of mankind" in which they have included a mutilated definition of genocide together with many controversial matters. This is meant to kill the Genocide Convention by putting it on ice and replacing it with the other document which is not enforceable - being merely a declaration.

${ }^{74}$ See Ivan S. Kerno, “In Memoriam: Vespasian V. Pella, 1897-1952” 46 AJIL (1952) 709-10; "Vespasien V. Pella," obituary, The New York Times (25 August 1952).
} 
on the question of defining aggression had submitted its report." 75 The question of how to define the crime of aggression became the draft code's undoing, and the project was shelved. ${ }^{76}$

It is tempting to dismiss Lemkin's actions as reflections of his "paranoia." Indeed, paranoid may be too sympathetic a characterization of the vitriolic assault Lemkin unleashed against Pella and others he perceived as supporting the ILC draft code. But even a paranoiac can have some insight. Lemkin immediately recognized the ILC draft code as a threat, but he missed the development of the threat posed by the emerging doctrine of exclusion.

Ultimately, it was the confluence of these two projects that has proved so harmful to the Genocide Convention.

\section{Early Exclusion}

As Lemkin was busy battling the ILC draft code, scholars began turning their attention the Genocide Convention. The Genocide Convention received little judicial attention between 1951, when the ICJ issued its judgment in the Reservations Case, and the 1990s, when events in the former Yugoslavia and Rwanda forced it back into the courts. ${ }^{77}$

\footnotetext{
${ }^{75}$ UN, The Work of the International Law Commission, 4th ed (New York: UN, (1988) 35-36, giving an overview of how the issue of aggression led to the failure of the draft code project. See also D. N. H. Johnson, "The Draft Code of Offences Against the Peace and Security of Mankind" 4 ICLQ (1955) 445, 458.

${ }^{76}$ See Benjamin Ferencz, Current developments: "the Draft Code of Offences Against the Peace and Security of Mankind" 75 AJIL (1981) 674, 675, explaining that "without a definition of aggression the code was incomplete, and without a code there was no need for a court. Thus, the definition, the code and the court were all linked together, and conveniently placed in the deep freeze by the Cold War. They would lie there undisturbed until the war in Southeast Asia began to wind down and the warming breezes of détente began to thaw the international atmosphere."

${ }^{77}$ But see Attorney General of Israel v. Adolf Eichmann, Case No. 40/61 (1961), 36 Intl L Rep 5, District Court of Jerusalem, Israel (11 Dec. 1961) at 57. The Eichmann case stands out as the only Cold War era genocide prosecution. The court doesn't really develop the concept of genocide but does emphasize the group element, declaring that "the crime of genocide ... which, it is true, is committed by the killing of individuals, but is intended to exterminate the nation as a group." Affirmed, Attorney-General of the Government of Israel v Eichmann (Israel Sup Ct, 1962), 36 Intl L Rep at 277.
} 
This legal dormancy allowed the scholarly discourse to flourish unaffected by legal exigencies. In this discussion, opinions as to what the Genocide Convention meant were lost in arguments about what the Convention ought to mean. Sometimes this normative argumentation was overt, with scholars simply declaring the Genocide Convention inadequate and proposing a "better" alternative. ${ }^{78}$ Oftentimes, however, these normative moves have been made sub rosa as scholars and activists have reinterpreted the Genocide Convention and its history.

Lemkin was among the first to comment on the Genocide Convention. Writing anonymously in a 1949 Yale Law Journal commentary, Lemkin explained,

[T]he crime includes only biological, and physical genocide. Original drafts made reference to "cultural" genocide, i.e., acts aimed at destruction of libraries, museums, schools, historical monuments, and religious edifices, or the suppression of language or printing media of a particular group. But the United States successfully urged exclusion of this form of genocide. The American delegation expressed the belief that the Convention should proscribe only acts directed toward physical destruction of the designated groups themselves, and that acts tending toward the destruction of their institutions should be dealt with in a subsequent treaty for the protection of minorities. ${ }^{79}$

This passage is worth parsing as it reveals some common mid-century assumptions about the Genocide Convention. Lemkin's observation that genocide “includes only biological, and physical genocide" should be read as indicating only that the provisions specifically addressing acts of cultural genocide had been voted out of the Convention. ${ }^{80}$ Thus, Lemkin

\footnotetext{
${ }^{78}$ Adam Jones, Genocide: A Comprehensive Introduction, 2nd ed (Abingdon, UK: Routledge, 2006) at 16-20, providing a compendium of alternative definitions. See also Ann Curthoys and John Docker, "Defining Genocide" in Dan Stone, ed, The Historiography of Genocide (Palgrave Macmillan, 2008) at 9-34 [Stone, Historiography].

${ }^{79}$ Anon (Raphael Lemkin) “Genocide: A Commentary on the Convention” 58 Yale L J (1949) 1142, at 45 [footnotes omitted].

${ }^{80}$ See UN Department of Public Information, What the United Nations is Doing: The Convention on Genocide (New York: UN, 1949) at 7, defining cultural genocide as the "deliberate destruction of the language, religion or culture of any national, racial or religious group." See also ibid. at 3:
} 
accurately reported the exclusion of language prohibitions and acts aimed at destroying cultural artifacts and monuments. This much was uncontroversial.

However, he also emphasized the American delegation's "belief" that the Convention should address "only acts directed toward physical destruction of the designated groups themselves" and that acts aimed at destroying their institutions should be addressed elsewhere. Notably, in stating that the Americans believed the Convention should proscribe only physical and biological genocide, he indicated that not even they believed the Convention actually did so. Instead, he is reporting that the Americans held a "belief" about how the Convention should be interpreted moving forward. He attributes this view only to the American delegation, implying that this view was not held more widely.

That same year, Josef Kunz, a prominent international law scholar, "noted that all forms of cultural genocide have, after long debate, been eliminated" from the Genocide Convention. ${ }^{81}$ He ignored the history of article 2(e) (prohibiting the forced transfer of children), which had been included in the Secretariat's draft as a means of cultural genocide, and which was understood to have a strong cultural pedigree. ${ }^{82}$ Nevertheless, insofar as he merely points out that several proposed means of genocide directly targeting group culture had been voted out of the Convention, this statement is relatively uncontroversial.

What are the acts [of genocide]? First, of course actual killing. But it is possible to destroy a group of human beings without direct physical massacre. So the Convention includes in the definition of genocide the acts of causing serious bodily or mental harm; deliberate infliction of conditions of life "calculated to bring about" physical destruction; imposing measures to prevent birth and, finally, of forcibly transferring children of one group to another group. These acts, records the Convention, constitute "Genocide."

${ }^{81}$ Josef L. Kunz, "The United Nations Convention on Genocide" 43 AJIL 738 at 742 (1949).

${ }^{82}$ See Secretariat's Draft, supra note 4. 
Nehemiah Robinson, an international lawyer with a recognized expertise in minority rights, also addressed the Genocide Convention, stating that "the Convention did not take over Article III of the draft of the Ad Hoc Committee dealing with 'cultural Genocide.' Instead it included, on a Greek motion, point (e) dealing with forced transfer of children (as was envisaged in the Secretariat's draft) as one of the acts of cultural Genocide." 83 Robinson seems to imply a quid pro quo agreement to replace article 3 of the Ad Hoc draft (addressing acts of cultural genocide) with article 2(e), prohibiting child stealing. Of course, there was no such quid pro quo, but he does admit that the drafters considered this a form of cultural genocide. He continued, stating, "The omission of Article III of the Ad Hoc Committee's draft was considered to represent a departure from the wording of the General Assembly's Resolution 96(1), which spoke of cultural contributions lost as a result of acts of Genocide." 84 As I show in my discussion of the preparatory work, this too is misleading. The drafting debates contain statements by several delegates indicating their belief that the final draft continued to embrace the cultural concerns of UNGA Resolution 96(1). ${ }^{85}$ Overall, Robinson's statement expands the doctrine of exclusion, but only slightly. It does, however, reveal the factual sleights of hand that are necessary to preserve the exclusion doctrine.

\footnotetext{
${ }^{83}$ Nehemiah Robinson, The Genocide Convention: A Commentary (Institute of Jewish Affairs, 1960) at 64 [footnotes omitted].

${ }^{84}$ Ibid. [footnotes omitted]. He continued:

The main arguments given for the exclusion were that "cultural" Genocide was too indefinite a concept to be included in a Convention; that the difference between mass murder and the closing of libraries, for instance, was too great; that cultural Genocide legitimately falls within the sphere of protection of minorities. Thus the U.S. delegation, for instance, contended that acts directed at the destruction of the institutions of groups to be protected by the Convention should be dealt with in a treaty for the protection of minorities.

${ }^{85}$ See discussion in chapter 4, at text accompanying notes 233-295.
} 
In 1959, Pieter Drost's influential book Genocide: The Crime of State significantly

expanded exclusion. ${ }^{86}$ According to Drost, supporters of the cultural genocide provision

argued that cultural genocide could not be separated from physical and biological genocide because the acts were complementary having the same objects and the same motives. ... In the minds of various representatives cultural genocide was not a less serious and horrible offence than the other manifestations of the crime. For millions in the East protection of sacred books and shrines was more important than life itself. $^{87}$

However, "[t]he majority [of drafters] thought that the protection of culture should be the object of another convention. ... After an extensive debate the Committee decided ... to delete entirely the Draft Article III on cultural genocide." ${ }^{88}$ According to Drost, this was for good reason:

Preservation of cultural goods, the safeguarding of the world's true treasury, is an international concern of the highest order. It is not to be achieved by a convention on genocide. The arts and sciences are to be defended in the person of their practitioners not under international criminal law but under an international law of human rights. ${ }^{89}$

Here, Drost's individualistic worldview is brought into sharp relief. The world's artistic and scientific "treasury" resides not in groups, but in individuals, so there is no justification for international law to protect the cultural aspects of group existence. After all, "[c]ulture is such a wide and vague conception that it cannot serve as the subject of a definition under criminal law." 90

\footnotetext{
${ }^{86}$ Ward Churchill, A Little Matter of Genocide: Holocaust and Denial in the Americas 1492 to the Present (San Francisco: City Lights Books, 1997) at 414-15, (describing Drost's influence).

${ }^{87}$ Pieter N. Drost, The Crime of State: Genocide: United Nations Legislation on International Criminal Law (A. W. Sythoff, 1959) at 59.

${ }^{88} \mathrm{Ibid}$.

${ }^{89} \mathrm{Ibid}$. at 32 .

${ }^{90} \mathrm{Ibid}$. at 43 .
} 
Drost argued that if the protection of culture had been the drafters' aim, they ought to have included cultural groups among those the Convention protects. ${ }^{91}$ This idea is sensible given Drost's individualistic idea of groups. According to him,

a cultural group need be neither a national nor a racial nor a religious group.... [B]ut in so far as "cultural goods" of whatever substance, character or quality may be said to belong to a cultural group of people, many other groups of common culture exist besides national, racial or religious groups. The world of arts and sciences consists of such cultural groups. In the past such scientific or artistic circles, communities, schools or whatever name these cultural minorities should be given, have been tortured, persecuted and destroyed. Cultural genocide? Physical genocide, no doubt!

However, while this approach is in keeping with Drost's individualism, it ignores the drafters' views. They clearly believed that in protecting national, ethnic, religious, and racial groups they were protecting groups cohering through culture. As Mr. Pérez Perozo quipped in the Sixth Committee debates, "[t]he purpose of the convention was not to protect any and every group; if that were the case, other groups of workers, artists, scientists, etc., should also be taken into consideration." 92

Drost was no friend of cultural protections, or even of the idea of culture. Like many commentators who followed, Drost blended his discussion of the Genocide Convention's actual meaning with discussion of what it ought "logically" to mean, forcing its text to conform to his preconceptions. According to him, cultural genocide was "foreign to the field of criminal law. In a convention on group murder it is completely out of place." ${ }^{\prime 93} \mathrm{He}$ even proposed his own definition of genocide as "the deliberate destruction of physical life of

\footnotetext{
${ }^{91}$ Ibid. 59-60.

${ }^{92}$ UN GAOR, Sixth Committee, 3rd Sess, 69th Mtg, UN Doc A/C.6/SR.69 at 58.

${ }^{93}$ Drost, supra note 87 at 11.
} 
individual human beings by reason of their membership of any human collectivity." 94

Whatever the benefits such a definition might possess, it clearly diverges from the Genocide Convention.

During its long Cold War legal dormancy, the Genocide Convention took on increased symbolic significance and became ever more contested. Throughout this period, few venues existed for addressing human rights violations, and the Genocide Convention stood alone among international human rights treaties in granting aggrieved states access to the International Court of Justice. This access, more hypothetical than real, brought the Genocide Convention constant attention from those hoping to widen its ambit to encompass a larger variety of misdeeds. Everyone, it seems - from superpowers to post-colonial states, from anti-war activists to oppressed minorities - attempted to reinterpret the convention according to one political agenda or another. In response, the United Nations commissioned two comprehensive reports on the Genocide Convention, the first in 1978 and the second in 1985. ${ }^{95}$ These two studies reveal strikingly divergent views on the nature of genocide. At the ECOSOC's request, the Commission on Human Rights, Sub-Commission on the Prevention of Discrimination and Protection of Minorities, requested that Nicodème Ruhashyankiko, the Rwandan representative, compile the first report. His report was a

\footnotetext{
${ }^{94} \mathrm{Ibid}$. at 125. See also Churchill, supra note 86 at 415 . Churchill "notes that Drost was a member of the Dutch establishment" who as a government lawyer was "intimately acquainted with his country's colonial policies and committed to maintaining them." It appeared to Churchill that "a primary motive in writing The Crime of State was to create as comprehensive and sophisticated an intellectual barrier as possible against the characterization of Dutch imperialism as being inherently genocidal."

${ }^{95}$ Nicodème Ruhashyankiko, Study of the Question of the Prevention and Punishment of the Crime of Genocide, UNESCOR, Commission on Human Rights, Sub-Commission on Prevention of Discrimination and Protection of Minorities, $31^{\text {st }}$ Sess, UN Doc. E/CN.4/Sub.2/416 (1978); Benjamin Whitaker, Revised and Updated Report on the Question of the Prevention and Punishment of the Crime of Genocide, UNESCOR, Commission on Human Rights, Sub-Comm'n on Prevention of Discrimination and Protection of Minorities, (1985) U.N. Doc. E/CN.4/Sub.2/1985/6 [Whitaker Report].
} 
lengthy survey of the Genocide Convention's history and contemporary thinking on areas of controversy. After canvassing the drafting debates, Mr. Ruhashyankiko declared simply and accurately that "the Sixth Committee decided not to include a provision on cultural genocide in the convention. .. ."96 $\mathrm{He}$ does not imply that the Convention excludes all cultural matters, only that the parties chose not to include a provision prohibiting certain acts against group culture.

However, the Ruhashyankiko report fell victim to the politics of genocide, when the Turkish government objected to his inclusion of the Armenian genocide among a list of historical genocides committed in the twentieth century. ${ }^{97}$ Facing fierce Turkish opposition, Ruhashyankiko removed that reference, but in the process angered Armenians and other parties. ${ }^{98}$ In the end, the report received a full printing but was not widely disseminated and had little effect, gathering dust in academic libraries. ${ }^{99}$

In 1983, the Sub-Commission on Prevention of Discrimination and Protection of Minorities recruited Benjamin Whitaker, a long-time Liberal British Parliamentarian and internationally recognized group rights activist, to compile a second report, one that would not flinch in coming to terms with the Armenian genocide. ${ }^{100}$ Whitaker met this challenge,

\footnotetext{
${ }^{96}$ Ruhashyankiko, ibid. at para 449.

${ }^{97}$ See William A. Schabas, Genocide in International Law: The Crime of Crimes 2nd ed (Cambridge: Cambridge University Press, 2009) at 556 [Schabas, Genocide 2d].

98 Ibid.

99 Ibid. at 557.

100 “Ben Whitaker,” obituary, The Guardian (15 June 2014).
} 
declaring "the Ottoman massacre of Armenians in 1915-1916" an example of genocide. ${ }^{101}$ In doing so, he outlined an unrelentingly materialist idea of genocide. ${ }^{102}$

Whitaker began his analysis from the presupposition that "[g]enocide is the ultimate crime and the gravest violation of human rights it is possible to commit." ${ }^{103}$ Since genocide is the worst of the worst, it must centre on the right to life. For after all, "[a]mongst all human rights, the primacy of the right to life is unanimously agreed to be pre-eminent and essential: it is the sine qua non, for all other human rights . . . depend for their potential existence on the preservation of human life." 104 Thus, the historical examples of genocide he provides involve only mass killings. Whitaker does address cultural genocide, but only to argue that it would be best addressed in an optional protocol to the Genocide Convention. ${ }^{105}$

Whitaker's is a muscular yet narrow interpretation of the Convention meant to protect the world from mass killings. Where Ruhashyankiko had compiled a comprehensive account of the controversies surrounding the Genocide Convention's interpretation, Whitaker presents its interpretation as fait accompli. He generally ignores the Convention's text and its nuance. Where the Ruhashyankiko report was relegated to the back shelves of academic libraries, Whitaker's report was widely disseminated and remains influential.

\footnotetext{
${ }^{101}$ Whitaker, supra note 95 at 9 [footnotes omitted].

${ }^{102} \mathrm{Ibid}$. at 10: "It could seem pedantic to argue that some terrible mass-killings are legalistically not genocide, but on the other hand it could be counter-productive to devalue genocide through over-diluting its definition."

${ }^{103}$ Ibid. at 5.

${ }^{104}$ Ibid.

${ }^{105} \mathrm{Ibid}$. at 17.
} 
By the late 1980s, the Genocide Convention's definition of genocide was under sustained attack. Social scientists were especially critical. ${ }^{106}$ As Drost had, this new generation of scholars found the Genocide Convention's text wanting and its motivations misguided. Most decried its omission of political and other "social" groups. They ignored its group orientation and simply conflated genocide with any incident of mass killing. ${ }^{107}$

In Churchill's assessment, “[b]y the mid-80's, iterations of the simplistic assertion that 'genocide equals mass murder' had accumulated to such an extent that it had come to constitute an orthodoxy of sorts." 108 As a particularly "reprehensible" example of this distortion, Churchill points to Chalk and Jonasson's The History and Sociology of Genocide which declares, "Genocide is a form of one-sided mass killing in which a state or other authority intends to destroy a group, as that group and membership in it are defined by the perpetrator." 109

He might have, just as aptly, pointed to Israel Charny, who offered a "generic definition" of genocide as "the mass killing of substantial numbers of human beings, when not in the course of military action against the military forced of an avowed enemy, under

\footnotetext{
${ }^{106}$ This chapter is concerned with the definition of genocide as it has developed within the legal discourse. For accounts of "genocide" within the social sciences, see Churchill, supra note 86 at 399-430; David Moshman, "Conceptions of Genocide and Perceptions of History" in Stone, Historiography, supra note 78 at 71-89.

${ }^{107}$ See George J. Andreopoulos, "The Calculus of Genocide" in George J. Andreopoulos, ed, Genocide: Conceptual and Historical Dimensions (Philadelphia: University of Pennsylvania Press, 1994) 1 at 3 [Andreopoulos, Genocide]: "The main criticisms [of the Genocide Convention] usually center on (1) the exclusion of political and social groups from those deemed worthy of protection; (2) the exact meaning of the intentionality clause in the Convention (article II); and (3) the absence of an international enforcement mechanism...."

${ }^{108}$ Churchill, supra note 86 at 423.

${ }^{109}$ Ibid. at 424 quoting Frank Chalk and Kurt Jonassohn, The History and Sociology of Genocide: Analyses and Case Studies (New Haven: Yale University Press, 1990) at 23.
} 
conditions of the essential defenselessness and helplessness of the victims." ${ }^{110}$ Charny took

on Lemkin's ghost, declaring that while

Lemkin correctly underscored the overriding motivation of many mass killings to exterminate a given people, and therefore wisely called to our attention that the murder of a people's culture or elimination of their rights and abilities to maintain biological continuity are also forms of destruction of the species to which we dare not be indifferent. First and foremost, however, we must have a language that clearly defines as genocide any actual biological murder of masses of people, even if the people are not all of the same ethnicity, religion, or race. ${ }^{11}$

For Charny, to allow the concept of genocide to encompass cultural concerns was to betray the individual victims of mass killings and to further imperil those facing such danger.

\section{The ILC, the Draft Code Redux}

Thus, exclusion dominated the academic literature when the ILC resumed the draft code project in $1981 .{ }^{112}$ It also came to dominate the work of the ILC, especially that of Doudou Thiam, appointed Special Rapporteur to the revived draft code project. In his fourth report on the draft code, Thiam defended his position that genocide is a type of crime against humanity by arguing that where one comes down on this issue depends on one's view of the Genocide Convention. ${ }^{113}$ If one considers the purpose of an act of genocide, which is "to

\footnotetext{
${ }^{110}$ Israel W. Charny, "Toward a Generic Definition of Genocide" in Andreopoulos, Genocide, supra note 107, 64 at 75.

${ }^{111}$ Ibid. Notably, Charny's "generic" definition was only part of a much more baroque classification of genocides, wherein he renames cultural genocide "ethnocide." (Ibid. 77.)

${ }^{112}$ Draft Code of Offences against the Peace and Security of Mankind, GA Res. 36/106, UN GAOR, 36th Sess, UN Doc A/Res/36/106. The General Assembly "[i]nvite[d] the International Law Commission to resume its work with a view to elaborating the draft Code of Offences against the Peace and Security of Mankind ...."

${ }^{113}$ Doudou Thiam, "Fourth Report on the Draft Code of Offences Against the Peace and Security of Mankind"(UN Doc A/CN.4/398) in Yearbook of the International Law Commission, 1986 vol II(1) (New York: UN, 1988) 53 at 58-60 (UNDOC, A/CN.4/SER.A/1986/Add.1 [part 1]) [Thiam, "Fourth Report"]. See also Doudou Thiam, "Thirteenth Report on the Draft Code of Offences Against the Peace and Security of Mankind" (UN Doc A/CN.4/466 and Corr.1) in Yearbook of the International Law Commission, 1995 vol II(1) 33 at 41 (UNDOC A/CN.4/SER.A/1995/Add.1 [Part 1]) [Thiam, "Thirteenth Report"]. Thiam's final report lists genocide as a crime co-equal, rather than subservient, to crimes against humanity.
} 
destroy, in whole or in part, a national, ethnical, racial, or religious group," then genocide stands independent from crimes against humanity. ${ }^{114}$ But when viewed according to "the number of victims," the boundary between genocide and crimes against humanity begins to blur. ${ }^{115}$ Preferring the blur and dismissing the purpose, Thiam insisted on listing genocide as a form of crimes against humanity.

He acknowledged Pella's argument that "the independence and separate existence of the Convention on Genocide should be maintained," but declared "[ $\mathrm{t}]$ hat extreme argument seems unacceptable; moreover, it was not accepted by the [ILC] in 1954."116 For, he argued, "[i]f all the wrongful acts which are the subject of a convention had to be excluded from the Code, the latter would be nothing more than an empty shell." ${ }^{117}$ Nevertheless, he attempted to split the difference, determining "that, for reasons which are based on the specific nature of the crime of genocide, the latter should be assigned a separate place among crimes against humanity."118 Thiam bypassed any substantive inquiry into the Genocide Convention's past

\footnotetext{
114 Thiam, "Fourth Report," ibid. at 58 [emphasis omitted].

${ }^{115} \mathrm{Ibid}$. Thiam assumes genocide contains an element requiring mass atrocity and then canvasses the scholarly literature to discover whether crimes against humanity similarly implies a mass element. Of course, the Genocide Convention contains no size element, nor, he admits, does the doctrine of crimes against humanity. (See Doudou Thiam, "Thirteenth Report," supra note 113 at 44, cataloging opposition to Thiam's size element.) Instead, Thiam's second "angle" on the Genocide Convention is nothing but the standard materialist overlay, which converts intent to destroy the group into intent to kill or otherwise harm a large number of individuals. Thiam also posits seriousness as a distinguishing factor, citing "Mr. Stefan Glaser [who] believes that genocide is 'only an aggravated case' of a crime against humanity. The two concepts differ only in degree and not in nature." (Ibid. citing Stefan Glaser, Droit International Pénal Conventionnel (Brussels: Etablissements Emile Bruylant, 1970) at 109.) Thiam does not explain how removing a few children from a small protected group is inherently more serious than mass killings prohibited as a crime against humanity.

116 Thiam, "Fourth Report," supra note 113 at 60.

${ }^{117} \mathrm{Ibid}$

118 Ibid. at 15, para. 54 [emphasis added]. Contra Note by the Secretariat (UN Doc E/A.25/3/Rev.1) supra note 23 at 4. Thiam's discussion on the distinctions between genocide and crimes against humanity ignored the 1948 note by the UN Secretariat on the relationship between these crimes. The Secretariat addressed the question, "does genocide come within the category of crimes against humanity as defined by the character of the international military tribunal?" To which it answered, "no." It admitted that "genocide, considered from the point of view of the actual facts which constitute it, is certainly included" in the Nuremberg Charter's list of acts
} 
as he proffered a materialist conception of genocide which all but restricts itself to acts of mass murder. ${ }^{119}$ He acknowledged but did not engage with genocide's group element, instead focusing on the size and severity of genocidal attacks. The ILC discussions were similarly unreflective.

The ILC first enunciated its cultural genocide stance in 1991, a position it reaffirmed

in 1996:

As clearly shown by the preparatory work for the [Convention], the destruction in question is the material destruction of a group either by physical or biological means, not the destruction of the national, linguistic, religious, cultural or other identity of a particular group. The national or religious element and the racial or ethnic element are not taken into consideration in the definition of the word "destruction," which must be taken only in its material sense, its physical or biological sense. . . [T] the Convention, as prepared by the Sixth Committee and adopted by the General Assembly, did not include the concept of "cultural genocide" contained in the [earlier] two drafts and simply listed acts which come within the category of "physical" or "biological" genocide. ${ }^{120}$

Although presented as a restatement of existing law, the ILC statement significantly expands exclusion. Applying the ILC standard, the Genocide Convention would exclude both acts of cultural genocide and-because it limits culpable destruction only to its "material sense"-

comprising crimes against humanity. Yet it argued that the Genocide Convention's group element sufficiently distinguished genocide so that it should be considered as an offense separate from crimes against humanity. After all, as the Secretariat pointed out, "The General Assembly wished genocide to be indictable as a separate offence." As it explained, "[t]he General Assembly wished to give special treatment to the crime of genocide because of the particular gravity of that crime, which aims at the systematic extermination of human groups." (Ibid. at 6.)

${ }^{119}$ But see Thiam, "Fourth Report," supra note 113 at 60 [emphasis omitted], arguing that "the ethnic group is based on a cosmogony. The racial element, on the other hand, refers more typically to common physical traits. It therefore seems normal to retain these two terms, which give the text on genocide a broader scope covering both physical genocide and cultural genocide." Thiam's statement is obscure. If he is arguing that because "ethnic" implies a group that coheres through culture, the Genocide Convention protects its cultural functioning, then he is directly contradicting the ILC's exclusion stance, which emerged five years later. It is also unclear how religious, national, or for that matter racial groups differ on cultural cohesion.

${ }^{120}$ ILC, 1996 "Draft Code," supra note 6 at 44-45 [footnotes omitted]. 
seemingly any act, even those acts specifically prohibited in article 2 , if it results in cultural destruction.

However, when it comes to the cultural existence of groups, the ILC seems to want it both ways. It declares, for example, that

[a] prohibited act [of genocide] must be committed against an individual because of his membership in a particular group and as an incremental step in the overall objective of destroying the group....

[T] he intention must be to destroy the group "as such," meaning as a separate and distinct entity, and not merely some individuals because of their membership in a particular group. ${ }^{121}$

In this manner, it uses the continued cultural existence of groups to limit the range of acts that can be considered genocidal. An otherwise genocidal act, they assert, must be aimed at destroying the group's existence as an entity, which seems to imply its continued cultural functioning. Yet it also declares that any otherwise genocidal act will be considered beyond the Convention's reach if it is intended to destroy the group's cultural existence. These two seemingly irreconcilable positions radically narrow the definition of genocide.

It is uncertain whether the ILC gave much thought to its cultural genocide stance. This matter was apparently considered in a subcommittee for which there are no records, and it received no real discussion in ILC meetings. ${ }^{122}$ But consider the targeted killing of a

${ }^{121}$ Ibid at 45 .

${ }^{122}$ I can find only one substantive mention of "cultural genocide" in the relevant ILC meetings: ILC, "Summary Record of the 2442nd Mtg" (UN Doc A/CN.4/SR.2442) in Yearbook of the International Law Commission, 1996 vol 1 (New York: UN 1998) at 72 (UNDOC A/CN.4/SER.A/1996). See also Thiam, "Fourth Report," supra note 113 at 15-16. Interestingly, Special Rapporteur Thiam's Fourth Report had touted the convention's cultural reach. According to him,

[t]he difference between the terms "ethnic" and "racial" is perhaps harder to grasp. It seems that the ethnic bond is more cultural. It is based on cultural values and is characterized by a way of life, a way of thinking, and the same way of looking at life and things. On a deeper level, the ethnic group is based on a cosmonogy. The racial element, on the other hand, refers more typically to common physical traits. It 
protected group's intelligentsia as a means of destroying that group: ${ }^{123}$ this should be an unambiguous act of genocide. Article 2(a) specifically prohibits killings, and in such a circumstance the act would be perpetrated in order to destroy the group. However, according to the ILC, it would not constitute genocide because killing a group's intelligentsia is intended to destroy the group as a cultural entity. ${ }^{124}$ Without its intelligentsia, a group stops functioning culturally, members fall away, and the group is destroyed, even though most members suffer no physical harm. In this manner, the ILC stance excuses killing, a physical act, because it causes cultural destruction. If the ILC had considered the matter and found some route out of this doctrinal dead end, they left no crumbs to follow.

therefore seems normal to retain these two terms, which give the text on genocide a broader scope [than the text addressing crimes against humanity] covering both physical genocide and cultural genocide.

123 This issue was considered in Prosecutor v Jelisić, IT-95-10-T, Judgment (14 December 1999) at para 82 (International Criminal Tribunal for the Former Yugoslavia, Trial Chamber) online: ICTY $<$ www.icty.org $>$ [Jelisić, Trial]. See also Prosecutor v Sikirica et al., IT-95-8-T, Judgment on Defence Motions to Acquit (3 September 2001) at para 77 (International Criminal Tribunal for the Former Yugoslavia, Trial Chamber) online: ICTY <www.icty.org >:"The important element here is the targeting of a selective number of persons who, by reason of their special qualities of leadership within the group as a whole, are of such importance that their victimization ... would impact upon the survival of the group as such." See also Prosecutor v Radoslav Brđanin, IT-99-36-T, Judgment (1 September 2004) at para 703 (International Criminal Tribunal for the Former Yugoslavia, Trial Chamber) online: ICTY <www.icty.org $>$ [Brđanin]. Notably, from the beginning, Lemkin had argued that the selective killing of cultural leaders was a signal act of genocide, a position he maintained long after the convention's conclusion. See, e.g., Raphael Lemkin, "Supplement" (undated) NYPL, supra note 2 (Reel 3, File 4) at 1: “[T] destroy a nation or a religious group 'in part' and 'as such' means to eliminate from a nation or a religious groups those elements which provide the forces of cohesion to the entire group and which are the residue of national conscience or religious inspiration and convictions."

${ }^{124}$ See Claus Kreß, “The Crime of Genocide Under International Law” 6 Intl Crim L Rev (2006) 461 at 492 , arguing that recognizing the killing of military-aged Bosnian-Muslim men as genocide "comes dangerously close to precisely that social concept of destruction which the ICTY chambers were . . a at pains to reject." [Emphasis in original.] See also David L. Nersessian, The Razor's Edge: Defining and Protecting Human Groups Under the Genocide Convention, 36 Cornell Intl LJ (2003) 293 at 324, cautioning, "If the qualitative approach is used at all, it must be applied in accord with the object and purpose of the Genocide Convention and limited to the physical and biological existence of the group." See also David Nersessian, Genocide and Political Groups (Oxford: Oxford University Press, 2010) at 44-45. 


\section{Shahabuddeen's Critique}

Judge Mohamed Shahabuddeen, formerly of the International Criminal Tribunal for

the former Yugoslavia (ICTY) and the ICJ, provided the most notable critique of exclusion.

In his Partial Dissenting Opinion in Prosecutor v. Krstić, Judge Shahabuddeen wrote,

The proposition that the intended destruction must always be physical or biological is supported by much in the literature. However, the proposition overlooks a distinction between the nature of the listed "acts" and the "intent" with which they are done.

From their nature, the listed (or initial) acts must indeed take a physical or biological form, but the accompanying intent, by those acts, to destroy the group in whole or in part need not always lead to a destruction of the same character. ...

The stress placed in the literature on the need for physical or biological destruction implies, correctly, that a group can be destroyed in non-physical or non-biological ways. It is not apparent why an intent to destroy a group in a non-physical or nonbiological way should be outside the ordinary reach of the Convention, ... provided that the intent attached to a listed act, this being of a physical or biological nature.

It is the group which is protected. A group is constituted by characteristics - often intangible - binding together a collection of people as a social unit. If those characteristics have been destroyed in pursuance of the intent which a listed act of a physical or biological nature was done, it is not convincing to say that the destruction, though effectively obliterating the group, is not genocide because the obliteration was not physical or biological.

The travaux preparatoires relating to the Genocide Convention are of course valuable; they have been and will be consulted with profit. But I am not satisfied that there is anything in them which is inconsistent with this interpretation of the Convention. However, if there is an inconsistency, the interpretation of the final text of the Convention is too clear to be set aside by the travaux preparatoires. On settled principles of construction, there is no need to consult this material, however interesting it may be. ${ }^{125}$

Judge Shahabuddeen exposes a series of apparent weaknesses and inconsistencies in the ILC approach. It is possible to quibble with his history, as there is ample evidence that a majority of the delegates considered the forcible transfer of children to be an act of a cultural

\footnotetext{
${ }^{125}$ Prosecutor v. Radislav Krstić, IT-98-33-A, Judgment, Partial Dissenting Opinion of Judge Shahabuddeen, (Apr. 19, 2004) at paras 48-54 (International Criminal tribunal for the former Yugoslavia, Appeals Chamber) online: ICTY <wwwicty.org> [footnotes omitted] [Krstić, Appeals].
} 
"nature." 126 In addition, it is not clear that his injunction against recourse to the preparatory work could or should be followed. Still, Judge Shahabuddeen's statement stands out as the most incisive critique of the cultural genocide exclusion. As he points out, the ILC exclusion stance (1) conflates prohibited acts with the destruction those acts are intended to cause; (2) violates accepted treaty-interpretive principles that prohibit turning to the Convention's preparatory work to settle this issue; and (3) misuses the preparatory work, because these materials do not provide exclusionists the support they claim.

\section{Exclusion's Internal Instability}

The ILC exclusion stance relies on a double proposition: first, that the Genocide Convention cannot reach matters of cultural destruction; and second, that it only encompasses physical and biological acts of genocide. As the ILC puts it, "the destruction in question is the material destruction of a group either by physical or biological means," so that "[t]he national or religious element and the racial or ethnic element are not taken into consideration in the definition of the word 'destruction,' which must be taken only in its material sense, its physical or biological sense ...."127 And according to the ILC, the drafters of the Genocide Convention deleted the cultural genocide provision and "simply listed acts which come within the category of 'physical' or 'biological' genocide." 128

\footnotetext{
${ }^{126}$ See UN GAOR, Sixth Committee, 3rd Sess, 82d Mtg, UN Doc A/C.6/SR.82 (1948) at 89. Mr. Maktos (United States) "felt that the Greek amendment should stand on its own and not be associated too closely with cultural genocide. Even if it were subsequently decided to include cultural genocide in the conventions, a judge considering a case of forced transfer of children would still have to decide whether or not physical genocide were involved." (Ibid.) Maktos' statement is the most forcible attempt to limit article 2(e). Mr. Vallindas (Greece) also stated, "It was not connected with cultural genocide, but with the destruction of a group-with physical genocide," although his stance on this issue had evolved significantly over the course of the argument. (Ibid.) Otherwise, delegate statements indicate they believed article 2(e) encompassed matters of cultural genocide.

${ }^{127}$ ILC, 1996 "Draft Code," supra note 6 at 45-46 [footnotes omitted].

${ }^{128}$ Ibid.
} 
In law, genocidal destruction is considered a matter of intent, or mens rea. According to the chapeau of article 2, a perpetrator must commit one of the prohibited acts "with intent to destroy ... a . . group, as such." Reflecting the goal of preventing genocide, the perpetrator need not achieve any degree of actual group destruction. Culpability is triggered by committing a prohibited act with the further intent of destroying the group. And in law, the acts by which the perpetrator intends to destroy the group are considered to comprise a separate element of the crime, its actus reus. Dressler explains that "except in relatively rare circumstances, a person is not guilty of an offense unless he performs a voluntary act ... that causes social harm (the actus reus), with a mens rea (literally, a 'guilty mind')."129 These two conceptually distinct elements comprise the whole of most any crime.

Parsing the ILC's stance reveals the dizzying circularity at exclusion's core. At its most basic level, the exclusionist argument breaks down like this: (a) Because the Genocide Convention excludes cultural genocide, article 2's prohibited acts must be of a physiobiological character; and (b) the Genocide Convention excludes cultural genocide, and we know this because only physical and biological acts are included. Thus, proposition (a) is true because (b) is true and we know (b) is true because (a) is true.

Article 2(e), prohibiting the forcible transfer of a protected group's children, brings the weakness of this argument into sharpest relief. Its ordinary meaning emphasizes processes of cultural destruction. It had been listed as a form of cultural genocide in the Secretariat's draft. ${ }^{130}$ And several Sixth Committee delegates commented that they believed

\footnotetext{
${ }^{129}$ Joshua Dressler, Understanding Criminal Law 4th ed (LexisNexis Mathew Bender, 2006) at 115 [footnotes omitted]: "Generally speaking, crimes have two components: the 'actus reus,' the physical or external portion of the crime; and the 'mens rea,' the mental or internal feature." (Ibid. at 81.)

${ }^{130}$ Secretariat's Draft, supra note 4.
} 
it was an act of cultural genocide. ${ }^{131}$ Nevertheless, exclusionists must reclassify it as an act of physio-biological genocide because if article 2(e) reaches cultural matters, it cannot be true that the Genocide Convention excludes cultural destruction.

Exclusionists must prove both elements. If article 2(e) were intended to reach acts of a cultural nature, then it cannot be true that the drafters intended to exclude all cultural matters and so there are no grounds for excluding cultural destruction. Conversely, if the drafters did not intend to exclude all matters of culture, and therefore to limit culpability only to physio-biological destruction, there are no grounds for restricting the article 2(e) to its purely physio-biological implications. Thus, exclusion rests on two legs, and neither is sound.

The circularity at the heart of the exclusionist argument appears to foster a conceptual slippage that spins mens rea and actus reus into one element. The Trial Chamber in Prosecutor v. Semanza made this mistake when it asserted that the Genocide Convention's drafters "unequivocally chose to restrict the meaning of 'destroy' to encompass only acts that amount to physical or biological genocide." ${ }^{\prime 132}$ Note that the court begins by discussing destruction, or mens rea, then shifts to address the acts by which this destruction is accomplished. ${ }^{133}$ This is like confusing the actus reus of burglary—the act of breaking and

\footnotetext{
${ }^{131}$ See above, chapter 4, text accompanying notes 233-270.

${ }^{132}$ Prosecutor $v$ Laurent Semanza, ICTR-97-20 Judgment and Sentence (15 May 2003) at para 315 (International Criminal Tribunal for Rwanda, Trial Chamber) online: ICTR < www.ictr.org > . As I discussed above in Chapter 4, the court's assertion that the delegates "unequivocally" circumscribed genocide in this manner is demonstrably false.

${ }^{133}$ See also Schabas, Genocide 2d, supra note 97 at 206-21, 270-72. To his credit, Schabas attempts to dissociate act and intent, covering cultural genocide in two separate sections of Genocide in International Law, the first on actus reus and the second addressing intent. Still, his efforts come to naught when he declares that "[w]hile these questions were not specifically debated during the drafting of article II, the spirit of the discussion resists extending the concept of destruction beyond physical and biological acts." (Ibid. at 271.) Leaving to the side the question of whether "the spirit of the discussion" is sufficient proof to displace a treaty's
} 
entering a house - with the mens rea, the intent to commit a felony therein. ${ }^{134}$ Both elements must be satisfied for an act to qualify as the crime of burglary, but they are distinct elements nonetheless. That courts and commentators struggle to maintain this most basic distinction reflects the tenuous, circular argument at exclusion's core.

\section{The Trajectory of Exclusion}

The case law itself provides the best evidence of exclusion's unsettled and incoherent character. The decisions divide into two broad camps: those taking a materialist approach, and those embracing the Convention's original culturalism. The materialists embrace the ILC exclusion stance, arguing that the Genocide Convention includes only physical and biological acts and should address only physical and biological destruction. Following Judge Shahabuddeen, culturalists concede — mistakenly — that the Genocide Convention prohibits only acts of physical and biological genocide but argue there are no grounds for discounting cultural destruction. Despite efforts by the ICTY Appeals Chamber and the ICJ to quash the debate, this issue continues to surface.

\section{The German Courts}

Exercising universal jurisdiction over crimes of genocide, in 1997 the Higher State Court in Düsseldorf, Germany, tried Nikola Jorgić, a Bosnian Serb, for crimes, including genocide, that he had allegedly committed as leader of a paramilitary unit in the former Yugoslavia. ${ }^{135}$ The litigation centred on interpretation of section 220 of the German Criminal

ordinary meaning, Schabas' comment repeats the ILC conflation by declaring "the concept of destruction" is bounded by the characteristics of the acts by which this destruction is carried out.

134 See Wayne LaFave, Criminal Law 3d (St. Paul, Minn: West Group, 2000) at 883.

${ }^{135}$ Prosecutor v Nikola Jorgić, [1997] IV-26/96; 2StE 8/96 (Germany, Higher State Court of Düsseldorf) online in translation: ICC Legal Tools Database < https:/www.legal-tools.org/doc/bd3e74/pdf/> [Jorgić, Trial];

Prosecutor v Nikola Jorgić, [1999] 3StR 215/98 (Germany, Federal Supreme Court) online in translation: ICC 
Code as well as articles 2 and 4 of the Genocide Convention. ${ }^{136}$ The court did not address the concept of genocide, except to declare, "The intention to destroy a group ... means destroying the group as a social unit in its specificity, uniqueness and feeling of belonging; the biological-physical destruction of the group is not required."137

When considering Jorgić's appeal, the Federal Constitutional Court of Germany (2000) acknowledged that "[i]n the literature on international law, the definition of the elements of genocide is regarded by a number of writers as being confined to the physical/biological destruction of a protected group or of a significant number of its members." 138 Nonetheless, the Constitutional Court declared, "This view is not compelling ... when the wording of the provision is taken into account."139 The Constitutional Court reaffirmed the lower courts' culturalism, stating,

The Higher Regional Court (OLG) and the Federal Supreme Court (BHG) found that $\S 220 \mathrm{a}$ of the German Criminal Code provides protection for groups. They have at the same time interpreted the concept of the intent to destroy that is contained in $\S 220 \mathrm{a}$ of the German Criminal Code in such a way that the destruction of a group, as well as part of a group that is geographically defined, includes the annihilation of a group as a

\footnotetext{
Legal Tools Database < https://www.legal-tools.org/doc/85b784/pdf/> [Jorgić, Appeal]. See also Elisa Novic, The Concept of Cultural Genocide: An International Law Perspective (Oxford: Oxford University Press, 2016) at $75-77$.

${ }^{136}$ Ruth Rissing-van Saan, "The German Federal Supreme Court and the Prosecution of International Crimes Committed in the Former Yugoslavia" 3 J Intll Crim Just (2005) 381, 398-99, explaining that "[t]he Constitutional Court interpreted the literal meaning of the domestic provisions in the light of the international crime of genocide in article II of the Genocide Convention, Article 4 ICTYSt. and article 6 ICCSt. Moreover, it found, after discussing the case law of the ICTY and the ICTR, that the Tribunals' findings had also proven that an understanding of genocide that went beyond biological-physical destruction of the protected group was possible." [Footnote omitted.]

${ }^{137}$ Jorgić, Trial, supra note 135 at $94-95$ [footnote omitted].

${ }^{138}$ Jorgic [2000] 2 BvR 1290/99, [2009] 135 ILR 152 at 161 (Germany, Federal Constitutional Court, BVerfG) [footnote omitted] [Jorgić, Constitutional Ct].

${ }^{139} \mathrm{Ibid}$. at 162 [footnote omitted].
} 
social unit with its special qualities, uniqueness and its feeling of togetherness, not exclusively their physical-biological annihilation. ${ }^{140}$

The Constitutional Court declared that the assertion that

the elements of the crime of genocide protect a legal interest that lies beyond the individual, namely the social existence of a group, finds its basis in the wording of the provision which requires that the intent to destroy be directed against the "group as such.” The intent to destroy required by $\$ 220$ a of the German Criminal Code, considering the natural meaning of the words, has a broader meaning than physicalbiological annihilation. ${ }^{141}$

Directly addressing article 2 of the Genocide Convention, it explained,

The English text of the Genocide Convention chooses a different, potentially broader, definition than the individual acts described in article 2(a) to (e) when it uses "destroy" with regard to the overarching "intent." Accordingly, it is generally only an assumption that the parameters of the wording would be exceeded if the intent to destroy related solely to a group's cultural characteristics. That interpretation of the wording can be justified also on the basis of the history of the drafting of the Convention. ${ }^{142}$

Thus, in the first conviction for genocide in the former Yugoslavia, courts embraced an unapologetically cultural approach to group destruction.

\section{The ICTR}

The International Criminal Tribunal for Rwanda (ICTR) began with a broadly

culturalist approach to genocide. In finding that rape can amount to genocide, the Akayesu tribunal emphasized the cultural destruction it is intended to cause. ${ }^{143}$ In considering whether rape falls under article $2(\mathrm{~d})$, as a measure to prevent births, it held

\footnotetext{
${ }^{140}$ Ibid. at 159 .

${ }^{141}$ Ibid. at $159-60$.

${ }^{142} \mathrm{Ibid}$. at 162 [footnote omitted]: "Accordingly, the systematic expulsion of a group from its traditional areas of settlement is, from the point of view of the elements of the offence, an act of genocide ...." (Ibid.)

${ }^{143}$ Prosecutor v Akayesu, ICTR-96-4, Judgment (2 September 1998) at para 507 (International Criminal Tribunal for Rwanda, Trial Chamber) online: <www.ictr.org $>$ [Akayesu]. See also, Prosecutor v. Kayishema \& Ruzindana, ICTR-95-1, Judgement (1 May 1999) at para 95 (International Criminal Tribunal for Rwanda, Trial Chamber) online: $<$ www.ictr.org $>$, endorsing this view.
} 
that the measures intended to prevent births within the group, should be construed as sexual mutilation, the practice of sterilization, forced birth control, separation of the sexes and prohibition of marriages. In patriarchal societies, where membership of a group is determined by the identity of the father, an example of a measure intended to prevent births within a group is the case where, during rape, a woman of the said group is deliberately impregnated by a man of another group, with the intent to have her give birth to a child who will consequently not belong to its mother's group. ${ }^{144}$

Subsequent courts have distanced themselves from Akayseu's overt culturalism, instead emphasizing the personal psychological trauma attendant to rape and how this might prevent women from procreating, but none have disavowed it. ${ }^{145}$ But the Akayesu court was right to highlight the role of cultural factors in making systematic rape an effective means of group destruction. Divorcing the psychological trauma suffered by women from the larger cultural context validates only part of the harm they have suffered and pushes the cultural impact back into the shadows, artificially truncating consideration of this act's true harm.

\section{The ICTY}

Early on, the International Criminal Tribunal for the Former Yugoslavia (ICTY) also appeared poised to embrace a culturalist approach. Its Trial Chamber "invite[d] the

\footnotetext{
${ }^{144}$ Akayesu, ibid at para 507. See also ibid. at para 731: "These rapes resulted in physical and psychological destruction of Tutsi women, their families and their communities. Sexual violence was an integral part of the process of destruction, specifically targeting Tutsi women and specifically contributing to their destruction and to the destruction of the Tutsi group as a whole."

${ }^{145}$ See Prosecutor v. Gacumbitsi, ICTR-2001-64, Judgment (June 17, 2004) at para 291(International Criminal Tribunal for Rwanda, Trial Chamber) online: <www.ictr.org>; Prosecutor v. Kajelijeli, ICTR-98-44A, Judgment (1 December 2003) at para 815 (International Criminal Tribunal for Rwanda, Trial Chamber) online: $<$ www.ictr.org $>$ [Kajelijeli]; Prosecutor v. Kamuhanda, ICTR-99-54A, Judgment and Sentence (22 January 2004) at para 634 (International Criminal Tribunal for Rwanda, Trial Chamber) online: <www.ictr.org $>$; Prosecutor v. Musema, Case No. ICTR-96-13, Judgment and Sentencing, (Jan. 27, 2000) at para 156 (International Criminal Tribunal for Rwanda, Trial Chamber) online: <www.ictr.org>; See also Payam Akhavan, "The Crime of Genocide in the ICTR Jurisprudence" 3 J Intl Crim J (2005) 989 at 1003. The ICTY adopted a similar approach to systematic rape. See Prosecutor $v$ Radislav Krstić, IT-98-33-T, Judgment (2 August 2001) at paras 509, 513 (International Criminal Tribunal for the Former Yugoslavia, Trial Chamber) online: ICTY <www.icty.org> [Krstić, Trial]; Prosecutor v. Stakić, Case No. IT-97-24, Judgment (July 31, 2003) at para 516 (International Criminal Tribunal for the Former Yugoslavia, Trial Chamber) online: ICTY $<$ www.icty.org $>$ [Stakić $]$.
} 
Prosecutor to consider broadening the scope of the characterisation of genocide to include other criminal acts listed in the first indictment than those committed in the detention camps." ${ }^{146}$ It explained that certain methods used for implementing the project of "ethnic cleansing" appear to reveal an aggravated intent as, for example, the massive scale of the effect of the destruction. The number of victims selected only because of their membership in a group would lead one to the conclusion that an intent to destroy the group, at least in part, was present. Furthermore, the specific nature of some of the means used to achieve the objective of "ethnic cleansing" tends to underscore that the perpetration of the acts is designed to reach the very foundations of the group or what is considered as such. The systematic rape of women, to which material submitted to the Trial Chamber attests, is in some cases intended to transmit a new ethnic identity to the child. In other cases, humiliation and terror serve to dismember the group. The destruction of mosques or Catholic churches is designed to annihilate the centurieslong presence of the group or groups; the destruction of the libraries is intended to annihilate a culture which was enriched through the participation of the various national components of the population. ${ }^{147}$

Taken together, the court argued, the elements that constitute ethnic cleansing might also support a charge of genocide. ${ }^{148}$

The Krstić Trial Chamber acknowledged a movement in customary international law to include ethnic cleansing as an act of genocide. It acknowledged UNGA Resolution 47/121,

\footnotetext{
${ }^{146}$ Prosecutor v Radovan Karadžić \& Ratko Mladić, IT-95-5-R61, IT-95-18-R61, Review of the Indictments Pursuant to Rule 61 of the Rules of Procedure and Evidence (11 July 1996) at para 95(International Criminal Tribunal for the Former Yugoslavia, Trial Chamber) online: ICTY <www.icty.org>.

${ }^{147}$ Ibid. at para 94.

${ }^{148}$ Ibid.
} 
which declared ethnic cleansing "a form of genocide"149 as well as the Jorgić decision. ${ }^{150}$

However, the Trial Chamber stated that

despite recent developments, customary international law limits the definition of genocide to those acts seeking the physical or biological destruction of the group. Hence, an enterprise attacking only the cultural or sociological characteristics of a human group in order to annihilate these elements which give to that group its own identity distinct from the rest of the community would not fall under the definition of genocide. $^{151}$

The Trial Chamber admitted "the Convention does not specifically speak to the point," but asserted that "the preparatory work points out that the 'cultural' destruction of a group was expressly rejected after having been seriously contemplated." 152

In upholding the Trial Chamber, the Appeals Chamber highlighted the cultural value of groups, explaining, "Those who devise and implement genocide seek to deprive humanity of the manifold richness its nationalities, races, ethnicities and religions provide. This is a crime against all of humankind, its harm being felt not only by the group targeted for

${ }^{149}$ The Situation in Bosnia and Herzegovina, GA Res 47/21, UN GAOR, 47th Sess, UN Doc A/Res/47/121 (1992). The General Assembly declared it was

[g]ravely concerned about the deterioration of the situation in the Republic of Bosnia and Herzegovina owing to intensified aggressive acts by the Serbian and Montenegrin forces to acquire more territories by force, characterized by a consistent pattern of gross and systematic violations of human rights, a burgeoning refugee population resulting from mass expulsions of defenceless civilians from their homes and the existence in Serbian and Montenegrin controlled areas of concentration camps and detention centres, in pursuit of the abhorrent policy of "ethnic cleansing," which is a form of genocide.

${ }^{150}$ Krstić, Trial, supra note 145 at para 579, note 1287, citing Jorgić, Constitutional Ct, supra note 138 at $161-$ 62.

${ }^{151}$ Krstić, Trial, ibid. at para 580. See also Lemkin, "Definition" [undated but post-1948] AJHS, supra note 11 (Box 2, File 2). Interestingly, Lemkin spotted this issue, writing, "One might argue that the deportation of the Moors from Spain was not an act of genocide. However, certain techniques used in this deportation amounted to an act of genocide. The Arabs were loaded on ships and transported to Africa under unbearable heat of the Mediterranean sun. Thousands of them died from sunstrokes... This is an act of genocide because the persons involved were subjected to conditions leading to death and these conditions were created purposefully with intent to destroy the group."

${ }^{152}$ Krstic, Trial, ibid. at para 576. In support of its contention, the court states only that "[t]he notion of a cultural genocide was rejected by the ... Sixth Committee by 25 votes to 6 ...." (Ibid. at note 1284.) 
destruction, but by all of humanity." 153 It also endorsed the Trial Chamber's finding "that, given the patriarchal character of the Bosnian Muslim society in Srebrenica, the destruction of such a sizable number of men would 'inevitably result in the physical disappearance of the Bosnian population at Srebrenica.",154

Nonetheless, it declared, "the Genocide Convention, and customary international law in general, prohibit only the physical or biological destruction of a human group." 155 The court provided no support for its first proposition that the Genocide Convention itself limits the scope of culpable destruction. Could this restriction be in the Convention's text or context? Or perhaps it is in the preparatory work or the circumstances of its conclusion? Because of the court's vague citations, there is no way of knowing. And in support of its second proposition, that customary law limits culpable destruction, the court only invokes the ILC statement and cites Schabas. ${ }^{156}$ Thus, the Krstić Appeals Chamber declares that exclusion is rooted in customary international law and the Convention itself, but besides a cursory citation of expert opinion, provides no evidence for this important departure from the Genocide Convention's text.

In 2001, Nikola Jorgić invoked the ICTY's Krstić decisions in his appeal to the European Court of Human Rights (ECHR), where he argued in part that the German courts

\footnotetext{
${ }^{153}$ Prosecutor v. Radislav Krstić, IT-98-33-A, Judgment (Apr. 19, 2004) at para 36 (International Criminal tribunal for the former Yugoslavia, Appeals Chamber) online: ICTY <wwwicty.org $>$ [Krstić, Appeals].

${ }^{154}$ Ibid. at para 28.

${ }^{155}$ Ibid. at para 25.

156 Ibid. at note 39, citing ILC, 1996 "Draft Code," supra note 6 at 90-91 and William A. Schabas, Genocide in International Law (2000) at 229.
} 
had misunderstood the definition of genocidal destruction contained in the Genocide

Convention. He asserted that the understanding of destruction used in his case

was contrary to ... the Genocide Convention as adopted by the community of states. In fact, according to the internationally accepted doctrine, genocide applied only to cases in which murder, extermination or deportation was carried out with intent to eliminate a narrowly defined group, that is, to destroy it in a biological-physical sense, not merely as a social unit. ${ }^{157}$

The ECHR weighed in, declaring “the national courts' interpretation of the crime of genocide could reasonably be regarded as consistent with the essence of that offence and could reasonably be foreseen by the applicant at the material time." ${ }^{158}$ In support of this determination, the court argued that the ICTY's decisions "expressly disagreed with the wide interpretation of the 'intent to destroy' as adopted by the United Nations General Assembly"159 and found that in the early 1990s, at the time Jorgic had committed the acts, there had been no materialist consensus around the definition of genocidal destruction. ${ }^{160}$ It also argued that the Genocide Convention's purpose, or "essence," could accommodate the protection of a group's social existence.

In Prosecutor v. Blagojević \& Jokić, an ICTY Trial Chamber relied on the German courts' decisions in Jorgić and Judge Shahabuddeen's dissent in Krstić to find that ethnic cleansing can amount to "the material destruction of the group," especially when such transfers involve "the separation of its members." 161 The Trial Chamber emphasized "that its

\footnotetext{
157 Jorgic v. Germany, No 74613/01, [2007] III ECHR 263 at 294 [Jorgic v Ger.].

${ }^{158}$ Ibid. at 299.

${ }^{159}$ Ibid. at 298, citing The Situation in Bosnia and Herzegovina, GA Res 47/21, UN GAOR, 47th Sess, UN Doc A/Res/47/121 (1992).

160 Jorgic v. Germany, ibid. at 298.

${ }^{161}$ Prosecutor v Vidoje Blagojević \& Dragan Jokić, IT-02-60-T, Judgment (Jan. 17, 2005) at para 666 (International Criminal Tribunal for the Former Yugoslavia, Trial Chamber) online: ICTY <www.icty.org >.
} 
reasoning and conclusion are not an argument for the recognition of cultural genocide, but rather an attempt to clarify the meaning of physical or biological destruction."162

Nonetheless, it declared

that the physical or biological destruction of a group is not necessarily the death of the group members. While killing large numbers of a group may be the most direct means of destroying a group, other acts or series of acts, can also lead to the destruction of the group. A group is comprised of its individuals, but also of its history, traditions, the relationship between its members, the relationship with other groups, the relationship with the land. The Trial Chamber finds that the physical or biological destruction of the group is the likely outcome of a forcible transfer of the population when this transfer is conducted in such a way that the group can no longer reconstitute itself - particularly when it involves the separation of its members. In such cases the Trial Chamber finds that the forcible transfer of individuals could lead to the material destruction of the group, since the group ceases to exist as a group, or at least as the group it was. ${ }^{163}$

In this manner, the Trial Chamber argues that the group's material existence depends upon its social coherence, its culture. What, it implies, is a human group but a cultural entity? And aren't serious attacks on its social and cultural cohesion aimed at its material destruction? In a footnote, the Appeals Chamber dismissed this critique, stating only "that displacement is not equivalent to destruction."164

In September 2006, between the Blagojević judgments, a court directly addressed whether an act specifically prohibited by article 2 should be considered outside the Genocide Convention's reach when it is intended to destroy the group through cultural processes. The Trial Chamber in Krajišnik faced the question of whether it is possible to discern the specific intent to destroy a group when killings are directed at disrupting the group's cultural

\footnotetext{
162 Ibid.

${ }^{163}$ Ibid.

${ }^{164}$ Prosecutor v Vidoje Blagojević \& Dragan Jokić, IT-02-60-A (9 May 2007) at note 337 (International Criminal Tribunal for the Former Yugoslavia, Appeals Chamber) online: ICTY <www.icty.org>.
} 
cohesion. ${ }^{165}$ The court declared, provocatively, that '“[d]estruction,' as a component of the mens rea of genocide, is not limited to physical or biological destruction of the group's members, since the group (or a part of it) can be destroyed in other ways, such as by transferring children out of the group (or the part) or by severing the bonds among its members." 166 In a footnote, it stated,

It is not accurate to speak of "the group" as being amenable to physical or biological destruction. Its members are, of course, physical or biological beings, but the bonds among its members, as well as such aspects of the group as its members' culture and beliefs, are neither physical nor biological. Hence the Genocide Convention's "intent to destroy" the group cannot sensibly be regarded as reducible to an intent to destroy the group physically or biologically, as has occasionally been said. ${ }^{167}$

The court dismissed the genocide charges, and so the Appeals Chamber did not address this statement. If it had, it surely would have corrected it in the same manner as it corrected Blagojević. ${ }^{168}$ Returning to the subject in 2010, an ICTY Trial Chamber in Prosecutor v. Popovic stated merely that “[t]he term 'destroy' in customary international law means physical or biological destruction and excludes attempts to annihilate cultural or sociological elements." 169

\footnotetext{
${ }^{165}$ Prosecutor v Momčilo Krajišnik IT-00-39-T (27 September 2006) at para 854 (International Criminal Tribunal for the Former Yugoslavia, Trial Chamber) online: ICTY <www.icty.org $>$ [Krajišnik].

166 Ibid.

${ }^{167} \mathrm{Ibid}$. at note 1701.

${ }^{168}$ See Elisa Novic, “Physical-biological or Socio-Cultural 'Destruction' in Genocide? Unraveling the Legal Underpinnings of Conflicting Interpretations" 17 J Genocide Res (2015) 64 at 69.

${ }^{169}$ Prosecutor v Vujadin Popovic, IT-05-88-T, Public Redacted Judgment vol 1 (10 June 2010) at para 822 (International Criminal Tribunal for the Former Yugoslavia, Trial Chamber) online: ICTY <www.icty.org $>$ [Popovic].
} 


\section{The ICJ}

In Bosnia v. Serbia (2007), the ICJ quoted the Krstic Trial Chamber to the effect that

"[a] clear distinction must be drawn between physical destruction and mere dissolution of a

group. $" 170$ It considered

that there is conclusive evidence of the deliberate destruction of the historical, cultural and religious heritage of the protected group during the period in question. The Court takes note of the submission of the Applicant that the destruction of such heritage was "an essential part of the policy of ethnic purification" and was "an attempt to wipe out the traces of [the] very existence" of the Bosnian Muslims. However, in the Court's view, the destruction of historical, cultural and religious heritage cannot be considered to constitute the deliberate infliction of conditions of life calculated to bring about the physical destruction of the group. Although such destruction may be highly significant inasmuch as it is directed to the elimination of all traces of the cultural or religious presence of a group, and contrary to other legal norms, it does not fall within the categories of acts of genocide set out in article II of the Convention. In this regard, the Court observes that during its consideration of the draft text of the Convention, the Sixth Committee of the General Assembly decided not to include cultural genocide in the list of punishable acts . . Furthermore, the ICTY took a similar view in the Krstić case, finding that even in customary law, "despite recent developments", the definition of acts of genocide is limited to those acts seeking the physical or biological destruction of a group. The Court concludes that the destruction of historical, religious and cultural heritage cannot be considered to be a genocidal act within the meaning of Article II of the Genocide Convention. ${ }^{171}$

${ }^{170}$ Case Concerning the Application of the Convention on the Prevention and Punishment of the Crime of Genocide (Bosnia and Herzegovina v. Serbia and Montenegro) [2007] ICJ Rep 47 at 123 [Bosnia v Serbia].

${ }^{171}$ Ibid. at 186. Notably, Schabas mis-cites this passage in support of his exclusionist stance. See Schabas, Genocide 2d, supra note 97 at 218. According to Schabas, the ICJ cited the Krstić Trial Chamber for the proposition

that even in customary law, 'despite recent developments,' genocide was limited to physical or biological destruction of a group."

In fact, the passage Schabas seems to be quoting reads that

even in customary law, "despite recent developments," the definition of acts of genocide is limited to those acts seeking the physical or biological destruction of a group.

(Bosnia v Serbia supra note 170 at 186 [emphasis added], citing Krstić, Trial, supra note 145 at para 580.) Of course, it is difficult to know which parts of the ICJ opinion Schabas meant to quote, as he bemuses by using closing quotation marks sans opening marks. However, the quoted passage still emphasizes prohibited acts; the glancing mention of destruction occurs only in relation to the prohibited acts. It may not be the blanket statement on destruction that Schabas believes, but its obscurity and incoherence do evidence exclusion's inherent instability. 
However, the ICJ statement on this issue was not as clear as it might have been. Notably, when it states that "[a]lthough such destruction may be highly significant . . . it does not fall within the categories of acts of genocide set out in article II of the Convention," the ICJ again conflates the acts by which genocide is carried out with the destruction those acts were aimed at achieving. ${ }^{172}$ Moreover, in stating that "the definition of acts of genocide is limited to those acts seeking the physical or biological destruction of a group," it commits an amateurish act of legal fictionalization in animating acts with agency. Acts, after all, might be directed at a result, but they seek nothing; the perpetrator is the one who seeks. By attributing intent to the act rather than the perpetrator, the court cordons the destruction analysis from the intent analysis of which it should be part. ${ }^{173}$ Finally, by addressing itself to the destruction of "heritage," the court emphasizes the material artifacts of group culture, leaving open whether attacks on the less tangible day-to-day social processes of group coherence might amount to genocide. ${ }^{174}$ Where the destruction of libraries, places of worship, and other cultural edifices could be considered a matter of "heritage," forced child removals, targeted killings, and systematic rape affect not heritage but ongoing group

\footnotetext{
172 Bosnia v Serbia supra note 170 at 185-86. See also Croatia v Serbia Preliminary Objections, supra note 5 at 464-65. The ICJ states that although its earlier decisions do "not have the force of res judicata ... [i]t sees no reason to depart from its earlier finding" that "the "deliberate destruction of the historical, cultural and religious heritage of the ... group ... does not fall within the categories of acts of genocide set out in article II of the"” Genocide Convention.

${ }^{173}$ What matters is whether the perpetrator intended his act to destroy a group, at least "in part." Of course, actual destruction is compelling proof of intent, but it is relevant only insofar as it speaks to the perpetrator's intent. By attributing intent to acts rather than perpetrators, the ICJ appears to foreclose this inquiry.

${ }^{174}$ See The Shorter Oxford English Dictionary, 5th ed, sub verbo "Heritage" 1) That which is or may be inherited; fig. the portion allotted to a specified person, group etc. that devolved on the heir at law as opp. to an executor. 2) The fact of inheriting; hereditary succession 3) A gift which constitutes a proper possession ... 4) Inherited circumstances or benefits ... Attrib. \& Comb.: In the senses 'forming part of a national or cultural heritage,' as heritage highway, heritage train, etc. 'concerned with the conservation and use of the national or cultural heritage,' as heritage group, heritage industry, ....” (Emphasis omitted.)
} 
function. Read in this light, Bosnia v. Serbia may not have been the full-throated endorsement of exclusion many have assumed.

In 2015, the ICJ expanded its destruction analysis, slightly. In Croatia v. Serbia, the court began by noting "that the travaux préparatoires of the Convention show that the drafters originally envisaged two types of genocide, physical or biological genocide, and cultural genocide, but that this latter concept was eventually dropped in this context." 175 The court also invokes the drafting debates as evidence of the drafters' intent to exclude those acts specifically prohibited under article 2 when they are intended to cause the group's cultural destruction. However, in taking this controversial leap, the court states only that "[i]t was accordingly decided to limit the scope of the Convention to the physical or biological destruction of the group." 176 The court does not say who "accordingly decided to limit the scope of the convention," or when such a restriction was imposed. And in support it cites only the ILC report, as relied upon by the court in Bosnia v. Serbia. ${ }^{177}$

The court then moves on to deploy its destruction analysis to restrict the ambit of the acts prohibited under the Genocide Convention. The court states,

It follows that "causing serious ... mental harm to members of the group" within the meaning of article II (b), even if it does not directly concern the physical or biological destruction of members of the group, must be regarded as encompassing only acts carried out with the intent of achieving the physical or biological destruction of the group, in whole or in part. ${ }^{178}$

\footnotetext{
${ }^{175}$ Application of the Convention on the Prevention and Punishment of the Crime of Genocide (Croatia $v$ Serbia), [2015] ICJ Rep 3 at 63 [Croatia v Serbia].

${ }^{176}$ Ibid. citing Bosnia v Serbia, supra note 170 at 186, citing ILC, 1996 “Draft Code," supra note 6 at 45-46.

177 Ibid.

${ }^{178}$ Ibid. The court continues,
}

As regards the forcible transfer of children of the group to another group within the meaning of article II (e), this can also entail the intent to destroy the group physically, in whole or in part, since it can have 
The court avoids addressing whether selective killings of religious, intellectual, or cultural leaders, which are intended to destroy the group by weakening its cultural cohesion, would now be excluded. Judge Cançado Trindade dissented, arguing that the "attempt to dissociate physical/biological destruction from the cultural one, for the purpose of the determination of genocide, appears to me an artificiality." 179

\section{The ICC}

At least one International Criminal Court (ICC) judge has been unwilling to commit herself to the ILC exclusion stance as adopted by the ICTY and ICJ. The Pre-Trial Chamber in Prosecutor v. Omar Hassan Ahmad Al Bashir rejected the view that ethnic cleansing can never amount to genocide. ${ }^{180}$ In her Partially Dissenting Opinion, Judge Anita Ušacka canvassed the case law and provided this interpretation:

Although the genocidal actus reus must consist of one of the listed acts, there has been disagreement over the question whether, for purposes of demonstrating that an accused possessed genocidal intent, it must be shown that the accused intended to cause the physical or biological destruction of the intended group. Further, there is a lack of consensus regarding what constitutes the physical destruction of the group. ${ }^{181}$

Judge Ušacka then asserted the court's right to apply Judge Shahabuddeen's “more expansive approach" to future proceedings against Al Bashir. ${ }^{182}$

consequences for the group's capacity to renew itself, and hence to ensure its long-term survival.

${ }^{179}$ Ibid. Dissenting Opinion of Judge Cançado Trindade, 202 at 346. See also ibid. at 345: "[C]an we, keeping in mind the victims, really dissociate physical/biological destruction from cultural destruction? In my perception, not at all; bearing in mind the relevance of culture, of cultural identity, to the safeguard of the right to life itself, the right to live with dignity."

${ }^{180}$ Prosecutor v. Omar Hassan Ahmad Al Bashir (Situation in Darfur, Sudan), Decision on the Prosecution's Application for a warrant of Arrest, Public Redacted Version, ICC-02/05-01/09 (4 March 2009) at para 145 (International Criminal Court).

${ }^{181} \mathrm{Ibid}$. Separate and Partially Dissenting Opinion of Judge Anita Ušacka at para 57.

${ }^{182} \mathrm{Ibid}$. at para 62. 


\section{Culture and Materialism: An Untenable Dichotomy}

Exclusionists believe the cultural components of a group's life can be cordoned from its continued physical existence. In practice, these things are far more difficult to distinguish. ${ }^{183}$ This is best illustrated by the act of selectively killing important group members. Killing is directly prohibited by article 2 of the Genocide Convention. Yet according to the ILC exclusion stance, courts should not consider possible cultural implications when assessing a perpetrator's intent to destroy a group by this act. Nevertheless, the Krstić Trial Chamber, which first incorporated the ILC exclusion stance into international case law, found that in selectively killing military-aged men, "the Bosnian Serb forces had to be aware of the catastrophic impact that the disappearance of the two or three generations of men would have on the survival of a traditionally patriarchal society."184 In Jelisic, the Trial Chamber determined that "substantial" could have both a qualitative and a quantitative meaning. ${ }^{185}$ That is, a group might be destroyed either by killing a significant proportion of the group's members or by selectively killing an important segment of the population, especially its leaders. ${ }^{186}$ According to the Trial Chamber,

[g]enocidal intent may ... manifest in two forms. It may consist of desiring the extermination of a very large number of the members of the group, in which case it would constitute an intention to destroy a group en masse. However, it may also consist of the desired destruction of a more limited number of persons selected for the impact that their disappearance would have upon the survival of the group as such. This would then constitute an intention to destroy the group "selectively."187

\footnotetext{
${ }^{183}$ See also my analysis, Kurt Mundorff, “Other Peoples' Children: A Textual and Contextual Interpretation of the Genocide Convention, article 2(e)" 50 Harv Intl L J (2009) 61 at 112-19.

${ }^{184}$ Krstić, Trial, supra note 145 at para 595.

185 Jelisić, Trial, supra note 123 at para 82.

${ }^{186} \mathrm{Ibid}$. See also Sikirica, supra note 123 at para 77. See also Brđanin, supra note 123 at para 703.

187 Jelisić, Trial, supra note 123 at para 82.
} 
Cultural factors are the hinge that allows the court to find that selective killings amount to genocide, because, absent cultural considerations, there is no demonstrable intent to destroy the group, and therefore no genocide. ${ }^{188}$

Preventing genocide is a major purpose of the Genocide Convention, as evidenced by its full title, Convention on the Prevention and Punishment of the Crime of Genocide. In this regard, it is common to assert that killing only a few individuals, or even a single individual, could amount to a violation of the Genocide Convention if such a killing were carried out with a further intent to destroy the group. The idea is to intervene in a genocide's earliest stages rather than waiting for mass tragedy. Therefore, at least on a theoretical level, killing only one individual in pursuance of a plan to destroy a group's material existence could be considered genocide. However, killing thousands of individuals would be excused if such killings were carried out in pursuance of a plan to destroy a group's cultural existence. ${ }^{189}$ This anomaly provides a road map to escape liability for genocide while actually increasing the number of those killed. ${ }^{190}$

\footnotetext{
${ }^{188}$ But see Nersessian, Political Groups, supra note 124 at 45 . Nersessian criticizes this approach, arguing that it presumes "that some human beings are (or were) inherently more valuable for the group's survival than others." But some individuals are, and this is true whether or not its offends Nersessian's individualistic egalitarianism. Killing a group's janitors, barbers, or merchants simply does not threaten group existence in the way killing its priests, intellectuals, or political leaders would.

${ }^{189}$ Douglas Singleterry, ““Ethnic Cleansing' and Genocidal Intent: A Failure of Judicial Interpretation?” 5:1 Genocide Stud and Prevention (2010) 39 at 58.

${ }^{190}$ Bosnia v Serbia, supra note 170 at 154-55, took an analogous approach when it determined that despite "overwhelming evidence" of "massive killings in specific areas and detention camps" against members of a protected group, no acts of genocide had occurred. The court declined to find the acts of mass murder amounted to genocide because "the fact that an essential motive of much of the Bosnian Serb leadership - to create a larger Serb State, by a war of conquest if necessary — did not necessarily require the destruction of the Bosnian Muslims and other communities, but their expulsion." (Ibid. at 196.) See also ibid. at 166, concluding "that the acts committed at Srebrenica falling within article II (a) and (b) of the Convention were committed with the specific intent to destroy in part the group of Muslims of Bosnia and Herzegovina as such; and accordingly that these were acts of genocide...."
} 


\section{Case Law Conclusion}

It is often said that a major role of human rights and war crimes trials is to document atrocity. Martha Minow argues that "[ $\mathrm{t}]$ rials can create credible documents and events that acknowledge and condemn horrors. Thus, they help to articulate both norms and a commitment to work to realize them." ${ }^{191}$ To the extent that this is a legitimate goal for international criminal law, and I believe it is, it is undercut by a refusal to consider the full effect of the crimes committed. Isolating cultural concerns from the measure of genocide avoids a true accounting of either the perpetrator's intent in destroying the group or the actual reach of that attack. It discounts the group's experience of genocide, declaring some concerns legitimate and others not. It results in a partial and arbitrary accounting of atrocity.

Perhaps the most striking feature of the discussion of exclusion in the case law is its near-total lack of substance. The ICTY and the ICJ have forged a customary law of exclusion based entirely on the ILC's unsubstantiated assertion that the Genocide Convention's preparatory work clearly shows its drafters only meant it to address physical and biological genocide and its mistaken assertion that the acts of genocide prohibited in article 2 only “come within the category of 'physical' or 'biological' genocide."192 To be sure, courts have invoked the text of the Genocide Convention, but only in the vaguest way, so that it is impossible to determine which language they rely upon. ${ }^{193}$ Courts have also cited the drafting debates, but again only in a cursory manner. ${ }^{194}$ To buttress their conclusions, they point to the

\footnotetext{
${ }^{191}$ Martha Minow, Between Vengeance and Forgiveness: Facing History After Genocide and Mass Violence (Boston: Beacon Press, 1998) at 50.

192 ILC, 1996 “Draft Code," supra note 6.

193 See e.g. Krstić, Appeals, supra note 125 at para 25, note 39.

${ }^{194}$ See e.g. Bosnia $v$ Serbia, supra note 170 at 185-86. Rejecting culpability for "the deliberate destruction of historical, cultural, and religious heritage" the court asserts only that "the Sixth Committee of the General
} 
ILC statement, to each other, ${ }^{195}$ or to Schabas, ${ }^{196}$ who argues that " $[\mathrm{w}]$ hile these questions were not specifically debated during the drafting of article II, the spirit of the discussions resists extending the concept of destruction beyond physical and biological acts." ${ }^{197}$ The result is a customary law of exclusion based entirely on ill-informed assertion backed up by ethereal conversational spirits.

Given the fractious character of this case law, Schabas' declaration that "the absence of cultural genocide" in the Genocide Convention "is a dead issue" "among international law-makers" seems premature. ${ }^{198}$ In fact, the approaches of the ICTR and the ICTY are rent by dissention and contradiction, and the ICJ and ICC have addressed the issue only in

\footnotetext{
Assembly decided not to include cultural genocide in the list of punishable acts" and cites the ILC, 1996 "Draft Code," supra note 6, and Kristić, Trial, supra note 145 at para 580. See also Croatia v Serbia, supra note 175 at 63. In what stands as the most thoroughgoing judicial consideration of the Genocide Convention's preparatory work, the court cites Ad Hoc Committee on Genocide, Draft Convention on Prevention and Punishment of the Crime of Genocide, UNESCOR, (1948) UN Doc E/794, which indicates that a majority of the delegates voted in favour of including acts of cultural genocide, and then cites the 83rd Session of the Sixth Committee, (UN GAOR, Sixth Committee, 3rd Sess, 83rd Mtg, UN Doc A/C.6/SR.83 [1948]), where the cultural genocide provision was voted down. But as I discussed above, there was significant opposition to the idea that all cultural considerations had been excluded. The court also cites itself in Bosnia $v$ Serbia, citing the ILC, 1996 "Draft Code." See also Krstić, Trial, supra note 145 at para 576. The court declares that "[a]lthough the Convention does not specifically speak to the point, the preparatory work points out that the 'cultural' destruction of a group was expressly rejected after being seriously contemplated." In the supporting footnote, it states merely that "[t]he notion of a cultural genocide was rejected by the General Assembly Sixth Committee by 25 votes to 6 with 4 abstentions." (Ibid. at note 1284.) It also cites the ILC, 1996 "Draft Code." See also Brđanin, supra note 123 at para 694, notes 1710, 1711, citing the ILC, 1996 "Draft Code," Krstić, Trial, supra note 145; Krstić, Appeals, supra note 153; Semanza, supra note 132; Kajelijeli, supra note 145). See also Kajelijeli, supra note 145 at para 808, citing ILC, 1996 "Draft Code,"; Semanza, supra note 132; and, Kayishema and Ruzindana, supra note 143. See especially Semanza, supra note 132 at para 315, note 535, citing only ILC, 1996 "Draft Code." Popovic, supra note 169 at para 822, note 2944 cites only Krstić Appeals, supra note 153, and Bosnia v Serbia, supra note 170.

${ }^{195}$ See Ibid. But see Stakić, supra note 145 at notes 60, 61, citing the Whitaker Report, supra note 95 at para 32.

${ }^{196}$ See Krstić, Appeals, supra note 153 at para 25, note 39. The court quotes the ILC and then asserts, "The commentators agree. See, e.g., William A. Schabas, Genocide in International Law (2000), p. 229, (concluding that the drafting history of the Convention would not sustain a construction of the genocidal intent which extends beyond an intent at physical destruction.)"

${ }^{197}$ Schabas, Genocide $2 d$, supra note 97 at 271 [emphasis added].

${ }^{198}$ Ibid. at 220.
} 
passing. This would be a more lively issue were it not for the interventions of Schabas and other like-minded scholars, who create a false picture of consensus.

\section{Conclusion}

This chapter has charted the origins of ILC draft code and the evolution of exclusion, documenting how these developments coalesced in the ILC's 1996 commentary. As it turns out, Lemkin was right to be concerned about the ILC. Incorporating the Genocide Convention into the draft code, and later the Rome Statute of the International Criminal Court, has encumbered it with ancillary elements, ultimately restricting its range and, I would argue, changing our basic conception of genocide. ${ }^{199}$ The doctrine of exclusion is perhaps the most significant of these changes.

Exclusion began with a simple observation that certain acts of cultural genocide had been voted out of the Genocide Convention. These acts, intended to directly attack a group's cultural cohesion, included prohibitions on language use and destruction of cultural monuments. But within months of codification, a new argument emerged that metastasized this uncontroversial observation into an assertion that the drafters had intended to exclude all cultural considerations from the Convention. Lemkin referred to this as the American "belief," a materialist overlay that the American delegation used to domesticate the

${ }^{199}$ See Rayfuse, supra note 10 at 63:

Other aspects of the Draft Code's relationship with the Genocide Convention are more problematic. Article 3 of the Genocide Convention provides that genocide, conspiracy to commit genocide, direct and public incitement to commit genocide, attempt to commit genocide, and complicity in genocide shall be punishable. Although the Draft Code includes commission, incitement, attempt, and complicity in article 2 , their application is limited by the requirement either that the crime did, in fact, occur or, in the case of attempt, that the crime was not completed because circumstances independent of the intentions of the person attempting the crime... [T] [Tis appears to impose a higher threshold than that set out in the Genocide Convention and could cause considerable difficulty in the prosecution of these crimes. 
Convention. ${ }^{200}$ As I've documented above, this viewpoint was controversial among the drafters and only ever found support among a minority of the parties. Even the Americans were never able to free themselves entirely from a more substantialist view of human groups.

By 1990s, the ILC had evolved the American belief into a legal doctrine whereby even those acts that the Genocide Convention had specifically prohibited would be excused if they destroyed a group through cultural means. In this manner, adherents to the American belief have been able to achieve through interpretation what they could not gain through negotiation. Despite its many weaknesses, exclusion's place seems increasingly secure.

${ }^{200}$ Anon (Raphael Lemkin) “Genocide: A Commentary on the Convention” 58 Yale L J (1949) 1142, 45. 


\section{Conclusion}

All your letters and communications are suffering from one disease; a complete ignorance of the basic concept of genocide. (Raphael Lemkin, 1950 ${ }^{1}$ )

if everything happens that can't be done

(and anything's righter

than books

could plan)

the stupidest teacher will almost guess

(with a run

skip

around we go yes)

there's nothing as something as one

one hasn't a why or because or although

(and buds know better

than books

don't grow)

one's anything old being everything new

(with a what

which

around we come who)

one's everyanything so

...

(E. E. Cummings, $1943^{2}$ )

On January 12, 1951, the day the Convention on the Prevention and Punishment of

the Crime of Genocide (Genocide Convention) entered into force, Lemkin counselled,

Those who will follow my example in engaging in a crusade for an idea, I offer the following pattern of my experience. First, you will be told the idea is not good; then, when they will find it good, a smell [sic] but skillful group of professional people in the same field will fight you openly or under cover; and when you will finally be very

\footnotetext{
${ }^{1}$ Raphael Lemkin to Willard Johnson, U.S. Committee for a U.N. Genocide Convention (2 January 1950) New York, American Jewish Historical Society, Raphael Lemkin Collection [AJHS] (Box 2, File 4).

${ }^{2}$ EE Cummings, Poetry: A Magazine of Verse 63 (July 1943) at 183.
} 
close to achieving your goal, they will try to make this idea accepted with slight changes and under a different name. All of that was tried on me in the last 18 years up to the lest [sic] General Assembly of the United Nations. The fight and obstacles put under way of a lonely crusader in any field might break his health, but never his spirit. $^{3}$

\section{As Lemkin continued his fight for the Genocide Convention, it demanded ever more of him} yet provided ever-diminishing rewards. His bid for a Nobel Peace Prize received scant support, publishers were unenthusiastic about his book proposals, employment was intermittent, and his health faltered. ${ }^{4}$ Yet he persevered.

When he died at fifty-nine, the New York Times reported that he had spent the summer outside the city working on his "autobiography, which would have been called

${ }^{3}$ Raphael Lemkin, Statement: "The Genocide Convention Goes Into Force Today" (12 January 1951) AJHS, supra note 1 (Box 6, File 2). Despite admitting he was "frightened by the number and gravity of obstacles which had to be overcome," Lemkin wrote,

The spiritual force of a humanitarian crusade is stronger than any obstacles so that individuals and governments must bow before this force. The spiritual force of the campaign against genocide became finally recognized by governments and received a diplomatic status of its own. For these reasons, I was able to approach directly heads of state, members of cabinet, members of parliaments, and to receive from them pledges for action which they have factually carried out, little mattered to them that I was only a private individual. In this way, it was possible for me to secure not only the cooperation of U.K. delegations for the adoption of the Convention but also the cooperation of governments and their parliaments for ratifications of the Convention. I make this statement and underline this fact for the benefit of those who tend to become cynical about humanity and who believe governments and states are amenable only to considerations of force and practicality and who also believe that this world became so brutalized that it is unable to carry on great humanitarian endeavors. (Ibid.)

See also Raphael Lemkin, (untitled, undated, first three pages missing) New York, New York Public Library, Archives and Manuscripts, Raphael Lemkin Papers [NYPL] (Reel 3, File 4) at 6. He warned that "[s]hould the plans of the secretive opponents of the Genocide convention materialize, the Convention will become 'deadwood' and will never be applied. This will be a loss without repair to mankind and especially to those nations which need the Convention for their own protection."

${ }^{4}$ John Cooper, Raphael Lemkin and the Struggle for the Genocide Convention (New York: Palgrave Macmillan, 2008) 265-67. 
'Unofficial Man." ${ }^{5}$ Having returned to the city on business concerning the book, "[h]e died in the public relations office of Milton H. Blow." After mentioning that only one other member of his extensive family had survived the Holocaust, the obituary ended by noting that "[h] was a bachelor."

Lemkin was survived only by his idea, genocide. But as I have shown, Lemkin's progeny has come under increasing attack. He knew this would happen. He warned that "[m]ore attacks on the Convention in one form or another are bound to come. This only proves the great value of the Convention. However, it was said before that vigilance is the price of liberty, in this particular case, vigilance is the price of humanity." $\mathrm{He}$ argued that the most dangerous attacks on his legacy would be the most difficult to recognize and cautioned vigilance because these individuals-lawyers, diplomats, and "human rights activists"_- “do not act openly."7

\section{Summary of the Argument}

Among the most damaging of these attacks has been the doctrine of exclusion, which would strip the Genocide Convention of any concern with culture. According to the International Law Commission, the Genocide Convention lists only physical and biological acts of genocide and cannot reach any attack if that attack was intended to cause the group's

\footnotetext{
5 "Raphael Lemkin, Genocide Foe, Dies," Obituary, The New York Times (30 August 1959). There is some dispute over the precise location of his death. Michael Ignatieff, "The Unsung Hero Who Coined the Term 'Genocide"' New Republic (21 Sept 2013) 220, online: New Republic <

https://newrepublic.com/article/114424/raphael-lemkin-unsung-hero-who-coined-genocide> recounts how Lemkin "collapsed at a bus stop on 42nd Street in New York in August 1959 and died at the age of 59, friendless, penniless, and alone, leaving behind a bare rented room, some clothes, and a chaos of unsorted papers."

${ }^{6}$ Raphael Lemkin, "The Continuing Fight for the Existence of the Convention" (undated) NYPL, supra note 3 (Reel3, File 4) at 13.

${ }^{7}$ Raphael Lemkin, letter to Major John Ennals, Association des Nations Unies (17 July 1948) AJHS, supra note 1 (Box 1, File 19).
} 
cultural, as opposed to physical or biological, destruction. However, the Genocide Convention's text contains no language either limiting it to only acts of cultural genocide or restricting its reach only to instances when a perpetrator intends a group's physical or biological destruction. Facing this absence, they argue that to understand the Convention we must disregard its text and look to its preparatory work, which, they assure us, evidences the parties' intent to completely exclude cultural concerns.

To be sure, the Convention's drafters did vote, repeatedly, to reject proposals criminalizing certain acts committed against a group's cultural manifestations. These included acts restricting a group's use of its own language, its right to educate its children in its own schools, and prohibitions on destroying important cultural artifacts or edifices. Some drafters found these provisions overly vague, while others considered these acts de minimis when placed alongside mass killings and the other acts prohibited as genocide.

Yet the Genocide Convention's preparatory work provides little indication that the parties had intended to place all cultural matters beyond its reach. Some parties favoured a materialist conception of genocide, but they were never able to garner majority support for this position. In fact, the drafters rejected provisions that would have created a purely materialist conception of genocide, one that actually would exclude cultural considerations. Moreover, even after the cultural genocide provisions had been voted out of the Convention, many drafters expressed their belief that the Convention continued to protect a group's cultural existence. Exclusionists silence these voices, reading them out of the historical record. Through interpretation, they grant the materialists a victory unachievable through negotiation. 
That the Genocide Convention embodies strong culturalist assumptions should be unsurprising, for Lemkin's idea and the Convention itself grew from a particular historical context, a time when the idea of culture dominated social and political thinking. It was the controlling idea with which other ideas were forced to conform, dominating social science, political thought, and even foreign policy. As I outlined in Chapter 2, the rapid and overwhelming success of Lemkin's idea of genocide resulted from the simple fact that it accorded well with the thinking of his time.

While it is possible to force a materialist interpretation onto the Convention's text, the Convention seems to resist, exposing any number of contradictions. Because of the poor fit between today's concepts and yesterday's commitments, courts have misunderstood the Genocide Convention's group protections. Instead of honouring the cultural life of groups, as the Genocide Convention asks them to, courts have hewed to exclusionism, which seeks to cordon all such considerations. The result is a distorted caricature of the concept of genocide joined to an unwieldy legal doctrine that is difficult to apply. In today's world, which is increasingly threatened by genocide, actual prosecutions for genocide are exceedingly rare.

\section{Limitations of This Study and Areas of Future Inquiry}

Almost inevitably, intellectual projects face constraints of time, format, skills, and opportunity. I think this is doubly true with a project such as this one, which has transgressed disciplinary boundaries in addressing a quintessentially international and cross-cultural topic. Perhaps the greatest limitation has been my embarrassing monolingualism. Although digital translation tools and cooperative friends have provided important help with certain significant documents, other areas of inquiry were foreclosed. I suspect, for instance, that the Spanish-language literature and archival materials contain a wealth of information on Mr. 
Pérez Perozo and Mr. Amado, along with other international lawyers from Latin America who played such a pivotal role in the Genocide Convention's drafting. The same could probably be said of delegates from other participating countries. While I was able to access archival documents related to the US State Department's involvement in the drafting process, I suspect similarly rich materials exist for each of the participating states. A truly international history of the Genocide Convention's origins awaits a scholar, or perhaps a group of scholars, better positioned to delve these resources.

As expansive as it is, this project has also been limited by the thesis format. At times it feels like as much writing has been cut from the final draft as has been included (although I hope this isn't true). The omitted material tended toward the tangential or esoteric and deviated from this project's core thesis. One such topic addressed the minorities protection regime established by the Minorities Treaties of Versailles and its role in shaping the Genocide Convention's drafters' ideas on the possibility of international governance. ${ }^{8}$ Another concerns the original antinomy between the Genocide Convention's group protections and the individualistic bent of the human rights doctrine as it emerged in the immediate postwar period. I look forward to exploring these topics in future writings. Various side topics have also tempted me in other directions. Like the exclusion doctrine, I suspect the stringent specific intent standard currently imposed on the Genocide Convention is arbitrary and would not hold up to a thorough historical treatment. Also remaining to be explored is the pivotal yet hidden role played by women in the development of international criminal law in the immediate postwar period. At a time when very few

\footnotetext{
${ }^{8}$ See e.g. Minorities Treaty between the Principal Allied and Associated Powers and Poland art. 9, June 28, 1919, 225 Consol. T.S. 412.
} 
women were provided the opportunity to earn law degrees, Justice Jackson recruited a number of female lawyers to staff the United States' delegation to the Nuremberg Trials. While they were forced to remain behind the scenes, their work was pivotal in shaping the prosecutions. Similarly, Marjorie Whiteman played an important but unheralded role at the State Department during this crucial time, and her influence is apparent in the archival materials. As well, an international network of women's social welfare organizations organized massive support in their public campaign for the Genocide Convention.

Finally, this project is intended more as an initial salvo: a sometimes impertinent imploration to reconsider the idea of culture in the origins and subsequent interpretation of the Genocide Convention. As much as any other legal history project, it relies on an interpretation of the documentary record and is therefore vulnerable to the interpretive biases and misinterpretations that I discussed in my first chapter. My hope is that this project will spark interest in this subject and spur scholars to look further into these materials. I'm sure they will find blind spots in my work along their way.

\section{Professor Popper's Paradigm}

Over the course of my research, this project transitioned from an exercise in treaty interpretation — understood broadly—to an exploration of historical change and its effect on meaning. To this point, I have emphasized the political and intellectual milieu of the immediate postwar period, mostly avoiding a broader discussion of the difference created by the intervening historical changes. Yet this difference is key. For, in the interim, a rapidly globalizing society has embraced an ethic of resurgent individualism that has reached into nearly every corner of intellectual life. It is this difference, between their collectivist concerns and our individualism, that makes the Genocide Convention's terms appear inscrutable. 
The career of the term "culture" might provide the best example of this tectonic shift. In Keywords, published in the mid-1970s, Raymond Williams addressed the history and "the range and overlap of meanings" of the term "culture." Against all this "complexity," it is clear that to Williams the anthropological idea of culture, denoting the way of life of a people, had come to prevail over other competing "senses" of the term. But as Williams was writing his Keywords entry, the idea of culture was already beginning a paradigmatic shift in meaning.

Thirty years later, when the Australian sociologist Tony Bennet addressed the meaning of "culture" in New Keywords, he emphasized the growing "misgivings" surrounding the anthropological idea of culture. ${ }^{10}$ He argued that it had "often led to a tendency to taxonomize cultures by providing a means of dividing societies into separate groups identified in terms of their distinctive beliefs and behaviors." He highlighted the way it had been used to divide "colonized populations" in order to maintain "colonial systems."11 And he quoted Adorno, noting that 'the single word 'culture' betrays from the outset the administrative view, the task of which, looking down from on high, is to assemble, distribute, evaluate and organize."

Bennet provides a litany of culture terms: gay culture, lesbian culture, ethnic cultures, diasporic cultures, transnational cultures, counter-cultures, club cultures, street cultures, drug cultures, body culture, consumer culture, prosthetic culture, sports culture, media culture, and

\footnotetext{
${ }^{9}$ Raymond Williams, Keywords: A Vocabulary of Culture and Society (London: Fontana Press, 1976) at 91.

10 Tony Bennet, "Culture" in Tony Bennet, Lawrence Grossberg, \& Meaghan Morris, eds, New Keywords: A Revised Vocabulary of Culture and Society (Blackwell, 2005) at 68.

${ }^{11}$ Ibid. quoting Theodore Adorno, The Culture Industry: Selected Essays on Mass Culture (1991) 93.
} 
visual culture, among others. ${ }^{12}$ Whatever one thinks of these terms (and most seem useful and valid), the proliferation of culture terms reveals a devaluing and erosion of, and perhaps a hostility to, the anthropological idea of culture, the very idea around which the Genocide Convention is oriented. Clearly a major historical shift has taken place.

To Elizabeth Borgwardt, the immediate postwar period was a time characterized by "a pragmatic willingness of policymakers and the general public to experiment on a grand scale" through planning and the creation of a new international order. ${ }^{13}$ During that narrow window, ideas flowed through newly porous borders, political and intellectual. But this window closed quickly, shutting out the anthropological idea of culture and other concepts used in discussing group life. ${ }^{14}$

The career trajectory of Margaret Mead, perhaps the leading anthropologist of that time, reveals policymakers' growing discomfort with particularistic concepts of group life. Following the war, Ruth Benedict and her friend Erich Fromm, a psychologist and prominent public intellectual, were approached by the Navy to join a new Human Relations Program, which would fund basic research in social science. In spring 1946, the Office of Naval Intelligence awarded Benedict a renewable annual grant of one hundred thousand dollars to

\footnotetext{
${ }^{12} \mathrm{Ibid}$. at 64 .

${ }^{13}$ Elizabeth Borgwardt, A New Deal for the World: America's Vision for Human Rights (Cambridge, MA: Belknap, 2005) at 86.

${ }^{14}$ Peter Mandler, Return From the Natives: How Margaret Mead Won the Second World War and Lost the Cold War (New Haven: Yale University Press, 2013) at 256 [Mandler, Return]. As Mandler documents, in the postwar years, cultural relativity was "threatened by powerful globalizing forces unleashed by the world war. Both the democratic and the communist versions of universalism had a powerful appeal. ... This appeal was not limited to developed-world internationalists; it spread like wildfire in these years among the new elites of the less-developed world as well."
} 
further her culture and personality research. ${ }^{15}$ In early 1947, this involvement blossomed into a centre for Research in Contemporary Cultures (RCC), directed by Benedict and funded by the US Navy's Office for Naval Research. ${ }^{16}$ Margaret Mead joined her at the RCC, where they planned a program to train workers in international relations and to compile a manual on the subject. ${ }^{17}$

Benedict died September 17, 1948, but Mead continued at the forefront of the postwar policy debates. She was recruited by the newly formed RAND Corporation, which had been set up by the Air Force primarily to conduct basic research into the methods of air warfare. She was tasked with developing cultural approaches to dealing with the Soviets. ${ }^{18}$ However, as the Korean War began, Mead's message of "Learning to Live in One World" with the Soviets proved unpopular at RAND, and in Autumn 1950 she left on less than amicable terms. ${ }^{19}$

RAND was rapidly turning away from collectivist concerns like "culture" as its scholars pioneered a return to methodological individualism cloaked in rational choice theory. Rational choice theory "place[s] a premium on the individual as the ultimate judge of

\footnotetext{
${ }^{15}$ David H Price, The Deployment and Neglect of American Anthropology in the Second World War (Durham, NC: Duke University Press, 2008) at 199.

${ }^{16}$ Mandler, Return, supra note 14 at 193.

${ }^{17}$ Ibid. at 194.

${ }^{18}$ See SM Amadae, Rationalizing Capitalist Democracy: The Cold War Origins of Rational Choice Liberalism (Chicago: University of Chicago Press, 2003) at 32-34 (founding of RAND); Peter Mandler, "One World, Many Cultures: Margaret Mead and the Limits of Cold War Anthropology" 68 Hist Workshop J (2009) 149 at 161; Mandler, Return, supra note 14 at 242-49 [Mandler, "One World"] (involvement with RAND ends). But see Price, supra note 15 at 39, pointing out that cultural anthropologists had long been involved in planning aerial bombing strategies.

${ }^{19}$ Mandler, Return, supra note 14 at 249. See also Mandler, "One World," supra note 18 at 167. In 1953, the anti-totalitarian, anti-historicist intellectual bent of America's early Cold War mobilization was realized as the Eisenhower administration took over from Truman and promptly culled the federal bureaucracy of anthropologists, staffing it instead with "retired businessmen and ... retired military officers."
} 
his or her subjectively chosen ends [and] any compromise of this individualist feature ... is regarded as a potential step toward authoritarianism and communism." ${ }^{20}$ The practitioners of this new approach saw it as an antidote to relativism and a bulwark against totalitarianism. ${ }^{21}$ They expected rational choice theory "to grow into a basic paradigmatic revolution in political science, sociology, anthropology and law," and it quickly jumped disciplinary boundaries $^{22}$ to exert a profound effect on these fields. ${ }^{23}$

Kenneth Arrow, a RAND scholar, developed these ideas in his early and influential book Social Choice and Individual Values, in which he does "not so much envision a shared social world as he does a collection of individuals whose identities are defined by their wellordered sets of preferences, and who strive to achieve their most preferred outcomes." ${ }^{24}$ As the economic historian S. M. Amadae emphasizes, the "thorough-going commitment to individuals' utility maximizing calculation in the arena of politics was designed from the beginning in opposition to idealistic democracy, socialist economics, and collectivist sentimentality." ${ }^{25}$ As Alex Abella argues, the ideas developed at RAND and weaponized for the Cold War "profoundly altered Western culture." ${ }^{26}$ Of course, these intellectual trends

\footnotetext{
${ }^{20}$ Amadae, supra note 18 at 18.

${ }^{21}$ Ibid. at 254-55. See also Alex Abella, Soldiers of Reason: The RAND Corporation and the Rise of the American Empire (Boston: Mariner, 2009).

${ }^{22}$ Amadae, supra note 18 at 148.

${ }^{23} \mathrm{Ibid}$. at 251-90.

${ }^{24}$ Ibid. at 131.

${ }^{25} \mathrm{Ibid}$. at 155.

${ }^{26}$ Abella, supra note 21 at 51. See also See Daniel Stedman Jones, Masters of the Universe: Hayek, Friedman and the Birth of Neoliberal Politics (Princeton University Press: Princeton, 2012) 126-33, describing the rise and content of PCT. These ideas were further developed through Public Choice Theory and likely found their widest audience when John Rawls applied them in his 1971 A Theory of Justice. (Amadae, supra note 18 at 145-55.) Notably, in 1964, Rawls had shop-talked his theory for the Committee for Non-Market Decision
} 
proved disastrous for the Herderian concepts of culturalism and nationalism that grounded the Genocide Convention.

RAND scholars were part of a much broader intellectual movement seeking to weaponize an amalgamation of individualism, science, and democratic theory against what they saw as state overreach at home and abroad. Karl Popper was the undisputed leader of this movement. In a series of books on The Logic of Scientific Discovery (1935), The Poverty of Historicism (1936), and The Open Society and its Enemies (1945), he enunciated a worldview founded on principles of science and individualism. ${ }^{27}$ Popper believed "the task of social theory is to construct and to analyse our sociological models carefully in descriptive or nominalist terms, that is to say, in terms of individuals, of their attitudes, expectations, relations, etc. - a postulate which may be called 'methodological individualism." ${ }^{28}$ Popper's agenda was an attack on nearly every idea held precious by Franz Boas and the social thinkers who engaged with the idea of culture. John O’Neil noted that Popper's critique "has been so persuasive that there appears to be no alternative philosophy of social science other than methodological individualism." 29

Although he had helped lay its intellectual foundation, Popper was uncomfortable with the "crude free market program" which emerged in the postwar years. ${ }^{30}$ Instead, it was

Making, attended by prominent Rational Choice Scholars, and had developed his thinking in dialogue with them. (Ibid. at 149.)

${ }^{27}$ Karl Popper, The Logic of Scientific Discovery (London, Routledge, 2002 [1935, in German; 1959, in English]); Karl Popper, The Poverty of Historicism (London: Routledge, 2002 [1936, in German; 1957, in English]); Karl Popper, The Open Society and its Enemies 2 vols (Princeton, Princeton University Press, 1945).

${ }^{28}$ Popper, Poverty, ibid. at 136 [emphasis in original].

${ }^{29}$ John O'Neil, "Scientism, Historicism and the Problem of Rationality" in John O’Neil ed., Modes of Individualism and Collectivism (New York: St. Martin's Press, 1973).

${ }^{30}$ Stedman Jones, supra note at 83. 
Friedrich Hayek, author of The Road to Serfdom (1944), who would come to lead a

movement pursuing a set of free-market ideas grounded in unbridled individualism. ${ }^{31}$ Several of the United States' prominent corporate leaders provided vital assistance to Hayek's free marketeers by underwriting publications, funding academic positions, and sponsoring cushy academic conferences through the Mont Pelerin Society. ${ }^{32}$ One society member, Milton Friedman, adopted an unrepentant laissez-faire approach to economics, which even Hayek felt had little chance of succeeding. ${ }^{33}$ Of course, Hayek was wrong, and Friedman's ideas swept Western economic and social thinking, finding perhaps their ultimate expression in Margaret Thatcher's 1987 assertion that "there's no such thing as society." 34 Rodgers describes this process as one in which

Market ideas moved out of economics departments to become the new standard currency of the social sciences. Certain game theory set-pieces - the free rider problem, the prisoner's dilemma, the tragedy of the commons-became fixtures of common sense. . . . Protean spill-over words like "choice" were called upon to do more and more work in more and more diverse circumstances. In the process some words and phrases began to seem more natural than the rest - not similes or approximations but reality itself. ${ }^{35}$

\footnotetext{
${ }^{31}$ See Angus Burgin, The Great Persuasion: Reinventing Free Markets Since the Depression (Cambridge, MA: Harvard University Press, 2012) at 101-22.

${ }^{32}$ See Kim Phillips-Fein, Invisible Hands: The Businessmen's Crusade Against the New Deal (New York: Norton, 2009) at 45-52, discussing early business support, which was crucial for the Mt. Perlin Society. See also Burgin, ibid. at 174, on how business support boosted Friedman's career.

${ }^{33}$ Burgin, supra note 31 at 185.

${ }^{34}$ See, "Margaret Thatcher: A Life In Quotes" The Guardian (8 April 2013) available at: https://www.theguardian.com/politics/2013/apr/08/margaret-thatcher-quotes.

${ }^{35}$ Daniel T. Rodgers, Age of Fracture (Cambridge, MA: Belknap Press, 2011) at 10-11. See also ibid. at 5:
}

[T]hrough more and more domains of social thought and argument, the terms that had dominated postWorld War II intellectual life began to fracture. One heard less about society, history, and power and more about individuals, contingency, and choice. The importance of economic institutions gave way to notions of flexible and instantly acting markets. History was said to accelerate into a multitude of almost instantaneously accessible possibilities. Identities became fluid and elective. Ideas of power thinned out and receded. In political and institutional fact and in social imagination, the 1930s, 1940s, and 1950s had been an era of consolidation. In the last quarter of the century, the dominant tendency of the age was 
According to David Engerman, "The rapid rise of universalistic social science, combined with a dramatic shift in political sensibilities, relegated particularist claims to the margins." ${ }^{\text {"36 }}$

Although it is tempting to credit a vast right-wing conspiracy of economists and business leaders with the reemergence of unbridled individualism, thinkers on the left embraced it just as enthusiastically. From the early 1960s and into the 1970s, as the New Left increasingly abandoned doctrines of collective action in favour of "therapeutic radicalism," individualism found fertile ground in the "Me Generation." 37 This generation unreservedly and understandably embraced the freeing of individuals from prejudices and status restrictions based on group affiliation. Although implementation was uneven, both the Left and the Right increasingly propounded an ethic of judging individuals on merit, not origins. Personal fulfillment and free expression became political ends, and any arbitrary restriction on an individual's "self-actualization" was denounced as unjust. Thomas Franck celebrated the post-World War II period in international law for delivering an "age of individualism." 38

toward disaggregation.

See also Kenneth J Arrow, "Methodological Individualism and Social Knowledge" 84:2 Am Econ Rev (1994) 1 at 4:

Social and historical determinism is not as popular viewpoint as it used to be, and an individualistic perspective is a guard against such theories. Whether in Marxist or other forms, such theories relied heavily on disembodied actors such as classes or national spirits, rather than on the actual persons. The newer trends in historical analysis are more concerned with contingency than with determinism, contingencies arising from the flexibility and freedom of individual human decision-making.

\footnotetext{
${ }^{36}$ Mandler, "One World," supra note 18 at at159, quoting David C Engerman, Modernization From the Other Shore: American Intellectuals and the Romance of Russian Development (Cambridge, MA: Harvard University Press, 2003) at 270-6. See also Amadae, supra note 18 at 251-90.

${ }^{37}$ Alan Brinkley, Liberalism and Its Discontents (Cambridge, MA: Harvard University Press, 1998) at 236.

${ }^{38}$ Thomas Franck, The Empowered Self: Law and Society in the Age of Individualism (Oxford: Oxford University Press, 1999) at 40.
} 
According to Franck, it was a time when individuals were gaining a right "to personal selfdetermination," the right to choose citizenships and assemble aggregate cultural identities. ${ }^{39}$

As it was incorporated by the academy, this ethic of personal development fed an increasing skepticism toward the anthropological idea of culture. In his important 1993 book, Culture and Imperialism, Edward Said attacked the concept of culture for conjuring a false dichotomy between the cultural and the material realms ${ }^{40} \mathrm{He}$ criticized scholars for using the false sense of perspective created by this division to carry out universalist interpretations, which they believed to be "free from attachment, inhibition, and interest." To Said, nothing could be further from the truth. Not only were the cultural and the material inseparable, but whether they realized it or not, these scholars were busily deploying cultural concepts in projects of colonial domination. ${ }^{41}$ As Susan Hegeman argues, Said's was only one of the

\footnotetext{
${ }^{39} \mathrm{Ibid}$. at 63.

${ }^{40}$ Edward W Said, Culture and Imperialism (New York: Vintage, 1993) at 56.

${ }^{41} \mathrm{Ibid}$. at 57 . He finished his book declaring,
}

No one is purely one thing. Labels like Indian, or woman, or Muslim, or American are not more than starting-points, which if followed into actual experience for only a moment are quickly left behind. Imperialism consolidated the mixture of cultures and identities on a global scale. But its worst and most paradoxical gift was to allow people to believe they were only, mainly, exclusively, white or Black, or Western, or Oriental. Yet just as human beings make their own history, they also make their cultures and ethnic identities. No one can deny the persisting continuities of long traditions, sustained habitations, national languages, and cultural geographies, but there seems no reason except fear and prejudice to keep insisting on their separation and distinctiveness, as if that was all human life was about. (Ibid. at 336.)

See also Rodgers, supra note 35 at 106. As Rodgers points out, "Culture was not in Foucault's vocabulary; power was to be found not in consciousness or ideology, he insisted, but in tactics and strategy." Rodgers asks, "[H]ad not the long, complex search for power's ever more subtle faces succeeded, at last, in finding nothing at all?" (Ibid. at 107.) See also Pierre Bourdieu, Distinction: A Social Critique of the Judgement of Taste, translated by Richard Nice (Cambridge, MA: Harvard University Press, 1984). Culture was in Bourdieu's vocabulary, although in his hands, groups in France became fluid factions of aligned individuals, rather than the durable entities imagined by Boas and Lemkin, and culture became merely a process by which certain individuals set themselves apart. 
more prominent voices in an academic climate growing hostile to the anthropological idea of culture. $^{42}$

At the start of the modern human rights movement in the immediate postwar period, the doctrine of human rights had been the site of a struggle between individualists, arguing for civil and political rights, and anti-colonial nationalists, who argued that human rights should include group rights to self-determination. In the 1970s, the democratic West finally wrested human rights doctrine from the increasingly discredited anti-colonial movement. ${ }^{43}$ As Western human rights activists operationalized it as a political weapon, they also stripped human rights of any robust group protections. This newly individualized conception of human rights fit well with the increasingly transcendent economistic individualism of the era and quickly became a cornerstone of the post-Cold War period's discourse and politics. ${ }^{44}$

However, the individualistic bent of human rights has not prevented the Genocide Convention from coming to be seen as a facet of the international human rights apparatus. In fact, Nersessian, among others, argues that the Genocide Convention should be interpreted in ways that better accord with the individualism of today's human rights. ${ }^{45}$

\section{An Exemplary Peremptory Norm}

Yet as Lemkin recognized, incorporating it into human rights would strip the Genocide Convention of its essence, its group focus. Moreover, as was widely acknowledged

\footnotetext{
${ }^{42}$ Susan Hegeman, Patterns for America: Modernism and the Concept of Culture (Princeton: Princeton University press, 1999) at 193-213, cataloging postmodern academic skepticism about culture.

${ }^{43}$ See Samuel Moyn, Human Rights and the Uses of History (London: Verso, 2014) at 94.

${ }^{44}$ See Lawrence M. Friedman, The Human Rights Culture: A Study in History and Context (New Orleans: Quid Pro Quo, 2011) at 34, arguing that individualized human rights reflects a broader individualizing global culture.

${ }^{45}$ David Nersessian, Genocide and Political Groups (Oxford: Oxford University Press, 2010) at 74.
} 
during its drafting, stripping the Genocide Convention of its group focus makes it redundant, synonymous with the doctrine of crimes against humanity.

Always prescient, Lemkin had seen this coming. He had assailed attempts to reconfigure the Genocide Convention to better fit the draft code and human rights measures for violating the principles of pacta sunt servanda and the inviolability of treaties. ${ }^{46} \mathrm{He}$ argued that the parties had agreed to specific commitments embodied in the treaty, and therefore any attempt to modify those commitments necessarily violated their rights to enforcement of those commitments.

Lemkin had it right. Since his death, the Genocide Convention has come to be seen as one of the bedrock principles of international law. In Congo v. Rwanda, the ICJ declared that "the prohibition of genocide" is "assuredly" a "peremptory norm of international law (jus cogens)":

"[T] he principles underlying the [Genocide] Convention are principles which are recognized by civilized nations as binding on States, even without any conventional obligation" and that a consequence of that conception is "the universal character both of the condemnation of genocide and of the co-operation required 'in order to liberate mankind from such an odious scourge"" .. . It follows that "the rights and obligations enshrined by the Convention are rights and obligations erga omnes." 47

As Antonio Cassese stated, "[I]t is now widely recognized that customary rules on genocide impose erga omnes obligations," and "[f]urthermore, those rules now form part of jus cogens

\footnotetext{
${ }^{46}$ Raphael Lemkin, Memorandum: "The Dangers of the Demand for Revision" NYPL, supra note 3 (Reel 3, File 3), arguing changes in the Chinese draft convention violated the principle of the sanctity of treaties.

${ }^{47}$ Case Concerning Armed Activities in the Territory of the Congo (New Application 2002) (Democratic Republic of the Congo v Rwanda), Jurisdiction and Admissibility, [2006] ICJ Rep 6 at 32-33, citing Reservations to the convention on the Prevention and Punishment of the Crime of Genocide, Advisory Opinion, [1951] ICJ Reports 15 at 23; Case Concerning Application of the Convention on the Prevention and Punishment of the Crime of Genocide (Bosnia and Herzegovina v Yugoslavia), Preliminary Objections, [1996] ICJ Rep 595 at 616 .
} 
or the body of peremptory norms; that is, they may not be derogated from by international agreement (nor a fortiori by national legislation)."48

In light of these considerations, those seeking to dilute the Genocide Convention's commitments through the doctrine of exclusion and other manoeuvres would seem to be misguided. Because the Genocide Convention is foundational to modern international law, it is human rights and the rest of international law that should bend to fit the Genocide Convention.

\section{The Dangerous Past}

If this is true, then properly understanding the Genocide Convention's commitments and its place in the broader corpus of international law requires locating the meaning of its terms in the time of its conclusion. The meaning of words shifts over time, so it is not sufficient to simply read the treaty's terms or to comb through its preparatory work. The words will appear familiar but may connote something different from the drafters'

\footnotetext{
${ }^{48}$ Antonio Cassese, International Criminal Law, 2nd ed (Oxford: Oxford University Press, 2008) at 130. See also, Application of the Genocide Convention on the Prevention and Punishment of the Crime of Genocide (Bosnia Herzegovina v. Yugoslavia (Serbia and Montenegro), Order of 13 September 1993, Separate Opinion of Judge Lauterpacht [1993] ICJ Rep 407 at 440, arguing that even the UN Security Council's power under Article 103 of the UN Charter must yield to jus cogens. International law recognizes that treaty parties may alter an agreement through subsequent practice, but it is difficult to conceive of circumstances in which subsequent practice might narrow the Genocide Convention's scope. Generally, modifications, even of multilateral treaties, are said to require unanimous consent by all parties. With a widely ratified treaty like the Genocide Convention, such consent is unlikely. See Alexander Orakhelashvili, "Restrictive Interpretation of Human Rights Treaties in the Recent Jurisprudence of the European Court of Human Rights" 14:3 EJIL (2003) 529 at 536, arguing with regard to the European Convention on Human Rights that "[s]ubsequent practice may not validly curtail, in scope or effect, the substantive rights and guarantees embodied in [such a treaty], .. . subsequent practice can only be relevant ... to the extent that it facilitates the effective operation or enforcement of the Convention." See also article 9 of the Genocide Convention, which states that any party may request revision of the Genocide Convention and "[t]he General assembly shall decide upon the steps, if any, to be taken in respect to such a request." Perhaps an unopposed and consistent pattern of practice by a convincing number of parties could broaden its scope, but considering the convention's jus cogens status, narrowing its scope without demonstrating near-unanimous support would be antithetical to current international law. (GA, International Law Commission, Martti Koskenniemi, "Difficulties Arising From the Diversification and Expansion of International Law: Report From the Study Group pf the International Law Commission: Fragmentation of International Law" UN Doc A/CN.4/L.682 [13 April 2006] at 184.)
} 
understanding of those terms. A credible interpretation requires moving beyond these materials to locate their key terms in the broader social and political debates of their time. It requires understanding not merely the problem the parties intended to solve in crafting the Genocide Convention, but the larger presuppositions that nurtured both the problem and the solution.

However, some would argue that recognizing the drafters' concerns reanimates the ugliness of their world. After all, the recognition of group difference might ground the Genocide Convention, but it also fed the Holocaust. In the world of the Genocide Convention's drafting, it was simply understood, if sometimes resisted, that one's group affiliations largely determined one's life trajectory. Housing, education, and jobs were commonly provided or denied according to one's race, ethnicity, or religious affiliation. If there has been any improvement over the past seventy-five years, it is that these practices have been rendered controversial. Although they persist, it is no longer simply assumed that Blacks cannot live in certain neighborhoods, that elite universities will exclude Jews, and that anything more than a rudimentary education would be wasted on indigenous children. There is also increasing skepticism toward ideas like "national character," according to which some human groups are deemed inherently lazy or industrious, loyal or duplicitous, clever or dimwitted. And racism, while it persists, is becoming increasingly odious. The thinking of their time, which now seems so awful, formed the mid-twentieth century world of the Genocide Convention's drafting. For better or worse — and it was often for the worse - theirs was a world dominated by group identity.

For decades, the Western intellectual project cultivated meritocratic individualism as it sought to delegitimate the group-centric thinking that empowered racial caste systems in 
the United States and elsewhere and produced atrocities like the industrial-scale murder of Jews. It sought permeable boundaries around families, ethnic groups, and nations in order to combat the tyrannies of racism, nationalism, and patriarchy embedded in our political and intimate relationships. These gains were hard won and are in constant danger of being undone. Today's human rights activists might argue that a Genocide Convention that glorifies atavistic group affiliations also reifies these divisions, divisions that have fuelled so much violence. According to this thinking, an individualistic interpretation is safer, even if it betrays the Convention's text, history, and teleology.

But this approach would also betray what I have come to believe is a fundamental wisdom embedded in the Genocide Convention: that group life is worthwhile and beneficial, even if it is often also problematic. At its core, the Genocide Convention embodies a deep respect for human diversity, the cultivation of difference. Diversity, as a value, says, "I am made better by the fact of our differences." Sometimes called pluralism, cultural relativism, or ethical nationalism, the principle of diversity has a lengthy pedigree in Western thought. This principle was very much alive in World War II's immediate aftermath, at least among Western intellectuals. To be sure, it was never really operationalized, as policymakers defaulted to expediency over principle. And its influence was short-lived, as human difference was increasingly effaced by Cold War universalism. But this does not rob diversity of its salience. In our age, when even the leading democracies flirt with rejecting liberal internationalism, and when group identities play an ever larger and more ominous role, the world may have need for Lemkin's concept of genocide, which grounds the prohibition of inter-group violence in the recognition of difference. In this way, the Genocide Convention reaches across the intervening decades to remind us of the value that is the 
human mosaic — not just to each group, but also to humanity as a whole, which is enriched and made better through the encounter with others. This reminder is as important now as it has ever been. 


\section{Bibliography}

\section{Archival Sources}

Cincinnati, The Jacob Rader Marcus Center of the American Jewish Archives, Raphael

Lemkin Papers [AJA].

College Park, MD, United States National Archives [NACP].

New York, American Jewish Historical Society, Raphael Lemkin Collection [AJHS].

New York, New York Public Library, Archives and Manuscripts, Raphael Lemkin Papers [NYPL].

New York City, United Nations Archives and Records Management Section [UNARMS].

\section{Jurisprudence}

Aegean Sea Continental Shelf Case (Greece v. Turkey), [1978] ICJ Rep 3.

Ambatielos Case (Merits Obligation to Arbitrate, Judgment (19 May 1953) Joint dissent of Judges McNair, Basadevant, Klaestad, and Read [1953] ICJ Rep 25.

Anglo-Iranian Oil Co. (United Kingdom v/Iran), Preliminary Objection, [1952] ICJ Rep 93.

Case Concerning the Application of the Convention on the Prevention and Punishment of the Crime of Genocide (Bosnia and Herzegovina v. Serbia and Montenegro) [2007] ICJ Rep 47.

Application of the Genocide Convention on the Prevention and Punishment of the Crime of Genocide (Bosnia Herzegovina v. Yugoslavia (Serbia and Montenegro), Order of 13 September 1993, Separate Opinion of Judge Lauterpacht [1993] ICJ Rep 407.

Case Concerning Application of the Convention on the Prevention and Punishment of the Crime of Genocide (Croatia v Serbia), Judgement, Preliminary Objections [2008] ICJ Rep 412.

Application of the Convention on the Prevention and Punishment of the Crime of Genocide (Croatia v Serbia), [2015] ICJ Rep 3.

Award in the Arbitration Regarding the Iron Rhine ("Ijzeren Rijn") Railway Between the Kingdom of Belgium and the Kingdom of the Netherlands (2005) 28 UNRIAA 35 at 65 (Permanent Court of Arbitration).

Barcelona Traction, Light and Power Company, Limited (Belgium v. Spain), Preliminary Objections [1964] ICJ Reports 6.

Border and Transborder Armed Action (Nicaragua v Honduras) (Jurisdiction and Admissibility) [1988] ICJ Rep 69. 
Canada-Term of Patent Protection (2000) WT/DS170/AB/R (Appellate Body Report), online: WTO $<$ docsonline.wto.org $>$.

Case Concerning the Arbitral Award of 31 July 1989 (Guinea-Bissau v Senegal), Dissenting Opinion of Judge Weeramantry [1991] ICJ Rep 130.

Case Concerning Armed Activities in the Territory of the Congo (New Application 2002) (Democratic Republic of the Congo v Rwanda), Jurisdiction and Admissibility, [2006] ICJ Rep 6.

Case Concerning Avena and Other Mexican Nationals (Mexico v. United States of America) [2004] ICJ Rep 12.

Case Concerning the Application of the Convention on the Prevention and Punishment of the Crime of Genocide (Bosnia and Herzegovina v. Serbia and Montenegro) [2007] ICJ Rep 47.

Case Concerning Application of the Convention on the Prevention and Punishment of the Crime of Genocide (Croatia v Serbia), Judgement, Preliminary Objections [2008] ICJ Rep 412.

Case Concerning Application of the Convention on the Prevention and Punishment of the Crime of Genocide (Bosnia and Herzegovina v Yugoslavia), Preliminary Objections, [1996] ICJ Rep 595.

Case Concerning Military and Paramilitary Activities in and Against Nicaragua (Nicaragua v United States), Jurisdiction and Admissibility, [1984] ICJ 392.

Case Concerning Oil Platforms (Islamic Republic of Iran v United States of America), Preliminary Objection, Judgment [1996] ICJ Rep 803.

Case Concerning Pulp Mills on the River Uruguay Judgment (Argentina v. Uruguay), (20 April 2010) [2010] ICJ Rep 14.

Case Concerning Kasikili/Sedudu Island (Botswana v. Namibia), Judgment of 13 December 1999, [1999] ICJ Rep. 1045.

Case Concerning the Temple of Preah Vihear (Cambodia v. Thailand), Preliminary Objections, [1961] ICJ Rep 17.

Case of the S.S. “Lotus” (France v Turkey), (1927) PCIH (Ser A) No 10.

Case Relating to Jurisdiction of the International Commission of the River Oder (United Kingdom, Czechoslovakia, Denmark, France, Germany, Sweden v Poland), Order of 15 August 1929, PCIJ (Ser A) No 23.

Cayuga Indians (Great Britain) v United States (1926) 6 Rep Int'1 Arbitral Awards 173

Competence of the General Assembly for the Admission of a State to the United Nations, Advisory Opinion, [1950] ICJ Rep 4.

Conditions of Admission of a State to Membership in the United Nations, Advisory Opinion, [1948] ICJ Rep 57.

Constitution of the Maritime Safety Committee of the Inter-Governmental Maritime Consultative Organization, Advisory Opinion (8 June 1960), ICJ Reports [1960] 150. 
Dispute Regarding Navigational and Related Rights (Costa Rica v. Nicaragua), [2009] ICJ Rep 213.

Effect of Reservations on the Entry Into Force of the American Convention on Human Rights (Arts 74 and 75) (1982) Advisory Opinion OC-2/82, Inter-Am Ct HR (Ser A) No 2.

Exchange of Greek and Turkish Populations (1925) Advisory Opinion, PCIJ (Ser B) No 10.

Fisheries Jurisdiction Case (United Kingdom v Iceland) [1973] ICJ Rep 3.

The Greco-Bulgarian Communities Case (1930), Advisory Opinion, PCIJ (Ser B) No 17.

India-Patent, Protection for Pharmaceutical and Agricultural Chemical Products, AB-19975 (1997), WT/DS 50/AB/R at para 43 (Report of the Appellate Body), online: WTO $<$ docsonline.wto.org $>$.

International Status of South West Africa (Advisory Opinion), [1950] ICJ Rep 128.

Interpretation of Peace Treaties with Bulgaria, Hungary and Romania (Second Phase), Advisory Opinion, [1950] ICJ Rep 221.

Island of Palmas Case (Netherlands, United States) (1928) 2 R. Int'1 Arb. Awards 831, 845 (permanent Court of Arbitration).

Jorgic [2000] 2 BvR 1290/99, [2009] 135 ILR 152 at 161 (Germany, Federal Constitutional Court, BVerfG).

Jorgic v. Germany, No 74613/01, [2007] III ECHR 263.

Korea - Definitive Safeguard Measures on Imports of Certain Dairy Products (1999), WTO Doc WT/DS98/AB/R.

LaGrand Case (Germany v United States of America), [2001] ICJ Rep 466.

Land, Island, and Maritime Frontier Dispute (El Salvador/Honduras: Nicaragua intervening) [1992] ICJ Rep 351.

Legal Consequences for States of the Continued Presence of South Africa in Namibia (South West Africa) Notwithstanding Security Council Resolution 276, Advisory Opinion, [1970] ICJ Rep 16.

Legality of the Threat or Use of Nuclear Weapons, Advisory Opinion [1996] ICJ Rep 226.

Lighthouses Case Between France and Greece, Separate Opinion of Judge Anzilotti, (1938) PCIJ (Ser A/B) No. 59.

Prosecutor v Akayesu, ICTR-96-4, Judgment (2 September 1998) (International Criminal Tribunal for Rwanda, Trial Chamber) online: <www.ictr.org $>$.

Prosecutor v Omar Hassan Ahmad Al Bashir, ICC-02/05-01/09 Decision on the

Prosecution's Application for a Warrant of Arrest Against Omar Hassan Ahmad Al Bashir(4 March 2009) at para 125 (International Criminal Court), 4 March 2009) online: ICC <icccpi.int>.

Prosecutor v Vidoje Blagojević \& Dragan Jokić, IT-02-60-T, Judgment (Jan. 17, 2005) (International Criminal Tribunal for the Former Yugoslavia, Trial Chamber) online: ICTY $<$ www.icty.org $>$. 
Prosecutor v Radoslav Brđanin, IT-99-36-T, Judgment (1 September 2004) (International Criminal Tribunal for the Former Yugoslavia, Trial Chamber) online: ICTY

$<$ www.icty.org $>$.

Prosecutor v Furundžija, Case No. IT-95-17/1-A (July 21, 2000) (the International Criminal Tribunal for the Former Yugoslavia, Appeals Chamber), online: ICTR < www.ictr.org $>$.

Prosecutor v Jelisić, IT-95-10-T, Judgment (14 December 1999) (International Criminal Tribunal for the Former Yugoslavia, Trial Chamber) online: ICTY <www.icty.org $>$.

Prosecutor v Jelisić, IT-95-10-A, Judgment (July 5, 2001) (International Criminal Tribunal for the Former Yugoslavia, Appeals Chamber), online: ICTR < www.ictr.org>.

Prosecutor v Nikola Jorgić, [1997] IV-26/96; 2StE 8/96 (Germany, Higher State Court of Düsseldorf) online in translation: ICC Legal Tools Database $<$ https://www.legaltools.org/doc/bd3e74/pdf/>.

Prosecutor v Nikola Jorgić, [1999] 3StR 215/98 (Germany, Federal Supreme Court) online in translation: ICC Legal Tools Database < https://www.legal-tools.org/doc/85b784/pdf/>.

Prosecutor v. Kajelijeli, ICTR-98-44A, Judgment (1 December 2003) (International Criminal Tribunal for Rwanda, Trial Chamber) online: <www.ictr.org>.

Prosecutor v Kambanda, ICTR-97-23-S, Judgment and Sentence (4 September 1998) (International Criminal Tribunal for Rwanda) online: ICTR $<$ ictr.org $>$.

Prosecutor v. Kamuhanda, ICTR-99-54A, Judgment and Sentence (22 January 2004) (International Criminal Tribunal for Rwanda, Trial Chamber) online: <www.ictr.org>.

Prosecutor v Radovan Karadžić \& Ratko Mladić, IT-95-5-R61, IT-95-18-R61, Review of the Indictments Pursuant to Rule 61 of the Rules of Procedure and Evidence (11 July 1996) (International Criminal Tribunal for the Former Yugoslavia, Trial Chamber) online: ICTY $<$ www.icty.org $>$.

Prosecutor v. Kayishema \& Ruzindana, ICTR-95-1-T, Judgement (1 May 1999) (International Criminal Tribunal for Rwanda, Trial Chamber) online: <www.ictr.org>.

Prosecutor v Radislav Krstić, IT-98-33-T, Judgment (2 August 2001) (International Criminal Tribunal for the Former Yugoslavia, Trial Chamber) online: ICTY <www.icty.org>.

Prosecutor v Radislav Krstić, IT- 98-33-A, Judgment (April 19, 2004) (International Criminal Tribunal for the Former Yugoslavia, Appeals Chamber) online: ICTY $<$ wwwicty.org $>$.

Prosecutor v. Radislav Krstić, IT-98-33-A, Judgment, Partial Dissenting Opinion of Judge Shahabuddeen, (Apr. 19, 2004) (International Criminal tribunal for the former Yugoslavia, Appeals Chamber) online: ICTY $<$ wwwicty.org $>$.

Prosecutor v Musema, ICTR-96-13-T, Judgment and Sentence (27 January 2000) (International Criminal Tribunal for Rwanda, Trial Chamber) online: ICTR $<$ ictr.org $>$.

Prosecutor v Vujadin Popovic, IT-00-39T, Public Redacted Judgment vol 1 (27 September 2006) (International Criminal Tribunal for the Former Yugoslavia, Trial Chamber) online: ICTY <www.icty.org $>$. 
Prosecutor v Rutaganda, ICTR-96-3-T Judgment and Sentence, (6 December 1999) (International Criminal Tribunal for Rwanda, Trial Chamber) online: ICTR $<$ ictr.org $>$

Prosecutor v Laurent Semanza, ICTR-97-20 Judgment and Sentence (15 May 2003) (International Criminal Tribunal for Rwanda) online: ICTR <www.ictr.org>.

Prosecutor v. Serushago, ICTR-98-39-S, Sentence (5 February, 1999) (International Criminal Tribunal for Rwanda, Trial Chamber) online: ICTR <ictr.org $>$.

Prosecutor v Sikirica et al., IT-95-8-T, Judgment on Defense Motions to Acquit (3 September 2001) (International Criminal Tribunal for the Former Yugoslavia, Trial Chamber) online: ICTY <www.icty.org $>$.

Prosecutor v. Stakić, Case No. IT-97-24, Judgment (July 31, 2003) (International Criminal Tribunal for the Former Yugoslavia, Trial Chamber) online: ICTY < www.icty.org>.

Prosecutor v Tadić, Case No. IT-94-1-A, Judgment (July 15, 1999) online: ICTR $<$ www.ictr.org $>$.

Reparation for Injuries Suffered in the Service of the United Nations, Advisory Opinion, [1949] ICJ Rep 174.

Reservations to the convention on the Prevention and Punishment of the Crime of Genocide, Advisory Opinion, [1951] ICJ Reports 15.

Reservations to the Convention on the Prevention and Punishment of the Crime of Genocide, Advisory Opinion of 28 May 1951, "Statement of Mr. Shabtai Rosenne (11 April 1951) [1951] ICJ Pleadings, Oral Arguments, Documents (vol 2) 328.

South West Africa Cases (Ethiopia v South Africa; Liberia v South Africa) Second Phase, [1966] ICJ Rep 6.

Trial of Josef Altstötter and Others, United Nations War Crimes Commission, Law Reports of War Criminals (London: His Majesty's Stationary Office, 1948) vol 6.

Trial of Dr. Joseph Buhler, Staatssekretär and Deputy Governor-General (1 $7^{\text {th }}$ of June $-10^{\text {th }}$ July, 1948) Supreme National Tribunal of Poland in United Nations War Crimes Commission, Law Reports of War Criminals, vol 14 (London: His Majesty's Stationary Office, 1948).

Trial of Haupsturmführer Amon Leopold Goeth, Commandant of the Forced Labour Camp Near Cracow, Supreme National Tribunal of Poland Cracow, $\left(27^{\text {th }}-31^{\text {st }}\right.$ Aug and $2^{\text {nd }}-5^{\text {th }}$ Sept. 1946) in United Nations War Crimes Commission, Law Reports of War Criminals, vol 7 (London: His Majesty's Stationery Office, 1948) 1.

Trial of Major War Criminals Before the International Military Tribunal, Nuremberg (14 November 1945 - 1 October 1946) vols. 1 - 43 (Nuremberg: Secretariat of the IMT, 1947).

Trial of Obersturmbannführer Rudolf Franz Ferdinand Hoess, Commandant of the Auschwitz Camp, Supreme National Tribunal of Poland $\left(11^{\text {th }}-29^{\text {th }}\right.$ March, 1947) in United Nations War Crimes Commission, Law Reports of War Criminals, vol 7 (London: His Majesty's Stationary Office, 1948).

Tyrer v. United Kingdom (1978), 26A ECHR (Ser A) 15, 2 EHRR 1. 
United States v. Josef Altstötter et al (the Justice case), Trials of War Criminals Before the Nuremberg Military Tribunals Under Control Council Law No. 10 (Washington: United States Government Printing Office, 1951) (Military Tribunal, Nuremberg, Germany, Oct 1946- Apr 1949) vol 3.

United States v. Flick et. al, Trials of War Criminals Before the Nuremberg Military Tribunals Under Control Council Law No. 10 (Washington: United States Government Printing Office, 1951) (Military Tribunal, Nuremberg, Germany, Oct 1946- Apr 1949) vol 9.

United States v. Greifelt (the RuSHA case), Trials of War Criminals Before the Nuremberg Military Tribunals Under Control Council Law No. 10 (Washington: United States Government Printing Office, 1950) (Military Tribunal, Nuremberg, Germany, Oct 1946- Apr 1949) vol 5.

United States v. Otto Ohlendorf, et al. (the Einsatzgruppen Case), Trials of War Criminals Before the Nuremberg Military Tribunals Under Control Council Law No. 10 (Washington: United States Government Printing Office, 1951) (Military Tribunal, Nuremberg, Germany, Oct 1946- Apr 1949) vol 4.

United States v. Pohl et. Al, Trials of War Criminals Before the Nuremberg Military Tribunals Under Control Council Law No. 10 (Washington: United States Government Printing Office, 1951) (Military Tribunal, Nuremberg, Germany, Oct 1946- Apr 1949) vol 5.

United States v. Ernst von Weizsaecker, et al. (the Ministries Case), Trials of War Criminals Before the Nuremberg Military Tribunals Under Control Council Law No. 10 (Washington: United States Government Printing Office, 1951) (Military Tribunal, Nuremberg, Germany, Oct 1946- Apr 1949) vols $12-14$.

\section{Treaties and Resolutions}

Adoption of the Convention on the Prevention and Punishment of the Crime of Genocide, GA Res 260 (III), UNGAOR, 3rd Sess, UN Doc A/Res/3/260 (1948).

Control Council Law No. 10, Punishment of Persons Guilty of War Crimes, Crimes Against Peace and Against Humanity in Trials of War Criminals Before the Nuremberg Military Tribunals Under Control Council Law No. 10 (Washington: United States Government Printing Office, 1951) vol 1 at XVIII, online: <http://avalon.law.yale.edu/imt/imt10.asp>.

The Crime of Genocide GA Res. 96(1) UN GAOR. $1^{\text {st }}$ Sess, UN Doc. A/BUR 5.50 (1946).

Convention on the Prevention and Punishment of the Crime of Genocide, 9 December 1948, 78 U.N.T.S. 277 (entered into force 12 January 1951).

Convention on the Prevention and Punishment of the Crime of Genocide, GA Res. 260A (III) 3rd Sess, UN Docs A/760 \& A/760/Corr.2; A/PV.179 (1948).

Draft Convention on Genocide, GA Res 180(II), UNGAOR, 2nd Sess, UN Doc A/Res/180(II) (1947).

Draft Code of Offences against the Peace and Security of Mankind, GA Res. 36/106, UNGAOR, 36th Sess, UN Doc A/Res/36/106. 
Establishment of an International Law Commission, GA Res 174 (II), UNGAOR, 2nd Sess, UN Doc A/Res/174(II) (1947).

Formulation of the Principles Recognized in the Charter of Nürnberg Tribunal and in the Judgment of the Tribunal, GA Res 177 (II), UN GAOR, 2nd Sess, UN Doc A/Res/177(II)

Formulation of the Principles Recognized in the Charter of the Nürnberg Tribunal and in the Judgment of the Tribunal, GA Res 177(II), UNGAOR, 2nd Sess, UN Doc A/RES/177 (1947).

The Situation in Bosnia and Herzegovina, GA Res 47/21, UNGAOR, 47th Sess, UN Doc A/Res/47/121 (1992).

Statute of the International Court of Justice, 26 June 1945, 59 Stat. 1055, 33 U.N.T.S. 993.

Vienna Convention on the Law of Treaties 23 May 1969, 1155 U.N.T.S. 331 (entered into force 27 January 1980).

\section{UN Documents}

Syria: Amendment to Article II, UNGAOR Sixth Committee, 3rd Sess, UN Doc A/C.6/234, 15 October 1948.

Note by the Secretary General: Ad Hoc Committee's Terms of Reference, UNESCOR, 3rd Sess, UN Doc. E/AC.25/2 (1948).

Ad Hoc Committee on Genocide, Basic Principles of a Convention on Genocide, Submitted by the Delegation of the Union of Soviet Socialist Republics, UNESCOR (1948) UN Doc E/AC.25/7 [Soviet Draft].

Draft Convention on Genocide: Report and Draft Resolution Adopted by Sub-Committee 2, UNGAOR, Sixth Committee, 2nd Sess, UN Doc A/C.6/190/Rev.1 (1947).

Draft Convention on Genocide: Amendments Submitted by the Delegation of the Union of Soviet Socialist Republics, UNGAOR, Sixth Committee, 2nd Sess, UN Do. A/C.6/201 (1947).

Union of Socialist Soviet Republics: Amendments to the Draft Convention (E794), UNGAOR, 3rd Sess, UN Doc. A/C.6/215/Rev.1 (1948).

Basic Principles of a Convention on Genocide (Submitted by the Delegation of the Union of Soviet Socialist Republics on 5 April 1948), UNESCOR, Ad Hoc Committee on Genocide, UN Doc. E/AC.25/7 (1948).

Draft Convention on the Crime of Genocide, UNESCOR, 3rd Sess, UN Doc E/447 (1948).

France: Amendments to the Draft Convention, UNGA, Sixth Committee, 3rd Sess, UN Doc A/C.6/224 (1948).

Note by the Secretariat, Ad-Hoc Committee on Genocide, Relations between the Convention on Genocide on the One Hand and the Formulation of the Nurnberg Principles and the Preparation of a Draft Code of Offences Against the Peace and Security on the Other UNESCOR (1948) UN Doc E/A.25/3/Rev.1. 
Report of the Sixth Committee: Genocide: Draft Convention and Report of the Economic and Social Council UNGAOR, 3rd Sess, UN Doc. A/760/Corr.2 (1948) E/AC.25/2 (1948).

Union of Soviet Socialist Republics: Amendments to Article II of the Draft Convention, UNGAOR, Sixth Committee, 3rd Sess, UN Doc. A/C.6/223 (1948).

United Nations, Rules of Procedure of the General Assembly UNGAOR (1947) UN Doc. $\mathrm{A} / 520$.

UNGAOR, 3d Sess, 178th \& 179th Plen Mtgs, UN Docs A/PV.178, A/PV.179 (1948).

Venezuela: Amendment to article II of the Draft Convention, UNGAOR, Sixth Committee, 3rd Sess, UN Doc. A/C.6/231 (1948).

\section{UN Reports}

Letter Dated 24 May 1994 From the Secretary-General to The President of the Security Council: Final Report of the Commission of Experts Established Pursuant to United Nations Security Council Resolution 780 (1992) UNSC, UN Doc S/1994/674 (1994).

Benjamin Whitaker, Revised and Updated Report on the Question of the Prevention and Punishment of the Crime of Genocide, UNESCOR, Commission on Human Rights, SubComm'n on Prevention of Discrimination and Protection of Minorities, (1985) U.N. Doc. E/CN.4/Sub.2/1985/6.

Draft Convention on Genocide: Report of the Economic and Social Council: Report of the Sixth Committee, 2nd Sess, UN Doc A/510 (1947).

Draft Convention on the Crime of Genocide, UNESCOR, 3rd Sess, UN Doc E/447 (1948).

Draft resolution on the Crime of Genocide (Request from the Delegations for Cuba, Indian and Panama for the Inclusion of an Additional Item in the Agenda) UNGAOR 1st Sess, UN Doc A/BUR/50 (2 Nov 1946).

GA, International Law Commission, Martti Koskenniemi, "Difficulties Arising From the Diversification and Expansion of International Law: Report From the Study Group pf the International Law Commission: Fragmentation of International Law" UN Doc A/CN.4/L.682 (13 April 2006).

Note by the Secretariat, Ad-Hoc Committee on Genocide, Relation between the Convention on Genocide on the one hand and the Formulation of the Nurnberg Principles and the Preparation of a Draft Code of Offences Against the Peace and Security on the Other UNESCOR (1948) UN Doc E/A.253/Rev.1.

Permanent Forum on Indigenous Issues, Forms of Education of Indigenous Children as Crimes Against Humanity? UNESCOR, 7th Sess, UN Doc E/C.19/2008/7 (2008).

Report of the International Commission of Inquiry on Darfur to the United Nations Secretary General Pursuant to Security Council Resolution 1564 of 18 September 2004 (Geneva: Office of the High Commissioner for Human Rights, 25 January 2005) online: un.org $<$ http://www.un.org/news/dh/sudan/com_inq_darfur.pdf $>$. 
Nicodème Ruhashyankiko, Study of the Question of the Prevention and Punishment of the Crime of Genocide, UNESCOR, Commission on Human Rights, Sub-Commission on Prevention of Discrimination and Protection of Minorities, $31^{\text {st }}$ Sess, UN Doc.

E/CN.4/Sub.2/416 (1978).

United Nations Diplomatic Conference of Plenipotentiaries on the Establishment of an International Criminal Court, Rome, 15 June -- 17 July 1998, vols 1-3, UNGAOR, UN Doc A/CONF.183/13 (2002) (Sales No. E .02.I.5 / ISBN 92-1-100883-2) online: UN < http://legal.un.org/icc/rome/proceedings/contents.htm>.

Ad Hoc Committee on Genocide, Draft Convention on Prevention and Punishment of the Crime of Genocide, UNESCOR, (1948) UN Doc E/794 [Ad Hoc Committee Draft].

\section{Iinternational Law Commission Reports}

"Report of the International Law Commission on the Work of its Forty-Third Session" (UN Doc A/46/10) in Yearbook of the International Law Commission 1991, vol 2, part 2 (New York: UN, 1994) at 102 (UNDOC A/CN.4/SER.A/1991/Add.1).

"Report of the International Law Commission on the Work of Its Forty-Eighth Session" (UN Doc A/51/10) in Yearbook of the International Law Commission 1996, vol 2, part 2 (New York: UN, 1998) at 45-46 (UNDOC A/CN.4/SER.A/1996/Add.1).

"Reports of the International Law Commission on the Second Part of its Seventeenth and on its Eighteenth Session" (UN Doc A/6309/Rev.1) in Yearbook of the International Law Commission 1966 vol. II (New York: UN, 1967) 169 at 219-20 (UNDOC, A/CN.4/SER.A/1966/Add.1)

International Law Commission, Report on the work of its Fifty-Eighth Session (2006), UNGAOR, 61st Session, 2006 Supp. No. 10, UN Doc A/61/10 (2006)

Vespasian Pella, "Mémorandum Présenté par le Secrétariat" (UN Doc. A/CN.4/39) in Yearbook of the International Law Commission 1950 vol. II (New York: UN, 1957) 281 at 351-52 (UNDOC. A/CN.4/SER.A/Add.1).

Sir Humphrey Waldock, "Third Report on the Law of Treaties" (UN Doc A/CN.4/167) in Yearbook of the International Law Commission 1962 vol. 2 (New York: UN, 1964) 1 (UNDOC, A/CN.4/SER.A/1962/Add.1).

Sir Humphrey Waldock, Special Rapporteur, "Sixth Report on the Law of Treaties (UN Doc. A/CN.4/186 and Add.1, 2/Rev.1, 3-7) in Yearbook of the International Law Commission 1966 vol. II (New York: UN, 1967) 169 at 99 (UNDOC, A/CN.4/SER.A/1966/Add.1).

J. Spiropolous, "Draft Code Against the Peace and Security of Mankind" (UN Doc A/CN.4/19 in Yearbook of the International Law Commission 1950 vol. II (New York: UN, 1957) 253 at 263 (UNDOC. A/CN.4/SER.A/Add.1)

J. Spiropoulos, "Second Report on A Draft Code of Offences Against the Peace and Security of Mankind" (UN Doc A/CN.4/44) at 43 in Yearbook of the International Law Commission 1951vol 2 (New York: UN, 1957) 43 at 59 (UNDOC A/CN.4/SER.A/1951/Add.1). 
Study of the Question of the Prevention and Punishment of the Crime of Genocide, Prepared by Nicodéme Ruhashyankiko, Special Rapporteur Commission on Human Rights,

UNESCOR, 31st Sess, UN Doc E/CN.4/Sub.2/416

Doudou Thiam, "First Report on the Draft Code of Offences Against the Peace and Security of Mankind" (UN Doc. A/CN.4/364) in Yearbook of the International Law Commission 1983 vol. II(1) (New York: UN, 1985) 137 at 139 (UNDOC. A/CN.4/SER.A/1983/Add.1 (part 1)

Doudou Thiam, "Fourth Report on the Draft Code of Offences Against the Peace and Security of Mankind"(UN Doc A/CN.4/398) in Yearbook of the International Law Commission, 1986 vol II(1) (New Yok: UN, 1988) 53 at 58-60 (UNDOC, A/CN.4/SER.A/1986/Add.1 [part 1]).

Doudou Thiam, "Thirteenth Report on the Draft Code of Offences Against the Peace and Security of Mankind" (UN Doc A/CN.4/466 and Corr.1) in Yearbook of the International Law Commission, 1995 vol II(1) 33 at 41 (UNDOC A/CN.4/SER.A/1995/Add.1 [Part 1]).

\section{Secondary Sources}

\section{Secondary Sources: Monographs}

Abella, Alex, Soldiers of Reason: The RAND Corporation and the Rise of the American Empire (Boston: Mariner, 2009).

Akhavan, Payam, Reducing Genocide to Law: Definition, Meaning, and the Ultimate Crime (Cambridge: Cambridge University Press, 2012).

Amadae, S.M., Rationalizing Capitalist Democracy: The Cold War Origins of Rational Choice Liberalism (Chicago: University of Chicago Press, 2003).

Anderson, Carol, Eyes Off the Prize: The United Nations and the African American Struggle for Human Rights, 1944-1955 (Cambridge: Cambridge University Press, 2003).

Auden, W.H., Collected Poems, Edward Mendelson, ed, (Random House: New York, 1976).

Azcárate, Pablo De, The League of Nations and National Minorities: An experiment (Carnegie Endowment for International Peace, 1945).

Banner, Lois W., Intertwined Lives: Margaret Mead, Ruth Benedict, and Their Circle (New York: Vintage Books, 2004).

Barnard, Frederick M., Herder's Social and Political Thought: From Enlightenment to Nationalism (Oxford: Oxford University Press, 1965).

Barnard, Frederick M., Herder on Nationality, Humanity, and History (Montreal: McGillQueen's University Press, 2003).

Bederman, David, Classical Canons: Rhetoric, Classicism and Treaty Interpretation (Aldershot: Ashgate, 2001).

Benedict, Ruth, Patterns of Culture (Boston: Houghton Mifflin, 1959). 
Berlin, Isaiah, Vico and Herder: Two Studies in the History of Ideas (New York: Viking Press, 1976).

Berlin, Isaiah, Against the Current: Essays in the History of Ideas (New York: Penguin, 1979).

Berlin, Isaiah, The Crooked Timber of Humanity: Chapters in the History of Ideas, ed by Henry Hardy (New York: Vintage Books, 1992).

Berlin, Isaiah, The Roots of Romanticism (Princeton: Princeton University Press, 1999).

Bischoff, Ralph F., Nazi Conquest Through German Culture (Cambridge, MA: Harvard University Press, 1942).

Bloch, Marc, The Historian's Craft: Reflections on the Nature and Uses of History and the Techniques and Methods of Those Who Write It, translated by Joseph R. Strayer (New York: Vintage, 1953).

Boas, Franz, Anthropology and Modern Life (New York: Dover, 1986).

Borgwardt, Elizabeth, A New Deal for the World: America's Vision for Human Rights (Cambridge, MA: Belknap, 2005).

Botting, Douglas, Humboldt and the Cosmos (London: Sphere Books, 1973).

Bourdieu, Pierre, Distinction: A Social Critique of the Judgement of Taste, translated by Richard Nice (Cambridge, MA: Harvard University Press, 1984).

Bourdieu, Pierre, Language and Symbolic Power, John B. Thompson, ed., trans. by Gino Raymond \& Mathew Adamson (Cambridge, MA: Harvard University Press, 1991).

Burgin, Angus, The Great Persuasion: Reinventing Free Markets Since the Great Depression (Cambridge Mass: Harvard University Press, 2012).

Buruma, Ian, Year Zero: A History of 1945 (New York: Penguin Books, 2013).

Bracher, Karl Dietrich, The Age of Ideologies: A History of Political Thought in the Twentieth Century (New York: Saint Martin's Press, 1984).

Brierly, J.L., The Law of Nations: An Introduction to the International Law of Peace, 6th ed (Oxford: Oxford University Press, 1963).

Brinkley, Alan, Liberalism and its Discontents Cambridge Mass: Harvard University Press, 1998).

Brucken, Rowland, A Most Uncertain Crusade: The United States, the United Nations, and Human Rights, 1941-1953 (Northern Illinois University Press, 2013).

Bruns, Gerald L., Hermeneutics Ancient and Modern (New Have: Yale University Press, 1992).

Caputo, John D., Radical Hermeneutics: Repetition, Deconstruction and the Hermeneutic Project (Bloomington: Indiana University Press, 1987).

Canales, Jimena, The Physicist and the Philosopher: Einstein, Bergson, and Debate that Changed Our Understanding of Time (Princeton: Princeton University Press 2015). 
Carr, Edward Hallett, The Twenty Years Crisis, 1919-1939: An Introduction to the Study of International Relations (New York: St. Martin's Press, 1939).

Cassese, Antonio, International Criminal Law, 2nd ed (Oxford: Oxford University Press, 2008).

Chadwick, H. Munro, The Nationalities of Europe and the Growth of National Ideologies (Cambridge: Cambridge University Press, 1945).

Churchill, Ward, A Little Matter of Genocide: Holocaust and Denial in the Americas 1492 to the Present (San Francisco: City Lights Books, 1997).

Clark, Elizabeth A., History, Theory Text: Historians and the Linguistic Turn (Cambridge, MA: Harvard University Press, 2004).

Claude, Inis, National Minorities: An International Problem (Cambridge, MA: Harvard University Press, 1955).

Clay, Catherine \& Leapman, Michael, Master Race: The Lebensborn Experiment in Nazi Germany (London: Hodder and Stoughton, 1995).

Cobban, Alfred, National Self-Determination (Chicago: University of Chicago Press, 1944).

Collingwood, R.G., The Idea of History. ed by T.M. Knox (Clarendon Press, 1946).

Cooper, John, Raphael Lemkin and the Struggle for the Genocide Convention (New York: Palgrave Macmillan, 2008).

Cottrell, Robert C., Roger Nash Baldwin and the American Civil Liberties Union (Columbia University Press: New York, 2000).

Cullen, Jim, The Art of Democracy: A Concise History of Popular Culture in the United States (New York: Monthly Review Press, 2002).

Dewey, John, Individualism Old and New (New York: Capricorn Books, 1962).

Douglas, R.M., Orderly and Humane: The Expulsion of the Germans after the Second World War (New Haven: Yale University Press, 2012).

Dressler, Joshua, Understanding Criminal Law 4th ed (LexisNexis Mathew Bender, 2006).

Drost, Pieter N., The Crime of State: Genocide: United Nations Legislation on International Criminal Law (A.W. Sythoff, 1959).

Dubnow, Simon, Nationalism and History, ed by Koppel S. Pinson (Philadelphia: Jewish Publication Society of America, 1958).

Dumont, Louis, Essays on Individualism: Modern Ideology in Anthropological Perspective (Chicago: University of Chicago Press, 1986).

Dumont, Louis, German Ideology: From France to Germany and Back (Chicago: University of Chicago Press, 1994).

Dworkin, Ronald, Law's Empire (Cambridge, MA: Belknap Press, 1986).

Eagleton, Terry, The Idea of Culture (Malden, MA: Blackwell, 2013).

Eliot, T.S., Notes Towards the Definition of Culture (New York: Harcourt Brace, 1949). 
Eliot, T.S., "Tradition and the Individual Talent" in Peter Washington, ed, Eliot: Poems and Prose (Knopf, 1998).

Elliott, Michael A., The Culture Concept: Writing and Difference in the Age of Realism (Minneapolis: University of Minnesota Press, 2002).

Epstein, Catherine, Model Nazi: Arthur Greiser and the Occupation of Western Poland (Oxford: Oxford University Press, 2010).

Erickson, Paul A. \& Murphy, Liam D., A History of Anthropological Theory 2nd ed (Peterborough, ON: Broadview, 2003).

Fish, Stanley, Is There a Text in This Class: The Authority of Interpretive Communities (Cambridge, MA: Harvard University Press, 1980).

Fish, Stanley, Doing What Comes Naturally: Change, Rhetoric and the Practice of Theory in Literary and Legal Studies (Durham, NC: Duke University Press, 1989).

Franck, Thomas, The Empowered Self: Law and Society in the Age of Individualism (Oxford: Oxford University Press, 1999).

Frank, Lawrence K., Society as the Patient: Essays on Culture and Personality (New Brunswick: Rutgers University Press, 1948).

Friedman, Lawrence M., The Human Rights Culture: A Study in History and Context (New Orleans: Quid Pro Quo, 2011).

Gadamer, Hans-Georg, Truth and Method, translated by Joel Weisheimer \& Donald G. Marshall (London: Bloomsbury, 1975).

Gadamer, Hans-Georg, Reason in the Age of Science, translated by Frederick G. Lawrence (Cambridge, MA: MIT Press, 1982).

Gaddis, John Lewis, Strategies of Containment: A Critical Appraisal of Postwar American National Security Policy (Oxford: Oxford University Press, 1982).

Gardiner, Richard K., Treaty Interpretation (Oxford: Oxford University Press, 2008).

Geertz, Clifford, The Interpretation of Cultures (New York: Basic Books, 1973).

Glendon, Mary Ann, A World Made New: Eleanor Roosevelt and the Universal Declaration of Human Rights (New York: Random House, 2001).

Goodrich, Peter, Reading the Law: A Critical Introduction to Legal Method and Techniques (Oxford: Blackwell, 1986).

Greig, D.W., Intertemporality and the Law of Treaties (London: British Institute of International and Comparative Law, 2001).

Harlan, David, The Degradation of American History (Chicago: University of Chicago Press, 1997).

Harris, Marvin, The Rise of Anthropological Theory: A History of Theories of Culture (New York: Crowell, 1968).

Hayes, Carlton J. H., The Historical Evolution of Modern Nationalism (New York: Macmillan, 1948). 
Hegeman, Susan, Patterns for America: Modernism and the Concept of Culture (Princeton: Princeton University press, 1999).

Heidegger, Martin, Being and Time, translated by John Macquarrie \& Edward Robinson (New York: Harper Perennial 2008).

Heller, Kevin Jon, The Nuremberg Military Tribunals and the Origins of International Law (Oxford: Oxford, 2011).

Heilbroner, Robert L., The Worldly Philosophers: The Lives, Times and Ideas of the Great Economic Thinkers 6th ed (New York: Simon \& Schuster, 1986).

Herder, Johan Gottfried, Another Philosophy of History and Selected Political Writings, translated by Ioannis D. Evrigenis \& Daniel Pellerin (Indianapolis: Hackett, 2004).

Herder, J.G. Sämtliche Werke, ed. B. Suphan (Berlin: Weidmann, 1877-1913) vol XXIII.

Herskovits, Melville J., Cultural Relativism: Perspectives in Cultural Pluralism (New York: Random House, 1972).

Hobsbawm, E.J., Nations and Nationalism Since 1780: Programme, Myth, Reality (Cambridge, UK: Cambridge University Press, 1990).

Hollinger, David A., In the American Province: Studies in the History and Historiography of Ideas (Baltimore: Johns Hopkins University Press, 1985).

Hollinger, David, Science, Jews, and Secular Culture: Studies in Mid-Twentieth Century American Intellectual History (New Brunswick: Princeton University Press, 1996).

Hughes, H. Stuart, Consciousness and Society: The Reorientation of European Social Thought, 1890-1930, rev ed (New York: Vintage Books, 1971).

Irvin-Erickson, Douglas, Raphaël Lemkin and the Concept of Genocide (Philadelphia: University of Pennsylvania Press, 2017).

Jones, Adam, Genocide: A Comprehensive Introduction, 2nd ed (Abingdon, UK: Routledge, 2010).

Jones, Daniel Stedman, Hayek, Friedman, and the Birth of Neoliberal Politics (Princeton: Princeton University Press, 2012).

Kackenbeeck, Georges, The International Experiment of Upper Silesia: A Study in the Working of the Upper Silesian Settlement, 1922-1937 (Oxford: Oxford University Press, 1942).

Kalman, Laura, The Strange Career of Legal Liberalism (New Haven: Yale University Press, 1998).

Kay, Harvey J., The Fight for the Four Freedoms: What Made FDR and the Greatest Generation Truly Great (New York: Simon \& Schuster, 2014).

Kohn, Hans, The Idea of Nationalism: A Study in its Origins and Background (New York: Macmillan Company, 1948).

Kolakowski, Leszek, Bergson (Oxford: Oxford University Press, 1985). 
Korey, William, An Epitaph for Raphael Lemkin (New York: Jacob Blaustein Institute for the Advancement Human Rights, of the American Jewish Committee, 2001).

Koskenniemi, Martti, The Politics of International Law (Oxford: Hart, 2011).

Kuhn, Thomas, The Structure of Scientific Revolutions (Chicago: University of Chicago Press, 1996).

Kuper, Adam, Culture: The Anthropologists' Account (Cambridge, MA: Harvard University Press, 1999).

LaFave, Wayne, Criminal Law 3d (St. Paul, Minn: West Group, 2000).

Lauterpacht, Hersch, International Law and Human Rights (FA Praeger, 1950).

LeBlanc, Lawrence J., The United States and the Genocide Convention (Durham, NC: Duke University Press, 1991).

Lee, Hermione ed, Stevie Smith: A Selection (London: Faber, 1983).

Lemkin, Raphael, Axis Rule in Occupied Europe: Laws of Occupation, Analysis of Government, Proposals for Redress (Washington DC: Carnegie, 1944).

Lemkin, Raphael, Lemkin on Genocide, Steven Leonard Jacobs, ed, (Lanham: Lexington Books, 2012).

Lemkin, Raphael, Totally Unofficial: the Autobiography of Raphael Lemkin, Donna-Lee Frieze, ed, (New Haven: Yale University Press, 2013).

Lewis, Mark, The Birth of the New Justice: The Internationalization of Crime and Punishment, 1919-1950 (Oxford: Oxford University Press, 2014).

Linderfalk, Ulf, On the Interpretation of Treaties: The Modern International Law as Expressed in the 1969 Vienna Convention on the Law of Treaties (Dordrecht: Springer, 2007).

Lowe, Keith, Savage Continent: Europe in the Aftermath of World War II (New York: Saint Martin's Press, 2012).

Maguire, Peter, Law \& War: International Law and American History, revised ed (New York: Columbia University press, 2010).

Malinowski, Bronislaw, A Scientific Theory of Culture and Other Essays (New York: Galaxy, 1960).

Mandler, Peter, Return From the Natives: How Margaret Mead Won the Second World War and Lost the Cold War (New Haven: Yale University Press, 2013).

Manganaro, Marc, Culture, 1922: The Emergence of a Concept (Princeton: Princeton University Press, 2002).

Mazower, Mark, No Enchanted Palace: The End of Empire and the Ideological Origins of the United Nations (Princeton: Princeton University Press, 2009).

McDougal, Myres, Harold Laswell \& James Miller, The Interpretation of Agreements and World Public Order: Principles of Content and Procedure (New Haven: New Haven Press, 1967). 
McMurry, Ruth Emily \& Lee, Muna, The Cultural Approach: Another way in International Relations (Chapel Hill: University of North Carolina Press, 1947).

Arnold McNair, The Law of Treaties (Gloucestershire: Clarendon Press, 1961).

Mill, J.S., On Bentham and Coleridge, ed by F.R. Leavis (London: Chato and Windus, 1950).

Minow, Martha, Between Vengeance and Forgiveness: Facing History After Genocide and Mass Violence (Boston: Beacon Press, 1998).

Morsink, Johannes, The Universal Declaration of Human Rights: Origins, Drafting and Intent (Philadelphia: University of Pennsylvania Press, 1999).

Morton, Jeffrey S., The International Law Commission of the United Nations (Columbia, SC: University of South Carolina Press, 2000).

Moyn, Samuel, The Last Utopia: Human Rights in History (Cambridge, MA: Belknap Press, 2010).

Moyn, Samuel, Human Rights and the Uses of History (London: Verso, 2014).

Nersessian, David, Genocide and Political Groups (Oxford: Oxford University Press, 2010).

Nicholas, Lynn H., Cruel World: The Children of Europe in the Nazi Web 240-58, 502-13

(New York: Vintage Books, 2005).

Niebuhr, Reinhold, The children of Light and the Children of Darkness: A vindication of Democracy and a Critique of its Traditional Defense (New York: Scribner's Sons, 1944).

Normand, Roger \& Zaidi, Sarah, Human Rights at the UN: The Political History of Universal Justice (Bloomington: Indiana University Press, 2008).

Northrop, F.S.C., The Taming of the Nations: A Study of the Cultural Bases of International Policy (New York: Macmillan, 1952).

Novic, Elisa, The Concept of Cultural Genocide: An International Law Perspective (Oxford: Oxford University Press, 2016).

Novick, Peter, That Noble Dream: The "objectivity Question" and the American Historical Profession (Cambridge, UK: Cambridge University Press, 1988).

Orakhelashvili, Alexander, The Interpretation of Acts and Rules in Public International Law (Oxford: Oxford University Press, 2008).

Pecora, Vincent P. ed, Nations and Identities: Classical Readings (Malden, MA: WileyBlackwell, 2001).

Phillips-Fein, Kim, Invisible Hands: The Businessmen's Crusade Against the New Deal (New York: Norton, 2009).

Pocock, J.G.A., Political Thought and History: Essays on Theory and Method (Cambridge: Cambridge University Press, 2009).

Polanyi, Karl, The Great Transformation (Boston: Beacon Press, 1944).

Popper, Karl, The Logic of Scientific Discovery (London, Routledge, 2002 [1935, in German; 1959, in English]). 
Popper, Karl, The Poverty of Historicism (London: Routledge, 2002 [1936, in German; 1957, in English]).

Popper, Karl, The Open Society and its Enemies 2 vols (Princeton, Princeton University Press, 1945).

Power, Samantha, A Problem From Hell: America and the Age of Genocide (New York: Harper Perennial, 2007).

Price, David H., The Deployment and Neglect of American Anthropology in the Second World War (Durham, NC: Duke University Press, 2008).

Rakove, Jack N., Original Meanings: Politics and Ideas in the Making of the Constitution (New York: Knopf, 1996).

Ricoeur, Paul, The Conflict of Interpretations: Essays in hermeneutics (Evanston:

Northwestern University Press, 1974).

Ricoeur, Paul, Interpretation Theory: Discourse and the Surplus of Meaning (Fort Worth: Texas Christian University, 1976).

Ricoeur, Paul, Hermeneutics and the Human Sciences, translated and edited by John B. Thompson (Cambridge, UK: Cambridge University Press, 1981).

Ricoeur, Paul, From Text to Action: Essays in Hermeneutics, II, translated by Kathleen Blamey, \& John B. Thompson (London: Continuum, 2008).

Robinson, Jacob, Karbach, Oscar, Laserson, Max M., Robinson, Nehemiah \& Vichniak, Marc, Were the Minorities Treaties a Failure? (New York: Institute of Jewish Affairs, 1943).

Robinson, Nehemiah, The Genocide Convention: A Commentary (Institute of Jewish Affairs, 1960).

Rodgers, Daniel T., Atlantic Crossings: Social Politics in a Progressive Age (Cambridge, MA: Belknap Press, 1998).

Rodgers, Daniel T., Age of Fracture (Cambridge, MA: Belknap Press, 2011).

Rorty, Richard, Consequences of Pragmatism: Essays, 1972-1980 Minneapolis: University of Minnesota Press, 1982).

Rose, J. Holland, Nationality in Modern History (New York: Macmillan, 1916).

Russell, Bertrand, The History of Western Philosophy (London: Routledge, [1946] 1996).

Said, Edward W., Culture and Imperialism (New York: Vintage, 1993).

Sandburg, Carl, "Landscape" in The Complete Poems of Carl Sandburg, revised ed, (San Diego: Harcourt, 1970).

Sands, Philippe, East West Street: On the Origins of "Genocide" and "Crimes Against Humanity” (New York: Vintage Books, 2017).

de Saussure, Ferdinand, Course in General Linguistics, ed by Charles Bally, Albert Sechehaye \& Albert Riedlinger, translated by Roy Harris (Chicago: Open Court, 1972).

Scalia, Antonin A Matter of Interpretation: Federal Courts and the Law, ed by Amy Gutman (Princeton University Press, 1997). 
Scalia, Antonin \& Garner, Bryan, Reading Law: The Interpretation of Legal Texts (Thompson/West, 2012).

Schabas, William A, Genocide in International Law (Cambridge: Cambridge University Press, 2000).

Schabas, William A, Genocide in International Law: The Crime of Crimes 2nd ed (Cambridge: Cambridge University Press, 2009).

Schechtman, Joseph B., European Population Transfers 1939-1945 (New York: Oxford University Press, 1946).

Schlesinger Jr., Arthur M., The Vital Center: The Politics of Freedom (Da Capo Press, 1988).

Schumpeter, Joseph A., Capitalism, Socialism and Democracy (New York: Harper Perennial, 2008).

Schwarzenberger, Georg, International Law 3rd ed, vol 1 (London: Stevens, 1957).

Sikka, Sonia, Herder on Humanity and Cultural Difference: Enlightened Relativism (Cambridge: Cambridge University Press, 2011).

Simpson, A.W. Brian, Human Rights and the End of Empire: Britain and the Genesis of the European Convention (Oxford: Oxford University Press, 2001).

Sinclair, I.M., The Viennna Convention on the Law of Treaties (Manchester: Manchester University Press, 1973).

Snyder, Timothy, Bloodlands: Europe Between Hitler and Stalin (New York: Basic Books, 2010).

Sprague, Homer B. ed., Masterpieces of English Literature (New York: JW Schermerhorn \& Co, 1874) vol 1.

Taylor, Telford. The Anatomy of the Nuremberg Trials: A Personal Memoir (New York: Knopf, 1992).

Thompson, E. P., The Romantics: England in a Revolutionary Age (New York: The New Press, 1997).

Thompson, John B., Studies in the Theory of Ideology (Cambridge: Polity Press, 1984).

Tully, James ed, Meaning and Context: Quentin Skinner and His Critics (Princeton, Princeton University Press, 1988).

Turner, James, Philology: The Forgotten Origins of the Modern Humanities (Princeton: Princeton University Press, 2014).

Van Damme, Isabelle, Treaty Interpretation by the WTO Appellate Body (Oxford: Oxford University Press, 2009).

Warnke, Georgia, Gadamer, Hermeneutics, Tradition and Reason (Cambridge, UK: Polity Press, 1987).

Werle, Gerhard, Principles of International Criminal Law (The Hague: T M C Asser Press, 2005). 
White, Hayden, The Content of the Form: Narrative Discourse and Historical Representation (Baltimore: The Johns Hopkins University Press, 1987).

Williams, Raymond, Culture and Society, 1780-1950 (London: Chato \& Windus, 1959).

Williams, Raymond Keywords: A Vocabulary of Culture and Society (London: Fontana Press, 1976).

Wimmer, Andreas et al, eds, Facing Ethnic Conflicts: Towards a New Realism (Lanham: Rowan and Littlefield, 2004).

Zimmern, Alfred E., Nationality and Government With Other War-Time Essays (New York: Robert McBride \& Company, 1918).

\section{Secondary Sources: Articles}

Akhavan, Payam, "The Crime of Genocide in the ICTR Jurisprudence" 3 J Intl Crim J (2005) 989.

Allott, Philip, "The Concept of International Law" 10 EJIL (1999) 31.

Amann, Diane Marie, "Group Mentality, Expressivism, and Genocide" 2:2 Intl Crim L Rev (2002) 93.

American Anthropological Association, Executive Board, "Statement on Human Rights" 49 American Anthropologist (1947) 539.

Anderson, Jill C., "Misreading like a Lawyer: Cognitive Bias in Statutory Interpretation" 127 Harv L Rev (2014) 1.

Arrow, Kenneth J., "Methodological Individualism and Social Knowledge" 84:2 Am Econ $\operatorname{Rev}(1994) 1$.

Bechky, Perry S., "Lemkin's Situation: Toward a Rhetorical Understanding of Genocide" 77 Brook L Rev (2011) 551.

Bartlett, Robert Merrill, "Pioneer vs. an Ancient Crime," The Christian Century (18 July 1956) 854.

Benhabib, Seyla, "International Law and Human Plurality in the Shadow of Totalitarianism: Hannah Arendt and Raphael Lemkin" 16:2 Constellations (2009) 321.

Boas, Franz, Letter "The Occurrence of Similar Inventions in Areas Widely Apart" 9 Science (1887) 486-87.

Bourdieu, Pierre, "Sociologists of Belief and Beliefs of Sociologists" 23:1 Nordic Journal of Religion and Society (2010) 1.

Crema, Luigi, "Disappearance and New Sightings of Restrictive Interpretation(s)" 21 Eur J Intl L (2010) 681.

Cummings, E.E. in Poetry: A Magazine of Verse 63 (July 1943) at 183.

Diamond, Cora, "Losing Your Concepts" 98 Ethics (1988) 255. 
Earl, Hilary, "Prosecuting Genocide before the Genocide Convention: Raphael Lemkin and the Nuremberg Trials 1945-1949”15 J. Genocide Res (2013) 317.

Elder, Tanya, "What You See Before Your Eyes: Documenting Raphael Lemkin's Life by Exploring His Archival Papers,1900-1959” 7 J Genocide Res (2005) 469.

Elias, T.O., "The Doctrine of Intertemporal Law" 74 AJIL (1980) 285.

England, Robert, “The Masaryk Mystery” 3 Dalhousie Rev (1952) 3.

Engle, Karen, "From Skepticism to Embrace: Human Rights and the American

Anthropological Association From 1947-1999” 23 Hum. Rts Q (2001) 536.

Ermarth, Michael, "The Transformation of Hermeneutics: 19th Century Ancients and 20th Century Moderns" 64:2 The Monist (1981) 175.

Ferencz, Benjamin, Current developments: "the Draft Code of Offences Against the Peace and Security of Mankind" 75 AJIL (1981) 674.

Ferencz, Benjamin, "An International Criminal Code and Court: Where They Stand and Where They're Going” 30 Colum. J. Transnat'l L (1992) 375.

Ferencz, Benjamin, “A Prosecutor's Personal Account: From Nuremberg to Rome” 52 J. of Int'l Affairs (1999) 455.

Finch, George, Editorial Comment "The Genocide Convention” 43 Am. J. Int'1 L. (1949) 732.

Fisher III, William W., "Texts and Contexts: The Application to American Legal History of the Methodologies of Intellectual History” 49 Stan L Rev (1996) 1065.

Fitzmaurice, Sir Gerald, “The Law and Procedure of the International Court of Justice:

Treaty Interpretation and Other Treaty Points” 28 Brit. YB Intl L (1951) 1.

Fitzmaurice, Sir Gerald, "The Law and Procedure of the International Court of Justice 19514: Treaty Interpretations and Other Treaty Points” 33 Brit Y.B. Int'1 L (1957) 203.

Fletcher, George P., The Storrs Lectures: "Liberals and Romantics at War: The Problem of Collective Guilt" 111 Yale LJ (2001) 1499.

Fletcher, George P., "Collective Guilt and Collective Punishment" 5:1 Theor Inq L (2004) 163.

Frieze, Donna-Lee, Introduction, "New Approaches to Raphael Lemkin" 15 J Genocide Res (2013) 247.

Gandhi, Mahatma, "A Letter Addressed to the Director-General of UNESCO” in UNESCO, ed, Human Rights: Comments and Interpretations (1949) 89.

Goodrich, Peter, “Historical Aspects of Legal Interpretation” 61 Ind LJ (1986) 331.

Gordon, Robert W., "Forward: The Arrival of Critical Historicism," 49 Stan. L. Rev. (1996) 103.

Higgins, Rosalyn, "Time and the Law: International Perspectives on an Old Problem" 46 ICLQ (1997) 501. 
Hohenberg, John, "The Crusade that Changed the UN," Saturday Review (9 November 1968) 86.

Hollinger, David, "Science as a Weapon in Kulturkampfe in the United States During and After WWII" 86 Isis (1995) 440.

Ignatieff, Michael, "The Unsung Hero Who Coined the Term 'Genocide"” New Republic (21 Sept 2013) 220.

Irvin-Erickson, Douglas, "Genocide, the 'Family Mind' and the Romantic Signature of Raphael Lemkin" 15 J. Genocide Res (2013) 273.

Johnson, D.N.H., "The Draft Code of Offences Against the Peace and Security of Mankind" 4 ICLQ (1955) 445.

Jonas, David S. \& Saunders, Thomas N., "The Object and Purpose of a Treaty: Three Interpretive Methods" (2010) 43 Vand J. of Transnat'l L 565.

Kerno, Ivan S., “In Memoriam: Vespasian V. Pella, 1897-1952” 46 AJIL (1952) 709.

Klabbers, Jan, "International Legal Histories: The Declining Importance of Travaux Préparatoires in Treaty Interpretation," 50:1 Netherlands Intl L Rev 267.

Kreß, Claus, “The Crime of Genocide Under International Law” 6 Intl Crim L Rev (2006) 461.

Kroeber, A.L., "The Superorganic" 19 Am Anthropologist (1917) 163.

Kunz, Josef L., Editorial Comment, "The Genocide Convention” 43 AJIL (1949) 732.

Kunz, Josef L., "The United Nations Convention on Genocide" 43 AJIL (1949) 738.

Kunz, Josef L., "Present-Day Efforts at International Protection of Human Rights: A General Analytical and Critical Introduction" 45 Proceedings of the American Society of International Law at its Annual Meeting, 1921-1969 (26-28 April 1951) 109.

Lauterpacht, Hersch, "Some Observations on the Preparatory Work in the Interpretation of Treaties" 48:4 Harv L Rev (1935) 549.

Lauterpacht, Hersch, "Restrictive Interpretation and the Principle of Effectiveness in the Interpretation of Treaties" (1949) 26 Brit YB Int'1 L 48.

Lemkin, Raphael, "Genocide" 15:2 The American Scholar (1946) 227.

Lemkin, Raphael, "Genocide a s Crime under International Law" 4 United Nations Bulletin (15 January 1948).

Anon (Lemkin, Raphael) "Genocide: A Commentary on the Convention" 58 Yale L J (1949) 1142 .

Linderfalk, Ulf, "Is the Hierarchical Structure of Articles 31 and 32 of the Vienna Convention Real or Not? Interpreting the Rules of Interpretation" 54:1 Netherlands Intl L Rev. (2007) 133.

Lippman, Matthew, "The Drafting of the 1948 Convention on the Prevention and Punishment of the Crime of Genocide" 3 BU ILJ 1 (1985). 
Mandler, Peter, "One World, Many Cultures: Margaret Mead and the Limits of Cold War Anthropology” 68 Hist Workshop J (2009).

McDonnell, Michael A. \& Moses, A. Dirk, "Raphael Lemkin as Historian of Genocide in the Americas" 7 J Genocide Res (2005) 501.

McDougal, Myres, “The International Law Commission's Draft Articles Upon

Interpretations: Textuality Redivivus" 61 AJIL (1967) 922.

McLachlan, Campbell, "The Principle of Systemic Integration and Article 31(30(C) of the Vienna Convention” 54 ICLQ (2005) 279.

Mundorff, Kurt, Note: "Children as Chattel: Invoking the Thirteenth Amendment to Reform Child Welfare” 1 Cardozo Pub. L. Pol'y \& Ethics J. (2003) 131.

Mundorff, Kurt, "Taking 2(e) Seriously: Forcible Child Transfers and the Convention on the Prevention and Punishment of the Crime of Genocide." Masters of Law Thesis, University of British Columbia. Available at https://circle.ubc.ca/ handle/2429/31682.

Mundorff, Kurt, "Other Peoples' Children: A Textual and Contextual Interpretation of the Genocide Convention, Article 2(e)" 50 Harv Int'1 L J (2009) 61.

Nersessian, David L., The Razor's Edge: Defining and Protecting Human Groups Under the Genocide Convention, 36 Cornell Intl LJ (2003) 293.

Nersessian, David, "Rethinking Cultural Genocide Under International Law" 2:12 Hum Rts Dialog (2 April 2005) 7-8.

Novic, Elisa, 'Physical-biological or Socio-Cultural 'Destruction' in Genocide? Unraveling the Legal Underpinnings of Conflicting Interpretations” 17 J Genocide Res (2015) 64.

Alexander Orakhelashvili, "Restrictive Interpretation of Human Rights Treaties in the Recent Jurisprudence of the European Court of Human Rights" 14:3 EJIL (2003) 529.

Preece, Jennifer Jackson, "Minority Rights in Europe: From Westphalia to Helsinki” 23 Rev Intl Stud (1997) 75.

Rayfuse, Rosemary, "The Draft Code of Crimes Against the Peace and Security of Mankind: Eating Disorders at the International Law Commission" 8 Crim LF (1997) 43.

Martin Ris, "Treaty Interpretation and ICJ Recourse to Travaux Préparatoires: Towards a Proposed Amendment of Articles 31 and 32 of the Vienna Convention on the Law of Treaties" 14:1 Boston College Int'1 \& Comp L Rev (1991) 111.

Rissing-van Saan, Ruth, "The German Federal Supreme Court and the Prosecution of International Crimes Committed in the Former Yugoslavia" 3 J Intll Crim J (2005).

Samson, Mélanie, "High Hopes, Scant Resources: A Word of Skepticism About the AntiFragmentation Function of Article 31(3)(c) of the Vienna Convention on the Law of Treaties" 24 Leiden J Int'1 Law (2011) 701.

Schabas, William A., "Genocide, Crimes Against Humanity, and Darfur: The Commission of Inquiry's Findings on Genocide” 27 Cardozo L Rev (2005) 1703.

Schabas, William, "Origins of the Genocide Convention: From Nuremberg to Paris" 40 Case West Res J Int'l L (2008) 35. 
Schachter, Oscar, "The Invisible College of International Lawyers" (1977) 72 Nw UL Rev 217.

Schaller, Dominik, “Raphael Lemkin's View of European Colonial Rule in Africa: Between Condemnation and Admiration" 7 J Genocide Res (2005) 531.

Segesser, Daniel Marc \& Gessler, Myriam, "Raphael Lemkin and the International Debate on the Punishment of War Crimes (1919-1948)" 7 J Genocide Res 453 (2005).

Simpson, A.W. Brian, "Britain and the Genocide Convention" 73:1 Brit YB Intl L (2003) 5.

Singleterry, Douglas, “'Ethnic Cleansing' and Genocide Intent: A Failure of Judicial Interpretation?" 5:1 Genocide Stud and Prevention (2010) 39.

Skinner, Quentin, "Meaning and Understanding in the History of Ideas" 8 History and Theory (1969) 3.

Sohn, Louis B., “The Development of International Law," 35:1 ABA J (1949) 56.

Stone, Julius, "Fictional Elements in Treaty Interpretation: A Study in the Judicial Process" (1953) 1 Sydney L Rev 345.

Schwarzenberger, Georg, "Myths and Realities of Treaty Interpretation: articles 27-29 of the Vienna Draft Convention on the Law of Treaties" 9 Va J Int'l L (1968) 1.

Taylor, Telford, "When a People Kill a People" Book Review of Genocide: Its Political Uses in the Twentieth Century by Leo Kuper, (28 March, 1982) New York Times Book Review 9.

Thirlway, Hugh, "The Law and Procedure of the International Court of Justice, 1960-1989, Part Three" 62:1 Brit YB Int'l L (1992).

Tolischus, Otto D., "Twentieth-Century Moloch: The Nazi-inspired Totalitarian State, Devourer of Progress - and of Itself," Book Review of Axis Rule in Occupied Europe by Raphael Lemkin, New York Times (21 Jan 1945) 102.

Toews, John E., "Intellectual History after the Linguistic Turn: The Autonomy of Meaning and the Irreducibility of Experience" 94 Am Hist Rev (1984) 879.

van Krieken, Robert, Rethinking Cultural Genocide: Aboriginal Child Removal and SettlerColonial State Formation, 75 Oceania (2004) 125.

Vrdoljak, Ana Filipa, "Human Rights and Genocide: The Work of Lauterpacht and Lemkin in Modern International Law" 20 EJIL (2009) 1163.

Wald, Patricia M., "Some observations on the Use of Legislative History in the 1981 Supreme Court Term" 68 Iowa L. Rev. (1983) 195.

Weiss-Wendt, Anton, "Hostage of Politics: Raphael Lemkin on 'Soviet Genocide"” 7 J Genocide Res (2005).

Wilkie, Meredith, Bringing Them Home: Report of the National Inquiry into the Separation of Aboriginal and Torres Strait Islander Children from Their Families, Human Rights and Equal Opportunity Commission (1997).

Yerbury, Colin “"The Sons of Freedom' Doukhobors and the Canadian State," 16 Canadian Ethnic Studies (1984) 47. 


\section{Secondary Sources: Book Chapters}

Lord Acton, "Nationalism - the Last Phase of Revolution" in Alfred Zimmern, ed, Modern Political Doctrines (Oxford: Oxford University Press, 1939).

Andreopoulos, George J., "The Calculus of Genocide" in George J. Andreopoulos, ed, Genocide: Conceptual and Historical Dimensions (Philadelphia: Univeristy of Pennsylvania Press, 1994) 1.

Barrett, John Q., 'Raphael Lemkin and 'Genocide' at Nuremberg” in Christoph Safferling \& Eckart Conze, eds, The Genocide Convention Sixty Years After its Adoption (TMC Asser Press, 2010) 35.

Bederman, David J., "Foreign Office International Legal History" in M. Craven, Malgosia Fitzmaurice, \& Maria Vogiatzi, eds, Time History and International Law (Leiden: Martin Nijhoff, 2007) 43.

Bennet, Tony, "Culture" in Tony Bennet, Lawrence Grossberg, \& Meaghan Morris, eds, New Keywords: A Revised Vocabulary of Culture and Society (Blackwell, 2005) 68.

Berman, Nathaniel, "The International Law of Nationalism: Group Identity and Legal History” in Robert J. Beck \& Thomas Ambrosio, eds., International Law and the Rise of Nations (Seven Bridges, 2002) 106.

Boas, Franz, "The Study of Geography" in George W. Stocking, Jr., ed, Volksgeist as Method and Ethic: Essays on Boasian Ethnography and the German Anthropological Tradition (Madison: University of Wisconsin Press, 1996) 9.

Bruns, Gerald, "The Problem of Figuration in Antiquity" in Gary Shapiro \& Alan Sica, eds., Hermeneutics: Questions and Perspectives (Amherst: University of Massachusetts Press, 1984) 167.

Buckley, Thomas, "'The Little History of Pitiful Events': The Epistemological and Moral Contexts of Kroeber's Californian Ethnology" in George W. Stocking ed., Essays on Boasian Ethnography and the German Anthropological Tradition (1996) 257.

Bunzl, Matti, "Franz Boas and the Humboldtian Tradition" in George W. Stocking, Jr., ed, Volksgeist as Method and Ethic: Essays on Boasian Ethnography and the German Anthropological Tradition (Madison: University of Wisconsin Press, 1996) 17.

Dilthey, Wilhelm, "The Hermeneutics of the Human Sciences" in Kurt Mueller-Vollmer, ed, The Hermeneutics Reader: Texts of the German Tradition from the Enlightenment to the Present (New York: Continuum, 1985) 148.

Dörr, Oliver, "Article 31: General Rule of Interpretation" in Oliver Dörr \& Kirsten

Schmalenbach, Vienna Convention on the Law of Treaties: A Commentary (Berlin: Springer, 2012).

Drumbl, Mark A., “'Germans are the Lords and Poles are the Servants': The Trial of Arthur Greiser in Poland, 1946" in Kevin Jon Heller \& Gerry Simpson, eds, The Hidden Histories of War Crimes Trials (Oxford: Oxford University Press, 2013) 411. 
Dupuy, Pierre-Marie, "Evolutionary Interpretation of Treaties: Between Memory and Prophecy" in Enzo Cannizzaro ed., The Law of Treaties Beyond the Vienna Convention (Oxford: Oxford University press, 2011) 123.

Eley, Geoff \& Suny, Ronald Grigor, "Introduction” in Geoff Eley and Ronald Grigor Suny, eds., Becoming National: A Reader (Oxford: Oxford University Press, 1996) 1.

Fish, Stanley, "Play of Surfaces: Theory and the Law" in Gregory Leyh ed., Legal Hermeneutics: History, Theory, and Practice (Berkeley: University of California Press, 1992) 297.

Heinemann, Isabel, "Until the Last Drop of Good Blood": The Kidnapping of "Racially Valuable" Children and Nazi Racial Policy in Occupied Eastern Europe, in A. Dirk Moses, ed, translated by Andrew H. Beattie, Genocide and Settler Society: Frontier Violence and Stolen Indigenous Children in Australian History (New York: Berghahn Books, 2004) 244.

Hollinger, David A., "Cultural Relativism" in Theodore M. Porter \& Dorothy Ross, eds, The Modern Sciences, in David C. Lindberg \& Ronald L. Numbers, eds, Cambridge History of Science vol 7 (Cambridge: Cambridge University Press, 2003) 708, at 714.

Hollis, Martin, "Say it with Flowers" in James Tully, ed, Meaning and Context: Quentin Skinner and His Critics (Princeton, Princeton University Press, 1988) 143.

Huber, Max, "The Swiss Concept of the State" in Alfred Zimmern, Modern Political Doctrines (Oxford: Oxford University Press, 1939) 215.

von Humboldt, Wilhelm, "The Nature and Conformation of Language" in Kurt MuellerVollmer, ed, The Hermeneutics Reader: Texts of the German Tradition from the Enlightenment to the Present (New York: Continuum, 1985) 98.

Klabbers, Jan, "Reluctant Grundnorm" in M. Craven, Malgosia Fitzmaurice, \& Maria Vogiatzi, eds, Time History and International Law (Leiden: Martin Nijhoff, 2007) 141.

Klabbers, Jan, "Virtuous Interpretation" in Malgosia Fitzmaurice, Olufemi Elias \& Panos Merkouris eds, Treaty Interpretation and the Vienna Convention on the Law of Treaties: 30 Years On (Leiden: Martinus Nijhoff, 2010) 20.

Kluckhohn, Clyde \& Kelly, William H., "The Concept of Culture" in Ralph Linton, ed, The Science of Man in the World Crisis (New York: Columbia University Press, 1945) 78.

Liss, Julia E., "The Bildung of Franz Boas" in George W. Stocking, Jr., ed, Volksgeist as Method and Ethic: Essays on Boasian Ethnography and the German Anthropological Tradition (Madison: University of Wisconsin Press, 1996) 155.

Llewellyn, Karl N., "Group Prejudice and Social Education” in R.M. MacIver, Civilization and Group Relationships (New York: Harper \& Brothers, 1945) 11.

Madison, G.B., "Gadamer and Ricoeur" in Richard Kearney, ed, Continental Philosophy in the 20th Century (London, UK: Routledge, 2012).

McLaren, John, "The State, Child Snatching, and the Law: The Seizure and Indoctrination of Sons of Freedom Children in British Columbia, 1950-1960" in John McLaren, Robert Menzies, and Dorothy E. Chunn, eds, Regulating Lives: Historical Essays on the State, Society, the Individual, and the Law (Vancouver: UBC Press, 2002) 259. 
Mead, Margaret, "Preface" in Ruth Benedict, Patterns of Culture (Boston: Houghton Mifflin, (1959).

Merkouris, Panos, Introduction: “Interpretation: Art or Science?" in Malgosia Fitzmaurice, Olufemi Elias \& Panos Merkouris eds, Treaty Interpretation and the Vienna Convention on the Law of Treaties: 30 Years On (Leiden: Martinus Nijhoff, 2010) 8.

Merkouris, Panos, “Third Party' Considerations” in Malgosia Fitzmaurice, Olufemi Elias \& Panos Merkouris eds, Treaty Interpretation and the Vienna Convention on the Law of Treaties: 30 Years On (Leiden: Martinus Nijhoff, 2010) 75.

Mill, John Stuart, Considerations on Representative Government in Vincent P Pecora, ed, Nations and Identities: Classical Readings (Malden, MA: Wiley-Balckwell, 2001) 142.

Moses, A. Dirk, "Raphael Lemkin, Culture and the Concept of Genocide" in Donald Bloxham \& A. Dirk Moses, eds, The Oxford handbook of Genocide Studies, (Oxford: Oxford University Press, 2010) 1.

Moshman, David, "Conceptions of Genocide and Perceptions of History" in Dan Stone, ed, The Historiography of Genocide (Palgrave Macmillan, 2008) 71.

Moyn, Samuel, "Personalism, Community, and the Origins of Human Rights" in Stefan Ludwig-Hoffmann, ed., Human Rights in the Twentieth Century (Cambridge: Cambridge University Press, 2011) 85.

O'Neil, John, "Scientism, Historicism and the Problem of Rationality" in John O'Neil ed., Modes of Individualism and Collectivism (New York: St. Martin's Press, 1973).

Renan, Ernest, "What is a Nation?" in Alfred Zimmern, ed, Modern Political Doctrines (Oxford: Oxford University Press, 1939).

"Report of the Liberal Industrial Inquiry" in Alfred Zimmern, ed, Modern Political Doctrines (Oxford: Oxford University Press, 1939).

Ricoeur, Paul, "The Hermeneutical Function of Distanciation" in Paul Ricoeur, From Text to Action: Essays in Hermeneutics, II, translated by Kathleen Blarmey (Continuum, 1991) 75.

Sands, Phillippe \& Commission, Jefferey, "Treaty Custom and Time:

Interpretation/Application?” in Malgosia Fitzmaurice, Olufemi Elias \& Panos Merkouris eds., Treaty Interpretation and the Vienna Convention on the Law of Treaties: 30 Years On (2010) 39.

Sapir, Edward, "Culture, Genuine and Spurious" in David G. Mandelbaum, ed, Selected Writings of Edward in Language, Culture and Personality (Berkeley: University of California Press, 1949) 308.

Sapir, Edward, "Cultural Anthropology and Psychiatry" in David G. Mandelbaum, ed, Selected Writings of Edward in Language, Culture and Personality (Berkeley: University of California Press, 1949) 509.

Sbolci, Luigi, "Supplementary Means of Interpretation" in Enzo Cannizzaro, ed., The Law of Treaties Beyond the Vienna Convention (Oxford: Oxford University Press, 2011).

Skinner, Quentin "A Reply to My Critics" in James Tully, ed, Meaning and Context: Quentin Skinner and His Critics (Princeton, Princeton University Press, 1988) 231. 
Skinner, Quentin, "Some Problems in the Analysis of Political Thought and Action" in James Tully, ed, Meaning and Context: Quentin Skinner and His Critics (Princeton, Princeton University Press, 1988) 97.

Skinner, Quentin, "'Social Meaning' and the Explanation of Social Action" in James Tully, ed, Meaning and Context: Quentin Skinner and His Critics (Princeton, Princeton University Press, 1988).

Tully, James, "The Pen is Mightier than the Sword" in James Tully, ed, Meaning and Context: Quentin Skinner and His Critics (Princeton, Princeton University Press, 1988).

\section{Websites}

Joshua Cherniss \& Henry Hardy, "Isaiah Berlin", Stanford Encyclopedia of Philosophy, online: https://plato.stanford.edu/entries/berlin/.

Maja Trochimczyk, "Essay: Rota (the Oath) University of Southern California, Polish Music Center, online $<$ https://polishmusic.usc.edu/research/national-anthems/rota-the-oath/ $>$.

Foreign Relations of the United States, 1948, General, The United Nations, vol 1, part 1, (Washington: Government Printing Office, 1948), Document 185 ("Minutes of the Ninth Meeting of the United States Delegation).

Foreign Relations of the United States 1948: General; the United Nations vol 1, part 1, (Washington: Government Printing Office, 1948) Document 183 ("Minutes of the Fourth Meeting of the United States Delegation to the Third Regular Session of the General Assembly, Paris, Hotel d Iéna, 24 September 1948, 9:15 am,") online: US State Department, Office of the Historian < https://history.state.gov/historicaldocuments/frus1948v01p1/d183>Paris, Hotel d'léna, 30 September 1948”), online: US State Department, Office of the Historian $<$ https:/history.state.gov/historicaldocuments/frus1948v01p1/d185>.

Franklin D. Roosevelt: "Address at Chicago, Ill.," October 14, 1936. Online by Gerhard Peters and John T. Woolley, The American Presidency Project.

$<$ http://www.presidency.ucsb.edu/ws/?pid=15185>.

\section{Other sources}

"Vespasien V. Pella," obituary, The New York Times (25 August 1952).

British House of Lords Debate, HL Deb 10 February 1948 vol 153 cc909-11.

The Truth and Reconciliation Commission of Canada, Honoring the Truth, Reconciling for the Future: Summary of the Final Report (2015).

A. Dirk Moses, Dust Jacket Blurb, on Douglas Irvin-Erickson, Raphaël Lemkin and the Concept of Genocide (Philadelphia: University of Pennsylvania Press, 2017).

UN, The Work of the International Law Commission, 4th ed (New York: UN, (1988). 
Matthew Cole, "The Language of Genocide” Bass Connections Field Paper: (Fall 2014) 8-9 online:

$<$ http://kenan.ethics.duke.edu/humanrights/files/2014/10/20141120LanguageofGenocideMatthewCole.pdf $>$

Raphael Lemkin, "Genocide Before the U.N: Importance of Resolution Declaring Crime International is Stressed," Letter to the Editor, The New York Times (8 November 1946).

A.L. Kroeber \& Clyde Kluckhohn, "Culture: A Critical Review of Concepts and

Definitions," 47:1 Peabody Museum Papers (Cambridge MA: Peabody Museum, 1952).

John Docker, Lecture: "Raphael Lemkin's History of Genocide and Colonialism" Paper for United States Holocaust Memorial Museum, Washington DC: Center for Advanced

Holocaust Studies (2004) online: United States Holocaust Memorial Museum

$<$ www.ushmm.org $>$.

Oxford English Dictionary, Online

Francis Biddle, "Prosecution of Major Nazi War Criminals: Report to President Truman," in Department of State Bulletin vol. 15 (24 November 1946) 954, 955.

Robert H. Jackson, "Planning Memorandum Distributed to Delegations at Beginning of London Conference, June 1945, Report of Robert H. Jackson, United States Representative to the International Conference on Military Trials 68 (1945), online: Yale Law School, Avalon Project $<$ http://avalon.law.yale.edu/subject_menus/jackson.asp $>$.

Thesaurus.com

Webster's Deluxe Unabridged Dictionary 2nd ed.

Bryan A Garner, Garner's American Usage 2nd ed (Oxford: Oxford University Press, 2003).

HW Fowler, New Fowler's Modern English Usage revised 3rd ed, revised by R.W.

Burchfield (Oxford: Oxford University Press, 1998)

The Shorter Oxford English Dictionary, 5th ed. 